DEPARTMENT OF THE INTERIOR

UNITED STATES GEOLOGICAL SURVEY

CHARLES D. WALCOTT, DIRECTOR

THE

\title{
COPPER DEPOSITS
}

OF THE

\section{CLIFTON-MORENCI DISTRICT, ARIZONA}

BY

WALDEMAR LINDGREN

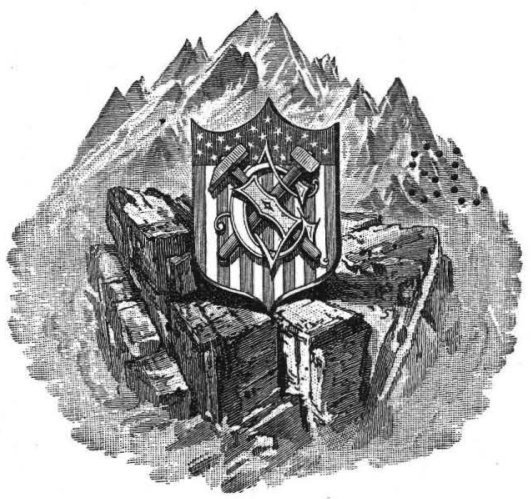

W A SHIN G TON

GOVERNMENT PRINTING OFFICE 1905 


U.SGEOLOGICALSURVEY
FEB 191906
LIBRARY.

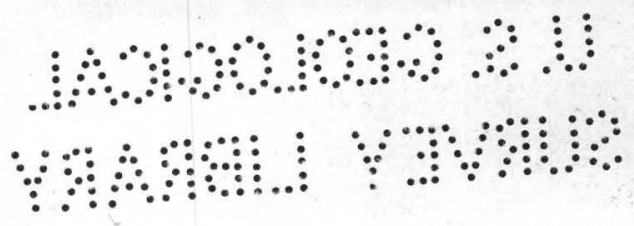




\section{CGNTENTS.}

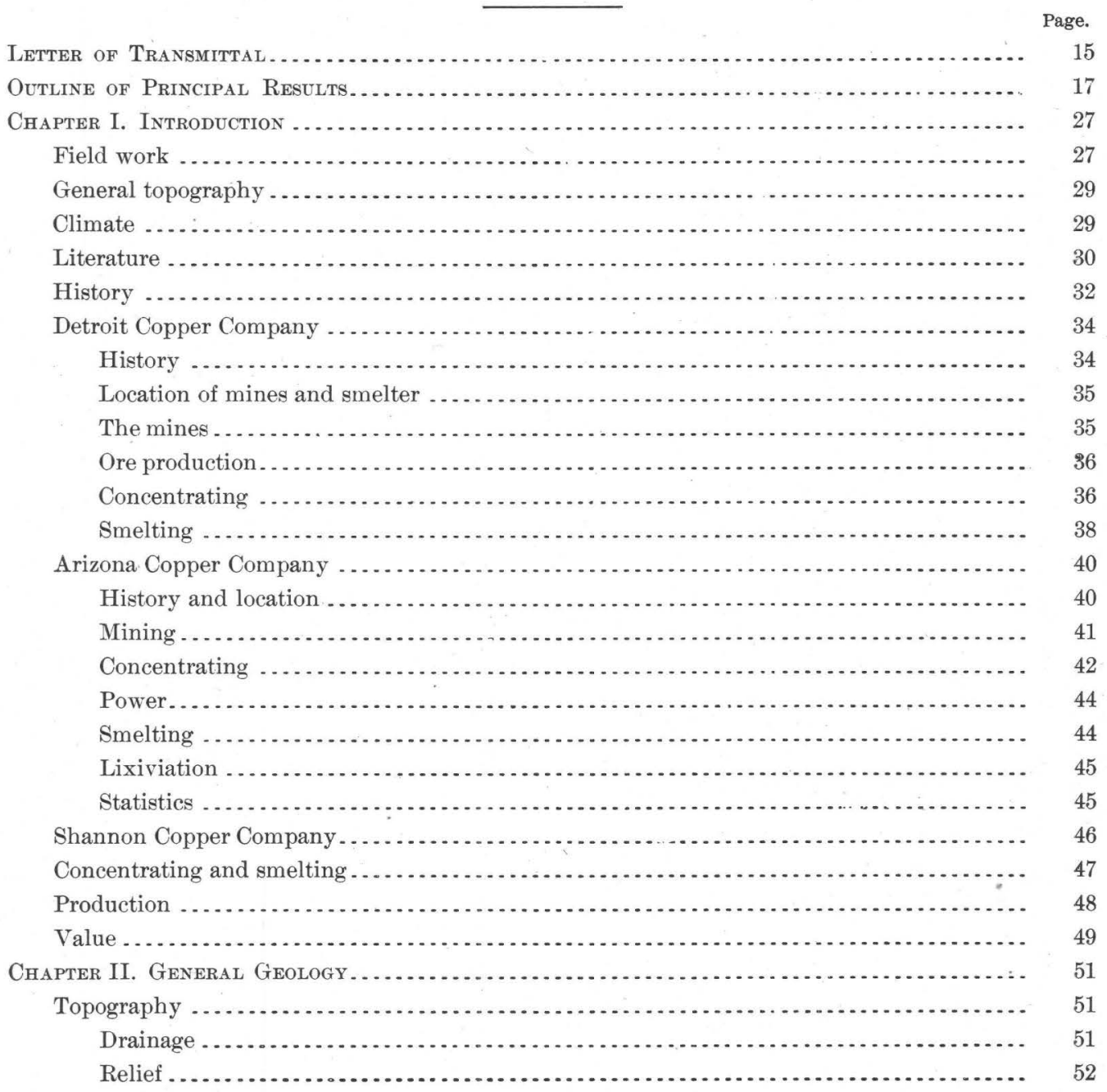


Chapter II. General Geology-Continued. Page.

Rocks . . . . . . . .

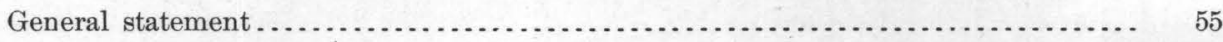

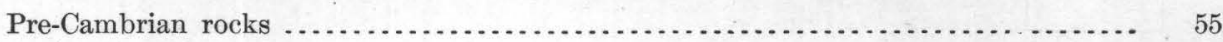

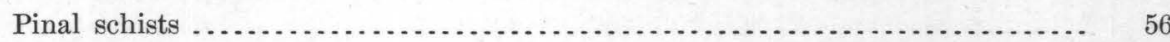

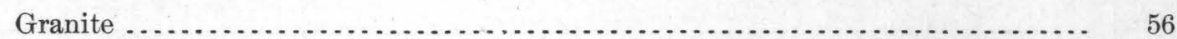

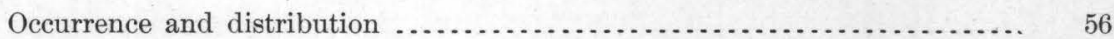

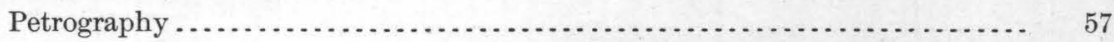

Dikes connected with the intrusion of pre-Cambrian granite $\ldots \ldots \ldots \ldots \ldots . .58$

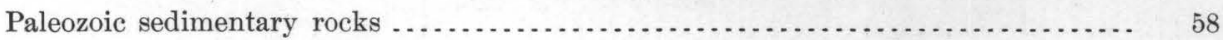

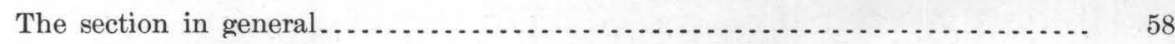

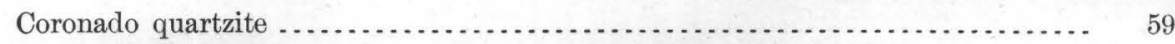

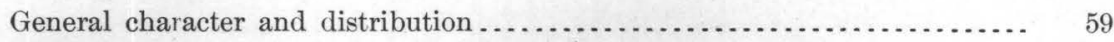

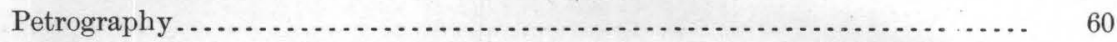

Conditions of deposition ....................................... 61

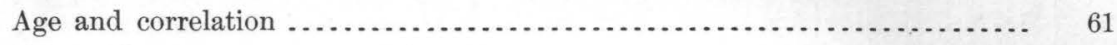

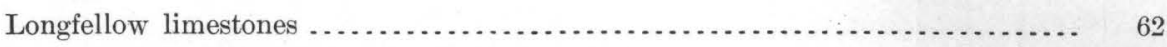

General character and distribution ............................... 62

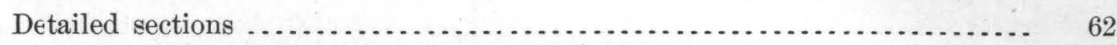

Petrography and analyses....................................... 63

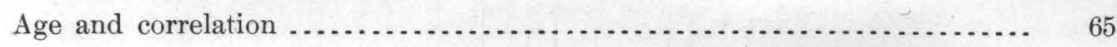

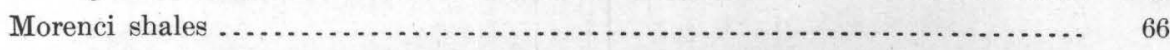

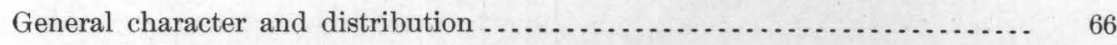

Petrography and analyses...................................... 67

Age and correlation............................................ 68

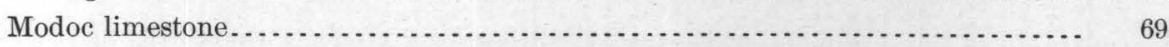

General character and distribution ............................. 69

Detailed descriptions........................................... 70

Petrography and analyses......................................... 70

Age and correlation.............................................. 71

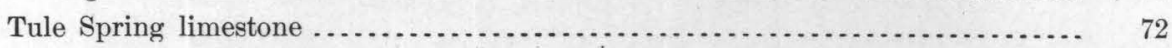

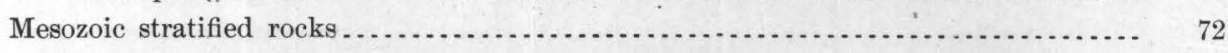

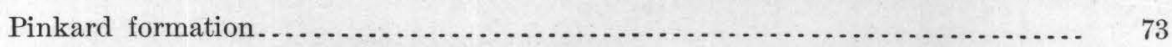

General character and distribution .............................. 73

Age and correlation........................................... 74

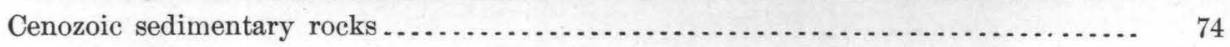

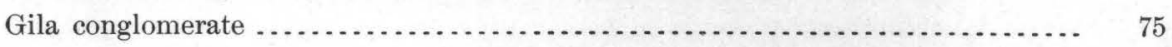

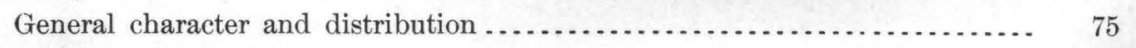

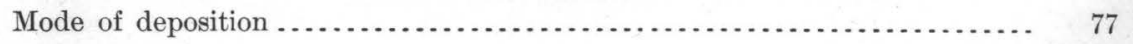

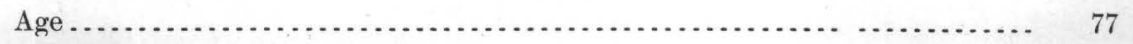

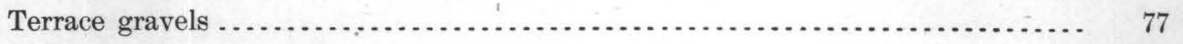

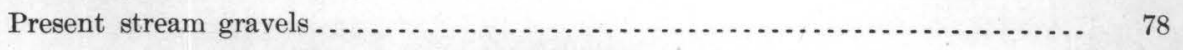

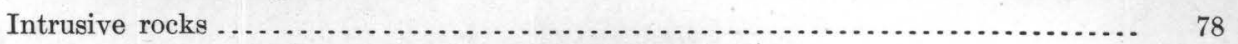

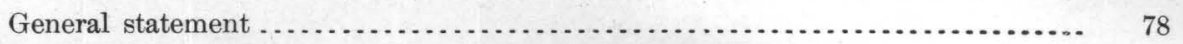

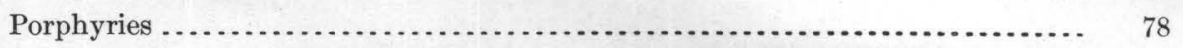

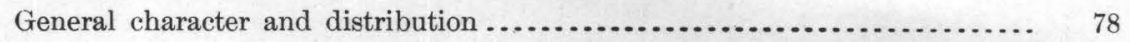


Chapter II. General Geology-Continued.

Rocks-Continued.

Intrusive rocks-Continued.

Porphyries-Continued.

Petrography of the granite-porphyries.

Petrography of the quartz-monzonite-porphyries . . . .

Petrography of diorite-porphyries .............................. 83

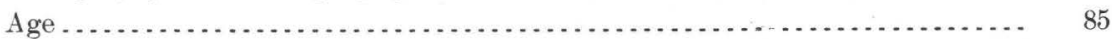

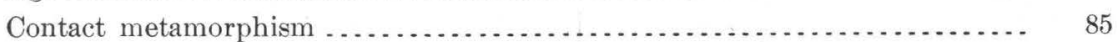

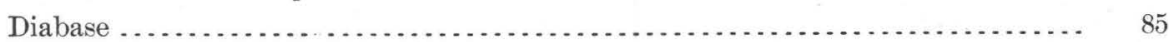

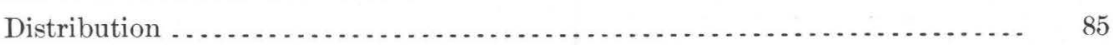

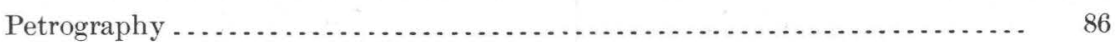

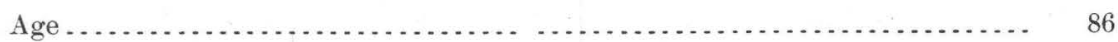

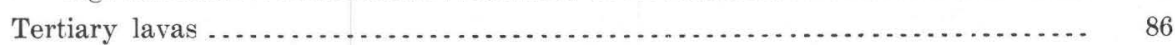

General statement ................................................ 86

Succession. . . . . . . . . . . . . . . .

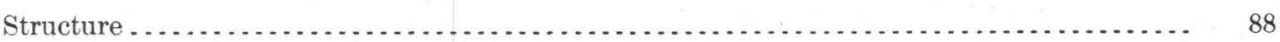

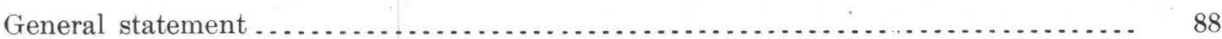

Dislocations due to intrusion.......................................... 88

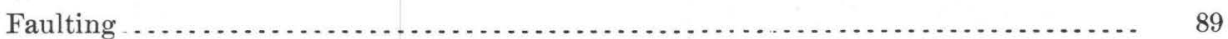

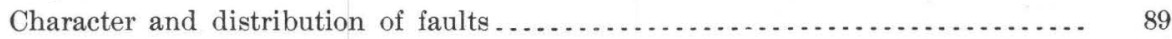

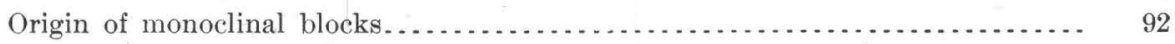

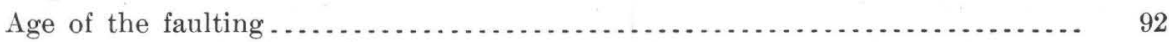

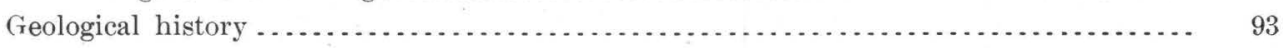

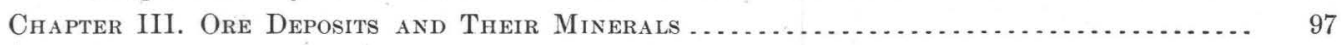

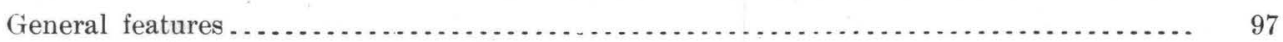

Geographic distribution . . . . . . . . . . . . . . . . . . . .

Minerals . . . . . . . . . . . .

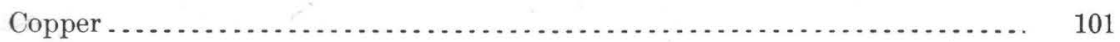

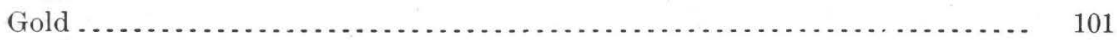

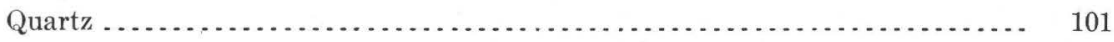

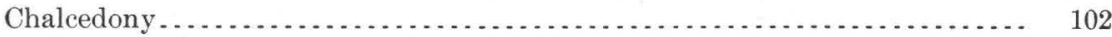

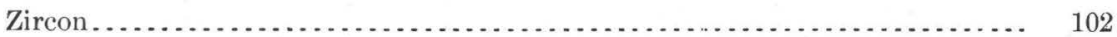

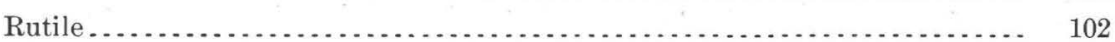

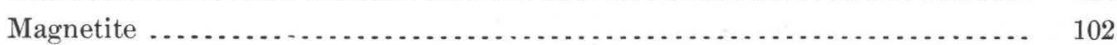

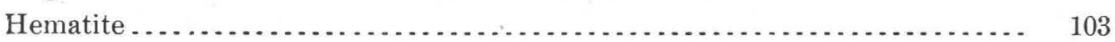

Limonite . . . . . . . . 103

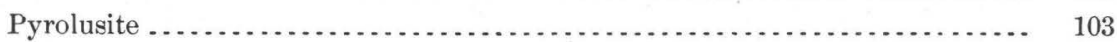

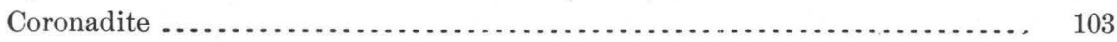

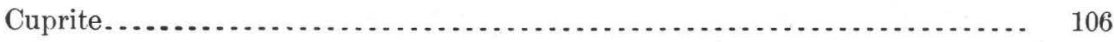

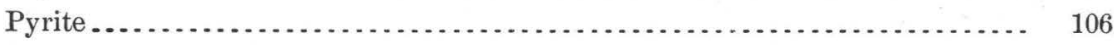

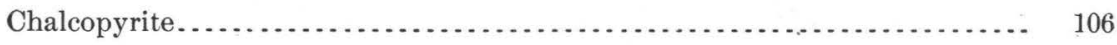

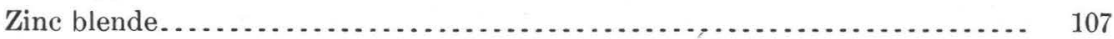

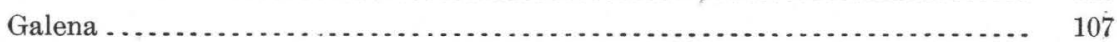

Molybdenite..................................................... 107

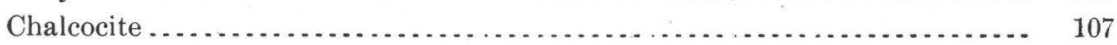

Covellite and bornite.......................................... 108 
Chapter iII. Ore Deposits and Their Minerals-Continued. Page. Minerals-Continued.

Antimonides and arsenides................................... 108

Tellurides and selenides....................................... 108

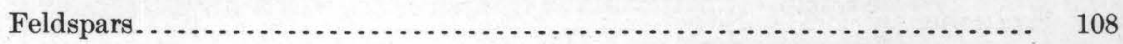

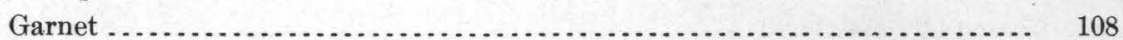

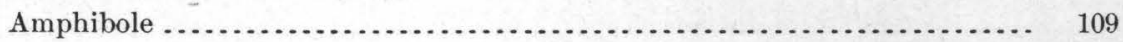

Pyroxene....................................................... 109

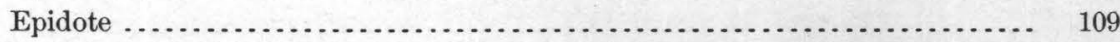

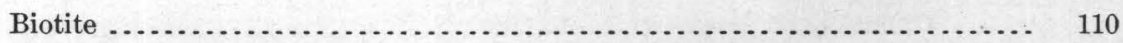

Muscovite .................................................. 110

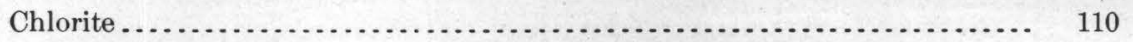

Serpentiue............................................. 110

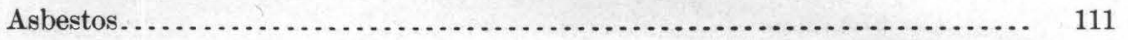

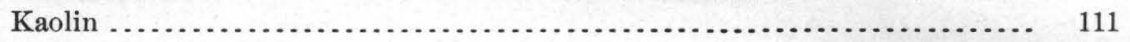

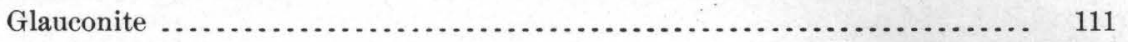

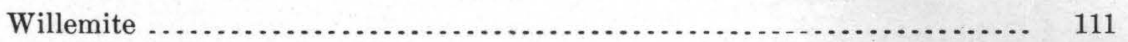

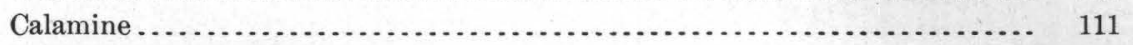

Dioptase....................................................... 111

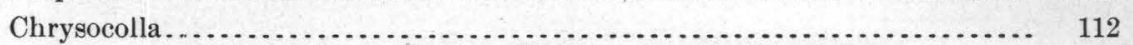

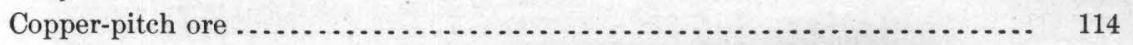

Morencite ...................................................... 115

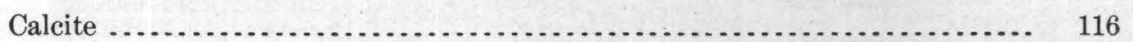

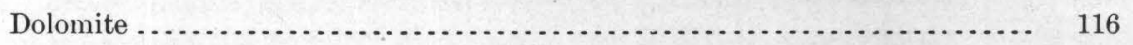

Carbonate of zinc.......................................... 117

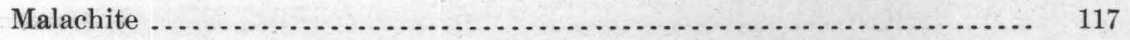

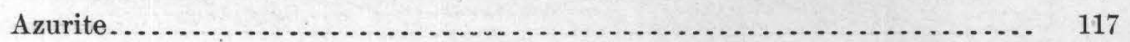

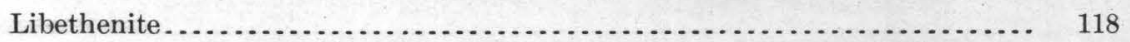

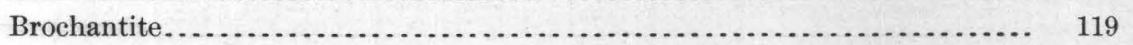

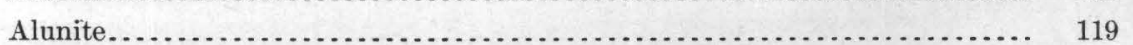

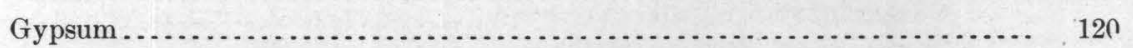

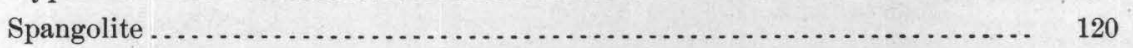

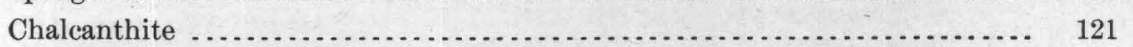

Goslarite and epsomite......................................... 121

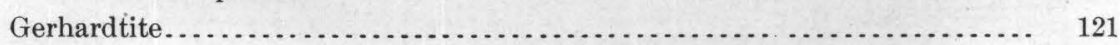

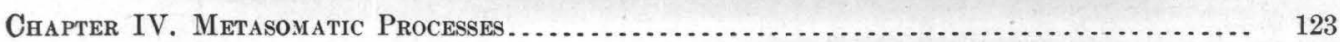

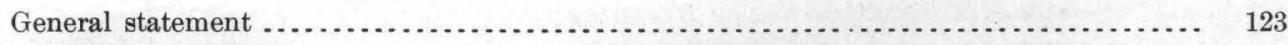

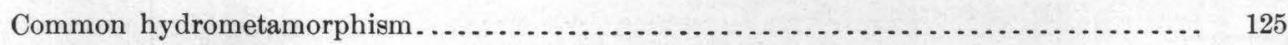

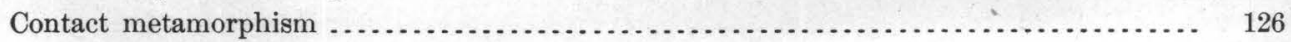

Review of localities and character of metamorphism..................... 126

The Morenci contact zone ........................................... 128

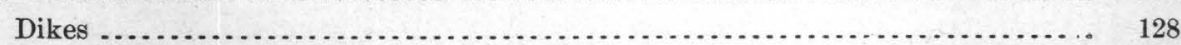

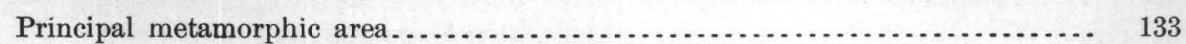

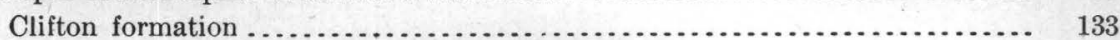

Modoc formation ................................................ 133

Morenci shales . . . . . . . . . . .

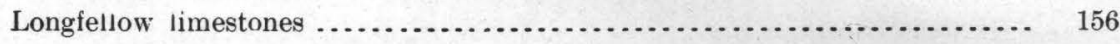


Chapter IV. Metasomatic Processes-Continued.

Page.

Contact metamorphism-Continued.

Contact zone of Shannon Mountain ...................................... 158

Summary and discussion ........................................... 160

Hydrothermal metamorphism........................................... 164

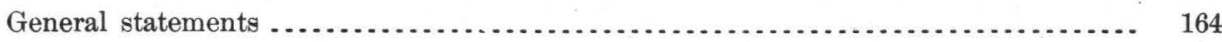

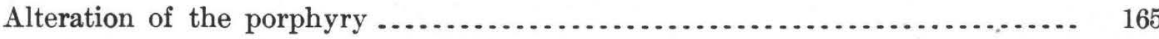

Altered areas.................................................... 165

Character of alteration........................................... 165

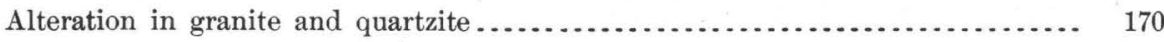

Alteration of limestone and shale .................................... 171

Relation of contact and hydrothermal metamorphism..................... 176

Processes due to oxidation and hydration in the contact-metamorphic zones and in the veins. $\quad 177$

General statement ................................................. 177

Processes in detail .................................................. 177

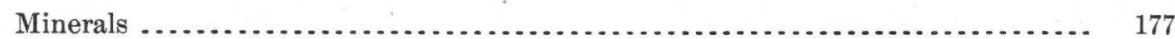

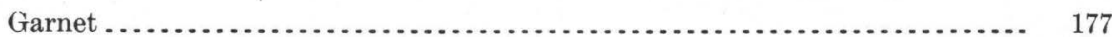

Epidote ......................................................... 178

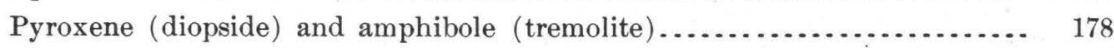

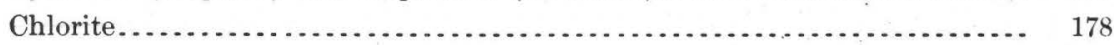

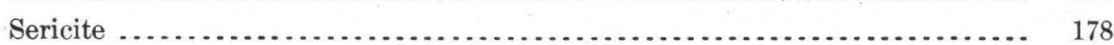

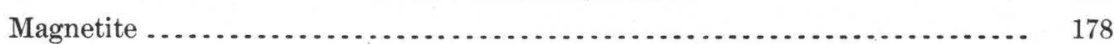

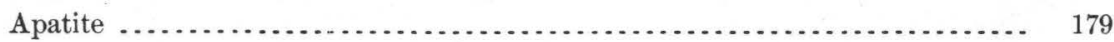

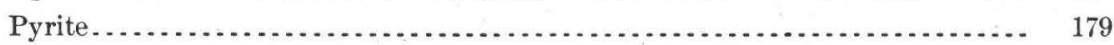

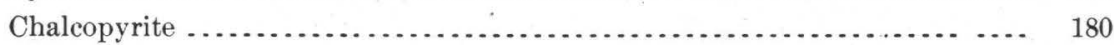

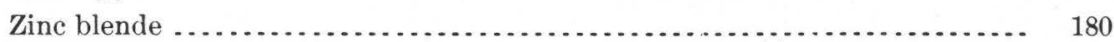

Order of oxidation .................................................. 180

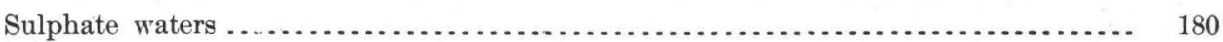

Processes in fissure veins in porphyry and limestone $\ldots \ldots \ldots \ldots \ldots \ldots \ldots \ldots \ldots \ldots \ldots . . .182$

Chalcocitization of the zinc blende ................................ 182

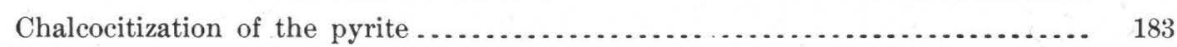

Oxidation of the chalcocite zone.................................. 186

Processes in deposits in limestone. . . . . . . . . . . . . . 189

Oxidizing processes in shale.......................................... 191

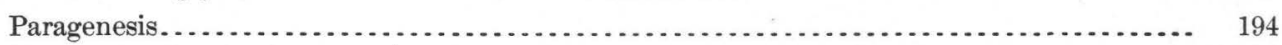

Chapter V. Principal Characteristics of Deposits . . . . .

Deposits of carbonates and oxides in limestone and shale...................... 195

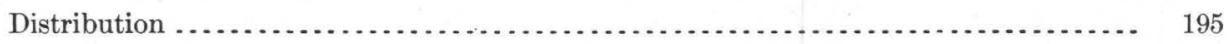

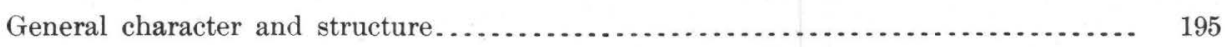

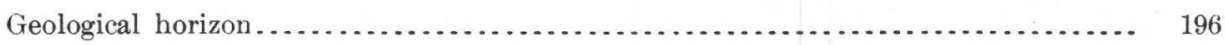

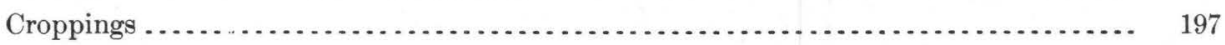

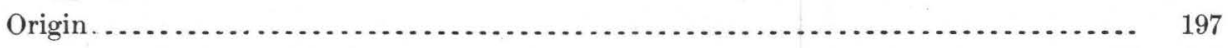

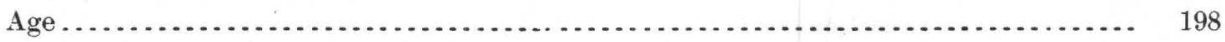

Fissure veins and related deposits......................................... 199

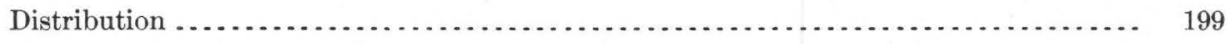

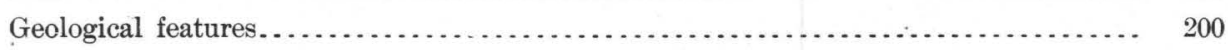


Chapter V. Principal Characteristics of Deposits-Continued. Page,

Fissure veins and related deposits-Continued.

Morenci and Metcalf type ............................................ 200

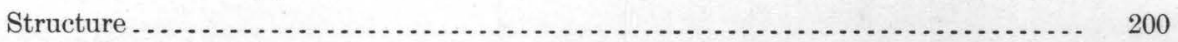

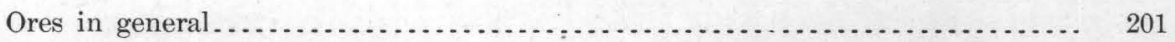

Alteration of the country rock . . .

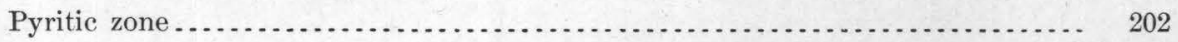

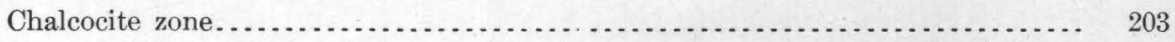

General character and extent ................................... 203

Ore bodies of the chalcocite zone ............................... 204

Relation of chalcocite zone to water level ........................ 206

Relation of the chalcocite zone to present surface .................. 206

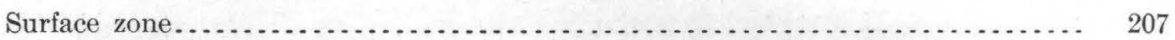

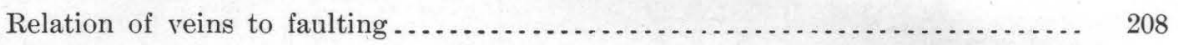

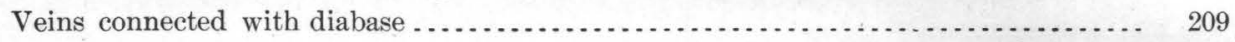

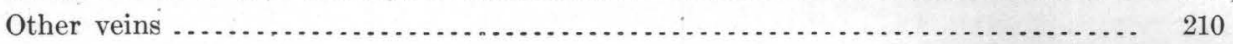

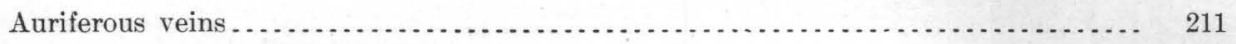

Gold-bearing gravels . . . . . .

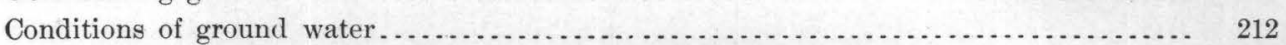

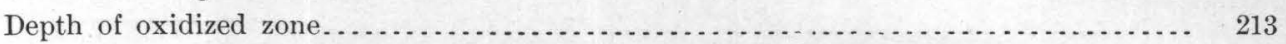

Fluid inclusions . . . . . . . . . .

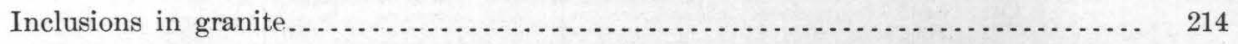

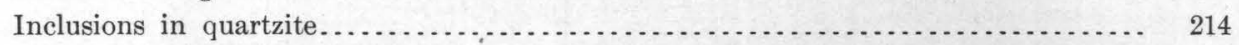

Inclusions in metamorphic limestones ............................... 214

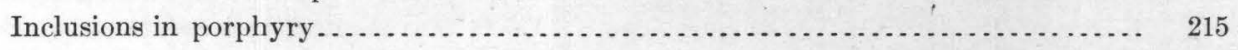

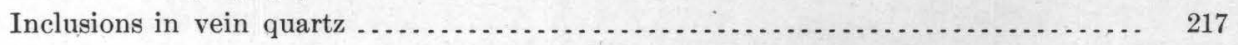

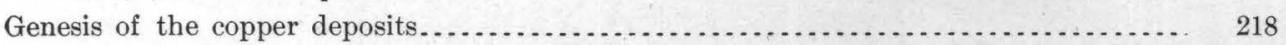

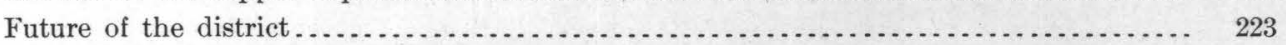

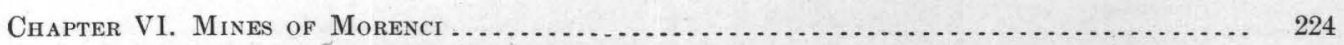

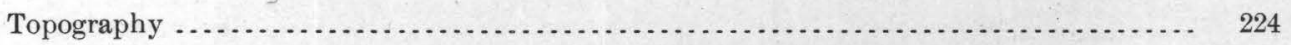

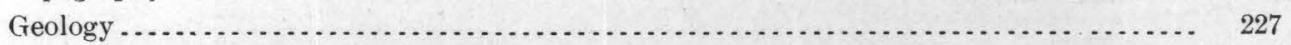

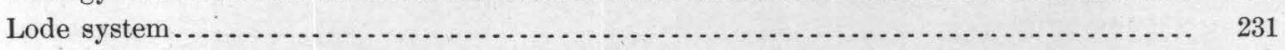

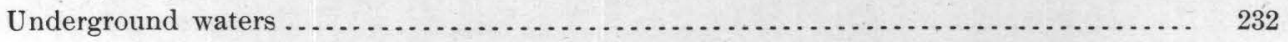

Details of mines.................................................... 233

Longfellow mine..................................................... 233

Production and development.................................. 233

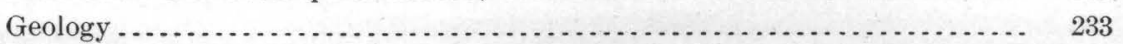

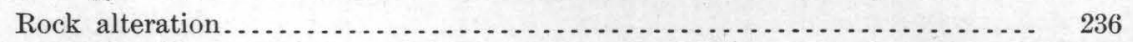

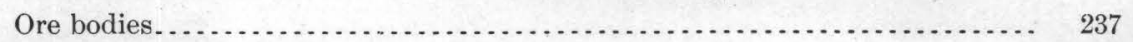

West slope of Modoe Mountain ...................................... 240

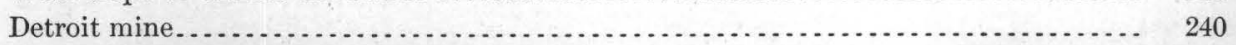

Production and development .................................... 240

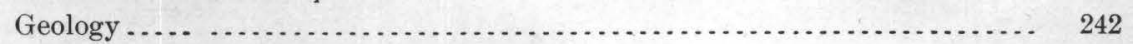

Ore bodies ..................................................... 243

Manganese Blue mine............................................. 245

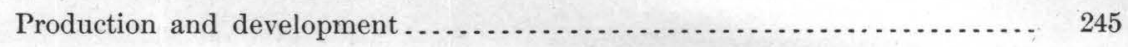

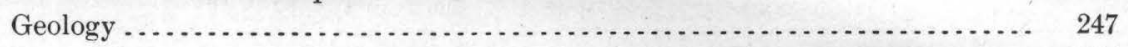

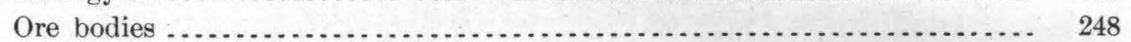


Chapter VI. Mines of Morenci-Continued.

Page.

Details of mines-Continued.

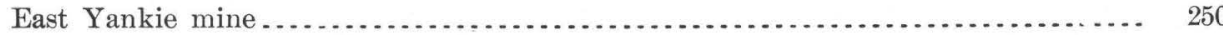

Location and development...................................... 250

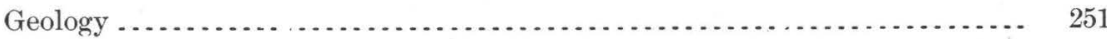

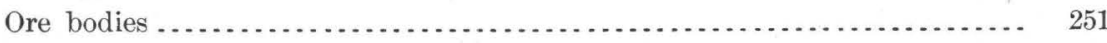

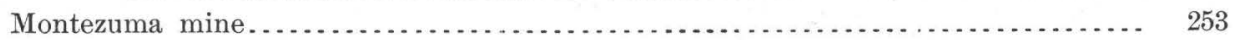

Location, production, and development.......................... 253

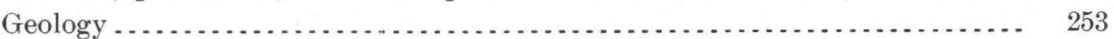

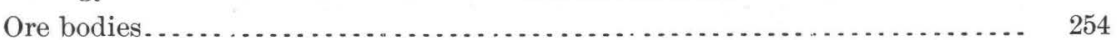

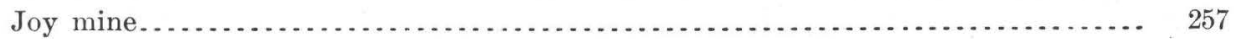

Location, production, and development......................... 257

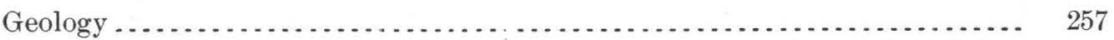

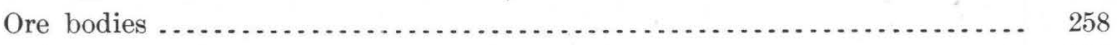

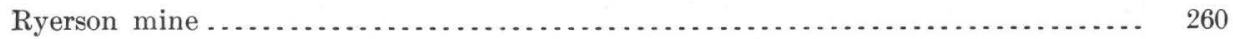

Location and production.................................... 260

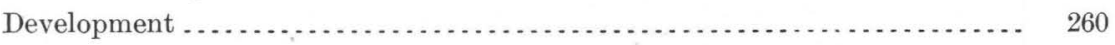

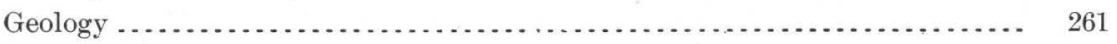

Copper minerals in the rocks................................. 263

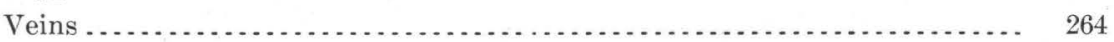

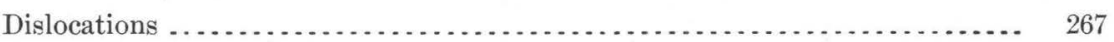

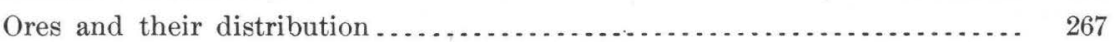

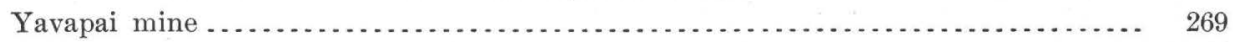

Location, production, and development ......................... 269

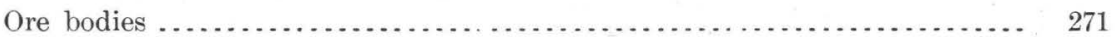

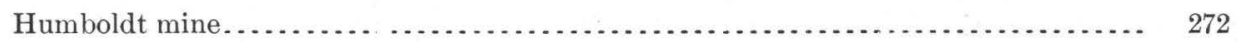

Location, production, and development....................... 272

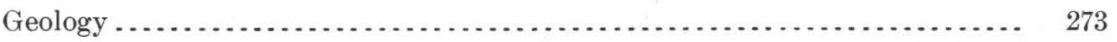

Lodes and their ore bodies .................................... 274

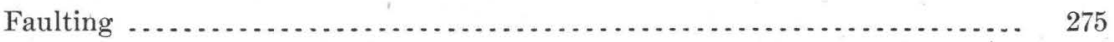

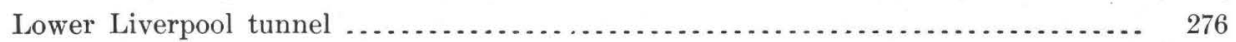

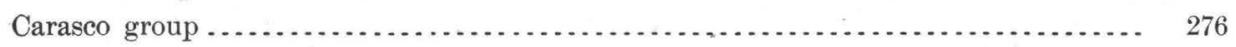

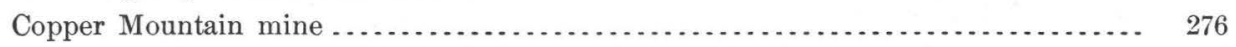

Situation, production, and development ........................... 276

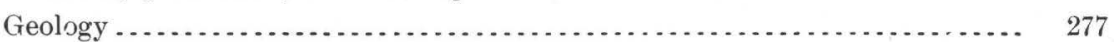

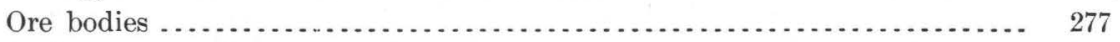

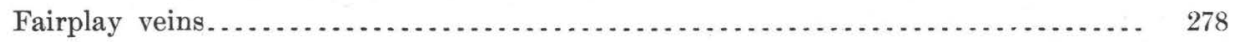

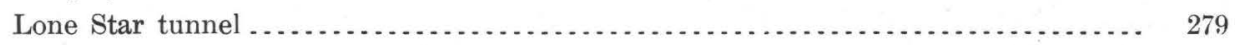

Butler tunnel. . . . . . . . . . .

Arizona Central mine............................................... 281

Location, production, and development ......................... 281

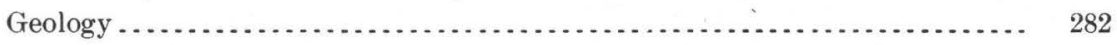

Arizona Central lode ........................................... 285

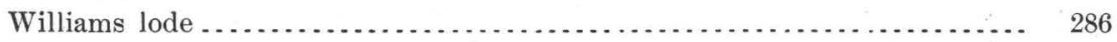

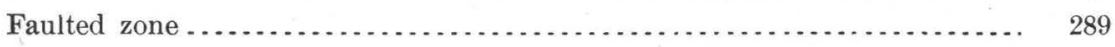

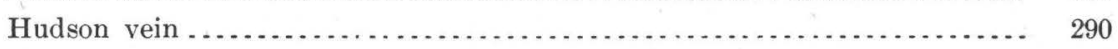

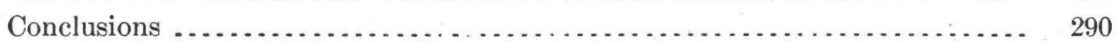


Page.

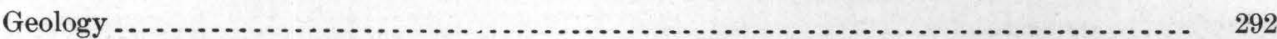

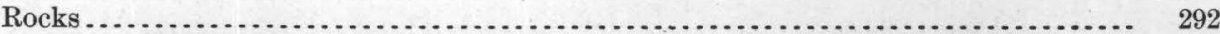

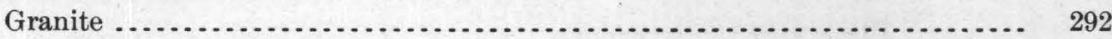

Sedimentary series............................................ 293

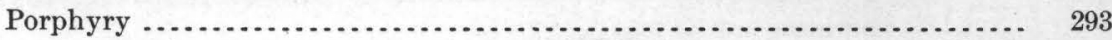

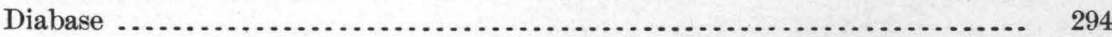

Contact metamorphism............................................ 294

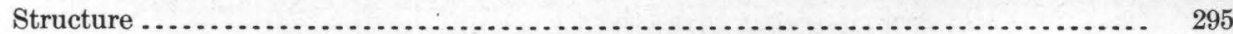

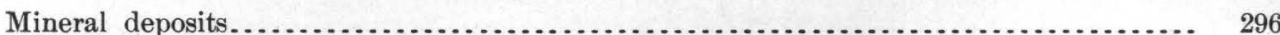

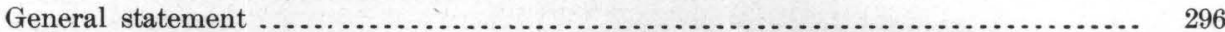

Detailed descriptions................................................ 296

Chapter ViII. Chase Creek Valley between Morenci and Metcalf.................. 299

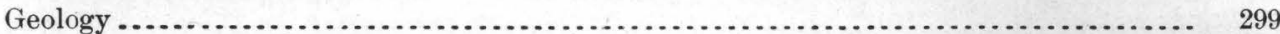

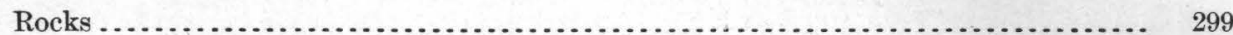

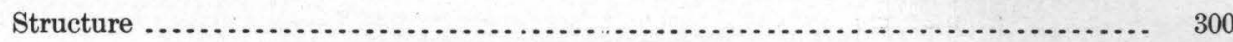

Mineral deposits........................................................ 301

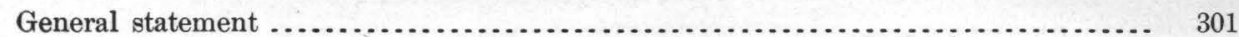

Detailed deseriptions................................................ 301

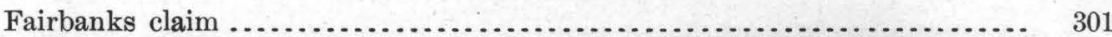

Copper Queen deposits....................................... 302

Mexican claim ............................................... 302

Las Terrazas.................................................. 303

Standard mine................................................... 303

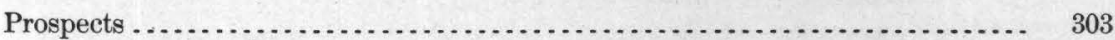

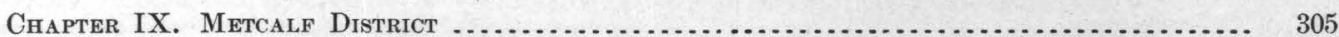

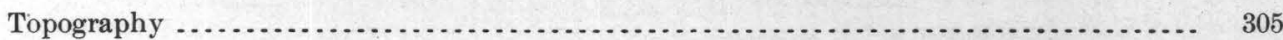

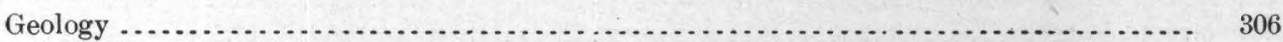

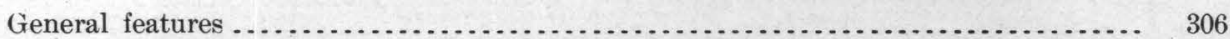

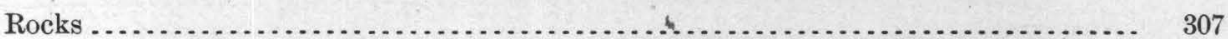

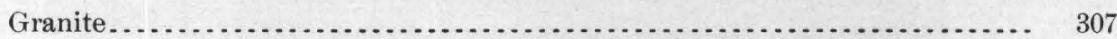

Sedimentary series............................................ 308

Metamorphism of the sediments .............................. 310

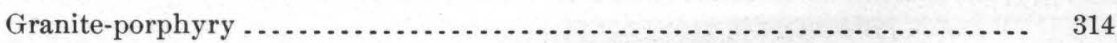

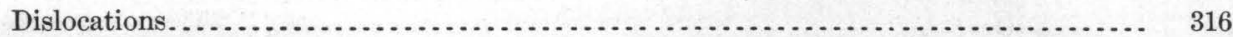

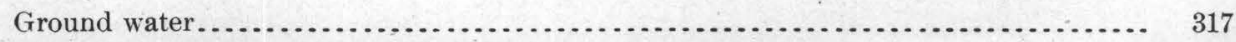

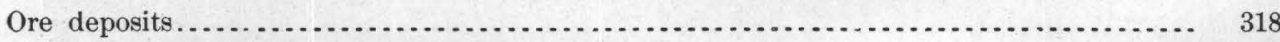

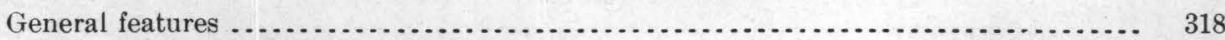

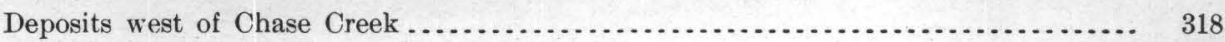

Deposits south of King Gulch....................................... 319

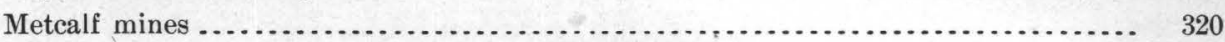

Shannon mine......................................................... 323

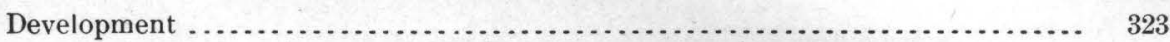

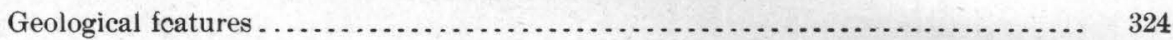


Chapter IX. Metcalf District-Continued.

Ore deposits-Continued.

Shannon mine-Continued.

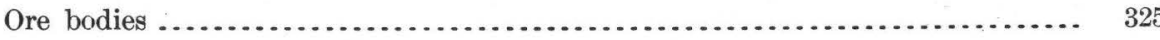

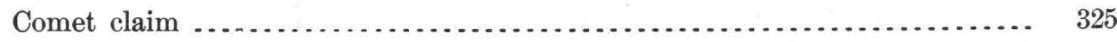

Black Hawk ore bodies..................................... 325

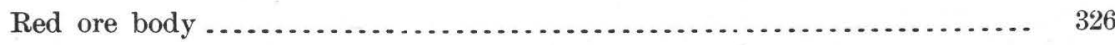

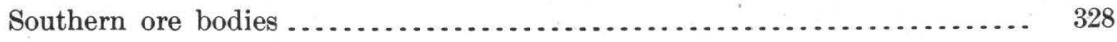

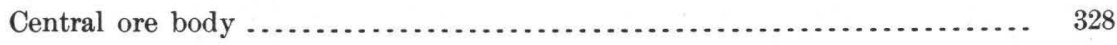

Analyses of ores.......................................... 329

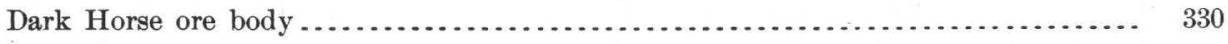

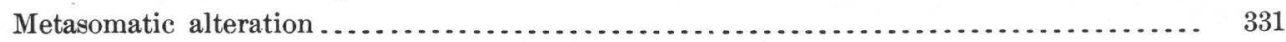

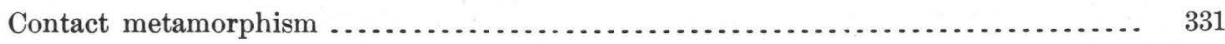

Eruptive after-effects. . . . . . . . . . 332

Oxidation and secondary sulphides................................... 333

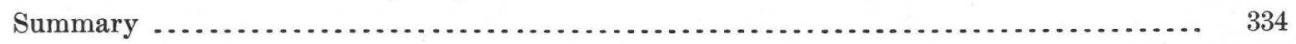

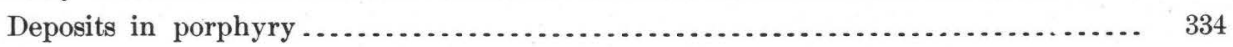

Deposits in limestone and shale ...

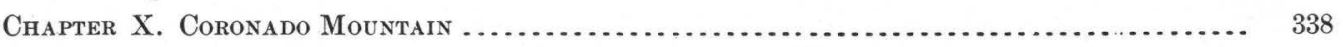

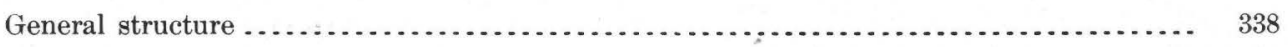

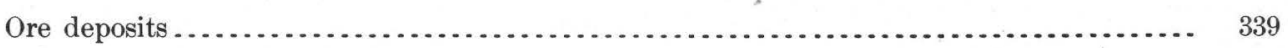

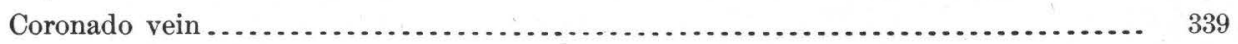

Development ................................................... 340

Country rock .................................................. 340

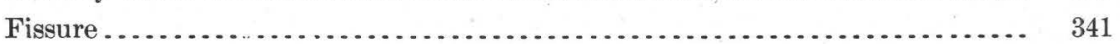

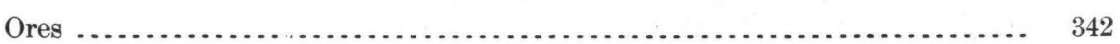

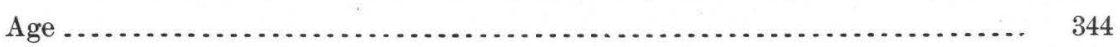

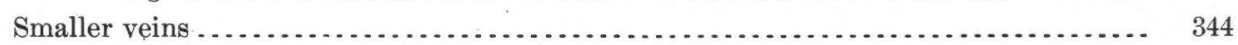

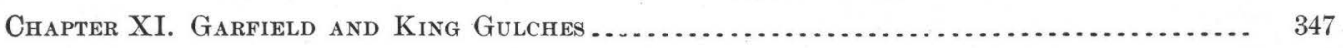

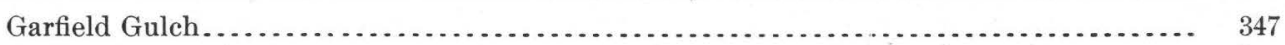

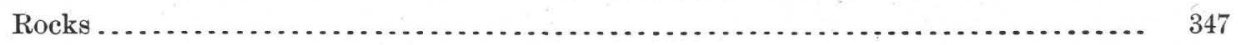

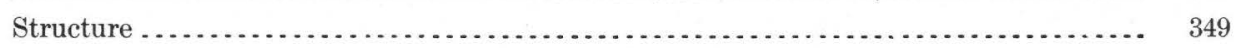

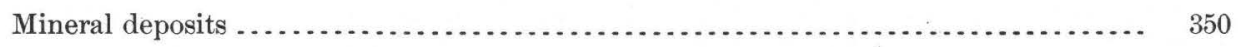

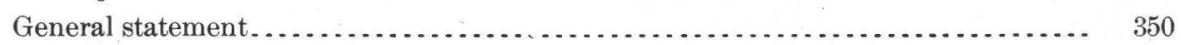

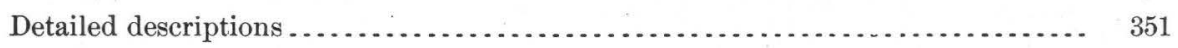

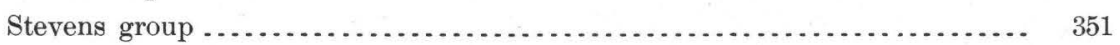

Garfield ........................................................... 352

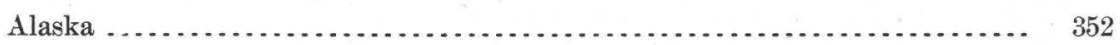

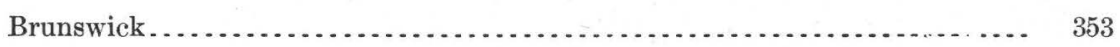

Trinidad . . . .

Virginia ...

Mammoth ......................................................... 353

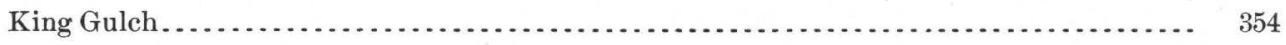

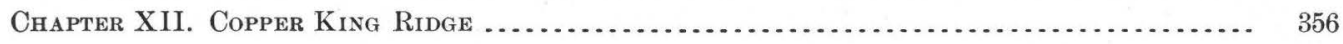

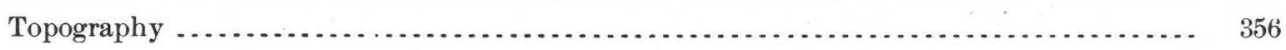

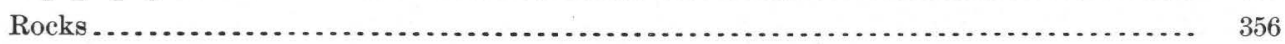


Chapter XII. Copper King Ridge-Continued. Page.

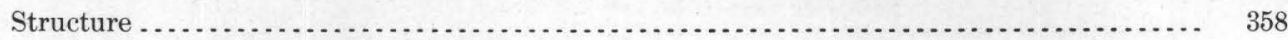

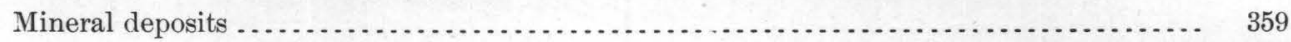

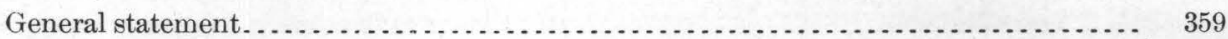

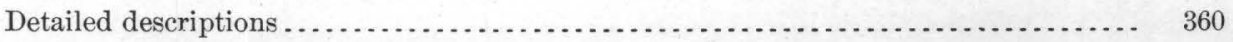

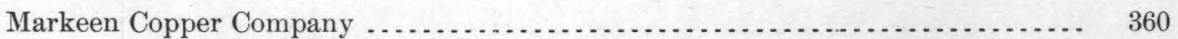

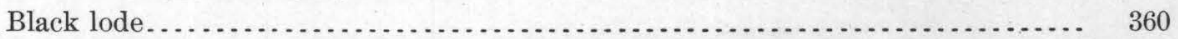

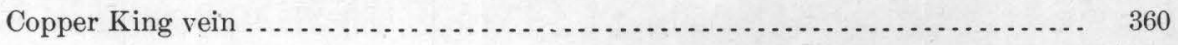

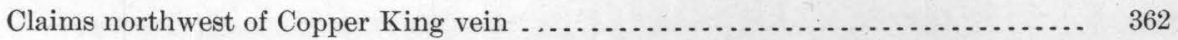

Veins in granite northeast of Copper King Mountain ..................... 363

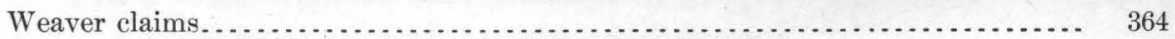

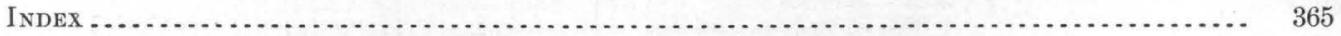




\section{ILLUSTRATIONS.}

Plate I. Geological map and sections of the Clifton-Morenci district . . . . . . . . . . . . . . In pocket.

Page.

II. $A$, San Francisco River 1 mile below Clifton; $B$, Clifton, Ariz., with smelting works of Arizona Copper Company in the foreground.

III. $A$, San Francisco River at Evans Point, 4 miles above Clifton; $B$, Bluffs of Gila conglomerate on San Francisco River 3 miles below Clifton ................ 52

IV. $A$, Foothills between Clifton and Morenci; $B$, Bluffs of rhyolite tuff on Eagle Creek.. $\quad 52$

V. $A$, Mouth of Morenci Canyon; $B$, Chase Creek Canyon ...................... 56

VI. $A$, View up Chase Creek from point on road between Clifton and Morenci; $B$, Cliffs on west side of Morenci Canyon.................................... 60

VII. Photomicrographs of ores and rocks ................................ 136

VIII. $A, B$, Photomicrographs of ores and rocks............................... 138

IX. $A, B$, Photomicrographs of ores and rocks . . . . . . . . . . . . . . . . . . . . . . 140

X. $A, B$, Photomicrographs of ores and rocks .............................. 142

XI. $A, B$, Photomicrographs of ores and rocks ............................. 144

XII. $A, B, C$, Photomicrographs of ores and rocks . . . .

XIII. $A, B$, Photomicrographs of ores and rocks ............................ 148

XIV. $A, B$, Photomicrographs of ores and rocks ........................... 150

XV. $A, B$, Photomicrographs of ores and rocks . . . . . . . . . . . . . . . . . . . . 152

XVI. $A, B$, Panoramic views of Morenci ...................................... 224

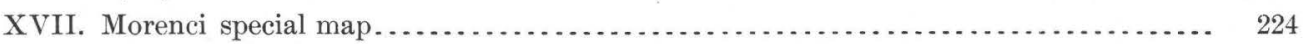

XVIII. Vein system and part of underground workings at Morenci . . . . . . . . . . . .... 232

XIX. Geological and topographical map of vicinity of Metcalf . . . . . . . . . . . . . 306

XX. $A$, View up toward Metcalf mines from Metcalf; $B$, View up toward Shannon

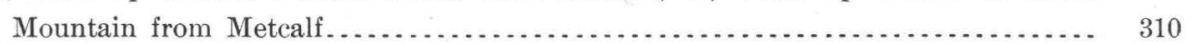

XXI. A, King Gulch, near Metcalf; $B$, Open cut on first level of Metcalf mines....... 316

XXII. View down from Shannon Mountain over Metcalf and lower Chase Creek Canyon. 320

XXIII. A, Shannon mine; $B$, View up Shannon incline from bottom of Chase Creek.... 324

XXIV. Map of part of underground workings of Shannon mine . . . . . . . . . . . . . . . ... 324

XXV. Vertical section across Shannon Mountain and Shannon Mine ................ 326

FIG. 1. Index map, showing position of Clifton quadrangle........................ 28

2. Paleozoic column at Morenci........................................... 59

3. Geological section along line A B on Morenci special map ................... 228

4. Geological section along line C D on Morenci special map . . . . . . . . . . . . . . . . 228

5. Vertical section of Longfellow mine....................................... 234 
7. Vertical section across Manganese Blue and Detroit mines..................... 241

8. Vertical cross section of Fairplay, Copper Mountain, and Manganese Blue mines... 246

9. Vertical section through East Yankie mine............................ 250

10. Diagrammatic vertical cross section of Montezuma vein...................... 253

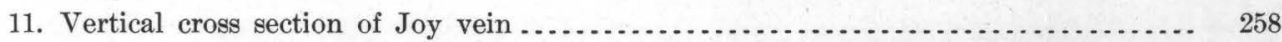

12. Plan showing workings, veins, and probable outlines of bodies of altered sedimentary rocks on the third level of the Ryerson mine....................... 260

13. Vertical section through Ryerson shaft ................................ 263

14. Vertical section along Ryerson lower adit .............................. 264

15. Vertical section across Yavapai and Ryerson mines........................ 265

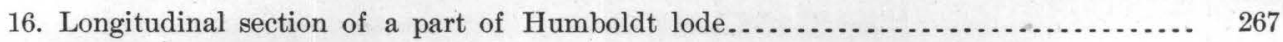

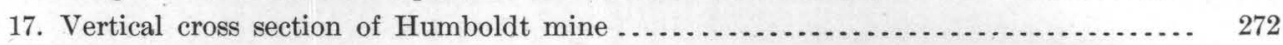

18. Vertical section following Williams vein and showing relations of ore bodies to

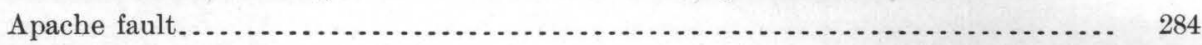

19: Diagrammatic vertical cross section of Coronado lode....................... 341 


\title{
LETTER OF TRANSMITTAL.
}

\author{
Departuent of The Interior, \\ United States Geological Survex, \\ Washington, D. C., September 13, 1904.
}

SIR: I transmit herewith a report on the "Copper deposits of the CliftonMorenci district, Arizona," by Waldemar Lindgren, and recommend its publication as a professional paper. This report contains much interesting and valuable information concerning one of the largest copper districts of the United States, and is a most important contribution to economic geology.

Very respectfully,

Hon. Charles D. Walcott,

C. W. Hayes,

Geologist in Charge of Geology.

Director United States Geological Survey. 



\section{OUTLINE OF PRINCIPAL RESULTS.}

GENERAL GEOLOGY.

The oldest rocks of the Clifton quadrangle are pre-Cambrian granite and quartzitic schists, separated by an important unconformity from the covering Paleozoic strata. The latter comprise a total thickness of 1,500 feet. At the base lie 200 feet of probably Cambrian quartzitic sandstone, succeeded by 200 to 400 feet of Ordovician limestones. About 100 feet of Devonian (?) shale and argillaceous limestones cover the Ordovician beds, while the uppermost part of the Paleozoic sediments consists of heavy-bedded pure limestones of lower Carboniferous (Mississippian) age with a thickness of 180 feet.

The Paleozoic strata, over limited areas, are overlain by Cretaceous shales and sandstones which have a thickness of several hundred feet and which are, at least in part, equivalent to the Benton formation. A second unconformity, less pronounced than the first, exists between the Paleozoic and the Cretaceous.

Masses of granitic and dioritic porphyries were intruded in the older rocks after the deposition of the Cretaceous series, and form stocks, dikes, laccoliths, and sheets.

All of the above-mentioned rocks have participated in an uplift and a warping or doming succeeded by faulting. The effects of vigorous faulting are especially striking. These movements took place during latest Cretaceous or earliest Tertiary time.

Enormous masses of lavas-basalt and rhyolite, with some andesite-covered all the above-described rocks during the Tertiary age, and now form a broad frame inclosing the comparatively little exposed older rocks in the center. Tertiary sediments are not known in this quadrangle.

Erosion has sculptured the rock masses of the quadrangle since early Tertiary time, and at many places has laid bare the older rocks by removal of the covering lavas. A part of the removed detritus - that carried away by the streams during Quaternary time-still lies spread out at the foot of the mountains as coarse and roughly bedded deposits - the Gila conglomerate. A change of level during later $16859-$ No. $43-05-2$ 
Quaternary time increased the erosive power of the streams and forced them to cut through the Gila conglomerate in box-like canyons a few hundred feet in depth, in which the waters now flow over sandy beds along well-graded river courses.

\section{THE COPPER DEPOSITS.}

The Clifton quadrangle contains many copper deposits. Copper is in fact the only metal produced in large amounts, and the deposits of copper ores at Morenci and Metcalf are among the most important in Arizona.

Production and development.-The ore deposits were discovered in 1872 , but for many years their development was slow because only rich ores could be utilized, the district being far distant from established lines of communication. Since 1890, however, the progress has been rapid. At the present time, large bodies of low-grade ore being utilized, the production has reached high figures. Two strong companies, the Detroit Copper Company and the Arizona Copper Company, have contributed by far the greatest part of the production since 1882. Since 1902 a third, the Shannon Copper Company, has been added. The mines of the Detroit company are located at Morenci, those of the Arizona company at Morenci and Metcalf, and those of the Shannon company at Metcalf.

In 1902 the total production rose to 49,500,000 pounds of copper; in 1903 it had attained $53,400,000$ pounds, with a value of about $\$ 7,400,000$. Of the production in 1903 the Arizona company contributed 30,228,000 pounds, the Detroit company $16,558,232$ pounds, and the Shannon company $6,600,000$ pounds. The ores mined average 3 or 4 per cent of copper. The monthly output of ore in 1902 was about 60,000 short tons. Of this, 47,000 tons were classed as concentrating ore and 12,000 tons as higher grade smelting ore, with 6 to 10 per cent copper. The Arizona company smelted the lowest grade of ore, while the Detroit company averaged somewhat higher. The ores of the Shannon company were in 1902 exclusively oxidized ores, containing about 8 per cent copper. Since then this company has also begun the mining of concentrating ore. By far the larger percentage of ore consisted of sulphide ore, containing pyrite and chalcocite. Of oxidized ores about 13,000 tons per month were mined at Metcalf, and a steadily diminishing amount from 1,500 tons per month at Morenci, making a total of 14,500 tons, or about one-fourth the total production. The output of oxidized ore at Metcalf will continue for a number of years and possibly increase. The oxidized ore mined by the Arizona Copper Company at Metcalf is the lowest grade utilized in the district, and probably contains on an average less than 3 per cent.

The total output of the district to the end of 1903 is estimated to be about 201,600 short tons of copper, having a value of approximately $\$ 60,500,000$.

Clifton is second in importance in Arizona as a copper-producing camp. 
In 1903 Bisbee produced 62,500,000, Clifton 53,400,000, and United Verde district 28,600 pounds of copper. The production of Arizona is at present a little more than one-fifth of the total production of the United States.

The Morenci and Metealf districts are not distinguished by the great depth attained in mining. At Metcalf all of the deposits are worked by open cuts or tunnels, as they occur near the surface of Shannon Mountain. At Morenci, where the more important deposits underlie Copper Mountain, two of the largest mines, the Copper Mountain and the Humboldt, are still worked by tunnels, though the latter has a shaft also; others, like the Arizona Central and the Ryerson, are opened by shafts less than 400 feet in depth. The celebrated Longfellow deposit was mined from four tunnel levels, the Manganese Blue by a shaft 400 feet deep, and the Detroit by a shaft about 300 feet deep.

Contact-metamorphic deposits.-There is no evidence of ore deposits having been formed in this region before the intrusion of porphyry. This event appears to be in most intimate connection with the origin of all the copper deposits in the region. Wherever the porphyry came into contact with the granite or the quartzite, little alteration is observed; but wherever we find the porphyry adjoining the limestones or the shales of the Paleozoic series very extensive contact metamorphism is noted, resulting in the formation of large masses of garnet and epidote. This alteration is particularly observable at Morenci. The whole Paleozoic series is affected, but more particularly the pure limestone of the lower Carboniferous, which, for a distance of several hundred feet from the contact, has been converted into an almost solid mass of garnet. The shales have suffered less from this metamorphism, but near the porphyry are apt to contain epidote and other minerals. This metamorphism appears not only at the contact of the main mass of porphyry forming the southern slope of Copper Mountain, but also in the hills between Morenci and the Longfellow mine, in which dikes have produced contact-metamorphic minerals along their sides. Wherever alteration has not masked the phenomena, magnetite, pyrite, chalcopyrite, and zinc blende accompany in various proportions the contact-metamorphic minerals, and are intergrown with them in such a way that the contact-metamorphic origin of these ores appears beyond doubt. In many places the ores have accumulated along certain horizons in the sedimentary series, evidently more suitable than others to the processes of alteration which produced the deposits. The origin of these contact-metamorphic deposits is conceived to be in the water and metallic substances which were originally contained in the magma of the porphyry, and which were released by decreasing pressure at the time of the intrusion of the rock into higher levels of the earth's crust. We may thus speak of these deposits as contemporaneous with the cooling and solidification of the porphyry. 
As to form, the ore deposits in limestone are often irregular, but more frequently, perhaps, assume a tabular shape, due to the accumulation of the minerals along certain planes of stratification or along the walls of dikes.

Oxidizing waters have very greatly altered the deposits in limestone. The sulphides have been converted into carbonates, and malachite and azurite are the most common ores. Cuprite also occurs extensively, and seems to form by preference in the shale forming part of the Devonian system. Chalcocite and other sulphides are almost entirely absent. The zine blende has been carried away as sulphate of zinc, which is frequently found in efflorescence on the walls of the tunnels. The magnetite and the garnet which originally formed a part of these deposits have also undergone decomposition, the resulting minerals being silica and limonite.

The celebrated Longfellow mine is worked on one of these deposits occurring as, roughly speaking, a funnel-shaped mass in the Ordovician limestone, between two large porphyry dikes. Farther west, along the main porphyry contact, the Montezuma is encountered, and farther on the Detroit and the Manganese Blue mines. Both of the latter mines were worked on several tabular ore bodies, three or more in number, occurring in horizons varying from Silurian to the lower Carboniferous. All of these deposits are now largely exhausted. They contained a large quantity of very rich carbonate and oxide ore. The extent of these ore bodies was, however, much smaller than the large masses of chalcocite ore which now form the. main support of the camp.

At Metcalf the Shannon mine contains several ore bodies of similar origin. A fragment of the Paleozoic series outcrops on Shannon Mountain, and is cut by an extensive system of porphyry dikes, which in the lower part of the mountain join the main part of a large intrusive body of porphyry. In several horizons the limestones are greatly altered, the final product generally being copper carbonates and limonite, with some quartz. In some places the ore bodies are less affected by oxidation, and their original character of garnet, epidote, magnetite, and sulphides may be plainly seen.

Oxidation by surface waters, as at the Shannon mine, also diffused much copper as chalcocite in some of the porphyry dikes, and the deposit in the Metcalf mine, or a lower spur of the same hill, consists chiefly of a body of extremely decomposed porphyry containing chalcocite and carbonates. Very probably this copper has migrated into the decomposing porphyry from bodies of contact-metamorphic rock at higher elevation, parts of which are probably now eroded.

Fissure veins. - At many places in the district the copper deposits consist of fissure veins, cutting alike porphyry, granite, and sedimentary rocks. From the avalable evidence it would seem that these veins had been formed a short 
time after the consolidation of porphyry. In lower levels the veins consist of pyrite, chalcopyrite, and zinc blende-magnetite being conspicuously absent. At the surface many of the veins have been completely leached, and now show nothing but limonite and silicified porphyry. This rule is, however, not a general one, as, especially in porphyry, oxidized ores are sometimes found in the outcrops of the deposits. Between the leached croppings and the deep ores of pyrite and chalcopyrite is a more or less extensive zone of chalcocite or copper glance, deposited by secondary processes on the pyrite.

The most important vein system is that which, under the general name of the Humboldt vein, extends from northeast to southwest through Copper Mountain at Morenci. The outcrops of this vein are practically barren, but at the depth of about 200 feet the deposit becomes productive and contains chalcocite, associated with pyrite. There are usually one or more central seams of massive chalcocite, some of which are fairly persistent. These seams are ordinarily adjoined by decomposed porphyry, now chiefly consisting of sericite and quartz, together with pyrite and chalcocite. These extensive impregnations of the country rock are rarely confined by distinct walls, but gradually fade into the surrounding porphyry. That these deposits are genetically connected with fissure veins, however, can not be doubted. In lower levels the ore is apt to change to pyrite and chalcopyrite. Both the Arizona Copper Company and the Detroit Copper Company are now working the low-grade bodies of chalcocite ore accompanying the veins. The reserves thus far opened assure a high production for many years to come.

Parallel veins, somewhat narrower, but similar in character, are those opened by the Arizona Central mine, also at Morenci. These veins are partly in porphyry, partly in contact-metamorphosed limestone. While malachite and azurite sometimes occur, they are by no means' as prominent as in the limestone deposits, and frequently the leached surface zone is immediately adjoined by the chalcocite ore.

The Coronado mine represents a different type of deposits. It is formed on a fault fissure between granite and quartzite, indicating a throw of at least 1,000 feet. The fissure is followed in places by a diabase dike, showing some effect of crushing and movement on the vein. The croppings contain copper carbonates and silicate, but these minerals change at slight depth to chalcocite, and still farther down it is believed that the ore bodies consist chiefly of pyrite and chalcopyrite.

Somewhat different again are the fissure veins on Markeen and Copper King mountains. The granite of this complex of hills is cut by a great number of porphyry dikes which generally have a northeasterly direction. Along many of these dikes movement and fissuring has taken place, and varying amounts of copper 
ores have been encountered. The veins contain comparatively little gangue, the copper minerals being chiefly distributed through the altered porphyry or through the granite adjoining the dike. At the surface a small amount of carbonates may be found, but they change at slight depth, sometimes only a few feet from the surface, into an ore composed of chalcocite and pyrite, which still farther down appear to change into pyrite and chalcopyrite. The most prominent deposit on this system of veins is the Copper King mine, which is situated only a few hundred feet below the summit of the mountain of the same name.

The main mass of porphyry between Morenci and Metcalf shows evidence of very strong mineralization throughout. A great number of fissure veins have been encountered in it, although most of them are neither persistent nor strong. Close to the surface the ores are apt to spread through a considerable mass of rock, and in some cases important bodies of chalcocite, due to secondary deposition on pyrite from solutions containing copper, have resulted. The granite adjoining this porphyry is sometimes also thoroughly altered and impregnated with pyrite and chalcopyrite. This may be seen in the narrow canyons of Chase Creek for a mile above Longfellow incline. While a number of more or less well-defined veins have been opened here, the results have not been encouraging.

Several smaller deposits of oxidized copper ores are found near Garfield Gulch and along Placer Creek.

Conditions of ground water.-Permanent water has not thus far been encountered in any of the mines in the whole district with which this report deals. Morenci is situated on the hills from 800 to 1,500 feet above the principal streams, Chase Creek and Eagle Creek, and the deepest workings in no place reach farther than 600 feet below the surface. The mines at Metcalf are situated on Shannon Mountain, from 500 to 1,200 feet above Chase Creek, and here, too, the workings are dry, except in one place, where a winze struck some standing water. The few shafts and prospects sunk in the bottom of Chase Creek are the only places containing permanent water.

The present stand of the water level, except along the creeks, is practically unknown. It probably rises as a slightly curved surface from the creek levels in toward the high hills. The total amount of water stored below this water level is probably small.

Depth of oxidized zone. - The presence of products of direct or indirect oxidation shows the depth to which the oxidizing waters or the sulphate solutions have penetrated; but this depth differs considerably in the porphyry and in the metamorphosed limestones. In that part of Copper Mountain which has been explored, the average depth below the surface of the lower limit of the chalcocite zone is from 400 to 600 feet. To this depth from the surface the sulphate solutions 
descended, and along important fissures they may have gone somewhat farther. The solutions not only followed fissures, but penetrated the porous, sericitized porphyry with considerable ease. On the other hand, the altered limestones and shales are very compact, nonporous, and impervious. Where circulation was facilitated by fissures, the rocks may be partly oxidized to a depth of 400 feet, but this is generally a maximum. There is no well-defined plane expressing the depth of oxidation. On the contrary, oxidation proceeds capriciously, entirely fresh sulphides being frequently found very close to the surface.

Summary of ore genesis. - It has been shown that the intrusions of stocks and dikes of granite-porphyry and quartz-monzonite-porphyry, which took place in late Cretaceous or early Tertiary time, produced an important contact metamorphism in shales and limestones of Paleozoic age which happened to adjoin them. This metamorphism resulted in metasomatic development of garnet, epidote, diopside, and other silicates, accompanied by pyrite, magnetite, chalcopyrite, and zinc blende. The sulphides are not later introductions, but contemporaneous with the other contact minerals.

The contact zone has received very substantial additions of oxides of iron, silica, sulphur, copper, and zinc, enough to form good-sized deposits of pure magnetite and low-grade deposits of chalcopyrite and zinc blende, all of which are entirely unknown in the sedimentary series away from the porphyry.

In view of the evidence, it appears impossible that circulating atmospheric waters have effected these changes. The occurrences of metamorphosed rocks are manifold and found under many varying conditions; there is only one common factor, and that is the presence of the porphyry. It is shown that the porphyry magma contained much water which held in solution various salts; among these were salts of some of the heavy metals. Sodic chloride and ferric oxide probably predominated. It is believed that the magma contained all of the substances mentioned above, and that large quantities of this gaseous solution (for the critical temperature must have been exceeded) dissolved in the magma were suddenly released by diminution of pressure as the magma reached higher levels and forced through the adjoining sedimentary beds, the purest and coarsely granular limestones suffering the most far-reaching alteration and receiving the greatest additions of substance. It is thus held that a direct transfer of material from cooling magma to adjacent sediments took place. The formation of garnet indicates large gains of ferric oxide and silica.

It is shown that fissures and extensive shattering developed both in porphyry and altered sediments after the congealing of the magma, and that these fissures and seams were cemented by quartz, pyrite, chalcopyrite, and zine blende, forming normal veins of the type of replacement veins. The amount of copper contained 
in these is usually very small. The bulk of the veins consists of pyrite. Two classes of veins may be distinguished. The usual type is practically always connected with granite-porphyry or quartz-monzonite-porphyry recurring in this rock or along dikes of the same. The smaller division consists of those connected in their occurrence with diabase dikes. The genesis of the former type will first be discussed.

As far as the metallic minerals are concerned there is a striking similarity between the veins connected with porphyry and the contact-metamorphic deposits. A relationship is also clearly seen in the remarkable action of the vein solutions on the adjoining wall rock wherever this is limestone-tremolite and diopside being formed in it by replacement. On the whole, iron and silica are the main substances added during contact metamorphism as well as during the vein formation.

A study of the fluid inclusions in the vein quartz indicates that the veins were formed by aqueous solutions and that these solutions were at a high temperature, for they contained various salts, in part those of heavy metals, especially iron, which have separated during the cooling of the crystallized quartz. This entirely eliminates the possibility of deposition by cold surface waters, and points to two or three eventualities: Deposition (1) by atmospheric waters heated by contact with the cooling porphyry, or (2) by ascending magmatic waters, or (3) by a mixture of both. In any case the metals must be derived from the porphyry or from deep-seated sources below the porphyry, for the presence of porphyry is the only common factor in all occurrences. It seems reasonably certain that parts of the mineral solutions were directly derived from and formed part of the porphyry magma, and probably they were entirely derived from this source. It seems likely that the fissuring which took place after the cooling opened vents of escape for magmatic waters under heavy pressure at lower levels, and that they ascended in these fissures, depositing the heavy metals and the silica and acquiring at the same time carbon dioxide from the sediments which they traversed.

It remained for the surface waters, as erosion gradually exposed the deposits, to alter and enrich them in manifold forms.

Some of the deposits, especially the fissure veins, were laid bare by erosion and attacked by surface waters at an early date, probably before the principal faulting movement, and certainly before the eruption of the Tertiary basalts and rhyolites. Oxidation has thus acted on them for a very long period.

The irregular and tabular deposits in limestone and shale have obtained their present form, partly by direct oxidation and partly by the influence of sulphate solutions derived from the disseminated chalcopyrite due to contact metamorphism; 
a great enrichment has taken place, due to decrease of volume and addition of copper from the circulating sulphate solutions. Some of the oxidized deposits in shale, however, may be wholly due to the precipitating power exerted by the kaolin in the shale on these sulphate solutions.

In the veins the history is more complicated. It has been shown that oxidation dates back to Tertiary time, and that the water level then was considerably higher than it is at the present time. By action of descending sulphate solutions on pyrite, chalcocite was deposited very extensively, and very likely the great vertical extent of the chalcocite zone, ordinarily from 200 to 500 feet, is due to slow and gradual changes in the water level. Disintegration and erosion removed the iron cap (the product of direct oxidation of the primary vein) and began to oxidize the exposed chalcocite zone. In practically all of the veins the surface zone of poor ore is due to the direct oxidation of chalcocite. The solutions from this part descend and add richness to the upper part of the remaining chalcocite zone. But at the present low stand of the water level and the exceedingly dry climate the lower limit of the chalcocite zone is probably almost stationary. 


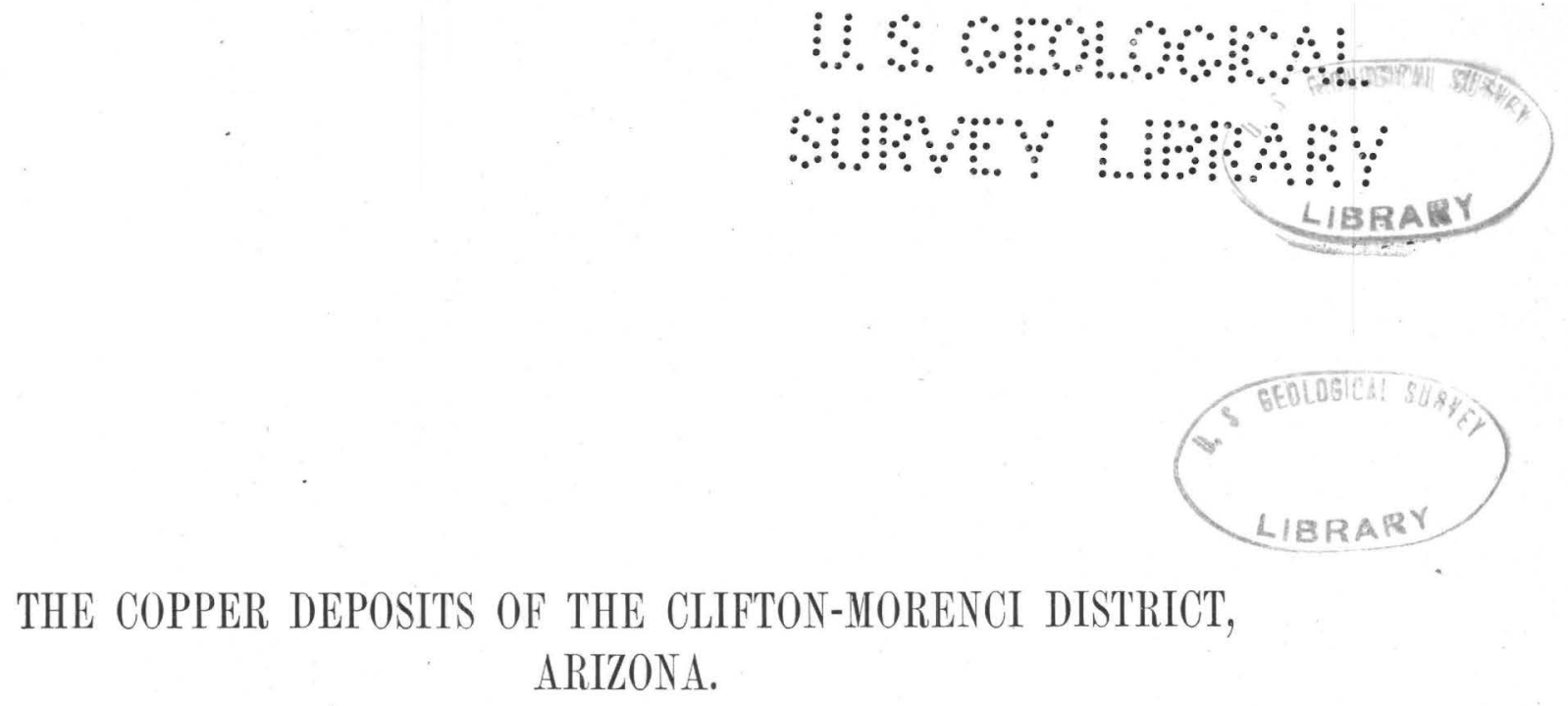

By Waldemar Lindgren.

CHAPTER I.

INTRODUCTION.

FIELD WORK.

The three most important copper districts of Arizona are located near Bisbee, Jerome, and Clifton, respectively.

Jerome is situated almost in the center of the Territory, near the head of Verde River. Bisbee and Clifton are both in the southeastern part of the Territory, the former near the Mexican boundary line at the southern end of the Mule Pass Mountains, while Clifton lies 120 miles farther north, near the New Mexican line on San Francisco River and not far from Gila River. At Bisbee the Copper Queen mine is the chief producer; at Jerome, the United Verde; in the Clifton district there are several important mines, located at Morenci and at Metcalf.

In 1898 Mr. S. F. Emmons, in charge of the investigation of metalliferous deposits of the Geological Survey, visited Clifton and formulated plans for future investigation. His general supervision and many helpful suggestions have greatly facilitated the successive stages of the work.

In 1900-1901 the topographical surveys were made by Mr. Jeremiah Ahern, Mr. E. M. Douglas being geographer in charge. The maps comprise a quadrangle with sides of 15 minutes, or about 15 by 17 miles, on the scale of 1 to 62,500 , and smaller maps, embracing the country in the immediate vicinity of Morenci and Metcalf, on the scale of 1 to 1,200. The two latter, as well as the economically important part of the large quadrangle map, are reproduced in this report.

In 1901 I was detailed to take up the geological work. The field work occupied the time from the end of October, 1901, to the beginning of May, 1902; during the larger part of this time I was most efficiently assisted by Mr. J. M. Boutwell. The office work was completed during the winter of 1902-3. 


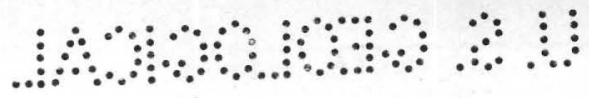

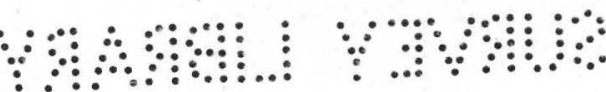

For paleontological determinations I am indebted to Messrs. George $\mathrm{H}$. Girty, E. O. Ulrich, T. W. Stanton, and Prof. H. S. Williams; and for many chemical analyses and determinations to the careful and thorough work of Dr.

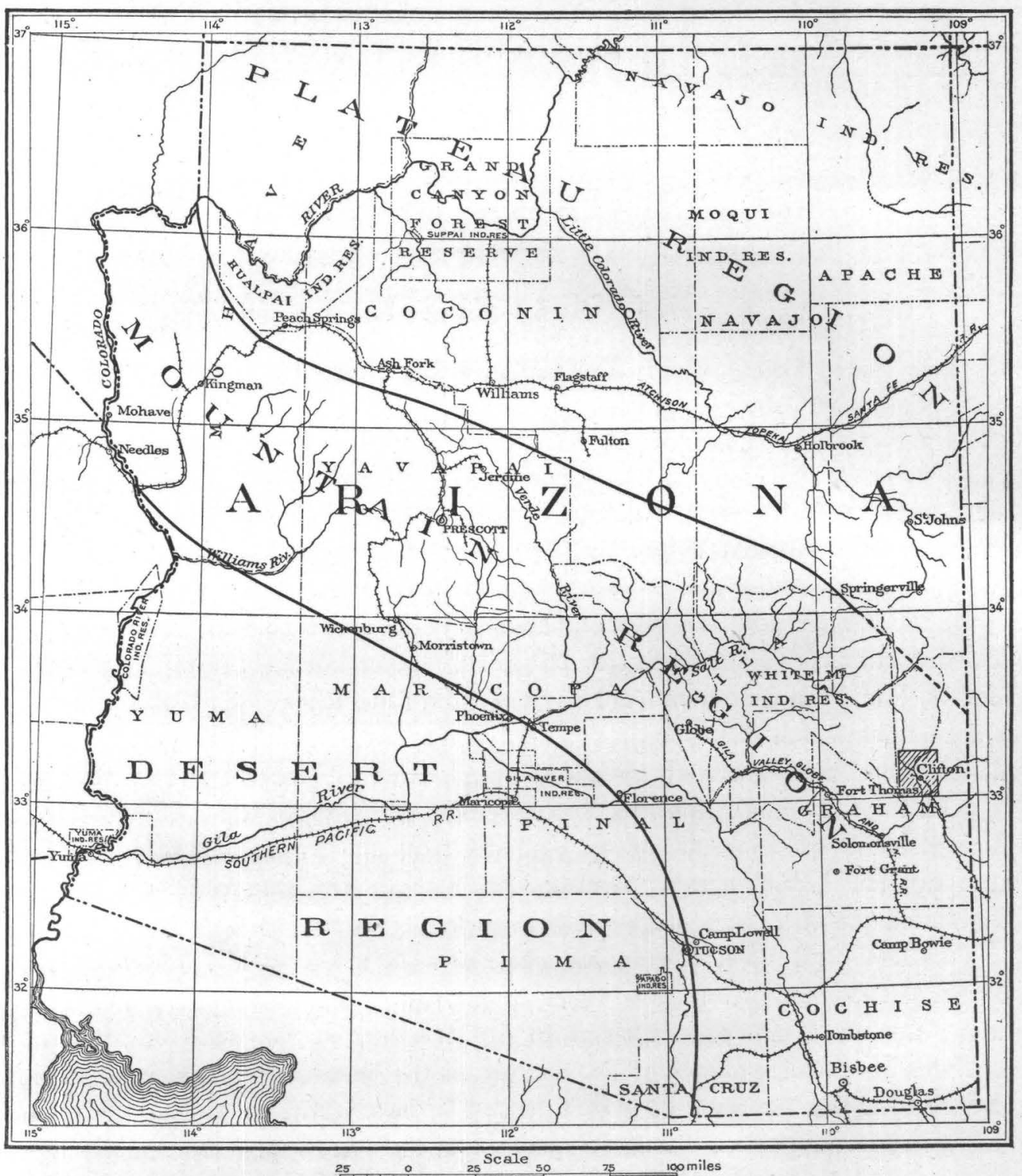

FIG. 1.-Index map, showing position of Clifton quadrangle.

W. F. Hillebrand. I am under great obligations to all mining men with whom I came into contact in the district for many courtesies extended, and especially for their cordial invitation, without reserve, to visit and examine their mines in 
detail and for permission to record their experiences concerning the mineral deposits. Particularly do I desire to express my thanks to Dr. James Douglas, as well as to Messrs. C. E. Mills, Gordon McLean, and Milton McLean, of the Detroit Copper Company; to Messrs. James Colquhoun, Paul Nicholas, and Alexander McLean, of the Arizona Copper Company; and to Messrs. Wiseman and W. T. Climo, of the Shannon Copper Company.

\section{GENERAL TOPOGRAPHY.}

The traveler bound for Clifton leaves the Southern Pacific Railroad at Lordsburg, N. Mex. The scenery at this point is characteristically New Mexican. The wide, almost level plains, which have an elevation of about 4,200 feet above the sea, are covered with scant grass and diversified by groups of yuccas. Low ranges of mountains appear on the horizon in several directions. The drainage is not well defined; parts of this area are probably closed basins, while others may have underground drainage connections with Mimbres River, which itself empties into a closed basin. The railroad from Lordsburg to Clifton continues over these plains for some 30 miles in a north-northwesterly direction, and then gradually descends to the level of Gila River, which here, near the New Mexico line, flows at an elevation of about 3,200 feet. Along the descent the plateau, evidently composed of heavy detrital masses, becomes extensively dissected by a network of little gullies, producing a kind of miniature badland scenery. Farther on, the Arizona and New Mexico line is crossed and the road enters the open, alluvial Duncan Valley on Gila River. This valley, which is several miles broad and long, is a prosperous agricultural section in which alfalfa and grain are raised. Below Duncan the road follows Gila River for 25 miles. The bottom lands become more narrow, and are bordered by low bluffs of basaltic rocks. Big cottonwood trees line the banks of the river, which ordinarily does not contain very much water, a large quantity being taken out for the purpose of irrigation above Duncan. At Guthrie the railroad crosses over to the north side of the river and continues over the gradually rising terraces of detrital material which occupy the country between San Francisco and Gila rivers. After a few miles the road begins to descend toward San Francisco-River, and continues along the base of the steep bluffs of consolidated gravels which here line the stream, until finally, 4 or 5 miles farther north, it reaches the town of Clifton, picturesquely situated along the narrow bottom lands, and shut in by high hills of granite, basalt, and rhyolite.

\section{CLIMATE.}

Like the other parts of southeastern Arizona, the Clifton district has an exceedingly arid climate, clearly enough evident in the absence or scantiness of vegetation. The rainfall, which naturally varies according to elevation, but 
scarcely exceeds 10 inches per annum in the lower parts of the region, is chiefly distributed over two wet seasons, one occurring in the late fall or during the winter, and the other during the late summer months - July and August. In the lower part of the district, at elevations from 3,000 to 4,000 feet, snow seldom falls and never remains on the ground for more than a very short time. On the higher ridges, above 5,000 and 6,000 feet-such as, for instance, at the head of Chase Creek - the snow may reach a depth of a foot or two and may remain for several weeks at a time. The summer rains are characteristic of the southern part of Arizona, and are important because they rapidly start the grass to a luxuriant growth.

Except for a few desert bushes the lower foothills are practically barren. In many places, however, grows the thorny long-stemmed bush known as Fouquiera splendens, whose bare stems are covered with brilliant scarlet flowers during the spring months. Up to elevations of 6,000 feet the ridges generally support no arboreal growth, although a number of species of agave and yucca are found on them. Above elevations of 6,000 feet, in sheltered locations, stunted trees of juniper and cedar are fairly common, and are extensively used as firewood. In certain places yellow pines also occur, and these may in some cases even be suitable for lumber. A growth of manzanita bushes and stunted oak is also found on the higher slopes. Large cottonwood trees grow along San Francisco River and Eagle Creek, and fairly large live oaks occupy the broad washes in some parts of the region.

\section{LITERATURE.}

The following list embraces the important publications in which are found direct references to the geology and mining industry of Clifton:

RAYMond, R. W. Mineral resources west of the Rocky Mountains: Report of Mining Commissioner, 7 volumes, $1870-1876$.

Contains many valuable data as to early mining in the district.

Gilbert, G. K. Report on the geology of portions of Nevada, Utah, California, and Arizona, examined in the years 1871 and 1872: U. S. Geog. Surv. West One-Hundredth Meridian, vol. 3, Geology, 1875, pp. 21-187, 507-567.

Describes relation of basin ranges to the plateau region of Nevada and Utah. Characterizes basin-range structure. Distinguishes three natural divisions in Arizona-the range region, the volcanic region, and the plateau region. Describes in general the geology and structure of each region in southeastern Arizona. Names, describes, and discusses the Gila conglomerate.

Hinton, R. J. Handbook to Arizona. San Francisco, 1878.

Contains historical data in regard to early mines and development.

Douglas, James. Clifton copper mines of Arizona: Eng. and Min. Jour., Feb. 21, 1880.

Hamilton, Patrick. Resources of Arizona. 3d ed., San Francisco, 1884.

An account of mines and mining containing much historical information. 


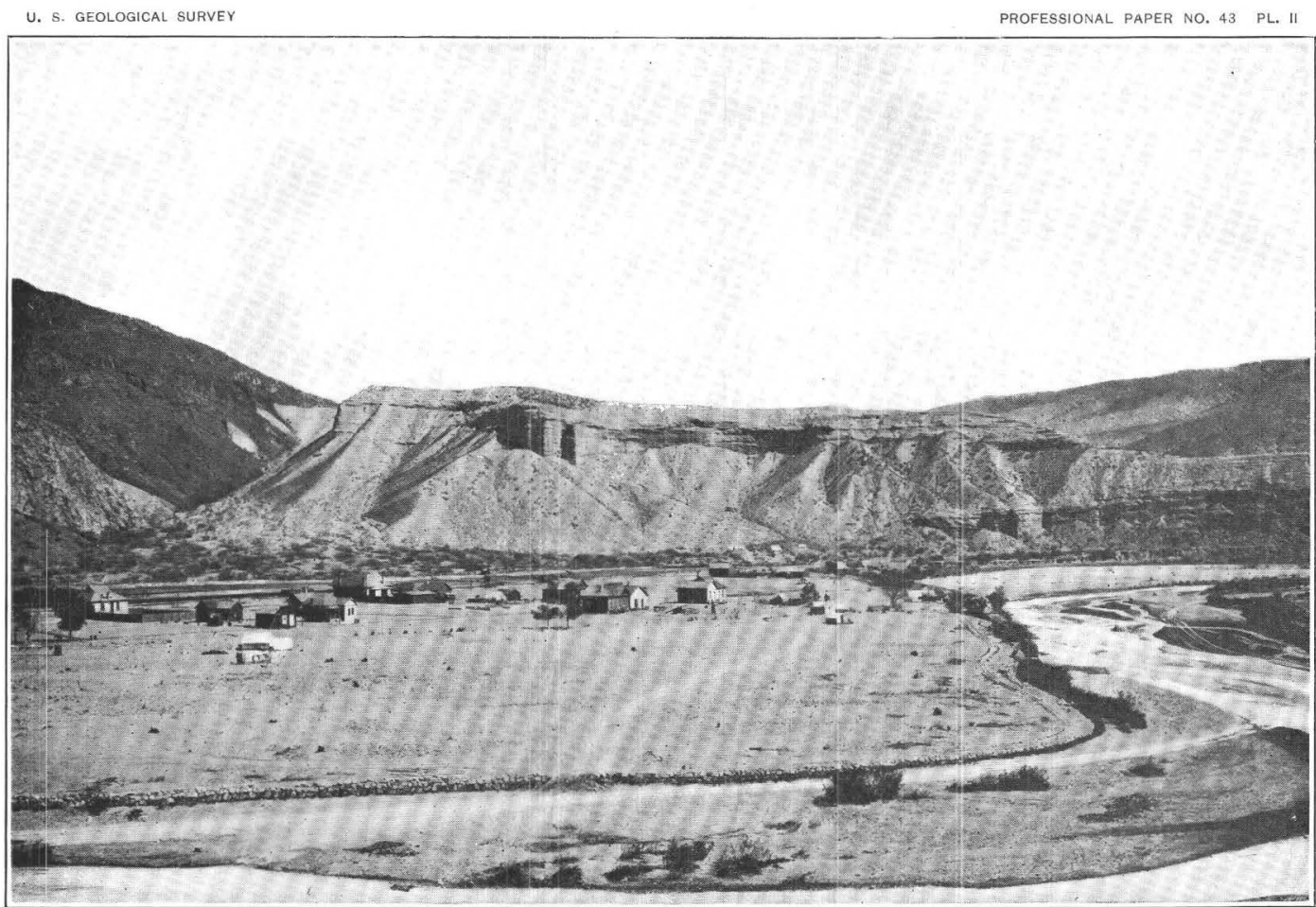

A. SAN FRANCISCO RIVER 1 MILE BELOW CLIFTON.

Beds of the Gila conglomerate rest against steeply sloping granite.

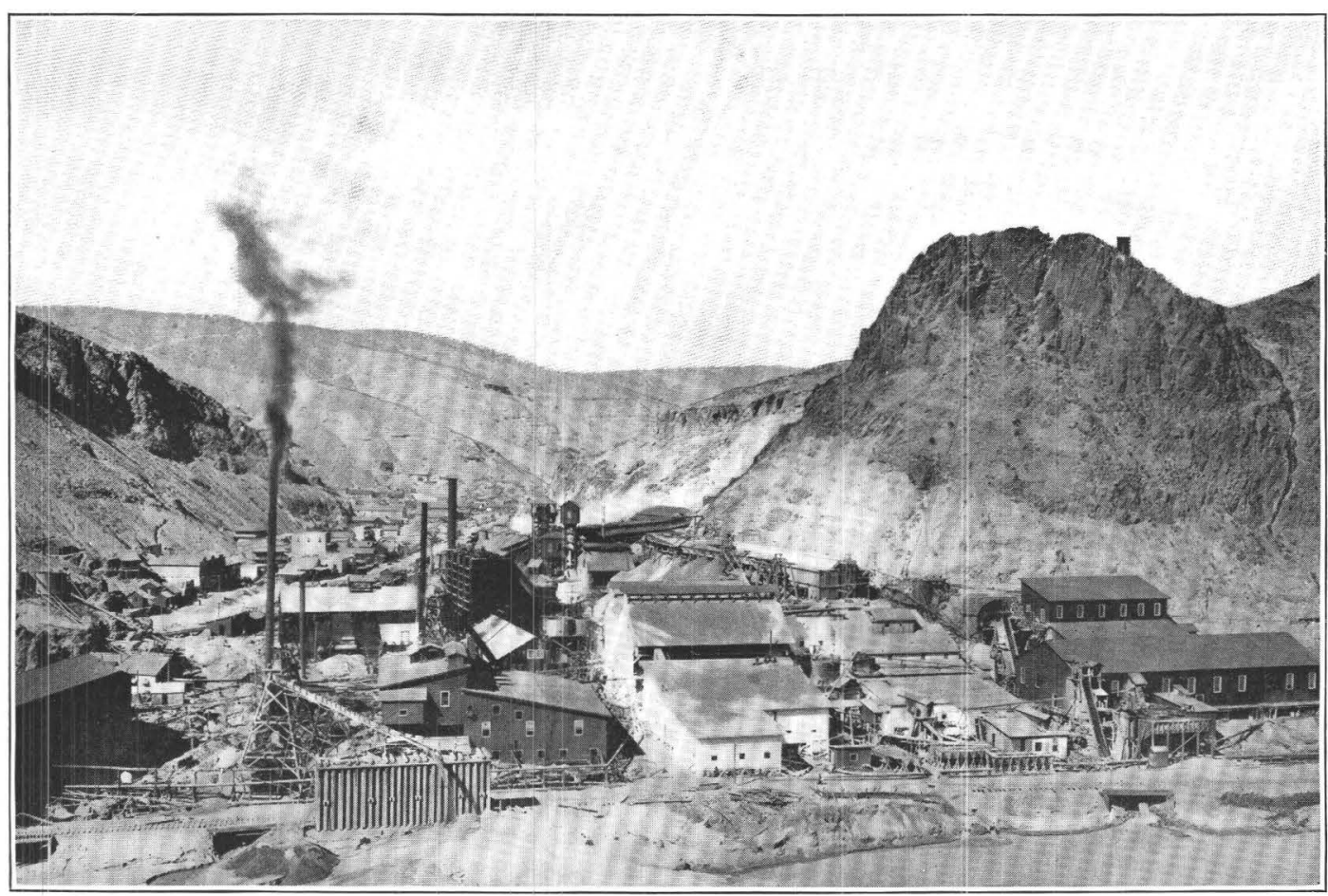

B. TOWN OF CLIFTON, WITH THE SMELTING WORKS OF ARIZONA COPPER COMPANY IN THE FOREGROUND. Hills of basalt and rhyolite. Granite ridge in the background. 

Wendt, Arthur F. Copper ores of the Southwest: Trans. Am. Inst. Min. Eng., vol. 15, 1887, pp. $25-77$.

This paper contains the first geological description of the Longfellow, Coronado, and Metcalf mines, and many important historical data regarding mining and smelting.

Henrich, C. Copper ore deposits near Morenci, Ariz.: Eng. and Min. Jour., Mar. 26, 1887, pp. 202-219.

This brief paper contains valuable statements as to the geological occurrence of the ores at Morenci, but does not mention the occurrences near Metcalf.

Douglas, James. Copper resources of the United States: Trans. Am. Inst. Min. Eng., vol. 19, 1891, p. 689.

Douglas, James. Historical sketch of copper mining in the United States: Mineral Industry, vol. 4, 1895, pp. 269-286.

Douglas, James. Copper industry of Arizona: Mineral Industry, vol. 6, 1897, pp. 227-232.

BLAKE, W. P. Mining in Arizona: Report of the Governor of Arizona to the Secretary of the Interior, 1899, pp. 43-109.

Emmons, S. F. Secondary enrichment of ore deposits: Trans. Am. Inst. Min. Eng., vol. 30, 1901, pp. 177-217.

Contains brief account of the occurrences of copper ores in the Clifton district.

In the Transactions of the Institute of Mining Engineers for 1887, Arthur F. Wendt published a paper on Copper Ores of the South, giving for the first time an account of the geological and technical conditions of the copper industries at Clifton and other points. The paper contains much valuable material, although the true significance of the geological phenomena is not always fully appreciated or rightly interpreted. The figures which accompany the paper, and which have been widely copied, partake more of the nature of rough sketches than of actual representation to scale.

Wendt divides the ores into those occurring in limestone, porphyry, and granite. The Longfellow mine is described in some detail and considered as a fissure vein, the author evidently using this term in a very wide sense. Many valuable analyses of ores are given. Metcalf is described as a "stockwerk" in porphyry. The Coronado vein is also described, and statements are made showing that the tenor of the ores in general diminishes rapidly as depth is attained, the rich copper ores giving way to poor pyrite and chalcopyrite.

-A short paper was published in the Engineering and Mining Journal, March 26 and April 2, 1887, by Carl Henrich, in which the deposits at Morenci are described. This paper contains much of interest and some very valuable generalizations. Again, some of the geological features are not correctly interpreted, but on the whole the paper is the best description of the deposits and their probable genesis which has thus far appeared. Henrich divides the deposits into three groups:

(1) Contact deposits, containing malachite, azurite, and cuprite ores. These occur on the contact of limestone and porphyry, and are sometimes entirely included in decomposed porphyry near the contact. 
(2) Deposits in limestone. These are similar to the first group. Wherever these ore bodies have been worked out an ore channel has been found connecting them with the contact zones.

(3) Deposits in porphyry. These consist of sheets and pockets in kaolinized porphyry. Near the surface in these deposits pockets of malachite have been found, some carrying large amounts of rich ore. In other places the ore bodies resemble, and may be called, fissure veins, as the ore doubtless fills fissures in porphyry; still Henrich would not consider them as normal fissure veins. No ore connections have thus far been traced between the different deposits, and it is not believed that any such connection exists. The gangue of the ores is nearly free from iron, containing only 1 or 2 per cent of that metal. The main gangue is kaolinized porphyry with a high percentage of alumina. The probable genesis is indicated as follows:

Through the sedimentary rocks an immense dike of porphyry broke, tearing the edges of the huge fissure. This outpour of porphyry probably brought with it the iron and copper in the form of copper glance, pyrite, and chalcopyrite. At the cooling of the porphyry, which must have been extremely slow, the disseminated sulphides probably concentrated and finally were deposited in the fissures and pockets of the porphyry formed by the cooling of the mass. The original deposit of copper as copper glance is asserted.

When the cooling was completed a period of leaching began, carrying the sulphates in solution. Probably at that time the climate was more moist than now. Henrich further believed that the contact and limestone deposits were of secondary origin, derived by the oxidizing action of atmospheric conditions on pyrite. He also expressed the conviction, fully borne out by subsequent developments, that the deposits of copper glance would yet contribute the largest amount of ore to the total production of the district.

\section{HISTORY OF THE DISTRIC'T.}

Like other mining districts of the Southwest, Clifton-Morenci has an interesting history. The earlier part, comprising the times of discovery and early development, teems with stirring episodes of frontier life at places far distant from lines of communication, where the pioneers were exposed under a burning southern sun to many privations and to dangers from hostile Apaches and from the lawless element for whom the boundary region between the United States and Mexico seemed to possess great attraction. These unfavorable conditions, however, produced a courageous self-reliance, no doubt contributing to the later and rapid advancement of the country. The second period, really beginning with the construction of the Southern Pacific Railroad, has been one of great and successful industrial development, which finally has resulted in placing the district in the first rank of the copper producers of this continent. 
A prospecting party from Silver City, N. Mex., discovered the mines in the vicinity of Clifton, in August, 1872, and the first mining district was organized under the name of Copper Mountain district. At that time there were only 18 or 20 men in the district; among them were Messrs. I. Stevens, Bob Metcalf, and Golden. Among the claims located at that date are mentioned the following: Arizona Central, Copper Mountain, Montezuma, and Yankie. A few days later the Longfellow mine and various claims at Metcalf were located.

At that time the conditions were not encouraging. The nearest railroad station was La Junta, Colo., 700 miles distant. No wagon road was as yet built; provisions and supplies were very high, and the communications frequently interrupted by bands of Apaches, ever on the alert to waylay the prospectors and teamsters. Indian raids continued at intervals, rendering the country unsafe till about 1885. On one occasion, in 1882, a number of miners were killed on Gold Creek, and the Indians even attacked the town of Morenci.

An interest in the mines was transferred by Metcalf to Lezinsky Brothers, of Las Cruces, N. Mex., who soon afterwards acquired nearly full ownership of the most important groups. In 1873 an adobe furnace was erected at Longfellow mine with a capacity of 1 ton a day, the blast being derived from bellows worked by hand. Next year the first water-jacket furnaces were built on San Francisco River near Clifton, copper plates first being employed instead of steel jackets. Reverberatory furnaces were not a success on account of the very basic ores and difficulty in obtaining fire bricks of good quality.

In 1879 the so-called baby-gage (20-inch) railroad was built by Lezinsky Brothers, connecting Metcalf and Clifton. Wendt states that the output of the Longfellow mine then was 40 tons a day of 20 per cent ore, the cost of mining being $\$ 10$ per ton. Operations on a larger scale became possible when the Southern Pacific Railroad was completed in 1881, and all expenses of mining and smelting became considerably lessened. In 1884 new reduction works were built at Clifton, with three furnaces of 60 tons, and two of 30 tons, capacity. A narrow-gage branch line was also built, connecting Clifton with Lordsburg on the main Southern Pacific line. Prospecting for gold became more active both in the Gold Creek drainage basin and in the Greenlee district a few miles due north of Clifton. River gravels bearing gold were worked at Oroville, 3 miles above Clifton. Silver deposits were opened at Granville, 12 miles north-northwest of Clifton. But these attempts at gold and silver mining did not prove very successful, and copper remained the mainstay of the camp.

In the meanwhile the Detroit Copper Company had developed its mines at Morenci with much success. At first the ores were smelted on San Francisco River a few miles below Clifton. In 1884 the location of the smelter was changed 16859-No. $43-05-3$ 
to Morenci, supplies being hauled by the Arizona and New Mexico Railroad to Longfellow, and thence up a 2,200-foot incline to the smelter level. From this time the production and the importance of the camp increased steadily. In 1893 the leaching treatment with sulphuric acid was introduced for the Metcalf ores. The two oldest companies have all along pursued the policy of extending their holdings and purchasing all promising claims. Many other companies conducted prospecting operations, but none of them, except the Shannon, have worked their properties on a large scale. About 1893 the great low-grade sulphide bodies of Copper Mountain at Morenci were discovered, and this effected wide-reaching changes. Extensive concentration plants were built and the small cupolas were replaced by great rectangular shaft furnaces with a capacity of up to 300 tons of charge per twenty-four hours. Great pumping plants were erected which elevated water from San Francisco River and Eagle Creek to Morenci.

In 1901 the Detroit Company completed a narrow-gage railroad from Guthrie, on Gila River, on the Arizona and New Mexico Railroad, to Morenci. The production of copper increased steadily, and in 1901 attaine̊d $38,000,000$ pounds. At the present time Clifton is a thriving town, with a population numbering several thousand. The smelting works of the Arizona Copper Company and of the Shannon Copper Company are located there. Metcalf is a smaller town, with a population of about 1,000. Morenci, high up on the hills west of Chase Creek, and some 4 miles north-northwest of Clifton, has a population of about 5,000. At all places the labor is largely Mexican. The wages of American miners average $\$ 3$, those of Mexicans $\$ 2.25$ and $\$ 2.50$, while common labor is paid from $\$ 1$ to $\$ 2$ a day.

The future of the camps is assured for many years, for the low-grade ore bodies, which are now the principal mainstay, are of very large extent, and the production bids fair to keep up at least the present rate for some time to come.

At the present time there are three large corporations possessing extensive mines and smelting works. Besides these a few smaller companies are developing claims and occasionally shipping ore. The large companies are the Arizona Copper Company, the Detroit Copper Company, and the Shannon Consolidated Copper Company. Among the smaller properties the New England Mining Company, the Clifton Consolidated Copper Company, the Standard Copper Company, the Markeen Company, and the company operating the Stevens Consolidated claims are the most important.

\section{THE DETROIT COPPER COMPANY.}

HISTORY.

The Detroit Copper Company was organized thirty years ago by Captain Ward. It began smelting the rich ore from its Morenci claims about 1882, the smelter being located 6 miles south-southeast of Morenci on San Francisco 
River. In 1884 the location of the smelter was changed to Morenci, where it has since remained. The holdings of the company and the plant have been steadily increased, especially since the discovery, in 1893, of the large low-grade bodies of Copper Mountain. About ten years ago the holdings and plant of the company were transferred to Dodge, Phelps \& Company, of New York, who have since continued the enterprise under the old name.

\section{LOCATION OF MINES AND SMELTER.}

The principal mines of the Detroit Copper Company, as well as the smelter, are located at Morenci. Besides the principal producing claims near the town, the company owns a number of prospects in the Gold Creek drainage, and also many partly developed claims between Morenci and Metcalf. Morenci is connected with the Arizona and New Mexico Railroad at Guthrie by a narrow-gage branch line. This railroad crosses Gila River near Guthrie, and extends across the rolling foothills of Gila Valley to San Francisco River, which is crossed 8 miles below Clifton. Thence the grade steadily ascends over the gravel hills to the mouth of Morenci Canyon, 1 mile below the town, and reaches Morenci by a series of four loops, ascending about 500 feet in that distance.

THE MINES.

The mining operations of the Detroit Copper Company are at present largely conducted in the great low-grade ore bodies underlying Copper Mountain. The removal of these necessitates overhand stoping with square sets, the stopes being afterwards filled as far as possible. The three principal mines owned by the company are (1) the Arizona Central, situated in the western part of Morenci and developed by a 300-foot shaft; (2) the Copper Mountain, situated in the middle of the town and developed by means of tunnels, and (3) the West Yankie, situated about one-half mile east of the town, the shaft being sunk to a depth of 200 feet. From this last mine large ore bodies under Copper Mountain are extracted. It also handles the largest tonnage. Besides these there are a number of smaller mines contributing certain amounts of ore. Among these may be mentioned the East Yankie, the Montezuma, and the Manganese Blue. In the mining operations as conducted here the timbering is the most expensive item after labor, which, of course, always comes first. The Detroit Copper Company draws its supply of timber from California or Oregon. The cost of mining probably varies between $\$ 1.50$ and $\$ 2$ a ton. The ore extracted from the mines is roughly sorted into smelting ore, which may be said to comprise everything containing above 8 per cent of copper, and concentrating ore, which consists of decomposed porphyry with finely disseminated pyrite and chalcocite. The ores may further be divided 
into oxidized ores, which contain cuprite, malachite, and azurite, and sulphide ores, which largely consist of a mixture of pyrite and chalcocite. The oxidized ores amount at present to only a small and diminishing part of the total output, and are principally produced from the Montezuma and the Manganese Blue mines.

\section{ORE PRODUCTION.}

The daily output from the mines of the Detroit Copper Company during the first four months of 1902 averaged as follows:

Daily output of copper ore, in tons, from mines of Detroit Copper Company.

[First, four months of 1902.]

\begin{tabular}{|c|c|c|c|}
\hline Mine. & $\begin{array}{l}\text { Smelting } \\
\text { ore. }\end{array}$ & $\begin{array}{l}\text { Concentrat- } \\
\text { ing ore. }\end{array}$ & Magnetite. \\
\hline Ryerson mine......................... & 90.80 & 211.33 & \\
\hline Arizona Central mine.................. & 26.75 & 65.80 & 15. 33 \\
\hline Copper Mountain mine................. & 11.12 & 53.60 & (........... \\
\hline Total ... & 128.67 & 330.73 & 15. 33 \\
\hline
\end{tabular}

At the time of this production the relative output of the three mines mentioned was as 5 to 3 to 3 , respectively, in the above order. Since then the East Yankie mine has acquired an importance equal to that of the Arizona Central and the Copper Mountain, owing to discoveries of large bodies of concentrating ore.

\section{CONCENTRATING.}

The larger part of the ore requires, as stated above, concentration before it can be smelted. It is difficult to say what the exact tenor of the concentrating ore amounts to. It probably varies between 3 and 5 per cent of copper. The concentrator is located near the West Yankie shaft, about half a mile east of Morenci, and is connected with the various mines by means of railroads. The principal tonnage, as stated before, is hoisted close to the concentrator. The capacity of the plant, which is considered a model of its kind, is from 12,000 to 14,000 tons a month, or from 400 to 466 tons a day. Latest advices in 1904 indicate the intention of the company to double the capacity of this plant. The water used for the concentrator is pumped from San Francisco River, the pumping station being located close to the railroad bridge, 8 miles below Clifton. The amount used is 150 gallons a minute of fresh water, but there are a number of settling tanks by means of which it is endeavored to prevent waste as far as possible. Four hundred gallons are allowed per ton of ore. The water is pumped against a head of 1,600 feet. The power driving the concentrator is 
derived from three gas engines of 100 horsepower each, the gas needed being produced in a plant of two Loomis generators, fed by bituminous coal. This plant, which is located some distance from the concentrator, has a capacity of $2,000,000$ cubic feet a day, and also furnishes motive power for several dynamos and for two gas engines of 200 horsepower each, which are needed in the smelter for blowers, pumps, etc.

The general plan of treatment in the concentrator is as follows:

Ore bins

2 punehed sheet-iron screens.

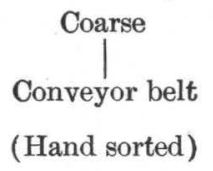

(Over 200 tons per month of high-
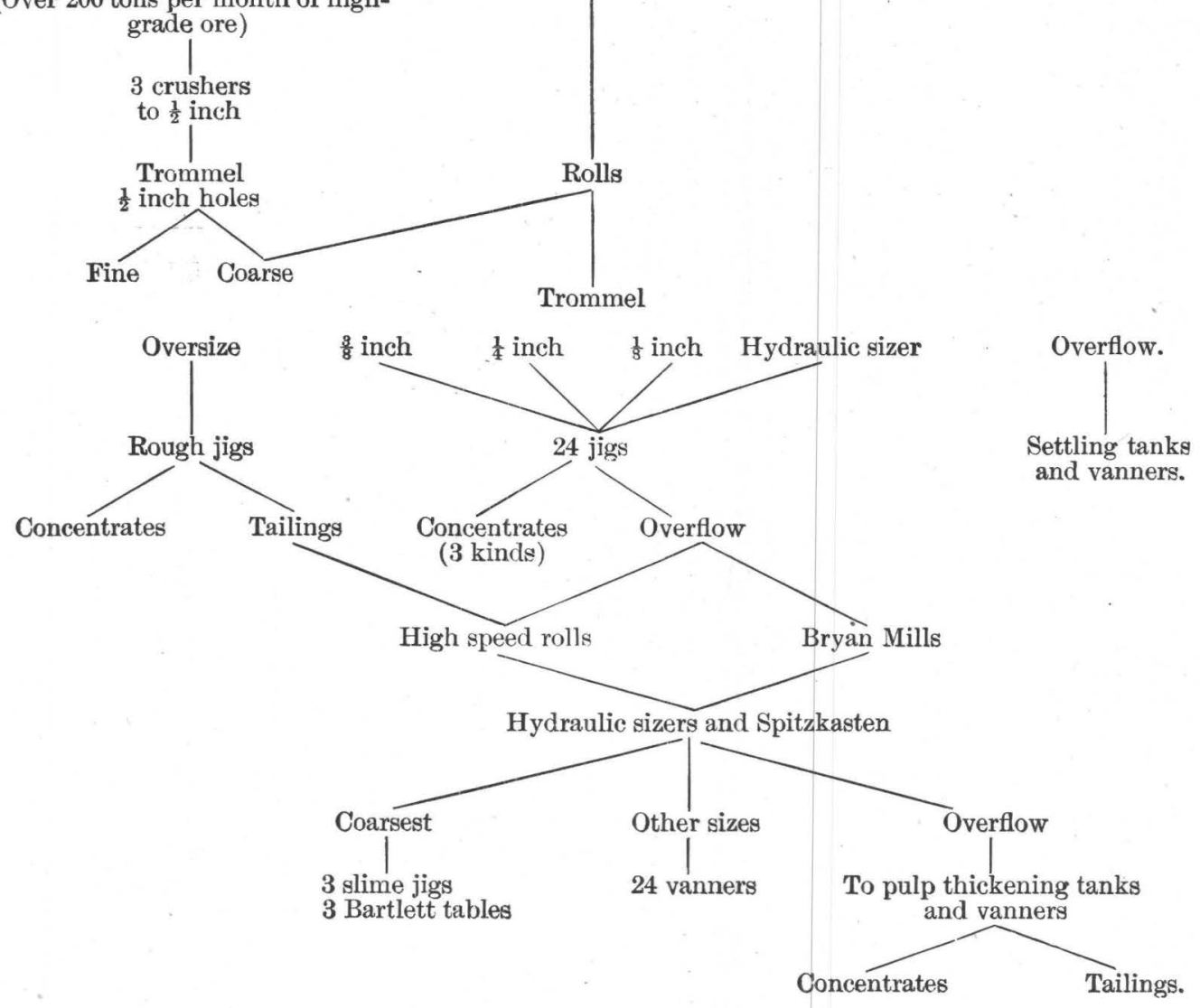


\section{SMELTING.}

The smelter of the Detroit Copper Company is situated immediately below the town, at a conveniently lower elevation than the mines and the concentrator. It consists of 4 blast furnaces with forehearths and 18 tuyères, and 1 newer furnace of the same size built separately from the rest. In these furnaces the ore is reduced to a high-grade matte, which is immediately conducted from the forehearths into 3 converters of the Bisbee or Leghorn type. The height of the 4 older furnaces is 6 feet from the tuyères to the charging floor, and the area at the tuyères 42 inches by 12 feet. The capacity is 130 tons of charge per twentyfour hours. The new furnace is similar to the old except in having a more pronounced bosh, and a height of 14 feet and 10 inches from tuyères to charging floor. The capacity is also greater, amounting to 170 tons of total charge per twentyfour hours.

The ores consist of a mixture of chalcocite and pyrite and oxidized ores that can conveniently be smelted without preliminary roasting. Great variations are shown in the composition of the ores. The following analyses may serve as samples:

Analyses of ores from Detroit Copper Company's mines, Morenci, Ariz.

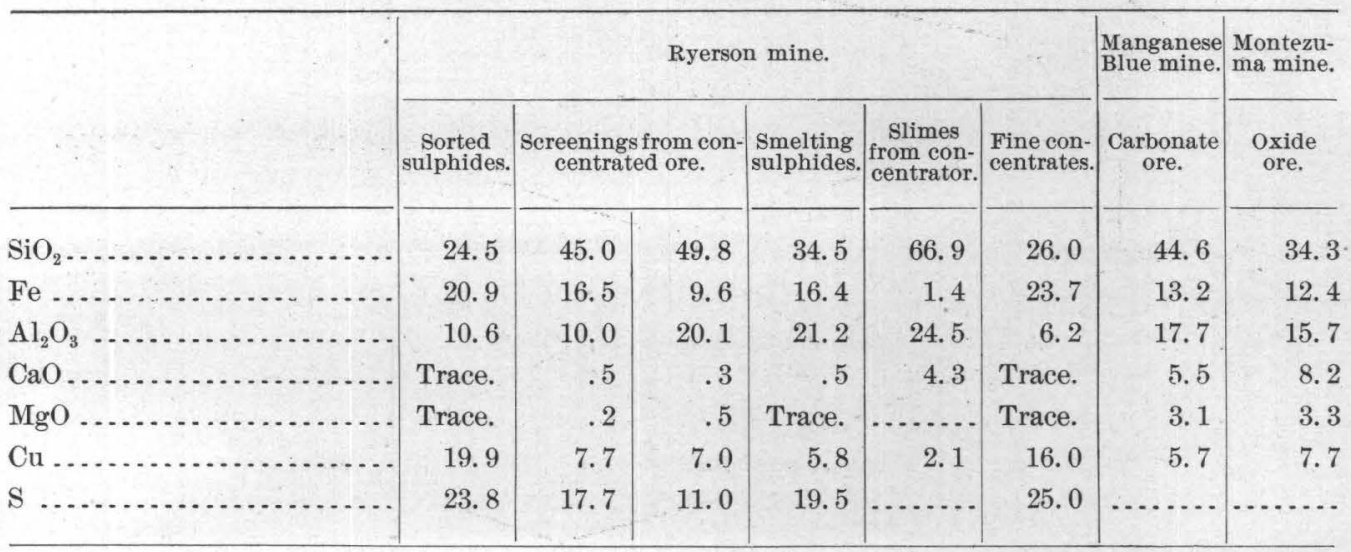

There is also occasionally a little manganese and zinc in the ores, the latter sometimes appearing in the matte. About 45 per cent of the ore treated consists of concentrates in briquetted form. The average ore and concentrates treated in the smelter contain about 11 per cent of copper. 
The matte has the following average composition:

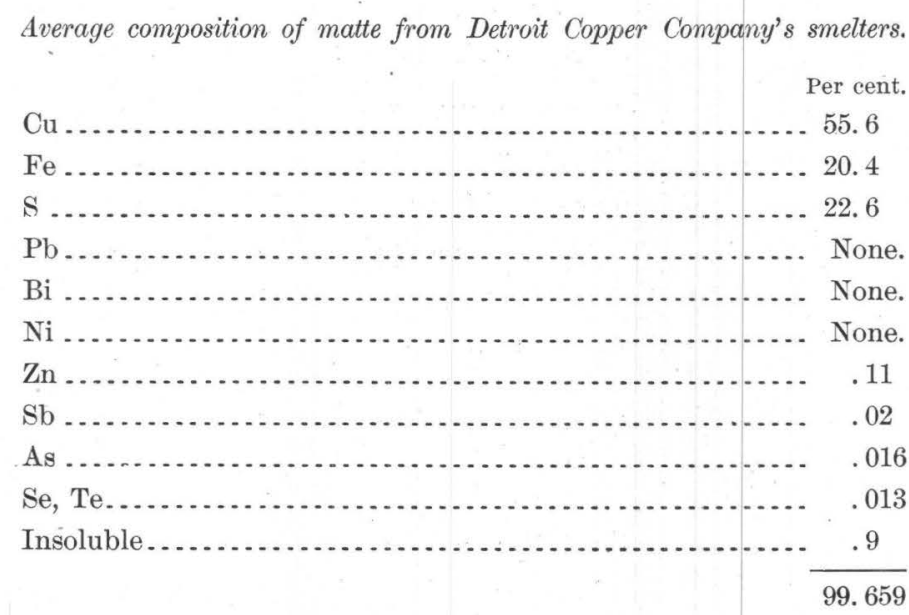

The flue dust has also been analyzed and is composed as follows:

Average composition of flue dust from Detroit Copper Company's smelters.

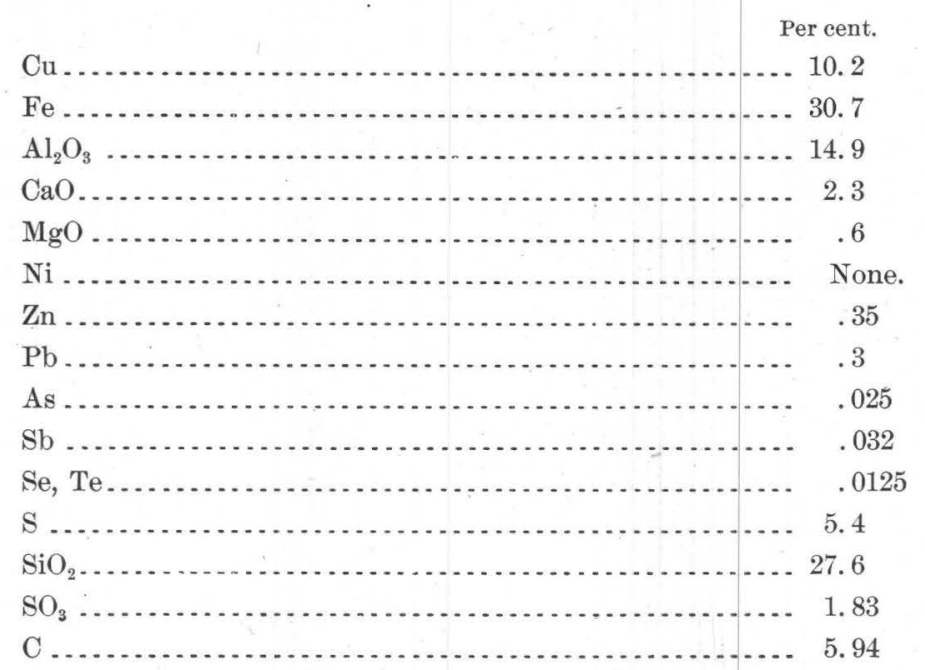

In the converters the copper matte is reduced to metallic copper about 99 to 99.8 pure. From the converters it is tapped into molds forming ingots weighing 285 pounds.

It is an interesting fact that gold and silver are practically absent from the ores, only traces being present. Even in the Bessemer copper there is so little silver that it would not ordinarily pay for further separation. 
It will be noted that of other metals there are only minute traces of lead, zinc, antimony, and arsenic.

An interesting further fact is that minute quantities of selenium and tellurium occur in the matte as well as in the copper and in the flue dust.

It is proposed to replace the present furnaces by new ones of far greater capacity. The proposed furnaces would have 40 tuyères of $4 \frac{1}{2}$ inches diameter and have an area of 42 inches by 22 feet at the tuyères. The distance from tuyères to feed floor is to be 12 feet, and the forehearth 15 feet in diameter. One of these furnaces was completed in 1904 and is the largest ever employed in copper smelting.

The favorable composition of the ores renders no other flux but limestone necessary, and fortunately this material is obtained in the immediate vicinity. A large quarry has been opened at the southwest side of the smelter, only a few hundred feet distant. The rock quarried consists of an almost pure, rather crystalline limestone of lower Carboniferous age; it contains 94 per cent of calcic carbonate. The iron ores (magnetite and limonite) occasionally needed are supplied by the mines of the company.

Silica for converter lining is obtained from a large body of quartzite in the North Star tunnel, and kaolin, which is mixed with this, is obtained in an almost pure state from the East Yankie mine.

\section{ARIZONA COPPER COMPANY.}

HISTORY AND LOCATION.

The Arizona Copper Company is chiefly controlled by Scotch capital. Its capitalization is $\$ 3,515,000$, in shares of $\$ 5$ par value.

The company in 1882 purchased the holdings of Lezinsky Brothers at Longfellow and at Metcalf, and since that time has steadily developed its properties and extended its plants, until at the present time it is the greatest producer in the Clifton district and one of the largest in Arizona. The property was bought shortly before the great discoveries were mado at Butte, Mont., at a time when copper brought 20 cents per pound. A railroad had to be built at great expense from Lordsburg to the mines. All these adverse influences caused the company many difficulties, which, however, were gradually overcome, largely by the able efforts of the manager, Mr. James Colquhoun. A few years ago the company began paying dividends, and is now in a prosperous condition. Dividends have been paid from 1896 up to the present time - in all, aggregating $\$ 3,900,000$.

The principal mines of the company are located at Morenci, or Longfellow, as the place was formerly called, and at Metcalf, a few miles above Clifton, on Chase Creek. At Longfellow and Morenci the company owns a great many 
claims curiously interlocking with those of the Detroit Copper Company. At Metcalf the company owns something like 40 claims. On the hills between Metcalf and Morenci it also owns a number of properties, which, however, it does not work at the present time. The remainder of the holdings of the Arizona Copper Company are located on Garfield Gulch and on the headwaters of King Gulch. On Garfield Gulch are located the producing claims Mammoth and Brunswick, while on the head of King Gulch are situated the Iolanthe, Dead Pine, and others, which have also produced considerable amounts of copper.

The smelting works of the company are located in the town of Clifton, at the junction of Chase Creek and San Francisco River. Clifton is connected with Lordsburg, on the main Southern Pacific line, by a broad-gage railroad, about 100 miles in length. This is owned by the Arizona and New Mexico Railroad Company, which is closely connected with the Arizona Copper Company. From Clifton a 36-inch-gage railroad extends up Chase Creek to Morenci, from which it is continued to Metcalf by a 20 -inch-gage railroad, originally built some thirty years ago by Lezinsky Brothers, the pioneer operators of the district.

At the present time it is proposed to replace the 20-inch-gage railroad from Longfellow to Metcalf by a 36 -inch gage. The distance to Metcalf is $6 \frac{1}{2}$ miles from Clifton and to Morenci about 4 miles.

\section{MINING.}

The mining operations of the Arizona Copper Company are scattered over a considerable territory. At Morenci the company owns several mines. Two of these-the Longfellow and the Detroit-are working oxidized copper ores contained in limestones, and these ore bodies are nearly exhausted. The largest tonnage of ore at Morenci is derived from the Humboldt mine, situated in the center of the town. This mine is developed by means of tunnels and a 400 -foot shaft. A narrow-gage railroad connects the mine with the concentrator, which is situated on the bluffs overhanging Chase Creek, not far from the Longfellow mine. From a point near the Longfellow mine an incline, descending about 800 feet in a total distance of about 2,200 feet, connects the mines and the concentrator with the narrow-gage railroad running along the bottom of Chase Creek.

The mining operations and methods of exploitation of the Arizona Copper Company are practically the same as those of the Detroit Copper Company, as both companies work under similar conditions.

The principal mines of the Arizona Copper Company at Metcalf are situated on Shannon Mountain, about 500 feet above Chase Creek, on the point between that stream and King Gulch. The different levels of the mine are connected with the railroad by means of two inclines, the longer one descending 500 feet 
in a horizontal distance of 1,000 feet. The mines at Metcalf are working large bodies of low-grade copper ores. There are some underground workings, these being mined in the usual way by means of square sets and filling. The larger part of the ore is, however, derived from open cuts, after the removal of the first 20 or 30 feet of barren material. Instead of the several open cuts at different levels now being worked, the company contemplates carrying a large open cut through the hill. The handling of the ore and the waste is to be facilitated by steam shovels and a self-acting incline, dumping the refuse in King Gulch.

On the south side of King Gulch are located the King and Jameson mines, which again are connected with the lower Metcalf incline by means of a long tunnel through Shannon Mountain and another incline extending high up on the slope south of King Gulch.

The narrow-gage road is extended from Metcalf about one-half mile westward up to Coronado Gulch, connecting there with an incline 3,200 feet long and sloping about $32^{\circ}$, which leads to the level of a tramway 1 mile long, which ends at the Coronado mine high up on the divide between San Francisco River and Eagle Creek. At this place the Arizona Copper Company operates the Coronado vein, exploiting it by means of tunnels, shafts, and one open cut. The latter is located about a mile from the main mine, in Horseshoe Gulch, and is connected with the mines by means of an aerial tramway.

The ores from the mines on Shannon Mountain, King Hill, and at Coronado Gulch are transported to the smelter at Clifton by means of the system of tramways and inclines explained above.

\section{CONCENTRATING.}

The larger part of the ore requires concentration before it can be smelted. All of the mines produce a certain amount of richer ore, which is roughly sorted at the mine, and which goes direct to the smelter. The larger part of the material, however, which contains from 3 to 5 per cent of copper, must first be subjected to concentration. The concentrating plants of the Arizona Copper Company are extensive, and are, roughly speaking, built in five units, each one capable of handling from 200 to 400 tons of ore. The concentrating ore from the Humboldt mine at Morenci ${ }^{a}$ is treated at the concentrator located near the Longfellow mine, the capacity of which is 9,000 tons per month, or 300 tons per day. The necessary water is piped through a 4-mile line from San Francisco River, and pumped against a head of 1,600 feet by three gas engines, aggregating 120 horsepower. From 150 to 180 gallons a minute of fresh water is used, the low

a The subject of concentration at Morenci was lately discussed by Mr. F. H. Probert in the Engineering and Mining Journal, June 29 and July 6, 1895. 
consumption being made possible by an extensive use of settling tanks. The concentrator is driven by a Corliss engine, now being changed to three Crossley gas engines. The ore is stated to be concentrated in the proportion of approximately 5 to 1 . The scheme of the concentration is as follows:

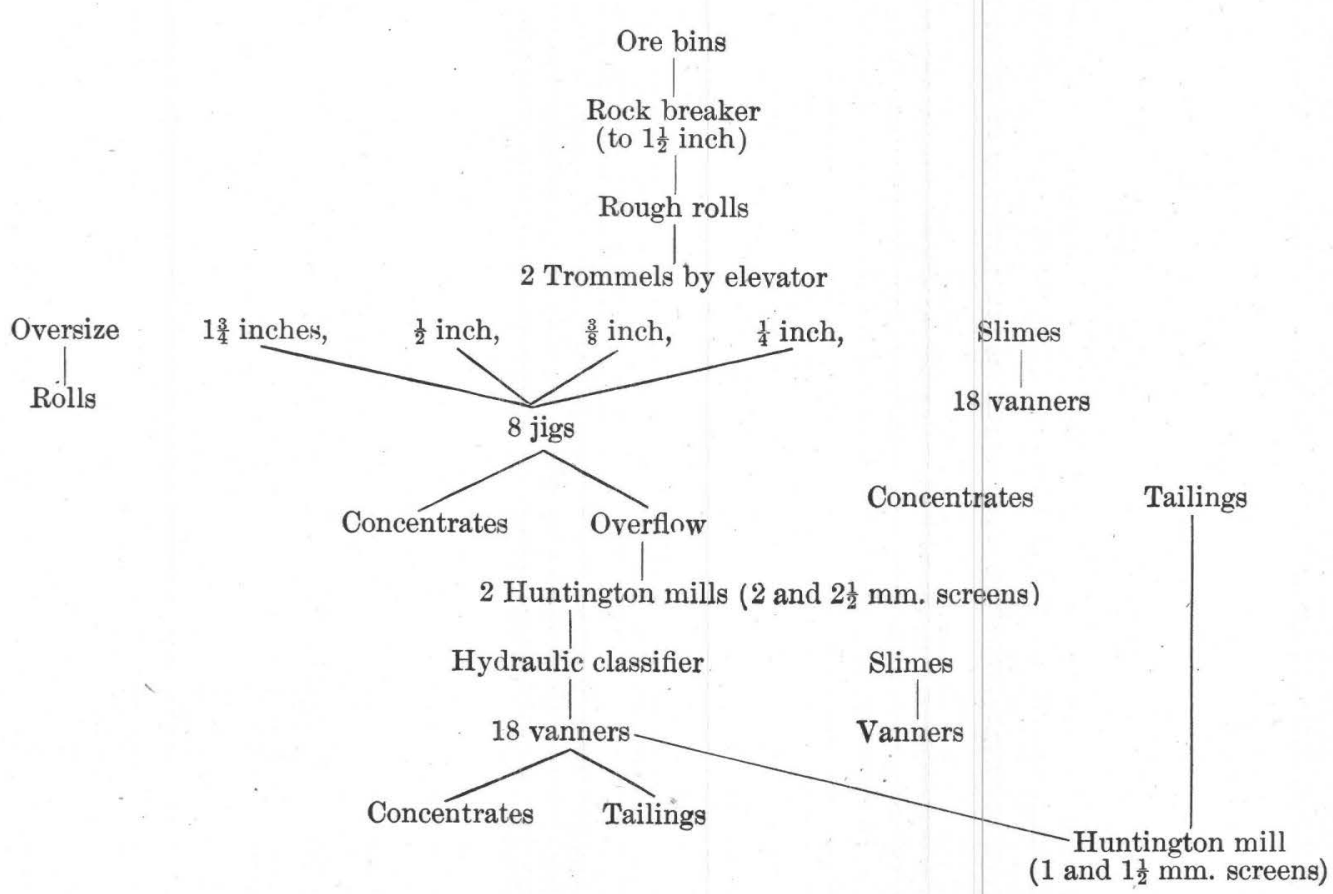

The remaining four sections of the concentrating plant are all located at Clifton, and are built on the following plan: 1 Blake crusher; 2 Cornish rolls; 2 revolving screens, each making 4 sizes; 8 jigs; 2 Huntington mills, No. 5; 18 Frue vanners, and 2 Wilfley tables for slime treatment. All tailings are treated in Huntington mills, each of which crushes at least 100 tons of tailings per twenty-four hours.

The ores from Metcalf present an interesting problem, inasmuch as they largely consist of decomposed porphyry with malachite and a little chalcocite. It has been found possible to treat these ores by concentration in connection with lixiviation by means of sulphuric acid. The section of the concentrating plant devoted to this ore has a capacity of 250 tons, and is equipped with 1 crusher, 2 coarse rolls, 2 sizing screens, and 8 jigs. There are no tables. The richest concentrates constitute smelting ore; the poorer grade is transferred to the lixiviation process, and the tailings are considered as waste. 
POWER.

The power plant at Clifton is very extensive, and consists of about 600 horsepower in steam engines, and about 1,200 horsepower in gas and gasoline engines. The concentrating and the Bessemer plants are run either directly or indirectly by gas engines. The necessary water is obtained from San Francisco River close by the works.

\section{SMELTING.}

The smelting plant consists of five furnaces 240 by 39 inches at tuyères, having a capacity of 250 tons of charge per twenty-four hours; there are also three stands and nine 7.5-ton Bessemer converters. The latter plant is expected to be doubled in size in order to come up to the productive capacity of the furnace plant. From the furnaces the matte is tapped into a reverberatory which keeps it at an even temperature for the converters. The ores treated consist of picked sulphide ore and concentrates, together with a certain amount of oxidized ores rich in iron.

Analyses of ores from Arizona Copper Company's mines.

\begin{tabular}{|c|c|c|c|c|}
\hline . & $\begin{array}{l}\text { Sulphide } \\
\text { concen- } \\
\text { trates. }\end{array}$ & $\begin{array}{l}\text { Sulphide } \\
\text { ore. } a\end{array}$ & $\begin{array}{c}\text { Concentrates } \\
\text { from Metealf } \\
\text { carbonate and } \\
\text { oxide ores. }\end{array}$ & $\begin{array}{l}\text { Longfellow } \\
\text { ores. }\end{array}$ \\
\hline $\mathrm{SiO}_{2} \ldots \ldots \ldots \ldots$ & 26.85 & 58.88 & 36.05 & b 43.70 \\
\hline Fe $\ldots \ldots \ldots$ & 15.04 & 4.50 & ............ & 18.08 \\
\hline $\mathrm{Fe}_{2} \mathrm{O}_{3} \ldots \ldots$ & ....... & ....... & 30.33 & \\
\hline FeS ......... & ....... & ........ & 4. 22 & ..... \\
\hline $\mathrm{Cu} \ldots \ldots \ldots \ldots$ & 23.30 & 6. 79 & .......... & 5. 10 \\
\hline $\mathrm{CuO} . . .$. & ....... & ......... & 12.25 & \\
\hline $\mathrm{ZnO} \ldots . .$. & ....... & ....... & .50 & \\
\hline $\mathrm{Al}_{2} \mathrm{O}_{3} \ldots$ & 8.92 & 19.78 & 6.94 & - \\
\hline $\mathrm{MnO} \ldots .$. & Trace. & (......... & ............ & .93 \\
\hline $\mathrm{CaO} \ldots \ldots . . . . . . . . .$. & .82 & 1. 16 & Trace. & 1. 68 \\
\hline $\mathrm{MgO} \ldots \ldots . . . . . . . . . . . . .$. & Trace. & ...... & Trace. & \\
\hline S.............................. & 19.80 & 3.90 & ........... & -......... \\
\hline Ignition . & & & 7.37 & \\
\hline
\end{tabular}


The large percentage of alumina necessitates the addition of lime, which is obtained in great purity from a quarry at Morenci.

Composition of slags from Arizona Copper Company's smelter.

\begin{tabular}{|c|c|c|c|}
\hline . & $\begin{array}{l}\text { Black cop- } \\
\text { per slag, } \\
1896 .\end{array}$ & $\begin{array}{l}\text { Matte slags. } \\
\text { (Matte50 } \\
\text { per cent } \\
\text { copper.) }\end{array}$ & $\begin{array}{c}\text { Converter } \\
\text { slags. }\end{array}$ \\
\hline $\mathrm{SiO}_{2} \ldots \ldots \ldots \ldots \ldots$ & 38.60 & 42.48 & 24.14 \\
\hline $\mathrm{FeO} \ldots \ldots \ldots \ldots \ldots \ldots$ & 42.12 & 22.89 & 62.25 \\
\hline $\mathrm{CaO} \ldots \ldots$ & 3.89 & 15.17 & ..... \\
\hline $\mathrm{Al}_{2} \mathrm{O}_{3} \ldots \ldots \ldots \ldots \ldots$ & 9.10 & 13.60 & 10.81 \\
\hline $\mathrm{MnO} \ldots \ldots \ldots \ldots \ldots$ & 1.54 & .42 & . \\
\hline MgO ................ & 2.52 & & $\ldots$. \\
\hline $\mathrm{Cu} \ldots \ldots \ldots \ldots . . . . . . .$. & 1. 76 & & 2.15 \\
\hline
\end{tabular}

Composition of Bessemer copper. a

During 1902 an average of 1,300 tons of copper a month were produced.

The Bessemer copper is shipped in ingots of the ordinary size; it averages $99 \frac{1}{3}$ per cent copper, and contains $3 \frac{1}{2}$ ounces silver and 0.1 ounce gold per ton. This is a little higher percentage of precious metals than is found in the copper produced by the Detroit Copper Company, and is probably due to the fact that the Metcalf ores are slightly richer in gold and silver than those from Morenci,

\section{LIXIVIATION.}

The second-class product from the concentrating plant for Metcalf oxidized ores is leached with sulphuric acid manufactured at the works in a plant the capacity of which is 10 tons of acid a day. The pyrite is obtained from the Joy mine at Morenci. The details of the leaching process are kept secret.

\section{STATISTICS.}

From the semiannual reports of the Arizona Copper Company some interesting data are obtained concerning the result of operations for the year ending September 30, 1903. A strike of the mine laborers interfered somewhat with the production during a couple of months of that term. The figures given are short tons of 2,000 pounds. 
In all, 442,855 tons of copper ore were treated, of which only about 8 per cent, or 36,000 tons, were first-cluss ore. The average yield of copper ores treated was 3.28 per cent, the first-class ores yielded an average of 12.5 per cent, and the concentrating ores 2.55 per cent. From 407,000 tons of concentrating ore a yield of 56,800 tons of concentrates was obtained, indicating a concentration of 7 to 1 . Of this amount 133,000 tons, or about 30 per cent, came from the Metcalf mines, indicating an output of about 350 tons a day, while the remainder was obtained from the Humboldt and Yavapai mines at Morenci, this ore being probably of somewhat higher grade than that from Metcalf.

In 1902 the output was as follows:

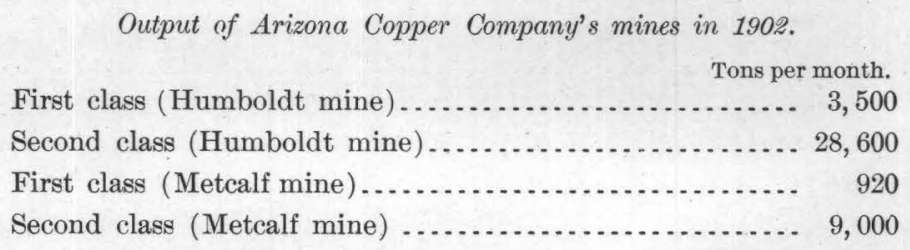

In 1903 the sulphuric-acid plant treated about 420 tons of pyrite per month from the Joy mine at Morenci and produced 3,471 tons of sulphuric acid. The leaching plant, utilizing this acid, treated 75,300 tons of tailings from the Metcalf, and produced 2,982,000 pounds of copper and 120 tons of bluestone.

The first-class ore yielded 4,245 tons and the concentrating ore 10,270 tons of copper.

The pay roll amounted to $\$ 1,500,000$ a year, and about 2,000 men were employed.

The output of the Arizona Copper Company for April, 1904, is reported as 1,173 short tons of Bessemer copper.

\section{SHANNON COPPER COMPANY.}

The Shannon Copper Company, with a capital stock of $\$ 3,000,000$, is of recent organization, the developments having been begun in 1900. Previously the company owned only one important claim, namely, the Shannon, but at that time acquired some adjacent ground, necessary to their operations, by purchase from the Arizona Copper Company. The property forms a compact body of about 25 claims, located near the summit of Shannon Mountain, which rises 1,200 feet above Chase Creek at Metcalf.

The recent development work has proved the existence of several ore bodies of large size, most of which are worked by underground stoping and the usual processes of square setting and filling. The outlet for the ore is furnished by means of an incline, descending to Chase Creek, one-half mile north of Metcalf, and having a total drop of 800 feet in a horizontal distance of 1,000 feet. At 
Chase Creek the ore is loaded into the cars of the Coronado Railroad Company, and transported 7 miles by rail to the Shannon smelter, which is located on the west bank of San Francisco River, 1 mile south of Clifton. This smelter was completed and blown in in May, 1902, and for some time kept running on high-grade ore obtained without concentration. In a short time, however, the necessity for a concentrator became apparent, and such a plant, with a capacity of 400 tons, is now erected on the hillside above the smelter.

The smelter, which is a thoroughly modern plant, consists of two furnaces, with a capacity of 300 tons of charge per twenty-four hours. The size at the tuyères is 44 by 170 inches, or an area of 52 square feet. The jackets are 13 feet high, and 4 charge spaces are provided on the feed floor. The crucible below the tuyères is 26 inches deep. It will be seen that these furnaces are the largest at present operated in the Clifton district, with the exception of the Detroit furnace, completed in 1904. The present capacity is reported to be about 500 tons of copper per month. During 1902, 2,340,000 pounds of copper were produced by direct smelting from ores, without concentration. In 1903 the output was 6,588,232 pounds, with every prospect of some increase during 1904. In February, 1905, a production of 344 tons is reported.

\section{CONCENTRATING AND SMELTING.}

It will be observed that the substitution of aluminous chalcocite ores in porphyry for the older, easily reduced carbonate and oxide ores in limestone has caused many changes in the processes of reduction. The Shannon Company alone has as yet large bodies of oxidized ores rich in iron. The method of treatment of the porphyry ores is in general to sort by hand as far as possible, then concentrate and smelt in cupolas with the addition of limestone and such oxidized ore as may be available. The concentration of the ores is difficult on account of the soft character of the copper glance, which causes rich slimes. To avoid excessive losses successively finer crushing is used, and the grade of concentrates is held rather low. They average perhaps 15 per cent copper. The ores are very soft and the capacity of the crushing machines is correspondingly great, which tends to cheapen the process. Considerable loss of copper is unavoidable and may range up to 25 or 30 per cent. Including losses in smelting, I should think it probable that the amount of copper recovered is 70 per cent of the assay value.

In smelting, the large percentage of chalcocite obviates the necessity for roasting. Much limestone flux is needed on account of the abundant alumina.

Regarding the tenor of the ore it is probable that the Arizona Copper Company at present works the lowest-grade ores in the district. The percentage 
has gradually decreased, giving evidence of the effect of large-scale mining and general economy in the treatment. The Metcalf ores are probably of slightly lower grade than the average.

As to the actual cost of mining and smelting no data are available for publication. The reports of the Arizona Copper Company do not contain figures from which these costs can be safely deduced

\section{PRODUCTION OF COPPER.}

Concerning the production of early days we have little reliable information. Previously to 1882 the Lezinsky Brothers are believed to have produced about $20,000,000$ pounds of copper, very little having been derived from other sources.

The following statistics are available:

Copper production of two principal Clifton copper companies, the total production of Arizona, and the production of the United States.

\begin{tabular}{|c|c|c|c|c|}
\hline Year. & $\begin{array}{l}\text { Arizona Copper } \\
\text { Company. }\end{array}$ & $\begin{array}{l}\text { Detroit Copper } \\
\text { Company. }\end{array}$ & Total of Arizona. & $\begin{array}{l}\text { Total of United } \\
\text { States. }\end{array}$ \\
\hline $1880 \ldots$ & Pounds. & Poninds. & $\begin{array}{l}\text { Pounds. } \\
\text { a } 2,000,000\end{array}$ & $\begin{array}{l}\text { Long tons. } \\
\qquad 27,000\end{array}$ \\
\hline $1881 \ldots$ & & ............ & $a 5,000,000$ & 32,000 \\
\hline $1882 \ldots$ & . & $1,442,935$ & $17,984,415$ & 40,467 \\
\hline $1883 \ldots \ldots$. & …...... & $2,819,530$ & $23,874,963$ & 51,574 \\
\hline $1884 \ldots \ldots . . . . . .$. & $3,539,556$ & $2,749,997$ & $26,734,345$ & 64,708 \\
\hline $1885 \ldots \ldots \ldots \ldots$ & $6,772,239$ & $3,345,523$ & $22,706,366$ & 74,052 \\
\hline $1886 \ldots \ldots \ldots$ & $5,513,549$ & $2,110,690$ & $15,657,035$ & 70,430 \\
\hline $1887 \ldots$ & $5,539,771$ & $4,175,717$ & $17,720,462$ & 81,017 \\
\hline $1888 \ldots . . .$. & $6,833,528$ & $5,235,797$ & $31,797,300$ & 101,054 \\
\hline $1889 \ldots \ldots \ldots$. & $6,787,201$ & $4,875,696$ & $31,586,185$ & 101,239 \\
\hline $1890 \ldots \ldots \ldots \ldots$ & $5,164,906$ & $4,906,704$ & $34,796,689$ & 115,966 \\
\hline $1891 \ldots$ & $5,673,611$ & $4,194,672$ & $39,873,279$ & 126,839 \\
\hline $1892 \ldots \ldots \ldots$. & $5,893,533$ & $1,918,594$ & $38,436,099$ & 154,018 \\
\hline $1893 \ldots . . . .$. & $7,871,819$ & $4,942,728$ & $43,902,824$ & 147,033 \\
\hline $1894 \ldots \ldots \ldots . . . .$. & $9,935,812$ & $5,577,744$ & $44,514,894$ & 158,120 \\
\hline $1895 \ldots \ldots \ldots \ldots$ & $11,308,910$ & $3,790,128$ & $47,953,553$ & 169,917 \\
\hline $1896 \ldots \ldots \ldots \ldots$ & $13,042,000$ & $7,016,348$ & $72,934,927$ & 205,384 \\
\hline $1897 \ldots \ldots \ldots$ & $13,727,911$ & $8,405,138$ & $81,530,735$ & 220,571 \\
\hline $1898 \ldots .$. & $18,169,096$ & $11,428,992$ & $111,158,246$ & 235,050 \\
\hline $1899 \ldots \ldots \ldots . .$. & $19,072,709$ & $13,906,253$ & $133,054,860$ & 253,870 \\
\hline $1900 \ldots \ldots . . . . .$. & $19,697,086$ & $10,749,258$ & $118,317,764$ & 270,588 \\
\hline $1901 \ldots \ldots \ldots . . . . .$. & $20,535,800$ & $17,535,000$ & $130,778,611$ & 268,782 \\
\hline $1902 \ldots \ldots \ldots \ldots \ldots \ldots \ldots \ldots \ldots \ldots \ldots$ & $30,821,842$ & $18,721,411$ & $119,944,944$ & 294,423 \\
\hline 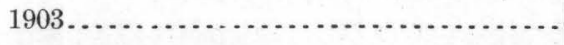 & $30,228,000$ & $16,558,232$ & $147,648,271$ & 311,627 \\
\hline
\end{tabular}


The production of the Arizona Copper Company and that of the Detroit Copper Company have been taken from Mineral Industry, published by the Engineering and Mining Journal, while the last two columns have been compiled from Mineral Resources of the United States, published by the United States Geological Survey.

The three most important producing districts in Arizona are the Clifton, Bisbee, and United Verde. From 1895 to 1901 the United Verde led in production, the maximum of $44,000,000$ pounds being attained in 1899. Bisbee was not far behind, the Copper Queen mine contributing practically the whole output. Clifton followed closely after Bisbee. The maximum output at Bisbee was obtained in 1901, in which year the former sequence was reversed, Bisbee leading with $39,800,000$ pounds, followed by Clifton with $38,000,000$ pounds and United Verde with $34,500,000$. In 1902 Clifton obtained the lead, the production rising to $49,500,000$ pounds. In 1903, however, Bisbee increased its output to $62,500,000$ pounds, due to the appearance of a new and important producing company, the Calumet and Arizona, while Clifton followed with 53,400,000 pounds and United Verde yielded 23,800,000 pounds.

The production of Arizona is at present a little more than one-fifth of the total production of the United States, the percentage having varied from 9.7 in 1887 to 23.4 in 1899 .

According to statistics the mines of the Arizona Copper Company have produced since discovery about 123,000 and those of the Detroit Copper Company 78,600 short tons, making a total of about 201,600 short tons of copper, an amount equal to a cube of copper with a side of about 90.5 feet. At an average price of 15 cents per pound this would represent a value of $\$ 60,500,000$.

\section{VALUE OF COPPER.}

Highest and lowest prices of Lake Superior ingot copper, by years, from 1860 to 1903. a

[Cents per pound.]

\begin{tabular}{|c|c|c|c|c|c|}
\hline Year. & Highest. & Lowest. & Year. & Highest. & Lowest. \\
\hline $1860 \ldots \ldots$ & 24 & $19 \frac{3}{4}$ & $1869 \ldots$ & $26 \frac{1}{2}$ & $21 \frac{7}{8}$ \\
\hline $1861 \ldots \ldots \ldots \ldots \ldots \ldots$ & 27 & $17 \frac{1}{2}$ & $1870 \ldots$ & $23 \frac{3}{8}$ & 19 \\
\hline $1862 \ldots \ldots$. & $32 \frac{7}{8}$ & $20 \frac{3}{4}$ & $1871 \ldots \ldots$ & 27 & $21 \frac{1}{4}$ \\
\hline $1863 \ldots \ldots$. & $38 \frac{1}{2}$ & 29 & $1872 \ldots$ & 44 & $27 \frac{1}{8}$ \\
\hline $1864 \ldots$ & 55 & 39 & 1873. & 35 & 21 \\
\hline $1865 \ldots . . .$. & $50 \frac{1}{2}$ & 28 & $1874 \ldots \ldots$ & 25 & 19 \\
\hline $1866 \ldots \ldots . . . .$. & 42 & $26 \frac{1}{2}$ & $1875 \ldots . . . . .$. & $23 \frac{7}{8}$ & $21 \frac{1}{2}$ \\
\hline $1867 \ldots \ldots \ldots \ldots \ldots \ldots \ldots \ldots$ & $29 \frac{1}{4}$ & $21 \frac{1}{2}$ & $1876 \ldots \ldots \ldots \ldots \ldots \ldots \ldots$ & $23 \frac{1}{4}$ & $18_{4}^{3}$ \\
\hline $1868 \ldots$ & $24 \frac{1}{2}$ & $21 \frac{1}{2}$ & $1877 \ldots \ldots \ldots \ldots \ldots \ldots$ & $20 \frac{1}{2}$ & $17 \frac{1}{2}$ \\
\hline
\end{tabular}

$a$ From Mineral Resources U. S. for 1903, U. S. Geol. Survey, 1904, p. 232.

16859-No. $43-05-4$ 
Highest and lowest prices of Lake Superior ingot copper, by years, from 1860 to 1903-Continued.

\begin{tabular}{|c|c|c|c|c|c|}
\hline Year. & Highest. & Lowest. & Year. & Highest. & Lowest. \\
\hline 1878 & $17 \frac{5}{8}$ & $15 \frac{1}{2}$ & $1891 \ldots$ & 15 & $10 \frac{1}{4}$ \\
\hline 1879 ................................ & $21 \frac{3}{4}$ & $15 \frac{1}{2}$ & 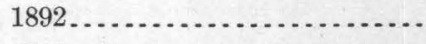 & $12 \frac{3}{8}$ & $10 \frac{1}{2}$ \\
\hline 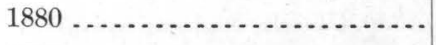 & 25 & $18 \frac{1}{2}$ & $1893 \ldots . . . . . . . . . . . . . . .$. & $12 \frac{1}{2}$ & $-9 \frac{3}{5}$ \\
\hline $1881 \ldots . .$. & $20 \frac{3}{8}$ & 16 & $1894 \ldots \ldots . . .$. & $10 \frac{1}{4}$ & 9 \\
\hline $1882 \ldots \ldots .$. & $20 \frac{3}{8}$ & $17 \frac{7}{8}$ & $1895 \ldots \ldots \ldots$ & $12 \frac{3}{4}$ & $9 \frac{1}{4}$ \\
\hline $1883 \ldots \ldots . . . .$. & $18 \frac{1}{8}$ & $14 \frac{7}{8}$ & $1896 \ldots . .$. & $11 \frac{3}{4}$ & $9 \frac{3}{4}$ \\
\hline $1884 \ldots \ldots$. & 15 & 11 & $1897 \ldots \ldots . . . . . . . . . .$. & 12 & $10 \frac{3}{4}$ \\
\hline $1885 \ldots \ldots . . . . . . . . . .$. & $11 \frac{1}{2}$ & $9 \frac{4}{5}$ & $1898 \ldots . . . . . . . . . . . . . .$. & $12 \frac{7}{8}$ & $10 \frac{9}{10}$ \\
\hline 1886 ..................... & $12 \frac{1}{8}$ & 10 & 1899 & $19 \frac{1}{2}$ & $13 \frac{1}{4}$ \\
\hline 1887 .................... & $17 \frac{3}{4}$ & $9 \frac{1}{2} \frac{9}{0}$ & $1900 \ldots \ldots$ & $17 \frac{1}{4}$ & $16 \frac{1}{8}$ \\
\hline $1888 \ldots$ & $17 \frac{4}{10}$ & $15 \frac{1}{2} \frac{7}{0}$ & 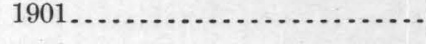 & 17 & $12 \frac{7}{8}$ \\
\hline $1889 \ldots \ldots \ldots$ & $17 \frac{1}{2}$ & 11 & $1902 \ldots \ldots \ldots$ & $13 \frac{1}{4}$ & $10 \frac{7}{8}$ \\
\hline 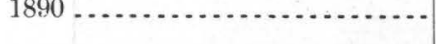 & $17 \frac{1}{4}$ & 14 & 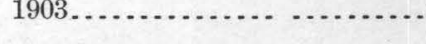 & 15 & 12 \\
\hline
\end{tabular}




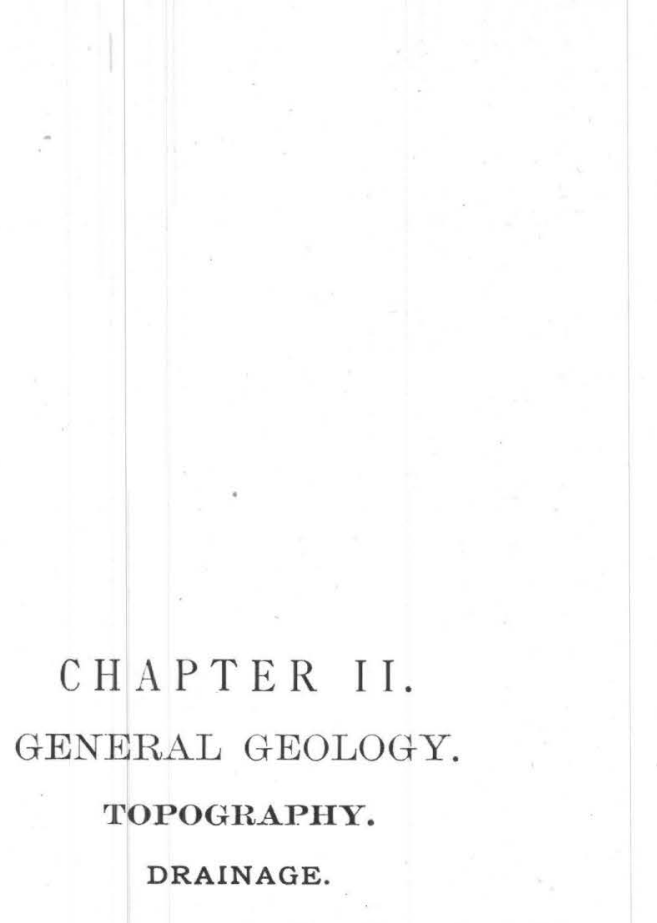

The principal stream of the region is San Francisco River, which heads in New Mexico, about 100 miles farther north, among Mogollones, Tularosa, Datil, and San Francisco ranges, and joins the Gila about 12 miles below Clifton, Ariz. About 40 miles north of Clifton it receives an important tributary called Blue River, which heads among the basaltic plateaus of the Prieto Range. The quantity of water carried by the San Francisco varies considerably, and is subject to very sudden increase by heavy freshets. The minimum quantity carried during the dry season is approximately a few hundred miner's inches. At all times it contains an abundant supply for the towns of Clifton and Morenci, as well as for the needs of the smelters located there. The water a few miles north of Clifton is of excellent quality, but near that town becomes more saline, due to numerous salt springs which discharge their contents into it. Some of these are found 1 mile north of Clifton; others carrying a large volume of very salt water enter 2 miles below the town, and at other places. Samples from the dam a short distance above Clifton show, according to Mr. J. Colquhoun, the following composition: Sodium chloride, 4.1 to 6.9 grains per gallon; carbonate of lime, 5 to 5.3 grains per gallon; total salts, 14.05 to 20.3 grains per gallon. Below Clifton the increase in salt, chiefly chloride of sodium, becomes very noticeable, the Shannon smelter, 1 mile below Clifton, experiencing considerable difficulty in securing a supply of sufficiently fresh water.

Below Clifton San Francisco River flows in a canyon a few hundred feet deep, cut in the detrital formations which here cover such great territory (PI. III, B). Above Clifton it flows in a canyon of older rocks, somewhat open in character and often characterized by a bluff a few hundred feet high close to the river. The canyon is by no means uniform in depth and slope. The presence of an older period of erosion is everywhere apparent, and the varying petrographic character of the rock greatly complicates the topography along the river. 
Except for Blue River the San Francisco receives few tributaries of importance. The principal one is Chase Creek, which heads among the high lava peaks 12 miles north-northwest of Clifton, and continues to its junction with the main river in a canyon cut to a depth of 1,000 feet or more.

The next important stream of the region is Eagle Creek, which joins the Gila a few miles below the mouth of the San Francisco. Eagle Creek extends from north to south and is about 40 miles long, its source being among the basaltic mountains of the Prieto Plateau. Like the San Francisco, it is bordered by narrow bottom lands along nearly its whole southerly course, and it flows in a very narrow and deeply incised canyon cut throughout in volcanic rocks, receiving few tributaries from either side $(\mathrm{Pl}$. IV, $B)$. It is a permanent stream and, like the San Francisco, is subject to sudden freshets, during which the volume of the water is for a short time amazingly increased.

\section{RELIEF OF DISTRICT.}

Kooking northward toward Clifton from the valley of Gila River several high ridges and complexes of rugged hills appear on the horizon, but neither from this place nor from better points of vantage nearer the foothills is it possible to discern any well-defined range system or any dominating central feature. Topographically the whole mountain region north of the river appears as a maze of short ridges and peaks.

The geological structure explains this condition of affairs very clearly. A core of older rocks, granites, limestones, and sandstones, lying chiefly between the two most important northern tributaries of the Gila in this region, and reaching elevations of over 7,000 feet, was first deeply and irregularly eroded, and, later, during the Tertiary period, was covered by immense masses of volcanic flows, chiefly rhyolites and basalts, very unequally distributed as to thickness and character. A constructive drainage was laid out over the lava flows and extensive erosion followed. The result of these conditions is an extreme irregularity of topography.

The southern part of the map (Pl. I) represents a broad plateau spreading at the foot of the mountains and having an average elevation of 4,000 feet. It descends gently southward from the edge of the mountains, extending from Eagle Creek on the west to beyond San Francisco River on the east. The lower parts of both of these watercourses trench it to depths of up to 700 feet, leaving grayish or brownish bluffs of lavas or gravels lining the watercourses. The plateau is furrowed by a maze of shallow and spreading ravines, rapidly deepening to box-like canyons near the main rivers. The formation is chiefly the semiconsolidated detritus of the Gila conglomerate. The road from Clifton to 
U. S. GEOLOGICAL SURVEY

PROFESSIONAL PAPER NO. 43 PL. III

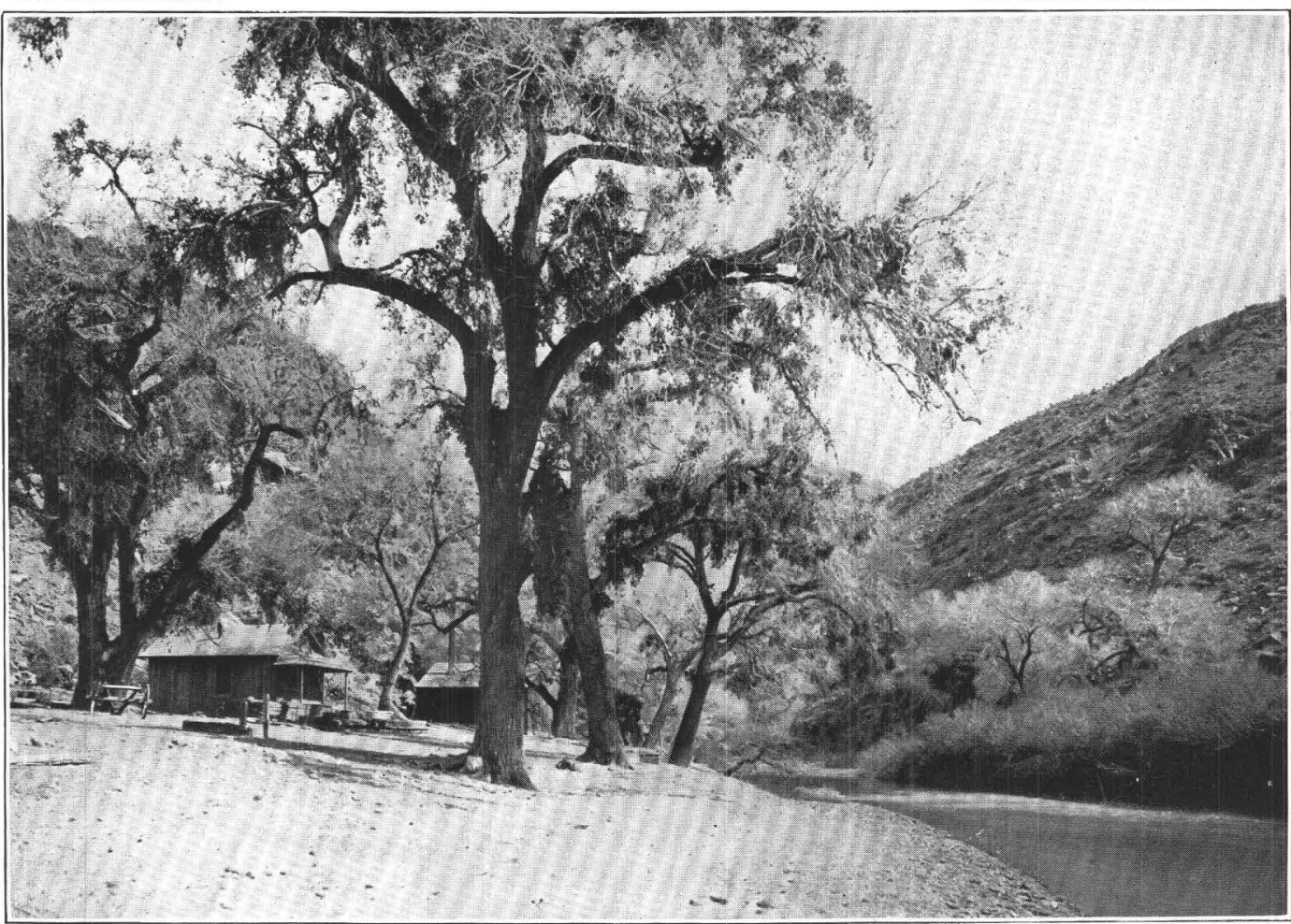

A. SAN FRANCISCO RIVER AT EVANS POINT, 4 MILES ABOVE CLIFTON.

Slopes of limestone and granite.

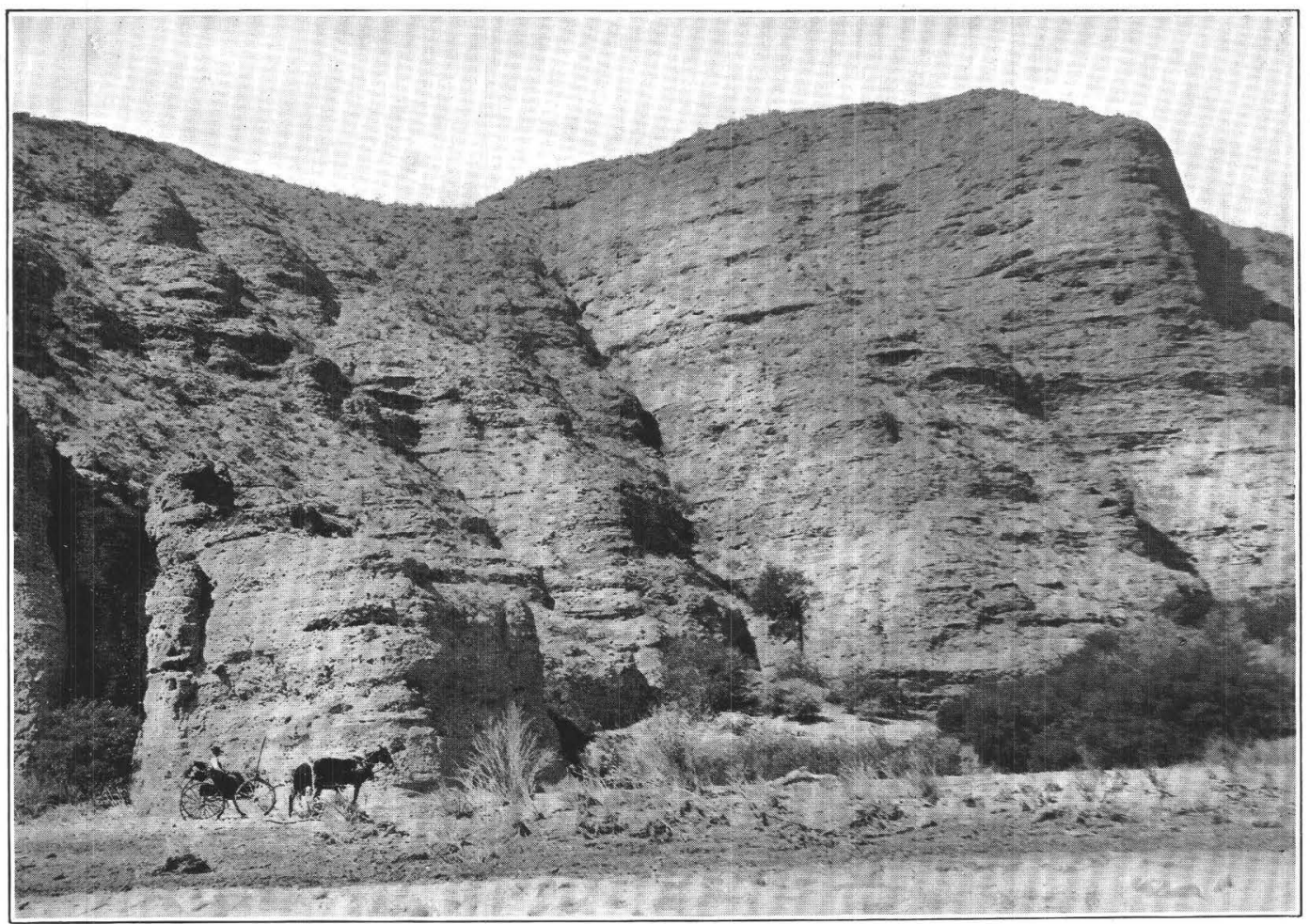

B. BLUFFS OF GILA CONGLOMERATE ON WEST SIDE OF SAN FRANCISCO RIVER 3 MILES BELOW CLIFTON. 



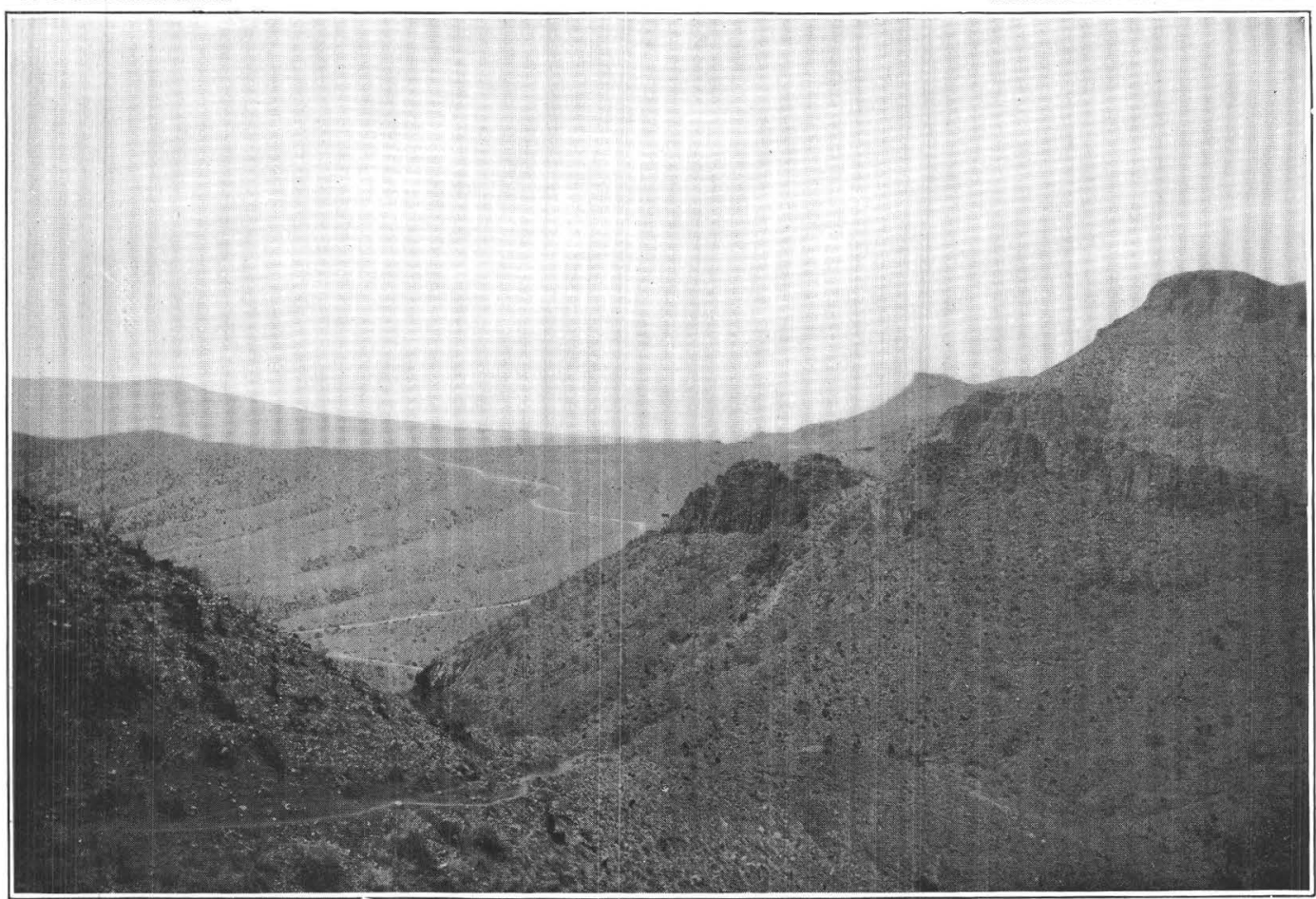

A. FOOTHILLS BETWEEN CLIFTON AND MORENCI.

Wagon road ascends smooth ridge of Gila conglomerate, west of Chase Creek. Cambrian quartzite (Coronado formation) capped by Ordovician limestone (Longfellow formation) to right.

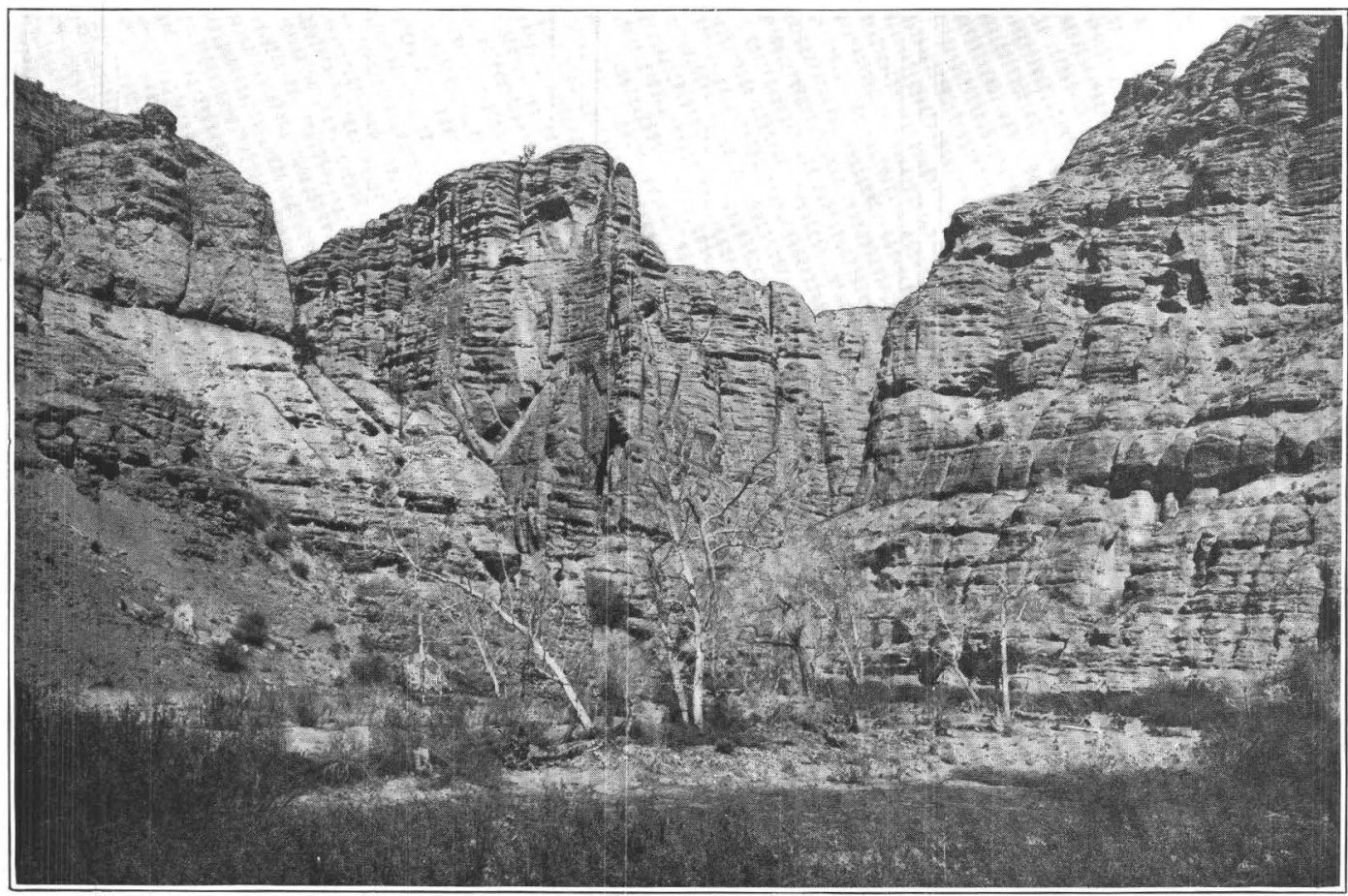

B. BLUFFS OF RHYOLITE TUFF 3 MILES BELOW PUMPING STATION ON EAGLE CREEK.

The bluffs are about 500 feet high. 

Morenci follows the narrow alluvial deposits of Chase Creek for 3 miles and then ascends the western slope 600 feet to the top of the barren and dry mesa (Pl. IV, A). A well-defined low escarpment of quartzite here marks the limit between the gravel plateau and the mountainous region to the north. For several miles northward extends a hilly region characterized by small peaks of porphyry and short ridges or sloping tables of limestone. The watercourses cut through the rim of the mountains in narrow canyons to spread out in more open basins near their headwaters; of this character are Gold Creek, Morenci Canyon, and the several intervening gulches.

Northwest of Morenci the general elevation increases rapidly. The central feature is formed by a high ridge of quartzite, porphyry, and granite, beginning at Copper Mountain and attaining 6,370 feet in elevation 2 miles from Morenci. From here the top continues fairly level up to the Coronado mine, 3 miles from Morenci. Eastward Coronado Gulch and the several branches of Concentrator Canyon descend to Chase Creek, separated by many and far-projecting salients. Westward similar deep gulches, the most prominent of which is Horseshoe Canyon, lead down to the lava plateau bordering the abrupt trench of Eagle Creek. Immediately north of the Coronado mine the central ridge again rises rapidly in Coronado Mountain, an imposing mass of red crumbling granite capped by a flat quartzite table breaking off perpendicularly for a couple of hundred feet.

From Coronado Mountain a magnificent view is obtained over the whole region, the most striking feature of which is perhaps the lack of regularity in the topographic forms. Toward the west a long and broad granite ridge projects, descending gradually from 7,500 feet, the elevation of Coronado Mountain, to 4,500 feet at a point 5 miles farther west, where it suddenly drops off to Eagle Creek. The area beyond Eagle Creek is occupied by high and very rough ridges of black basaltic lavas, separated by deep ravines. Eastward from Coronado Mountain precipitous slopes of red granite lead down to Santa Rosa Canyon, which empties into Chase Creek at Metcalf. Lower ridges of the same material rise again east of Santa Rosa Canyon, to descend in precipices to the level of Chase Creek. North of Coronado Mountain, Knight Creek emptying into Eagle Creek cuts back to within 1 mile of Chase Creek, from which it is separated by a gap with an elevation of 6,500 feet. North of this creek the lavas cover the old rocks and are carved into a most irregular complex of sharp ridges, some of which rise to elevations of 7,900 feet.

Chase Creek Canyon, cutting through the heart of the copper-producing district, is a most interesting and picturesque topographic feature. Three miles northwest of Clifton the monotonous gray bluffs of semiconsolidated gravels are replaced by granite walls, ranging upward to a thousand feet in height. Near 
the Longfellow incline the granite on the west side is capped by bluffs of quartzite and limestone, while a similar, though smaller, faulted-down quartzite table caps its eastern slope. For $1 \frac{1}{2}$ miles ahove the Longfellow incline the canyon is very narrow and deep. The prevailing rock is a granite greatly altered, silicified, and impregnated with decomposing pyrite; owing to this it weathers in most fantastic forms, overhanging cliffs alternating with deeply incised gorges and needle-like pinnacles, the dark-red color of the rock lending additional weirdness to the scene, especially when colors and shadows are emphasized by the setting sun. A little stream of bright-green water trickles along the bottom; numerous mining tunnels are opened along the sides, and the available level space is frequently insufficient for the track of the Coronado Railroad, which follows the canyon up to Metcalf.

A mile below Metcalf the canyon widens as the softer porphyry is entered, and small spaces of alluvial gravel appear, probably brought down from the great amphitheater of the Coronado and Santa Rosa canyons.

At the town of Metcalf two important tributaries join Chase Creek. From the west Coronado and Santa Rosa gulches descend in narrow canyons with precipitous grade, draining the eastern slope of Coronado Mountain. Three thousand feet west of Metcalf they join, and continue down to Chase Creek in an open valley with a bowlder-covered bottom several hundred feet wide, bearing ample evidence of the frequent occurrence of violent cloudbursts on the flanks of Coronado Mountain. From the east King Gulch descends in a narrow, extremely rocky canyon, broken by one sudden drop of a hundred feet and having a grade of 500 feet in 1 mile; it heads 3 miles to the northwest, near the 7,000-feet-high Malapais Peak, which, as its name implies, is carved in jagged outlines from the great Tertiary lava flows. A débris fan of great bowlders at the mouth of the canyon shows the torrential character of the watercourse, which ordinarily is entirely dry.

The most prominent feature of the topography at Metcalf is Shannon Mountain, rising in pyramidal form 1,200 feet above the town, with yellowish-gray lower slopes broken by rough crags of decomposed porphyry and surmounted by the black iron cap of the outcrops of the Shannon mine.

Above Metcalf Chase Creek Canyon contracts again and for $1 \frac{1}{2}$ miles forms a less conspicuous duplicate of the lower granite canyon. The grade is about 200 feet to the mile. Garfield Gulch, on which several important mines and prospects are situated, enters from the east. Above this gulch the most conspicuous features are the great granite bluffs on the west side, which drop off almost perpendicularly for a thousand feet to a sloping mass of débris near the creek. The head of Chase Creek is only a few miles distant, located among the high 
lava peaks of the northern part of Clifton quadrangle. The total drainage area is about 22 square miles.

The area which drains directly into San Francisco River north of Clifton possesses divers topographic features. The well-graded river, which has a fall of 20 feet per mile, emerges from the older rocks at Clifton, where it has carved picturesque cliffs from the lavas underlying the gravel terraces of the Gila formation. For a few miles northward it flows in a canyon about a thousand feet deep, with moderate slopes, which occasionally break into precipitous bluffs of limestone or granite. Above this point the canyon may be said to be a double one. Its tortuous course is first adjoined by steep lava bluffs from 500 to 700 feet high. A gentler slope then follows, gradually leading up to the high black lava peaks on the east side. On the west side this gradual ascent leads up to precipitous, dark-red, in places flat-topped, granite bluffs, 1,500 to 2,000 feet high, again surmounted by the great masses of Markeen and Copper King mountains on the south (3,300 feet above the river) and the lava peak of Malapais on the north, all of which form part of the divide between Chase Creek and San Francisco River. The canyon of the latter stream is not the result of a single and simple period of erosion, but rather the consequence of orographic movements and at least two periods of erosion. These relations are more fully discussed in the text of the Clifton folio.

\section{ROCKS.}

GENERAL STATEMENT.

The rocks are divided into two series. The older consists of a basement of pre-Cambrian schists and granite, upon which rests unconformably a Paleozoic series 1,000 feet thick of limestones, shales, and quartzites, overlain by Cretaceous shales and sandstones at least several hundred feet thick; masses of granitic and dioritic porphyries are intruded into all of these rocks. The younger series, of Tertiary and Quaternary rocks, consists of various lavas and of an extensive formation of partly consolidated coarse gravels called the Gila conglomerate.

\section{PRE-CAMBRIAN ROCKS.}

It appears most natural to first describe the old basement upon which the sedimentary systems have been deposited and through which the much later intrusions of porphyry and overflows of basalt and rhyolite have forced their way. While the Cambrian system has not been proved to exist in this region by complete paleontological evidence, there can be little doubt that the Coronado quartzite represents this period, and it is certain that its base marks the most 
prominent unconformity in the early geological history of this vicinity. The pre-Cambrian basement consists chiefly of granite and allied rocks, much more rarely of schists.

\section{PINAL SCHISTS.}

Eight miles north of Morenci, near the head of Chase Creek and Sardine Creek, a formation of fine-grained schists is exposed below the Coronado quartzite. The small areas are surrounded by basalt and have been exposed only through the erosion of the covering flows of this rock. The schists strike east and west and have a steep dip to the south. The prevailing mass consists of reddish, fissile, and very fine-grained quartz-sericite-schist, though smaller bands and masses of an amphibolitic rock are also present. The sericite-schist is probably of sedimentary origin.

On account of the striking similarity in geological position and petrographic character to the Pinal schists which Mr. Ransome ${ }^{a}$ describes from near Globe, Ariz., I have not hesitated in correlating the occurrence just described with that formation. The relation between the granite and the schists can not, in this case, be established with certainty, but, from the occurrence of a small pegmatite dike in schist found in the gulch just south of Sardine Creek, it seems likely that here, as well as at Globe, the granite is younger than the schists and intrusive in them. There is a very striking unconformity between the Coronado quartzite and the Pinal schists and the latter should doubtless be referred to the Algonkian or to the Archean. How unsatisfactorily the line is drawn between these two systems has already been emphasized by Mr. Ransome. ${ }^{b}$

\section{GRANITE.}

Occurrence and distribution.-The rock which almost universally underlies the Paleozoic sedimentary series is a normal granite, consisting of orthoclase, albite, quartz, and biotite; the orthoclase quite generally prevails over the other constituents and may be so abundant as to cause transitions to quartz syenites and normal syenites.

Broadly speaking, the granite areas form a belt several miles wide between the sunken limestone blocks of the southern foothills and the heavy lava flows of the northern mountains. Topographically they form two prominent domeshaped masses, rising to elevations of 7,000 feet, separated by the deep trench of Chase Creek, and scarred by many deep ravines. Coronado Mountain forms the westerly area, while the complex of Markeen and Copper King mountains rises between San Francisco River and Chase Creek. 


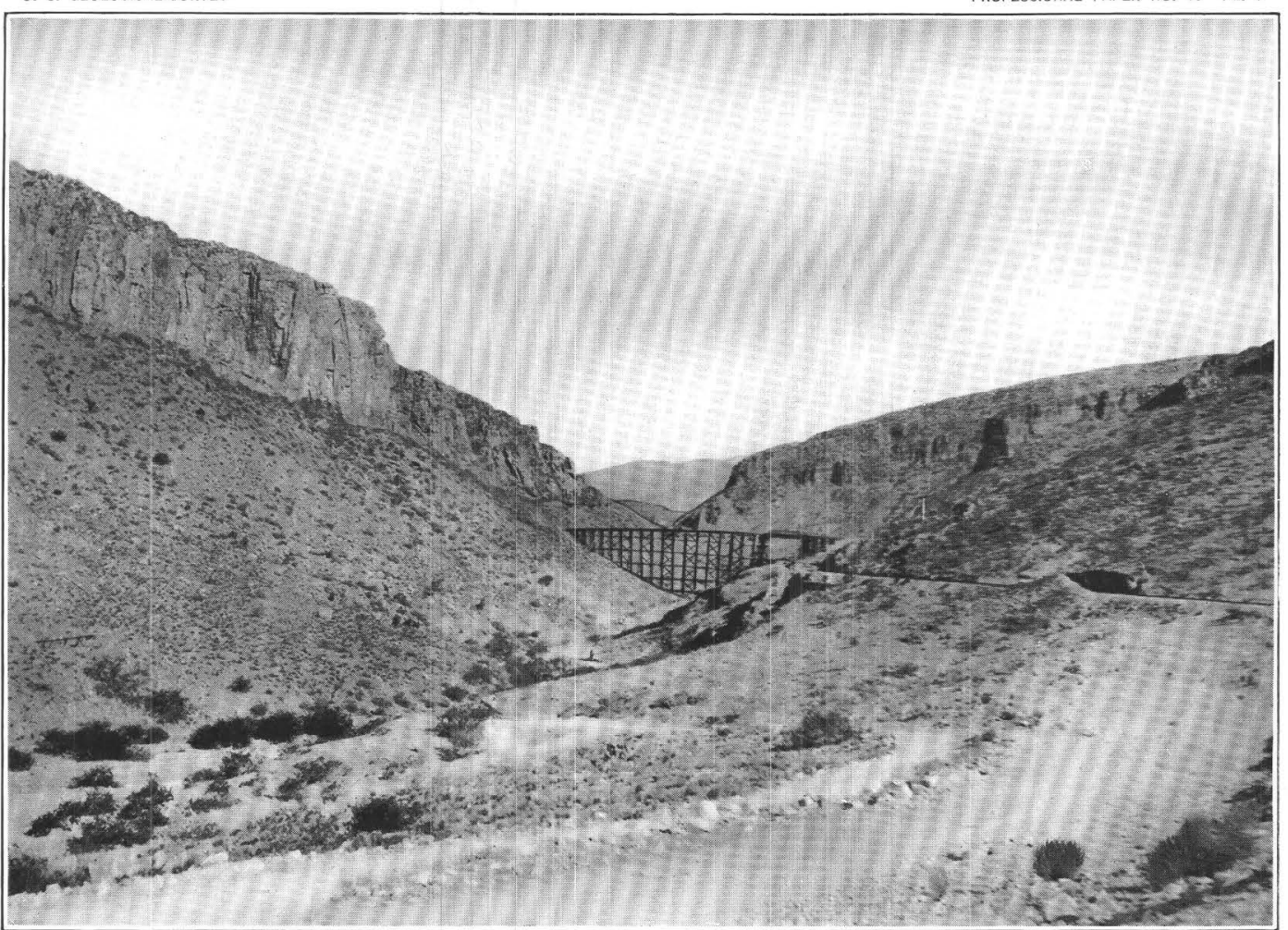

A. MOUTH OF MORENCI CANYON, LOOKING UP TOWARD MORENCI.

Cambrian quartzite to the left, Ordovician limestone to the right. Copper Mountain fault, separating the two, follows bottom of canyon.

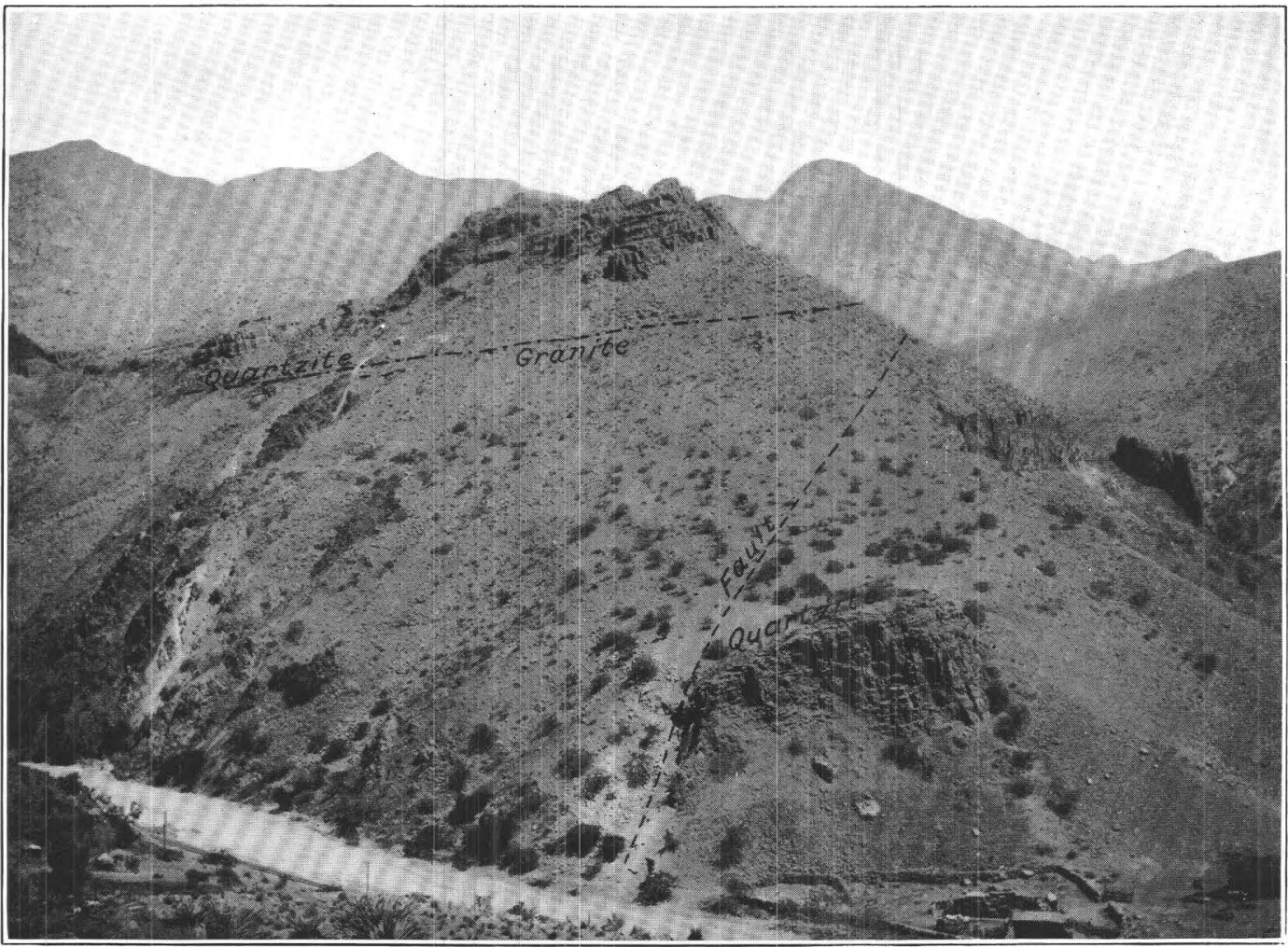

B. CHASE CREEK CANYON, LOOKING NORTH AT POINT WHERE CLIFTON-MORENCI ROAD TURNS UP OVER THE GRAVEL HILLS. Granite and Cambrian quartzite separated by fault. Near top of ridge quartzite rests normally on granite. High granite mountains (Markeen,
Copper King) in background. 

Several smaller areas of granite occur among the faulted blocks northwest of Morenci; the Copper King granite extends across Chase Creek and follows the margin of the foothills for several miles south of Morenci; and a smaller detached area outcrops a couple of miles southeast of Clifton between the Gila conglomerate and the Coronado quartzite. The boundaries of the areas are formed by the covering or intruding later formations, which may consist of Cambrian quartzite, irruptive porphyries, Tertiary lavas, or Quaternary gravels, or again by fault lines which may bring any one of the formations present in the area in contact with the granite.

The prevailing color of the granite is red, ranging from a yellowish red to a deep brownish red, all due to the finely disseminated ferric oxide so common in the orthoclase. The outcrops are large and rounded, but without exhibiting, except locally, a very marked "wool-sack structure." The surface is covered by a thin layer of coarse sand, due to disintegration, in places where erosion has not acted with unusual vigor. The steep slopes of ravines and fault scarps, especially those on the west side of Chase Creek above Metcalf, show a prominent sheeting or jointing. The .joints usually have a northeast or north direction and, standing almost vertical, separate the rock into thick benches.

The weathering on Copper King Mountain is of a similar character, the sandy gentler slopes contrasting with the imposing dark-red cliffs, cut up into angular blocks by irregular joint planes, and facing San Francisco River.

The granite of Chase Crreek between Morenci and Metcalf is altered by quartz cementation and pyritic impregnation; oxidation has given it specially bright red and yellow colors, while the outcrops are extremely rough and irregular, with pinnacles and deep recesses. Fresh granite is only obtainable at points of intense erosion or where mining operations have penetrated the decomposed surface. The coarse-grained character remains constant over the whole area.

Petrography.-The typical granite, as shown, for instance, at Sycamore Gulch near the Poland prospect, is a reddish-brown coarse-grained rock, consisting of reddish, only occasionally light-green, feldspar grains, averaging perhaps $5 \mathrm{~mm}$. in diameter, light-gray quartz in smaller grains often intergrown with the feldspar, and a small amount of black biotite in inconspicuous aggregates; occasionally a grain or two of hornblende is present, but never, as far as known, any muscovite. The ferromagnesian silicates are rarely seen in specimens from the surface, having been decomposed to dull grayish or greenish secondary minerals.

In thin section large grains of orthoclase are most prominent. Microperthite is also very common, occurring in intergrowth with orthoclase. A few grains of 
a plagioclase with narrow striation were noted in some specimens. They are greatly sericitized, making determination difficult, but appear to be albite. Quartz abounding in fluid inclusions is always present, but often as small grains and in micropegmatitic intergrowth with orthoclase or perthite. Magnetite and zircon are accessories. The structure of the rock is normally granitic. In nearly all specimens from near the surface the feldspars are clouded by kaolin and sericite, while the biotite is entirely converted to sericite and chlorite. Occasional modifications occur, but are seldom conspicuous. As mentioned above, the orthoclase may locally increase, changing the rock to a quartz-syenite. Hornblende may increase, as shown in the cuts of the Coronado Railroad, 850 feet above the place where the wagon road leaves Chase Creek and ascends the hill toward Morenci. This rock is a normal granular aggregate of orthoclase, microperthite, and quartz, and probably a little individual albite, with rather abundant prisms and grains of green hornblende, and a considerable amount of magnetite or ilmenite. The quartz is present in only moderate quantity and partly in granophyric intergrowth with the feldspars. Sericite, chlorite, epidote, and pyrite have developed subordinately as secondary minerals.

Local modifications of still more basic character are very uncommon, the only one observed being in the bottom of a gulch 2 miles south of the point where the Coronado vein crosses the ridge summit. The granite here contains a small mass chiefly consisting of hornblende, soda-lime feldspar, and grains of magnetite or ilmenite.

Dikes connected with the intrusion of pre-Cambrian granite.-The intrusive character of the granite is inferred, although in this region no direct proof is available, no contacts with older rocks being visible. While dikes of coarse pegmatite are almost wholly absent, there are, in many places, irregular masses or well-defined dikes of granitic aplite, a medium-grained rock identical in composition with the normal granite, but of a more even-grained, "sugary" texture. These aplitic dikes, whose genetic connection with the granite is very clear, have not been separated from the latter rock on the map. Dikes of rhyolite, basalt, or of various intrusive porphyries, are abundant in places and will be described under their proper headings.

PALEOZOIC SEDIMENTARY ROCKS.

THE SECTION IN GENERAL.

Above the granite rests, in the vicinity of Clifton and Morenci, a thickness of about 1,000 feet of Paleozoic stratified rocks, comprising the Cambrian, Ordovician (formerly called lower Silurian), Devonian (?), and Carboniferous systems. 
They have been subdivided (see fig. 2) into Coronado quartzite (probably Cambrian), Longfellow limestone (Ordovician), Morenci shales (probably Devonian), and Modoc limestone (Mississippian, or lower Carboniferous).

The Pennsylvanian is not known to be present in the area here discussed, but heavy limestone beds of this series, several hundred feet thick, are found conformably overlying the Mississippian in the northerly part of the Clifton quadrangle. There is no known unconformity in the whole Paleozoic column, though by no means all of the subdivisions of the systems have been shown to be present.

Compared to other places in Arizona the thickness of the Paleozoic column is slight. Mr. Ransome describes 1,700 feet of strata from Globe ${ }^{a}$ and over 5,000 feet from Bisbee. ${ }^{b}$

\section{CORONADO QUARTZITE.}

General character and distribution.--Resting immediately on the granite basement, the Coronado quartzite has a wide distribution and is everywhere easily recognized. It consists chiefly of heavy beds of brown, pink, or maroon quartzitic sandstones, usually characteristically jointed, as shown on Pl. VI, which represents an exposure about 2 miles south of Morenci. Its lowest member is a quartzite conglomerate, up to 50 feet thick, but this is missing in many sections. Several smaller areas of this formation conspicuously crown the summit and westerly slope of Coronado Mountain. The largest area, covering several square miles, lies a thousand feet lower on the south side of the great Coronado fault fissure, and forms a fault block, broken by many minor dislocations, but, on the whole, dipping gently westward. Minor patches cover the granite in upper Chase Creek Valley, or are bounded by short fault

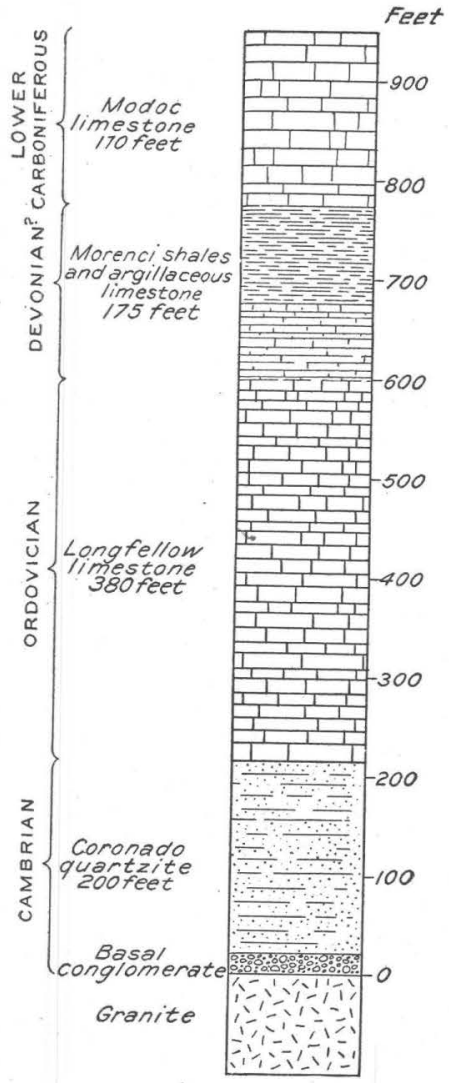

FIG. 2.-The Paleozoic columnar section at Morenci. planes, while eastward similar areas cap the granite bluffs overlooking San Francisco River. At lower elevations a continuous band of this formation begins near the Longfellow incline on the west side of Chase Creek Canyon and, following it for a couple of miles, swings southwest, with foothills facing the

a Ransome, F. L., Geology of the Globe copper district: Prof. Paper U. S. Geol. Survey No. 12, 1903.

$b$ Ransome, F. L., The geology and ore deposits of the Bisbee quadrangle, Arizona: Prof. Paper U. S. Geol. Survey No. 21,1904 . 
gravel plains of Gila conglomerate, and continues to a point 3 miles south of Morenci. A few exposures of the formation, resting on granite, are also found on the east side of San Francisco River.

In many places erosion has left only a thin cover of quartzite lying upon the granite. Where the whole thickness of the formation remains, as near Morenci, it attains a maximum of 250 feet, but this is not maintained at all exposures; near the mouth of Apache Gulch, due south of Morenci, there are only from 100 to 150 feet exposed. The basal conglomerate, consisting of a maximum of 50 feet of well-washed quartzite cobbles, cemented by granitic sand and gradually changing into sandy beds, is well exposed in the bluff forming the summit of Coronado Mountain, and is present at many other localities, but is not a universal feature. At the foot of Longfellow incline it is only 2 feet thick. Two miles southwest of Morenci the following section was observed:

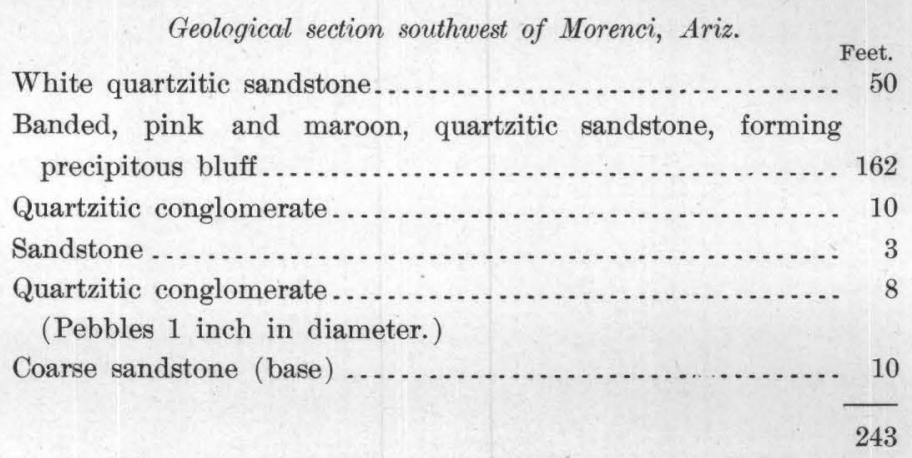

Near the mouth of Apache Gulch, south of Morenci, the conglomerate is lacking, sandstones resting directly on the granite. A characteristic exposure from Morenci Canyon is shown in Pl. VI, $B$.

In the great fault block covering the western slope of the ridge south of the Coronado mine, a clearly defined stratification is often wanting; the basal conglomerate is occasionally present in slight development, while as frequently it is missing. In such case the exact line of demarcation between granite and detrital rock may be difficult to perceive; the underlying granite appears disintegrated, bearing evidence of pre-Cambrian weathering. Thin strata of olive-colored shale were observed in a few places; for instance, near the top of the formation on the summit of Coronado Mountain, and in the gulch just south of the Longfellow incline in Chase Creek.

Petrography.--The rock is usually thick bedded, though sometimes delicately banded in detail, and shows various colors from light pink to darkest maroon; the distinguishing color of the outcrops is dark brown. Properly speaking, it is a hard quartzitic sandstone of varying grain, most commonly, however, showing grains averaging $1 \mathrm{~mm}$. in diameter. Near the base are intercalated beds of coarser 


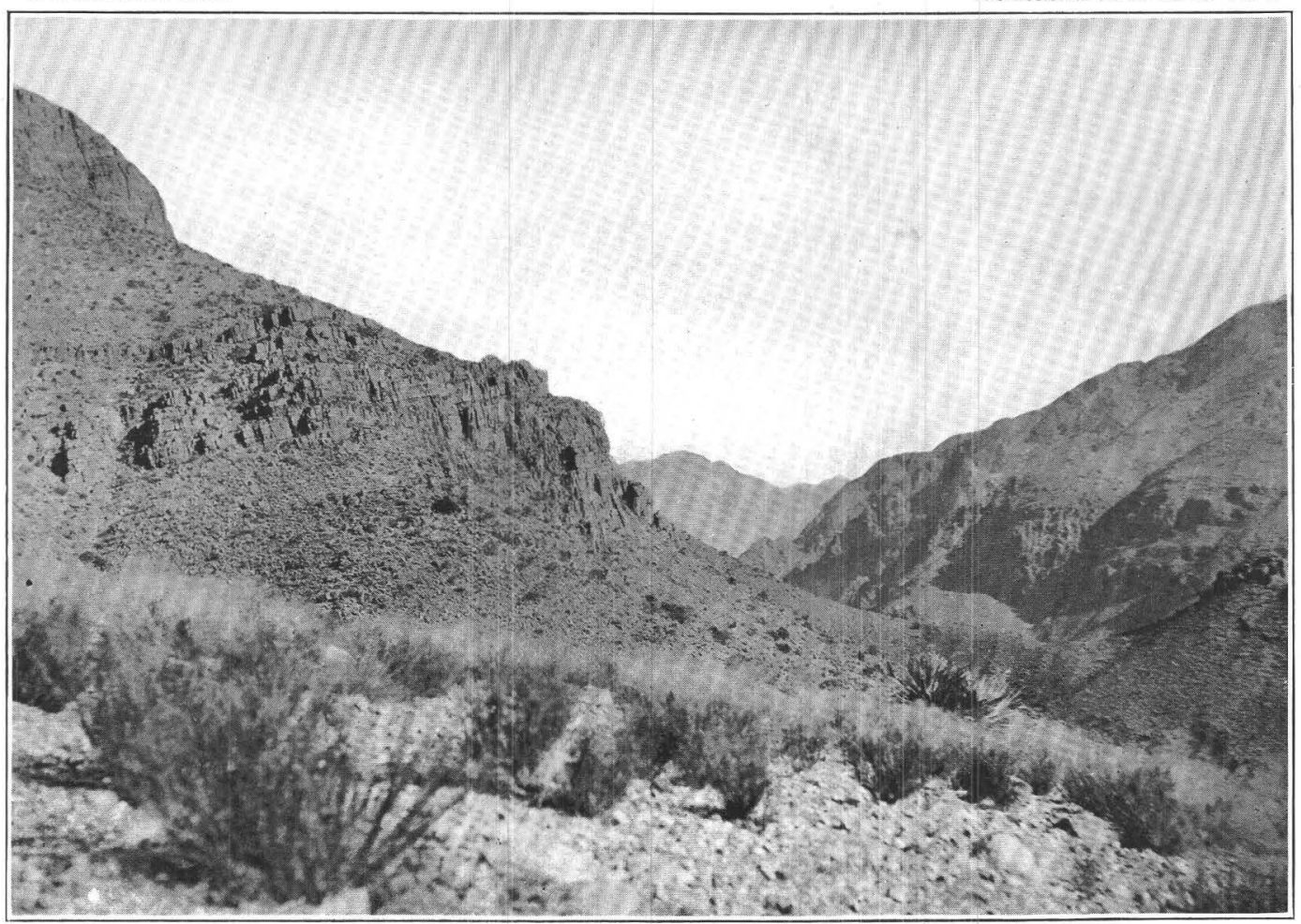

A. VIEW UP CHASE CREEK FROM POINT ON ROAD BETWEEN CLIFTON AND MORENCI.

$$
\text { Cliff of Coronado quartzite on left, capped by Longfellow limestone. }
$$

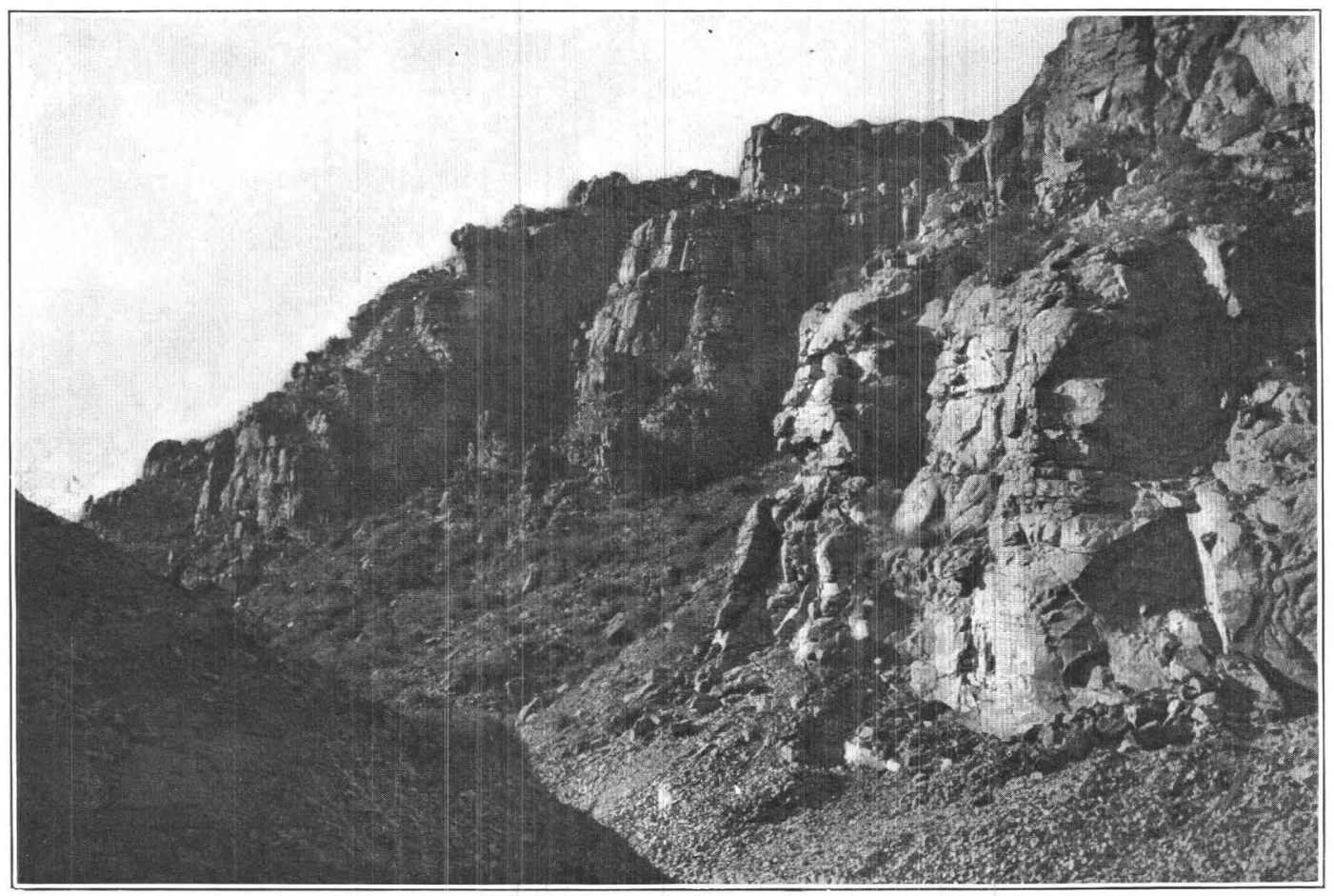

B. CLIFFS ON WEST SIDE OF MORENCI CANYON, SHOWING CORONADO QUARTZITE. 
grain, which at many places change into coarse conglomerates. The clastic grains almost universally consist of light-gray granitic quartz, are generally rounded, and contain abundant fluid inclusions. Grains of sericitized orthoclase are occasionally found, but no other rocks are represented. The cement consists chiefly of sericitic particles, mixed with fine granitic detritus. The whole indicates very clearly derivation by slow processes from a disintegrating granite, the feldspar of which has had ample time to become converted into sericite and kaolin.

By secondary ore-forming processes pyrite may develop metasomatically, both in quartz grains and cement; in a few places near Morenci this quartzite is mined as ore.

The conglomerate consists exclusively of well-washed cobbles and pebbles of a somewhat harder quartzite than that which forms the mass of the formation; neither granite nor aplite was found in it at any of the numerous places in which it was examined. The derivation is plainly from pre-Cambrian quartzite masses. Such rocks have not been found in the area here discussed, but occur farther north in the Pinal formation in the same Clifton quadrangle. The absence of granite fragments bears still further evidence of the deep pre-Cambrian disintegration of the granite.

Conditions of deposition. - The even bedding of the body of the Coronado formation shows deposition in a large body of water, and while the marine origin of the top strata is proved by the occurrence of fossil shells, it seems probable that the conglomerate is a fluviatile deposit gradually merging into marine conditions. Its very irregular occurrence and thickness, as well as the disintegration of the underlying granite, confirm this conclusion. The pre-Cambrian land surface was evidently one of gentle outline, except for some projecting masses of old quartzite and schists. The present surface of contact between the granite and the Coronado formation is greatly modified by warping and dislocation.

Age and correlation.-The determination of the Coronado formation as Cambrian is largely circumstantial, based chiefly on its well-defined position as a distinct division of quartzose sediments below Ordovician limestone and above an unconformity of the first importance. The only fossils thus far found in the Coronado formation were discovered by Mr. Boutwell in olive shales, 25 feet below the top of the quartzite, in a section just south of the Longfellow incline in Chase Creek, and consist of small lingula-shaped shells.

Mr. Charles D. Walcott has given the following opinion of them: "One species is represented - a small form of Lingulella. Similar forms are found in the Middle Cambrian of the Grand Canyon. Your material is, however, so imperfect that I do not like to base specific determination upon it."

The quartzites at the base of the Paleozoic section have a very wide distribu- 
tion in Arizona. Mr. Dumble ${ }^{a}$ describes such quartzites from the Dragoon, Whetstone, Chiricahua, and Mule Mountains, and refers to them as the Dragoon quartzites. Mr. Ransome has examined a similar but much thicker and more variable group of formations at Globe and given it the name of the Apache group. $^{b}$ The Bisbee equivalent Mr. Ransome refers to as the Bolsa quartzites, the thickness of which ranges up to 500 feet. $^{c}$ No fossils have been found at either of these localities.

LONGFELLOW LIMESTONES.

General character and distribution.-Under this formation name have been grouped a maximum thickness of about 400 feet of strata conformably covering the supposed Cambrian (Coronado quartzites) and consisting of limestones usually more or less dolomitic and gradually growing more siliceous near their lower limit. The upper 150 feet always form a prominent bluff of brownish limestone, while the lower 250 feet contain more shaly strata, usually forming a more gentle slope leading down to the steep quartzite bluff beneath (Pls. IV, $A ; \mathrm{V}, B$ ).

The formation is extensively developed in the southern marginal mountain region. Bluffs of it line San Francisco River for a couple of miles north of Clifton, the areas forming deeply sunken blocks at the foot of Copper King Mountain. An area aggregating a few square miles is exposed east and south of Morenci, here again forming a series of faulted blocks. Another block about 1 square mile in size lies north of Gold Creek on the slope toward Eagle Creek. Many smaller detached masses are known; some of them occur at the northern edge of the district near the line where the older formations dip below the southern edge of great lava areas.

Detailed sections. - One of the type localities examined is along the steep bluffs on the western side of Chase Creek Canyon. The best section obtained runs northeast from the high limestone point one-fourth mile south of Modoc Peak, the beds being well exposed below the Carboniferous and Devonian along the steep slope of Chase Creek Canyon.

Geological section one-fourth mile south of Modoc Peak.

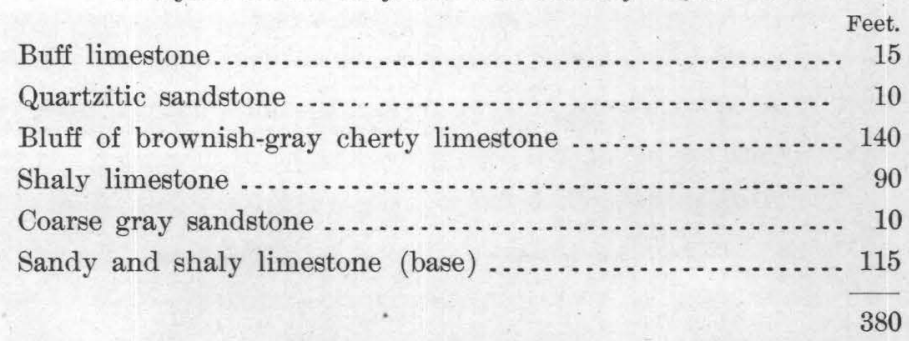

$a$ Dumble, E. T., Notes on the geology of southeastern Arizona: Trans. Am. Inst. Min. Eng., vol. 31, 1902, pp. 696-715. ${ }^{b}$ Ransome, F. L., Geology of Globe copper district, Arizona: Prof. Paper U. S. Geol. Survey No. 12, p. 28.

o Ransome, F. L., Geology and ore deposits of ${ }_{i} B i s b e e$ quadrangle, Arizona: Prof. Paper U. S. Geol. Survey No. 21, p. 28. 


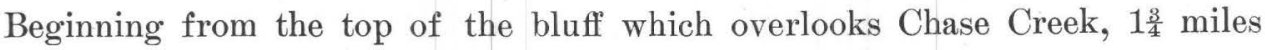
southeast of Morenci, the following section was obtained. The summit of this bluff probably does not correspond to the upper limit of this formation.

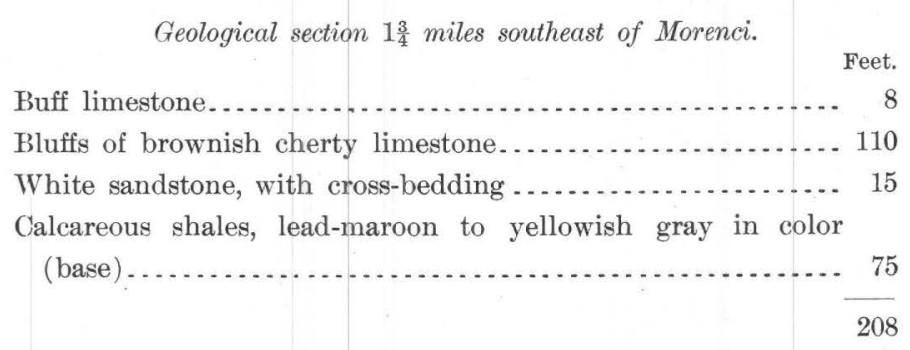

A part of the lower shales is probably displaced by an intrusion of porphyry, which here separates the Longfellow limestone from the Coronado quartzite.

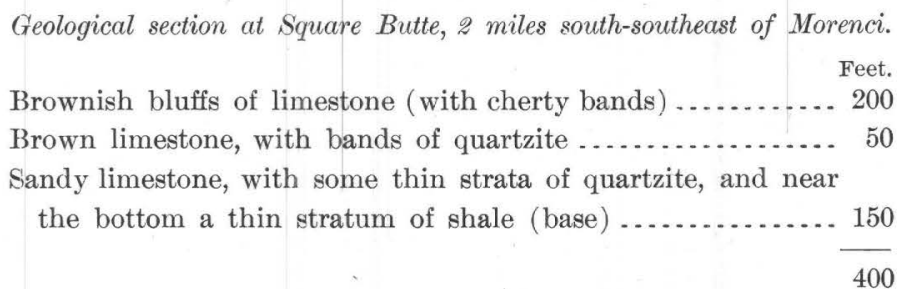

Near Garfield Gulch, 2 miles north of Metcalf, in Chase Creek Canyon, the series, whose whole thickness between Devonian and Cambrian seems to be present, amounts to only 140 feet. The upper part consists of heavy brown limestone, the middle of gray sandy limestone, and the lower of lime shales.

At the small, isolated limestone mass of Shannon Mountain, near Metcalf, 200 to 250 feet of dolomitic limestones were noted, lying between the Morenci shales and the Coronado quartzite. The color is yellowish brown, the upper part being heavy bedded and the lower more shaly.

Petrography and analyses.-A typical specimen of the cherty limestone shows that it is chiefly composed of coarsely crystalline calcite in irregular grains. There is evidently but little dolomite or magnesite present, but certain irregularly distributed strata contain more. Few of the rocks thus far examined consist of typical dolomite. The rock contains many small quartz grains, probably largely of clastic origin. The chert occurs in irregular bands or nodules, which under the microscope appear as an aggregate of greatly varying grain. Some of it consists of irregular quartz grains, while other parts contain much cryptocrystalline and fibrous chalcedonic material. Ragged calcite grains lie embedded in this mass, giving distinct evidence of the metasomatic origin of the chert by replacement of calcite by siliceous waters. The normal rocks contain no pyrite nor other sulphides. The Longfellow limestone is, as a rule, too siliceous to be used for quicklime or smelting flux. A number of partial analyses have been made of it at 
Morenci in the laboratory of the Detroit Copper Company by Mr. L. R. Wallace. This horizon is in the lower half of the Longfellow limestone.

Partial analyses of limestone at the rear of boiler room of Detroit Copper Company's smelter.

\begin{tabular}{|c|c|c|c|c|}
\hline & $\mathrm{CaCO}_{3}$. & $\mathrm{MgCO}_{3}$ & $\mathrm{SiO}_{2}$ & $\begin{array}{c}\mathrm{Fe}_{2} \mathrm{O}_{3} \\
\mathrm{Al}_{2} \mathrm{O}_{3}\end{array}$ \\
\hline $\begin{array}{l}\text { Lower stratum (contains small } \\
\text { pockets of copper carbonate) }\end{array}$ & 56.4 & 9.0 & 30.0 & 2.6 \\
\hline Upper stratum ......................... & 90.08 & 1.5 & 4.7 & 2.0 \\
\hline
\end{tabular}

The following series of partial analyses are of limestones from the base of the hill in Morenci Canyon west of the smelter up to Hernández's wood yard, a vertical distance of 100 feet; the horizon comprises the uppermost 100 feet of the Longfellow limestone:

Partial analyses of limestone from Morenci Canyon west of smelter.

\begin{tabular}{|c|c|c|c|c|}
\hline & $\mathrm{CaCO}_{3}$. & $\mathrm{MgCO}_{3}$ & $\mathrm{SiO}_{2}$ & $\begin{array}{l}\mathrm{Fe}_{2} \mathrm{O}_{3}+ \\
\mathrm{Al}_{2} \mathrm{O}_{3} .\end{array}$ \\
\hline $1 \ldots .$. & 57.0 & 35.0 & 5.5 & 0.5 \\
\hline $2 \ldots \ldots \ldots$ & 55.0 & 29.0 & 5.5 & ... \\
\hline $3 \ldots$. & 88.0 & .5 & 9.5 & .6 \\
\hline $4 \ldots \ldots+1$. & 90.0 & .6 & 5.4 & .7 \\
\hline $5 \ldots \ldots \ldots \ldots \ldots$ & 89.4 & .6 & 7.8 & .4 \\
\hline $6 \ldots \ldots \ldots$ & 89.4 & 1.0 & 7.0 & .7 \\
\hline $7 \ldots \ldots \ldots$ & 90.7 & .8 & 5.8 & .7 \\
\hline $8 \ldots \ldots \ldots$. & 82.3 & 1.5 & 12.6 & 1.0 \\
\hline $9 \ldots \ldots$ & 86.6 & 2.0 & 8.3 & .5 \\
\hline $10 \ldots \ldots$ & 90.7 & .5 & 6.5 & .5 \\
\hline $11 \ldots \ldots \ldots$ & 86.0 & 1.5 & 9.8 & .6 \\
\hline $12 \ldots \ldots \ldots \ldots$ & 84.6 & .5 & 13. 6 & .5 \\
\hline $13 \ldots \ldots \ldots$ & 89.8 & 2.2 & 5.9 & .5 \\
\hline $14 \ldots \ldots \ldots \ldots$ & 88.0 & 1.5 & 6.2 & ... \\
\hline $15 \ldots \ldots$ & 86.2 & 2.2 & 8.0 & .4 \\
\hline $16 \ldots \ldots$ & 86.2 & 2.5 & 8.9 & .6 \\
\hline $17, \ldots \ldots$ & 84.6 & 2.0 & 10. 0 & .9 \\
\hline $18 \ldots \ldots \ldots \ldots \ldots$ & 76.5 & 5.0 & 14.5 & 1. 0 \\
\hline $19 \ldots \ldots$ & 86.0 & .5 & 11.0 & .6 \\
\hline $20 \ldots \ldots$ & 69.5 & 10.2 & 14.5 & 1.0 \\
\hline $21 \ldots \ldots$ & 73.0 & .6 & 24.0 & .6 \\
\hline $22 \ldots \ldots$ & 72.0 & .5 & 25.0 & .5 \\
\hline 23 (base) & 68.0 & 1.5 & 27.6 & .5 \\
\hline
\end{tabular}

The increase in silica toward the base of the bluff is very noticeable. 
The Longfellow limestones, exposed on Shannon Mountain, are largely metamorphosed; many of them would seem to be somewhat dolomitic in composition. An analysis made for the Shannon Copper Company of a hard, blue, fine-grained limestone from the Black Hawk tunnel 30 feet above the top of the Coronado quartzite runs as follows:

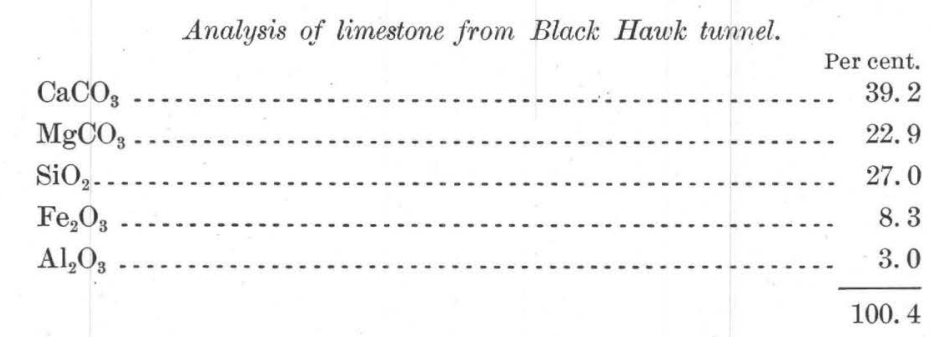

It is probable, however, that the specimen analyzed contained some pyroxene and epidote, due to metamorphic processes.

Age and correlation.-Fossils are very searce throughout the Longfellow limestone. In the lower, shaly part the only occurrence thus far found is in the second of the detailed sections; 20 feet above the top of the quartzite a few small lingulas were found, together with crinoidal remains. Mr. Charles D. Walcott states that, while no very certain determination of age can be based on them, they probably indicate the uppermost part of the Cambrian; there is thus a possibility that a part of the Longfellow formation may be of Cambrian age. The best fossils were found in a layer of yellowish-gray shaly limestone at the top of the same section and consisted of gasteropods and fragments of trilobites, the latter in part very large. A similar fauna was found one-half mile farther northwest on the same ridge in the same stratigraphical position, and also in a gulch one-fourth mile northeast of Newtown in the same vicinity.

On these fossils Mr. E. O. Ulrich reports as follows:

"The fossils contained in the lots submitted (lots 7, 8, 9, and 10), collected by Mr. J. M. Boutwell, are on the whole so poorly preserved and incomplete that I am not willing to make a positive specific identification at the present time. Still, the general aspect of the collections and, in particular, the 'association' of generic types leave no doubt in my mind concerning the age indicated by the fossils.

"The four lots all indicate practically the same time interval-it is not unlikely that they are all derived from the same bed, which I believe the evidence in hand warrants me in placing in the Calciferous age (= early Ordovician).

"All four lots contain a species of Raphistomina or of some related gasteropod genus, an Ophileta, a Dalmanella similar to D. hamburgensis Walcott, a species of Camarella or Syntrophia, a new type of Cephalopoda near Endoceras, an early type of Asaphus, a small Dikellocephahus (?), and a larger trilobite related to Bolbocephalus."

16859-No. $43-05-5$ 
Four miles west of Morenci, on the slopes toward Eagle Creek, is a large area of the upper part of Longfellow limestone. Flat gasteropods, similar to Raphistomina, were observed in the center of this area and near the principal trail crossing it.

As far as known this is the first definite occurrence of the Ordovician system discovered in Arizona. Mr. Ransome has found no rocks indicating this age in the Globe ${ }^{a}$ or in the Bisbee ${ }^{b}$ districts. In both places Devonian strata, chiefly consisting of limestones, directly overlie the Cambrian.

A broad belt, in which Ordovician strata are abundantly developed, is found in western Nevada, extending from the vicinity of Eureka down to within 40 miles of the great bend of Colorado River and the Arizona line.

The distribution of the system within this area is discussed in the reports on the fortieth parallel, ${ }^{c}$ in Hague's ${ }^{d}$ and Walcott's ${ }^{e}$ monographs on the Eureka district, and in a recent bulletin by Mr. J. E. Spurr. ${ }^{f}$ The nearest point of this belt is about 350 miles distant from Clifton in a westerly direction. Along the Grand Canyon of Colorado River the Ordovician is thus far not known; neither does it occur in southwestern Colorado. On the other hand, Mr. G. B. Richardson ${ }^{g}$ has recently found the formation strongly developed at El. Paso and other places in western Texas. North of this point it is known to occur along eastern Colorado, as, for instance, in the Pikes Peak quadrangle. Mr. Ellis Clark $^{h}$ reports its presence, possibly together with Silurian, at the Lake Valley silver mines in the south-central part of the territory, and more careful search will probably show its presence at many other points in New Mexico.

\section{MORENCI SHAIES.}

General character and distribution.-Between the Modoe formation of the Carboniferous and the Longfellow formation of the Ordovician are conformably intercalated a group of strata which have tentatively been referred to the Devonian system. The rocks consist of about 100 feet of clay shales underlain by 75 feet of compact and fine-grained argillaceous limestone; this lower part is, however, missing in some parts of the Clifton quadrangle, and as, moreover, it can not conveniently be mapped separately on a small scale it has been grouped with the shales into one formation on Pl. I, while on the special map (Pl. XVII) the two members have been separated.

$a$ Prof. Paper U. S. Geol. Survey No. 12, 1903.

$b$ The geology and copper deposits of Bisbee, Ariz.: Trans. Am. Inst. Min. Eng., Feb., 1903.

$c$ King, Clarence, U. S. Geog. Exp. Fortieth Parallel, 1871, 1872, 1873.

$d$ Hague, Arnold, Geology of the Eureka district: Mon. U. S. Geol. Survey, vol. 20, 1892.

$e$ Walcott, C. D., Paleontology of the Eureka district: Mon. U. S. Geol. Survey, vol. 8, 1884

$f$ Spurr, J. E., Descriptive geology of Nevada south of the fortieth parallel: Bull. U. S. Geol. Survey No. 208, 1903.

$g$ Oral communications.

$h$ Trans. Am. Inst. Min. Eng., vol. 34, 1894, p. 138. 
Though not occupying large surface areas it is present wherever the compassing formations occur; for instance, on San Francisco River a short distance above Clifton, in the vicinity of Morenci, and near Garfield Gulch. It usually forms a gentler slope between the bluffs of Modoc and Longfellow limestone.

Petrography and analyses.-The clay shales are fissile black rocks, fairly hard when fresh, but crumbling easily and softening and becoming grayish on exposure. Under the microscope they show the usual cryptocrystalline aggregate of clay shales with abundant greenish minute flakes and fibers, probably consisting of glauconite. Small cubes of pyrite occur sparingly. Calcic carbonate is often entirely absent. A specimen from below the Detroit Copper Company's limestone quarry contained, according to $\mathrm{Mr}$. L. R. Wallace, 2 per cent of CaO. A slightly hardened but otherwise typical rock taken 30 feet east of the big dike crossing the trail from Newtown to the top of Longfellow incline, near Morenci, gave:

Analysis of clay shale, No. 318, Clifton collection.

[W. F. Hillebrand, analyst.]

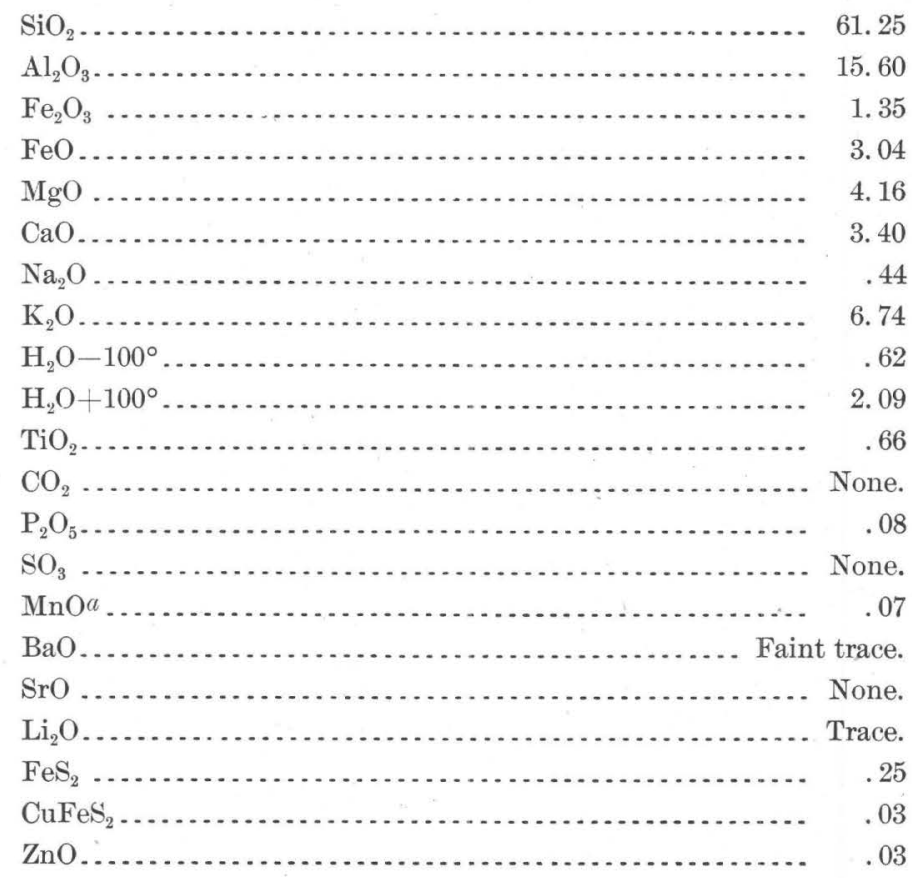

99.81

$a$ Partly $\mathrm{MnO}_{2}$. 
The analysis indicates a fairly typical clay shale, the high percentage of $\mathrm{K}_{2} \mathrm{O}$ being characteristic of many of these rocks. Less common is the large amount of $\mathrm{CaO}$, which evidently is not present as carbonate but as some silicate, probably epidote. The rock is somewhat hardened by the adjacent intrusive mass and slight metamorphic changes may have taken place. The copper and zinc present in minute quantities are also believed to be derived from the intrusive rock, as ores of these metals of contact-metamorphic origin occur only a few hundred feet away. In the section near Morenci, one-fourth mile south of Modoc Mountain, the shale contains near its top strata a dark-gray fine-grained dolomite, weathering yellowish red.

The limestone underlying the shales appears in most typical form at Morenci, while north of Metcalf a corresponding member could not be found.

This limestone, about 75 feet thick, is nearly black when fresh, extremely fine grained, and breaks under the hammer with a ringing sound into shelly fragments. The outcrops are well stratified in thin benches which appear peculiarly pitted by weathering and have a bluish-gray color altering on oxidation to a yellowish tone. In thin sections the rock is very fine grained, consisting chiefly of calcite, though some small rhombohedrons of dolomite are present. Minute cubes of pyrite are scattered through the mass.

A specimen from the lower part of this member at Blas Hernández's house, opposite the Detroit smelter, gave the following result:

Analysis of limestone from near Detroit Copper Company's smelter.

[L. R. Wallace, analyst.]

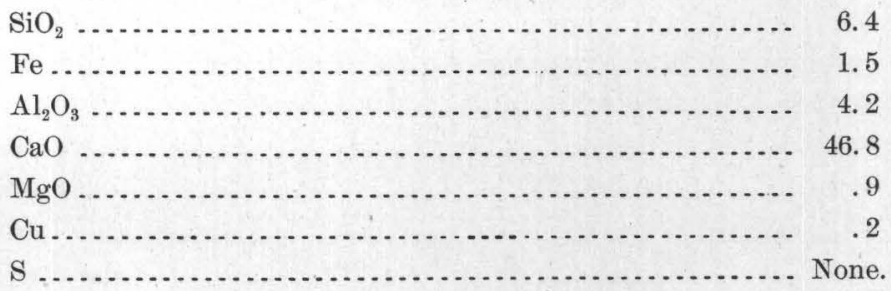

The total percentage of carbonates would be about 85.4. Silica and alumina are both high, indicating admixture of clayey substance.

Age and correlation. - While no fossils have been found in the shales, the argillaceous limestone contains at many points near Morenci a scant fauna of corals and gasteropods, all of them noticeably stunted and small in development. On these Prof. H. S. Williams reports as follows: 
"The material presents a few fragments of fossils and is probably all from a single formation. There is very little, however, that is thoroughly diagnostic of a particular horizon. The species are:

? Zaphrentis sp.............. A small form.

Crinoid stems . . . . . . . . . . Too imperfect to generically identify.

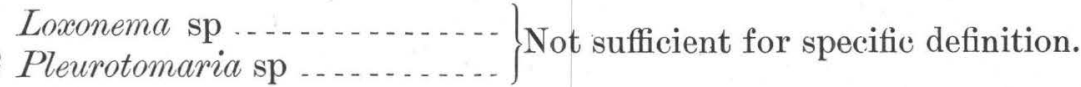

Schizophoria ef. ivanofi Tsch _. A small imperfect specimen of which I wrote in the letter to Mr. Girty, referred to as follows:

"The specimen approaches the Orthis ivanofi Tsch. type of Russia more closely than our eastern forms of Schizophoria McFarlani, which is quite consistent with the hypothesis that it belongs to the same fauna as that of the Devonian sent by Ransome from the Globe quadrangle.

"Although the typical species of the Globe and Bisbee quadrangles Devonian are not present, the Schizophoria is so diagnostic of the same general fauna that I am of opinion that you will be safe in calling it Devonian, though nothing in the lot will certainly exclude it from either Silurian or Carboniferous so far as the present evidence goes. I would classify the horizon as probably Devonian, awaiting more perfect fossil evidence for a closer correlation."

Mr. Ransome found a well-developed Devonian horizon at Bisbee, Ariz., ${ }^{a}$ consisting of 340 feet of dark-colored, compact limestones with some intercalated shales, and refers to it as the Martin limestone. At Globe, Ariz., he discovered 700 feet of buff and gray limestones, which he referred to the same age, but which seem to present no petrographic similarity to the Clifton-Morenci ${ }^{b}$ occurrence.

In the Grand Canyon section Mr. C. D. Walcott ${ }^{c}$ found 100 feet of Devonian strata resting with slight unconformity on the Cambrian Tonto group.

\section{MODOC LIMESTONE.}

General character and distribution.-The Modoc formation, which represents the lower Carboniferous or Mississippian series, consists of about 170 feet of coarse blue or gray limestones, with subordinate strata of quartzite and dolomite. The gray limestone, which forms a prominent cliff, is the characteristic part of the formation and recurs at many places.

The areas covered by the Modoc limestone are not extensive, scarcely aggregating more than 1 square mile on the general map (Pl. I), but the formation is of the greatest interest and importance in connection with metamorphic phenomena

$\alpha$ Prof. Paper U. S. Geol, Survey No. 21, 1904, p. 33.

$b$ Prof. Paper U. S. Geol. Survey No. 12, 1903, p.'39.

$c$ Pre-Carboniferous strata in the Grand Canyon of the Colorado, Arizona: Am. Jour. Sci., 3d ser., vol. 26, 1883, p. 438. 
and the copper deposits caused by them. Small areas outcrop on top of some bluffs along the river north of Clifton; others cover Modoc Mountain near Morenci and the opposite (west) side of Morenci Canyon, and still others cap Shannon Mountain and several hills in the watershed of Garfield Gulch.

Detailed descriptions. - The Morenci sections are practically identical. One of them extends from the summit of a high limestone point one-fourth mile south of Modoc Mountain down toward Chase Creek, forming the upper part of the complete general section from Carboniferous to Cambrian and to the granite; the other extends westward from the first railroad loop below the Morenci smelter. Thin strata of supposed Cretaceous age here cap the Modoc formation.

Geological section south of Modoc Mountain.

1. Blue, coarse, fossiliferous limestone in 2-3 feet thick

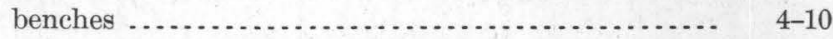

2. Light-gray coarse limestone with crinoid stems, 2 feet benches; vertical joints ("Gray Cliff" member).... $75-85$

3. Light-grayish-brown dolomitic limestone ........... 60

4. White or reddish calcareous quartzite, forming sharply defined stratum ............................... $15-17$

5. Massive bench of gray, coralliferous limestone ........ $\quad 8-10$

$162-182$

On Shannon Mountain the dolomitic stratum seems to be lacking. The section, though obscured by metamorphism, is as follows:

Geological section on Shannon Mountain.

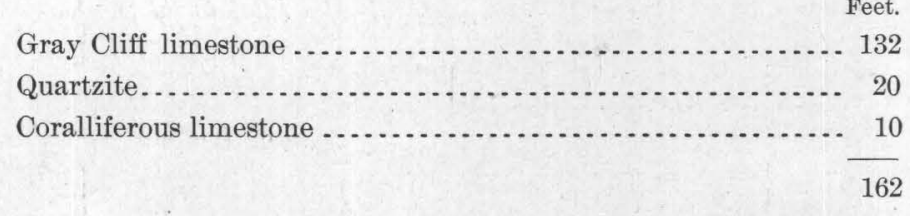

In the faulted limestone block just west of the mouth of Garfield Gulch, in Chase Creek Canyon, above Metcalf, the brown dolomitic stratum is again absent and the formation consists simply of 150 feet of light-gray bluffy limestone, equivalent to No. 2 in the first section.

Petrography and analyses.-In contrast to the siliceous limestone of the Longfellow formation, the Modoc limestones are exceptionally pure. The top stratum in the first section consists of coarse, bluish, almost pure limestone. The second stratum, the "Gray Cliff limestone," as it may be appropriately designated, is likewise a coarse granular rock of dark-gray color on fresh frac- 
ture, but weathering to lighter-gray tints. Specimens from Morenci consist of large irregular grains of calcite, the only other constituents noted being a few shreds of bright-red ferric oxide or hydrate. This gray limestone is extensively used as flux, being quarried at Morenci by both of the principal mining companies and on Shannon Mountain by the Shannon Copper Company.

Many technical analyses have been made of it, a few of which are here quoted:

Partial analyses of limestones from the Modoc formation.

\begin{tabular}{|c|c|c|c|c|c|}
\hline & $\mathrm{CaCO}_{3}$. & $\mathrm{MgCO}_{3}$ & $\mathrm{SiO}_{2}$. & $\begin{array}{c}\mathrm{Al}_{2} \mathrm{O}_{3} \text { and } \\
\mathrm{Fe}_{2} \mathrm{O}_{3}, a\end{array}$ & Insoluble. \\
\hline 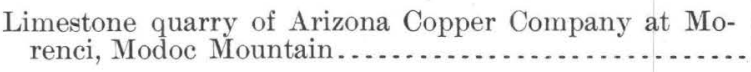 & 95.52 & 0.69 & & 0.92 & 1. 06 \\
\hline 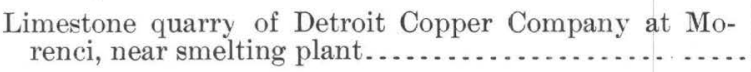 & 94.00 & & 1.00 & 2. 70 & \\
\hline Limestone quarry, Shannon Mountain, near summit..... & 82.50 & 9.54 & 1.34 & 1. 66 & \\
\hline
\end{tabular}

a Mostly ferric oxide.

It will be noted that the rock from Shannon Mountain, though similar in appearance and texture to the Morenci limestone, contains much more magnesic carbonate. It is very coarsely crystalline and almost white.

The beds immediately underlying the Gray Cliff limestone consist of heavy benches of light-brownish-gray limestone, weathering drab, and containing a few minute crystals of pyrite. In thin section it proves to be a fine- and even-grained dolomite:

Partial analyses of dolomite underlying pure limestone close to the Morenci smelter.

[L. R. Wallace, analyst.]

\begin{tabular}{|c|c|c|c|c|c|}
\hline & $\mathrm{CaCO}_{3}$ & $\mathrm{MgCO}_{3}$. & $\mathrm{SiO}_{2}$ & $\mathrm{Fe}_{2} \mathrm{O}_{3}$ & $\mathrm{Al}_{2} \mathrm{O}_{3}$ \\
\hline West end of quarry & 57.5 & 37.60 & 0.3 & 1.8 & 0.4 \\
\hline East end of quarry & 56.00 & 36.00 & 1.0 & 2 & \\
\hline Pure dolomite ..... & 54.35 & 45.65 & …... & & \\
\hline
\end{tabular}

Bed No. 4 in the first detailed section underlying the brown dolomite is very constant near Morenci, though it has not been found in the northern part of the Clifton quadrangle; it consists of a hard quartzitic sandstone, the grains being well rounded and cemented by calcite. The basal member of the formation is a heavy band of coralliferous bluish-gray limestone, which does not contain much dolomite. 
Age and correlation.-The Modoc limestone is fossiliferous throughout, wellpreserved species being found in it in the top, basal, and intermediate members. The determinations by Dr. G. H. Girty show that the formation throughout belongs to the Mississippian series of the Carboniferous system-i. e., to the lower Carboniferous. The determinations are as follows:

On trail to Silver Basin, $1 \frac{1}{2}$ miles southeast of Morenci; from the Coralliferous limestone, the basal member of Modoc formation: Rhipidomella Michelini?, Spirifer centronatus, and Seminula humitis?

In the section one-fourth mile south of Modoc Mountain, Morenci; from the Coralliferous limestone: Zaphrentis sp.

In the gap 1,000 feet south of Modoc Mountain; from the Coralliferous limestone: Zaphrentis sp., and Spirifer cf. centronatus and S. Forbesi.

In outcrops 850 feet S. $18^{\circ}$ E. from Modoc Mountain; from the top of the Gray Cliff limestone, No. 2 of first detailed section (p. 70): Orthis sp.

In outcrops 850 feet S. $18^{\circ}$ E. from Modoc Mountain, at an elevation of 5,100 feet; from heavy blue limestone, No. 1 of first detailed section (p. 70): Lithostrotion? sp., Menophyllum sp., Favosites sp., Granatocrinus sp., Platycrinus, Fenestella sp., Orthothetes inæqualis?, Spirifer near Spirifer keokuk, Spiriferina.

Many other fossil localities were found in the northern part of the Clifton quadrangle.

As is well known, the Mississippian series is extensively developed throughout the West. At Globe, Ariz., ${ }^{a}$ Mr. Ransome found this series present in the upper part of the Globe limestone, while at $\mathrm{Bisbe}^{b}$ he has referred 700 feet of strata to the same horizon under the name of the Escabrosa limestone.

\section{TULE SPRING LIMESTONE.}

This formation, which consists of heavy-bedded bluish-gray limestones with a characteristic upper Carboniferous or Pennsylvanian fauna, does not occur in the area here discussed (Pl. I), but is fairly extensively developed in the northern part of Clifton quadrangle. Near Morenci Mesozoic strata, not recognized elsewhere, unconformably overlie the lower Carboniferous.

\section{MESOZOIC STRATIFIED ROCKS.}

The Jurassic and Triassic are apparently not represented in this area, but rocks belonging to the Cretaceous have been found near Morenci. 
PINKARD FORMATION.

General character and distribution. - The Pinkard formation consists of a series of sandstones and shales with a thickness of several hundred feet. The best exposures are found in Silver Basin Creek, 2 miles southwest of Morenci, and in the Eagle Creek foothills, 4 miles distant in the same direction. The gently -upturned strata here surround an oval mass of diorite-porphyry intruded in them. In the porphyry stock of Gold Creek many smaller metamorphosed patches of the same strata occur. Modoc Mountain at Morenci is capped by a small area of the same strata, and a somewhat larger mass is exposed on the ridge overlooking thè head of Morenci Canyon on the south and west side; it is here again intruded by porphyries and partly metamorphosed by them.

The lowest part of this formation consists of black shales, which occupy considerable areas in Silver Basin; their upper part is made up of alternating shales and yellowish-gray sandstone, in places calcareous. A section from the top of the hill one-fourth mile southwest of Morenci smelter, eastward, shows the following succession, the beds here being somewhat metamorphosed:

Geological section southwest of Morenci smelter.

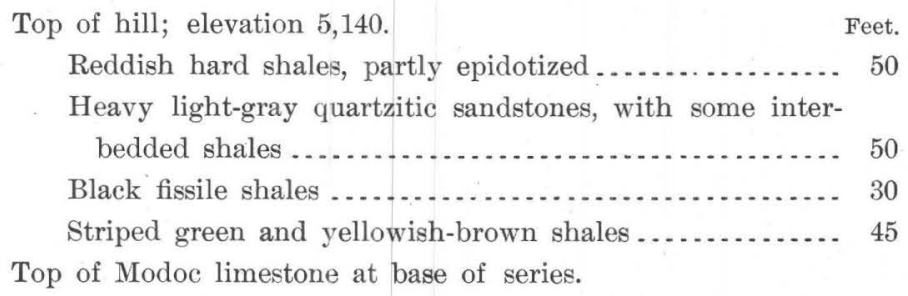

On the trail to Silver Basin, $1 \frac{1}{2}$ miles southwest of Morenci, is an outcrop of the Morenci shales covered by a thin bench of limestone, evidently corresponding to the base of the lower Carboniferous (the coralliferous limestone, No. 5 in detailed section, p. 70). Above this lie knotty arenaceous shales of greenish-gray color and a thin layer of yellowish limestone, clearly corresponding to the base of the Pinkard formation and northward overlain by the shales of Silver Basin. The total thickness present is difficult to measure on account of probable dislocations.

Thin strata of epidotized brown and greenish shales cover the summit of Modoc Mountain, overlying the uppermost stratum of the Modoc formation.

There is evidently an unconformity between the lower Carboniferous and the Cretaceous. It seems rather to be an unconformity by erosion than a structural break. 
Age and correlation.-Fossils were found in a calcareous sandstone overlying shale in a gulch one-half mile southeast of the porphyry hill with bench mark $5,175,2 \frac{1}{2}$ miles south-southwest of Morenci. The elevation is here close to 4,000 feet. The fossil bivalves are well preserved and some of the species are rather abundant. On this collection Dr. T. W. Stanton reports as follows:

"The fossils submitted include:

Fossils from calcareous sandstone south-southwest of Morenci.

Mactra sp. related to M. Warreneana M. \& H.

Corbula sp.

Cardium sp.

Astarte? sp.

Cyrena? sp.

\author{
Turritella sp. \\ Dentalium sp. \\ Glauconia coalvillensis Meek. \\ Tugnellus fusiformis Meek.
}

The last two species are characteristic forms of the Colorado group, which elsewhere are known only in the upper part of the Fort Benton formation and its equivalents."

At the eastern side of Silver Basin, $1 \frac{1}{2}$ miles southwest of Morenci, great numbers of small Astarte n. sp. were found, occurring in the lowest horizon almost immediately above the basal member of the Modoc formation. While these fossils are not conclusive as evidence of age, there can be no doubt that the strata are equivalent to the fossiliferous horizon described above. No fossils have thus far, in spite of careful search, been found in any other part of the Pinkard formation.

Cretaceous and Jurassic strata are known from the plateau province of northeastern Arizona. At Bisbee Mr. Dumble ${ }^{a}$ recently discovered the Cretaceous, and Mr. Ransome ${ }^{b}$ has described it more in detail. There are over 4,000 feet of Cretaceous strata which are referred to as the Bisbee group and subdivided into four formations. The upper surface at Morenci, as well as at Bisbee, is everywhere one of erosion, and thus the original thickness is, in both cases, unknown. From considerations of topography it is scarcely likely, however, that the total thickness at Morenci ever approached that at Bisbee. At Globe and other points in the interior of Arizona the Cretaceous has not thus far been found.

\section{CENOZOIC SEDIMENTARY ROCKS.}

No sediments of Tertiary age have been found, the volcanic flows of that period apparently always resting on a deeply eroded land surface. Strata of Quaternary age are, however, extensively developed, the most important formation being known as the Gila conglomerate.

$a$ Trans. Am. Inst. Min. Eng., vol. 31, pp. 703-706; Prof. Paper U. S. Geol. Survey No. 21, 1904, pp. 56-73.

$b$ Trans. Am. Inst. Min. Eng., February, 1903. 
GILA CONGLOMERATE.

General character and distribution.--This name was first applied by Mr. G. K. Gilbert to extensive and deeply eroded valley deposits extending along Gila River from the mouth of the Bonito up into western New Mexico. Mr. Gilbert ${ }^{a}$ characterizes the formation as follows:

"The bowlders of the conglomerate are of local origin, and their derivation from particular mountain flanks is often indicated by the slopes of the beds. Its cement is calcareous. Interbedded with it are layers of slightly coherent sand and of trass, and sheets of basalt; the latter, in some cliffs, predominating over the conglomerate. One thousand feet of the beds are frequently exposed, and the maximum exposure on the Prieto is probably 1,500 feet. They have been seen at so many points by Mr. Howell and myself that their distribution can be given in general terms. Beginning at the mouth of the Bonito, below which point their distinctive characters are lost, they follow the Gila for more than 100 miles toward its source, being last seen a little above the mouth of the Gilita. On the San Francisco they extend 80 miles; on the Prieto, 10; and on the Bonito, 15. Where the Gila intersects the troughs of the Basin Range system, as it does north of Ralston, the conglomerate is continuous with the gravels which occupy the troughs and floor the desert plains. Below the Bonito it merges insensibly with the detritus of Pueblo Viejo Desert. It is, indeed, one of the 'Quaternary gravels' of the desert interior, and is distinguished from its family only by the fact that the watercourses which cross it are sinking themselves into it and destroying it instead of adding to its depth."

The Gila conglomerate occupies about 30 square miles in the southeast corner of Clifton quadrangle. It skirts the flanks of the Morenci hills and the southeastern slopes of Copper King Mountain, attaining marginal elevations of about 4,500 feet, the ridges sloping thence southward, at a grade of 100 to 200 feet to the mile, until they abruptly drop off into the canyon of the San Francisco, 400 to 500 feet deep. A long bay of this formation extends northward into the mountain area, following the western side of San Francisco River up to a point 10 miles north of Clifton, where it forms small patches on basalt and rhyolite at elevations of 4,500 feet. The thickness exposed near Clifton is 600 feet, while along the river canyon, due east of Copper King Mountain, it almost reaches 900 feet. Along San Francisco River it does not extend more than 25 miles north of the Gila.

The material of the Gila formation consists almost exclusively of coarse subangular gravels, appearing more or less distinctly stratified by nonpersisting streaks or lenses of sand, and containing fragments of all of the older rocks of the mountains. In most places basalts and rhyolites predominate, as is natural

$a$ Gilbert, G. K., Preliminary geological report: U. S. Geog. Surv. W. 100th Mer., vol. 3, Appendix D, 1874, p. 540. 
when we consider that at the time when these deposits were being accumulated a much larger part of the quadrangle was covered by volcanic flows than at present. Other rocks may, however, locally preponderate; thus, for instance, below the area of porphyry, a few miles southwest of Morenci, where the gravels consist almost exclusively of coarse diorite-porphyry, often, indeed, difficult to distinguish from the deeply weathered outcrops of the same rock. Along the lower part of Eagle Creek volcanic rocks are extremely abundant in the Gila conglomerate, and the dividing line between this and the underlying basaltic and rhyolitic tuffs in places becomes indistinct.

Along San Francisco River and Chase Creek the erosion has in many places produced steep or nearly perpendicular bluffs of Gila conglomerate, usually pitted by reason of the gradual weathering out of the larger pebbles. Where volcanic rocks predominate the conglomerate is often well cemented, and in many places must even be blasted along railroad euts and tunnels.

From Morenci down to Clifton the gravels are roughly stratified, largely subangular, and the pebbles rarely attain over 1 foot in diameter. Volcanic rocks, granite, limestone, and quartz porphyry are mixed. They are not greatly consolidated, though forming small cliffs in places. The gravels contain a considerable amount of sand, but it is intimately mixed with the coarse material and rarely occurs in isolated streaks. The color of the Gila conglomerate is reddish to grayish white, especially in places where long-continued exposure has had opportunity to oxidize the iron.

In Ward Canyon the gravels lean up against the steep fault plane along which the granite here breaks off. North of the canyon patches of gravel lie on the granite at higher elevations of 4,300 feet. These were probably once connected with the great table of gravel south of the canyon, which has the same elevation, apparently showing that there has been no considerable dislocation of the conglomerate since its deposition.

The gravel bluffis begin almost immediately below Clifton, where they are seen leaning up against granite and basalt (Pl. II, A), and continue along the river for many miles. Excellent exposures are seen $1 \frac{1}{2}$ miles below the new Shannon smelter, especially on the west side (PI. III, B). The sandy river bottom is here from 300 to 600 feet wide; in several places there are narrow terraces of gravel, at most 100 feet above the creek. The bluffs, which in places are almost perpendicular, rise to a height of about 400 feet; the conglomerate is well cemented (railroad tunnels will stand in it without timbering) and is roughly stratified by small streaks of sand. On the whole, there is little sand and few indications of cross-bedding. The material consists of rhyolite, basalt, granite, 
and porphyry, all subangular, the fragments attaining 2 feet in diameter, but averaging about 8 inches. Some of the material on top of the bluff seems better rounded than the rest. South of San Francisco River the same formation continues over the undulating foothills down to the Gila, but the pebbles of the conglomerate become distinctly finer. At the Gila the formation leans against hills of basalt and other lavas.

Mode of deposition.-The Gila conglomerate is unquestionably of fluviatile origin, and was deposited during an epoch in which the lower reaches of the rivers gradually lost their eroding and transporting powers, while disintegration progressed rapidly in the mountains. Especially was it active among the loose masses of lava, which then covered so much of this quadrangle, from which intermittently torrential streams brought down vast masses of the crumbling rocks. The climatic conditions were then probably very similar to what they are at present.

The volcanic outbursts of the Tertiary took place under conditions of active erosion, the different flows being often deeply dissected before the eruption of the next mass. This epoch of erosion doubtless continued for a short time after the close of the igneous activity, for we find the Gila conglomerate deposited on an uneven and in places deeply dissected surface. A deep and narrow canyon was cut corresponding to the present San Francisco River, with a course parallel, but about a mile farther west; this is clearly marked by the bay of gravels now cut across by Chase Creek between Clifton and the Morenci foothills without exposing the bed rock. As far as known, the Gila conglomerate has not been warped or dislocated by faulting in this area, though studies extended over a wider field may very possibly modify this conclusion.

Age.-No fossils have been found in the formation. Mr. Gilbert, followed by Mr. Ransome, assigns an early Quaternary age to it, and no evidence from this region conflicts with this conclusion.

TERRACE GRAVELS.

Small benches of terrace gravels appear at a few places along San Francisco River and Eagle Creek, especially in the lower part of the stream courses. Such gravels are found on Eagle Creek in small bodies 100 to 200 feet above the creek in its lower course, and about 50 feet above the creek near the northern end of the quadrangle. Similar benches are found along the San Francisco. The Shannon smelter is built on one of them, which is exposed 1 mile below Clifton, rising 60 to 100 feet above the water level. These gravels, indicating a temporary check in the erosive power of the stream, are much later than the Gila conglomerate, and are referred to the late Quaternary. 
PRESENT STREAM GRAVELS.

The most recent Quaternary formation is the alluvium contained in San Francisco River and Eagle Creek. Both streams are well graded and occupy a continuous strip of sandy and gravelly bottom land, sometimes, however, narrowing to a width of only 100 or 200 feet. Just below Clifton the sandy alluvium of San Francisco River attains the unusual width of 2,000 feet.

\section{INTRUSIVE ROCKS.}

GENERAL STATEMENT.

Granting intrusive origin to the basal pre-Cambrian granite, there is a second and much younger series of igneous rocks contained as stocks, dikes, sheets, and laccoliths in all of the lower Cretaceous, Paleozoic, or pre-Cambrian formations. The time of intrusion of these falls between the middle Cretaceous and the middle Tertiary periods, but they far antedate the Tertiary lavas, which are spread out over their eroded surface. Porphyries of granitic, monzonitic, or dioritic affiliations predominate; diabase occurs in subordinate amounts and would appear to be somewhat later than the porphyries. The great dislocations followed these intrusions.

\section{PORPHYRIES.}

General character and distribution.-The porphyries form an almost continuous series of light-gray acidic or predominatingly feldspathic rocks, ranging from diorite-porphyry through monzonite-porphyry to granite-porphyry. Between the last two divisions no line can be drawn, but the diorite-porphyry occupies a somewhat more individual position.

The area covered by porphyry on the general map (Pl. I) hardly amounts to 9 square miles. The rock is extensively developed in the Morenci hills between Eagle Creek and Chase Creek, but also reaches up from the canyon of the latter on the north and the east flanks of Copper King Mountain.

The principal area forms a stock extending with jagged contacts for 7 miles in a northeast direction from the Eagle Creek foothills by Morenci to 1 mile northeast of Metcalf, where it splits up in very numerous dikes, all having a northerly or northeasterly trend. The northern half of this stock and its dikes is chiefly contained in granite, while the southern part is surrounded by Cretaceous shales and sandstones, Cambrian quartzites, or Ordovician limestones, and breaks up into a complicated mass of dikes and sheets near the point where the rocks dip below the basalts, which fill the valley of Eagle Creek. A narrow dike, breaking through Cretaceous sediments, connects this area with an oval mass of porphyry containing $1 \frac{1}{2}$ square miles, and almost entirely surrounded by slightly 
upturned Cretaceous sediments: This mass is evidently a laccolith. Dikes and rounded masses of the same rock are contained in the gently rolling Cretaceous area east of this laccolith.

At Shannon Mountain and Morenci, where the porphyry adjoins Paleozoic strata, the latter close to the contact contains a number of well-defined dikes. A persistent sheet of porphyry follows in places the division plane between Coronado quartzite and Longfellow limestone. Again, in the western portion of the great stock, the latter breaks up into a network of dikes and sheets, chiefly intercalated between the Ordovician strata. North of Metcalf, in Garfield Gulch and at the foot of the great lava masses of Malapais Mountain, are several smaller areas of porphyry, appearing as stock-like masses in granite, but frequently changing to sheet intrusions wherever in contact with limestones.

Summing up, it may be said that porphyries preferably occur as stocks and dikes in the granite, while in the Paleozoic sediments they are apt to take the form of sheets or sills. In the Cretaceous sediments again the tendency is to form laccolithic masses, probably because of the lighter weight and greater flexibility of superincumbent sediments.

The northeastern half of the principal stock, from Morenci to Metcalf, consists of granite-porphyries distinguished by large porphyritic quartz crystals. Many of the dikes, also, conform to this type. From Morenci to near the southwestern end of the stock the prevailing rock consists of monzonite-porphyry, containing quartz chiefly in the groundmass; the same is, as a rule, true of the dikes near Morenci; while the smaller areas inclosed in the mesh of altered sediments near the Eagle Creek basalt, as a rule, consist of diorite-porphyry. Diorite-porphyry also makes up the great laccolith mass in the southwestern foothills and the dikes in that vicinity; it also appears in Garfield Gulch and near the head of Placer Gulch.

Granite or monzonite-porphyry then chiefly occurs as stocks or dikes, while diorite-porphyry forms most of the sills, sheets, and laccoliths.

Petrography of the granite-porphyries.-As stated above, the northern end of the great porphyry stock from Morenci to beyond Metcalf consists of graniteporphyry, forming a belt from 1 to 2 miles wide. Within this area the rocks are almost universally affected by the introduction of quartz, pyrite, and sericite. The yellowish or reddish-brown outcrops, tinted by oxidizing pyrite, are apt to appear in extremely rough forms, well shown near the mouth of King Gulch, at Metcalf (Pl. VII, A). Fresh rock is almost impossible to obtain, the best being bleached and traversed by a network of quartz veinlets. Specimens from a railroad cut just south of King Gulch show on fresh fracture pale-greenish-gray color and contain closely massed dull-white feldspar crystals, at most 2 or $3 \mathrm{~mm}$. 
in length. There are also well-defined bipyramidal quartz crystals several millimeters in diameter, and sparingly represented biotite crystals converted into chlorite.

The groundmass is fine grained, and now consists chiefly of sericite and quartz; sericite has also largely invaded the feldspar phenocrysts, especially the orthoclase. The feldspars consist partly of orthoclase and partly of sharply defined albite crystals. A partial analysis of this rock by Dr. W. F. Hillebrand gave the following percentages: $\mathrm{SiO}_{2}, 69.13 ; \mathrm{CaO}, 0.22 ; \mathrm{Na}_{2} \mathrm{O}, 3.01$, and $\mathrm{K}_{2} \mathrm{O}, 3.94$.

Besides a large amount of quartz the rock would thus contain 23.5 per cent of the orthoclase molecule, 25.1 per cent of the albite molecule, and 1.1 per cent of the anorthite molecule. It clearly belongs to the granite-porphyry, the large amount of individually developed albite being especially notable.

The stock at the head of Placer Creek is similar in character, but the rock is fresher and contains more biotite as well as a little secondary epidote, a mineral which is absent in the porphyries of the Metcalf basin. Its presence indicates an approach to monzonitic and dioritic modifications. Many of the dikes east and west of Metcalf also belong to the granite-porphyriès, though quartz-monzonitic facies are more common. One dike at Las Trajas mine, a mile south of the Coronado vein, is especially rich in quartz.

Petrography of the quartz-monzonite-porphyries.-The rocks of the great stock at Morenci and Gold Gulch basin, together with many dikes, belong to this type, which, as well as the preceding division, have a close structural and genetic connection with the ore deposits. North and northeast of Morenci quartz cementation and pyritic dissemination are generally present and often accompanied by extensive sericitization. In this area the outcrops are reddish or yellowish red, and weather in irregular eraggy form. The rock is most typically developed in the Gold Gulch basin, where mineralization is slight or absent. Here it disintegrates easily to a sandy, yellowish soil and slightly rounded outerops; entirely compact and fresh rocks are not easily found. Specimens from the divide between Gold Gulch and Morenci Canyon, due west of Morenci, are light colored, with fairly abundant greenish biotite foils up to $2 \mathrm{~mm}$. in diameter; the feldspar prisms of light-yellowish-gray color are closely massed and reach a length of 3 to $4 \mathrm{~mm}$., while the quartz phenocrysts rarely attain $2 \mathrm{~mm}$. in diameter and show no well-defined bipyramidal form.

Under the microscope orthoclase, albite, and oligoclase, with an occasional crystal of labradorite, are shown to be present. The plagioclastic feldspars often show well-developed zonar structure. The groundmass is coarsely microcrystalline, consisting of quartz and nonstriated feldspar grains, with occasional octahedrons of magnetite. Sericite is present in the feldspars, while chlorite has 
formed from the biotite; a little secondary epidote also occurs. A partial analysis of this rock gave:

Partial analysis of No. 10, Clifton collection.

[W. F. Hillebrand, analyst.]

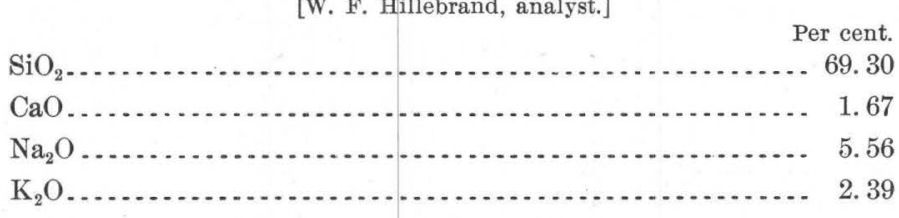

Similar porphyries make up the largest part of Copper Mountain and form the matrix of the chalcocite ore, but, as a rule, sericitization prevents exact determination.

The freshest porphyry obtainable was collected in the first level of the Ryerson mine in the crosscut to the Wellington vein, 100 feet north of the Ryerson stopes. The rock is similar to the one just described, though not quite as fresh. It shows the same closely massed, small, usually striated feldspar prisms; a few small and greenish biotite foils as well as some inconspicuous quartz phenocrysts are seen. All these constituents are embedded in an abundant light-greenish-gray flinty groundmass. The feldspar phenocrysts consist of albite and oligoclase, with some orthoclase. The groundmass is fine-grained microcrystalline, with much quartz and orthoclase. Accessories are apatite, titanic iron ore, and zircon.

Of secondary materials sericite, epidote, chlorite, serpentine, and pyrite are present in moderate amounts, but their presence would not seriously alter the composition of the rock. As this specimen would seem to most closely represent the prevailing rock of Copper Mountain, it was analyzed, with the following result:

Analysis of quartz-monzonite-porphyry from Ryerson mine; No. 211, Clifton collection.

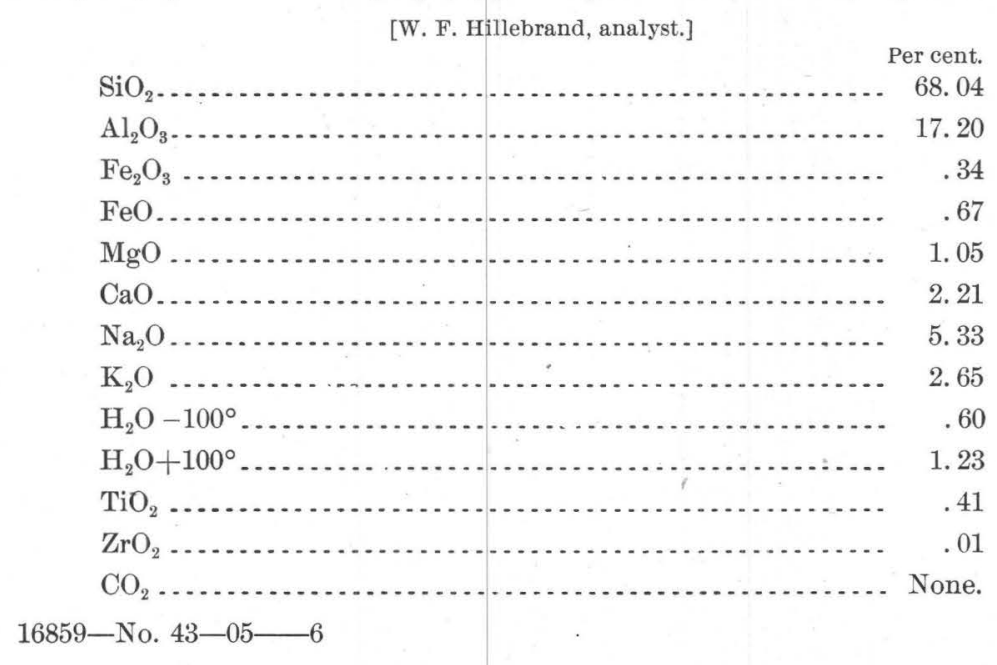


Analysis of quartz-monzonite-porphyry from Ryerson mine; No. 211, Clifton collection-Continued.

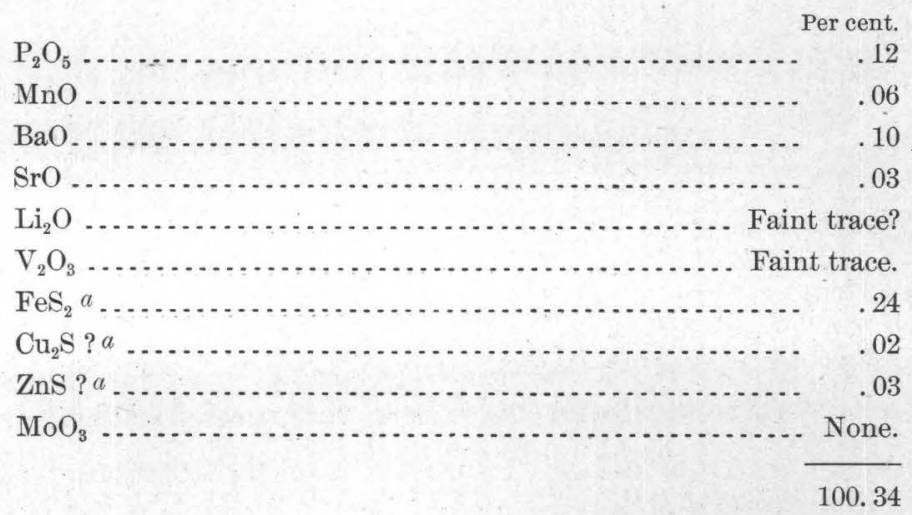

A fairly large amount of $\mathrm{CaO}$ and a strong preponderance of sodium distinguishes this porphyry from that of the Metcalf type. A rough calculation shows the rock to contain:

Percentage of minerals in quartz-monzonite-porphyry from Ryerson mine.

Orthoclase molecule.............................. 16

Albite molecule ................................... 45

Anorthite molecule................................ 10

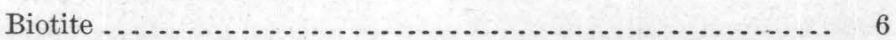

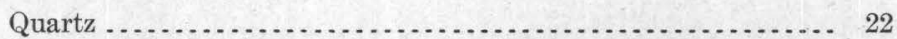

Titanic iron ore .................................... 1

100

While exact data can not be obtained, the rock probably contains equal quantities of orthoclase (mostly in groundmass) and albite, aggregating 38 per cent against 24 per cent $\mathrm{Ab}_{2} \mathrm{An}$.

It would thus represent an almost typical quartz-monzonite-porphyry, applying Professor Brögger's definition of the granular rocks to their porphyries.

Similar porphyries fresh enough to be determined were noted from the Longfellow mine and from the stope level of the Copper Mountain mine at the head of the incline (Nos. 10, 211, 233, 220, 197 of Clifton collection).

A gradual increase in calcium, iron, and magnesium brings us to another series of quartz-monzonite-porphyries, similar in appearance to those just described except that hornblende sometimes occurs with the biotite, and that the fine-grained flinty groundmass is of a darker-greenish color. Quartz is not present as phenocrysts. This kind of porphyry is not represented in the great stock, nor in any other large areas, but is common among the dikes. 
To this class belong some dikes in the second level of the Arizona Central mine at Morenci, one occurring near the breast of the Hudson crosscut and the other on the northwest wall of the Arizona Central vein, 200 feet northeast of the shaft. Both are grayish-green porphyries with small and closely massed, but inconspicuous, feldspar crystals. The rectangular prisms consist chiefly of andesine; there are a few small quartz grains and fairly abundant prisms of hornblende; the groundmass is microcrystalline, fine grained, in places micropoikilitic, and evidently contains orthoclase. Of secondary minerals epidote and pyrite are the most prominent.

The long and prominent dike cutting across southward from Modoc Mountain (see p. 128) consists of a similar rock. The abundant phenocrysts are andesine and oligoclase, with some orthoclase. The ferro-magnesian silicates are mostly decomposed, one prism of hornblende, now converted to chlorite and epidote, being noted. The groundmass is microcrystalline, consisting of quartz and unstriated feldspar. Some sericite and much epidote are present, the latter here and there replacing whole feldspar crystals.

Many dikes east of Chase Creek also belong to this class; for instance, that which is followed by the Copper King vein.

Under this heading may also be described an unusually fresh dike rock from the Montezuma mine, Morenci, Waters shaft level, 135 feet northwest of the main vein. In thin section it shows well-defined and abundant phenocrysts of andesine up to $2 \mathrm{~mm}$. in length, while there are few, if any, orthoclase crystals. Both hornblende and biotite, with a few grains of black iron ore, are present. The groundmass is microcrystalline, consisting of quartz and minute prismatic feldspar crystals, the latter irregularly distributed within the small quartz grains. As usual, the biotite is converted to chlorite and some epidote, the latter also replacing some of the andesine; some calcite is present in groundmass and phenocrysts, but very little sericite was noted.

Petrography of diorite-porphyries.-These rocks have usually a light-yellowish or greenish-gray color, weathering to dull brownish yellow; they form rounded outcrops with sandy soil, the abundant detached fragments being generally also rounded, but rather by disintegration than by transportation. The Gila conglomerate below these porphyry hills consists nearly exclusively of the same cobbles. The diorite-porphyries, as stated above, preferably form laccolithic masses in Cretaceous sediments, or sheets or sills, more rarely dikes, in the Paleozoic strata. A favorite place of intrusion of these sills is between the Coronado and Longfellow formations.

The dome-shaped hill at Morenci, almost due south of the smelter, forms an excellent example of the occurrence and type of this rock. A specimen (No. 15, 
Clifton collection) of this rock shows abundant prisms of white feldspar up to $4 \mathrm{~mm}$. in length, and of narrow dark-green hornblende up to $1 \mathrm{~cm}$. in length, together with a few grains of black iron ore. These phenocrysts are embedded in a scant greenish groundmass. In thin section the beautifully developed feldspars prove to be a rather basic labradorite with zonar structure; the hornblende is of ordinary greenish-brown color, while the groundmass eonsists of small, thick rectangular prisms, in part orthoclase; between these is a still finer microcrystalline mass of unstriated feldspar and quartz. Small amounts of chlorite and epidote are present, but no pyrite. A partial analysis runs as follows:

Partial analysis of No. 15, Clifton collection.

[W. F. Hillebrand, analyst.]

Per cent.

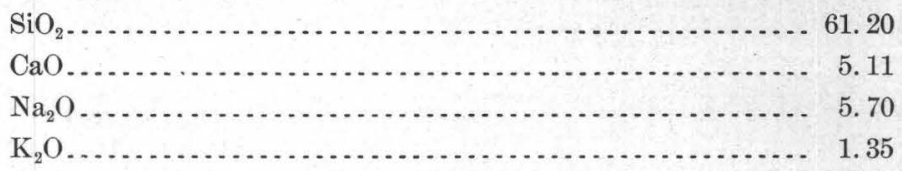

Typical specimens from the porphyry 1 mile north of the point where Gold Gulch enters the Eagle Creek basalt flows form an exact counterpart of the above description. This porphyry forms a complicated stock-like intrusion in the Longfellow limestone. In reality it is probably a sheet with many intercalated and parallel strata of limestone. Entirely similar are the rocks from one of the small laccolithic masses in Cretaceous strata 2 miles southwest of Copper Mountain, and the large laccolith 3 miles south-southwest of Copper Mountain conforms to the same type.

The porphyry from the small stock on Garfield Gulch at the Mammoth mine is perhaps rather a monzonite-porphyry. It is slightly brownish in color and contains abundant small and well-defined erystals of a triclinic feldspar well filled with sericite and calcite, probably andesine, together with pseudomorphs of epidote and chlorite after hornblende in a microcrystalline groundmass of unstriated feldspar and quartz.

Fine-grained dark-green (melanocratic) porphyries do not occupy large areas. A specimen collected 2 miles southwest of Copper Mountain, near the contact of the great stock with the Cretaceous rocks on the south side, is of this kind and contains many slender hornblende needles. Under the microseope these prove to be of pale-green color and partly altered to bastite, while the groundmass consists of long prisms of feldspar, probably labradorite, together with small needles of hornblende and a little magnetite. This type properly belongs to the dike rocks and the dioritic lamprophyres.

The diorite-porphyries rarely contain copper ores and seldom pyrite; chlorite, much epidote, calcite, and a little sericite are the principal secondary minerals. 
Age.-Petrographically it is not possible to separate the different classes of porphyry described above except by artificial lines. Geologically the same applies; beyond question they solidified from one magma, intruded about the same time. While it may not be advisable to draw too wide-reaching conclusions from the data, it would seem as if the deeper parts of the magma were the more acidic, while the upper and marginal parts more nearly approach dioritic types. The magma invaded the upper crust after the deposition of the Cretaceous beds (equivalent to the Benton), and the probably late Tertiary lavas flowed over their deeply eroded surface. Hence, we may safely place their eruption in the later Cretaceous or in the earliest Tertiary. No part of the areas now exposed ever reached the surface as it was at the time of intrusion. The magma invaded Cretaceous beds, and we may be sure that a considerable thickness of similar beds once covered the now exposed laccoliths. How much, it is impossible to say. The Cretaceous at the present time is only a few hundred feet thick; but as the Bisbee beds exceed 4,000 feet in thickness the possibility of solidification at that depth must be conceded. On the other hand, it does not seem at all likely, from what we now know of the geology of this region, that the magma was covered to a depth much greater than 4,000 feet.

Contact metamorphism.-While the diorite-porphyries have changed the surrounding sedimentary beds but little by the heat and emanations of the magma, the quartz-monzonite-porphyries and the granite-porphyries have generally exerted a profound alteration, especially in the Paleozoic limestones and shales. On account of its great importance, this subject will be discussed in a separate chapter. The contacts are sharp, and there is no evidence whatever of assimilation of the sediments by the intrusive magma.

\section{DIABASE.}

Distribution.-A dark-green medium-grained rock which proves to be diabase occurs in scant development as dikes and, more rarely, as sheets in widely distant places. Occasional dikes are found in the Gold Creek basin in monzoniteporphyry; at the Virginia, Trinidad, Brunswick, and Garfield mines at or near Garfield in granite; at the Coronado mine between granite and quartzite, and, finally, in the lower part of Sycamore Creek as an intrusive sheet or horizontal dike in granite. In no place are the dikes more than 100 feet wide, and usually they are much less. They are connected with a class of fissure veins carrying copper, but it is only a small division, containing as its most important representative the Coronado vein. In development and interest the diabase of the Clifton district does not begin to equal the occurrence at Globe, Ariz., so well described by Mr. Ransome. ${ }^{a}$ 
Petrography.-The freshest rock is exposed in Sycamore Gulch, where there are no copper deposits connected with it. The rock forms dark-gray rounded outcrops and is a typical medium-grained diabase, chiefly composed of labradorite and augite with normal diabase structure.

The Coronado vein (p. 339) follows in part of its course a diabase dike up to 70 feet wide, but the rock is usually greatly altered. A specimen from a small vein 200 feet above the Horseshoe shaft and the same distance south of the main vein is fairly fresh and is a typical fine-grained diabase. Although much augite still remains between the feldspar prisms, most of it is converted into chlorite. The feldspar contains some sericite. A little pyrite is also present. Rocks from the dike along the main vein are dull dark green and very much altered, showing lath-like sericitic feldspars, chlorite replacing augite, and leucoxene replacing ilmenite.

The Black lode (p. 360) follows a diabase dike up to 40 feet wide, similarly altered, and the other occurrences mentioned under the heading "Distribution" are also of the same type.

Age.-As a dike of diabase breaks through porphyry in Gold Creek basin, 2 miles due west of the railroad station at Morenci, it seems likely that the diabase is somewhat later than the porphyry, but it is not probable that the time of their eruptions differed much.

\section{THE TERTIARY LAVAS.}

General statement.-North of Clifton the Tertiary lavas cover enormous areas. The southern edge of the great lava fields, which probably extend northward for 100 miles up to the San Francisco Mountains, is located a few miles north of Metcalf; besides, the same eruptive rocks practically cover the eastern side of San Francisco River down to the latitude of Clifton and the whole valley of Eagle Creek down to Gila River. Within the central parts of the mountains containing the copper deposits they are almost absent. In some places erosion may have removed them, but it is not likely that they ever covered the domes of Coronado and Copper King mountains. Their age can not be determined with exactness, but many considerations point to the late Tertiary as their time of eruption. Copper deposits do not occur in them, though a little native copper is reported from an amygdaloid basalt in Sardine Creek. They have suffered very little from the great faulting movements which in the main must have preceded their eruption. Of little importance in a study of the metalliferous deposits, they will be briefly passed over in this report, a fuller account of them being reserved for the text of the Clifton folio.

Succession.-A repeated succession of rhyolite and basalts with subordinate andesites characterizes the Clifton volcanic series. The eruptions began by rhyo- 
lites, massive and tuffaceous, which now form the reddish bluffs on both sides of the town of Clifton. This rhyolite, which in reddish groundmass carries small phenocrysts of feldspar, quartz, and biotite, is somewhat different in appearance from the yellowish-gray, more normal, succeeding rhyolite eruptions. A partial analysis by $\mathrm{Mr}$. George Steiger gave the following percentages: $\mathrm{SiO}_{2}, 67.37 ; \mathrm{CaO}$, $1.55 ; \mathrm{Na}_{2} \mathrm{O}, 2.16$, and $\mathrm{K}_{2} \mathrm{O}, 5.96$, showing that this rock stands in a peculiar manner between the true rhyolites, the dacites, and the trachytes. The rhyolite was covered with black fine-grained basalts, over which poured out heavy sheets of gray or brown pyroxene-andesites, sometimes containing olivine. This is well exposed in the bluff northeast of Clifton. A few miles farther north, on the river, this is covered by thick flows of scoriaceous basalt, having their origin somewhere near Sunset Peak and thinning out very much along the river.

A second eruption of rhyolite took place, this time in the form of lightyellowish or brownish tuff breccias. Most of these seem to have flowed down from the upper river, 10 miles north of Clifton, but there was also one local eruption of massive rhyolite near the mouth of Hackberry Gulch, a few miles north of the town.

This eruption was succeeded by numerous basalt flows, aggregating 1,500 feet in thickness, well exposed by the deep trench of Sardine Creek, north of the area shown on $\mathrm{Pl}$. I. These basalts also show in dark-brown outerops on the north side of Garfield Gulch, though they are there only about 300 feet thick; they also form the basement of Mount Malapais. To the same epoch belong probably also the basaltic flows which form the whole southern valley of Eagle Creek and the high ridges west of it. A considerable epoch of erosion followed after the second great basaltic eruptions; Eagle Creek excavated its canyon to a depth at least as great as it has attained at present, and the northern basalt hills were deeply trenched.

After this followed the third and last great rhyolite eruption, which appears to have originated from the high points near Mount Malapais and the summits near the head of Whitewater Creek. The yellowish-gray masses of tuff breccia, similar to those of the second rhyolite eruption in San Francisco River, poured down westward, covering the upper basin of Eagle Creek and, narrowing down to a thinner stream, filled the lower basalt canyon of Eagle Creek. Renewed Quaternary erosion has reexcavated the trench, but along its steep buttresses enough of the rhyolite tuff remains to show the former configuration of the country. These bluffs, illustrated in PI. IV, $B$, are very picturesque, the pleasing bright green of the cottonwoods and sycamores lining the watercourse appearing in sharp contrast against the glaring and arid desolation of the volcanic cliffs. 
STRUCTURE.

GENERAL STATEMENT.

As indicated in fig. 1 (p. 28), the Territory of Arizona presents three physiographic regions, divided by northwest and southeast lines. The northeasterly area comprises the high plateau region, characterized by undisturbed stratification of beds ranging from the Cambrian to the Cretaceous. The central or mountain division contains a great number of often high but usually narrow ranges trending north and south or northwest and southeast and separated by débris-filled valleys. In the southwesterly or desert division the valleys are more extensive, while the ranges trending northwest are shorter and less conspicuous.

In fig. 1 the line between the plateau and mountain provinces is drawn a few miles north to Clifton. While this is probably correct, the basaltic lavas cover so much of the older rocks that the limit can not be accurately defined. Neither is the mountain region well defined in this vicinity, for no distinctly trending ranges can be identified. Perhaps it would be most accurate to define the region as the broken-down edge of the plateau. A glance at the map shows the multitude and importance of faults; a more careful search will show that the Tertiary volcanic rocks and the Gila conglomerate have not participated in the faulting movement, ${ }^{a}$ which practically was confined to one epoch falling between the intrusion of the porphyry (latest Cretaceous or earliest Tertiary) and the eruption of the lavas (late Tertiary).

\section{DISLOCATION DUE TO INTRUSIONS.}

During the unbroken period of sedimentation from the Cambrian to the Carboniferous the strata remained horizontal. The unconformity between the Cretaceous and the Carboniferous is not strongly marked and, during the deposition of the former, the older strata preserved an approximately horizontal position. The first marked disruption of the stratified formations (which were 1,200 feet thick, at least, and probably much more, for the original depth of Cretaceous sediments is in doubt) occurred at the intrusion of the porphyry. That this movement was most violent can not be doubted, for a body of magma 7 miles long by 2 miles wide is not intruded in the basement granite and overlying sediments without seriously affecting the position of the latter. The magma, which probably did not reach the surface, must have bulged the uppermost Cretaceous strata; it certainly dislocated the Paleozoic rocks extensively, injected itself between the beds, and tore large parts away from the edges of the

$a$ This is not strictly accurate, as a few minor faults have been observed in the basaltic flows, and at least one fairly large fault was observed in the great volcanic area northeast of Sardine Creek. But for practical purposes the statement holds good. 
fractured masses. The effects of these dislocations by intruding magma are best seen in the confused geological structure of the lower Gold Creek basin.

A most important structural line was determined by this intrusion. The direction of the stock was northeast, and the dike system at its northern end, as well as the mineral lodes formed later, followed the same strike. Certain prominent fissures with northeast strike, soon to be filled with cupriferous minerals, were opened shortly after the intrusion, and somewhat later began the principal faulting movements, the general results of which consist in a settling and breaking down of the edge of the mountains toward Gila Valley.

FAULTING.

The faults appear most abundant in the sedimentary area, partly because more easily identified there by aid of the members of a comparatively thin series of strata. This difference is partly due, however, to the fact that the two principal granitic areas, Coronado and Copper King mountains, occupy positions of resistant buttresses between which the fractured sediments have settled. In the porphyry stock there are undoubtedly many faults which have not been recognized.

The fault planes divide the sediments into blocks of varying extent and shape; these are nearly always monoclinal and have gentle dips prevailingly to the west and north, rarely to the south and east; they average about $12^{\circ}$, while dips of more than $30^{\circ}$ are very seldom encountered.

\section{CHARACTER AND DISTRIBUTION OF FAULTS.}

The faults are not difficult to trace in the sedimentary areas, for the different strata are ordinarily easily identified; the larger dislocations often, but by no means always, carry contact breccias, the best instance of this being the great Coronado fault. In places where the exposures are exceptionally good, as, for instance, south of Modoc Mountain, Morenci, a multitude of small dislocations may accompany the larger faults and it is sometimes difficult to decide which to represent on the map and which to leave out. The minor dislocations have seldom left any traces on the topography, except that they are sometimes, as near Morenci, followed by gulches; but the large faults around the buttresses of Coronado and Copper King are certainly still marked by precipitous bluffs. The best instance of this is seen back of the small limestone mass at the eastern foot of Coronado Mountain.

The faulting is in most cases of a normal character, implying a relative downward movement of the hanging wall. The sections (Pl. I) give convincing evidence of this. The strike of the fault planes varies greatly, but the two or three principal dislocations have an east-west or a northeast-southwest direction. 
There is another system striking northwest-southeast, as shown near Morenci, but the planes dividing the smaller fault blocks are apt to take any direction. The faulting appears to have been confined to one epoch, the larger blocks naturally breaking first. The dip or hade of the dislocating planes is generally steepover $60^{\circ}$ from the horizontal. In places flatter faults are met with, especially outside of the area shown in Pl. I, and some of them are of very peculiar character, the limestone having been separated from the underlying quartzite and drawn down over the more resistant granite.

Beginning from the north, the great dome of Coronado Mountain, partly covered with gradually curved quartzite areas that bend down to the west and north, breaks off to the south and east by the Coronado fault. This at first has an east-west direction, but nearer Chase Creek evidently swings around northeast and is traceable to a point just west of the junction of Garfield Gulch and Chase Creek. The vertical throw is at least 2,000 feet in Horseshoe Gulch, where the fault is first seen emerging from under the covering basalts; 2 miles farther east it has decreased to 1,200 , increasing again to 2,000 feet at the point where the dislocation dips under the volcanic masses north of Garfield Gulch, always counting the vertical distance between the base of the quartzite on the summit and that in the down-thrown block. The actual displacement on the fault plane may have been less on account of distributed movement in the granite, which is in part sheeted, but the prominent and imposing bluff along the lower slopes of the mountain indicates that most of the movement took place within a very short horizontal distance. The continued steep slope of Coronado Mountain west of Horseshoe Gulch indicates a probable continuation of this dislocation, now swung in a west-north west direction. Wherever determinable, the hade of the fault is from $45^{\circ}$ to $70^{\circ}$ south or east. Complicated fault blocks fill the "graben" or deep structural depression about Metcalf, and then the Coronado quartzite (which, on account of its position on the granite and its frequent preservation, it is well to select as a guiding horizon) rises again, by step faults, and probably also by bending, to the summit of the second buttress, the northeasterly trending Copper King Ridge. No quartzite remains on top of Copper King Mountain, but it is preserved, at elevations of 5,800 feet, on the same ridge north of Sycamore Creek, and no great error is likely to occur in assuming that the summit mentioned (elevation 6,825 feet) is near the now eroded base of the Coronado quartzite.

The thrown block south of the Coronado mine is extensively broken by small faults, but on the summit of the ridge the quartzite continues almost level for 2 miles southward. Here the quartzite block ends and a precipitous slope of granite leads down about 800 feet to the level of the porphyry ridges connecting with Copper Mountain at Morenci. This escarpment probably represents the con- 
tinuation of an important east-northeast dislocation, definitely recognized at the Cayuga and Soto prospects in Pinkard Gulch; it forms a second important step down from the heights of Coronado to the plains of the Gila. From the Soto fault down along the Eagle Creek foothills to the great porphyry laccolith, no important faulting has been recognized. This may be partly due to the great difficulty of identifying horizons in the confused mass of porphyry and detached sedimentary fragments. The Soto fault has not been traced across the porphyry at Chase Creek; in fact, east of that stream the movement, as explained above, took place in an opposite direction by downthrow of the northern blocks, on account of the resisting buttress of Copper Mountain.

About a mile northeast of Morenci the great Concentrator fault is encountered. Granite and quartzite have been brought in juxtaposition by this for a vertical distance of 1,000 feet from the bottom of Chase Creek Canyon to the summit of the hill at the Arizona Copper Company's concentrator. It is accompanied by many step faults to the south until, on the east slope of Modoc Mountain, the quartzite has regained its position in the regular series there exposed. Here the movement on the principal plane has evidently been greater, gradually diminishing by step faults southward (Pl. I, pocket). The Concentrator fault continues across Chase Creek Canyon, rapidly gaining in vertical throw as the buttress of Markeen Mountain is approached. - At the southerly foot of this mountain, east of Chase Creek, the down-thrown quartzite block is visible and has suffered a dislocation of at least 2,000 feet. The same fault line now crosses under the Gila conglomerate to Oroville and, still hidden, continues on the northwest side of the San Francisco River in a north-northeast direction for several miles to Sycamore Gulch, beyond which it can not be traced. Although the actual fault plane is covered, the presence of the dislocation is amply proved by the Longfellow limestone, which is exposed for several miles along the bed of San Francisco River, indicating a vertical throw of 3,000 feet, the greatest thus far shown in the district. The up-thrown block is marked by a precipitous wall of red granite, magnificently exposed for 6 miles along the west side of the river. Step faulting may possibly have occurred, but no trace of it remains and the sections indicate a dislocation confined within small horizontal distance.

The Concentrator fault can not be traced far eastward into the porphyry stock north of Morenci. Southward of it, in the Morenci foothills, the sedimentary series is broken into blocks by three principal and many smaller northwest faults, along which divers displacements have taken place (Pl. I). At the point in Chase Creek where the Morenci road turns up the hillside there is exposed on the east side of the canyon a very excellent illustration of the breaking up of 
the strata into blocks; a small area of Coronado quartzite has become detached from the main mass on the ridge above and settled down along fault planes almost to ereek level (Pl. V, B).

\section{ORIGIN OF MONOCLINAL BLOCKS.}

In the preceding pages the dip of the stratification in the blocks has not been considered, but in explaining the structure it is a factor which must not be overlooked. An inclination of the strata may be due to initial dip; this is not likely to have application in the present case, except possibly in the lowest strata of the Coronado quartzite. The intrusion of porphyry would seriously affect the sedimentary beds, at least in the immediate vicinity of the larger' stocks. Many such disturbances are formed along the contact at Morenci, the principal one probably consisting in bringing up the underlying quartzite more or less continuously all along the edge of the porphyry. Similar lifting and tilting of the beds by sheets and laceolithic masses are common in the Gold Creek basin and around the contacts of the great laccolith southwest of Morenci.

But aside from these local causes there is, as explained above, a universal monoclinal tilting present in nearly all of the blocks and usually directed toward southwest, west, or northwest, more rarely to other points of the compass. It is impossible to explain this by assuming breaks in horizontal beds followed by normal faulting, though unequal settling may have produced local and irregular dips. The question is an important one for many districts of the West, and this locality seems to offer at least a partial explanation of the modus operandi of this structural movement. On the great buttresses, especially on Coronado Mountain, detached masses of the Coronado quartzite occur, resting on the basal granite. It is found that these do not lie horizontal, but dip like the rest of the series at angles of $10^{\circ}, 15^{\circ}$, and even $20^{\circ}$. In other words, the granite has been deformed as well as the sedimentary series; it has evidently acted as a somewhat plastic body, and its surface, as well as the covering beds, has suffered dome-shaped warping or gentle folding before the breaks and the settling of the block occurred. The ultimate cause of these movements still remains a subject of speculation.

\section{AGE OF THE FAULTING.}

The folding and dislocations took place after the intrusion of the porphyry and a long time before the principal lava eruptions, for a period of very active erosion preceded the Tertiary volcanic flows, and the orographic movements imply a somewhat plastic condition of the granite only possible under a considerable load. The faulting then falls between latest Cretaceous and middle Tertiary. The age of the minor masses of diabase occurring in this region 
compared with that of the faults is less certain. The diabase appears to be somewhat younger than the porphyry, and its intrusion may have occurred almost simultaneously with the faulting.

At Globe, ${ }^{a}$ in central Arizona, where similar extensive shattering has taken place, Mr. Ransome finds that the principal faulting has taken place after the eruption of certain dacitic surface lavas, but before the deposition of the Gila conglomerate and certain associated basalts. The time of this faulting is tentatively placed in the middle of the Tertiary period. In this region there are only small areas of rocks comparable to the dacite of Globe (p. 87), and these represent the earliest eruptions of Tertiary lavas. It is not possible to state with positive assurance that the faulting preceded the earliest rhyolitic eruption, but the probability that it did so is very great.

Repeated faulting on a small scale took place after the lava eruptions, and possibly even after the deposition of the Gila conglomerate, but it is entirely subordinate compared with the earlier period of intense movement.

\section{GEOLOGICAL HISTORY.}

The oldest records are less well preserved than in other parts of Arizona, but still reach back to pre-Cambrian times, when a low, gently undulating land area of red coarse granite, with more prominent points of harder quartzitic schists, spread out where the hills of Morenci and Coronado now lift their summits high above the sea level. Dim indications point still further back to a far older basement on which these quartzite schists were deposited, to mountain building forces which compressed the sediments, lifted them and rendered them schistose; to an intrusion of red granite which almost engulfed the sediments; and to a long period of erosion which planed down the rough topography, produced by the orogenic forces, to the smooth outlines of the undulating plain referred to above. Animal and vegetable life probably did not grace that barren land, but the rains and the storms beat on its surface then as now, for underneath the covering sediments is clear evidence of weathering, disintegration, and oxidation.

At first streams flowed over its surface, accumulating in their beds pebbles of resistant quartzite from neighboring areas.. The uneven distribution of this basal conglomerate proves that the land area was somewhat accentuated, while the fairly even thickness of the covering, Coronado quartzite, shows that the topography was not of a rough character. Gradual mingling of sandy conglomerates into sandy disintegrated rock also indicates the epoch when the sea had not yet invaded this land.

But the marine invasion was not distant, and soon the waves covered the low hills. Abrasion by the sea and erosion by the streams of remaining land areas

a Prof. Paper U. S. Geol. Survey No. 12, p. 104. 
soon accumulated the Coronado sandstones, in the uppermost part of which scant shell remains point to a Cambrian age. Submersion and deposition continued unbroken during the Ordovician period, bat the sediments soon became prevailingly calcareous. The Silurian, properly speaking, seems absent, though no unconformity can be observed between the Ordovician Longfellow limestones and the covering, probably Devonian, strata.

The sea grew more shallow, but no granite or quartzite remained above water to supply sediments; these came from more distant quarters. The limestones became argillaceous and soon changed into clay shales, designated the Morenci shales. Both of these terranes have been referred to the Devonian on rather scant evidence from a meager fauna.

Above the Morenci shales, in a deepening sea, were deposited a series of limestones, first dolomitic, then remarkably pure, and afterwards coarsely crystalline-the Modoc limestone of the lower Carboniferous, or Mississippian, epoch. The sedimentation continued still further, and on top of these limestones was deposited another series, that of the Pennsylvanian epoch, or upper Carboniferous, also appearing as heavy-bedded limestones. Throughout the whole of the Carboniferous animal life was abundant and has been well preserved in the rocks.

The time interval between the Carboniferous and the middle Cretaceous is not represented by any sediments; there is, on the contrary, evidence of an epoch of erosion, for the Cretaceous rests unconformably on the lower Carboniferous at Morenci, where the upper Carboniferous is not present.

The disturbance was, however, not great and the later strata must have been deposited on the nearly horizontal, though partly eroded, Carboniferous. The last subsidence under the Cretaceous sea was of only moderate depth, the sediments consisting of coarser sandstones and carbonaceous shales, clearly not derived from the granite of this vicinity, but rather from somewhat distant land areas. The total thickness of Cretaceous is unknown; the larger part of the series may in fact have been removed by erosion.

This long era of deposition without far-reaching orogenic disturbances was followed by intense intrusive activity, beginning in the earliest Tertiary, or in the latest Cretaceous. Masses of acidic porphyries, associated with diorite-porphyries, invaded the lithosphere, filled great spaces made for them by gradual or violent dislocations, and congealed to stocks, sheets, dikes, and laccoliths in the disrupted granite and sediment. These intrusions form practically one connected mass from Eagle Creek to Copper King Mountain, which has been exposed only by subsequent erosion.

The intrusive bodies thus consolidated far below the surface of that time. Just how far is doubtful, but probably not more than 4,000 feet, and their 
upper portions, and the laccoliths may have been covered by a very much smaller thickness of strata.

The porphyries in cooling produced far-reaching metamorphism of such of the adjacent sediments as were susceptible of this alteration, and the introduction of sulphides of various kinds accompanied the contact metamorphism. Shortly after the consolidation fissures broke open following the general northeast direction of the stock and dikes, and were filled with cupriferous pyrite, zinc blende, and other minerals. Soon after the time of the intrusion an uplift must have taken place, raising the heavily sediment-laden crust to high elevations, throwing them, as well as the underlying partly plastic granite, into gentle dome-shaped swells or anticlines. Finally, the load proving too heavy, the risen area broke into fragments, which gradually settled down, forming monoclinal blocks around the more resistant buttresses of Coronado and Copper King mountains, and fracturing still further as they settled.

The country was now a land area with rough topographic features, to which the faulting contributed important elements. An active erosion following the epoch of faulting has not been able to entirely efface this influence, and, though obscured by the Tertiary lava flows, these fault scarps are still dominant features visible in the granite bluffs of Coronado and Copper mountains and the downthrown valley between them.

During this epoch of erosion the principal valleys, like those of Chase Creek and San Francisco River, were carved. San Francisco Valley is, however, primarily of structural origin, being determined by the great Oroville fault.

Volcanic eruptions of great volume occupied the latter part of the Tertiary period, and consisted chiefly of thrice-repeated rhyolite and twice-repeated basalt flows, with subordinate masses of andesite. In places they are over 1,500 feet thick and almost entirely surrounded the old granitic buttresses.

Next followed a second epoch of erosion, accompanied by deposition of thick detritus in front of the mountains-the coarse accumulations which have been called the Gila conglomerate; much material for this was supplied by the enormous volcanic masses north of the plains. This epoch is referred to the early Quaternary.

A notable depression in the level of deposition during the late Quaternary was followed by renewed activity of the streams, not only in the hills, but on the sloping plains of the Gila. The course of Eagle Creek, previously outlined between the second basaltic and third rhyolitic flows, became definitely established and rapidly deepened to a box canyon. Likewise the final course of the San Francisco was fixed, the river, under fresh impetus, sweeping out the Gila conglomerate from its upper course and cutting a canyon 600 feet deep in that 
material in its lower reaches. The region gradually became sculptured into the forms of to-day, when, as far as the San Francisco and the Eagle are concerned, a condition of equilibrium has been established in which no further erosion and but little deposition takes place in the stream bed.

Lastly must be mentioned the gradual changes that have been going on since the mineral deposits were first exposed by erosion-a continuous oxidation, solution, and redeposition of minerals, among these the copper ores, within the zone easily accessible to surface waters. Inconspicuous and slow as these processes are, they have resulted in the transformation of poor primary ores into the rich and extensive bodies which have placed the Clifton-Morenci district among the first ranks of copper producers. 


\section{CHAPTER III. \\ ORE DEPOSITS AND THEIR MINERALS.}

GENERAL FEATURES.

Almost all of the mineral deposits of the Clifton-Morenci district contain copper as the principal valuable metal. In a small class of veins, however, gold occupies this position, and some irregular deposits of magnetic iron ore occur in the contact zones of the porphyry. While the district produces copper to the value of $\$ 7,500,000$ per annum, the gold output is insignificant. The iron ores are of value only as flux for copper smelting.

The economically most important copper ore is chalcocite or copper glance $\left(\mathrm{Cu}_{2} \mathrm{~S}\right)$; more rarely cupriferous pyrite or chalcopyrite is treated as ore, while bornite and covellite are practically absent. Of oxidized copper minerals, azurite, malachite, brochantite, chrysocolla, and cuprite are of common occurrence, together with native copper, but the quantity of this class of ore is annually diminishing. Gold and silver are present only in traces in the ordinary copper ores of Morenci and Metcalf.

The occurrence takes many forms. A first great division consists of irregular or roughly tabular bodies of oxidized ores in limestone or shale near porphyry contacts. Below the zone of oxidation these irregular bodies may contain disseminated chalcopyrite and zinc blende. A second great division consists of lodes or veins-in other words, deposits clearly connected with fractures and fissures. These fissure veins cut across limestone, shale, porphyry, and granite, usually near the igneous contact, and contain pyrite and chalcocite, associated in the upper levels of the mines with cuprite, native copper, and some carbonates, silicates, and sulphates of copper. Genetically connected with fissure veins are also the irregular disseminations of pyrite and chalcocite sometimes occurring in porphyry. A closely connected class of fissure veins follows porphyry dikes in granite. A smaller division of veins is connected with diabase dikes in granite, or along important fault planes. 
With all the diversity of form and content, a review of the deposits brings out one prominent fact. All of the ore deposits, except the small class connected with diabase dikes, are intimately associated with granite-porphyry or quartzmonzonite-porphyry. They occur either in dikes or stocks of these porphyries or in sedimentary rocks or granite not far from the contact. There can be no doubt whatever that some connection exists between the acidic porphyries and the ore deposits.

The difference in accompanying gangue minerals is as striking as the diversity in form. The fissure veins in porphyries, granite, and similar acidic rocks contain a quartz-sericite gangue with little, if any, calcite. The irregular and tabular deposits in limestone are followed by magnetite, garnet, epidote, pyroxene, amphibole, calcite, and quartz. Fissure veins in limestone are accompanied by quartz, magnetite, and amphibole as metasomatic minerals.

It has long been conceded that the oxidized copper ores, like malachite and azurite, have been formed from sulphides by the subjection of the latter to the altering influences of atmospheric waters, containing oxygen and carbon dioxide, and that if the deposit admits being followed down to sufficient depth the unaltered sulphides will be found replacing the oxides, carbonates, and sulphides.

A most important fact brought out by a study of these deposits is that chalcocite, the cuprous sulphide, $\mathrm{Cu}_{2} \mathrm{~S}$, is here likewise of a secondary character, and that it has been deposited by reactions primarily due to the oxidizing influence of atmospheric waters on those deposits which erosion has brought sufficiently near the surface; proofs of this will be presented in a subsequent chapter. At present the deposits of commercial importance are mainly those which contain oxidized copper ores or chalcocite. In other words, the oxidizing action of surface waters seems to be necessary to enrich the deposits sufficiently for profitable exploitation. This is simply a statement of facts as far as our present knowledge of the district reaches, and by no means excludes the possibility that workable pyritic ore bodies may be found. Wherever the products of oxidation are absent, chalcopyrite and cupriferous pyrite, associated with zinc blende, form the ores, which ordinarily are of very low grade.

Summing up, we have this preliminary classification of deposits containing payable copper ores:

Deposits in limestone and shale, not connected with fissure veins (all carry oxidized ores almost exclusively; rarely chalcocite):

Irregular bodies near contacts of main stock or dikes.

Tabular bodies near contacts of main stock or dikes following stratification.

Tabular bodies, following contacts of porphyry dike. 
Fissure veins:

Normal veins in porphyry or in any of the other rocks near porphyry contacts. The pay part includes both the central, sharply defined veins and the surrounding partly replaced porphyry, forming together a lode. They carry chalcocite as the important ore. In upper levels they sometimes also carry oxidized ores.

Normal veins, following porphyry dikes in granite, and carrying chalcocite and oxidized copper ores.

Normal veins following diabase dikes. These carry chalcocite and oxidized copper ores.

Stockworks. Irregular disseminations in porphyry, quartzite, and other rocks. Contain chalcocite and oxidized copper ores.

This classification is based on the occurrence and form. A more general genetic system, given in another chapter, will show a somewhat different arrangement.

\section{GEOGRAPHIC DISTRIBU'TION.}

The copper deposits are scattered over a belt of country 3 to 4 miles wide, beginning at the Eagle Creek foothills, extending in a northeast direction across to Chase Creek, and thence gradually narrowing to a point in Sycamore Gulch on the Copper King Ridge. The length of this belt is 8 or 9 miles, and it is practically coextensive with the great porphyry stock and its northeasterly dikes, a fact of the greatest importance, substantiating the assertion on a preceding page that the copper deposits are most intimately connected with the porphyry.

The southwestern part of the belt contains seattered deposits of no great present value, consisting of irregular masses in limestone and small fissure veins, many of which in Gold Creek basin and vicinity contain some gold. Morenci on the southeastern contact, between porphyry and limestone, is one of the most important points. The limestones close to the main contact and between dikes contain irregular and tabular deposits of very rich oxidized ores. The Longfellow, Detroit, and Manganese Blue mines belong to this class, now almost exhausted. Moreover there exists on both sides of the main contact a most important system of northeasterly trending veins containing enormous deposits of low-grade chalcocite ores, changing to poorer primary sulphides at varying depth. Such chalcocite ore the great Ryerson, Copper Mountain, East Yankie, and Arizona Central mines are exploiting. A number of prospects, mostly fissure veins, are scattered between Morenci and Metcalf, a second great center of the mining industry. At Metcalf the Shannon copper mines are being worked on irregular and tabular bodies of oxidized ore in limestone close to the main porphyry contact, while some porphyry dikes and part of the main porphyry stock are valuable on account of disseminated chalcocite and its products of oxidation. 
At the old Metcalf mines irregular bodies of chalcocite ore are contained in the soft and sericitic granite-porphyry. Across King Gulch is located the King mine, one of the best-defined fissure veins of the district. Two miles west of Metcalf and high up on the ridge above it is the Coronado lode, a large deposit located on an important fault fissure and connected with a diabase dike. Irregular deposits in limestone and fissure,veins of some value occur near Garfield Gulch on the northwest side of the porphyry stock. Northeast of Metcalf on the Copper King Ridge a great number of fissure veins occur, nearly always following porphyry dikes in granite, but few of them are of great economic importance. The largest deposit is found near the summit of Copper King Mountain, and is known as the Copper King mine. In the extreme northeast end of the copper belt the amount of copper ore on the veins decreases, and instead a considerable amount of gold appears, a metal which, together with silver, is almost. entirely absent from the Morenci deposits and very sparingly present in the Metcalf district.

The granite mass of Coronado Mountain, the southern part of the Morenci Hills, including the great laccolith of diorite-porphyry and the sunken limestone block east of San Francisco River, are barren of copper deposits. Barren, likewise, are the Tertiary basalts, rhyolites, and andesites.

Morenci and Metcalf are the only important places where the Paleozoic limestone, which appears to be the most favored locus of the ores, comes in close contact with the great porphyry stock, and at both these places most extensive and interesting alterations have taken place in the sedimentary rocks near that contact - alterations which, as will he shown, are due to metamorphism exerted by the molten intruding magma on the limestones. A similar metamorphic action is noted in almost all cases where the sedimentary rocks come in contact with graniteporphyry or quartz-monzonite-porphyry, while at the contacts of the diorite-porphyry these effects are far less pronounced.

On the whole, the ores throughout this region are so closely connected with metamorphic processes of various kinds that it will be necessary to study these in more detail before the ore deposits can be intelligently described.

\section{MINERALS.}

The following list gives the modes of occurrence of the minerals known from the Clifton district, and also, in case of rarer species, their composition and physical characteristics. Eight or nine of the ore minerals have not been previously described from the district, one (libethenite) is new to the United States, and two (coronadite and morencite) are considered as new mineral species. 
Copper.-Metallic copper is always a secondary product in the copper deposits at Clifton. It is rare in the irregular limestone deposits, occurs sometimes in the lodes in porphyry, and is frequent in the upper levels of the veins which cut through shale, limestone, and associated porphyry dikes. Principal occurrences are in the Metcalf mines and in the Williams vein of the Arizona Central mine, at Morenci. As a rule the copper is associated with cuprite at the upper limit of the chalcocite zone. It has been found at the Shannon mine in limonitic and kaolinitic porphyry in spongy masses of bronzy color, consisting of small distorted crystals. In the Metcalf open cuts it is found in large irregular masses, intergrown with cuprite and covered with carbonates, silicates, and sulphates of eopper. The matrix is a sericitic chalky porphyry. At the same mine it occurs in stopes 40 feet above Wilson level, about 200 feet below the surface, in sericitic porphyry, included in cuprite and also associated with chalcocite. At Morenci it occurs with chalcocite and cuprite in the Joy vein, 200 feet below the surface. It is also common in fine distribution all along the Williams vein. On the intermediate level of the Arizona Central mine, 400 feet from the shaft and about 200 feet below the surface, a vein of solid copper was found in the Williams vein. It occurred in sericitized porphyry, which all along contains a little chalcocite and native copper. The vein formed a sheet of copper, in places 8 inches thick, standing nearly vertical and striking eastnortheast. It was followed down to the third level, where, however, it is less well defined and splits up into several seams. This copper had in places a remarkable, fibrous structure, perpendicular to the plane of the vein, such as occasionally is exhibited by the chalcocite seams, of which it is believed to be a pseudomorphic development. In one specimen two sheets of copper were found separated by sooty chalcocite. The direct reduction of chalcocite to copper without the intermediary stage of cuprite has not found a ready explanation. In the Butler and London tunnel a little native copper was found in a seam of dark clay 300 feet below the surface in an unproductive part of the workings.

Gold.-Occurs native with galena in the Hormeyer mine, a fissure vein in limestone on the ridge between Chase Creek and Morenci Canyon, 2 miles south of Morenci, and in many small seams and fissures in Gold Gulch and vicinity. As placer gold it is found in Gold Gulch, as fine flakes in the gravels along the Morenci Canyon, about 4 miles below the town, and in several places in gravels along San Francisco River, the best prospects occurring near Oroville, where washing has been attempted.

Quartz.-This mineral is of common occurrence. It is an important constituent of the granite and of the quartzite derived from that rock. It occurs in 
the form of chert or fine-grained varieties in the Longfellow limestones. It further forms bipyramidal crystals in the granite-porphyry and quartz-monzoniteporphyry and also enters into their groundmass. In the metamorphosed limestones it is found in small quantities. As seams and veinlets it is abundant in altered porphyry and in the granite near the porphyry. It forms a small part of the great productive veins of pyrite and chalcocite. Finally it is a product of surface oxidation of metamorphic limestone, the lime-iron garnet especially forming quartz and limonite upon oxidation. In the veins and seams the quartz is very rarely crystallized, the only exception being found in certain parts of the Fairplay veins, at Morenci, and in a peculiar filled vein of drusy quartz, pyrite, chalcopyrite, and zinc blende, crossing the Lone Star tunnel (see p. 279). When due to surface oxidation of the metamorphosed limestone, small druses of crystals may also be formed.

Chalcedony.-Part of the cherty material in limestone may more properly come under this heading than under quartz. Specimens of this mineral were also found loose on the surface of Shannon Mountain. Microscopically it was observed occasionally formed together with quartz and kaolin during the process of chalcocitization of the pyrite. Opal is also deposited at times during this process.

Zircon.-Occurs as microscopic crystals in the granite and in the porphyry.

Rutile.-Dark-brown microscopic prisms determined as rutile are of common occurrence in the sericitized porphyry and are probably due to alteration of titaniferous magnetite.

Magnetite.-This mineral occurs sparingly as irregular grains in the granite, diorite-porphyry, granite-porphyry, diabase, basalts, and andesites of the region. In part, however, especially in the more basic rocks, titano-magnetite and ilmenite replace the normal mineral. In great quantities the mineral appears in the contact metamorphic limestones and dolomitic limestones, where it is associated with garnet, amphibole, pyroxene, and sulphides. In structure it is usually granular, but when disseminated in limestone it also occurs in crystallized form. It is found wherever contact-metamorphic alteration has taken place; especially large masses, economically important as flux for smelting purposes, occur in the Manganese Blue and Arizona Central mines, as well as on the hill slope southwest of the latter mine. A large body also occurs in the gap where the road to Eagle Creek descends into the Gold Gulch Valley. To a minor degree it is also formed as a metasomatic product in limestone, rarely in porphyry, along the walls of the fissure veins which cross these rocks. It alters to limonite and sometimes also to hematite, as well shown in the "iron stopes" of the Manganese Blue mine. 
Hematite.-Occurs somewhat sparingly as a product of contact metamorphism associated with quartz, garnet, epidote, and magnetite; associated with quartz in contact breccias of granite and porphyry at Metcalf. Occasionally it occurs as translucent foils in vein quartz. Sometimes it is due to surface oxidation of magnetite and garnet, as at the Modoc mine, at Morenci.

Limonite.--This mineral is very abundant within the zone of surface oxidation, and is always characterized by earthy appearance and yellowish-brown color. Most of it appears in the oxidized limestone deposits and in the decomposed metamorphosed limestones. In porphyry it is less abundant, though everywhere present in small quantities in the uppermost oxidized zone. Large masses occur associated with kaolin in the East Yankie mine (Longfellow deposits) and with magnetite in the Manganese Blue mine. Under the microscope it is translucent, yellowishbrown, with strong, double refraction and aggregate-fibrous structure between crossed nicols.

Pyrolusite.-Common in black, often sooty, masses in the zone of surface oxidation of metamorphosed limestones and in the copper deposits contained in this rock. Associated with quartz, azurite, and malachite. Not found as a structurally distinct mineral; often mixed with limonite and hematite.

Coronadite. - On the dump of a small shaft on the west end of the Coronado vein, three-fourths of a mile west of Horseshoe shaft, fairly large amounts of a dark metallic mineral were found intimately intergrown with quartz and decomposing into limonite. The vein at this end shows no copper minerals, but is stated to contain some gold; its surface ores are reported to have been worked in an arrastre in the early days of the camp. In color this mineral is black and its structure delicately fibrous. The hardness is about 4 and the streak black with brownish tinge.

A thin section proves it to be opaque and in reflected light its fibrous and homogeneous structure is well brought out. It cements angular quartz grains and its secondary nature is clearly indicated. In general aspect it is not unlike psilomelane. A preliminary examination by Dr. W. F. Hillebrand showed that it contained the oxides of lead and manganese; as it did not seem to correspond to any known mineral species a separation and analysis was made by Doctor Hillebrand, who states his results as follows:

- Long-continued efforts by the use of heavy solutions to secure pure material for analysis were not attended with success. The ultimate product of specific gravity, 5.246 at $22^{\circ}$, yielded, on decomposition by hydrochloric acid, a residue of from 6 to 7 per cent, which consisted mainly of silica, with a small amount of alumina, etc. Its presence would not have mattered much had it been quite indifferent to acids, but its partial solubility, as shown by the varying amounts undissolved on different trials and similar varying amounts of alumina and per- 
haps other minor ingredients found in solution, render the calculation of molecular ratios not altogether certain in all cases. The composition as found is:

Analysis of coronadite from Coronado vein, Arizona.

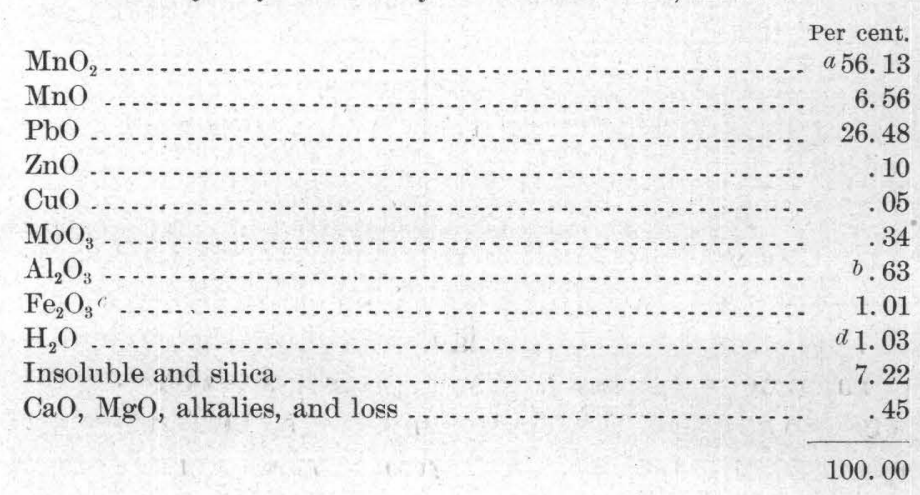

"The material available did not admit of determining quantitatively the vanadium, which may be present in rather more than a mere trace, but neither it nor the phosphorus can influence materially the ratios given below. The vanadium would be effective in two ways: (1) By requiring a base for its neutralization, if existing as an acid constituent, and (2) by liberating chlorine when acted on by hydrochloric acid, and thus affecting the values found for peroxide oxygen. If the iron exists in the ferrous state, it, too, would affect the values found for the peroxide oxygen, and consequently for both the oxides of manganese. Assuming it to so exist and applying the proper corrections, also deducting from the lead oxide an equivalent for the molybdenum, assuming its existence as molybdate of lead, the following are the results:

Molecular ratio of coronadite.

$\left.\begin{array}{l}\mathrm{MnO}_{2} \ldots \ldots .56 .68 \div 87.0=0.6515 \\ \mathrm{MnO} \ldots . .5 .11 \div 71.0=.0861 \\ \mathrm{PbO} \ldots \ldots .25 .96 \div 222.9=.1165 \\ \mathrm{FeO} \ldots \ldots .91 \div 72.0=.0126 \\ \mathrm{ZnO} \ldots \ldots .910 \div 81.0=.0012 \\ \mathrm{CuO} \ldots \ldots . .05 \div 79.0=.0006\end{array}\right\} .217=1.00$

"If the mineral is to be regarded as anhydrous, the comparatively simple formula $\mathrm{R}^{\prime \prime}\left(\mathrm{Mn}_{3} \mathrm{O}_{7}\right)^{\prime \prime}$ satisfies the above ratio, and it may be written structurally:

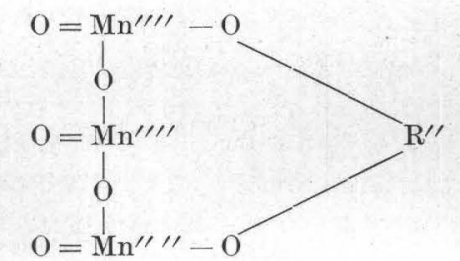

in which $\mathrm{R}^{\prime \prime}=\mathrm{Pb}^{\prime \prime}$ or $\mathrm{Mn}^{\prime \prime}$. This is to be regarded as a saturated salt of one of

$a$ Mean of 56.10 and 56.16. Total $\mathrm{Mn}$ as $\mathrm{MnO}$ from $\mathrm{MnSO}_{4}, 52.38$ per cent. Peroxide oxygen, 10.31 per cent. $b$ With a little $\mathrm{TiO}_{2}, \mathrm{P}_{2} \mathrm{O}_{5}$, and $\mathrm{V}_{2} \mathrm{O}_{5}$.

$c$ State of oxidation not known.

d Nothing at $100^{\circ}$, only 0.14 per cent below $200^{\circ}$. 
the numerous possible derivatives of ortho-manganous acid that may be derived from it by removal of water, in the present case as follows:

$$
3 \mathrm{H}_{4} \mathrm{MnO}_{4}-5 \mathrm{H}_{2} \mathrm{O}=\mathrm{H}_{2} \mathrm{Mn}_{3} \mathrm{O}_{7} \text {. }
$$

An acid of the same empirical formula would result by removal of two molècules of water from three of metamanganous acid, $\mathrm{H}_{2} \mathrm{MnO}_{3}$.

"It is probably best to rest for the present content with the above relatively simple formula and to regard the water found as due to incipient alteration. But if the water is to be considered as wholly or in part essential, and, furthermore, constitutional-and this may very well be the proper view to take-then the formula becomes much more complex, namely, $\mathrm{R}_{4}^{\prime \prime} \mathrm{H}_{2}\left(\mathrm{Mn}_{12} \mathrm{O}_{29}\right)$, when none of the water is allotted to the foreign matter. This formula is still referable graphically to a more highly condensed manganous acid and a number of isomers would be possible.

"Such intricate formulas as this should not cause the least surprise, however unlikely they may at first appear to be. The great number of manganites, in varying degrees of saturation and hydration, observed in nature and prepared artificially, some of them of even greater complexity than the above, are certainly not all mixtures of only a few simply constituted molecules. A very short study of the graphic formula corresponding to the above empirical formula $\mathrm{R}_{1}^{\prime \prime} \mathrm{H}_{2}\left(\mathrm{Mn}_{12} \mathrm{O}_{29}\right)$ will show what a vast number of closely related bodies are theoretically possible by hydrating the molecule step by step, or by adding to or reducing the number of divalent atoms, or substituting for them those of another valance. Similar varieties in great number would be derivable from other condensed manganous acids of both higher and lower orders, and it is plain that because of the very slight differences in percentage composition between many of them it is almost as hopeless to expect analysis to reveal the exact empirical formula in the majority of cases as it is for the enormously complex albuminous bodies of organic chemistry. This is especially true because in so many cases the mineral manganites described are far from being homogeneous species. They are either mixtures of two or more of these closely related complex molecules or else are contaminated by foreign bodies. It is not surprising then that so many compounds of uncertain formula that may be regarded as salts of manganous acid have been prepared in the laboratory or are found in nature. From the known tendency of these bodies to form under laboratory conditions which may very well be repeated in their general character in nature, it is to be expected that a vast number of mineral manganites should exist, and it ought rather to excite surprise than otherwise if two or more are not formed simultaneously from the same solution. This, together with inherent difficulties of analysis, would offer a simple explanation of the fact that so few of the analyses made lead to rational formulas. If formed from solution their original state might well be one of hydration, either as regards water of crystallization or of constitution. The temperature at which the water is expelled in the present case indicates constitutional water."

A search of the literature has not revealed a native manganite carrying a high percentage of lead, although artificial compounds have been prepared. For this reason, and because of its distinctly crystalline character, the present mineral seems worthy of receiving a specific name. The one proposed is coronadite, 
after the famous explorer of that portion of the American continent from which the Territories of New Mexico and Arizona have been formed.

Cuprite.-Cuprous oxide, $\mathrm{Cu}_{2} \mathrm{O} ; 88.8$ per cent $\mathrm{Cu}$. This handsome dark-red translucent mineral, often beautifully crystallized in cubes or distorted capillary form (chalcotrichite), occurs at Morenci and Metcalf as a product of surface oxidation. It formed an important part of the Longfellow ores, but is otherwise not common in the deposits in limestone. Its normal occurrence is at the upper limit of the chalcocite zone as a product of decomposition of the latter mineral; as, for instance, on the second level of the Joy vein and on the water-shaft level of the Montezuma vein; in the Arizona Central mine on the deepest levels, 200 to 300 feet below the surface, near the contact of porphyry and metamorphic rock, where it is often deposited on magnetite and associated with limonite; in the open cuts and on the Wilson level of the Metcalf mine as irregular veinlets in serieitized porphyry, where, as often elsewhere, it is intergrown with native copper. It is also frequently found distributed in fine scales on the joints of the altered clay shale of the Arizona Central, the Detroit, and the Manganese Blue mines.

Pyrite. $-\mathrm{FeS}_{2}$. This is the only iron sulphide observed, marcasite and pyrrhotite ${ }^{a}$ not being known from the district. It is extremely common in disseminated form and in veinlets in the metamorphosed limestone and shale, and sometimes in quartzite and granite. It is equally common in the altered porphyry, where it is always associated with sericite, and is found on the fissure veins in porphyry and in metamorphic rocks in large masses often several feet wide and sometimes, as in the Joy vein, 50 feet wide; here it generally occurs as coarsely granular masses with occasional small crystals showing in drusy cavities. Larger well-developed crystals are not common, but are found with quartz in the Hudson and Fairplay veins, as well as in a small filled vein in the Lone Star tunnel, all at Morenci; the usual combination in this case is cube and pyritohedron. The occurrences in almost all cases except those just mentioned indicate origin by replacement of limestone, shale, or porphyry.

Chalcopyrite. $-\mathrm{Fe}_{2} \mathrm{Cu}_{2} \mathrm{~S}_{4} ; 34.5$ per cent $\mathrm{Cu}$. This mineral occurs sparingly on the lower levels of the veins of Morenci, intergrown with pyrite and zine blende; also in similar position in veinlets or disseminated in porphyry. Rarely it is associated with chalcocite, as was the case in the Black stope of the second level of the Ryerson mine; such a connection would suggest its origin as due in this case to secondary sulphide formation by solutions from above, for it is known that chalcopyrite, as well as chalcocite, may form under such conditions. The mineral is very abundant in disseminated forms, as well as in veinlets, in the metamorphic limestone of Morenci; also in shale in the Shannon mine. It may

$a$ Grains of pyrrhotite were observed in a contact-metamorphic Cretaceous shale from lower Gold Creek. 
form irregular aggregates or grains in otherwise little-altered limestone near the porphyry contacts, or occur intergrown with garnet, epidote, or pyroxene in the highly altered rock, almost always being also associated with magnetite, pyrite, and zinc blende. Much of the pyrite from the lower levels of the Morenci vein, and also that disseminated in other rocks like quartzite, contains about one-half per cent of copper, probably due to a mechanical admixture of chalcopyrite, difficult to detect either by the naked eye or by the microscope.

Zinc blende (sphalerite).-This sulphide occurs under practically the same conditions as chalcopyrite, with which it is usually associated. It is common, disseminated in the hard limestones or metamorphic rocks, and is also frequent in the lower levels of the vein, where it is associated with much pyrite and some chalcopyrite. It is not known to occur in oxidized deposits or in the zone of sulphide enrichment, nor is it formed by these secondary processes anywhere in the district. As an exceptional occurrence it is found crystallized with pyrite, chalcopyrite, and drusy quartz on a filled vein in the Lone Star tunnel. Its forms are a combination of cube and two tetrahedrons (Penfield). The zinc blende is easily oxidized, and, aside from a few rarer occurrences, its products only appear as efflorescing sulphates on the walls of the mine workings in the upper oxidized zone.

Galena.-Of rare occurrence; reported from the Stevens group near Garfield Gulch, from the fissure veins of Dorsey Gulch, and from a few other localities.

Molybdenite.-MoS. This mineral is frequently found in the Morenci fissure veins in primary association with pyrite, chalcopyrite, and zinc blende; analyses have also revealed its presence in small quantities in the ordinary smelting ore. As dark-gray foils it occurs in a quartz vein in granite on the northeast side of Chase Creek 1 mile above the Longfellow incline, associated as above. Microscopically it was noted in the deep levels of the Montezuma pyrite vein, where it formed dark-gray fluffy aggregates in quartz (Pl. XII, A).

Chalcocite. $-\mathrm{Cu}_{2} \mathrm{~S} ; 79.8$ per cent $\mathrm{Cu}$. The cuprous sulphide is very common in the Clifton district, in fact constituting at present the principal valuable mineral in the ores. It occurs, chiefly intergrown with pyrite, in the altered porphyry as disseminated grains or as solid seams or veins, which rarely exceed 2 or 3 feet in thickness. It is never crystallized, but has ordinarily an earthy or sooty appearance and black color; scratching it with a knife reveals the semisectile character and metallic luster. In a few small massive veinlets the normal metallic luster and dark-gray color appear on fractures; a fibrous or columnar structure of the mineral is known on small seams in shale from the Montezuma mine. The mineral prefers porphyry, and the great bodies of ore now worked all oecur in this rock, but it is not entirely unknown in the irregular deposits 
in limestone generally carrying cuprite and copper carbonates. A partial analysis of massive ehalcocite from the Montezuma mine, Morenci, gave (W. F. Hillebrand, analyst) 96 per cent $\mathrm{Cu}_{2} \mathrm{~S}$ and 2.4 per cent $\mathrm{FeS}_{2}$, the latter probably mechanically admixed.

The chalcocite is everywhere, in this district, a secondary mineral, formed by the replacement of pyrite by means of descending solutions of cupric sulphate.

Pl. XIV illustrates the typical appearance of the chalcocite ore. The deposition of the mineral was accompanied by the formation of quartz, chalcedony, and kaolin. In the veins in porphyry the chalcocite ore begins 100 to 200 feet below the surface and continues to a depth of 400 feet, or even more, when it is usually replaced by pyrite, chalcopyrite, and zinc blende.

- Covellite and bornite.-Rarely observed minerals. Covellite was noted from the Ryerson and Montezuma mines.

Antimonides and arsenides.-These minerals are not known to occur in the district. Analyses of flue dust reveal very small quantities of arsenic and antimony.

Tellurides and selenides.-The same statement applies to these minerals. As shown by the flue-dust analysis (p. 39), a minute amount of tellurium must be contained in the ores. This association of copper and tellurium has been noted before, and it is known that in copper refining some by-products contain a considerable quantity of that element.

Feldspars.-Orthoclase, as reddish grains, is found in granite, and sometimes in the clastic rocks derived from it; likewise in the phenocrysts and groundmass of granitic. and monzonitic porphyries and in rhyolite. Microcline and perthite occurs in granite; albite in granite and in granite-porphyries. Acidic oligoclase is found in the latter rocks and in the monzonite-porphyry; labradorite and andesine in diorite-porphyry, diabase, and basalt. Feldspars of all kinds are conspicuously absent in the metamorphic rocks and in the pyrite veins.

Garnet.-Garnet occurs in the Clifton district, exclusively in the altered limestones; it is throughout, as far as known, an andradite or lime-iron garnet of typical composition, yellowish to dark-brown color, and usual resinous luster. For analyses see page 134. Commonly occurring in massive form, it sometimes appears as small crystals of usual dodecahedral form, embedded in calcite, and is frequently revealed by the microscope in well-defined hexagonal sections in the limestone close to more extensive areas of garnet. The larger masses are isotropic, but the crystals ordinarily show the optical anomalies of the species, consisting in sectors and concentric bands with double refraction; this is usually feeble with light-gray colors, but in places bright-yellow interference colors are noted. 
The garnet when derived from the pure limestones of the Modoc formation forms large masses 50 to 100 feet thick, as on the western slope of Modoc Point at Morenci and on top of Shannon Mountain at Metcalf. The siliceous and dolomitic limestones of the Longfellow formation both at Morenci and Metcalf also contain garnet in places, irregularly distributed together with epidote, pyroxene, and magnetite, as in the Yavapai, Manganese Blue, and Arizona Central mines, and many other places. The only place outside the immediate vicinity of Morenci and Metcalf where garnet has been found is in Gold Gulch and Pinkard Gulch, and here only in smaller masses.

Garnet frequently occurs intergrown with magnetite, pyrite, zinc blende, and chalcopyrite (Pls. VII, IX, and X, A). It decomposes to quartz and limonite, the lime being carried away as carbonate. Other products of oxidation associated with it are malachite and azurite.

Amphibole.-Common hornblende forms part of the diorite and some of the monzonite-porphyries, and occurs in places in the granite. A colorless amphibole, which the analysis of a rock containing it shows to be tremolite or the nearly pure metasilicate of magnesia and lime, occurs in the metamorphic dolomitic limestones of Morenci and Metcalf and also in altered shades, always forming minute or microscopic prisms of normal optical behavior. It is also formed in the limestone wall rock of pyritic veins at Morenci and Metcalf. The tremolite weathers to chloritic and serpentinoid minerals, sometimes also to a variety of asbestos.

Pyroxene.-The common augite forms part of the diabases and basalts, but does not occur in the porphyries. A colorless variety, apparently corresponding to pure lime-magnesia pyroxene, or diopside, is of very frequent occurrence in the metamorphosed limestones of the Longfellow formation. The manner of formation by metasomatic replacement is shown in Pl. VII, $B$. The association is with the other contact-metamorphic silicates, magnetite, and sulphides. It may also form in the limestone wall rock adjoining pyritic veins. Like the tremolite the diopside alters near the surface to chloritic and serpentinoid minerals.

Epidote.-This yellowish-green mineral, a silicate of lime, ferric iron, and alumina, appears as a secondary product in the feldspars of some monzonite and diorite porphyries. Its principal occurrence is, however, in the metamorphic rocks, where it is in intimate intergrowth with garnet, magnetite, pyroxene, pyrite, chalcopyrite, and zine blende; frequent in the altered Longfellow limestones, sometimes in large masses, as at the Joy mine, third and fourth levels. It occurs further, abundantly in places, in the altered Devonian and Cretaceous shales on the ridge west of the Arizona Central, as far west as the Eagle Creek road at the gap leading down to Gold Gulch. In metamorphism along dikes it is the mineral usually immediately adjoining the porphyry. 
Well-defined crystals are very rarely observed. The mineral is granular, and has all the characteristics of normal epidote rich in iron. Epidote rock decomposes at the surface to an earthy, yellowish-green mass, as shown, for instance, near the Arizona Copper Company's hospital at Morenci and near the Shannon Gap, Metcalf. Qualitative analysis of the former revealed much water and ferric oxide, together with a little $\mathrm{CaO}, \mathrm{Al}_{2} \mathrm{O}_{3}, \mathrm{MgO}, \mathrm{CuO}$, and a trace of $\mathrm{ZnO}$. The microscope shows indefinite microcrystalline aggregates, which probably chiefly consist of hydrous ferric silicate, the lime having largely been extracted.

Biotite.-This black mica is found sparingly in the granite and monzonite porphyries, in the granite (usually decomposed), and in the rhyolites of Clifton. It is not known to occur in the contact-metamorphic rocks, not even from the shales.

Muscovite.-As a primary mineral muscovite does not enter the composition of the Clifton rocks; but in the fibrous-felted form usually called sericite it is extremely common in the porphyries and also to some extent in the granites and quartzites in the vicinity of the mineral deposits. During the common surface decomposition sericite is apt to form to a limited extent in the feldspars of igneous rocks. Along the veins, however, sericitization is a most important process, the rocks for long distances from the vein being completely changed to felted sericite and quartz. Practically the whole of Copper Mountain and large parts of the porphyry between Morenci and Metcalf and at the latter place are thus changed. The composition of the mineral is shown calculated from analyses on page 170 . It is occasionally present in the metamorphosed clay shales. The microscopic aggregates show under the microscope the normal behavior of the mineral. Sericite resists further decomposition very energetically, and the quartz sericite rocks, unless containing very much pyrite, form hard blocky outcrops. A limited amount of kaolin is formed from the sericite under the influence of waters containing free sulphuric acid.

Chlorite.-As a product of common hydrometamorphism from surface waters, chlorite forms from biotite and hornblende in granite and in the porphyries. To some extent varieties with little iron result from decomposition of pyroxene and amphibole in metamorphic rocks. The garnet does not decompose into chlorite. Small foils of a dark-bluish chlorite were noted in a limestone from the south slope of Copper Mountain and from other places near Morenci in metamorphic rocks.

Serpentine.-This mineral results very frequently from the hydration of the pyroxene and amphibole in metamorphic limestone due to surface waters. Pureyellow translucent serpentine occurs on the ridge west of Morenci as irregular masses in limestone just below the garnet contact. Almost pure serpentine with 
magnetite occurs at the Thompson mine on the summit of the same ridge, near the porphyry contact; it is dark green, streaked, and contorted, having seemingly resulted from replacement of shaly material. Serpentine nowhere forms large areas. Its characteristics under the microscope are normal.

Asbestos. - The metamorphic rocks in places also contain asbestos as a result of hydration. The mineral is found nesr the Arizona Copper Company's hospital at Morenci, and in pieces over a foot long, much resembling fossil wood, in the Black Hawk No. 3 tunnel at Metcalf. The silky white fibers extinguish between crossed nicols at angles of $20^{\circ}$, and are probably altered actinolite. They are contained in honeycombed limonite masses.

Kaolin.-As a secondary product kaolin is not uncommon at Morenci, and to less extent also occurs at Metcalf. It does not form during the sericitization of the porphyry which accompanied the formation of the pyritic veins, but accompanies in small amounts the chalcocite in the veins in porphyry, and the copper earbonates in the decomposed deposits in limestone. It occurs as veinlets in the quartz in the Humboldt, Ryerson, and other mines, and as large masses in the Longfellow mine (East Yankie claim), where it is adjoined by much limonite and is often very pure. Sometimes it is delicately veined by malachite and incloses small grains of cuprite with native copper and limonite. It also occurs in pure condition at the Mammoth mine in Garfield Canyon, and at the Copper Mountain mine, Morenci, in snow-white mammillary masses with azurite and malachite. Kaolin is evidently easily formed by the action of free sulphuric acid on clay shale or porphyry; the sericite of the altered porphyry is only attacked by this acid with great difficulty.

Glauconite.-A greenish mineral, resembling glauconite, oceurs in the shales of the Morenci formation and also in the green shales which, near the mouth of Apache Gulch, overlie the Coronado quartzite.

Willemite. $-\mathrm{Zn}_{2} \mathrm{SiO}_{4}$. This rare silicate of zinc was found by Mr. Boutwell, as very small grayish crystals on a fragment of garnet rock, in the Modoc open cut on the north side of Modoc Mountain. These crystals were identified by Messrs. Pirsson and Penfield, of Yale University, who state that the stout hexagonal prisms look exactly like those from the original locality at Moresnet.

Calamine.- $(\mathrm{ZnOH})_{2} \mathrm{SiO}_{3}$. Small transparent rhombic crystals of calamine were identified by Doctor Hillebrand and myself on a specimen of decomposed garnet rock from the Shannon mine, just above the lime quarry.

Dioptase. $-\mathrm{H}_{2} \mathrm{CuSiO}_{4}$. The silicate of copper, dioptase, has been found at only a few localities. Very beautiful specimens, which, however, are by no means common, have long been known from the classic locality, the Kirghese Steppes, Russia, and more recently from the French Kongo State, Africa. Dioptase is 
seldom found in the United States, the only recorded occurrences being at the Bon Ton mines, Chase Creek, near Clifton, Ariz., as noted by R. C. Hills, ${ }^{a}$ and from near Riverside, Pinal County, Ariz., as noted by W. B. Smith. ${ }^{b}$ Wellcrystallized specimens were found on an old dump of the Stevens group of mines, on the west side of Chase Creek, near Garfield Gulch (p. 351). They occurred in a small chimney of chrysocolla ore in limestone, now worked out, in a locality believed to be the same as that described by Mr. Hills. The dioptase crystals were submitted to Prof. S. L. Penfield, who remarks on them as follows:

"The crystals, measuring from 1 to $2 \mathrm{~mm}$. in diameter, occur closely grouped together, lining cavities in a brown ferruginous gangue impregnated with amorphous green material which is probably chrysocolla. The color of the dioptase is a beautiful emerald green. The habit of the crystals, shown by the accompanying figure [PI. VII, E, F], is that which is most commonly observed and is especially characteristic for dioptase; prism of the second order $\alpha(11 \overline{2} 0)$, terminated chiefly by the rhombohedron of the first order $s(02 \overline{2} 1)$, and with small faces of the rhombohedron of the third order $x(13 \overline{4} 1)$. As is common on this species, the prismatic faces are vicinal and the $s$ and $x$ faces are striated parallel to their mutual intersection edges, hence the crystals are not suited for getting accurate measurements of the angles with the reflection goniometer. One crystal was measured, and the angles of one of the rhombohedral zones, given below, are sufficiently close to the calculated values to establish the identity of the forms.

$$
\begin{aligned}
& \text { Table of angles measured. } \\
& \text { Measured. Caleulated. } \\
& a x, \quad 11 \overline{2} 013 \overline{4} 1=28^{\circ} 55^{\prime} \quad 28^{\circ} 48^{\prime} \text {. } \\
& s \quad s^{\prime}, 02 \overline{2} 1 \overline{2} 021=83 \quad 48 \quad 84 \quad 33 . \\
& s^{\prime} \quad a^{\prime \prime}, \overline{2} 021 \overline{11} 20=48 \quad 18 \quad 47 \quad 43 .
\end{aligned}
$$

By crushing some of the material, embedding in oil under a cover glass, and examining in convergent polarized light, occasional fragments were found which gave a normal uniaxial interference figure, with numerous rings indicating high birefringence. The character of the birefringence was found to be positive. Thus, in all of its crystallographic and optical relations the material studied is like typical dioptase from other localities."

Chrysocolla. $-\mathrm{CuSiO}_{3}+\mathrm{nH}_{2} \mathrm{O} ; 36.05$ per cent $\mathrm{Cu}$. This mineral oceurs very commonly in the oxidized part of the deposits, but does not, except in some cases, constitute an important ore. On the whole it is more abundant in the deposits in porphyry and granite than in those in limestone. The usual bluish-green or dirty-green colors and conchoidal fracture characterize it. It occurs in seams or coatings at many of the mines, abundantly in the Mammoth mine on contact fissures between porphyry and limestone; at several prospects on the Stevens group in Chase Creek near Garfield Gulch; in the Las Terrazas fissure 
vein in porphyry near Metcalf; at the Metcalf mines; at many of the prospects between that place and Morenci, and at the Modoc open cut, Morenci. A technical analysis of chrysocolla ore from Las Terrazas mine by the Arizona Copper Company gave:

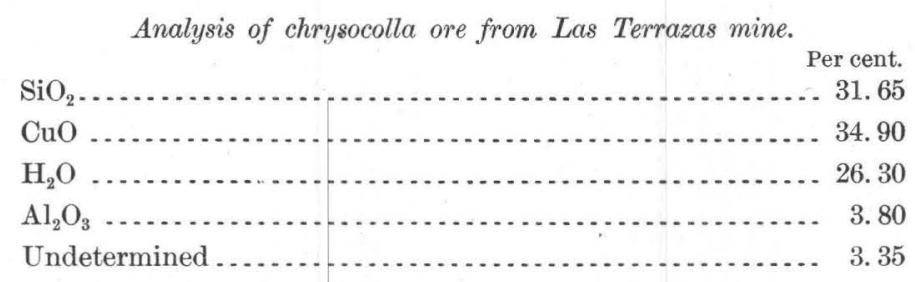

Normal chrysocolla should have 34.2 per cent $\mathrm{SiO}_{2}, 45.2$ per cent $\mathrm{CuO}$, and 20.5 per cent $\mathrm{H}_{2} \mathrm{O}$, but the analyses show great divergency, many probably being mixtures. Moreover, what has been called chrysocolla probably includes two mineral species.

The optical characteristics of chrysocolla seem imperfectly known. Dana states correctly that it is eryptocrystalline, while many other text-books, notably one issued in 1902 by Professor Miers, call it. "amorphous."

In most cases the mineral indeed seems cryptocrystalline with bluish-gray colors of interference. But this is by no means universal. Chrysocolla from the Modoc open cut appears as mammillary crusts of bluish-green color on "copperpitch ore." The latter is isotropic and undoubtedly a distinct mineral from the chrysocolla; it is of a brown color in varying tints, some of it opaque and showing evidence of concentric deposition. On top of the chrysocolla are thin crusts of quartz and some calcite. The chrysocolla has three different structural forms, as seen under the microscope: (1) Cryptocrystalline to microcrystalline aggregates of particles with high birefracting index; (2) very fibrous and felted aggregates of the same substance, giving undulatory effects between crossed nicols and medium high colors; (3) fibrous crusts on top of the first-named form or thin layers between masses of the same, the individuals having such a remarkably parallel orientation that the aggregate of them appears almost like single crystals between crossed nicols, with black shadows sweeping across them when the table is turned. Extinction is parallel to the fibers; double refraction strong, about like augite; character negative. The same optical characteristics were repeatedly observed in thin sections of chrysocolla from Metcalf and other places. Reniform deposits were sometimes noted, the center of cryptocrystalline material being coated with coarsely fibrous and highly birefringent material.

Sections from the Coronado and Metcalf mines often show pseudomorphs of pyrite, consisting of a shell of limonite with a kernel of fibrous chrysocolla. $16859-$ No. $43-05-8$ 
Specimens from the Rattlesnake claim, $1 \frac{3}{4}$ miles northwest of Morenci, stowed cryptocrystalline chrysocolla containing needles of a doubtful mineral with parallel extinction and birefringence about like quartz. The material contains a considerable amount of phosphoric acid and also a little lead.

The observations of Jannetaz ${ }^{a}$ on chrysocolla from Boleo, Baja California, Mexico, led to the same results as described above, but seem generally to have been overlooked by editors of text-books.

Copper-pitch ore.-Under this old German name is described a dark-brown to black substance, sometimes dull, but generally with glassy to resinous luster; hardness, about 4; streak, dark brown. It occurs among the products of oxidation of the deposits in limestone, as at the Detroit and Longfellow mines and the Modoc open cut at Morenci, and is associated with azurite, malachite, and chrysocolla, often inclosing these minerals or replacing in branching veinlets, together with azurite, a shale-like mass, probably largely composed of kaolin. In thin sections it is sometimes opaque, but often also translucent, gradual transitions obtaining in the same section, and occurs in irregular or concretionary masses, often containing small embedded crystals of a doubtful mineral, possibly a silicate of zinc. Between crossed nicols the translucent mineral always proves entirely isotropic and, except for varying depth of color and the small crystals mentioned, is entirely homogeneous.

A rough preliminary analysis by Dr. W. F. Hillebrand of selected pitch-black material from the Detroit mine gave:

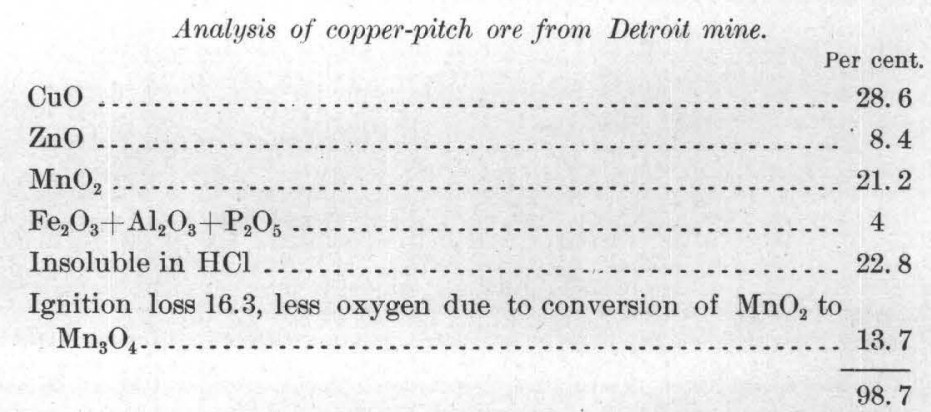

Similar material surmounted by crusts of chrysocolla from the Modoc open cut contained much $\mathrm{MnO}_{2}$ with a good deal of $\mathrm{CuO}$ and $\mathrm{ZnO}$ and is thus evidently the same substance. To this analysis Doctor Hillebrand remarks that $\mathrm{Mn}$ is largely but not certainly wholly present as $\mathrm{MnO}_{2}$. The insoluble portion consists . of silica; it is wholly separated by acid without need of evaporation and is nearly all soluble in dilute $\mathrm{KOH}$. It is not possible to say whether $\mathrm{SiO}_{2}$ is in combination or as opal, but it can not be present in any other form. 
Most of these copper-pitch ores, known from many districts, have been described as impure chrysocolla. As shown by the optical characteristics, however, they are not a mixture, and they certainly do not contain any chrysocolla, the characteristics of which are very different. They probably represent a series of closely related compounds, the chemistry of which has not yet been fully elucidated. Prof. G. A. Koenig ${ }^{a}$ describes a similar mineral with the same isotropic character from Bisbee and names it melanochalcite. Its composition is different, as shown by the following analysis:

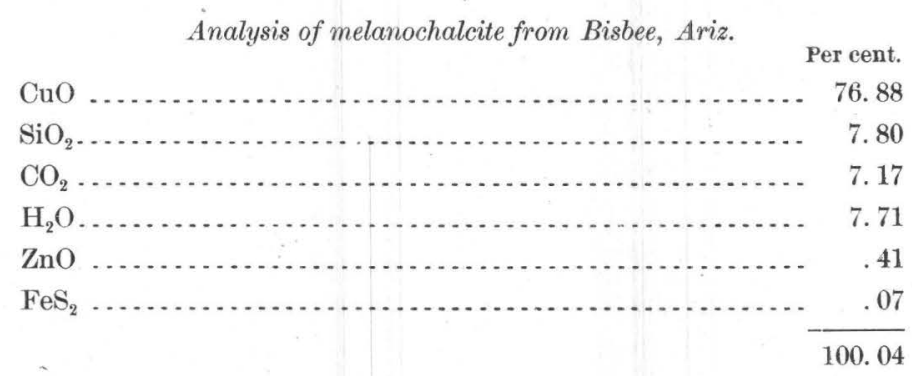

Mr. Koenig considers it as a basic salt of an ortho-silico-carbonic acid. No $\mathrm{CO}_{2}$ was found in the Morenci minerals. In conclusion, it would seem that the chemistry of these copper-pitch ores would bear further examination.

Morencite.-In a lime shale on the intermediate level of the Arizona Central mine, Morenci, 200 feet below the surface, brownish or greenish spreading masses were found containing brownish-yellow, silky, fibrous seams. The inclosing material consists largely of the same material as the seams, but impure and mixed with a little chlorite and pyrite. The whole bears evidence of being a product of oxidation of some contact metamorphic mineral.

The fibrous mineral on the seams forms a felted aggregate as seen under the microscope, but it is well individualized and contains few impurities except a little pyrite and chlorite. The minute fibers are brownish yellow and slightly pleochroic, being darker when parallel to the principal section (opposite the behavior of biotite); the birefringence is strong and extinction probably strictly parallel to the fibers. No mineral corresponding to this has been described, but, although its individual character is beyond doubt, the analysis does not lead to a satisfactory formula. The material for the analysis was picked out carefully under the lens and, examined under the microscope, proved satisfactorily pure.

Doctor Hillebrand, who analyzed it, remarks as follows:

"The analysis afforded the results of the first column of figures below. In deducing the molecular ratios of the second column there has been deducted sufficient lime to form apatite with the phosphoric oxide. 


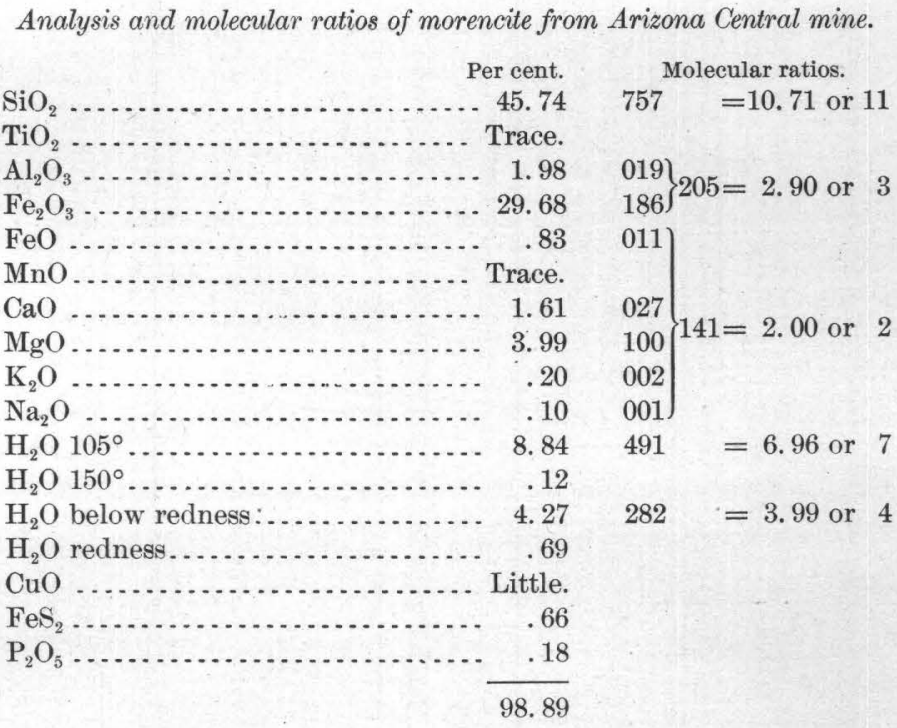

"It would seem from the temperatures at which the water is driven off that this must exist in two conditions, and that four-elevenths of it must be held more securely than the remaining seven-elevenths. The attempt to account for four molecules of water as constitutional, however, led to no simple or seemingly probable formula, whereas if all water is excluded the ratio is that of a metasilicate $-\mathrm{R}_{2}^{\prime \prime} \mathrm{R}^{\prime \prime \prime}{ }_{6}\left(\mathrm{SiO}_{3}\right)^{\prime \prime}{ }_{11}$. On the other hand, to include the whole of the water as essential to the silicate molecule, for which there is little ground in view of the ease with which most of it is expelled, leads to an orthosilicate ratio- $\mathrm{H}_{22}^{\prime} \mathrm{R}_{2}{ }_{2} \mathrm{R}^{\prime \prime \prime}{ }_{6}\left(\mathrm{SiO}_{4}\right)^{\prime \prime \prime \prime}{ }_{11}$."

On the whole, considering also the bad summation of the analysis, it is more rational to regard the mineral as a hydration product of an original metasilicate molecule than to attempt to construct a complex formula which could have but a very doubtful value. Considering that the mineral is not a mixture but is optically well individualized, it has been thought best to fix its identity by means of the name of morencite.

Calcite.-In almost pure, fairly coarse, granular form, this mineral constitutes the uppermost 100 feet of the Modoc formation (lower Carboniferous). In the Longfellow formation it is also abundantly represented, but there it is always associated with silica and sometimes with dolomite. It occurs further in the contact metamorphic rocks in very coarsely granular masses, or as small veinlets with magnetite and pyrite. It appears more rarely as small rhombohedral crystals ( $1 / 2 \mathrm{R}$ and $\mathrm{R}$ ) on decomposing metamorphic rocks, especially in the copper deposits contained in them, as at the Modoc mine on drusy quartz rock, and at the Detroit mine on partly altered shale.

Dolomite.-Occurs in granular form as beds in the lowest part of the Modoc formation, and mixed with calcite in places throughout the Longfellow formation. 
It is further contained as a secondary product in small fissures in lime shale and porphyry in the Ryerson mine, and is then usually of earthy appearance and with cryptocrystalline development.

Carbonate of zinc.-The presence of carbonate, and probably also silicate, of zinc is indicated, according to Doctor Hillebrand, in some of the "cap rock" from Shannon Mountain, consisting chiefly of magnetite and garnet. This is also borne out by the analysis on page 314 .

Malachite.- $(\mathrm{CuOH})_{2} \mathrm{CO}_{3} ; 57.4$ per cent $\mathrm{Cu}$. Malachite, a basic cupric carbonate, is one of the most common of oxidized copper ores in the irregular and tabular deposits in limestone, while it is far less abundant in the lodes contained in porphyry. The finest specimens came from the Detroit (Humming Bird), Manganese Blue, and Longfellow mines at Morenci; but few, if any, of the mines are entirely without it. It occurs in intimate association with kaolin, limonite, azurite, and brochantite. The mineral is monoclinic and often occurs in complicated twins and fibrous bunches of erystals. Simple crystals are usually very small; the basal cleavage is excellently developed. Very fine radiating bunches were obtained in the Standard mine, a mile below Metcalf; the larger crystals are flat prisms with well-developed clinopinacoid, while some microseopic single crystals proved to be thick-tabular with predominant basal plane. Malachite has a light-green color and shows in simple crystals a notable pleochroism ranging on the basal plane from $\mathfrak{b}$ yellowish green to $\mathfrak{c}$ bluish green. Single prismatic crystals also show slight pleochroism. In larger prismatic crystals complicated twinning generally obscures the pleochroism. The axial plane lies in the clinopinacoid, and it is stated that it makes an angle of $23 \frac{1}{2}^{\circ}$ with the vertical axis, but the maximum extinction in the prismatic zone in the material examined is only $17 \frac{1}{2}^{\circ}$. Superimposed individuals are the rule in the larger crystals, and these remain light between crossed nicols. The index of refraction is $1.87-1.88$; the maximum birefringence is high, probably in the vicinity of 0.1 , as a rule giving rise to greenish white of a higher order. Malachite generally occurs in fibrous aggregates, sometimes forming perfect spheres and often intergrown with crusts of azurite. It often develops by replacement in shale as small crystals, grains, or fibers $(\mathrm{Pl} . \mathrm{XV}, A)$. A small spherical mass of crystals consisting of malachite was found on Metcalf Hill and doubtless represents a pseudomorph after azurite.

Azurite.- $(\mathrm{CuOH})_{2} \mathrm{Cu}\left(\mathrm{CO}_{3}\right)_{2} ; 55.22$ per cent $\mathrm{Cu}$. This beautiful dark azureblue mineral, which is also a basic cupric carbonate, accompanies malachite in the oxidized deposits in limestone, and is not so often found in the fissure veins in granite and porphyry. In the Longfellow, Detroit, Manganese Blue, and Shannon mines it formed large masses of ore, while it scarcely occurs in 
the great chalcocite veins of Copper Mountain, not even in the upper levels. It is not uncommon in the porphyry of the Metcalf mines, but there smaller masses of limestone are not far distant. Azurite frequently occurs well erystallized in monoclinic tabular or wedge-like forms, and these crystals may either develop in open spaces or replace soft rocks like kaolinized shale. The crystals often combine to sheave-like or spherical aggregates, sometimes weighing 40 pounds or even more. These stalactitic masses occurred, among other places, in the Detroit mine ${ }^{a}$ in crusts alternating with malachite, the mineral occasionally having fibrous structure. The association with kaolin is frequently noted, also with the black copper-pitch ores. As to succession it is often the latest mineral formed. Whether formed by replacement or crustification, azurite is apt to develop in large single individuals, appearing in thin section with wedge-shaped outlines, and extinguishing parallel to the extension of the crystal. There is a slight pleochroism, $\mathfrak{x}$ paler blue, $\mathfrak{a}$ and $\mathfrak{t}$ deep pure cobalt blue. The birefringence is rather high.

Libethenite. $-\mathrm{H}_{2} \mathrm{Cu}_{4} \mathrm{P}_{2} \mathrm{O}_{10}$. This hydrous basic phosphate of copper was found 30 feet below the tunnel level of the Coronado mine in the main ore shoot. It is a matter of interest to record its occurrence, for this rare mineral has never before been noted in the United States. It occurs in small crystals, less than $1 \mathrm{~mm}$. in length, deposited in cavities and seams in a quartzite gangue. The mineral was identified by Prof. S. L. Penfield, who also kindly measured and figured the crystals. Professor Penfield describes the mineral as follows:

"The only associated minerals are occasional clusters of minute quartz crystals and small tufts of radiated malachite needles. The color of the libethenite varies from light to dark olive green, depending upon the size of the erystals. The habit of the crystals, as shown by the accompanying illustration, is a combination of the prism $m$ (110) and brachydome $e$ (011), which is exactly like that commonly observed on libethenite from foreign localities. On an occasional crystal the brachypinacoid $b$ (010) was also observed. Although the crystals are brilliant, the faces are generally vicinal and give uncertain or multiple reflections of the goniometer signal. The best reflections were obtained from the faces of the dome $e$, and three measuremenis of $e_{\lambda} e^{\prime}, 011_{\wedge} 0 \overline{1} 1$ gave $69^{\circ} 52^{\prime}, 70^{\circ} 18^{\prime}$, and $70^{\circ} 14^{\prime}$. The last measurement, obtained from the best reflections, is close to the value $70^{\circ} 8^{\prime}$, obtained by Rose. The best measurement of the prismatic angle gave $m_{\wedge} m^{\prime \prime \prime}, 110,1 \overline{1} 0=87^{\circ} 11^{\prime}$, which, considering the vicinal character of the prismatic faces, is reasonably close to the value of Rose, $87^{\circ} 40^{\prime}$, as given in Dana's Mineralogy. A small crystal resting on a prismatic face, when examined in convergent polarized light, showed an optical axis nearly in the center of the field, with the dark bar running at right angles to the vertical axis, thus indicating that the optical axes are in the plane of the base, as determined by Des Cloizeaux. The presence of copper, water, and phosphoric anhydride were determined by chemical tests." 
A more detailed research would probably reveal small quantities of phosphates from other mines near Morenci. They are certainly not abundant.

Brochantite. $-\mathrm{H}_{6} \mathrm{Cu}_{4} \mathrm{SO}_{10} ; 56.10$ per cent $\mathrm{Cu}$. This basic sulphate of copper is usually supposed to be one of the rarer minerals of this metal. It was, however, discovered at a few places near Metcalf and Morenci in well-developed crystals, and this led to a systematic microscopic examination of the green ores, hitherto supposed to be malachite. The result was surprising, as the mineral was proved to be of extremely common occurrence, mostly intergrown with malachite, which had effectively masked its presence. It is believed that a careful examination of many so-called malachites from other districts will disclose the overlooked importance of brochantite as a copper ore.

Brochantite is frequently crystallized in the short but stout rhombic prisms combined with dome and brachypinacoid characteristic of the species. Needleshaped and flat crystals are more rare. The erystals are usually of small size and frequently microscopic. The mineral occurs as lighter or darker emerald-green crusts on limonite or sericitized porphyry from the red-ore body in the Shannon mine, from the Metcalf mines, and from many other places; as fine-grained aggregates in altered porphyry from the Shannon mine near the surface, where it constitutes valuable ore with up to 30 per cent copper; as flat pieces or even foils with almost pearly luster, in croppings from the King vein, filling seams and coating porphyry fragments; as flat stellar aggregates of bluish-green foils in croppings of the Copper Queen mine between Morenci and Metcalf; and finally, at places near Morenci, as, for instance, in the Copper Mountain and Montezuma mines, at the latter locality replacing chalcocite. It would probably not be found absent from any mine in the district containing oxidized copper ores. On the whole the mineral is most abundant in fissure veins in porphyry, though also occurring in the irregular deposits in limestone. Malachite often develops later than the brochantite.

Brochantite has an excellent cleavage parallel to the brachypinacoid. The macropinacoid is the axial plane, and the acute bisextrix is seen emerging in cleavage foils. The pleochroism is very slight. The birefringence is much lower than that of malachite, being about equal to that of augite. This, as well as the absence of twins, distinguishes brochantite from malachite. The reaction for sulphuric acid is, of course, a valuable aid.

Alunite. $-\mathrm{K}_{2} \mathrm{O}, 3 \mathrm{Al}_{2} \mathrm{O}_{3}, 4 \mathrm{SO}_{3}, 6 \mathrm{H}_{2} \mathrm{O}$, This white and inconspicuous sulphate of potassium and aluminum was found filling a narrow seam on a contact between shale and porphyry in the main adit of the Ryerson mine at Morenci, where it forms a white earthy mass not unlike kaolin.

It is also found in some altered porphyries of the same mine associated with 
pyrite and kaolin. It occurs here as microscopic rhombohedral crystals showing quadratic or hexagonal sections; as grains or irregular masses; and as fibrous aggregates. The birefringence is of medium strength, the colors at most reaching pale yellow. The index of refraction is low.

Gypsum.- $\mathrm{CaSO}_{4}+2 \mathrm{H}_{2} \mathrm{O}$. Common in oxidized deposits in limestone, as may be expected from the fact that a large part of the copper carbonates are formed by reaction between sulphates and calcium carbonates. Specimens of gypsum from the Manganese Blue mine inclose plates and crystals of cuprite.

Spangolite. $-\mathrm{H}_{18} \mathrm{Cu}_{6} \mathrm{AlClSO}_{19}$. This peculiar mineral, essentially a highly basic sulphate of copper and-alumina with chloride of copper, was discovered and described by Prof. S. L. Penfield ${ }^{\alpha}$ some fifteen years ago. The specimen came from some point within 200 miles of Tombstone, Ariz., and probably from one of the great copper camps of the territory. Somewhat later it was identified by Prof. H. A. Miers on two specimens from Cornwall, England, but the American locality has not yet been found. It is therefore a matter of interest to record its discovery on some specimens from the Metcalf mine of the Arizona Copper Company, taken from the workings in the great open eut not more than 100 feet below the surface. These specimens consist of white sericitized granite-porphyry, in part silicified, and traversed by veinlets and irregular masses of cuprite; the cuprite contains native copper and is covered by crusts of malachite, brochantite, and chrysocolla. A soft and scaly bluish-green coating on the chrysocolla proved to consist of microscopical hexagonal crystals or cleavage foils, remaining dark between crossed nicols. It was identified by Doctor Hillebrand as spangolite, a determination in which Professor Penfield concurred. No measurable crystals were found and the mineral is very inconspicuous. It is difficult, if not impossible, to obtain material entirely free from accompanying minerals.

Concerning the chemical examination, Doctor Hillebrand reports as follows:

"Selected bluish flakes from this specimen gave tests for water, and the sulphate and chlorine ions, besides copper. There was too little of this pure material to permit a test for alumina, but the mixed copper minerals composing the greater part of the specimen showed the presence of this body. It seems therefore probable on these grounds alone that the bluish flakes are spangolite. Vanadium, phosphorus, and arsenic are absent. The closed-tube reactions of the mixed copper minerals are very striking. Water is given off first. Then appears suddenly a white sublimate $\left(\mathrm{AlCl}_{3}\right.$ ?) near the assay which seems to form or at once change to minute colorless drops. This deposit can be driven slowly up the tube, followed at its lower, sharply defined edge, by dark yellow-brown drops $\left(\mathrm{CuCl}_{2}\right.$ ?) which on cooling solidify to greenish crystalline aggregates, and the part of the tube between them and the assay shows under the lens delicate feathery crystallizations like frost markings on window panes. Down in the flame 
the glass becomes colored red $\left(\mathrm{Cu}_{2} \mathrm{O}\right.$ ?) and in parts yellow. On charcoal the blowpipe flame is colored azure blue and at the same time green.

"In order to compare the above closed-tube behavior with that of undoubted spangolite, a small fragment of the latter, offered by Doctor Penfield, was tested. It gave water and then a white sublimate like the one above mentioned, followed by a dark olive-brown liquid, which on cooling passed through lighter shades of color and solidified as a bright-green ring. In general this behavior is very like that of the mixture under examination from Clifton."

Chalcanthite or blue vitriol. $-\mathrm{CuSO}_{4}+5 \mathrm{H}_{2} \mathrm{O} ; 25.3$ per cent $\mathrm{Cu}$. Common as filling of small fissures, as coatings, or as efflorescences in the lodes in porphyry of Copper Mountain and elsewhere, especially above the upper limit of the chalcocite zone, but very rare below this limit. In one of the upper levels of the Joy shaft it forms stalactites almost filling the tunnels. It occurs in fibrous or distinctly crystallized forms. Melanterite, or common copperas $\left(\mathrm{FeSO}_{4}+7 \mathrm{H}_{2} \mathrm{O}\right)$, is not abundant, while pisanite, the sulphate of copper and iron, probably occurs together with the chalcanthite. No ferric sulphates have been found.

Goslarite and epsomite. $-\mathrm{ZnSO}_{4}+7 \mathrm{H}_{2} \mathrm{O} ; \mathrm{MgSO}_{4}+7 \mathrm{H}_{2} \mathrm{O}$. These occur as white, long, and delicate capillary efflorescences on the walls of tunnels, and soon disintegrate to a powder in the air. There are evidently several isomor. phous mixtures of this series.

Dr. W. F. Hillebrand identified goslarite with some magnesia, and a little lime, copper oxide, and manganese, from the Arizona Central mine. Epsomite and a mixture of epsomite and goslarite was found in the Montezuma mine, as well as a sulphate containing both zinc and copper.

Gerhardtite. $-\mathrm{H}_{6} \mathrm{Cu}_{4} \mathrm{~N}_{2} \mathrm{O}_{12}$. The cliffs of granite-porphyry in the deeply eroded Chase Creek Canyon at Metcalf show in many places a bright-green coating of some copper mineral, which, no doubt, is formed by the trickling of atmospheric waters over and through rocks containing a small percentage of copper. This is not surprising, for porphyry in this vicinity is altered throughout by quartz cementation and disseminated cupriferous pyrite. This "green paint," as it is frequently called, is not soluble in water, and, when more closely examined, consists of small, dark-green, roughly mammillary forms coating the rock to a thickness of a few millimeters. Examination by the microscope fails to reveal any recognizable mineral in the cryptocrystalline mass.

Chemical examination by Doctor Hillebrand led to the interesting discovery that the copper minerals present consist of a nitrate and a chloride, neither of which has been found elsewhere in the mines of the district. Detrital grains and some silica seem associated with these compounds. The nitrogen is difficult to account for, in the absence or scarcity of animal substances which might have 
yielded it. Possibly it is contained in the porphyry. Doctor Hillebrand's remarks concerning this mineral are as follows:

"The closed-tube reactions of the copper minerals forming the mixture on this specimen are as striking in their way as those of the mixture containing spangolite described elsewhere. Water first appears, then brownish nitrous vapors, followed by a sublimate which is not very volatile, which becomes black on further heating, but on cooling yellow-brown. The glass at the bottom of the tube is often yellowbrown when cold. After some hours the sublimate nearly disappears or becomes greenish from absorption of water. If the water which condenses in the upper part of the tube on first applying heat is driven out by the flame and the mouth of the tube is held in the flame, this is colored deep green by a volatile copper compound (chloride?). On charcoal the flame is azure blue and at the same time green. Vanadium is absent.

"The mixture contains presumably the basic nitrate gerhardtite and a chloride which is perhaps atacamite. Spangolite the chloride can hardly be, for the slight amount of $\mathrm{SO}_{3}$ shown by test does not seem sufficient to account for the large amount of chlorine."

The only place from which gerhardtite has previously been identified is at the Jerome mines in the central part of Arizona, where it is associated with cuprite and malachite. It was discovered by Messrs. H. L. Wells and S. L. Penfield. 


\section{H A P T E R I V. \\ METASOMATIO PROCESSES.}

GENERAL STATEMENT.

Metasomatic processes are those by which, through chemical reactions, and mainly by aid of water, one mineral is changed into another. In practically all cases they cause a partial or a complete change in the chemical constitution of the mineral and involve loss or gain of substance. On account of our lack of knowledge of the exact reactions involved, it may sometimes be difficult to decide whether a replacement is effected by separate dissolving and filling, or by one or several chemical reactions. In cases of complete molecular replacement, such as galena after calcite, the replacing mineral was probably present in the active solution, partly dissociated or ionized. The solution of a certain quantity of the original mineral caused a separation of a corresponding quantity of the ions of the replacing substance according to physico-chemical laws. If carried out on these lines the process is necessarily molecular and chemical. Where two solutions existed-one dissolving, the other depositing-and where a certain time intervened, the process is a mechanical one and should not, I think, be considered metasomatic. In some cases the distinction may be difficult to draw.

Rocks are metasomatic if any or all of the constituent minerals have undergone partial or entire metasomatic changes. It is thus not necessary that they should, as a whole, have suffered a change in their chemical composition, though in the great majority of cases this has undoubtedly taken place, at least to some extent. Metasomatism, then, is a wide term, including the earliest transformations after the rock has been formed and the last ones active in it until disintegration finally destroys it. A still wider term is "metamorphism," which covers any changes in composition or structure of a rock through whatever agency and whether with or without gain or loss of substance.

From the standpoint of the mining geologist, these processes are of paramount interest, and it has been thought best to devote a separats chapter to them in the discussion of the ore deposits of Clifton-Morenci. 
That form of metamorphism which is associated with long-continued and strong pressure, and which, besides metasomatic changes, results in schistose or slaty structure, is singularly absent in the Clifton district. The only epoch in which dynamo-metamorphic processes were active here on a large scale antedates the Cambrian age. Schists of various kinds, principally quartzitic, constitute the Pinal formation, which is not represented within this special area, though occurring in the northern part of the Clifton quadrangle. Similar dynamo-metamorphism has not been repeated in this region since that very ancient epoch, though the rocks were subjected to stresses during the intrusion of the porphyries, during the opening of fissures which followed that event, and during the epoch of extensive faulting which followed still later. On prominent vein and fault fissures some crushing has taken place, accompanied by an incipient schistose structure, but in no case does this change extend far from the original break.

The changes to be considered are then almost wholly metasomatic, and their discussion may be grouped in several divisions:

Common hydrometamorphism.-This, which is also described as static metamorphism, includes the changes effected under the influence of ordinary percolating waters at a moderate depth, but distinctly below the zone of active oxidation. The principal minerals formed are epidote, chlorite, serpentine, pyrite, zeolite, muscovite, quartz, etc. Feldspars are ordinarily not formed. These conditions evidently rather involve transformation of material than gain or loss of substance for the rock as a whole.

Contact metamorphism.-In the immediate proximity of intrusive granites, granite-porphyries, diorites, and many other allied rocks, extensive changes have often been produced in the inclosing formations. Most susceptible to change are clay shales and limestones, which are frequently entirely metamorphosed, both as to structure and composition. The principal minerals formed are garnet, epidote, wollastonite, pyroxene, amphibole, magnetite, and pyrite in the limestones, and amphibole, epidote, feldspars, biotite, andalusite, and quartz in clay shales. These changes, which have been studied at a great number of places throughout the world, are usually attributed to the combined influence of heat and magmatic water pressing outward from the cooling intrusive rock. It is usually stated that little gain or loss of substance has taken place in contactmetamorphic rocks. This statement is not, however, in entire agreement with the results obtained during this examination.

Hydrothermal metamorphism.--Still another form of metasomatic action is caused by hot or "thermal" waters, usually ascending along fissures and acting upon the surrounding rocks. This alteration is in most cases confined to the close vicinity of the fissures. Much of the ore may be produced in this manner 
by replacement of country rock. The minerals most commonly formed in this district are pyrite, sericite, calcite, and quartz, but it will be shown that magnetite, pyroxene, amphibole, and epidote may also be formed by these agencies. Feldspars are not commonly produced by this mode of metasomatism. Extensive gains and losses of substance often take place during this process.

Processes of oxidation.-Under this heading will be described the alterations which the rocks undergo at or near the surface under the influence of oxidizing atmospheric waters. Especially interesting are the changes suffered by the contactmetamorphic rocks and by those previously affected by hydrothermal metasomatism. Both of these usually contain sulphides with valuable metals. The pure atmospheric waters are, by action on these sulphides, rapidly converted to mineral waters of great strength, and as such are the agencies chiefly responsible for the concentration of metals into deposits of economic importance. It will be shown that formation of chalcocite or cuprous sulphide is indirectly due to these oxidizing waters, and that thus not only oxygen salts but also sulphides may result from this alteration. Gains and losses of substance are usually very great.

\section{COMMON HYDROMETAMORPHISM.}

This form of metamorphism affects the rocks of the district only to a limited degree. In the siliceous limestones of the upper part of the Longfellow formation it finds expression in fairly extensive replacement of the calcium carbonate by cryptocrystalline or fibrous silica, largely of chalcedonic character. This chert is grayish in color and forms irregular seams or bunches in which ragged residual masses of calcite may be embedded.

In the quartzitic sandstones of the Coronado formation the cementing material is largely converted into sericite, but otherwise there is little alteration. The pure Modoc limestones and dolomites have suffered no change.

The granite is generally affected by a chloritization of the biotite, which usually has entirely destroyed that mineral. In some varieties containing hornblende secondary epidote and pyrite have formed. The feldspars contain a small amount of sericite.

More extensive but still not materially affecting the character of the rock are the changes in the porphyries, especially in those approaching dioritic composition. The most pronounced changes refer to the hornblende and the biotite, both of which alter to chlorite, frequently containing grains of epidote. Hornblende also changes to a mineral like bastite. Besides, epidote generally replaces the plagioclastic feldspars, developing in them as large and sharply defined grains, sometimes giving the mineral an appearance of primary origin. Scattered chlorite also migrates into feldspars and groundmass. A little sericite is contained in the 
feldspars, and grains of pyrite are apt to develop in the ferro-magnesian silicates. Kaolin is not prominent in these rocks and probably forms chiefly close to the surface of the ground. All these changes take place independently of any mineral deposits, lodes, or veins, and are more or less extensively developed in all areas of porphyry.

The changes in the Tertiary surface lavas are insignificant and chiefly consist in the formation of chlorite and serpentine.

\section{CONTACT METAMORPHISM.}

While granite and quartzite have undergone little change in contact with porphyry, great alterations have taken place in the limestones and shales adjoining that rock. These changes may be noted along the contacts of the great porphyry stock as well as near dikes or smaller masses.

\section{REVIEW OF LOCALITIES AND CHARACTER OF METAMORPHISM.}

A great mass of diorite-porphyry, apparently laccolithic, $1 \frac{1}{2}$ by 1 mile in size, is intruded in the Cretaceous strata 3 miles southwest of Morenci. The sedimentary rocks are very little altered at the contact; at most a hardening and some development of epidote are noticeable. The same applies to the smalier areas of porphyry northeast of this mass. One of them, one-half mis south of Morenci, forms the top of a hill and rests on Cretaceous sediments, shales, and sandstones, which appear reddish and in places contain much epidote, but are not otherwise much altered. The metamorphism becomes more intense going north, and appears to be due to the vicinity of the contact of the main stock. Along the Eagle Creek foothills north of Gold Creek diorite-porphyry again prevails and contains many slab-like inclusions of varying size of Ordovician limestone, but at the contacts of these practically no alteration is visible. The same applies to the long sill of diorite-porphyry intruded all along the contact between the Coronado quartzite and the Longfellow limestone, and to the little stock of the same rock which occupies the basin of Garfield Gulch north of Metcalf.

From all this it appears that the diorite-porphyry exerts a very slight action on the surrounding sediments, whether they be limestone or shale.

Very different conditions obtain at the contacts of the quartz-bearing porphyries, mainly quartz-monzonite-porphyry and granite-porphyry. The Cretaceous strata which cross Gold Creek in irregular masses, deeply indented and torn by the porphyry, are decidedly altered. The shale and fine-grained sanastone are very much hardened, becoming sometimes even flinty and of black or dark-green color. They contain a little epidote, pyrrhotite, and pyrite, besides more or less green hornblende, which has developed in the mass of the shale and in the 
cement of the sandstones. In places the sandstone has acquired a quartzitic appearance; but withal the alteration does not compare in intensity with that suffered by the Paleozoic limestones.

At the mouth of Pinkard Gulch, where the Ordovician shaly limestone is greatly cut by dikes and masses of porphyry, some of the included masses are almost wholly converted to epidote with magnetite and garnet; copper stains are abundant, and many small prospects have been opened. Between this place and the Soto mine, where Gold Creek crosses the Soto fault separating Ordovician limestone from granite, the same phenomena are repeated; garnet and epidote occur abundantly at the contacts and also along certain strata. But the alteration is not always extensive and some limestone masses seemed to have escaped almost entirely.

For a mile northeast and southwest of Morenci the stock of monzoniteporphyry borders against the whole sedimentary series, which is less cut up than in the Gold Creek basin. Alteration has developed on a large scale; over an average distance of 1,500 feet from the contact the rocks are greatly transformed, in places to a width of even 2,000 feet (Pl. XVII). There is very material difference in the manner of alteration of the various strata. Dikes both inside and outside of the altered zone are followed by bands of metamorphosed rocks. The alteration shows no dependence upon fissures or veins, the only factor which seems to have any influence being the proximity of intrusive bodies.

The Cretaceous sandstones and shales on Modoc Mountain and on the hills south and southwest of. Morenci are altered to quartzites and epidote-amphibole schists, the latter of dark-green color and increasing size of grain as the porphyry is approached. The Modoc limestone, as well as the underlying dolomite, is most susceptible to change; a whole block of this formation extending from Modoc Mountain to the Copper Mountain faults has been almost bodily converted into a mass of calcium-iron garnet. This applies also to the exposure of the same formation in the next block, between the Apache and the Copper Mountain fault, exposed south of the smelter. It is entirely converted to garnet and epidote for 2,000 feet from the contact, while the underlying shale and limestones remain almost entirely unaltered.

More or less disturbed masses of Morenci shales and Longfellow limestone adjoin the porphyry and extend along it for $1 \frac{1}{2}$ miles. The shale is converted to dense greenish rocks rich in epidote, amphibole, and pyrite, while the limestone contains garnet, epidote, pyroxene, amphibole, specularite, magnetite, pyrite, chalcopyrite, and zinc blende, in irregularly distributed masses. Garnet, however, does not form large bodies, as in the case of the Modoc limestone. Smaller, unaltered masses of limestone are sometimes contained in these areas. 
Biotite, muscovite, and feldspars are almost entirely absent among the contactmetamorphic minerals.

From Morenci to Metcalf the porphyry stock borders against granite, but at the latter place a small area of the Paleozoic series directly adjoins the graniteporphyry and is cut by several dikes projecting from it (Pls. I and XIX). The phenomena described at Morenci are here repeated. Practically the whole area is affected by the alteration. Chalcopyrite and pyrite form abundantly, together with garnet, pyroxene, and epidote. The small down-faulted limestone area at the mouth of Garfield Gulch is unaltered, except where a little epidote and magnetite appears in the immediate contact of the small dikes of diorite-porphyry traversing it.

The stock of monzonite-porphyry at the head of Placer Gulch has produced a somewhat capricious alteration. While the limestone adjoining on the north is not noticeably altered, the many small inclusions of the same rock in the southern part of the stock are partly converted to epidote and magnetite, and frequently show copper stains. The long dike traversing limestone near the head of Sycamore Gulch has changed the rock but little, epidote appearing only in places.

The stock at the head of Silver Creek, near the northern limit of the district, is composed of diorite-porphyry and has not changed the surrounding rock.

The general mode of occurrence of this peculiar alteration decidedly eliminates it from being classed with either regional metamorphism or common hydrometamorphism or hydrothermal metamorphism. The determining factor is evidently the presence of a quartz-bearing porphyry.

Taken in connection with the widespread and well-known occurrence of just such alteration in the immediate vicinity of intrusive bodies, there need be no hesitation in referring these changes to contact metamorphism.

THE MORENCI CONTACT ZONE.

DIKES.

In describing the complicated phenomena here shown it is perhaps best to begin with the dikes cutting the relatively unaltered strata on the east slope of Modoc Mountain, in the vicinity of the Longfellow incline. Most of these dikes distinctly alter the inclosing rocks; but the change is not always uniform, varying in different parts of the same dike and affecting each formation in somewhat distinctive manner.

A well-defined dike of quartz-monzonite-porphyry 20 to 50 feet wide starts from near the summit of Modoc Mountain and continues southeasterly, erossing the deep gulch separating that point from the high limestone cliff at the eastern margin of the area shown on the special map (PI. XVII). The dike can be traced a few hundred feet outside of the limit of this area, but the exposures are not good and little contact metamorphism seems to exist. At the edge of this district it crosses the Morenci shales. These are greenish and distinctly hardened near the contact, but a few feet away regain their ordinary appearance. 
In the Longfellow limestone, near the bottom of the gulch in a prospect tunnel, the dike is adjoined by about 2 feet of epidote and specularite, with a little garnet and green copper stain. On the northwest side of the gulch the dike is excellently exposed on the steep slope for a vertical distance of several hundred feet up to the summit of Modoc Mountain. Along both sides of it runs a darkbrown zone, caused by the oxidation of pyrite in the altered belt and contrasting with the fresher gray limestones. The alteration has proceeded irregularly, in some places extending horizontally along the strata to a distance of 20 feet from the dike, but ordinarily occupying a width of only a few feet. The dike rock contains a small amount of epidote and pyrite, but is hard and very little altered. There is no evidence of dislocations or fissures along either wall.

A small tunnel near the bottom of the gulch on its northwest side gives good exposures of the altered zone, there only a few feet wide. The rock, bordering against the porphyry with sharp contact, is very hard and fresh, streaky gray and yellowish in color, and contains irregular masses of yellowishbrown garnet; chalcopyrite and zine blende in moderate amounts are disseminated through the garnet. Thin sections show the garnet partly massive, partly in well-defined dodecahedral crystals, the latter with decided birefringence and division in sectors (Pl. VII, $A$ and $C$ ). It contains grains and smaller masses of chalcopyrite and zinc blende embedded in a manner to indicate contemporaneous crystallization. The gray parts between the crystals and larger areas of garnet prove to be thoroughly crystalline limestone of granular, noninterlocking structure. Much finely divided calcite is included both in the massive garnet and in the separate crystals of that mineral which form in the crystalline limestone. The residuary character of the calcite is very evident under the microscope. Quartz occurs in some places as coarse aggregates of anhedrons, and fine-grained, colorless pyroxene develops occasionally in the calcite grains. The line of division between the altered and unaltered rock is very irregular but rather sharp. It seems altogether out of the question that the apparently very pure limestone could have contained enough ferric oxide to form this amount of garnet.

A little higher up the dike enters the dense, dark-gray, argillaceous Devonian limestone. Here the alteration is not extensive, but always shows near the contact, extending irregularly from it. For about 1 foot from the contact the limestone is almost completely converted to epidote; between this and the unaltered limestone is a 5-inch transition zone, containing small but very abundant garnets, developing in the calcite. This relation of garnet and epidote has been repeatedly observed along many of these dikes. Immediately adjoining the intrusive mass epidote forms; garnet begins to develop a few feet farther away from the dike. Copper stains occur in places.

$16859-$ No. $43-05-9$ 
Still a little higher up on the slope the dike enters the Morenci shales. For a few feet from the contacts the shale is very hard and greenish; it has also lost much of its fissility. Some 20 or 30 feet away there is no external evidence of metamorphism, and the rock appears with its usual fissility and dark-gray color. Small specks of pyrite are common throughout this formation.

A thin section of the apparently unaltered shale (No. $313 \mathrm{Cl}$. A) shows a cryptocrystalline aggregate, with evenly distributed flocculent grains of epidote, amounting to at least 5 per cent of the mass. A considerable part of the remainder consists of dirty-green extremely fine aggregates, of chloritic appearance, but showing rather vivid colors of interference; in view of the chemical composition, it seems plausible to regard them as glauconite, especially as glauconite in larger grains has been observed in the Cambrian shales just above the top of the Coronado formation. The colorless cryptocrystalline mass in which these minerals are contained is probably kaolin. Sericite is practically absent. A greater amount of recrystallization has taken place than the exterior of the rock would lead one to suspect.

The altered rock adjoining the dike, although macroscopically of differing appearance, is, under the microscope, very similar to the rock just described. The epidote is more abundant and better individualized; and from the glauconitic material there seems to be forming another substance, likewise with vivid colors of interference and fibrous in structure, which probably is an amphibole. The two rocks just described were analyzed with the following result:

Analyses showing result of contact metamorphism on black Devonian shale.

[W. F. Hillebrand, analyst.]

\begin{tabular}{|c|c|c|c|c|c|}
\hline & (313 Ci. A.) & $\begin{array}{l}\text { II. } \\
\text { (312 Cl. A.) }\end{array}$ & & (313 Ci. A.) & $\begin{array}{l}\text { II. } \\
\text { (312 Cl, A.) }\end{array}$ \\
\hline $\mathrm{SiO}_{2} \ldots$ & 61.25 & 60.51 & $\mathrm{CO}_{2}$ - & None. & None. \\
\hline $\mathrm{Al}_{2} \mathrm{O}_{3} \ldots \ldots \ldots \ldots$ & 15.60 & 15.81 & $\mathrm{P}_{2} \mathrm{O}_{5} \ldots \ldots$ & 0.08 & 0.08 \\
\hline $\mathrm{Fe}_{2} \mathrm{O}_{3} \ldots \ldots \ldots \ldots$ & 1.35 & 1. 40 & $\mathrm{SO}_{3} \ldots \ldots \ldots \ldots \ldots \ldots$ & None. & None. \\
\hline $\mathrm{FeO} \ldots \ldots \ldots \ldots$ & 3.04 & 2. 64 & MnO $\ldots \ldots \ldots \ldots \ldots \ldots$ & a. 07 & a. 11 \\
\hline $\mathrm{MgO} \ldots \ldots . . . . . . . . .$. & 4. 16 & 4.25 & $\mathrm{BaO} \ldots . .$. & Trace. & .17 \\
\hline $\mathrm{Ca}$ & 3.40 & 2.34 & $\mathrm{SrO} \ldots . .$. & None. & .01 \\
\hline $\mathrm{Na}_{2} \mathrm{O} \ldots \ldots \ldots$ & .44 & 1. 26 & $\mathrm{Li}_{2} \mathrm{O} \ldots \ldots$ & Trace. & Trace. \\
\hline $\mathrm{K}_{2} \mathrm{O} \ldots \ldots$ & 6.74 & 8.27 & $\mathrm{FeS}_{2} \ldots \ldots$ & $\{.25$ & $\{.04$ \\
\hline $\mathrm{H}_{2} \mathrm{O}-\ldots$ & .62 & .59 & $\mathrm{CuFeS}_{2} \ldots$ & ${ }^{b}\{.03$ & Trace. \\
\hline $\mathrm{H}_{2} \mathrm{O}+\ldots \ldots$ & 2.09 & 1.90 & $\mathrm{ZnO}, \ldots . . . . . . . . . .$. & .03 & .02 \\
\hline $\begin{array}{l}\mathrm{TiO}_{2} \\
\mathrm{ZrO}_{2}\end{array}$ & $\begin{array}{r}.66 \\
\text { Trace? }\end{array}$ & $\begin{array}{r}.68 \\
\text { Trace. }\end{array}$ & & 99.81 & 100.08 \\
\hline
\end{tabular}

a Partly $\mathrm{MnO}_{2}$.

$b$ Total $\mathrm{S}, 0.14$.

$c$ Total $\mathrm{S}, 0.025$.

I. Fresh black Devonian shale; on trail from Newtown to Longfellow, 30 feet southwest of large porphyry dike.

II. Contact-metamorphic black Devonian shale; on trail from Newtown to Longfellow mine, at contact of large porphyry dike. 
The composition of the unaltered rock differs somewhat from that of a normal clay shale; the considerable percentage of lime in absence of carbon dioxide and the very large amount of potash are especially remarkable. The analysis confirms the microscopic diagnosis of epidote, kaolin, and a mineral related to glauconite, although the latter does not appear to be present in the amount which the quantity of potash would indicate.

The only change of note in the rock adjoining the contact is decrease in lime and increase in alkalies, but neither is decided enough to justify any generalizations. The water has not decreased. Practically the only change is thus in a development of an amphibole from the chloritic constituents. The principal mineral deposits and the main altered zone are so near that no safe deductions can be made from the very small amounts of zinc and copper present in both rocks.

From the Devonian shale the dike enters the lowest member of the Modoc formation, indicated on the map as the coralliferous lime. This very compact bed, which is only 6 to 10 feet thick, is entirely unaltered, even at the immediate contacts. Above this the dike penetrates the upper part of the Modoc formation, which is completely changed to the heavy brownish masses of garnet rock with epidote and magnetite, which occupy the summit and western slope of Modoc Mountain. The change to garnet begins immediately above the coralliferous lime and spreads irregularly from the dike for a hundred feet southward. It is not certain to what extent this porphyry dike has caused the change, for there are several other dikes which join near the summit and the area falls within the general contact-metamorphic zone. At any rate, both sharply defined walls of the dike consist of garnet rock, while in the dike itself an unusually extensive replacement by epidote has taken place.

Most of the other dikes on the southeast side of Modoc Mountain show similar changes along their contacts, but the exposures are rarely good. Five hundred feet south of the summit two dikes traverse the Modoc limestone, and show well-developed contact zones of epidote-garnet-magnetite rock. Copper stains and epidote appear along the contacts of the several dikes descending toward the Longfellow incline from Modoc Mountain, but oxidation has generally obscured the exposures. Below the brake house of the Longfellow incline are found the continuations of several of the dikes of Modoc Mountain. They show copper stains and epidote, together with a little pyrite on both sides. Two hundred feet below the brake house is met the porphyry sill, which lies at the base of the Longfellow formation, and which follows this horizon for a mile or more southward; but, while for the greater part of this distance the sill exerts little contact metamorphism, a great deal of epidotization is noted at this particular place in the shaly limestone for 40 or 50 feet above and below the contacts. The metamorphism is observed to a lesser degree on the next ridge south, 
where a prospect has been opened on account of the copper stain shown in the epidote. South of this almost all trace of alteration at the contact disappears.

On the fourth tunnel level of the Longfellow mine the contact of the middle or sheet-porphyry dike with the Longfellow limestone is well exposed. The contact is closely welded and no evidence of joints or fissures can be seen. While the limestone some distance away is almost fresh-containing only a little pyrite-that next the contact is greenish and filled with small grains of pyrite and chalcopyrite; it also contains thin seams of the same minerals. Under the microscope a granular crystalline limestone still forms the main mass, but has embedded in it a maze of minute colorless prisms of a prroxene, probably diopside; a photograph of this slide is shown on Pl. VII, $B$. The calcite also contains grains of pyrite and chalcopyrite, intergrown with magnetite; veinlets of calcite, chalcopyrite, and pyrite cut across the rock.

On the ridge 100 feet above the office of the Arizona Copper Company at the Longfellow incline is a big open cut traversed by three narrow porphyry dikes, as shown on Pl. XVII. Large tumbled blocks lie in this cut, broken down from a bed of the hard and dense Devonian limestone; these must have almost adjoined the dikes. The limestone is nearly unaltered except that long radiating needles of an amphibole, probably tremolite, and intergrown grains of pyrite and magnetite lie embedded in it. A few of the blocks contain, however, seams and irregular masses of yellowish-brown garnet, light-colored zinc blende, and chalcopyrite. Near these masses the dark-gray compact limestone becomes greenish and mottled, while the size of the calcite grains increases. A little quartz appears between the calcite grains, and small garnets develop in them. This borders pretty sharply against a coarse-grained aggregate of calcite, garnet, zinc blende, chalcopyrite, and granular quartz (PI. IX), intergrown in a manner to indicate contemporaneous crystallization by replacement. Other specimens show fine birefringent garnets, embedded sometimes in irregular grains of quartz, and sometimes in coarse calcite grains (PI. VIII, B). Small prisms of diopside have also developed, as well as grains of chalcopyrite.

The north dike of the Longfellow mine (close to the Longfellow hoist) has also exerted a strong influence on the limestone adjoining, converting it into garnet, magnetite, and much epidote. Most of these exposures are now difficult to study on the surface on account of extensive oxidation, unless, as in the Longfellow open cut, some portions happen to remain unaltered.

Many more examples might be described, but from the preceding it is evident that, independently of fissures and other ducts of mineral waters, local alterations take place along the contacts of quartz-bearing porphyry dikes by which garnet, epidote, diopside, tremolite, magnetite, pyrite, chalcopyrite, and zinc blende are formed by replacement of limestone; garnet forms especially in the Modoc pure limestone, while diopside and tremolite are more apt to appear in the sometimes 
dolomitic Longfellow limestone. Generally speaking this means an access of silica, iron, sulphur, copper, and zinc, for the limestones do not in any place contain these constituents in sufficient amount. This is evident in the case of the silica and iron, and, even admitting that the limestone might contain traces of sulphur, copper, and zinc, it is difficult to conceive of any adequate process of concentration which would be operative under the conditions obtaining during the intrusion. The only source available would appear to be the molten porphyry magma. It has been shown that the dikes likewise exert a change in the clay shales, apparent in texture, color, and hardness, but the evidence does not show that the composition of the rock has been materially altered. While the alteration is general, its intensity varies greatly in different parts of the dike and in the various strata which it traverses.

\section{PRINCIPAL METAMORPHIC AREA.}

Within the main metamorphic area it is not always possible to identify the several formations, nor to decipher the structure. It can be done, however, in a general way and it seems best to describe the altered rocks according to the formations to which they belong.

Pinkard formation.-Hard, reddish, slaty rocks with much epidote in streaks and bunches cover the top of Modoc Mountain and undoubtedly belong to the Pinkard formation. Similar rocks occupy the high hills 1,000 feet southwest of the smelter, where those nearest to the porphyry are decidedly more altered.

The same formation is believed to occupy the high hill shown on the south edge of the special map from the Thompson mine to the Morenci-Eagle Creek road. The alteration is here very strong, and slaty green rocks have resulted with epidote and occasional smaller masses of magnetite. A typical rock from the northeast slope of this hill is hard, flinty, streaked dark green and grayish green with much minutely divided pyrite. Under the microscope the principal mass consists of streaks of fibrous amphibole with disseminated epidote, pyrite, and quartz grains; these constituents are embedded in a cryptocrystalline mass which in part may represent the original shale substance. It probably contains quartz, kaolin, and chlorite. The summit of this hill, which is a few hundred feet outside of the southern margin of the area mapped, consists of a small area of hard dark-gray quartzite.

Modoc formation. - This occupies the whole west slope of Modoc Mountain. Its southeastern part is almost wholly unaltered, a very irregular line with frequent detached altered masses dividing this from the metamorphic portion. This locality is of great importance, for the identification of the thoroughly altered rock as the Modoc formation is absolutely certain. The contact line with unaltered rock is usually sharply defined. 
Near this contact line the Modoc limestone becomes very crystalline-changes in fact to a coarse marble of crumbling granular structure, as may be well seen at the limestone quarry of the Arizona Copper Company; then, within a few feet, it becomes transformed to a mass of dark yellowish-brown garnet rock, with which are occasionally associated masses of greenish-yellow epidote and black magnetite. On the surface processes of oxidation often veil the true character of the rocks, but the exposures at the Modoc open cut, in the gulch coming down at the smelting works and on the path between the smelter and the Detroit Copper Company's limestone quarry, leave no room for doubt as to the character of the main mass as garnet rock. An ill-defined area northeast of the smelter has been mapped as partly altered rock.

The garnet has colors ranging from yellow to dark brown, most commonly yellowish brown, like dark honey. Samples from near the Detroit smelter, from the Shannon mine at Metcalf, and from the third level of the Arizona Central mine (the latter from the Longfellow formation) have been analyzed and proved to be an almost pure andradite or lime-iron garnet $\left(3 \mathrm{CaO}, \mathrm{Fe}_{2} \mathrm{O}_{3}, 3 \mathrm{SiO}_{2}\right)$. Quantitative analyses were made of two specimens, as shown below:

Analyses of garnet and garnet rocks.

[George Steiger, analyst.]

\begin{tabular}{|c|c|c|c|}
\hline & I. & II. & III. \\
\hline $\mathrm{SiO}_{2} \ldots \ldots \ldots$ & 42.63 & 36.26 & 35.5 \\
\hline $\mathrm{Al}_{2} \mathrm{O}_{3} \ldots \ldots \ldots$ & 1.53 & .78 & \\
\hline $\mathrm{Fe}_{2} \mathrm{O}_{3} \ldots \ldots \ldots \ldots$ & 31.41 & 32.43 & 31.5 \\
\hline $\mathrm{FeO} \ldots \ldots \ldots$ & .30 & .32 & \\
\hline $\mathrm{MgO}, \ldots . . . . . . . . .$. & None. & None. & -. \\
\hline $\mathrm{CaO} \ldots \ldots$. & 23.37 & 29.67 & 33 \\
\hline $\mathrm{Na}_{2} \mathrm{O} \ldots \ldots$ & (n...... & None. & \\
\hline $\mathrm{K}_{2} \mathrm{O} \ldots \ldots \ldots$ & ....... & None. & \\
\hline $\mathrm{H}_{2} \mathrm{O}-105^{\circ} \mathrm{C} \ldots .$. & & .13 & \\
\hline $\mathrm{H}_{2} \mathrm{O}+105^{\circ} \mathrm{C} \ldots \ldots .$. & ....... & .44 & \\
\hline $\mathrm{TiO}_{2} \ldots \ldots \ldots$ & None. & None. & \\
\hline $\mathrm{CO}_{2} \ldots \ldots \ldots \ldots$ & ......... & None. & \\
\hline $\mathrm{P}_{2} \mathrm{O}_{5} \ldots \ldots \ldots$ & Trace. & .06 & \\
\hline $\mathrm{MnO} \ldots \ldots . . . . . . .$. & .43 & .27 & \\
\hline $\mathrm{CuO} \ldots$. & None. & ........ & \\
\hline $\mathrm{ZnO} . . . . . . . .$. & None. & .......... & - $\ldots$. \\
\hline & 99.67 & 100.36 & 100 \\
\hline
\end{tabular}

I. From trail between smelter and Detroit Copper Company's lime quarry. Representative rock. Modoc horizon, No. 406, Clifton collection.

II. Summit, Shannon Mountain. Modoc horizon, No. 317, Clifton collection.

III. Typical composition of andradite. 
PLATE VII. 


\section{PLATE VII.}

\section{Photomicrographs of Ores and Rocks.}

A, Contact-metamorphic rock (310 Cl. A) at contact of porphyry dike, 1,000 feet east-southeast of Modoc Mountain.

Garnet developing in crystalline limestone of Longfellow formation. Dark gray=garnet, with intimately mixed residuary calcite; light gray=granular calcite.

Ordinary light. Magnified 15 diameters.

$B$, Contact-metamorphic rock (362 Cl. A) at contact of porphyry dike, fourth tunnel level, Longfellow mine; Longfellow formation.

Prisms and grains of diopside developing in granular limestone. Darker masses=finegrained diopside.

Ordinary light. Magnified 62 diameters.

G, Contact-metamorphic rock (310 Cl. A) at contact of porphyry dike, 1,000 feet east-southeast of Modoc Mountain.

Garnet and sulphides developing in crystalline limestone of Lnngfellow formation. Black in center=zinc blende; black at margin of open field=chalcopyrite; light gray=isotropic garnet (in places hexagonal birefringent bands indicating dodecahedrons); dark gray= calcite, chiefly residuary granular masses in garnet.

Ordinary light. Magnified 15 diameters.

$D$, Contact-metamorphic rock (260 Cl. A) from Arizona Central mine, third level near shaft; Longfellow formation.

Black=chalcopyrite intergrown with garnet; gray=garnet mixed with a little residuary calcite and granular diopside; white=small aggregates of quartz.

Ordinary light. Magnified about 15 diameters.

$E$, Dioptase erystal, clinographic projection.

$F$, Dioptase erystal, orthographic projection.

$G$, Libethenite crystal, clinographic projection.

$H$, Libethenite crystal, orthographic projection. 

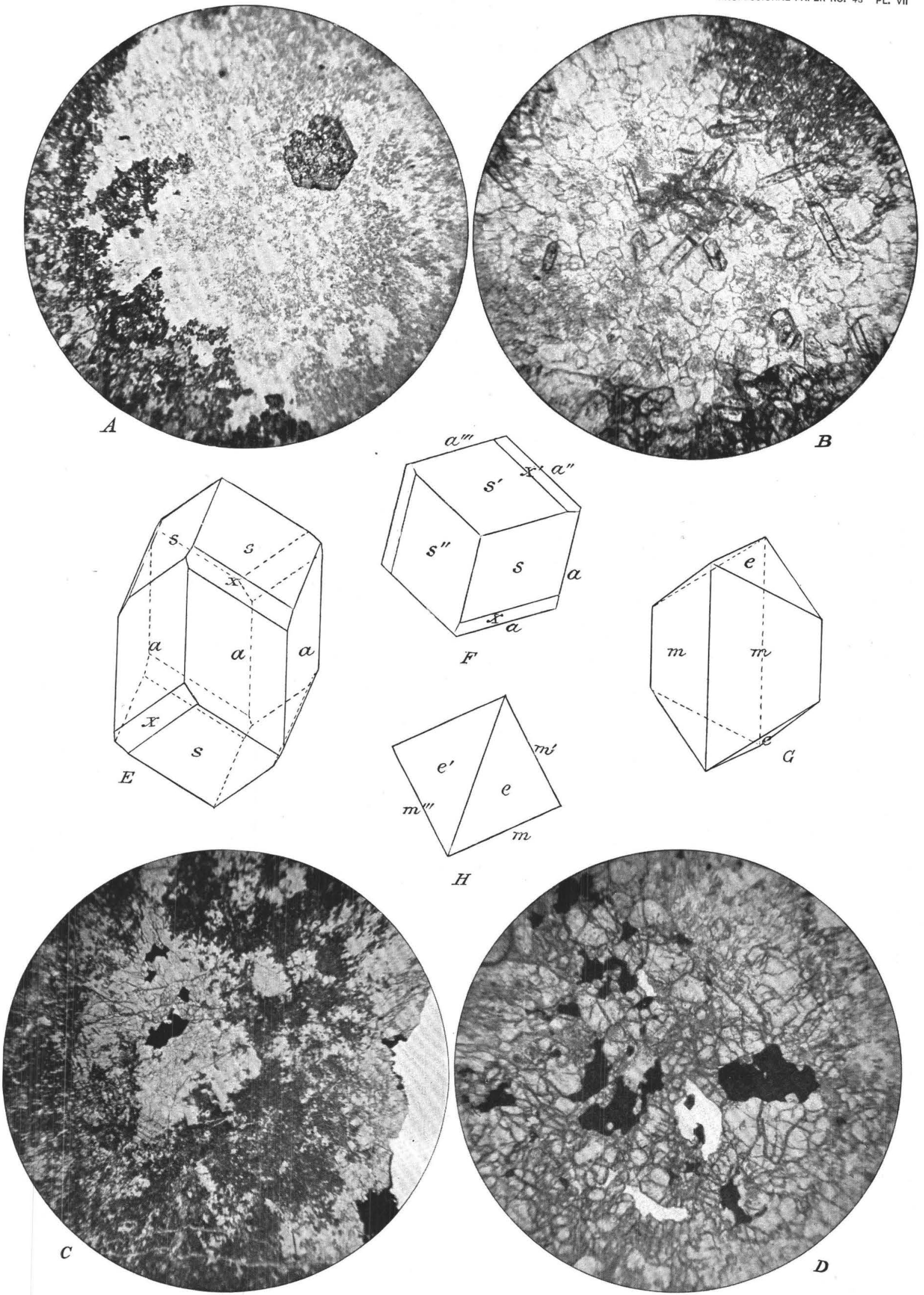

PHOTOMICROGRAPHS OF ORES AND ROCKS 

PLATE VIII. 


\section{PLATE VIII.}

\section{Photomicrographs of Ores and Rocks.}

A, Contact-metamorphic rock (321 Cl. Á) from ridge of Shannon Mountain, 500 feet south of Shannon Gap; Modoc formation.

Dark gray=garnet crystals developing in crystalline limestone (light gray). The latter also contains some microscopic pyroxene crystals.

Ordinary light. Magnified 15 diameters.

$B$, Contact-metamorphic rock $(246 \mathrm{Cl}$. A) from Longfellow mine, surface, 100 feet above office of Arizona Copper Company; Devonian limestone in Morenci formation.

$\mathrm{C}=$ coarsely crystalline calcite; $\mathrm{Q}=$ quartz, coarsely granular; $\mathrm{G}=$ crystals of garnet, birefringent and with zonar structure, developing in quartz and calcite; $\mathrm{Cu}=$ chalcopyrite. Ordinary light. Magnified 22 diameters. 

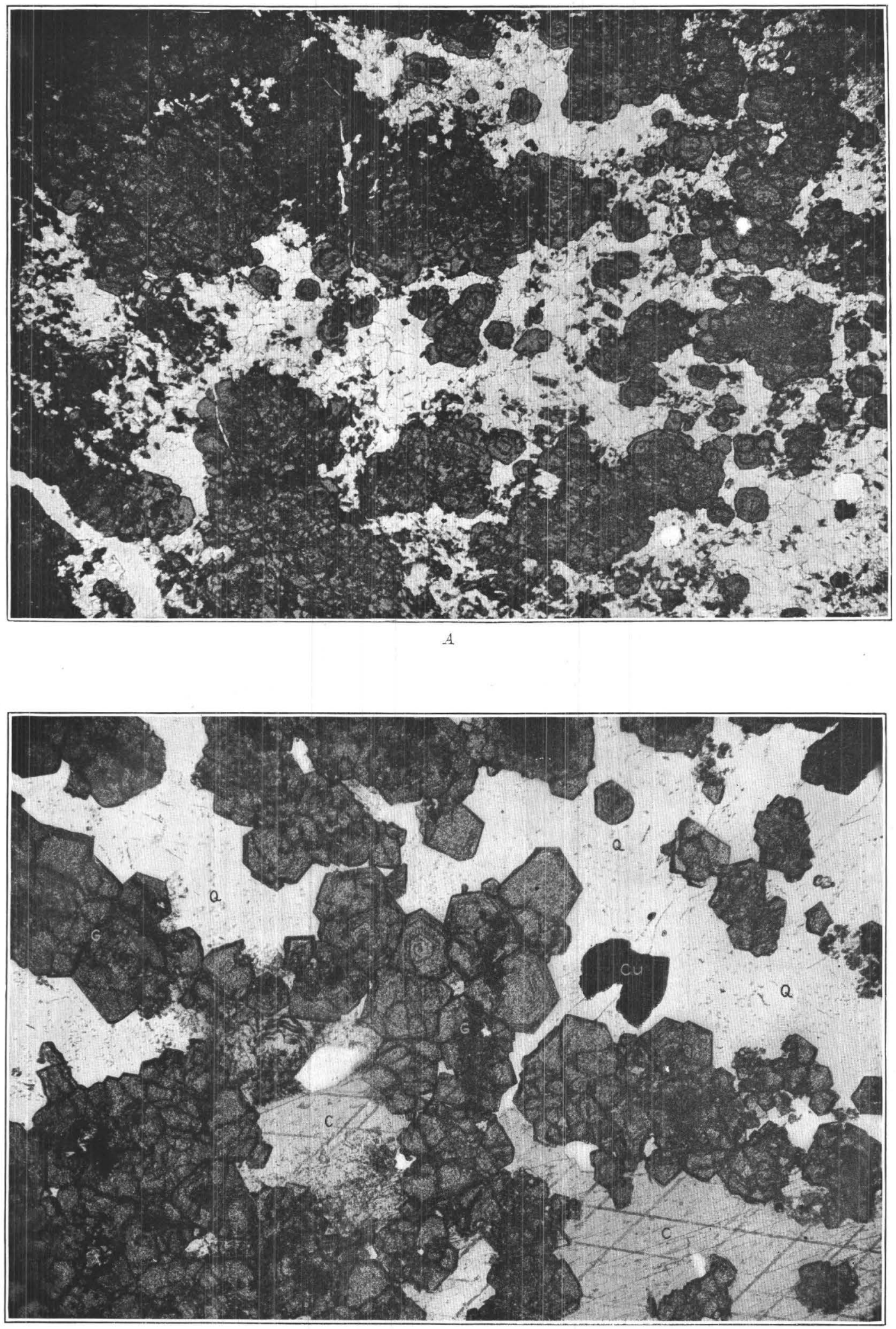

$B$

PHOTOMICROGRAPHS OF ORES AND ROCKS. 



\section{PLATE IX.}




\section{PLATE IX.}

\section{Рhotomicrographs of Ores and Rocks.}

A, Contact-metamorphic rock (249 Cl. A) from surface pit of Longfellow mine, 100 feet above Arizona Copper Company's office.

Fine-grained Devonian limestone, metamorphosed to coarse calcite, garnet, quartz, zinc blende, and chalcopyrite.

Ordinary light. Magnified 22 diameters.

$B$, Key to $A$ : Fc=Fine-grained calcite of normal limestone, with dotted line indicating approximate transition to coarse calcite; $\mathrm{C}=$ coarse-grained calcite; $\mathrm{Q}=$ quartz; $\mathrm{S}=$ sericite; $\mathrm{G}=$ garnet; $\mathrm{Z}=$ zinc blende; $\mathrm{Cu}=$ chalcopyrite; $\mathrm{O}=$ open field. 


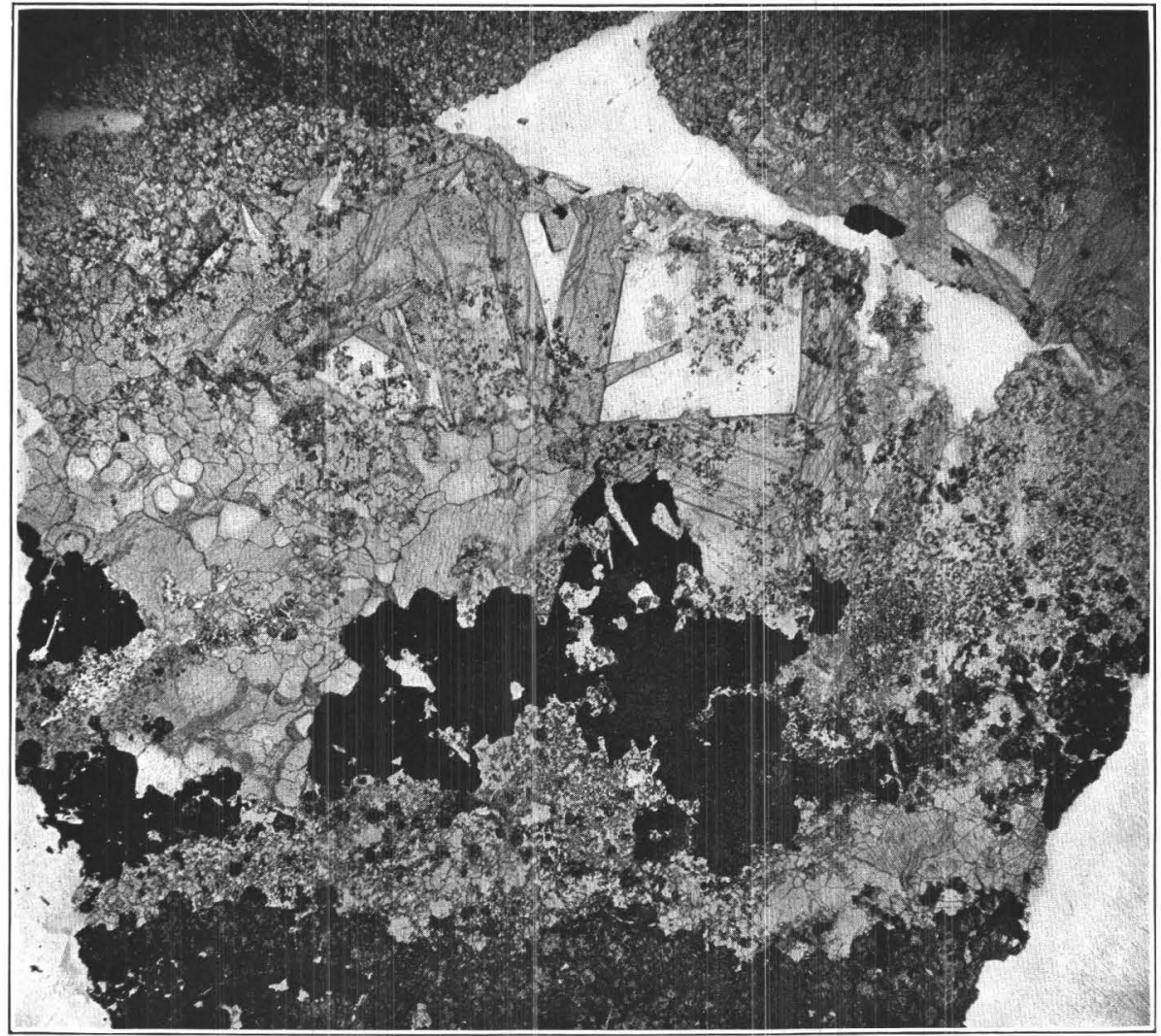

$A$

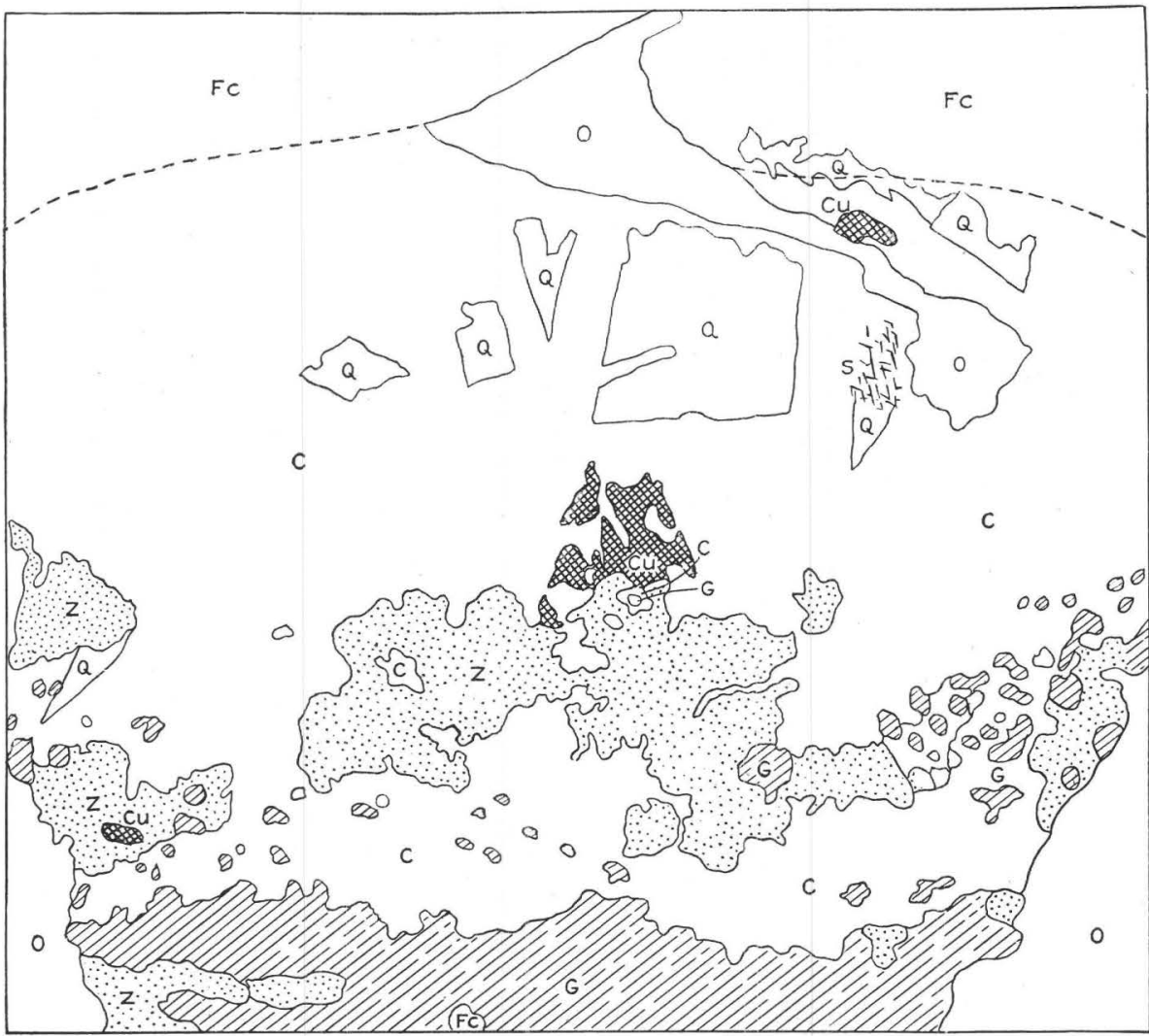

PHOTOMICROGRAPHS OF ORES AND ROCKS. 



\section{PLATE X.}




\section{PLATE X.}

\section{Photomicrographs of Ores and Rocks.}

A, Contact-metamorphic rock (226 Cl. A) from Arizona Central mine, first level, 91 feet below surface. First erosscut to Williams vein, north of shaft.

Pyritic ore from contact-metamorphic rocks, derived from limestone of Longfellow formation. $\mathrm{C}=$ residuary calcite; $\mathrm{P}=$ pyrite $\mathrm{M}=$ magnetite; $\mathrm{Cu}=$ chalcopyrite; $\mathrm{Z}=$ zinc blende.

Magnified 22 diameters. Drawn from photograph by reflected light.

$B$, Contact-metamorphic rock (337 Cl. A) from Shannon mine, Metcalf; breast No. 3 Black Hawk tunnel, April, 1902.

Derived from limestone of Longfellow formation. L=fine-grained magnesian limestone, partly contact metamorphosed, and containing grains of diopside, magnetite, and pyrite; $\mathrm{C}=$ calcite veins. containing intergrown grains of magnetite and pyrite (M P) and few small tremolite prisms; veinlets adjoined by gradually fading zone of tremolite $(\mathrm{T})$, partly crystallized in minute prisms next to the calcite.

Magnified 22 diameters. Ordinary light. 

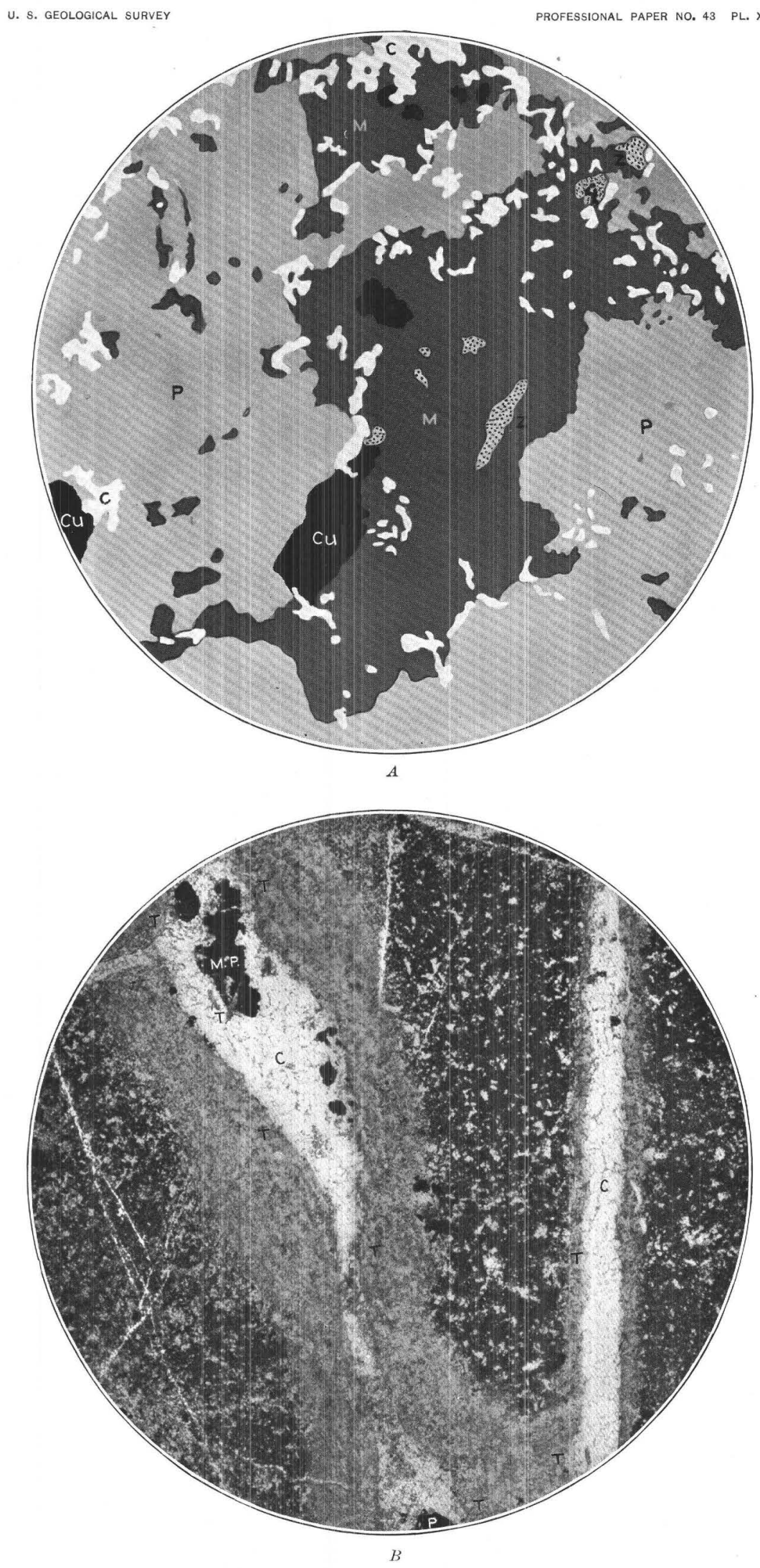

PHOTOMICROGRAPHS OF ORES AND ROCKS. 



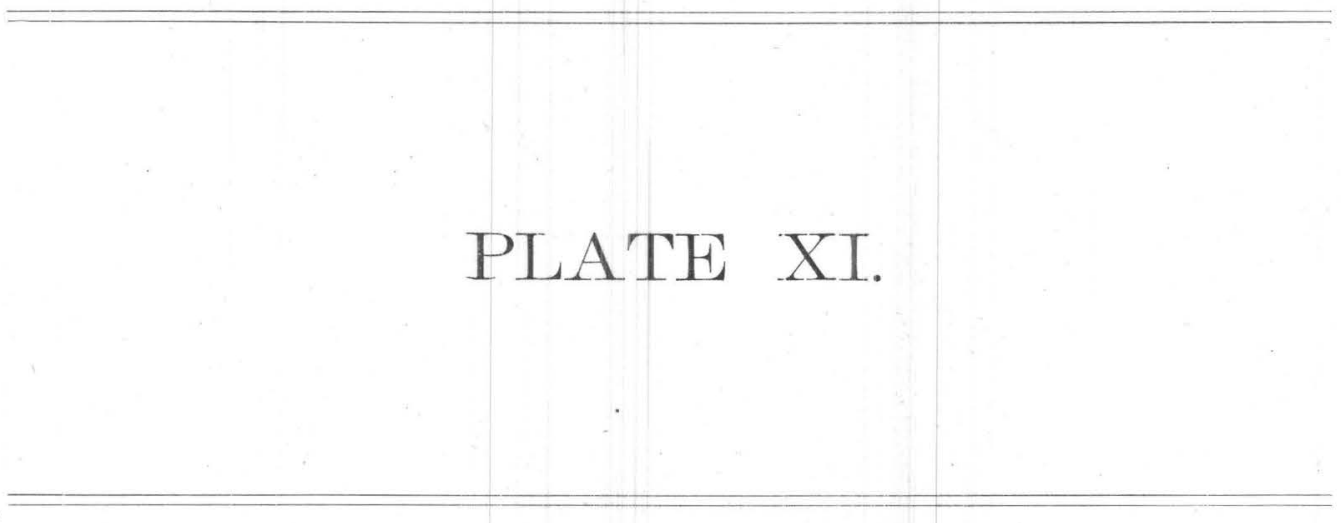




\section{PLATE XI.}

\section{Photomicrographs of Ores and Rocks.}

A, Contact-metamorphic rock $(172 \mathrm{Cl}$. A) from Fairplay road, east slope of Copper Mountain.

Medium-grained limestone from Longfellow formation with magnetite and chalcopyrite.

Mottled white and gray=granular limestone; black=magnetite (sharply defined grains) developing by replacement; black grain at $\mathrm{Cu}=$ chalcopyrite; $\mathrm{C}=$ chlorite; $\mathrm{O}=$ open field.

Orđinary light. Magnified 44 diameters.

$B$, Contact-metamorphic rock (same specimen).

Magnetite (black, sharply defined grains) developing by replacement in granular limestone.

Ordinary light. Magnified 44 diameters.

144 

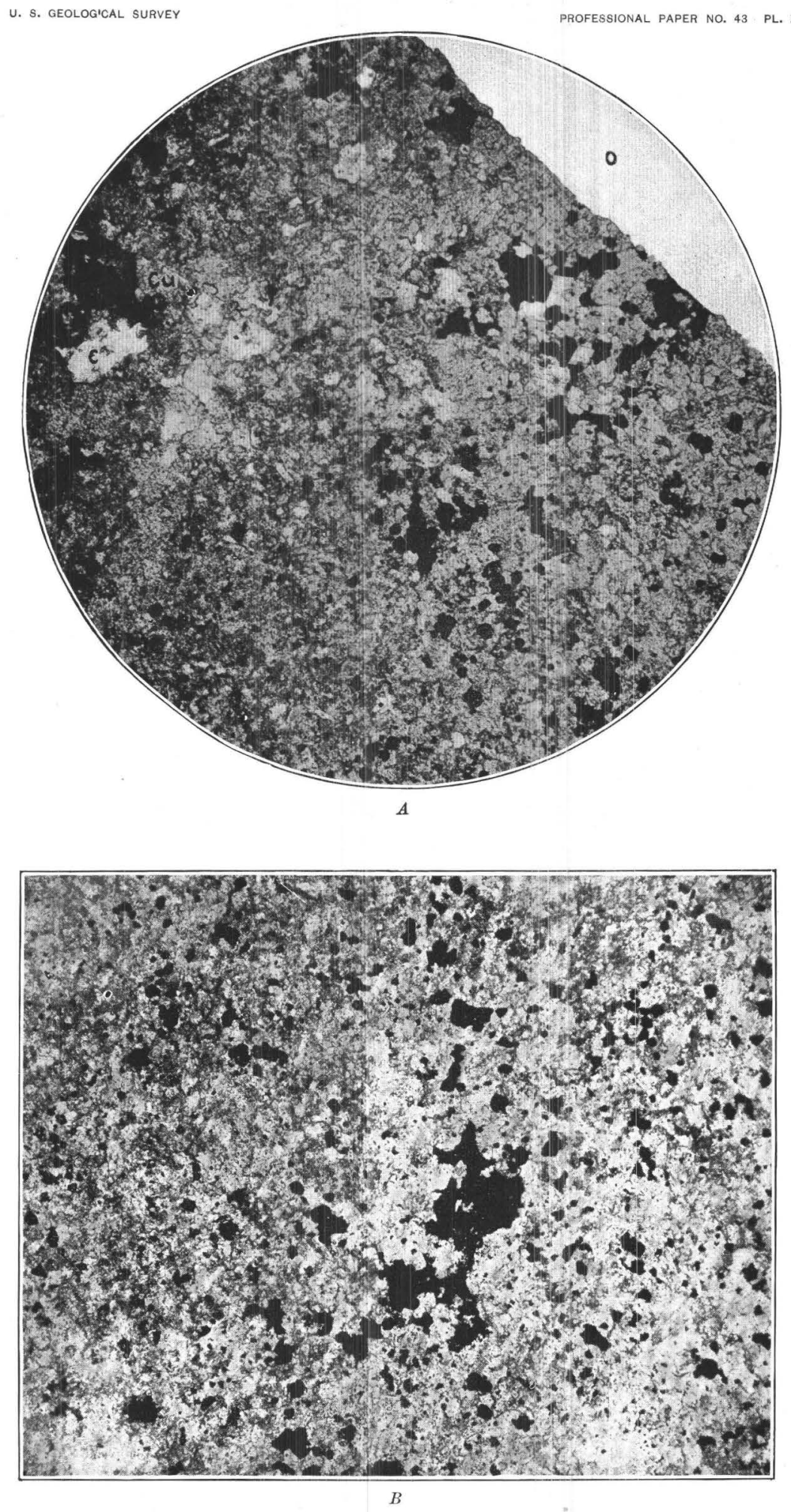

PHOTOMICROGRAPHS OF ORES AND ROCKS, 



\section{PLATE XII.}




\section{PLATE XII.}

\section{Photomicrographs of Ores and Rocks.}

A, Vein quartz (204 Cl. A) from Montezuma mine, big pyrite vein 170 feet southwest of main shaft at deep level about 150 feet below surface.

White $(\mathrm{Q})=$ medium-grained quartz; black $(\mathrm{P})=$ crystals of pyrite; black $(\mathrm{M})=$ aggregates of molybdenite seales; dark gray $(\mathrm{S})=$ aggregates of sericite. This pyritic ore with about one-half per cent of copper was probably formed by replacement of porphyry along fissure.

Ordinary light. Magnified 22 diameters.

$B$, Vein quartz (205 Cl. A) from same locality.

Normal, coarse-grained, idiomorphic vein quartz with fluid inclusions. Probably formed by filling of open cavity.

Polarized light. Magnified 22 diameters.

C, Ore (202 Cl. A) from Montezuma mine, shale stopes on Waters shaft level 50 feet below surface.

Black $=$ chalcocite in process of oxidation to brochantite (white and light gray); brochantite alters in the veinlets to malachite (dark gray).

Ordinary light. Magnified 22 diameters. 


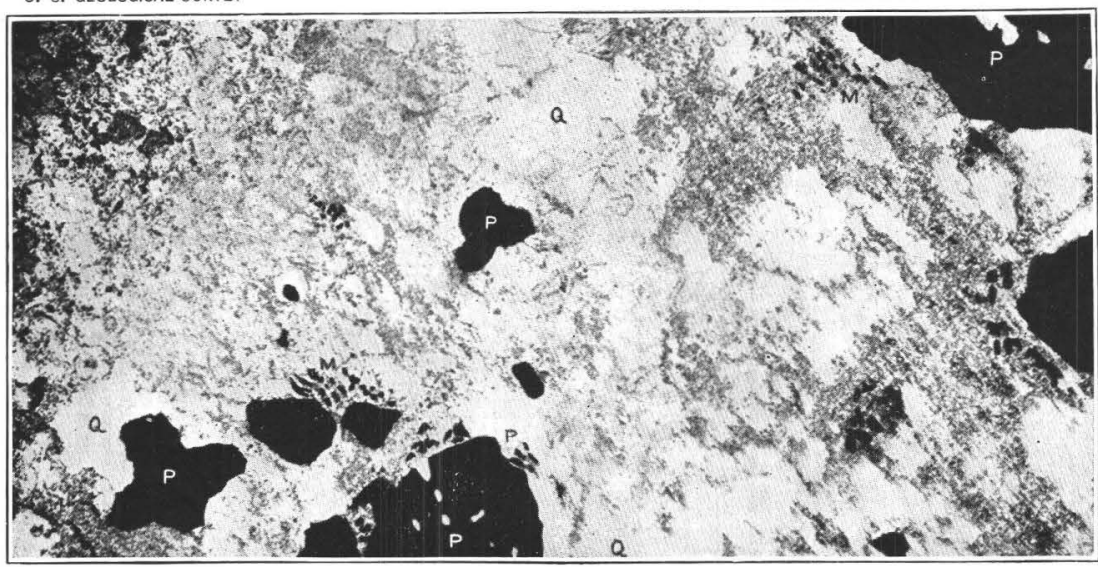

$A$
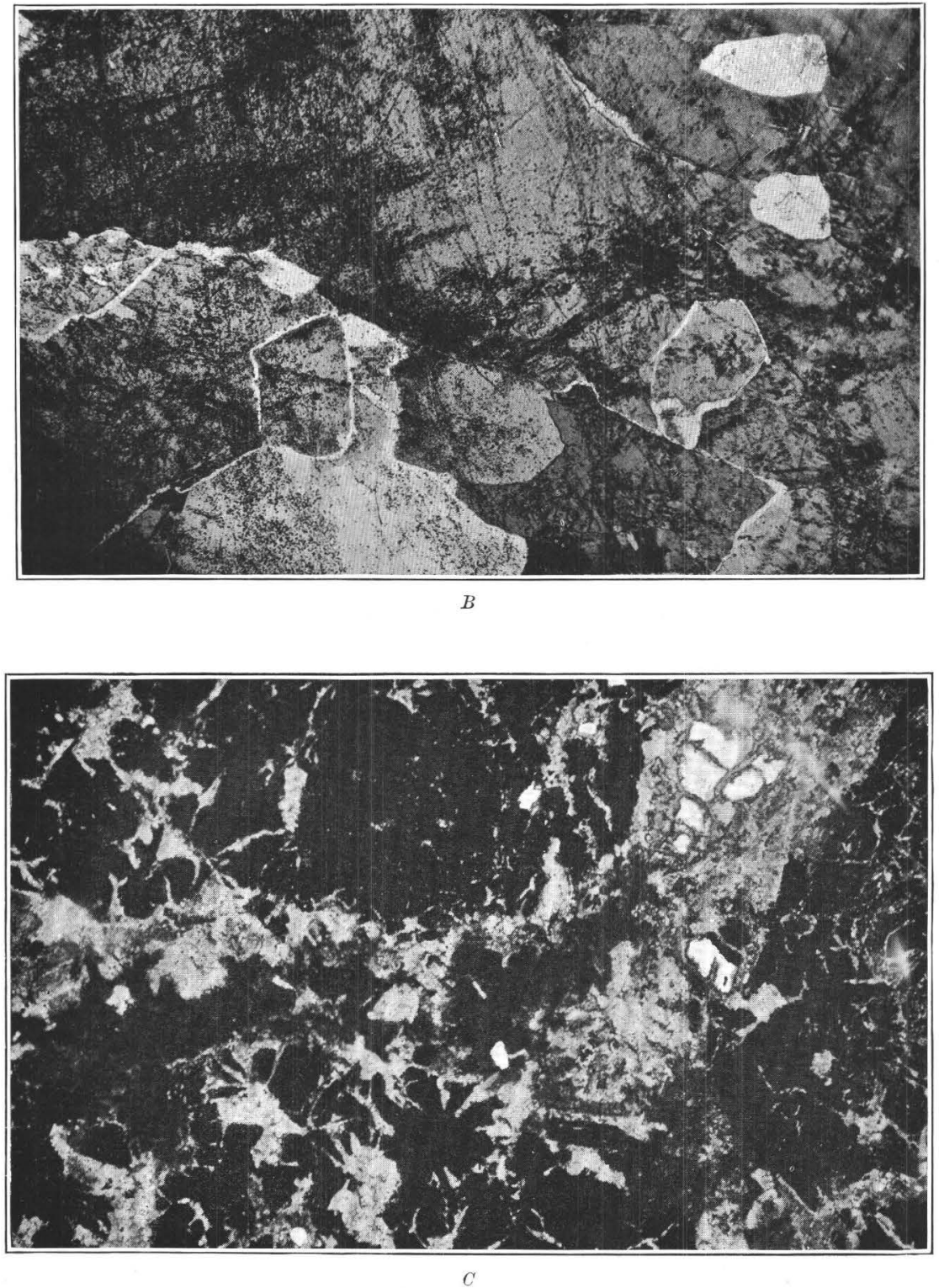

PHOTOMICROGRAPHS OF ORES AND ROCKS. 

PLATE XIII. 


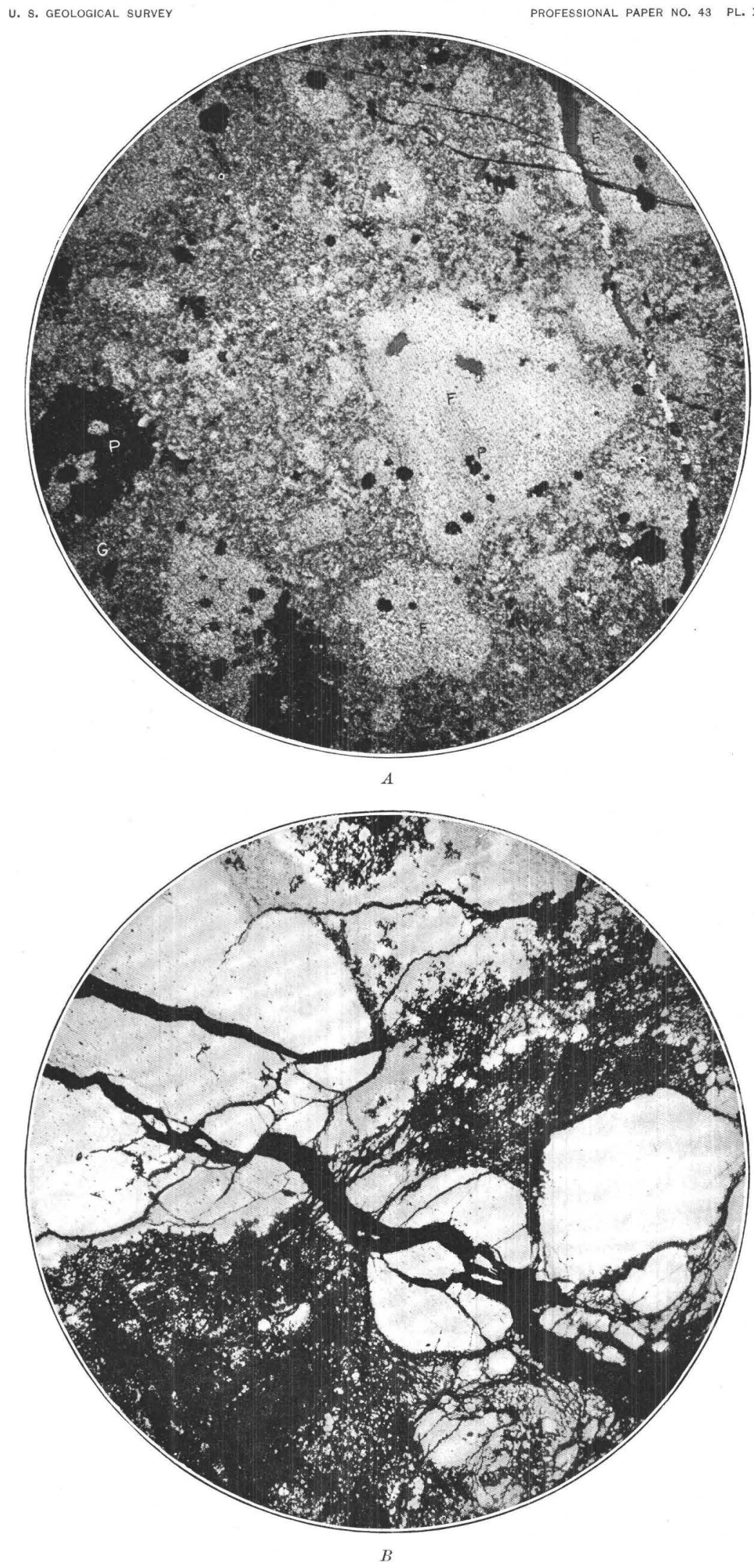

PHOTOMICROGRAPHS OF ORES AND ROCKS. 

PLATE XIV. 


\section{PLATE XIV.}

\section{Photomicrographs of Ores and Rocks.}

$A$, Chalcocite ore (209 Cl. A) from Ryerson mine, first level, at elevation of 4,748 feet. Drift on Humboldt vein, 150 feet north of end line Morenci claim. Lower limit of chalcocite zone.

Dark gray $=$ chalcocite, developing by replacement in pyrite (light gray). The chalcocite is accompanied by small amounts of microcrystalline quartz, sericite shreds, and kaolin. Black areas represent open field.

Reflected light. Magnified 22 diameters.

$B$, Chalcocite ore (69 Cl. A) from Butler vein, Butler and London tunnel.

Sericitized porphyry with pyrite, partly replaced by chalcocite.

$\mathrm{G}=$ groundmass of porphyry, chiefly microcrystalline quartz with shreds of sericite; $\mathrm{P}=$ pyrite $\mathrm{C}=$ chalcocite.

Reflected light. Magnified 22 diameters. 

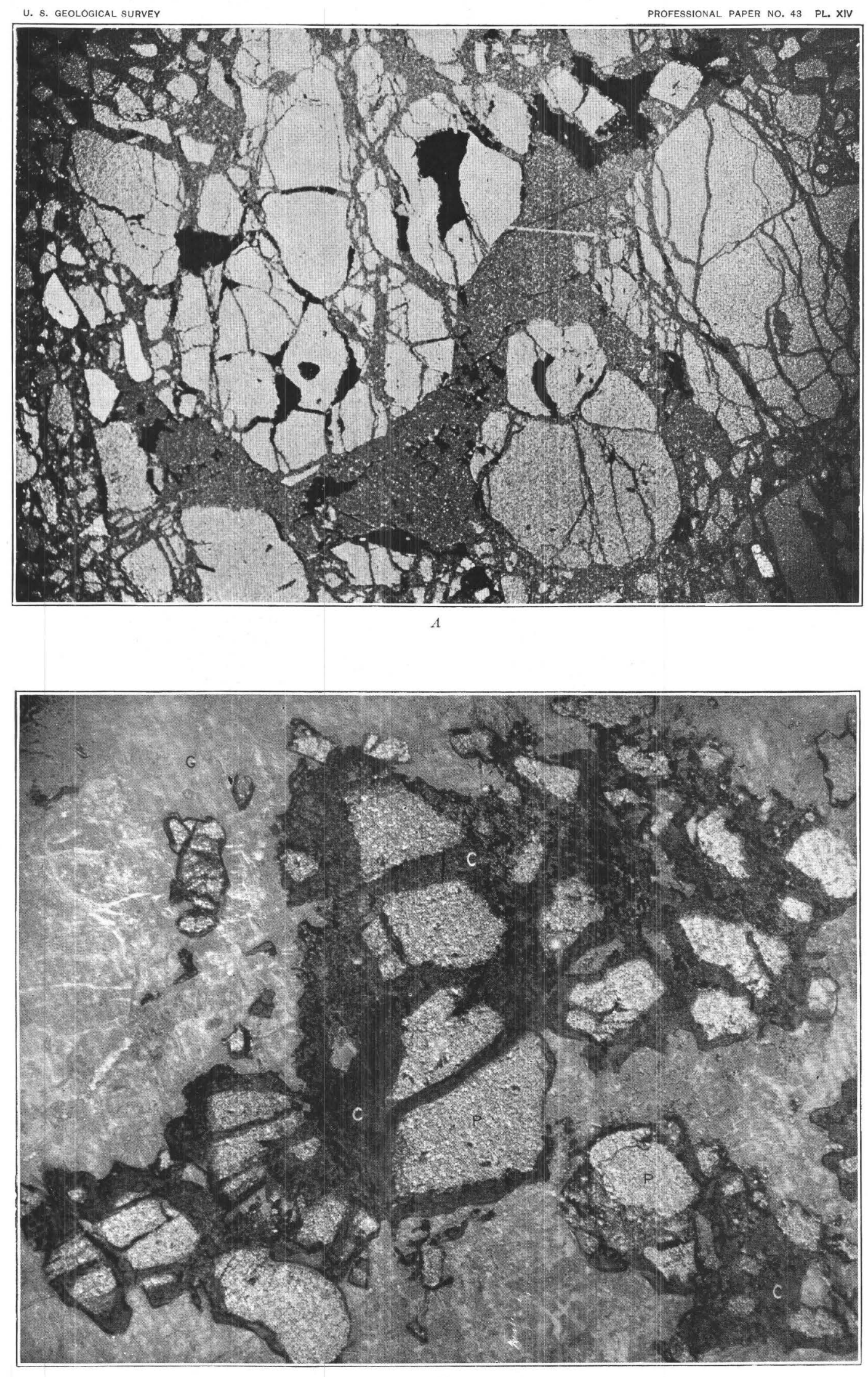

$B$

PHOTOMICROGRAPHS OF ORES AND ROCKS. 



\section{PLATE XV.}




\section{PLATE XV.}

\section{Photomicrographs of Ores and Rocks.}

A, Malachite ore ( $254 \mathrm{Cl}$. A) from Detroit mine.

$\mathrm{M}=$ radial malachite, developing by replacement in partly contact-metamorphosed shale (S), consisting of kaolin, epidote, amphibole, glauconite, sericite, etc. Microcrystalline malachite also develops among the constituents of the shale.

Ordinary light. Magnified 25 diameters.

$B$, Azurite ore (254 Cl. A) from Detroit mine.

$A=$ crystals of azurite partly twinned, developing by replacement in contact-metamor- phosed shale (S), consisting of amphibole, sericite, and kaolin (?).

Ordinary light. Magnified 25 diameters. 

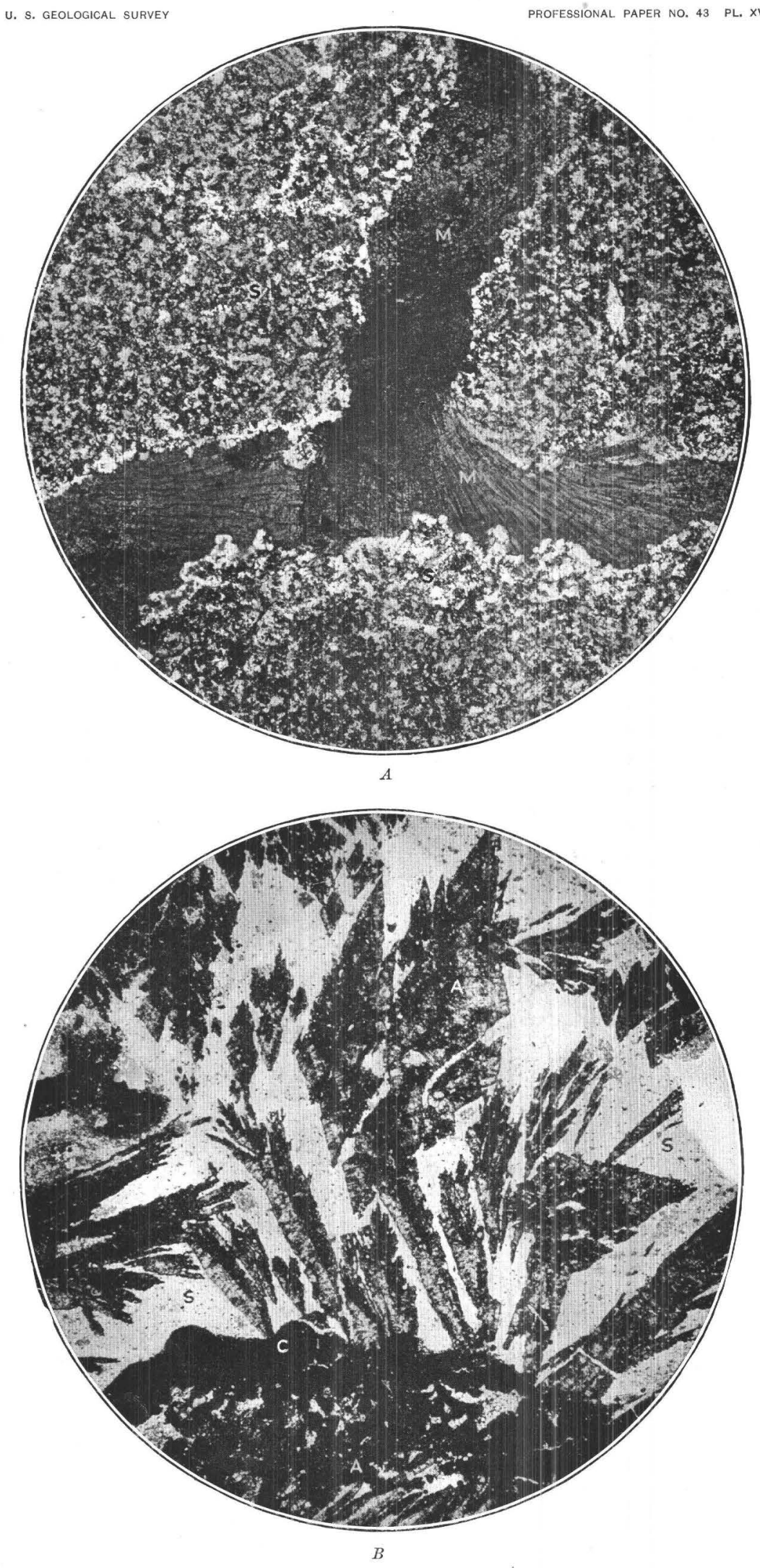

PHOTOMICROGRAPHS OF ORES AND ROCKS. 

A thin section of No. I shows that it is to some extent affected by oxidation, which has produced a network of granular quartz and limonite or hematite along fracture lines. There is also a little residuary calcite included in the massive garnet, but so little that it would scarcely show in an ordinary analysis. The garnet is yellowish in transmitted light and practically isotropic, except in some places, where appear hexagonal bands of varying color, indicating dodecahedral crystallization. These bands show distinct but faint birefringence. Allowing for the surplus of $\mathrm{Fe}_{2} \mathrm{O}_{3}$ and $\mathrm{SiO}_{2}$, indicated by the microscope, the garnet must be a very nearly pure andradite.

No. II shows almost pure garnet substance under the microscope and corresponds to the formula of-

$$
\begin{aligned}
& 18(\mathrm{CaFeMn}) \mathrm{O} .7\left(\mathrm{Fe}_{2} \mathrm{Al}_{2}\right) \mathrm{O}_{3} \cdot 20 \mathrm{SiO}_{2} \\
& \mathrm{Ca}_{2} \mathrm{Fe}^{\prime \prime}: \mathrm{Mn}=1: .008: .007 \\
& \mathrm{Fe}^{\prime \prime \prime}: \mathrm{Al}=1: .04
\end{aligned}
$$

While copper stains are found at many places in the garnet rock, and valuable copper ores, chiefly chrysocolla, occur in it at the Modoc open cut, unaltered sulphides have not been found within this area. They are no doubt present to a limited amount, but surface oxidation has changed them entirely to various minerals, such as malachite, willemite, chrysocolla, and copper-pitch ores.

The total thickness of the Modoc formation at Morenci is 170 feet; the upper 85 feet consist of heavy-bedded pure limestone, underlain by 60 feet of brownish fine-grained rocks which to some extent consist of dolomite. The two lowest members are a 15-foot band of sandstone and a 10-foot stratum of pure limestone. It is the upper member of pure limestone which is so extensively converted into garnet. The lowest limestone member resists metamorphism strongly, and is found little altered in the Detroit mine in the center of the metamorphic area. At its northern edge it seems, however, to have succumbed to the altering influences; this is also true in other places, notably in the exposures just north of the slag dump at the smelter. Sufficient data were not obtained to show conclusively how the stratum of dolomite acts under metamorphosing influences, but to judge from the exposures near the smelter and on Modoc Mountain, it also changes to garnet.

In the exposures of the Modoc formation on the slope southwest of the smelter similar interesting phenomena are observed. About due south of the smelter 112 feet of Modoc limestones are exposed, including 10 feet of coralliferous lime, 35 feet of brown dolomite, and 50 feet of the upper Gray Cliff limestone, all covered by Cretaceous strata. A short distance westward these limestones become suddenly and completely altered, appearing now as a cliff of garnet with large masses of magnetite. The coralliferous lime resists 
alteration longest, the dolomite next, but both are here converted into garnet. Whether this garnet differs from the normal andradite was not ascertained. The Gray Cliff limestone is as usual most easily altered and continues thus changed for several hundred feet beyond where alteration ceases in the underlying dolomite and coralliferous lime. This band of garnet rock is traceable for 1,500 feet into the town of Morenci, where further identification becomes impossible. For at least half of this distance there is little or no alteration visible in the underlying shales and limestones of the Morenci formation.

Over large areas, then, the Modoc formation, and especially its upper and thickest member, the Gray Cliff limestone, has become almost completely changed to lime-iron garnet, with some epidote and magnetite. The limestone is an extremely pure rock of its kind, containing about 96 per cent of carbonate of lime, and it is very clear that in order to effect this change all of the $\mathrm{CO}_{2}$ must be expelled and large quantities of $\mathrm{SiO}_{2}$ and $\mathrm{Fe}_{2} \mathrm{O}_{3}$ must be added.

In order to trace the precise mode of alteration it would be important to know the relation of volume of original and changed rock, but unfortunately there seems to be no exact way of getting at this problem. Judging from thickness and appearance of the altered formations I believe that neither great increase nor great reduction of volume has taken place. By the following ealculation we may arrive at an understanding of the quantities involved in this transformation.

In 1 cubic centimeter of $\mathrm{CaCO}_{3}$ are contained $1.52 \mathrm{~g}$. $\mathrm{CaO}$ and $1.19 \mathrm{~g} \cdot \mathrm{CO}_{2}$, making a total of $2.71 \mathrm{~g}$.

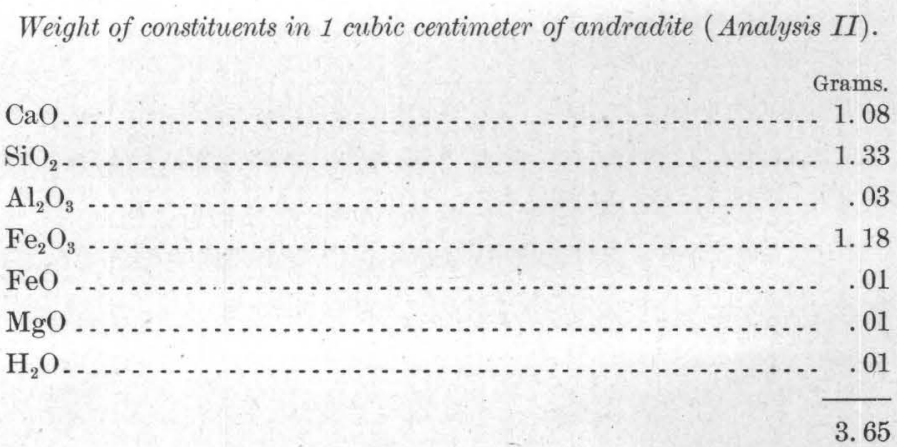

If the whole of $\mathrm{CaO}$ in $1 \mathrm{~cm}^{3} \mathrm{CaCO}_{3}$ has been used to convert the rock into garnet, then this volume becomes $1.40 \mathrm{~cm} .^{3}$ garnet - that is, the volume is increased about one-half during the contact metamorphism. This has almost certainly not taken place. On the other hand, if there has been no change of volume during the alteration, $0.46 \mathrm{~g}$. of $\mathrm{CaO}$ has been carried away together with $1.19 \mathrm{~g}$. $\mathrm{CO}_{2}$, while $1.33 \mathrm{~g}$. $\mathrm{SiO}_{2}$ and $1.18 \mathrm{~g}$. $\mathrm{Fe}_{2} \mathrm{O}_{3}$ have been added. In other words, 460 kilos $\mathrm{CaO}$ and 1.190 kilos $\mathrm{CO}_{2}$ have been carried away per cubic meter, while 1,330 
kilos $\mathrm{SiO}_{2}$ and 1,180 kilos $\mathrm{Fe}_{2} \mathrm{O}_{3}$ have been added, the latter amount being a minimum because of the magnetite so frequently found associated with garnet. These are astonishing figures, and give an idea of the vigorous transfer of material which took place during the contact metamorphism.

Morenci shales.-These can be traced approximately around the north side of Modoc Mountain by the Longfellow and Montezuma mines and the gap at the Arizona Copper Company's hospital down into the town; they are exposed in the Detroit and Manganese Blue mines, in the Butler and Hudson crosscuts of the Arizona Central mine, and probably also show along the railroad between the Detroit Copper Company's store and the Arizona Central mine. They are again found in the southern part of Morenci, forming thus a continuous belt through the altered area. The alteration seems most intense in the center of the town, where the shale is nearest to the porphyry mass.

In general the shales when altered form gray or dark-green, dense, flinty rocks with streaks and seams of epidote and specks of pyrite. Specimens from the Montezuma mine are dark gray, somewhat mottled, nonfissile, and are cut by small veinlets of epidote and pyrite. In thin section the rock is identical with that described on page 130, which contains flocculent aggregates of epidote and much dirty-greenish glauconite (?), from which fibers of amphibole appear to develop. The cryptocrystalline mass between these constituents probably consists of quartz and kaolin. The shale from the first level of the Detroit mine is a compact, hard, greenish-gray rock, imperfectly fissile and containing no calcite. In thin section the rock is seen to consist of some granular, flocculent epidote with much amphibole in felted aggregates. A clear mass of low double refraction lies between the needles, but could not be definitely identified; a few very small grains of striated feldspar, probably of metamorphic origin, were observed. The second body of oxidized ores in the Detroit mine is contained in this rock. Another, a brownish and partly oxidized shale from 20 feet below the Waters shaft level, Montezuma mine, now contains abundant prisms and grains of pyroxene, embedded in a mass of slightly greenish muscovite. The latter is an unusual mineral in this contact zone.

The unaltered shales have, in the first place, a rather unusual chemical composition, shown in analysis on page 130; mineralogically they contain epidote, quartz, kaolin, and a large amount of a mineral related to glauconite. Along dikes they have not suffered great alteration, but within the main contact zone epidote, pyrite, and an amphibole develop in them. In how far this is connected with a chemical change I have not the data to say definitely; if anything, magnesia and lime have been added, but there is no evidence of the great access of iron and silica shown by the contact-metamorphosed Modoc formation. No chalcopyrite 
nor zinc blende were observed. If commonly present they could hardly have escaped notice, for the shales are hard and not easily affected by oxidation.

Longfellow limestones.-These rocks occupy the largest area in the contact zone and border directly against porphyry. Together with the shales they make up the larger area of the general altered zone indicated on the special map.

It has been shown that the Longfellow formation consists of about 400 feet of limestones and lime shales, containing dolomitic rocks at intervals, but on the whole prevailingly calcitic; they contain much more silica, chiefly as chert, than does the Modoc formation. Iron is present in very small amount, while they may contain up to 3 or 4 per cent of alumina.

The alteration of this formation offers much variety. In some places, even near the porphyry contact, small and irregular areas have almost entirely escaped metamorphism; for example, at the southwest corner of the district covered by the special map and near the Ryerson hoist. In places heavy masses of garnet, epidote, and magnetite have formed, but more common is a partial alteration with residual calcite, resulting in pyroxene, magnetite, and sulphides. Pyrite, chalcopyrite, and zinc blende occur abundantly wherever oxidation has not changed them.

Heavy masses of garnet and magnetite occur on both sides of the north dike in the East Yankie mine. In the eastern part of the Yavapai and Montezuma mines there are large quantities of epidote, and the bottom level of the Montezuma (elevation 4,688 feet), connecting that mine with the Ryerson, traverses hard masses of garnet, pyrite, and magnetite. Thin sections show these minerals in intimate intergrowth, indicating beyond doubt simultaneous crystallization; they also contain some colorless pyroxene and residual masses of calcite. Magnetite and pyrite, in various parts of the slide, envelop each other.

In the Manganese Blue and Copper Mountain mines occur large masses of magnetite, partly oxidized to limonite, and also some garnet. Ccarse aggregates of epidote and magnetite oceur at the mouth of the Copper Mountain tunnel. In the Ryerson mine a development of garnet in the altered limestones is not common; in the main adit level, 100 feet south of Ryerson vein, however, hard greenish and brownish mottled rocks are met, containing little specks and seams of chalcopyrite. Under the microscope a part of the slide consists of granular epidote, with some prisms of the same mineral. The remainder is composed of irregular masses of granular calcite, containing grains of epidote, rounded crystals of garnet, and irregular grains of chalcopyrite, intergrown with garnet and epidote. Throughout the calcite are also found minute foils of dark-red specularite.

In Arizona Central mine a 200 -foot-wide mass of garnet with sulphides is exposed on the first level in the crosscut between the Arizona Central and 
Williams veins. It is a very intimately intergrown coarse aggregate of pyrite, chalcopyrite, dark-brown zinc blende, and magnetite. Both pyrite and magnetite, the most abundant constituents, appear in granular masses, showing a tendency to erystallization (Pl. X, A).

On the intermediate level of the same mine, near its west end, close to the fault here cutting across the veins, a large mass of magnetite intergrown with chalcopyrite of the same age was found and some tons of this were actually extracted as ore. This is the only instance known here of commercial ore occurring in unoxidized contact-metamorphic rocks.

On the bottom level of the same mine in the crosscut from the shaft extremely hard garnet rocks were encountered. These, which are entirely fresh, consist of coarsely granular garnet, epidote, a colorless pyroxene, probably diopside, with magnetite, pyrite, and chalcopyrite, intergrown as described. A little calcite and microcrystalline quartz are also present (PI. VII, D). A body of pure granular magnetite was stoped on this level for fluxing copper ores. It was 150 feet long and about 30 feet wide, wholly embedded in metamorphic rocks, and without sharp contacts.

Exposed along the road from Morenci to Eagle Creek (shown near the lower edge of the special map) is an area of coarsely crystalline garnet-epidote with one or two large masses of magnetite. A prospect containing much unaltered chalcopyrite is opened in this rock at the roadside. This area runs out irregularly south of the road and is covered by metamorphosed shale. It probably belongs to the Longfellow formation.

As stated above, a more common form of alteration is one in which there is much residual carbonate. These rocks are greenish gray or mottled gray and green, effervesce freely with cold acids, and commonly contain visible particles of magnetite and sulphides. In many of them some dolomite is admixed with the calcite. Grains and ragged prisms of a diopside-like pyroxene develop in them, more rarely epidote. Anhedrons of magnetite, pyrite, zinc blende, and chalcopyrite are irregularly distributed in the carbonates, sometimes in large quantities. It is characteristic that these four minerals oceur in intimate intergrowth; each one may develop any of the others. Such rocks occur in the Ryerson, Yavapai, Montezuma, Copper Mountain, and Arizona Central mines. Large masses of them probably contain up to 1 per cent of copper, especially in the Yavapai mine, and it is easily seen that oxidation of them might well develop payable ore bodies from such raw material. One of them from the Fairplay road, 1,300 feet N. $76^{\circ} \mathrm{W}$. from the Detroit Copper Company's store, is figured in Pl. XI. It is a partly dolomitic rock with interlocking grains of carbonates of lime and magnesia. Grains and imperfect crystals of magnetite develop abundantly, in metasomatic 
manner, in the calcite and the dolomite. The only other constituents are scattered foils of chlorite, anhedrons of titanite (?), and aggregates of chalcopyrite, the latter in places intergrown with magnetite.

On the whole, there is in the Longfellow limestone a distinct belt of intense and almost complete alteration to garnet, diopside, epidote, etc. Roughly speaking, it follows the main contact from the point where the limestones first come into contact with the porphyry, in a northeasterly direction through the Arizona Central, Manganese Blue, Montezuma, and East Yankie mines (north dike Longfellow), to the place where the limestones cease. This belt is only about 600 feet wide and mine workings to the southeast of it run into much less altered rock. Those parts of the limestone series which project into the porphyry, or which are entirely surrounded by it, seem on the whole less altered.

These rocks of the Longfellow formation have certainly received an access of iron, sulphur, copper, and zinc. Whether magnesia and silica have been added is more doubtful; in some cases it would seem that this has happened, but as it is known that the formation contains a certain amount of both of these substances, it is hardly possible to answer that question with much assurance, as vigorous transferring of material may have occurred between the various beds.

Considering the wide distribution of sulphides and magnetite throughout this contact-metamorphic zone, it is evident that the later processes of oxidation here encountered a most fruitful field for the concentration of copper ores.

CONTACT ZONE OF SHANNON MOUNTAIN.

On Shannon Mountain, at Metcalf, an entirely similar set of phenomena are encountered. A mass of down-faulted sediments comprising the whole series from the Coronado quartzite to the Modoc limestone and occupying an area of about 100 acres lies here at the contact of the main stock and is cut by several dikes extending from it. A detailed description may be found on page 305 . The Modoc limestone, which here contains 3 per cent of silica, lime, and iron, and 9 per cent of magnesic carbonate, is converted to a mass of dark-brown garnet and iron ore much oxidized in places, forming the summit of the mountain. An analysis of this garnet is given on page 134. Small masses of highly crystalline crumbling limestone are preserved in some places and give good opportunity for studying the transformation into garnet; as usual this takes place rather abruptly. PI. VIII, A, illustrates the development of small crystals of garnets and pyroxene in the limestone at the contact. Near the contact small masses of garnet rock are inclosed in the coarsely crystalline limestone. Sections of these show closely massed erystals of garnet, between which lies a little residual calcite and a few grains of quartz. While copper stains are abundant in these 
rocks and the products of oxidization contain much zinc, no unaltered sulphides, except a few grains of pyrite, have been observed.

The dolomite member found at Morenci in the lower part of the Modoc limestone is not represented here. The Morenci formation is as usual represented by shales which contain epidote and oxidized copper ores, especially near the dike contacts. In certain parts of the shales seams of pyrite and chalcopyrite are very abundant, but these are probably rather produced by hydrothermal than by contact metamorphism.

The Longfellow limestone is most altered on the side of the main porphyry stock and along the dikes, but is more or less affected throughout the whole area. The bluish-gray and rather dense limestones are to some extent dolomitic and contain more or less silica. The same irregular alteration noted at Morenci characterizes it here. Garnet has developed in several places, notably near the red ore body, near the top of the Longfellow formation, and along a porphyry dike on the northeast side of the limestone area. In the red ore body the rocks are very much oxidized, but on its outskirts specimens were found consisting of partly decomposed garnet with included grains of chalcopyrite. On the same level (Boulder tunnel, end of north drift) specimens were collected showing a greenishgray, fine-grained limestone with abundant grains of chalcopyrite; toward one end of the specimen this changes gradually into massive garnet, containing grains of chalcopyrite. Seams containing pyrite and chalcopyrite also cut through the rock. Thin sections show that pyroxene, garnet, and epidote alternately prevail in different parts of the same slide. Very intimate intergrowth of chalcopyrite and epidote was observed, and the garnet contains a network of chalcopyrite, probably due to replacement of residuary calcite between the garnet grains. In other sections the garnet includes grains of chalcopyrite of simultaneous crystallization. Veinlets of pyrite and chalcopyrite, associated with epidote, calcite, and a little diopside, cut the rock in places and, spreading from them, chalcopyrite has occa sionally replaced the garnet. This specimen shows evidence of two periods of mineralization, one being distinctly connected with the general metamorphism of the rock, and the other with later vein action. Entirely unoxidized metamorphic rocks are exposed in the Black Hawk No. 3 tunnel, 160 feet below the Boulder tunnel, in the lower part of Longfellow formation. The rocks are grayish green and fine grained; they consist of calcite, diopside, and tremolite, with scattered grains of magnetite, pyrite, and chalcopyrite. Veinlets of coarse calcite, with intergrown grains of pyrite and magnetite, cross the rock and are adjoined by a zone of alteration about half the width of the vein, consisting of colorless tremolite prisms (Pl. X, B). 
SUMMARY AND DISCUSSION.

The above description has shown that in the limestones and shales near the contact of the main stock and the dikes of quartz-monzonite-porphyry and granite-porphyry the following minerals have been formed by practically simultaneous replacement: Garnet, epidote, pyroxene (diopside), amphibole (tremolite), magnetite, specularite, pyrite, chalcopyrite, and zinc blende. This metamorphism is directly dependent upon the proximity of the contact and apparently also upon the acidic character of the porphyry, the diorite-porphyry exerting little influence, while the granite-porphyry and the monzonite-porphyry produce an intense alteration. It is not - except to a minor degree as qualified below under the heading of hydrothermal metamorphism-due to waters circulating on fissures and must be ascribed to the direct influence of some substance contained in the molten magma of porphyry. The altered rocks have beyond all doubt generally received a great access of iron, sulphur, copper, and zinc, and in the case of pure limestones, which over large areas have become converted into almost pure garnet rocks, have received immense amounts of ferric oxide and silica.

While the main contact zone is clearly dependent upon the proximity of the principal stock of porphyry, it seems that some of the dikes near that contact have exerted a specially strong influence. In the limestones-even in those of greatest purity - massive epidote is apt to develop along the immediate contact of the dikes, thus implying a limited transfer of alumina. A few feet away the garnet begins, and of course, as a lime-iron silicate, contains a very small proportion of alumina (see analyses on p. 134), probably almost exactly the amount originally contained in the limestone.

The contacts with the porphyry are sharp and show no indication of assimilation. The contact-metamorphic rocks are always - when unaffected by oxidation-hard and compact; oxidizing waters find it much more difficult to attack them than the porous porphyry. Considering that great amounts of carbon dioxide up to 40 per cent-have certainly been expelled during the metamorphism, a great shrinkage of volume should have taken place which could hardly fail to be noticed in the structure and thickness of the metamorphosed strata. I believe that in general this loss has been fully counterbalanced by additions of substance from the magmatic waters.

Comparing these contact phenomena with those of other localities described in the literature a great many points of similarity appear at once. Characteristic, among other things, is the slow change of the shales and the sudden metamorphism of the limestones, especially the pure limestones, which, if metamorphosed at all, attain their full metamorphic development almost at once. 
Most of the described contact zones refer to granites or diorites; no changes along the contacts of porphyries comparable to the Morenci and Metcalf zones have ever been examined, so far as I am aware.

Vesuvianite and wollastonite, common in many contact zones, have not been identified with certainty in this district. The alteration of the shales is also peculiar. Instead of the ordinary knotty schist and hornfels, with a great development of biotite, andalusite, staurolite, and feldspars, there is found at Morenci a greenish hornfels, with much amphibole (tremolite), epidote, pyrite, and magnetite. The Morenci shales are somewhat unusual in composition, with high lime, magnesia, and iron. Amphibolitic hornfels is, however, not unknown, and has been described by Professor Brögger from the Christiania field.

The question whether contact-metamorphic rocks simply represent a recrystallization, or whether they have received additional substance from the cooling magma, is a most important one. Professor Rosenbusch believes that little or no additional substance has been received, and considers that it is possible to determine the original character of metamorphic rocks from their present composition. ${ }^{b}$

Professor Zirkel ${ }^{b}$ says that in nearly all cases the contact-metamorphic rocks simply represent a recrystallization of original constituents. He believes that the contact metamorphism took place by reason of the pressure and heat exerted by the molten rock, and speaks rather slightingly of the view that substance from the magma can be transferred to the surrounding strata, although admitting that in one or two cases it seems to have happened. Professor Brögger, to whom we owe a most careful description of the Christiania contact zone, states that the alteration at that place seems to involve chiefly a recrystallization, although certain of the phenomena strongly suggest local accession of material, though perhaps rather from adjacent strata than from the intrusive body.

The idea of determining the original composition of metamorphic rocks is followed out by Dr. J. Barrell in his study of certain contact-metamorphic rocks of Montana. In his paper ${ }^{c}$ he advances the generalization that "carbonic acid is expelled only where the siliceous impurities of the limestone are sufficient to combine with the lime set free." Based on this he obtains the further result that a great loss of volume has taken place, and that it is possible to calculate original constituents, kaolin, silica; magnesite, and calcite from any given rock more or less altered to wollastonite, garnet, epidote, etc. If these statements are

a "Man kann es also als ein Gesetz aussprechen dass bei der Kontaktmetamorphose um Tiefengesteine das Eruptivgestein nur physikalisch und im allgemeinen nicht durch Stoffabgabe chemisch wirkte." Micr. Physiogr., $3 d$ ed., p. 85.

${ }^{b}$ Lehrbuch der Petrographie, 2 d ed., vol. 1, pp. 587-588.

$c$ Am. Jour. Sci., vol. 13, April, 1902. 16859-No. $43-05-11$ 
really meant as generalizations, as would appear from the paper, they are not supported by convincing proofs. Magmatic additions are mentioned, but receive scant treatment. ${ }^{a}$

This seems a rather crushing array of testimony from the petrographic side, and it has even been intimated by Professor Klockmann, ${ }^{b}$ in a recent paper combating the theory of transfer of material from magmas to sediments, that it ought to be sufficient to settle the question. While I do not doubt in the least the correctness of the conclusions drawn in individual cases by such eminent authors as Professors Rosenbusch and Zirkel, it is certain that contact metamorphism manifests itself in many various ways, and that the particular phases connected with mineral deposits have been rather conspicuously neglected by many petrographers, whose data and statements in regard to the occurrence of ores, even in ordinary rocks, has always seemed to me to suffer somewhat from lack of detail and precision.

On the other hand many French authors, among these Professor Michel Lévy, and lately Prof. J. H. L. Vogt, ${ }^{c}$ of Christiania, together with a growing number of younger scientific men, have strongly contended that many substances are given off by the cooling magma and enter the adjoining strata. This view is shared by myself and expressed in a recent paper on contact-metamorphism deposits. ${ }^{d}$

The truth seems to be that in many cases no perceptible accession of substance from the magma has taken place, while perhaps in as many more important additions have been received. How far the heat and the gases from the intruded magma will penetrate and what effects they will produce depends on many factors. As shown above, the composition of the magma is sometimes a factor of importance. In the case of the Morenci contact zone the amount of substance available seems to stand in direct relation to the amount of quartz in the porphyry. In many intrusive bodies there may be a very small quantity of water gas present; the access of material may then be slight, and the contact phenomena mostly due to the heat of the rock. The difference in susceptibility of the various beds is also strongly marked; all investigators agree on this point. In this district impure and very compact limestones resist alteration much more than coarse-grained pure rocks of the same kind, and, as shown above, the change in composition in the case of clay shales is extremely slight.

$a$ Weed, W. H., Geology and ore deposits of Elkhorn mining district, Montana: Twenty-second Ann. Rept. U. S. Geol. Survey, pt, 2, 1901 .

$b$ Zeitschr. prakt. Geol., vol. 12, 1904, p. 78

$c$ See, for instance, The genesis of ore deposits: Trans. Am. Inst. Min. Eng., 1902, p. 648.

d Op. cit., p. 716 
Study of the Morenci contact zone as a whole proves conclusively that most important accessions of substance have been received. The rocks inside of the altered zone contain an enormous amount of sulphur, iron, copper, and zinc. Iron is of course contained in the unaltered rocks to some extent, but in nothing like the quantities accumulated in the contact zone; sulphur, copper, and zinc in noticeable amounts are absent from the unaltered rocks. Were they present to the amount of a small fraction of the percentage contained in the contact zone, direct observation and surface oxidation would easily expose their presence. The minerals in which these substances are contained were certainly formed contemporaneously with the ordinary contact minerals.

The metasomatic development of magnetite in pure limestones may be observed in almost countless localities at Morenci and Metcalf. We know that iron was not contained to this amount in the original rock, but to demonstrate its actual derivation is of course difficult. The question becomes clear only when we compare the contact zone as a whole with the original unaltered rocks.

It seems very strange that anyone can doubt the possibility of such additions and overlook what must happen when a magma in aqueous fusion is suddenly brought up to higher levels and strongly ionized water gas, above the critical temperature, is largely released from its bonds. It must of necessity contain dissolved substances. Even at comparatively low temperatures water is one of the most powerful solvents known, and its action, when a perfect gas, is probably far in excess of that at $100^{\circ}$ or $200^{\circ}$. It is well known that some rapidly congealed rocks like the "pitchstone" from Saxony contains up to 8 per cent water, indicating an amount of water gas which, at $+4^{\circ}$, would correspond to 250 or 300 liters per cubic meter of magma. All magmas may of course not have contained this amount. The water gas seems to have penetrated the limestones like a sponge, inducing extreme molecular mobility. Even if we deny any additions of substance a most remarkable transferring of substance has taken place in the rock, as shown, for instance, by large crystals of garnet in limestones of uniform composition and containing far less iron and silica than the amounts required by the newly formed mineral. ${ }^{a}$ In a chapter on inclusions cogent proof will be brought that the magma actually was accompanied by water containing dissolved a large amount of substances.

A misapprehension of the character of contact deposits seems to exist in many quarters, as shown, for instance, by Professor Klockmann, ${ }^{b}$ in considering the

a E. Weinschenk, Vergleichende Studien ueber den Kontaktmetamorphismus: Zeitschr. Deutsch. geol. Gesell., vol. 54,1902, p. 443.

$b$ Zeitschr. prakt. Geol., vol. 12, p. 75 . 
presence of minerals containing boron, fluorine, etc., as necessary to prove the contact-metamorphic character of these deposits. To such arguments I would reply that the character of magmatic waters evidently varies greatly in different magmas. Some may carry large amounts of the substances mentioned, as shown by the presence of tourmaline, cassiterite, and other minerals in the contactmetamorphic rocks, while others may be almost wholly deficient in these and carry instead sulphur, copper, iron, and other metals. Any attempt to reduce the wonderful variety in the contact-metamorphic deposits to a single pattern is doomed to failure.

In a short paper dealing with contact-metamorphic deposits in North America $^{a}$ I emphasized the irregular form of most ore deposits of this kind and stated that they only occur close to the contact or at most a hundred feet away. In view of better acquaintance with this type this statement should be modified; as far as we know at present they may occur several hundred or even 2,000 feet away from the contact. In fact, disseminated sulphides and magnetite occur at Morenci up to 2,000 feet from the main contact.

A tabular form of deposits is often noted; this is usually due to the strongly marked difference in susceptibility of the various beds. Wherever the deposits have been enriched by oxidation the form may be more or less dependent upon those changes.

Mr. W. H. Weed has noted this tabular shape in contact deposits at Cananea, Mexico, and makes the form a basis of classification. ${ }^{b}$ I do not believe, however, that distance from contact (within limits given above) or shape are at all essential, and can find no mineralogical differences between deposits varying in these respects.

\section{HYDROTHERMAL METAMORPHISM.}

GENERAL STATEMENTS.

Both the porphyry and the contact zone at Morenci and Metcalf are traversed by quartzose fissure veins containing cupriferous pyrite and zinc blende. Over an extensive area between Morenci and Metcalf, and especially at Metcalf, the porphyry and the granite are shattered and recemented by quartz veinlets. These phenomena must of necessity have taken place after the consolidation of the porphyry. Their study and relation to contact metamorphism, which doubtless chiefly took place before and during the consolidation of the magma, thus becomes of the greatest importance. The porphyry adjacent to these lodes and occupying 
the shattered zones which accompany them, alters to a sericite-quartz-pyrite rock, while in the limestone the phenomena are more complex. The veins are here often surrounded by narrow zones of tremolite.

\section{ALTERATION OF THE PORPHYRY.}

Altered areas.-A series of lodes with northeast trend cut through the porphyry at Morenci, extending from the saddle west of Copper Mountain to the Detroit concentrator. Other parallel veins follow the Arizona Central dike. The whole of Copper Mountain and the dike mentioned are altered, though in a few places unaltered porphyry may locally appear in some of the crosscuts in the mines. The great porphyry ridge west of Copper Mountain is chiefly composed of unaltered porphyry, and fresh porphyry is correspondingly exposed in the western part of the Lone Star and the central part of the Butler tunnel (see Pl. XVIII). Many of the dikes have been followed by fracture zones and have become more or 'less thoroughly altered. Among these are the Joy dike, the West Yankie dike at the Detroit concentrator, and many others near the Montezuma mine. Others remain practically unaffected; among them are several smaller dikes in the Arizona Central mine, one or two in the Ryerson and the Montezuma mines, and several among those cutting Modoc Mountain and the Longfellow mine. Toward the north end of Butler tunnel, near the Carasco mine, the alteration again increases and extends more or less continuously by the Fairbanks and Copper Queen mines to Metcalf.

At Metcalf a large area extending from the Standard and King mines up to and including Shannon Mountain with the Metcalf mines is occupied by porphyry filled by irregular quartz seams and completely sericitized. This altered zone also extends over a part of the hills west of the town. Practically all of the dikes on Shannon Mountain are similarly altered.

It is plain from this statement that this rock alteration is not confined to the immediate vicinity of lodes, veins, and veinlets, but spreads over larger areas corresponding to the general outline of the shattered zone. The same altered rocks are found on all levels in the mines within this zone.

The porphyry seems to possess a certain porosity and looseness of grain, making it easily permeable to solutions. This quality also finds expression in the rounded outcrops and sandy soils of the unaltered areas.

Character of alteration. - The sericitized rock becomes bleached, dull white, and chalky; the feldspar prisms lose their luster; albite and oligoclase, as well as orthoclase, become filled with sericite foils, at first oriented parallel to the 
cleavage, and later completely pseudomorphed by a sericite felt mixed with occasional quartz grains. No epidote nor chlorite develop in the feldspars. The quartz phenocrysts remain unaltered. The biotite first becomes converted to chlorite and sericite, and is sometimes also pseudomorphed to the latter mineral. In wholly altered rocks the chlorite is transformed to irregularly spreading serpentine, often difficult of detection. A little epidote is occasionally present. Kaolin and chalcedonic quartz are found in places, but are connected with a later process of chalcocitization.

In the groundmass of the porphyry the feldspars are transformed into an aggregate of sericite, the quartz grains remaining unaltered. Finally pyrite forms more or less abundantly, usually in cubes or pentagonal dodecahedrons, sometimes also in octahedrons, and develops by replacement in the groundmass as well as in the feldspars, more rarely in the quartz grains; chalcopyrite, zine blende, and molybdenite are rarely observed. The original magnetite in the porphyry is evidently transformed into pyrite. The titanium in the ilmenite or in the magnetite assumes the form of small dark-brown prisms of rutile.

Very commonly seams of allotriomorphic granular or partly idiomorphic quartz traverse the rocks. In certain parts chalcocite is very abundant, in intimate intergrowth with pyrite; but this is a later development and will be described under processes due to oxidation.

The process just described is thoroughly characteristic for the whole area mentioned above. Even in the most-altered rocks the original structure is often plainly visible (Pl. XIII, A).

A series of analyses were made of these altered porphyries of Copper Mountain at Morenci.

No. $\mathrm{I}$ is a comparatively fresh porphyry from the first level of the Ryerson mine, and, it is believed, represents the typical original rock of that altered zone. Description of this may be found on page 81 .

No. II was taken adjoining a 2 -inch pyrite vein in the foot wall of the Humboldt vein at the southwestern end of the drift, near the line between Morenci and Eagle claims. It is a soft, white, chalky rock with scattered pyrite; on a few seams a little chalcocite appears. This locality is 600 feet below the surface and somewhat below the chalcocite zone, properly speaking; some oxidation and chalcocitization of the vein is, however, present. The rock is principally a felted mass of sericite with some granular quartz, and is cut by veinlets of kaolin. Pyrite is developed throughout in grains and crystals; none appear, however, in the kaolin veinlets. A little zinc blende, chalcopyrite, and molybdenite occur as irregular grains and aggregates; also a few prisms of rutile and isolated zircons. 
No. III was taken from the intermediate level of the Ryerson mine, 550 feet west of West Yankie shaft, about 300 feet below the surface. It is a hard, white, quartzitic porphyry with scattered small pyrite crystals. The original structure is almost lost, but under the microscope the outlines of feldspar crystals are still visible. The rock consists chiefly of a very fine sericite felt with granular quartz; the latter also occurs as veinlets with pyrite. Chalcocite does not occur abundantly in these hard and siliceous altered rocks.

No. IV is from one of the big stopes of Humboldt lode, Ryerson mine, above the lower adit level, and about 450 feet below the surface. It is a soft, white, chalky rock, with gritty feel, from the many included quartz grains, cut by many small seams of pyrite and chalcopyrite. In thin section the porphyry structure is retained, as well as the contours of the feldspars. They are, however, entirely converted into sericite felt; the groundmass consists of granular quartz, well filled with sericite foils. Remnants of biotite crystals are transformed to sericite and serpentine. Pyrite occurs in crystals and anhedrons, largely in the altered feldspars, but also occurs with small masses of granular quartz. One zircon and some doubtful rutile crystals were noted.

No. V was collected from the surface of the northeast spur of Copper Mountain, 500 feet southwest of West Yankie shaft, where it formed brownish-gray hard outcrops. It is of dull-white color, the porphyry structure still visible. A thin section shows it to be an entirely sericitized rock with pseudomorphs of feldspars and biotite. The groundmass consists mainly of fine-grained quartz, with sericite foils. No pyrite is present. 
From the data of analyses and sections the rocks were calculated as follows; the computations were kindly undertaken by Mr. L. C. Graton:

Analyses of fresh and altered porphyry from the mines at Morenci.

[W. F. Hillebrand, analyst.]

\begin{tabular}{|c|c|c|c|c|c|}
\hline & (211 ci. A.) & $\begin{array}{l}\text { II. } \\
\text { (315 Ci. A.) }\end{array}$ & $\begin{array}{l}\text { III. } \\
\text { (314 Cl. A.) }\end{array}$ & $\begin{array}{l}\text { IV. } \\
\text { (73 Cl. A.) }\end{array}$ & $\begin{array}{l}\text { V. } \\
\text { (336 Cl. A.) }\end{array}$ \\
\hline $\mathrm{SiO}_{2} \ldots \ldots$ & 68.04 & 46. 67 & 69.55 & 64.88 & 72.78 \\
\hline $\mathrm{Al}_{2} \mathrm{O}_{3} \ldots \ldots \ldots \ldots \ldots \ldots$ & 17. 20 & 20.92 & 16. 43 & 16.41 & 15.35 \\
\hline $\mathrm{Fe}_{2} \mathrm{O}_{3} \ldots \ldots \ldots \ldots$ & .34 & a. 37 & b. 46 & \multirow{2}{*}{ c. 65} & .55 \\
\hline $\mathrm{FeO}$ & .67 & a. 36 & b. 11 & & .10 \\
\hline $\mathrm{MgO}$. & 1.05 & .85 & .62 & 1.12 & .89 \\
\hline $\mathrm{CaO} \ldots \ldots \ldots$ & 2.21 & .15 & .15 & .11 & .14 \\
\hline $\mathrm{Na}_{2} \mathrm{O} \ldots \ldots \ldots$ & 5. 33 & .16 & .17 & .12 & .36 \\
\hline $\mathrm{K}_{2} \mathrm{O} \ldots \ldots \ldots \ldots$ & 2.65 & 4. 33 & 5.05 & 4. 96 & 5.00 \\
\hline $\mathrm{H}_{2} \mathrm{O}-\ldots .$. & .60 & .94 & 1.00 & .83 & 1.21 \\
\hline $\mathrm{H}_{2} \mathrm{O}+\ldots \ldots \ldots$ & 1. 23 & 5. 01 & 2. 69 & 2. 74 & 3.22 \\
\hline $\mathrm{TiO}_{2} \ldots \ldots \ldots$ & .41 & .43 & .41 & .38 & \\
\hline 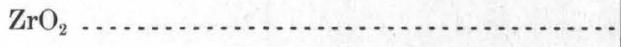 & .01 & Trace? & Trace. & Trace. & Trace. \\
\hline $\mathrm{CO}_{2} \ldots \ldots \ldots$ & None. & None. & None. & None. & None. \\
\hline $\mathrm{P}_{2} \mathrm{O}_{5} \ldots$ & .12 & .15 & .05 & .12 & .05 \\
\hline 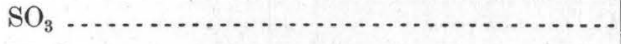 & (n...... & .18 & .10 & .10 & .08 \\
\hline 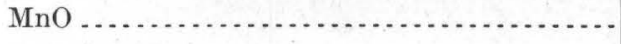 & .06 & None. & None. & Trace? & None. \\
\hline $\mathrm{BaO} \ldots \ldots$ & .10 & .04 & .05 & .07 & .02 \\
\hline SrO $\ldots \ldots \ldots \ldots$ & .03 & None. & None. & Trace. & None. \\
\hline $\mathrm{Li}_{2} \mathrm{O}$ & Trace? & Trace. & Trace? & Trace. & Trace. \\
\hline $\mathrm{V}_{2} \mathrm{O}_{3} \ldots \ldots$ & Trace: & ....... & ......... & .......... & ......... \\
\hline $\mathrm{FeS}_{2} \ldots \ldots \ldots$ & .24 & 19. 18 & 3.09 & 4. 96 & .06 \\
\hline 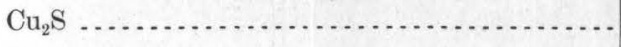 & .02 & .24 & .07 & 2.42 & \\
\hline $\mathrm{Zn} \ldots \ldots \ldots \ldots \ldots \ldots$ & $\ldots .$. & .... & (n..... & None. & \\
\hline ZnS... & .03 & .32 & $\ldots . .$. & & ....... \\
\hline Mo.... & None. & ....... & ........... & None. & ........... \\
\hline $\mathrm{MoS}_{2} \ldots \ldots$ & (n........ & .20 & None. & (............. & (........... \\
\hline & 100.34 & 100.50 & 100.00 & 99.87 & 100.26 \\
\hline
\end{tabular}

a These values are quite uncertain.

${ }^{b}$ Approximate.

$c$ As $\mathrm{Fe}_{2} \mathrm{O}_{3}$.

I. Fresh monzonite-porphyry. Ryerson mine, first level.

II. Altered monzonite-porphyry. Ryerson mine, first level; drift on Humboldt vein at end of small crosscut in foot wall 40 feet east of Humboldt claim line.

III. Altered (silicified) porphyry. Ryerson mine, intermediate level, 550 feet west of West Yankie shaft.

IV. Altered porphyry within chalcocite zone. Ryerson mine, lower adit level, Humboldt vein, from stopes 70 feet wide, 80 feet above level.

V. Altered porphyry. From slope of Copper Mountain, 500 feet southwest of West Yankie shaft. 
Mineral contents of fresh and altered quartz-monzonite-porphyries.

\begin{tabular}{|c|c|c|c|c|c|}
\hline & I. & II. & III. & IV. & V. \\
\hline 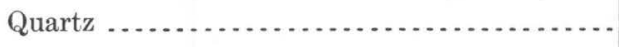 & 21.35 & 19. 13 & 49.33 & 43.03 & 50.81 \\
\hline Orthoclase (mol.) . . . . . . . . . . & 13.12 & .......... & ........ & ........ & ........ \\
\hline Albite (mol.) . . . . . . . . . . . . . . . . . . . . & 45.26 & ..... & ....... & ...... & ........... \\
\hline Anorthite (mol. ) $\ldots \ldots \ldots \ldots \ldots \ldots \ldots \ldots$ & 9.52 & ..... & $\ldots \ldots$. & $\ldots \ldots . . . . .$. & $\ldots \ldots . .$. \\
\hline 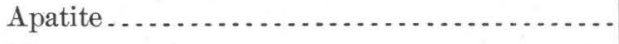 & .28 & .36 & .12 & .30 & .12 \\
\hline (n. & .02 & $\ldots . . . .$. & $\ldots \ldots . . . .$. & $\ldots \ldots . . .6$ & ......... \\
\hline Magnetite .. & .41 & ...... & $\ldots$ & $\ldots . .$. & $\ldots . . . .$. \\
\hline Ilmenite.... & .81 & $\ldots .$. & - & $\ldots . . .$. & $\ldots \ldots$. \\
\hline 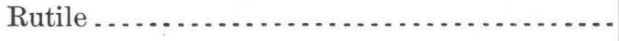 & $\ldots \ldots \ldots$ & .43 & .41 & .38 & .45 \\
\hline - & 3.75 & 38.50 & 43.44 & 44.94 & 44.29 \\
\hline Kaolin .... & $\ldots \ldots . . . . .6$ & 17.90 & $\ldots \ldots . . . . . .1$ & ............. & $\ldots \ldots . . . . .$. \\
\hline (n) & a 3.04 & $\ldots \ldots \ldots$ & $\ldots \ldots \ldots$. & 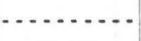 & (.......... \\
\hline 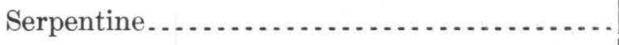 & b. 98 & $c 2.81$ & $d 1.71$ & e 2.74 & $f 2.71$ \\
\hline Epidote .... & $g .59$ & $\ldots \ldots . . . .$. & .43 & .......... & $g .36$ \\
\hline 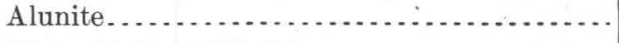 & $\ldots \ldots . .$. & $.46(?)$ & $.26(?)$ & $.26(?)$ & $21(?)$ \\
\hline Water (below $100^{\circ}$ C. ) . . . . . . . . . . . . . . . . . . & .60 & .94 & 1. 00 & .83 & 1. 21 \\
\hline $\mathrm{FeS}_{2} \ldots \ldots \ldots \ldots \ldots \ldots$ & .24 & 19.18 & 3. 09 & 4. 96 & .06 \\
\hline $\mathrm{Cu}_{2} \mathrm{~S} \ldots \ldots \ldots$ & .02 & .24 & .07 & 2.42 & ...... \\
\hline $\mathrm{ZnS} \ldots . . .$. & .03 & .32 & $\ldots \ldots . . . .$. & $\ldots \ldots . . . .$. & $\cdots+$ \\
\hline \multirow[t]{2}{*}{$\mathrm{MoS}_{2} \ldots \ldots$} & $\ldots \ldots \ldots$ & .20 & . . . . . . . & . . . . . . & ...... \\
\hline & 100.02 & 100.47 & 99.86 & 99.86 & 100. 22 \\
\hline
\end{tabular}

a Amesite, $\mathrm{MgO}: \mathrm{FeO}=6: 1$.

$b 0.39$ per cent $\mathrm{MgO}, 0.19$ per cent $\mathrm{H}_{2} \mathrm{O}$ residue, with 0.40 per cent $\mathrm{SiO}_{2}-$ too high in $\mathrm{H}_{2} \mathrm{O}$ for serpentine

c 0.84 per cent $\mathrm{MgO}, 0.29$ per cent $\mathrm{FeO}, 0.53$ per cent $\mathrm{H}_{2} \mathrm{O}$ residue, with 1.15 per cent $\mathrm{SiO}_{2}-$ too high in $\mathrm{H}_{2} \mathrm{O}$ for serpentine. a 0.62 per cent $\mathrm{MgO}, 0.39$ per cent $\mathrm{H}_{2} \mathrm{O}$ residue, with 0.70 per cent $\mathrm{SiO}_{2}$ corresponds fairly well to Deweylite.

e1.11 per cent $\mathrm{MgO}, 0.49$ per cent $\mathrm{H}_{2} \mathrm{O}$ residue, with $1.12 \mathrm{SiO}_{2}$ - too high in $\mathrm{H}_{2} \mathrm{O}$ for serpentine.

$f 0.89$ per cent $\mathrm{MgO}, 0.95$ per cent $\mathrm{H}_{2} \mathrm{O}$ residue with 0.87 per cent $\mathrm{SiO}_{2}$ - too high in $\mathrm{H}_{2} \mathrm{O}$ for serpentine.

$g \mathrm{Al}_{2} \mathrm{O}_{3}: \mathrm{Fe}_{2} \mathrm{O}_{3}=4: 1$.

The principal results effected by the alteration will be readily seen from these two tables. The altered rocks consist chiefly of sericite, pyrite, and quartz, with a little serpentine. Kaolin occurs only in No. II, which is the only specimen taken immediately adjacent to an important seam or vein; calcite is entirely absent from all of the specimens. The silica has not been materially changed, except in No. II, where it is lowered corresponding to the high percentage of kaolin. Alumina seems generally constant, but has been increased in No. II; this increase is, however, probably only apparent and due to conversion of sericite to kaolin, with attendant setting free of some chalcedonic or opaline silica. $\mathrm{TiO}_{2}$, $\mathrm{ZrO}_{2}$, and $\mathrm{P}_{2} \mathrm{O}_{5}$ remain constant. $\mathrm{MgO}$ has likewise suffered no change. On the other hand, practically all $\mathrm{CaO}$ and $\mathrm{Na}_{2} \mathrm{O}$ has been carried away and a substantial addition of $\mathrm{FeS}_{2}$ and $\mathrm{K}_{2} \mathrm{O}$ has been made. As a nearly constant proportion was 
found between the various constituents of the sericite in Analyses II-V, the average composition could be calculated as follows:

Average analysis of sericite from Morenci mines.

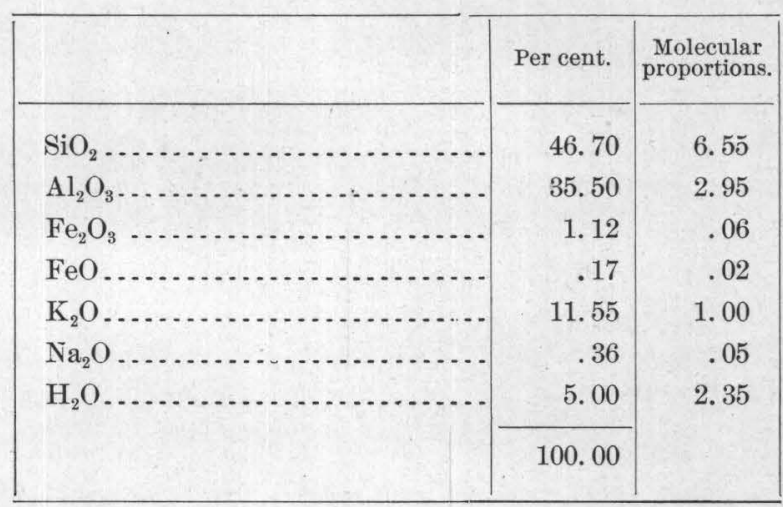

Molecular weight, 847.

The whole course of the alteration indicates waters distinctly deficient in alkaline carbonates, but probably rich in iron and silica; this conclusion is important, as it tends to connect the alteration genetically with the porphyry. (See under Genesis, p. 220.) These veins are, according to the character of alteration, related to those of Freiberg, Saxony, and Silver City and De Lamar, Idaho. They are very different from the normal gold-quartz veins of California, which were formed by waters very rich in alkaline carbonates and probably also in lime.

\section{ALTERATION IN GRANITE AND QUARTZITE.}

The granite, which is very generally somewhat altered for a considerable width all along the eastern contact of the porphyry stock, is best exposed in Chase Creek Canyon between Longfellow incline and Metcalf. The alteration chiefly consists in sericitization of the orthoclase and the introduction of veinlets of quartz with pyrite. This altered area, which contains many prospects, but no important mines, finds a superficial expression in red fantastically weathered outcrops due to oxidation of pyrite. Similar alteration is noted to a smaller extent along the numerous fissure veins following porphyry dikes, which are so common on Copper King Mountain. At the foot of the Longfellow incline the quartzite is mineralized, containing several per cent of pyrite and about half a per cent of copper. Cubes of pyrite develop both in the cement and in the quartz grains. The cementing material is already largely converted into sericite, so there is scant room for further change in this direction. At the East Yankie mine, near Morenci, this cupriferous pyritic quartzite has been further enriched by the introduction of chalcocite, rendering it a valuable concentrating ore. 
All of these changes, excepting the last-mentioned one, are probably due to the same waters which so radically altered the porphyry of Morenci and Metcalf.

ALTERATION OF LIMESTONE AND SHALE.

It is not to be supposed that this widespread hydrothermal alteration which affected porphyry, granite, and quartzite would be without effect on the limestone and shale, which, more or less contact-metamorphosed, adjoin the altered area of porphyry, and which also are traversed by fissure veins. Aside from the larger lodes at Morenci, such as the Joy, Montezuma, Arizona, Central, and Williams, the sedimentary rocks contain in places an abundance of seams containing, besides quartz and a little calcite, amounts of pyrite, magnetite, chalcopyrite, and zinc blende. At Metcalf exactly the same conditions prevail, some of the seams containing in addition a little epidote. Wherever these veins and seams cut through shale no marked alteration can be observed along them, whether the shale be moderately or wholly changed by contact-metamorphic processes.

But in limestone a different condition of affairs prevails. For a certain distance from the vein, ordinarily not more than a few inches or a few feet, the limestone is bleached and heavily impregnated with pyrite. A typical example is shown on Pl. X, $B$, representing a dolomitic limestone from the Black Hawk No. 3 tunnel of the Shannon mine. The rock is grayish green and partly altered, containing besides much fine-grained calcite aggregates of colorless pyroxene and amphibole. This is cut by veinlets of coarse calcite, containing intergrown anhedrons of pyrite and magnetite, with a little chalcopyrite. Adjoining these veinlets and extending about half of their width are altered bands in which the limestone has been completely converted to prisms of colorless amphibole, probably tremolite. One or two of the same prisms are also contained in the veinlet itself, which apparently is produced by filling. Thus the metasomatic change exerted by the waters flowing through this fissure consists in the conversion of dolomitic limestone to tremolite.

At Morenci many similar instances were observed and proved. On the fourth level of the Joy mine the vein consists of a well-defined steep hanging wall, adjoined by a sheeted and bleached zone, some 10 feet wide, heavily impregnated with pyrite. A crosscut runs out in the foot wall for 100 feet to the deep Joy shaft (fig. 11). The first part of this, next the vein, consists of partly altered lime shale; then follows about 25 feet of hard, solid epidote rock, which again is adjoined by the same greenish limestone; finally at the shaft another mass of solid epidote makes its appearance along the wall of the Joy porphyry dike. The contacts of limestone and epidote are remarkably sharp. The limestone 
about 25 feet from the shaft contains several smaller veins of solid pyrite, each a few inches wide and surrounded by a distinct zone of bleached and pyritic rock rapidly fading out into the ordinary greenish limestone. There is some slight oxidation, but not enough to materially influence the results. Specimens were collected of these typical occurrences and analyzed, as shown below:

Analyses showing alteration of limestone adjoining pyrite veins.

[W. F. Hillebrand, analyst.]

\begin{tabular}{|c|c|c|c|c|c|}
\hline & $\begin{array}{l}\text { I. } \\
\text { (263 cl. A.) }\end{array}$ & $\begin{array}{l}\text { II. } \\
\text { (264 Cl. A.) }\end{array}$ & & $\begin{array}{l}\text { I. } \\
\text { (263 ci. A.) }\end{array}$ & $\begin{array}{l}\text { II. } \\
\text { (264 Ci. A.) }\end{array}$ \\
\hline $\mathrm{SiO}_{2} \ldots \ldots$ & 17.08 & 42.03 & $\mathrm{P}_{2} \mathrm{O}_{5}, \ldots \ldots \ldots$ & 0.16 & 0.42 \\
\hline $\mathrm{Al}_{2} \mathrm{O}_{3} \ldots \ldots \ldots$ & 2.34 & 3.16 & $\mathrm{SO}_{3} \ldots \ldots \ldots$ & .13 & .75 \\
\hline $\mathrm{Fe}_{2} \mathrm{O}_{3} \ldots \ldots \ldots$ & & 1.18 & $\mathrm{MnO} \ldots \ldots \ldots \ldots \ldots$ & .26 & .18 \\
\hline $\mathrm{FeO} \ldots$ & .10 & .84 & $\mathrm{BaO} . . . . . . .$. & None? & None. \\
\hline $\mathrm{MgO} \ldots .$. & 12.38 & 20.25 & $\mathrm{SrO} \ldots$. & None. & None. \\
\hline $\mathrm{CaO} \ldots$. & 32.48 & 10.41 & $\mathrm{Li}_{2} \mathrm{O} \ldots \ldots$ & Trace. & Trace. \\
\hline $\mathrm{Na}_{2} \mathrm{O} \quad \ldots . . . . . . . . . . . .$. & .09 & .06 & $\mathrm{FeS}_{2} \ldots \ldots \ldots$ & $b 1.50$ & c 8.10 \\
\hline $\mathrm{K}_{2} \mathrm{O} \ldots \ldots$ & .10 & .12 & $\mathrm{CuFeS}_{2} \ldots \ldots \ldots$ & b. 18 & c 1.67 \\
\hline $\mathrm{H}_{2} \mathrm{O}-\ldots \ldots \ldots$ & .95 & 1.07 & $\mathrm{CuO}$ & ...... & .83 \\
\hline $\mathrm{H}_{2} \mathrm{O}+\ldots \ldots$ & 3.01 & 4. 25 & $\mathrm{ZnO}$ & .99 & .58 \\
\hline $\mathrm{TiO}_{2} \ldots \ldots$ & .27 & .31 & & 99.55 & 99.79 \\
\hline $\mathrm{ZrO}_{2} \ldots \ldots$ & .02 & Trace. & & & \\
\hline $\mathrm{CO}_{2} \ldots \ldots \ldots$ & 26.85 & 3.58 & & & \\
\hline
\end{tabular}

I. Magnesian limestone. Joy mine, in crosscut to shaft on fourth level. No. 263, Clifton collection.

II. Alteration product of No. 263. Rock in contact with pyritic vein. Joy mine, fourth level, adjoining small pyrite vein in crosscut to shaft. No. 264 , Clifton collection.

No. I represents apparently unaltered rock 10 inches from the 2 -inch pyrite vein in the crosscut from the Joy vein to the Joy shaft, at the 4 -foot level. It is a light-brownish-gray, dull, limestone-like rock traversed by several faint, parallel, wavy streaks of greenish material along which small grains of pyrite, zinc blende, and magnetite are visible. Under the microseope it shows a prevailing mass of fine-grained calcite, but contains, pervading the aggregate and appearing in irregular spots between the grains, a colorless substance of weak refraction and birefringence. In places it is almost isotropic, while more commonly wavy dark or light-gray colors appear between crossed nicols, indicating an extremely fine felted structure. The general appearance is that of serpentine, and there can be little doubt that this substance replaces another mineral which had formed between the calcite grains. A few grains of magnetite and pyrite were noted.

From the analysis it is apparent that there is more of this magnesian silicate than would be supposed at first glance, and that it is in part probably composed 
of chlorite. This is very possible, since in very fine aggregates chlorite and serpentine are sometimes difficult to distinguish.

No. II was taken from the narrow, distinctly visible, altered zone immediately adjoining a small vein of solid pyrite in limestone, and only 8 inches from the slightly altered limestone represented by No. 263. The rock is greenish gray, rather fine grained, and fairly soft; it contains large pyrite grains and a few small particles of magnetite, chalcopyrite, and zinc blende. Under the microscope it is shown to consist of irregularly oriented prisms of colorless amphibole, between which lie a few calcite grains. Aggregates of low double refraction, probably bastite and chlorite, separate the prisms of amphibole. In places larger masses of calcite show clearly the structure of limestone, the grains pierced by needles of amphibole. There are partly idiomorphic, fairly large pyrite crystals and small aggregates of chalcopyrite, the latter intergrown with magnetite or surrounded by it. The sulphides are contained both in the amphibole and the calcite.

The analyses may be calculated as follows:

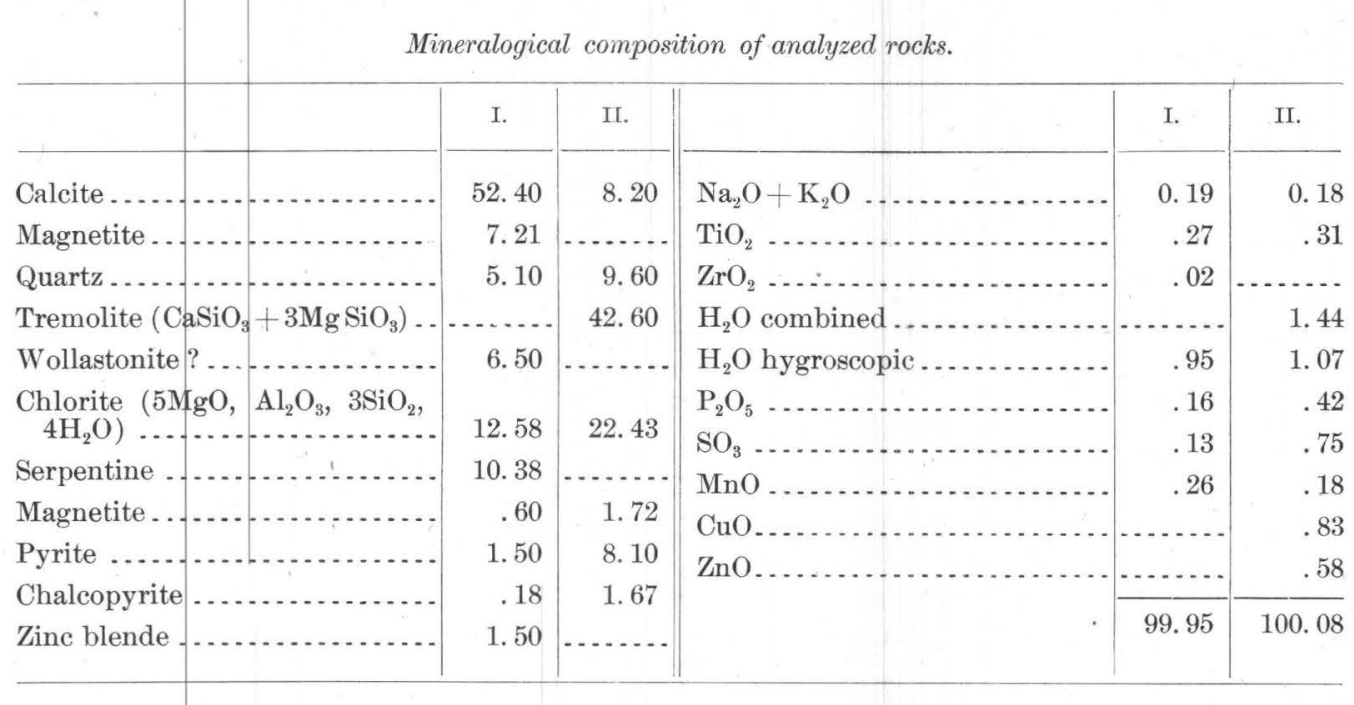

There is a small excess of lime in No. I which has been calculated as wollastonite, although this mineral was not observed in the slide; neither was epidote noted in the section. There is also an excess of $\mathrm{SiO}_{2}$ not observed in the rock and probably present in eryptocrystalline form. A deficiency of 0.5 per cent sulphur indicates partial oxidation; some of this sulphur is present as $\mathrm{SO}_{3}$.

In No. II the $\mathrm{CaO}$ necessary for $\mathrm{CO}_{2}$ was first subtracted. On the basis of the remaining $\mathrm{CaO}$ the tremolite was calculated and the remaining $\mathrm{MgO}$ used for chlorite. In this slightly more $\mathrm{Al}_{2} \mathrm{O}_{3}$ than the 3.16 per cent given in the analysis was used; hence the excess in summation over the analysis. Oxidation 
has set in, as clearly indicated by $\mathrm{SO}_{3}$; both phosphates and hydrous sulphates are probably present.

A comparison between the two analyses shows that the altered rock adjoining the vein has received a substantial addition of silica and magnesia, together with sulphides of iron and copper; also that it has suffered a considerable loss of lime. It seems entirely improbable that the proportion of $\mathrm{CaO}$ to $\mathrm{MgO}$ of the limestone could have changed greatly within the interval of 8 inches which separated the specimens. Consistent with the great mineralogical change a very great loss of $\mathrm{CO}_{2}$ is noted. An increase of combined water is indicated, but this is accounted for by the presence of a certain amount of oxidized salts of iron and copper.

Alkalies are present in both specimens in very small amounts, and the absence of any concentration of $\mathrm{K}_{2} \mathrm{O}$ in No. 264 is in contrast to the great accumulation of this substance in the altered porphyries. The percentage of titanium remains practically constant, as is usual in altered wall rocks.

The rock No. I is already somewhat metamorphosed and hydrated, as shown by the large amount of chlorite contained. Probably this chlorite is formed from tremolite, and this, as well as the magnetite and sulphides, may be due to the same vein-forming influences which have caused such a profound change in No. II. At any rate, it is certain that the metasomatic change along this vein consists in the abundant development of tremolite from a somewhat magnesian limestone. It may be of interest to follow the chemical changes involved in this, taking for greater simplicity a hypothetical case of a dolomitic limestone composed of 75 per cent $\mathrm{CaCO}_{3}$ and 25 per cent $\mathrm{MgCO}_{3}$.

For the calculation we may first tentatively assume constant magnesia-that is, assume that the unit weight of limestone has not received any addition or loss of this oxide. Supposing an original limestone of the composition shown under A, which alters to a tremolite of the composition B, we need, to obtain tremolite from the unit weight of this limestone, the quantities shown under C.

Changes involved in transformation of dolomitic limestone to tremolite.

\begin{tabular}{|c|c|c|c|}
\hline & A. & B. & C. \\
\hline $\mathrm{SiO}_{2} \ldots$ & $\ldots$ & 58 & 24.0 \\
\hline $\mathrm{CaO}$. & 42 & 13 & 5.4 \\
\hline $\mathrm{MgO}$. & 12 & 29 & 12.0 \\
\hline \multirow[t]{2}{*}{$\mathrm{CO}_{2} \ldots$} & 46 & .... & . \\
\hline & 100 & 100 & 41.4 \\
\hline
\end{tabular}

This involves a gain of 24 parts $\mathrm{SiO}_{2}$ and a loss of 36.6 parts $\mathrm{CaO}$, as well as of 46 parts $\mathrm{CO}_{2}$; or, in other words, a total loss of 58.6 parts, or over 50 per 
cent. The loss in volume is even greater. If additions of magnetite and sulphides have taken place the losses will be somewhat smaller, and an original per cent of silica will also reduce the last figure to some extent. Such a loss of volume seems, however, improbable, and we are driven to the assumption of an access of $\mathrm{MgO}$. Should this access amount to 17 parts $\mathrm{MgO}$ the gains of $\mathrm{SiO}_{2}$ and $\mathrm{MgO}$ would exactly balance the loss of $\mathrm{CO}_{2}$ and $\mathrm{CaO}$ and there would be only a slight reduction of volume.

In the Montezuma mine, along the great pyritic lode, similar alteration has taken place. Specimens of fresh and altered limestone at a smaller vein in the foot wall of the large one showed similar relations to those described from the Joy mine. These smaller veins were selected for tests because it was possible to obtain fresh and altered rocks closely together. The original rock is a finegrained dark-gray limestone containing small grains of magnetite, pyrite, chalcopyrite, and zinc blende, while the altered rock looks dull, earthy, and greenish gray. It contains aggregates of ragged and imperfectly developed pyroxene (diopside) with some magnetite. Between the pyroxene grains lies fibrous serpentine or chlorite. If the mineral is diopside it would of course have a com position similar to tremolite. In places, however, the alteration of limestone and lime shale takes a different course and results in sericite. The big pyrite stopes of the Joy mine, sometimes 30 or 40 feet wide, are adjoined by a whitish, soft rock which surely is an altered sediment, although the rock from which it was derived can not be positively identified. The altered product consists of felted sericite, with small, scattered, and in part intergrown aggregates of pyrite, magnetite, and zinc blende.

More definite results were obtained from the examination of the pyrite vein on the first level of the Montezuma, some 30 feet below the rich chalcocite zone encountered on the water-shaft level. The massive pyrite vein is here very distinct, 2 to 4 feet wide, with a well-defined foot wall. A couple of feet away, in the foot wall, the rock is a dense gray limestone, with veinlets and specks of magnetite, pyrite, and zinc blende. The latter are associated with fine fibrous aggregates of serpentine or chlorite. The rock effervesces freely with cold acids, and contains only a small amount of silica, alumina, and other impurities. Near the vein the rock $(372 \mathrm{Cl}$. A) changes to greenish-gray color, and proves to consist chiefly of sericite of greenish color, grains of the above sulphides (pyrite being frequently coated with magnetite), and a certain amount of serpentinoid substance.

Immediately at the vein the rock $(373 \mathrm{Cl}$. A) is whitish-gray, soft, with much pyrite, and consists chiefly of the same greenish sericite and granular quartz. No. 372 contained much silica, considerable alumina and magnesia, also pyrite, 
and very little lime. A determination of alkalies gave $\mathrm{K}_{2} \mathrm{O}, 3.63$ per cent; $\mathrm{Na}_{2} \mathrm{O}$, 0.25 per cent; titanium, about 1 per cent. No. 373 contained the same bases as No. 372; alkalies: $\mathrm{K}_{2} \mathrm{O}, 3.95$ per cent; $\mathrm{Na}_{2} \mathrm{O}$, 0.16 per cent. (Analyses by Dr. W. F .Hillebrand.)

\section{RELATION OF CONTACT AND HYDROTHERMAL METAMORPHISM.}

The alteration of limestone along fissure veins to tremolite or diopside with magnetite and sulphides is, as far as I am aware, a process which has not been described previously. Ordinarily, limestone alters next to fissure veins to dolomite or quartz or jasperoids. ${ }^{a}$ The access of silica and iron and the mineralogical result of the process here discussed undoubtedly connects it in some way with contact metamorphism, and it is also probable that this kind of transformation took place at high temperature comparatively soon after the solidification of the porphyry.

At first glance it might seem plausible to assign all the changes, which have taken place in the metamorphic zone to the same hydrothermal alteration which has affected the porphyry along the fissure veins. This view, however tempting, is surely incorrect. Instead of one set of phenomena, we have two related and, in part, superimposed processes. Among the proofs of this are the absence of sericitization in the porphyry of many dikes which have exerted strong contact metamorphism, and, further, the entire independence which the masses of extremely altered garnet-magnetite rock show in regard to the fissure veins, and their distinct dependence on contact of dikes and main stock. The vein alteration produces dull earthy rocks from the limestone, while contact metamorphism results in hard, compact, granular rocks. On the other hand, there is undoubtedly a certain relation between the two processes, for amphibole and pyroxene occur in the true contact-metamorphic rocks, and the intergrowth of magnetite and pyrite is characteristic of both. I should, therefore, conclude that after the completion of the contact metamorphism, properly speaking, and after the consolidation of the porphyry, an extensive fissuring took place, and solutions derived from the cooling porphyry, probably ascending and laterally extending from this rock, flowed through these fissures. Everything indicates that these solutions were closely related to those which emanated from the magma at the moment of intrusion, and, in fact, were similar in general composition.

As to the quantitative relation of contact metamorphism and hydrothermal metamorphism it is difficult to speak with absolute certainty. In some parts of the contact-metamorphic rocks small seams with sulphides and magnetite are very abundant (for instance, in the Yavapai mine), and it is not easy to say how much 
of this should be credited to each form of alteration, for the sedimentary rocks were evidently solid during the intrusion, and seams filled with sulphides may well have formed in them. Generally speaking, they would be, and in fact are at present, much less permeable to solutions than the porphyry, as shown by the slight depth which oxidation has attained in them, and it is believed that the hydrothermal solutions were chiefly confined to cracks and fissures, in contradistinction to the much more searching action of gaseous water. The facts above given show, indeed, how slight is the lateral spread of alteration from the veins. That the solutions producing the contact metamorphism effected such intense results is probably due to a far greater degree of heat and gas pressure existing.

\section{PROCESSES DUE TO OXIDATION AND HYDRATION IN THE CONTACT- METAMORPHIC ZONES AND IIN THE VEINS.}

GENERAL STATEMENT.

Under the above heading are included the changes due to oxidation at the immediate surface, or weathering, by which the rock is broken down and loses its identity; and also various changes and interchanges of minerals usually accompanied by hydration and sometimes effected at considerable depths below the surface, but in all cases primarily due to surface waters and to the oxygen which they contain. To a large extent, these processes come under the division of common hydrometamorphism, but the many peculiar reactions taking place in the mineralized zone renders it advisable to discuss this area separately. Outside of this area, where special conditions of abundant sulphides and many minerals rich in iron prevail, weathering plays an unimportant part. Owing to climatic conditions, erosion and disintegration proceed far more rapidly than does the chemical decomposition of the minerals.

The ultimate tendency of surface weathering, then, is to destroy the rock and to produce a few extremely resistant minerals which will ultimately form part of the soil. Among these, limonite, kaolin, and quartz are the most prominent, while the lime, magnesia, and alkalies are largely carried away as carbonates by surface waters.

\section{PROCESSES IN DETAIL.}

MINERALS.

Garnet.-The brown or yellow lime-iron garnet of the districts becomes uniformly converted into cellular masses of limonite and hematite, together with quartz, the latter sometimes crystallized. Under the microscope the decomposition is seen to proceed from a network of little fissures. The quartz is in places very 16859-No. $43-05-12$ 
fine grained, almost cryptocrystalline, but is apt to suddenly change to more coarsely crystalline aggregates. The lime must be carried away as carbonate; secondary calcite crystals are sometimes seen surmounting the decomposing garnet. The process is confined to a shallow zone at most 100 feet below the surface, although in ore bodies or along fissures where oxidation has been energetic it may take place at much greater depth, probably down to 400 feet. Seams of black oxides of manganese occur frequently.

Epidote.-Epidote crumbles near the surface to yellow or brown soft masses which contain much $\mathrm{H}_{2} \mathrm{O}$ and $\mathrm{Fe}_{2} \mathrm{O}_{3}$, together with a little $\mathrm{Al}$, ( $\mathrm{Ca}, \mathrm{Mg}$, and $\mathrm{Cu}$, probably a mixture of ill-defined hydrous silicates. When not directly exposed to oxidation, it is very resistant.

Pyroxene (diopside) and amphibole (tremolite).-The colorless diopside and tremolite so common in the altered limestones also resist direct oxidation very strongly, but are very susceptible to hydration below the surface. Abundant pale-green chlorite is developed from both minerals; this takes place at depths of several hundred feet below the surface, especially near fissures. The chlorite occupies spaces between the prisms, has normal optical characters, and probably corresponds approximately to the composition $5 \mathrm{MgO}, \mathrm{Al}_{2} \mathrm{O}_{3}, 3 \mathrm{SiO}_{2}, 4 \mathrm{H}_{2} \mathrm{O}$. The process involves loss of Ca, as carbonate, while the small amount of alumina in the rocks is probably sufficient for the development of chlorite. Occasionally, as in the second ore body of the Detroit mine, tremolite takes up much water, 17 per cent in one case, and becomes converted to asbestos-like minerals. Another phase of alteration of tremolite and diopside is that resulting in serpentine, frequently occurring together with chlorite, as, for instance, in the case shown by the analysis on page 173 . This serpentine is sometimes found infiltrating the less-altered limestones near rocks with much pyroxene, as yellowish-green, translucent veinlets, replacing the carbonate.

Chlorite.-Chlorite changes to limonite and quartz under strong oxidizing conditions. Below the surface hydrated ferric silicates seem to form from it in some places (see "Morencite," p. 115), with loss of part of the magnesia. Under influence of vein-forming solutions in the altered porphyry chlorite alters to serpentine.

Sericite.-Sericite is decomposed with great difficulty, and is abundantly present at the very surface. A small part of it seems to alter to kaolin, but probably only under the influence of solutions containing free sulphuric acid. In rare instances it seems to have been wholly dissolved, as above the cuprite zone in the Montezuma mine in porphyry.

Magnetite.-This mineral oxidizes at the surface to hematite, which is usually loose and cellular, and black from accompanying peroxide of manganese. Limon- 
ite is the final product. Near fissures and in ore bodies in altered limestone the oxidation of magnetite may proceed to a depth of 200 feet or more.

Apatite.-Under the influence of vein-forming solutions apatite is not in general attacked, which seems peculiar, as it certainly is acted on by carbonated surface waters. This finds expression in the sparing occurrence of copper phosphates in the oxidized ores at several places in the district. Except in one case, it was impossible to determine specifically the mineral formed.

Pyrite.-The oxidation of pyrite is a subject which has been extensively discussed by many writers on chemical geology, but, as remarked by Mr. Ransome,${ }^{a}$ it is still in need of treatment from the experimental standpoint. ${ }^{b}$ At the surface pyrite in general oxidizes according to the formula:

$$
\mathrm{FeS}_{2}+70+\mathrm{H}_{2} \mathrm{O}=\mathrm{FeSO}_{4}+\mathrm{H}_{2} \mathrm{SO}_{4} \text {. }
$$

This reaction involves several intermediate stages in which $\mathrm{S}, \mathrm{H}_{2} \mathrm{~S}$, and $\mathrm{SO}_{2}$ may be formed. The ferrous sulphate upon further oxidation yields ferric sulphate, and the latter is easily decomposed to various basic sulphates and ferric hydrates and free acid. The sulphuric acid is ready to oxidize remaining pyrite, if cupriferous (see p. 183), while the ferric sulphate also attacks pyrite and other sulphides, changing them to sulphates, being itself reduced to ferrous sulphate. A cycle of reactions will thus be initiated which will continue until all of the sulphides exposed to oxidation have been transformed into various oxysalts and most of the iron has changed to limonite. Pseudomorphs of limonite after pyrite have been noted under the microscope in decomposed porphyries from Coronado and Metcalf, and some of these carry a kernel of chrysocolla.

Such "iron caps" as are seen at the outcrops of veins in regions where oxidation proceeds undisturbed by erosion are generally absent in this district. The veins are rather marked by siliceous outcrops containing a small amount of oxidized copper ore and little limonite; some of them are entirely barren. The ore bodies in limestone contain, it is true, much limonite, but that is rather due to reactions between sulphate and carbonate than to direct oxidation. No basic ferric sulphates have been found on the surface or in the mine workings. It is therefore concluded that the waters which percolated through the deposits very soon lost

$a$ Prof. Paper U. S. Geol. Survey No. 21, 1904, p. 155

$b$ The subject is treated in:

Bischof, G., Lehrbuch der chemischen und physikalischen Geologie, 2d ed., vol, 3, Bonn, 1866

Roth, J., Allgemeine und chemische Geologie, vol. 1, Berlin, 1879.

Doelter, C., Chemische Mineralogie, Leipzig, 1890.

Brauns, R., Chemische Mineralogie, Leipzig, 1896.

Emmens, S. H., The chemistry of gossan: Eng. and Min. Jour., vol. 54, 1892, pp. 582-583.

Penrose, R. A. F., The superficial alteration of ore deposits: Jour. Geol., vol. 2, 1894, pp. 288-317.

Emmons, S. F., The secondary enrichment of ore deposits: Trans. Am. Inst. Min. Eng., vol. 30, pp. 177-217.

Weed, W. H., The enrichment of gold and silver veins: ibid., pp. 424-448.

Weed, W. H., Enrichment of metallic veins by later metallic sulphides: Bull. Geol. Soc. Am., vol. 11, 1900, pp. 179-206.

Winchell, H. V., Synthesis of chalcocite: Bull. Geol. Soc. Am., vol. 14, pp. 269-276. 
their oxygen and that of the products resulting from the decomposition of the pyrite only ferrous sulphate and dilute sulphuric acid are of importance for the changes which have taken place below the croppings.

Chalcopyrite.-Direct oxidation of chalcopyrite yields cuprie and ferrous sulphates as follows:

$$
\mathrm{CuFeS}_{2}+8{ }^{\prime}=\mathrm{CuSO}_{4}+\mathrm{FeSO}_{4} \text {. }
$$

The $\mathrm{FeSO}_{4}$ is subject to the already discussed alterations. Granular chalcopyrite from the altered limestone of the Arizona Central mine, for instance, changes to limonite, as is well shown in specimens.

Zine blende.-Under oxidizing conditions this mineral yields zinc sulphate very easily.

\section{ORDER OF OXIDATION.}

The general order of attack by oxygen is said to be as follows: ${ }^{a}$ Arsenopyrite, pyrite, chalcopyrite, blende, galena, and chalcocite, the last being the most resistant.

Van Hise ${ }^{b}$ says that the sulphides of iron, copper, zinc, lead, and silver will be oxidized in the order given. How far this may be relied upon is doubtful; it is probably true for only one set of conditions as to mass, aggregate, and character of solutions, and varies also in the different sulphur compounds of each metal. In the Clifton district, for instance, chalcocite is often entirely oxidized, while much pyrite remains.

\section{SULPHATE WATERS.}

The waters descending from the surface of the ground into the lodes, as well as into the pyritized and sericitized porphyry and the altered limestone, should contain, as essential constituents, ferrous, cupric, and zinc sulphates, together with some free sulphuric acid. Any oxygen they might contain would almost at once be absorbed by the ferrous sulphate. Even if free sulphuric acid were lacking, an acid reaction would soon obtain by electrolysis. To the acid solution of iron, copper, and zinc must be due most of the important changes which have transformed the low-grade lodes and the disseminated copper ores in the limestone into commercially important ore bodies. All three sulphates, especially those of copper and zinc, are found as efflorescences in the mine workings.

The relative stability of the sulphates appears to be as follows: Ferrous sulphate, cupric sulphate, zinc sulphate, and lead sulphate, the last being the most stable. The first three are very easily soluble in water-in fact, more so than most other substances - and this great mobility explains many of the remarkable 
transformations effected. As I have found erroneous statements on this subject in some of the literature on ore deposits, the following figures are given. They are mostly from Comeys's Dictionary of Solubilities:

Table of parts of different salts dissolved by 100 parts of water at different temperatures centigrade.

\begin{tabular}{|c|c|c|c|c|c|c|c|}
\hline - & $0^{\circ}$. & $10^{\circ}$ & $15^{\circ}$. & $20^{\circ}$. & $50^{\circ}$. & $80^{\circ}$. & $100^{\circ}$. \\
\hline $\mathrm{Na}_{2} \mathrm{SO}_{4}+10 \mathrm{H}_{2} \mathrm{O} \ldots \ldots \ldots \ldots \ldots$ & 5.00 & & & $a 480.00$ & & & \\
\hline $\mathrm{CaSO}_{4}+2 \mathrm{H}_{2} \mathrm{O} \ldots \ldots \ldots$ & .205 & & & ......... & & & .2174 \\
\hline $\mathrm{MgSO}_{4}+7 \mathrm{H}_{2} \mathrm{O} \ldots \ldots \ldots \ldots$ & 73.00 & & & 116.00 & & & (n......... \\
\hline $\mathrm{FeSO}_{4}+7 \mathrm{H}_{2} \mathrm{O} \ldots \ldots \ldots \ldots \ldots$ & ......... & & 45.50 & (.......... & & & 333.00 \\
\hline $\mathrm{CuSO}_{4}+5 \mathrm{H}_{2} \mathrm{O} \ldots \ldots \ldots \ldots$ & $b 23.47$ & 37.00 & & 42.33 & 65.83 & .... & 203.32 \\
\hline $\mathrm{ZnSO}_{4}+7 \mathrm{H}_{2} \mathrm{O} \ldots \ldots \ldots \ldots \ldots$ & 115.00 & 138.00 & & 161.00 & & 442.00 & 654.00 \\
\hline $\mathrm{Al}_{2}\left(\mathrm{SO}_{4}\right)+18 \mathrm{H}_{2} \mathrm{O} \ldots \ldots \ldots \ldots . . . . . . . .$. & 8685 & & & $\ldots \ldots$ & & & $1,132.00$ \\
\hline
\end{tabular}

Recent investigations by $\operatorname{Etard}^{a}$ have shown that nearly all of the hydrous sulphates have a maximum of solubility at a certain temperature beyond which the solubility decreases, sometimes very rapidly. This is due to the decomposition of certain of the hydrated salts at given temperatures and is especially marked in the case of ferrous sulphate, which becomes practically insoluble at $+155^{\circ} \mathrm{C}$. Potassium sulphate is an exception, increasing steadily in solubility.

The turning point of the solubility curves lies at $34^{\circ} \mathrm{C}$. for $\mathrm{Na}_{2} \mathrm{SO}_{4}+10$ $\mathrm{H}_{2} \mathrm{O}$, at $80^{\circ}$ for $\mathrm{FeSO}_{4}+7 \mathrm{H}_{2} \mathrm{O}$ and $\mathrm{ZnSO}_{4}+7 \mathrm{H}_{2} \mathrm{O}$, and at $130^{\circ}$ for $\mathrm{CuSO}_{4}+5 \mathrm{H}_{2} \mathrm{O}$. The temperature obtaining in the oxidized zone of these deposits probably nowhere exceeded $100^{\circ}$ and ranged from that figure down to the average temperature prevailing in the region; that is, to somewhere about $+15^{\circ} \mathrm{C}$.

Mr. Winchell states that the mine waters of Butte contain considerable amounts of cuprous salts, presumably cuprous sulphate. ${ }^{b}$ The method by which this result was obtained is not given. This would seem desirable, as it is said to be very difficult to detect cuprous salts in a mixed solution. While not denying the possibility of their existence in intermediate reactions, I do not believe that they formed an important part of the mine waters in the Clifton-Morenci district. At the present time, while moisture percolates, as shown by efflorescences and stalactites of sulphate, no waters can be obtained in sufficient quantities for examination. The sulphate solutions act somewhat differently in' the porphyry and in the limestone-shale series. In the former, more porous, rock they spread easily and percolate downward, while the altered shale and limestone offer considerable resistance. 
PROCESSES IN FISSURE VEINS IN PORPHYRY AND LIMESTONE.

The most important of these consists in the formation of chalcocite by the action of cupric sulphate on pyrite and zinc blende. That certain salts will be decomposed by metallic sulphides and precipitated as sulphides has long been known. The reactions established by Schuermann ${ }^{a}$ show the following series in the order of their affinity for sulphur: Mercury, silver, copper, bismuth, cadmium, antimony, tin, lead, zinc, nickel, cobalt, iron, arsenic, thallium, and manganese. A salt of any metal in the series would be decomposed by the sulphide of any succeeding metal and the first metal precipitated as sulphide. If secondary deposition of sulphides by reaction of pyritic ores on descending waters has taken place in an ore deposit containing silver, copper, lead, and zinc, these sulphides would be arranged according to this rule in zones in the following order: Argentite, chalcocite, bornite, chalcopyrite, galena, zinc blende, pyrite at bottom.

In the lodes at Morenci, where practically only copper, zinc, and iron are present, the lower limit of the chalcocite zone seems to lie about 400 feet below the surface, though it varies considerably in different parts of the camp. Below this depth the veins consist of massive pyrite with which is intimately intergrown equally massive zinc blende and chalcopyrite, the latter in small amounts. The gangue consists of very little quartz. The minerals in the chalcocite zone consist almost exclusively of pyrite and chalcocite. Above the chalcocite zone the lodes are usually leached and almost barren, continuing thus to the surface.

\section{CHALCOCITIZATION OF THE ZINC BLENDE.}

The blende of the bottom zone exposed in the first, second, and third levels of the Ryerson mine is doubtless a primary mineral deposited contemporaneously with the pyrite; the manner of intergrowth in solid masses precludes any other supposition. In the chalcocite zone and in the barren surface zone zinc minerals seem to be almost entirely absent. The manner in which zinc blende is attacked and copper sulphide deposited is well seen in specimens from the first level of the Ryerson, some 30 feet below the bottom of the principal chalcocite zone, along the Humboldt vein, 400 feet below the surface. The well-defined vein of solid pyrite with admixed zinc blende varies from 1 to 6 feet in thickness and is not altered as a whole. Along the foot wall, however, is a seam of kaolin showing a slight green copper stain. Within one-half inch of this seam the fine-grained, almost black, zinc blende, which is intergrown with some pyrite, becomes dull and sooty and shows the presence of some covellite, a mineral of very rare occurrence at Morenci. Under the microscope the rock exhibits much

a Liebigs Ann. d. Chem., vol. 249, 1888, pp. 326-350. Emmons, S. F., Trans. Am. Inst. Min. Eng., vol. 30, p. 212. Weed, W H., Trans. Am. Inst. Min. Eng., vol. 30 , p. 428. 
shattering, and the zinc blende is seen to be surrounded by dark borders, not however, so clearly defined as in the case of the chalcocitization of pyrite. Chemical examination showed the presence of abundant copper in the altered part. The pyrite apparently does not precipitate $\mathrm{Cu}_{2} \mathrm{~S}$ or $\mathrm{CuS}$ while zinc blende is present. Associated with the blende are grains of chalcopyrite, whether secondary or not could not be definitely ascertained. The kaolin, or a related mineral, and aggregates of chalcedony fill the branching veinlets in the rock. The zine blende is thus attacked and converted into covellite and probably also chalcocite with simultaneous deposition of kaolin and chalcedony. No sericite forms. As covellite is unknown higher up in the main chalcocite zone, it follows that it must soon be reduced to chalcocite. The principal reaction is doubtless expressed by:

$$
\mathrm{ZnS}+\mathrm{CuSO}_{4}=\mathrm{ZnSO}_{4}+\mathrm{CuS} .
$$

Thus zinc blende is here clearly the first mineral to cause sulphide deposition from solutions of cupric sulphate, which agrees with its relative position in Schuermann's series.

The zinc sulphate, being very easily soluble, is carried away. No efflorescences of zinc sulphate were found in the chalcocite zone of the veins in porphyry, though it occurs commonly enough in the oxidized zone of contact metamorphic sediments. If, as probable, the attacking waters, besides sulphates, contained free sulphuric acid, the decomposition of the blende would probably be facilitated.

No secondary zine blende has been found in any part of the mines, while, according to Schuermann's reactions, zinc should be precipitated as sulphide by pyrite. Secondary zinc blende, possibly formed according to this reaction, has, however, been reported from various mining districts. ${ }^{a}$

CHALCOCITIZATION OF THE PYRITE.

According to Dr. H. N. Stokes, ${ }^{b}$ dilute $\mathrm{H}_{2} \mathrm{SO}_{4}$ will not act upon pure pyrite. Reaction takes place, however, when the pyrite is cupriferous and likewise when $\mathrm{H}_{2} \mathrm{SO}_{4}$ is allowed to act on chalcopyrite. Doctor Stokes ${ }^{e}$ has also shown that a neutral solution of cupric sulphate will act on pyrite at $100^{\circ}$ and $180^{\circ}$ as follows:

$$
5 \mathrm{FeS}_{2}+14 \mathrm{CuSO}_{4}+12 \mathrm{H}_{2} \mathrm{O}=7 \mathrm{Cu}_{2} \mathrm{~S}+5 \mathrm{FeSO}_{4}+9 \mathrm{H}_{2} \mathrm{SO}_{4}+3 \mathrm{H}_{2} \mathrm{SO}_{4} \text {. }
$$

The last $\mathrm{H}_{2} \mathrm{SO}_{4}$ is formed by the oxidation of the sulphur of $\mathrm{FeS}_{2}$. The formation of $\mathrm{H}_{2} \mathrm{SO}_{4}$ was proved by quantitative analysis. The reaction is not as simple as thus expressed, for some $\mathrm{CuS}$ is formed, less at $100^{\circ}$ than at $180^{\circ}$. Cuprous sulphate also plays a part in the reaction as an intermediate product, 
according to Doctor Stokes. Similar equations would no doubt explain the for mation of covellite $(\mathrm{CuS})$, bornite $\left(3 \mathrm{Cu}_{2} \mathrm{~S}+\mathrm{Fe}_{2} \mathrm{~S}_{3}\right)$, and chalcopyrite $\left(\mathrm{Cu}_{2} \mathrm{~S}+\mathrm{Fe}_{2} \mathrm{~S}_{3}\right)$, for it is well known that these sulphides form under conditions analogous to those of chalcocite. Doctor Stokes considers it likely that the reaction likewise goes on, though more slowly, between $+100^{\circ}$ C. and $+20^{\circ} \mathrm{C}$., the range of temperature probably existing in the deposit during the period of sulphide deposition.

Mr. H. V. Winchell ${ }^{a}$ in a most interesting experiment obtained the mineral chalcocite from the action of $\mathrm{CuSO}_{4}$ on pyrite in the presence of much $\mathrm{SO}_{2}$. It seems very unlikely; however, that $\mathrm{SO}_{2}$ was present in the requisite amounts during the deposition of the chalcocite, so that the experiments and equation of Doctor Stokes more likely represents what actually happened. That $\mathrm{SO}_{2}$ is formed in small quantities during the oxidation of pyrite in open air is true. Ferric sulphate is also formed, and as the two are incompatible the result will be sulphuric acid and ferrous sulphate. During this stage of open-air oxidation sulphites may possibly form, but is is very difficult to imagine that they could remain stable. As the waters percolate downward through the mass of unoxidized pyrite present at Clifton a short distance below the surface that mineral will soon reduce the ferric to ferrous sulphate and thus the principal active reagents will soon be limited to ferrous sulphate, cupric sulphate, and free $\mathrm{H}_{2} \mathrm{SO}_{4}$. It is stated in Mr. Winchell's paper that $\mathrm{SO}_{2}$ is formed by the action of ferrous or cupric sulphate on pyrite or chalcopyrite, but even if small quantities of sulphur dioxide did form they would probably soon be oxidized by an excess of cupric sulphate.

The very fact that during the experiments of Mr. Winchell cupric sulphate was for a long time in contact with pyrite without causing a precipitate would seem to show that the evolution of $\mathrm{SO}_{2}$ must be excessively slight. The synthesis of chalcocite effected by $\mathrm{Mr}$. Winchell is a highly important experiment, but it does not seem to apply to conditions at Clifton-Morenci, partly for reasons already given, partly because the reaction is a metasomatic interchange between pyrite and the solutions, not a simple product of precipitation.

On the other hand, it is certainly true that no chalcocite has as yet been produced artificially by replacemenc of pyrite at ordinary temperatures, and such as doubtless prevailed during the formation of the mineral. The question is thus to some extent yet open.

The equations given by Prof. C. R. Van Hise ${ }^{b}$, for the formation of chalcocite seem open to criticism, as they require the presence of oxygen, which was evidently not present in the chalcocite zone, and as they are generally based on 
cuprous sulphate, which is only stable in the presence of an excess of cupric sulphate and probably only of importance as an intermediate product. Doctor Stokes ${ }^{a}$ has further found that at $200^{\circ}$ a mixture of ferrous and cupric sulphates gives metallic copper and ferric oxide. As such mixtures must have been present in the sulphate water, and as no such products resulted, it is clear that no such temperature prevailed when the chalcocite was formed.

In this district the formation of chalcocite from pyrite is a most important process, to which most of the ore bodies owe their origin. This process is, throughout, one of replacement, chalcocite bodily replacing the pyrite, and it is so uniformly developed that one description answers for all localities. It acts on the solid pyrite seams and veins as well as on the sericitized and pyritic porphyry. To a limited extent it takes place in the metamorphic rocks, but on the whole these are so much less pervious to solutions than the porphyry that few important ore bodies have thus resulted. By chalcocitization the massive veins of pyrite become transformed into solid masses of black dull chalcocite, while the sericitized porphyry becomes filled with grains and little seams of the same mineral. The first constitutes high-grade ores, the second the low-grade. A residue of pyrite, not yet acted upon, is nearly always present. Thus a vein of massive, sooty material cutting the shale in the Montezuma mine contained 96 per cent $\mathrm{Cu}_{2} \mathrm{~S}$ and 2.4 per cent $\mathrm{FeS}_{2}$, and pyrite may be easily seen in nearly every specimen of low-grade porphyry ore. The pyrite first becomes coated with a black stain; in a more advanced stage the chalcocite penetrates the pyrite on cracks and fissures in all directions (Pl. XIV); finally it almost entirely replaces it. The chalcocite has an easily recognized, dull-black color and its sectile character is proved in thin sections, by the deep striations produced by the emery during the grinding. Kaolin gouge always accompanies chalcocite when occurring as massive veins; in the chalcocitized porphyry the process is nearly always attended by a formation of a little brownish kaolin, together with microcrystalline quartz or more often chalcedony; these minerals encircle the pyrite or traverse the chalcocite as minute veinlets, distinctly later than the alteration of the porphyry to sericite and pyrite. Sericite does not form during chalcocitization; on the contrary, the kaolin is formed at the expense of that mineral. Almost solid masses of chalcocite up to 20 or 30 feet thick have been mined in the Ryerson and Humboldt mines. The transition from chalcocite to unaltered pyrite at the lower limit of the zone is remarkably sudden. Usually a change takes place within 25 feet, sometimes within 10 feet, from rich chalcocite ore to pyrite with one-half to 1 per cent copper. Chalcopyrite is rarely found as a secondary mineral, but has been observed as small grains inclosed in chalcocite veinlets 
which cut through pyrite in the Ryerson vein; it is here also accompanied by a little bornite. Other specimens of sericitized porphyry from the same mine show a coating of covellite instead of chalcocite on the pyrite grains. In the "black stope" of the intermediate level of the same mine chalcocite is said to have occurred mingled with chalcopyrite, which probably was due to secondary sulphide deposition.

\section{OXIDATION OF THE CHALCOCITE ZONE.}

In the absence of a typical "iron cap" we are forced to the belief that the space between the top of the chalcocite zone in the veins and the surface is occupied by the products of oxidation of chalcocite and pyrite, the only two ore minerals present in that zone. As reagents we have here ferrous sulphate, possibly with a small amount of ferric sulphate, further cupric sulphate, sulphuric acid, and oxygen, the first four derived from the oxidation of chalcocite and pyrite near the surface. The ferric sulphate is rapidly converted into ferrous salt by the plentiful pyrite. Chalcocite under the influence of oxygen changes to cuprite and cupric sulphate:

$$
2 \mathrm{Cu}_{2} \mathrm{~S}+\mathrm{O}=2 \mathrm{CuS}+\mathrm{Cu}_{2} \mathrm{O} ; \mathrm{CuS}+4 \mathrm{O}=\mathrm{CuSO}_{4} .
$$

Cuprite indeed is found abundantly just above the chalcocite zone, both in veins in limestone (Montezuma and Joy mines, Morenci) and in porphyry (Metcalf mines). Metallic copper is very easily produced from cuprite by sulphuric acid:

$$
\mathrm{Cu}_{2} \mathrm{O}+\mathrm{H}_{2} \mathrm{SO}_{4}=\mathrm{Cu}+\mathrm{CuSO}_{4}+\mathrm{H}_{2} \mathrm{O} .
$$

In fact, metallic copper is frequently observed in most intimate intergrowth with cuprite in this zone (quoted occurrences and in Arizona Central mine). In some cases (Montezuma vein) where much sulphuric acid must have been present, the sericite in the altered-porphyry dike accompanying the vein is wholly dissolved, having as gangue a porous, loose mass of quartz grains. The cuprite formed usually spreads irregularly in the wall rocks of the vein. Specimens from the Metcalf mines 40 feet above Wilson level and about 200 feet below the surface consist of light-gray sericitized granite-porphyry with seams of massive dark-red cuprite and scattered grains of the same mineral. The microscope shows the rock to be a normal, entirely sericitized porphyry, extensively fractured, and traversed by irregular veinlets of dark-red translucent cuprite with small grains of native copper and a few remaining chalcocite grains. The veins often traverse the quartz phenocrysts (Pl. XIII, B), and are largely formed by replacement along initial cracks, partly also by mechanical filling. Cuprite also spreads in dendritic forms through the mass of the porphyry, accompanied by a little darkbrown limonite, a mineral which, however, is not usually found together with 
cuprite in the veins. Similar ore was extracted in 1902 from the Montezuma vein, Waters Shaft level, where for some distance at the upper part of the chalcocite zone this mineral and cuprite occurred together. Seams several inches wide of dull sooty chalcocite contain dark-blue spots of covellite, as required by the formulas given above, and are traversed by later seams of cuprite.

The same intimate intergrowth of cuprite and native copper is frequently observed in Williams vein, Arizona Central mine. Sheets of copper are found on seams, incrusted with cuprite. There are also veins, several inches thick, of native copper which have that fibrous structure perpendicularly to the plane of the vein sometimes noted in chalcocite from this district, and which certainly represent direct pseudomorphs after chalcocite. This occurs from 250 to 280 feet below the surface. The chemical explanation of this replacement is not quite clear. The indirect way indicated above would hardly form massive pseudomorphs. Another possible way is by ferric sulphate, if this could have main. tained its existence down to the required depth, thus:

$$
\mathrm{Cu}_{2} \mathrm{~S}+3 \mathrm{Fe}_{2}\left(\mathrm{SO}_{4}\right)_{3}+4 \mathrm{H}_{2} \mathrm{O}=2 \mathrm{Cu}+6 \mathrm{FeSO}_{4}+4 \mathrm{H}_{2} \mathrm{SO}_{4} \text {. }
$$

Ransome ${ }^{a}$ suggests, quoting. Brauns, that ferrous sulphate may act as a reducing agent and precipitate cuprous oxide from cupric salts. This seems hardly probable, for cupric sulphate and ferrous sulphate appear to mix in all proportions without reaction. Stokes's ${ }^{b}$ reaction of $\mathrm{FeSO}_{4}$ and $\mathrm{CuSO}_{4}$ forming hematite and native copper at $200^{\circ}$ is very interesting, but probably has no application in the present case.

The zone of cuprite and metallic copper has rarely great vertical extension. Both minerals are rapidly. converted into cupric sulphate, brochantite, with subordinate malachite and azurite, by sulphuric acid and carbon dioxide; but these products again are soon dissolved by free sulphuric acid forming from pyrite, some of which mineral tenaciously remains until the very last, and the copper salts descend to help enrich the cuprite zone. Thus the uppermost 100 to 200 feet of the veins are usually barren. This applies to the Montezuma and Joy veins, and in a lesser degree to the Arizona Central mine, where the oxysalts of copper reached the surface in places. At the Metcalf mines the zone of oxidized ore reaches to within 30 feet of the surface, where the ore becomes too poor to mine and where limonite, absent below, begins to be deposited on seams. The most important copper minerals in the oxidized zone of the veins in porphyry are brochantite and chrysocolla, although wherever carbonate solutions were obtainable malachite and azurite also occur. Some very fine specimens from the Metcalf mines some 60 feet below the surface and about 100 feet above the chalcocite zone offer excellent illustrations of these processes. The white serici- 
tized porphyry contains replacement veins and irregular bodies of cuprite, mostly massive and containing streaks of native copper. Green, partly crystallized or mammillary crusts of green minerals cover the cuprite. The earliest of these are intimately intergrown, bluish-green chrysocolla, brochantite, and malachite, the former two prevailing. Azurite is usually the last mineral formed, sitting in well-defined crystals in cavities of the brochantite and chrysocolla. Flakes of spangolite on the chrysocolla testify to the presence of acid solutions capable of dissolving alumina. A dark-yellowish-brown mineral, either limonite or a ferric silicate, is also present in small quantities.

Other specimens from the open cuts on the first level show veinlets of malachite, in part certainly replacing sericite, and associated with a gangue of fines grained quartz and limonite. At other places in the Metcalf mines malachite and brochantite occur as filled veinlets and the latter is frequently found as well-developed minute crystals. Specimens from the Copper Queen mine show chrysocolla concentrically deposited on loose pieces of porphyry and surmounted by fine crystals of azurite.

It is not necessary that this complete cycle of transformations should be followed, for brochantite and malachite direct from chalcocite has often been observed. Brochantite $\left(\mathrm{H}_{6} \mathrm{Cu}_{4} \mathrm{SO}_{10}\right)$ probably forms as follows:

$$
2 \mathrm{Cu}_{2} \mathrm{~S}+10 \mathrm{O}+4 \mathrm{H}_{2} \mathrm{O}=\mathrm{H}_{6} \mathrm{Cu}_{4} \mathrm{SO}_{10}+\mathrm{H}_{2} \mathrm{SO}_{4} .
$$

Chalcocite is not attacked by either strong or dilute $\mathrm{H}_{2} \mathrm{SO}_{4}$, while hydrochloric acid decomposes it with development of $\mathrm{H}_{2} \mathrm{~S}$. In a specimen from the Montezuma mine the chalcocite appears as if shattered, and on all seams brochantite develops by replacement. Farther away from the sulphide the brochantite partly changes to malachite $(\mathrm{Pl}$. XII, C). Direct transformation to malachite has also been observed at a prospect near Metcalf.

The common occurrence of brochantite, the basic sulphate of copper, has been emphasized in the chapter on mineralogy. Its "habitat" is chiefly in the porphyry and not far below the surface. It is probably a very common mineral, though usually taken for malachite. It is very easily reproduced in different ways. ${ }^{a}$ Chrysocolla forms in most eases from cuprite, but $\operatorname{Roth}^{b}$ says also that it results by interchange between cupric silicate and alkaline silicates. It is somewhat soluble in water, containing $\mathrm{CO}_{2}$, and is easily decomposed by acids.

The absence of these oxysalts from the immediate surface zone of most of the veins seems to indicate that they have been dissolved by waters containing $\mathrm{H}_{2} \mathrm{SO}_{4}$ and $\mathrm{CO}_{2}$. The solutions were carried down to deposit still more copper in the upper and always richest part of the chalcocite zone. 
With some exceptions the croppings of the Copper Mountain veins contained in porphyry are almost absolutely barren of copper minerals. Where the outerops can be accurately placed, which is not often the case, they merely consist of sericitized porphyry cemented by veinlets of quartz. The pyrite, copper salts, and limonite have been carried away, as illustrated by Analysis V on page 168. The top of the chalcocite zone is 100 to 200 feet below the surface. As usual, the upper half of the zone is much the richer. At its upper limit the porphyry containing chalcocite and pyrite becomes brown and rusty. The chalcocite disappears rapidly, but some cupric sulphate is universally present as efflorescences and seams in the rock. Limonite is fairly abundant in seams and throughout the rock. Some pyrite remains to the last and disappears wholly only a very short distance below the surface. Malachite, chrysocolla, and allied minerals occur only in insignificant amounts. For some reason there has been here a more energetic oxidation of the chalcocite with direct conversion to eupric sulphate, which in turn has descended and enriched the upper chalcocite zone. We may assume that the following equations represent what has taken place:

$$
\begin{aligned}
& \mathrm{Cu}_{2} \mathrm{~S}+\mathrm{O}_{5}=\mathrm{CuSO}_{4}+\mathrm{CuO} \\
& \mathrm{CuO}+\mathrm{HSO}_{4}=\mathrm{CuSO}_{4}+\mathrm{H}_{2} \mathrm{O}
\end{aligned}
$$

In some cases, however, bunches of chalcocite continue along the main veins close to the surface, and on the Fairplay claim, at Carasco, and near the Liverpool tunnel chrysocolla and other oxysalts are found near the surface.

Cupric oxide (melaconite or tenorite) has not been found in these deposits either in the chalcocite or in the oxidized zone.

\section{PROCESSES IN DEPOSITS IN LIMESTONE.}

The processes which have resulted in the oxidized deposits which form irregular or tabular masses in limestone or shale are materially different from those prevailing in the veins. They are partly due to direct oxidation and largely to the effect of sulphate solutions. Most of the ore bodies are situated near the surface like the Detroit, Longfellow, and Shannon deposits, or near a fault facilitating the percolation of solutions. Although direct evidence is not available in every case, it is certain that the original material in most cases consisted of lean chalcopyrite ores mingled with pyrite, magnetite, and zinc blende. These were, according to accidents of contact metamorphism, locally more concentrated in irregular masses or along certain strata. Free oxygen, free sulphuric acid, ferrous and cupric sulphates with an abundance of carbonate of lime were the reagents employed by nature. Oxygen and carbon dioxide alone in many cases doubtless produced limonite and malachite directly from the sulphides, but the 
most important reactions surely were those between carbonate of lime and sulphate solutions partly derived from points near the surface.

$$
\begin{gathered}
2 \mathrm{CuSO}_{4}+2 \mathrm{CaCO}_{3}+\mathrm{H}_{2} \mathrm{O}=(\mathrm{CuOH})_{2} \mathrm{CO}_{3}+2 \mathrm{CaSO}_{4}+\mathrm{CO}_{2}, \\
\text { or cupric sulphate }+ \text { calcite }=\text { malachite }+ \text { calcic sulphate; } \\
3 \mathrm{CuSO} \mathrm{O}_{4}+3 \mathrm{CaCO}_{3}+\mathrm{H}_{2} \mathrm{O}=(\mathrm{CuOH})_{2} \mathrm{Cu}\left(\mathrm{CO}_{3}\right)_{2}+3 \mathrm{CaSO}_{4}+\mathrm{CO}_{2}, \\
\text { or cupric sulphate }+ \text { calcite }=\text { azurite }+ \text { calcic sulphate. }
\end{gathered}
$$

According to a well-known reaction, ferric hydrate will be produced from ferrous sulphate and calcite, and in this manner is explained the occurrence of malachite, azurite, and limonite on these deposits. The copper contained in the contact metamorphic rocks will thus be enriched by precipitation of the transported cupric sulphate. Reduction of volume by the removal of gypsum contributes to the enrichment. In confirmation of the correctness of this reaction crusts of replacing malachite and azurite frequently surround residual rounded masses of limestone. This was particularly well shown in an excavation at the surface near the Ryerson shaft, Morenci, and in the Boulder tunnel, Shannon mine, Metcalf. In part, however, the process is one of erustification, as was well shown in the beautiful stalactitic masses of malachite and azurite formerly found in the Detroit and Manganese Blue mines, and to some extent yet occurring in the red and central ore bodies of the Shannon mine. A specimen from the latter locality shows stalactitic crusts of black copper-pitch ore and dull-black material with much manganese; on this is deposited coarsely crystalline azurite with a little kaolin, which again is surmounted by fine fibrous malachite; in places occurs a second generation of azurite alternating with copper-pitch ore. Other specimens show crusts of dark-green brochantite, limonite, again surmounted by fibrous pale-green malachite.

In the old irregular azurite stopes in the Copper Mountain tunnel at Morenci the partly contact-metamorphosed limestone is converted to a loose yellowish aggregate containing bunches of small azurite crystals and many small pale-green balls of radially fibrous malachite. The matrix consists chiefly of a kaolin-like material, containing roughly 27 per cent $\mathrm{H}_{2} \mathrm{O}, 29$ per cent $\mathrm{SiO}_{2}, 36.5$ per cent $\mathrm{Al}_{2} \mathrm{O}_{3}$, and 3.3 per cent $\mathrm{MgO}$. (Hillebrand, analyst.)

The garnet and magnetite, frequently forming the gangue of these deposits, likewise alter to ferric hydrate and quartz with removal of lime. Gypsum is not uncommonly found as silky foils, and was especially noted from the Montezuma and Manganese Blue mines.

Besides these principal processes there are many others of subordinate importance. Chrysocolla forms where silica is abundant, as in masses of garnet (Modoc mine), and is usually associated with copper pitch ores and seams of black manganese, probably impure pyrolusite. Brochantite is not common. 
The zinc sulphide contained in the primary veins, below the chalcocite zone, is there converted to zinc sulphate and practically eliminated from the oxidized zone. In the deposits in the altered limestones no such complete elimination takes place, for carbonate of zinc and the two silicates are occasionaily found; much zine also goes into copper-pitch ores, and the cap rock of partly oxidized magnetite and garnet at the Shannon mine contains some of it as carbonate and silicate. In the ore bodies proper the zinc forms a very small percentage. Efflorescences of zinc sulphate, with which are also mixed the sulphate of magnesia and copper, are of very common occurrence in old mine workings in shale and limestone.

The final result of the oxidation and enrichment of the altered limestone will be limonite, quartz, malachite, and azurite, with more or less kaolin. The lime is almost eliminated, while silica and alumina form residual concentrations.

Chalocite is rarely an important mineral in these deposits. Cuprite, ordinarily absent, occurred extensively in some parts of the Longfellow mine, under exactly what conditions is not known.

\section{OXIDIZING PROCESSES IN SHALE.}

The occurrence of cuprite in clay shale is a common phenomenon at Morenci. Disseminated in small flakes it is plentiful in the Hudson crosseut of the Arizona Central mine 150 feet below the surface, and bodies of it were extracted in 1902 in the Manganese Blue and Montezuma mines, 100 to 150 feet below the surface. It also occurs disseminated with the thick shale beds underlying the second ore body in the Detroit mine. The two lower ore beds of the Manganese Blue mine, now worked out and inaccessible, also carried predominant cuprite ore. The occurrence in the Longfellow mine may also have been partly associated with shale. The cuprite occurs as flakes on the bedding planes of the dark-gray or black shale, or disseminated through it in veinlets which to some extent are formed by replacement. No particular gangue mineral seems to be associated with the mineral, except limonite in the richer occurrences. The cuprite is partly altered to malachite, this being proved by seams of the latter mineral cutting across the first. These occurrences of cuprite seemed at first difficult to explain, but recent interesting experiments by Doctor Kohler, ${ }^{a}$ who shows that solutions of copper sulphate filtered through kaolin become hydrolyzed by adsorption, throw much light on the subject. The copper is precipitated as oxide, and sulphuric acid is set free. Organic matter contained in the kaolinic shales would easily account for further reduction to cuprous oxide and native copper, if indeed this be not accomplished directly by the free sulphuric acid. 
Dr. E. C. Sullivan, who for some time had been working on the phenomena of adsorption by kaolin, kindly consented to make some experiments on the Morenci shale analyzed and described on page 67 , with a view to ascertaining its action on solutions of cupric sulphate. A preliminary statement by Doctor Sullivan of the interesting results of this inquiry is here appended.

"Fifty grams of shale, finely ground in agate mortar, were placed in 100 cubic centimeters of solution of cupric sulphate containing 0.0025 gram of copper per cubic centimeter. After standing for four days, with occasional shaking, the solution contained but 5 per cent of that amount of copper. A solution of the same strength had lost all its copper after four months' contact with shale. A concentrated solution with original content of 0.7645 gram copper per cubic centimeter had but 0.7058 gram copper per cubic centimeter after a few days' contact, 100 cubic centimeters of solution thus giving up nearly 0.6 gram copper $(0.75 \mathrm{~g}$. cupric oxide, $\mathrm{CuO}$ ) to 50 grams shale.

"A certain amount of acid radical is also taken from the solution by the shale. This loss in one experiment with the dilute copper sulphate mentioned was something over 10 per cent of the total $\mathrm{SO}_{4}$.

"The shale in turn gives off a part of its constituents to the solution, about 0.2 gram having been found in 100 cubic centimeters after treatment with the dilute copper-sulphate solution. This is 0.4 per cent of the 50 grams sbale taken. Of this dissolved matter, mostly present as sulphate, one-third to one-half was potassium oxide, most of the remainder being magnesium oxide and calcium oxide with sodium oxide, manganese oxide, ferric oxide, and silica in smaller quantities.

"The acidity of the solution was not increased by removal of copper, analysis showing that copper precipitated in excess of that equivalent to the acid radical removed was replaced in solution by other bases as sulphates."

In that part of the Longfellow deposit contained in the East Yankie mine masses of very pure kaolin occur together with separated masses of cellular limonite. Neither contains much ore and both are probably derived from clay and lime shales. The kaolin contains little aggregates of cuprite with metallic copper and both alter to malachite, which traverses the rock in delicate veinlets. Sometimes the cuprite is surrounded by little aureoles of limonite and malachite.

Azurite is also no stranger in the shale deposits, as shown, for instance, in the second ore body of the Detroit mine. The mineral has a strong tendency to develop metasomatically in the partly contact-metamorphosed shale, as shown by Pl. XV, B. Specimens show a grayish compact shale, more or less deeply colored by malachite and containing fine replacement crystals of azurite. In thin section the shale consists of a microcrystalline aggregate of sericite and tremolite, full of minute grains and crystals of malachite which also occurs as fibrous replacement veins. Besides the minerals mentioned there is formed by replacement of the shale a dark-brown translucent and isotropic copper-pitch ore which assumes 
round concretionary forms. Cases have been observed in the Copper Mountain mine in which azurite envelops grains of undecomposed pyrite accompanied by a little limonite.

Another interesting occurrence is that of cuprite on magnetite, observed on the intermediate level of the Arizona Central mine, 200 feet below the surface. About 200 feet below the surface at a strong slip, not far from the great disturbance of the Apache fault, a seam of chalcocite in porphyry alters to cuprite near a mass of magnetite here adjoining the porphyry. Fine crystals of cuprite sit on open fissures of dissolution in the magnetite and are accompanied by limonite and fibrous crusts of some manganese ore. The magnetite probably plays no direct part in this reaction, which more likely is due to direct oxidation.

It is well known that the "clay substance" in plastic clays, together with any potassium they may contain, dissolves entirely in strong sulphuric acid, as well as in hydrochloric acid. It is certain that kaolinite is likewise decomposed by strong acids, though a statement to the contrary is found in Dana's System of Mineralogy. That dilute sulphuric acid produces similar results more slowly is very probable and is supported by many observations at Morenci. Thus alumina acquires a considerable mobility wherever acid solutions are present. An illustration of this is furnished by specimens of greenish compact shale from the Longfellow mine, which are traversed by seams of quartz and manganese dioxide. Between these seams the clay shale is partly dissolved and a series of irregular cavities formed, often coated by calcite crystals in flat rhombohedrons. Pure-white kaolin frequently occurs with azurite at Morenci, its formation being easily explained by the action of aluminum sulphate on free silica in the presence of cupric sulphate, thus:

$$
\begin{gathered}
\mathrm{Al}_{2}\left(\mathrm{SO}_{4}\right)_{3}+3 \mathrm{CuSO}_{4}+3 \mathrm{CaCO}_{3}+2 \mathrm{SiO}_{2}+6 \mathrm{H}_{2} \mathrm{O}=3 \mathrm{CuO}, 2 \mathrm{CO}_{2}, \mathrm{H}_{2} \mathrm{O}+ \\
\mathrm{H}_{4} \mathrm{Al}_{2} \mathrm{Si}_{2} \mathrm{O}_{9}+3 \mathrm{CaSO}_{4}+3 \mathrm{H}_{2} \mathrm{SO}_{4}+\mathrm{CO}_{2} .
\end{gathered}
$$

The aluminum sulphate formed by the attack of sulphuric acid on clay substance is extremely soluble in water, and is thus easily transported. During the oxidation of clay shales pure kaolin in nodules is very apt to form, as seen in the Detroit mine, and this in itself seems to imply solution and transportation.

Sericite is undoubtedly more resistant than kaolin, but evidence from the Montezuma mine shows that it may be attacked. The presence of alunite, an almost insoluble sulphate of aluminum and potassium, in the Ryerson mine points in the same direction. It occurs here both in seams and in the altered rock, clearly replacing the sericite; the pyrite in the same rock is, however, not attacked, and we may, therefore, refer its origin to sulphuric-acid solutions without free oxygen.

16859-No. $43-05-13$ 
No secondary pyrite appears to have been formed at any time in the zones of direct or indirect oxidation. Considering that cupric and ferrous sulphate certainly occur mixed in various proportions in the oxidizing waters, it is certainly remarkable that the oxysalts of copper are almost entirely free from iron. Only the soluble sulphates seem to have some slight inclination to crystallize in isomorphous mixtures.

\section{PARAGENESIS.}

The minerals formed during successive stages may be summarized as follows: Veins-

Primary processes-Pyrite, chalcopyrite, zine blende, molybdenite (rarely magnetite), sericite, quartz (rarely tremolite, diopside, and epidote).

Introduction of iron, sulphur, zinc, copper, potassium, and silica. Elimination of calcium and sodium.

Processes of oxidation-

Action of sulphate solutions without oxygen-Chalcocite (rarely covellite, chalcopyrite, and bornite), quartz, chalcedony, kaolin, alunite.

Introduction of copper. Elimination of zine, some iron and sulphur.

Action of directly oxidizing solutions-Cuprite, native copper, brochantite, malachite, chrysocolla (rarely azurite), chalcanthite, limonite, quartz.

Introduction of carbon dioxide. Elimination of sulphur, together with some iron and copper.

Contact deposits-

Primary processes-Pyrite, magnetite, chalcopyrite, zinc blende, molybdenite, specularite, garnet, epidote, diopside, tremolite, quartz.

Introduction of much iron and silica, together with copper, zine, molybdenum, sulphur, possibly magnesia. Elimination of carbon dioxide and probably some lime.

Processes of oxidation-Limonite, malachite, azurite, cuprite, rarely native copper and chaleocite, copper-pitch ore, chrysocolla, goslarite, zine carbonate, willemite, calamine, pyrolusite, quartz, calcite, chlorite, serpentine.

Introduction of carbon dioxide and additional copper. Elimination of calcium, sulphur, some zinc and iron. 


\section{H A P T E R V. \\ PRINCIPAL CHARACTERISTICS OF DEPOSITS.
DEPOSITS OF CARBONATES AND OXIDES IN LIMESTONE AND SHALE. DISTRIBUTION.

These deposits are chiefly confined to the vicinity of Morenci and Shannon Mountain, the principal occurrences being those of the Manganese Blue, Detroit, Copper Mountain, Montezuma, and Longfellow mines at the former place, and that of the Shannon mine at the latter. Smaller deposits occur at the head of Placer Gulch and at the Stevens mines near the mouth of Garfield Gulch.

\section{GENERAL CHARACTER AND STRUCTURE.}

In their present form these deposits contain practically all of the oxysalts of copper known from the district, but consist chiefly of malachite, azurite, and cuprite, with very subordinate occurrences of native copper and chalcocite. In most cases these are associated with much limonite, manganese dioxide, kaolin, and soft yellowish material which in a large proportion of the deposits proves to be decomposing and hydrated forms of tremolite, diopside, epidote, or garnet; some quartz is also present. The copper minerals are sometimes deposited by crustification, when zinc and manganese salts usually also appear, or form as replacements in lime or shale. Exceptionally, as in the Stevens mines, deposits of chrysocolla with limonite occur in wholly unaltered limestone:

The carbonate ores, which generally prevail in the deposits contained in limestone, are malachite and azurite, the latter sometimes forming large aggregates of crystals. Formerly the ore was often extremely rich, great masses yielding 20 per cent having been of common occurrence, but practically all of these deposits except some in the Shannon mine have now been worked out. There was great demand for this ore, which natually yielded most easily to metallurgical treatment, and the deposits were thus rapidly exhausted. The ores contain very small quantities of gold and silver, the amount of silver per ton rarely rising to 1 ounce and the amount of gold rarely exceeding 50 cents per ton.

The form of these deposits is sometimes entirely irregular, as shown in the small azurite stopes of Copper Mountain. The Longfellow deposit was shaped 
like an inverted pyramid, its greatest depth being about 400 feet from the surface (figs. 5 and 6). Most common, however, is a roughly tabular form following certain beds in the sedimentary series. This is the form in the Montezuma, Detroit, Manganese Blue, and Shannon mines (Pl. XXV and figs. 7 and 8). In the three latter there are several ore-bearing beds, one above the other, 4 of them in the Manganese Blue and 3 in the Detroit. The horizontal extent of these tabular deposits varies greatly, but rarely exceeds 300 or 400 feet, and the two dimensions are apt to be approximately equal. The thickness varies from 1 or 2 feet up to 25 or 30, and occasionally this last is exceeded. The boundaries are rarely regular and the pay ore shades imperceptibly into the rock. One of the exceptions from the last rule is found in the second ore body of the Detroit, which lies between shale and limestone. The ore, which chiefly consisted of oxidized metamorphic shale with much azurite, and which was about 5 feet thick, bordered against the upper limestone with a well-defined and irregularly pitted surface, probably due to erosion by acids during the oxidizing process. Still another form is shown by many of the smaller ore bodies along the Central, Black Hawk, and Shirley dikes at the Shannon mine. These lie as tabular masses along one or both contacts of the dikes and, though only a few feet in width, are sometimes continuous for several hundred feet.

Quartz-monzonite-porphyry or granite-porphyry are found in the immediate vicinity of all of these deposits. The ore bodies of Copper Mountain are the only ones situated directly at the contact of the main porphyry stock. All of the others show a very decided dependence on the porphyry dikes rather than on the main mass of that rock. Thus the Longfellow lies between three dikes, which, together with a fault plane, determine its outlines (figs. 5 and 6). The Detroit and Manganese Blue are confined between the Joy and Humming Bird dikes, which are about 400 feet apart (fig. 7). The ores run up against these dikes, which themselves contain very little pay ore and that rather as chalcocite than as oxysalts. The Shannon red and central ore bodies (PI. XXV) are also situated in the same way, as are the otherwise very different chrysocolla pockets of the Stevens mines.

This dependence is still more marked in those deposits which follow some of the Shannon Mountain dikes. In this case the dike itself contains in places a little chalcocite and cuprite.

\section{GEOLOGICAL HORIZON.}

The deposits are not tied to any particular horizon, but are distributed through the whole Paleozoic series. None have, however, been found in the Cretaceous rocks. In the Longfellow and the Manganese Blue the ore bodies 
occur throughout the Longfellow limestone. In the Montezuma they are found in the Morenci shales. In the Modoc and Detroit mines they occur in several horizons of the Modoc limestone. The same is repeated at Metcalf.

\section{CROPPINGS.}

It seems characteristic of these deposits that they frequently outcrop almost at the surface. As illustrating this may be mentioned the azurite stopes following the Shannon dikes, the central ore body in the same mine, the Longfellow mine, and the big upper ore bodies in the Detroit and Manganese Blue mines. Azurite appears in fact to resist decomposition more strongly than most of the other oxysalts of copper.

\section{ORIGIN.}

Driving laterally, or sinking deeper from these ore bodies, is apt to develop hard metamorphosed limestone with chalcopyrite, garnet, epidote, and other mineral of the contact-metamorphic group. Such was found laterally and at the bottom of the Longfellow mine, 400 feet below the surface, and in the Detroit and Manganese Blue mines at depths of between 400 and 500 feet. In the Detroit mine garnet intergrown with azurite often occurs in the upper ore body, and tremolite with the same mineral in the second tabular mass of ore. Entirely similar conditions obtain in the Shannon mine. From all these data, explained in more detail in the chapter on metamorphic processes, the very confident conclusion has been drawn that the majority of these deposits have been formed by the oxidation of irregular or tabular masses of low-grade ore, consisting of chalcopyrite, pyrite, zinc blende, and magnetite, associated with contact-metamorphic silicates, such as the lower mine workings have disclosed in such abundance, for instance, in the Yavapai mine. The oxidation has been accompanied by great enrichment on account of reduction of volume and introduction of additional eopper in sulphate solution. The principal reaction involved seems to be that between calcium carbonate on one hand and the sulphates of ferrous iron and copper on the other hand, resulting in ferric hydrates, copper carbonates, and gypsum.

The oxidation does not extend down to any well-defined water level, which must be far below the deepest workings, but acts most irregularly, sometimes leaving fresh metamorphic limestone at the surface and again reaching down to a depth of 400 feet along fissures and faults. The present ore bodies probably fell an easier prey to oxidation by reason of their richness in sulphides and their favorable exposure to percolating waters. In such position are the upper ore bodies of the Detroit and Manganese Blue. In other cases the oxidation was facilitated by means of fault planes and porphyry dikes. These agents doubtless 
caused the concentration of copper in the Longfellow mine (figs. 5 and 6), and the Copper Mountain fault easily carried solutions down to the lower ore bodies of the Manganese Blue (fig. 7). At the Shannon mine the ore bodies were easily accessible to surface waters.

For some of these deposits the origin indicated above is probably not applicable. Among these the most prominent group is formed by the cuprite deposits in shale, both in the pure clay shales of the Morenci formation and the lime shales of the Longfellow formation. Here the cuprite occurs disseminated or in filled or replaced veinlets frequently changed to malachite, and the ordinary contact minerals are absent. These deposits, of which the lower beds in the Manganese Blue and some beds in the Montezuma mine furnish the best examples, are evidently derived from percolation along shale beds of copper-sulphate solutions, which, according to the reaction described by Kohler, ${ }^{a}$ deposit copper oxide and liberate sulphuric acid.

In a few other cases, notably in the Stevens mines at Garfield Gulch, the oxidized ores, chiefly chrysocolla, form irregular masses surrounded by limonite in apparently unaltered limestone, but lying closely adjacent to a porphyry dike. It is difficult to arrive at definite conclusions as to the origin of these deposits where no direct evidence of contact metamorphism exists. The sulphides from which the oxidized ores are directly derived may, in this case, well have been deposited by the vain-forming solutions spreading irregularly in the limestone. If so, these ore bodies would belong to a somewhat later period than those due to contact metamorphism. In the Shannon mine some of the Morenci shales contain much chalcopyrite, principally in little seams, and it is considered probable that this impregnation also dates from the vein-forming epoch.

Only a limited number of the more important ore bodies of carbonates and oxides have been mentioned, but it should be remembered that the contactmetamorphic areas of limestone and shale, both at Morenci and at Metcalf, are full of smaller deposits and pockets of the same kind as those described in this chapter.

AGE.

To the principal class of contact-metamorphic deposits an age equal to that of the porphyry intrusion must be ascribed - that is, they were formed in latest Cretaceous or earliest Tertiary times. The agency was in all probability magmatic solutions, emanating from the porphyry. But these deposits were of low grade, and their concentration to bodies of workable copper ores took place later, and by the agency of descending atmospheric waters, as evidenced by the complete oxidation of the ores. That this process of oxidation is still in progress is certain. 
Another question is as to the date of beginning of oxidation. It is certain that the oxidation began at the moment the first oxidizing surface waters reached these deposits. This depended on the rate of progress of erosion, which may have been materially different in various places. There is no reason why, in some cases, the oxidation may not have begun in Tertiary time, for just before the great volcanic eruptions of that period erosion had cut down to the same gradient it has now attained. Similar conditions and active erosion followed the Tertiary outbursts and preceded the deposition of the Gila conglomerate.

An important dislocation - the Copper Mountain fault-cuts across the limestones which contain the Manganese Blue ore bodies. There is very little ore on this fault, and the oxidized ore bodies, according to best authority, butted directly against it. As shown by fig. 7, the oxidation has reached a depth of about 400 feet on the foot-wall side, but scarcely more than 200 feet on the hangingwall side, which has moved down relatively about 225 feet. The principal epoch of faulting in this district was later than the intrusions of porphyry and earlier than that of the Tertiary lava flows. At the time of the faulting it is probable that a considerable thickness of Cretaceous strata covered the ore-bearing limestones in the Morenci basin, and, therefore, bearing in mind the great resistance of the contact-metamorphic rocks to oxidation, it is likely that no part of this oxidation took place earlier than the dislocation along the fault. After the faulting extensive degradation followed, and the access of surface waters was much facilitated by the fissures. My conclusion would be that oxidation of the Morenci contactmetamorphic deposits began rather early in Tertiary time, before the eruption of the andesites, rhyolites, and basalts.

\section{FISSURE VEINS AND RELATED DEPOSITS.}

\section{DISTRIBUTION.}

The fissure veins on the whole follow the porphyry stock, extending northeasterly from Gold Gulch, among the Eagle Creek foothills, by Morenci and Metcalf, to Copper King Mountain; their last outliers are found at Sycamore Gulch northeast of that peak. The belt is about 9 miles long and from 2 to 4 miles wide. Small and irregular veins outcrop in Gold Gulch, and a strong and productive vein system passes through Morenci, on both sides of the contact. Small fissures and extensive mineralized zones characterize the vicinity of Metcalf and Chase Creek between Metcalf and the Longfellow incline. The great Coronado fissure occupies a position by itself on top of the ridge south of Coronado Mountain. Finally a small group is found at Garfield Gulch, while a strong, but thus far not very productive, vein system follows the porphyry dikes of Copper King Mountain. 
GEOLOGICAL FEATURES.

The veins occur in practically all of the older rocks of the district, but are never found in the Tertiary eruptives, basalt, rhyolite, and andesite. At Morenci they cut the Cretaceous and Paleozoic strata, all more or less contact metamorphosed. The best veins are contained in porphyry or are not far from the contact. At Metcalf they occur in porphyry or granite; in the Chase Creek Canyon chiefly in granite, though usually close to porphyry dikes; at Garfield Gulch one vein lies on the contact between porphyry and limestone; the Coronado vein follows a fault fissure between quartzite and granite, accompanied by a diabase dike; smaller veins, associated with diabase dikes, occur at Garfield Gulch and vicinity. There are a few deposits which do not resemble the prevailing type at all, but, like the Hormeyer vein, contain gold and silver with lead, or, like the Black Lode, contain the very unusual association of chalcopyrite, magnetite, and epidote. With all this diversity, practically all of these veins are closely connected with granite-porphyry, quartz-monzonite-porphyry, or diabase, either cutting these rocks directly or following dikes of them, or at least occurring in the immediate vicinity of important dike systems.

Leaving out of consideration for the present the few deposits of abnormal character, the discussion will first be confined to the prevailing Morenci and Metcalf type, including those ore-bearing dikes and irregular zones of dissemination which are clearly genetically connected with the fissure veins.

\section{MORENCI AND METCALF TYPE.}

\section{STRUCTURE.}

Most of the Morenci and Metcalf veins have a northeasterly strike and a steep northwesterly or southeaste:ly dip; a few between Morenci and Metcalf have a northerly strike, and a minor system of veins near Metcalf course northwesterly. Still, the northeasterly trend is characteristic, and this trend is also that of the porphyry stock and of practically all the porphyry dikes. This is in marked contrast to the trends of the fault lines, which do not seem to follow any well-defined direction, and to the course of the rbyolite dikes on Copper King Mountain, which have a northwesterly direction. As shown on the mine map (PI. XVIII) there are two groups of characteristically linked lode systems at Morenci, both forming flat curves, with the convex side toward the southeast, one chiefly in the porphyry stock near the contact and the other entirely in the metamorphic rocks. The length of this system is less than 2 miles. Individual veins are rarely traceable far, and may dip steeply either northwest or southeast. The Copper King vein, on the mountain of the same name, is probably traceable 
for $1 \frac{1}{2}$ miles; it is the longest vein in the district. On this a vertical depth of 600 feet is attained. Few of the Morenci workings penetrate more than this distance below the surface of Copper Mountain. The irregular zones of dissemination, as at the Metcalf mines, show small fissures and veinlets running in all directions, but here also a northeasterly striking sheeting of the country rock prevails. Altered and ore-bearing dikes often also show northeasterly sheeting with pyrite seams parallel to the walls.

The veins always have one or more well-defined walls, frequently well polished and striated. Movement has always taken place along them, though the dislocations were seldom of great magnitude. The regularity of the principal fissures and their conjugated character (that is, their dipping in opposite directions) make it exceedingly probable that they are due to compressive stress acting in a general northwest-southeast direction. In this respect these vein systems differ little from those of many other mining districts of the West.

\section{ORES IN GENERAL.}

The ores consist of predominating pyrite with chalcopyrite, zine blende, molybdenite, chalcocite, cuprite, and various oxysalts of copper, among which chrysocolla, brochantite, and malachite are the most common. The gangue occurs in subordinate quantities and consists exclusively of quartz. Experience has shown that each vein usually contains three zones in vertical distribution, as follows:

Ore zones in the Morenci and Metcalf type of fissure deposits.

Surface zone.........50 to 200 feet deep from the croppings; contains oxidized copper minerals or is barren.

Chalcocite zone........ 100 to 400 feet in vertical extent; possibly more in places; contains chalcocite and pyrite.

Pyritic zone.......... Begins 200 to 600 feet below the surface; contains pyrite, chalcopyrite, zinc blende, and molybdenite.

It has been shown in the chapter on metamorphic processes that the minerals of the upper two zones have resulted from those of the pyritic zone by processes of direct and indirect oxidation; that the chalcocite is wholly derived from replacement of pyrite, probably by aid of cupric sulphate solutions; and that the surface zone has been derived from the chalcocite zone by its gradual and direct oxidation. It has further been emphasized that the pyritic zone has thus far been found to be poor, and rarely makes commercial copper ore; that the chalcocite zone produces the richest ore, and that the richest part of it is near its upper limit; and, finally, that the leached zone is usually poor and sometimes practically barren. 


\section{ALTERATION OF THE COUNTRY ROCK.}

The veins are accompanied by complete sericitization of adjoining porphyry, and this alteration, especially at Morenci and Metcalf, spreads over a distance of many hundred feet, evidently on account of the great permeability of the rock to solutions. Thus, at Morenci, practically the whole vein system is encased in rocks, which now, whenever untouched by chalcocitization or direct oxidation, consist of pyrite, sericite, and quartz, with minor quantities of chalcopyrite and zinc blende. At Metcalf a large part of the porphyry shown on the special map is similarly altered. Detailed studies of these processes may be found in Chapter IV.

In the contact-metamorphic sedimentary rocks, which were evidently much more impervious to solutions, the limestone is converted into tremolite or diopside, with pyrite, zinc blende, and some magnetite; more rarely the process takes a similar course, as in porphyry, and yields sericite with hydrated magnesian silicates. But the intense alteration is confined to the immediate vicinity of the vein.

PYRITIC ZONE.

This part, representing the veins as they were before oxidizing processes had transformed them in manifold shape, is well exposed in the deeper levels of the Ryerson, Montezuma, and Joy mines. In the Joy mine it begins about 300 feet from the surface and is well exposed by the third and fourth levels. In the Montezuma west vein the pyrite appears 250 feet below the surface; but in the east vein at less than 150 feet. In the Ryerson mine the average depth at which this zone begins is 400 feet (fig. 16). In a few places, especially below the summit of Copper Mountain, it has not yet been reached at 600 feet (fig. 17). In the Arizona Central mine it has not yet been found at 300 feet below the surface (fig. 18).

The copper values of this pyritic ore are usually low-ordinarily, in fact, below 1 per cent. But the explorations of this zone have not thus far been extensive enough to warrant the statement that no commercially important bodies will be found. It has been suggested that another oxidized zone may be found below the pyritic ores, but this seems at least very unlikely. The zones of pyritic and sericitized porphyry surrounding the veins proper are likewise poor and contain as a rule only traces of copper. The metal seems to occur chiefly, if not wholly, in finely distributed chalcopyrite. The zinc blende is subordinate and thus far has not been found in commercially important quantities; the same applies to molybdenite.

The pyrite occurs in bodies up to 40 feet wide; in the Joy mine it is extracted to supply the sulphuric-acid plant at Clifton with raw material. 
At the Metcalf mines few lodes of noteworthy size have been found, but on the Wilson level, about 250 feet below the top of the hill, the veinlets and seams contain almost only pyritic material. In the King and Jameson veins, each having attained about 250 feet below the surface, the pyritic zone has not yet been encountered. The Copper King mine, on the mountain of the same name, in 1902 showed chalcocite ore 300 feet below the surface, but has since been deepened to 800 feet, and I am informed that some payable pyritic ore has been found in the lower levels. At this and other mines oxidation is often apparent immediately along the fissure planes, while the mass of the vein is still entirely unaffected by it.

The veins usually show a distinct foot wall, while the hanging wall is often less well defined. It is characteristic that pyrite predominates in the veins, and forms a sheet varying in thickness from a mere seam to 40 feet. It is massive and granular, but wherever quartz gangue is present a tendency to crystallization is shown by the pyrite. Chalcopyrite has not been found in erystallized form, and it is very seldom that zine blende thus occurs. In the Fairplay vein on Copper Mountain, and in the small Hudson vein (Arizona Central) pyrite occurs in illdefined crystals with prevailing octahedrons. In the altered porphyry, on the other hand, cubes prevail. Quartz, with some sericite, constitutès the only gangue mineral. The quartz occurs very sparingly and is rarely well crystallized. Sericite often separates the pyrite grains. The appearance of the ore and the structure of the vein point to replacement as the principal mode of formation. In most cases the massive pyrite seems to have been country rock, in which pyritization has been carried on to its extreme result, leaving only some quartz and sericite to represent the original character (Pls. XII, $A$, and XIV).

Lastly, mention should be made of an exceptional vein which cuts across the Lone Star Tunnel at Morenci. It is only 8 inches wide at most, but consists of a gangue of drusy, well-crystallized quartz, intergrown with blende, pyrite, and chalcopyrite, the first two minerals in part crystallized. It bears distinctly the marks of a filled open space along a fissure, and thus differs decidedly from the others. The Hudson, a narrow vein in the Arizona Central mine, is somewhat similar to this type.

\section{CHALCOCITE ZONE.}

General character and extent. - In the chalcocite zone, commercially the most important of the three, that mineral has largely, but rarely wholly, replaced the pyrite, both in the massive veins and in the zones of pyritization and sericitization surrounding them. It is generally sharply separated from the pyritic zone, the transition from payable ore to low-grade pyrite taking place within 10 or 20 feet. This was repeatedly observed in the Joy, Montezuma, and Ryerson mines. The 
chalcocite zone is always richest in its upper part and gradually grows more pyritic until the sudden transition just mentioned takes place. Below this level evidence of chalcocitization can be found only along the fissure planes. The massive pyrite veins are transformed into pure chalcocite or more commonly into a mixture of chalcocite and pyrite, while the zine blende is eliminated by conversion to soluble sulphate. This forms high-grade ore, with over 5 per cent in copper, and sometimes up to 50 per cent, while the pyritized porphyry turns into low-grade ores with from 2 per cent to 5 per cent of copper. To these large lowgrade bodies the recent great development of the industry is due.

In some mines the chalcocite ore begins almost from the surface; as, for instance, at the Copper King and Jameson veins, and in the insignificant bodies found near the bottom of Chase Creek Canyon. But at Morenci the depth from the surface is rarely less than 200 feet.

The depth on the vein attained by the chalcocite zone from the beginning of direct oxidation to the upper limit of the pyritic zone varies greatly; it is sometimes less than 100 feet, as in the Joy and Montezuma veins (figs. 10 and 11), while under Copper Mountain the average would be somewhat over 200 feet, though directly below the summit it is 300 feet, and the bottom in some places has not yet been reached at that depth (figs. 7, 8, 14, and 17). In general, the upper limit would be represented by a curved surface somewhat less convex than the contour of the mountain. The lower limit is not so regular, but seems on the whole to be flatter, while great irregularities may sometimes exist (fig. 16), no doubt due to exceptional conditions of circulation of surface waters. In the Arizona Central mine partial oxidation has penetrated the chalcocite zone to a depth of 300 feet below the surface, probably owing to its situation underneath a wide gulch. At the Metcalf mines the zone is small and not distinct, the chalcocite being greatly mixed with cuprite. In the Metcalf King mine it has not yet been reached at a depth of 200 feet.

Ore bodies of the chalcocite zone.-In the Copper Mountain mines the veins, of which the Wellington, Kyerson, Humboldt, and West Yankie are the most important, cut across both porphyry and metamorphic limestone (Pl. XVIII and fig. 12). The great ore bodies are almost exclusively confined to the porphyry, and when a vein carrying chalcocite enters the sedimentary masses sometimes included in the porphyry, it ordinarily becomes narrow, poor, or barren (fig. 14). The veins themselves are rarely over a few feet wide, more commonly 12 or 18 inches, and consist of a massive streak of sooty chalcocite ore of great richness. Following this seam are sometimes very large masses of low-grade ore-usually soft whitish porphyry, containing disseminated grains and little seams, running in all directions, of chalcocite and pyrite. The stopes of 
low-grade ore ordinarily range from a few feet up to 50 or more in width; many are 200 feet long and have been stoped for that vertical distance. The great body of concentrating ore between the two Humboldt walls, which dip toward each other, is about 300 feet long up to 200 feet wide, and has been stoped for a vertical distance of nearly 200 feet (fig. 14).

The Humboldt foot wall (Pl. XVIII) continues extremely well defined from the Ryerson mine into the Arizona Copper Company's properties, where it crosses the Wellington vein; here again very large ore bodies, in some cases up to 200 feet wide, are found which have been stoped over a vertical distance of 300 feet (fig. 17).

These bodies usually continue throughout the depth of the chalcocite zone, provided no bodies of metamorphic shale or limestone are encountered, in which case they immediately become impoverished.

While the Fairplay veins, which are entirely contained in porphyry, are not quite so large and the rock is apt to be hard and siliceous, 4 large stopes are opened on them at present, the most extensive being 100 feet long, 35 feet wide, and at present (1903) 160 feet high.

Some masses of low-grade ore in porphyry are less directly connected with separate and distinct fissures, as, for instance, the Eagle stope in the Humboldt mine and the stopes in the Yavapai mine. In the latter the ores seem to follow two porphyry dikes from 10 to 100 feet wide, which, previous to chalcocitization, were already converted into sericite, quartz, and pyrite, and thus offered a congenial place for circulation of copper solutions (fig. 15). Here again the adjoining limestone, though containing disseminated chalcopyrite, proved largely impermeable to oxidizing solutions. These stopes in the Yavapai are considered to belong to the West Yankie lode and form in fact a sheeted zone with many pyritic seams parallel to the walls of the dike. Ore-bearing dikes of the same kind occur in the Shannon mine at Metcalf (Pl. XXV).

In the Arizona Central mine the Williams vein generally follows a porphyry dike of very varying width; most of the ore is contained in it. Farther west it strikes into the larger porphyry masses and the ore bodies widen correspondingly. In the Montezuma vein the chalcocite zone is less developed; most of it seems to have been oxidized. But here too the vein partly followed a dike of porphyry, and the mixture of cuprite and chalcocite which formed the ore was best and largest wherever the porphyry widened out (Pl. XVIII and fig. 18).

In the East Yankie mine a great east-west fault is encountered, along which occur more or less extensive masses of Coronado quartzite, usually embedded in porphyry (fig. 9 and $\mathrm{Pl}$. XVIII). The quartzite is here of a peculiarly loose and crumbling nature, often difficult to distinguish from the altered por- 
phyry. It contains pyrite and sericite as products of early alteration, and is thus equally well adapted as the porphyry for the precipitation of chalcocite. Very large, irregular bodies of low-grade ore have recently been found in this vicinity. All along this fault line the quartzite is pyritized and sericitized; in the bottom of Chase Creek a tunnel has been opened on it in quest of material for converter lining; at this place where no chalcocite has been deposited it contains about one-half per cent of copper, probably as chalcopyrite. Masses of low-grade ore, comparable to those at Morenci, occur at Metcalf, but here the sulphides are mostly converted to oxysalts.

The ore shoots of the Morenci veins are thus materially different from those usually found in gold and silver veins. Their greatest extension is horizontal rather than vertical, and their size depends more on conditions of circulation of surface waters than upon original distribution of copper in the primary veins. Prospecting must rather proceed laterally, guided by favorable indications, than seek extreme depth.

Relation of chalcocite zone to water level.-In the published descriptions of chalcocite ores from other districts this secondary sulphide is always said to develop at or just below the water level. This clearly does not apply to the district here discussed, for in none of the mines has the water level thus far been reached. Nearly all of the mines are, in fact, entirely dry, both in the chalcocite zone and in the pyritic zone.

Chalcocite perhaps forms at the present time in the upper levels of the belt occupied by this mineral where copper-sulphate solutions from oxidizing chalcocite above are abundant and free oxygen absent, but I doubt very much that it is actively forming in the lower levels of the zone. Direct oxidation has, in fact, already penetrated to the deepest levels attained in the pyritic zone; at present it works here chiefly along fissures and seams, but is probably slowly spreading.

I regard the chalcocite zone as formed about an ancient water level, much higher than the present. During the epoch of the Gila conglomerate the water level was surely at least several hundred feet higher than it now is, and it was probably still higher during Tertiary time, in which a moist elimate most likely prevailed.

Relation of chalcocite zone to present surface.-The payable deposits lie, as a rule, at a considerable elevation underneath the hills and ridges. No large deposits have thus far been opened on the lower slopes of Chase Creek Canyon or along its bottom. The Standard and Copper Queen and the Metcalf and Longfellow mines are all about 700 to 800 feet above the bottom of the creek. Only higher up along its course, near Garfield Gulch, a few minor deposits approach the level of the valley. In the canyon below Metcalf many veins have 
been opened in the granite, but they show low values; chalcocite in many places is close to the surface, but the mineral shows ordinarily only as a slight coating on the pyrite. This topographical distribution is the more remarkable when it is recalled that the erosion of Chase Creek Canyon probably antedates the Gila conglomerate, and that, therefore, oxidation would apparently have had a long time in which to act. It confirms the results reached above as to the great age of the chalcocite zone, and emphasizes the slow rate at which oxidation has proceeded.

SURFACE ZONE.

The veins rarely show typical gossan or iron cap with an abundance of limonite and rich, oxidized ores. Their croppings are either entirely barren or contain only a moderate amount of copper, but much richer ore is ordinarily found just above the chalcocite zone. A brief review will indicate the conditions prevailing in different veins.

At Metcalf (Pl. XIX) the wide and strong King lode carries malachite, brochantite, and chrysocolla in very siliceous gangue from the croppings to a depth of 200 feet. The ore is of medium or low grade. No chalcocite has thus far been met. In the Jameson vein, lower down on the slope toward King Gulch, the zone of oxidized ores is shallow and chalcocite was found a short distance below the surface. In the stockwork of seams in the Metcalf mines (Pl. XXII), situated on a high and narrow ridge between Chase Creek and King Gulch, the upper 30 or 40 feet are poor or barren, consisting of siliceous and sericitic porphyry; below this is a great mass of low-grade ore with malachite, chrysocolla, brochantite, cuprite, native copper, and in places a little chalcocite. At a distance of 170 feet below the surface cuprite and chalcocite prevail, while a short distance below this the pyritic zone seems to bave been reached.

In the sericitized porphyry dikes of the Shannon mine the oxidized ores sometimes reach the surface, but more commonly the surface is poor and the chalcocite begins some 50 feet below it.

At the Copper King mine, on the mountain of the same name, carbonate ores were found at the surface and descended in places to a depth of 200 feet. Chalcocite was found only near the surface, where the rock was exceptionally hard. Somewhat below the 300 -foot level chalcocite is reported to be replaced by pyritic ore.

At Morenci the Joy and Montezuma veins in limestone and shale show barren and ill-defined croppings. About 100 feet below the croppings cuprite and malachite appear, and at a depth of 200 to 250 feet the richest bodies of chalcocite, partly oxidized to cuprite, are found (figs. 10 and 11). In the Arizona Central and Williams veins the croppings contained malachite and azurite, forming payable ore. 
Lower down chalcocite appeared, but it is partly oxidized down to the greatest depth attained, 300 feet, and there is no sharply defined line between the two zones (fig. 18).

The Fairplay vein also contained some payable oxidized ore near the surface, but at a depth of 100 feet changed into chalcocite. Croppings of poor chrysocolla ore mark the north-south vein at the Liverpool tunnel on the north side of Copper Mountain, and these, 180 feet lower, are replaced by a vein of massive chalcocite 1 or 2 feet wide.

The Copper Mountain system, consisting of the Wellington, Ryerson, Humboldt, and West Yankie veins, have barren and almost unrecognizable croppings in porphyry, but develop copper carbonate where cutting through limestone. The surface croppings show very small amounts of limonite and the pyrite is wholly oxidized. A short distance below the surface, however, pyrite appears, seamed and surrounded by rusty limonite and efflorescences. Veinlets of blue copper sulphate are very common. At a depth from the surface of 100 to 200 feet (the latter below the summit of Copper Mountain) chalcocite begins to appear and the limonite ceases altogether.

The chalcocite seems to be almost wholly transformed to soluble sulphate, as does also the pyrite. There is practically no payable ore containing malachite, chrysocolla, brochantite, etc.

From the preceding it seems clear that the surface zone is not due to direct oxidation of the primary vein, but rather entirely to the oxidation of the chalcocite zone. This confirms results reached elsewhere as to the great age and gradual erosion of the latter zone.

RELATION OF VEINS TO FAULTING.

The great faults of Morenci are certainly of more recent origin than the veins, for they dislocate them in many instances; but it is not easy to determine the lateral or vertical throw from the position of the veins, on account of the difficulty of identifying the several seans and slips. In the Copper Mountain, Humboldt, and Arizona Central mines the faults cut across the chalcocite zone, but their relation to the pyrite zone can not be seen. In several places rich disseminated chalcocite ore is separated by the fault from barren porphyry, which bears clear evidence of surface leaching. In the Copper Mountain mine on the main-adit level this occurs in the Arizona Central vein, and the leached part is on the eastern or downthrown side of the Copper Mountain fault, as would have been the case if the faulting were later than the formation of the chalcocite. But the evidence does not in this particular case show a greater depth of the chalcocite ore on the eastern side, as would be expected. In the Humboldt mine 
(fig. 17) brecciated zones are encountered, which are parallel and in all probability contemporaneous with the great faults, and these inclose fragments of chalcocite ore, showing that they succeeded the chaleocitization. On the whole, the evidence is fairly conclusive that the faulting took place after part at least of the chalcocite had been formed; the latter process may have and probably did continue after the faulting, and the decisive evidence which the chalcocite zone might have given in regard to such a movement would thereby have been blotted out. Without expressing too positive an opinion it may be pointed out that east of the Copper Mountain fault, the vertical throw of which is about 200 feet, chalcocite ore is found on a much lower level than it has been shown to occupy on the west side.

There seems to be no reason to divide the faulting movement into two or several epochs. As, moreover, the faulting antedates the great volcanic flows, and must be of rather early Tertiary age, there is great probability that the oxidation of the veins had begun already at that date and at least a considerable part of the chalcocite zone had been formed.

On page 99 the conclusion has been reached that the oxidation of the contactmetamorphosed limestone had not begun at the time when the Copper Mountain fault was broken open. These two conclusions are not necessarily contradictory, for the veins would be much more easily accessible to surface waters than the hard altered rocks could be.

None of the veins connected with porphyry follow the great faults, but instead occupy an independent and older system of fissures. But as the faults furnished easy paths for circulating and oxidizing solutions, it is not surprising that bunches of oxidized ore are found in places on these fault planes. The ore in this case is usually cuprite. Thus smaller masses of oxidized ore have been found at several places along the Copper Mountain fault, as, for instance, at a depth of over 300 feet, and at several places above, in the Manganese Blue and Copper Mountain mines. On the Apache fault cuprite ore is found where it crosses the Lone Star tunnel and has been stoped above this level. In the Longfellow mine bunches of cuprite ore occurred on the minor fault, which here dislocates the strata. In the East Yankie disseminated chalcocite ores have recently been found accompanying the great quartzite fault.

VEINS CONNECTED WITH DIABASE.

These are but few in number and the opportunity for their study has not been so good as in the case of the other deposits. Among the smaller veins near Garfield Gulch, the Garfield, Trinidad, and Brunswick are mentioned in the chapters of detailed descriptions. The Brunswick is a small vein in granite,

$16859-\mathrm{No} .43-05-14$ 
following a narrow diabase dike, but has shipped a considerable amount of ore. Above the lower tunnel, which is situated but little higher than the bottom of Chase Creek, the ore consists of about 25 per cent chalcocite and 75 per cent oxidized material, mainly malachite. A winze, below tunnel level, is said to have exposed good chalcocite ore, intergrown with pyrite.

The most important deposit of this class is the Coronado lode, which follows an important fault fissure, with the probable vertical throw of 1,200 feet, between quartzite and granite. A diabase dike follows this fissure in places and shows a width varying from a few feet up to 70 feet. The disturbed zone of the fault is usually wide, often reaching 60 feet. At the Horse Shoe shaft the lode is fully 200 feet wide, consisting of altered granite and contact breccia (fig. 19). It is traceable for nearly 2 miles from the east side of the ridge down to the Eagle Creek foothills, where it disappears underneath the basalt.

The ores of the Coronado mine do not occur as filling in open fissures. A sericitic alteration accompanied by quartz cementation has taken place in the friction breccia, diabase, and crushed material along this great fault; malachite and chrysocolla, the latter especially abundant, occur in this as seams, usually replacing the rock, associated with quartz and kaolin as the last product of oxidizing action. In the main workings this oxidized ore is underlain by chalcocite ore of secondary origin, which occupies a vertical distance of 200 or 300 feet, the upper limit being about 300 feet below the surface. In places, however, the chalcocite reached the surface. Below this, pyritic ores will probably prevail, though along a fissure of this size it would not be surprising to find that the chalcocite in some places had descended still farther. Thorough exploration in the last two years has proved chalcocite ore bodies of promising extent on the deepest level underneath the western slope and about 500 feet below the top of the ridge.

In ores and character of mineralization the Coronado lode is thus very similar to the veins connected with porphyry, but the fact of its occupying one of the fault fissures, which elsewhere are later than the mineral veins, points to a more recent vein-forming period, most likely genetically connected with the intrusion of the diabase dikes.

\section{OTHER VEINS.}

Finally mention should be made of a number of deposits which differ more or less from the types already described. Among these is the Mammoth vein in Garfield Gulch, situated on a contact fissure between limestone and porphyry and carrying chrysocolla only in kaolin gangue. No sulphides have been found. No ore is reported to have been found below tunnel level, and it is possible that no 
primary vein ever existed here, but that the chrysocolla has been formed by descending copper solutions migrating from elsewhere during the epoch of oxidation and precipitated by adsorption of the kaolin.

The Black lode on Markeen and Copper King mountains is another peculiar type of fissure vein which for 2 miles follows dikes of granite porphyry and diabase, evidently occupying the same dike fissure. The ore is low grade and has not thus far been found to be payable; it consists of pyrite, chalcopyrite, epidote, and magnetite, a most unusual combination in a fissure vein. Little opportunity was afforded for its study. Native copper appears near the surface, but so do also the minerals mentioned above.

\section{AURIFEROUS VEINS.}

Gold and silver are practically absent in the Morenci ores. The bessemer copper, in which these metals would naturally appear greatly concentrated, contains only a few ounces of silver and a small fraction of an ounce of gold per ton, not enough to pay for separation. A number of samples of pyrite ores and chalcocite ores from veins at Morenci as well as contact-metamorphic sulphide ores from the same place were assayed for gold and silver. Traces of both were uniformly found, but in only one case was there obtained a weighable amount of gold ( 80 cents per ton). No concentration of gold or silver has taken place during chalcocitization or oxidation. The Metcalf ores are reported to contain slightly more gold than those at Morenci, and in the outlying districts deposits of the same general character and age contain less copper and more gold.

Among these are first to be mentioned the Gold Gulch veins, which have been worked intermittently and on a small scale for many years. Little opportunity was afforded for their study; they form generally narrow and irregular oxidized veins which probably belong to the same age as the veins of Morenci. In the oxidized ore the gold is free and the surface ores have been worked in many old arrastres. Lower down, if the veins remain payable, the gold will probably not be free.

Several minor ore deposits of a character very different from those at the principal mines occur on the limestone ridge extending southeasterly between Chase Creek and Morenci Canyon. Many of these small prospects are irregular bunches, apparently replacements in limestone containing comb quartz, limonite, calcite, galena, lead carbonates, a little copper, and native gold. On the trail along the Chase Creek slope from Longfellow incline to the Hormeyer mine, about halfway between these two points, the Cambrian quartzite is faulted by a fissure plane striking northwesterly, and the northeastern block has dropped about 150 feet. A sill of porphyry overlıs the quartzite, separating it from the 
limestone. Prospects have been opened along this fault both at the horizon of the porphyry and below it. The ore is rusty and decomposed, showing some partly decomposed pyrite.

The Hormeyer mine is the most important of these deposits. It is located in the limestone overlying the quartzite 1 mile east-southeast from the Detroit Copper Company's store at Morenci. It has been worked at intervals during the last few years, and the developments consist chiefly of two levels or tunnels. The total product is believed to have been $\$ 30,000$, chiefly in gold. The croppings are situated at an elevation of 4,760 feet, the top of the Coronado quartzite appearing 100 feet below, on the Chase Creek slope. The deposit is a fissure vein following a porphyry dike, this dike being an offshoot from the main sill of porphyry which so persistently follows the contact of quartzite and limestone in this vicinity. The strike of the vein is northeasterly. The croppings consist of cellular quartz stained yellow by lead oxide. The ore contains a little copper, a great amount of lead carbonate, and native gold. The lowest tunnel, located at an elevation of 4,500 feet, is run along a porphyry dike 6 feet wide, which probably is a continuation of the one noted at the upper tunnel. No ore has thus far been found in the lower level.

The ores of Copper King mine contain from $\$ 1$ to $\$ 4$ per ton in gold. Northeast of Copper Mountain the same vein system continues in granite, usually following porphyry dikes, but here carries less copper and considerably more gold. The croppings yield light gold in the pan, and, in tunnels 50 to 100 feet below, sulphide ore is found in many places, consisting of auriferous pyrite, chalcopyrite, zinc blende, and galena. The value of these veins is as yet problematical.

\section{GOLD-BEARING GRAVELS.}

The gravels lying in front of the hills of older rocks at Morenci and Clifton are auriferous in places. Placers of some value were worked in Gold Gulch, but are now exhausted. An unsuccessful attempt was made some years ago to mine, by the hydraulic method, the bench gravels of San Francisco River, which doubtless derived their gold from the veins northeast of Copper Mountain. The Gila conglomerate south of Morenci contains a little fine gold, which is concentrated in shallow gullies. Payable placers have not been found.

\section{CONDITIONS OF GROUND WATER.}

Permanent water bas not thus far been encountered in any of the mines in the whole district with which this report deals.

Morenci is situated on hills from 800 to 1,500 feet above the principal streams-Chase Creek and Eagle Creek-and the deepest workings in no place 
reach farther than 600 feet below the surface. A little seepage from the surface takes place in case of heavy rains or from the local water supply, and some drifts and crosscuts underneath the town are somewhat damp, especially in the Manganese Blue and Arizona Central mines.

The mines at Metcalf are situated on the high Shannon Mountain from 500 to 1,200 feet above Chase Creek, and here, too, the workings are dry, except in ne place in the Shirley tunnel (p. 318), where a winze struck some standing: water. The few shafts and prospects sunk in the bottom of Chase Creek are the only places containing permanent water. The Copper King mine, situated a few hundred feet below the summit of the mountain of the same name, has a shaft 600 feet deep. In this some crevices with water were found, but soon drained out and no more has come in.

The present stand of the water level, except along the creeks, is practically unknown. It will probably rise as a slightly curved surface from the creek levels in toward the high hills. The total amount of water stored below this water level is probably small.

\section{DEPTH OF OXIDIZED ZONE.}

The presence of products of direct or indirect oxidation shows the depth to which the oxidizing waters or the sulphate solutions have penetrated. In discussing this subject it is necessary to separate the porphyry and the metamorphosed limestones, as they act very differently. In that part of Copper Mountain which has been explored, the average depth of the lower limit of the chalcocite zone is 400 feet, but it increases in places to 500 or even 600 feet. To this depth from the surface the oxidizing solutions descended, and along important fissures they have gone somewhat deeper. But the solutions not only followed fissures but penetrated the porous sericitized porphyry with considerable ease. On the other hand the altered limestones and shales are very compact, nonporous, and impervious. Where circulation was facilitated by fissures, as in the Manganese Blue and Joy mines, the rocks may be partly oxidized to a depth of 400 feet, but this is generally a maximum. There is no well-defined plane expressing the depth of oxidation, which on the contrary proceeds extremely capriciously, entirely fresh sulphides being frequently found very close to the surface.

\section{FLUID INCLUSIONS.}

Fluid inclusions have been observed in the quartz grains of the granite, the quartzite, the porphyry, and the vein quartz occurring in this district. There is nothing uncommon in this; it is indeed the ordinary condition of affairs. As these fluid inclusions beyond doubt contain aqueous solutions, it may be regarded 
as certain that such fluids were present when the quartz grains in question were formed. Attention may be called, however, to certain phenomena in these inclusions which have not been deseribed previously, and which are believed to be of more frequent occurrence than has been suspected.

INCLUSIONS IN GRANITE.

Inclusions filled with a fluid and a bubble of some gas occur abundantly in the quartz grains of all of the granites examined. They are rare, though not unknown, in the feldspars. The form is round or elliptical, or may be that of a negative quartz crystal with prism and pyramid. The size averages about $0.02 \mathrm{~mm}$. The relation of volume between fluid and bubble varies considerably among inclusions in the same grain. In the smaller inclusions the bubble frequently is in active motion. Heated to $40^{\circ}$ or $50^{\circ} \mathrm{C}$. there is no perceptible change in volume of liquid or bubble, and consequently it may be considered certain that the fluid is not liquid carbon dioxide, which has sometimes been observed in the granites, but chiefly water. In some, but by no means all, of the inclusions there is also a solid body contained in the fluid; in some cases this is a transparent cube, in others and more commonly it is an irregular grain or a rod of similar material. This also has occasionally been observed and described in granites from other districts.

\section{INCLUSIONS IN QUARTZITE.}

The grains of the Coronado quartzites being derived from the pre-Cambrian granites, it is only natural that similar inclusions should be found in them. The grains in the quartzite from the East Yankie mine at Morenci show them beautifully, many containing grains or imperfect cubes of a transparent material. Entirely similar inclusions are contained in the quartzite from the foot of the Longfellow incline. Though this quartzite carries secondary pyrite, it is very evident that the inclusions have nothing to do with this later introduction.

\section{INCLUSIONS IN METAMORPHIC LIMESTONES.}

The metamorphism of the limestone to garnet, epidote, diopside, quartz, and other minerals took place under conditions of high temperature and pressure, and almost certainly in the presence of aqueous solutions in fluid or gaseous form. It is a curious fact that these minerals only very exceptionally contain fluid inclusions. The quartz grains formed seem entirely homogeneous and free from these interpositions. Only one or two very small inclusions with moving bubble were noted. The same applies to the garnet and other heavy minerals. The calcite would hardly be expected to preserve any such inclusions on account of its perfect cleavage. 


\section{INCLUSIONS IN PORPHYRY.}

The inclusions in the porphyry are again practically confined to the quartz grains contained in it. They occur chiefly in the phenocrysts, but also in the quartz of the groundmass, where they are usually very small. Naturally the diorite-porphyries are poor in inclusions, but they appear abundantly in the granite-porphyries and the quartz-monzonite-porphyries, with which the ore deposits are chiefly connected. They are found throughout the Metcalf graniteporphyry, which is characterized by large bipyramidal quartz phenocrysts, and they are almost equally common in the smaller quartz crystals of the Copper Mountain porphyry of Morenci. The sericitization of the porphyry affects them but little, for the quartz grains of the porphyries are very rarely altered by this process. In specimens taken from the oxidized zone near the surface many of the inclusions are empty, probably due to the cracking of the grains and attending expulsion of the highly compressed fluid.

The peculiar feature of these fluid inclusions is that they contain as a rule, besides the gas bubble, an extremely sharply defined cube of transparent material and a smaller opaque particle. The very frequent recurrence of this association is a proof that these bodies are not accidental inclusions, but were present, dissolved in the fluid, at the time the quartz crystallized and imprisoned the drop of solution.

The inclusions are elliptical, irregularly rounded, or show the form of their host-that is, a hexagonal pyramid with short prism. Their size ranges from those barely visible up to $0.02 \mathrm{~mm}$. in diameter; this is about the maximum. A frequently recurring size is $0.012 \mathrm{~mm}$. Their distribution in the phenocrysts is irregular; they are not ranged along any given plane or surface. Moving bubbles are often noted in the smaller inclusions. Heating to $40^{\circ}$ and up to $80^{\circ}$ does not noticeably affect the relation of fluid cube and gas; they do not therefore consist of carbon dioxide, but of some aqueous solution. The proportion of volume between bubble and inclusion is not constant; many of them contain large gas bubbles and others quite small ones. To some extent this may be explained by leaking, but comparison of a great number in very fresh rocks makes it certain that there is considerable variation in this proportion. The fluid is colorless.

The cube of transparent salt is very sharply defined and well developed. In polarized light it appears isotropic. Its size varies but is usually of about the same volume as the bubble, and occupies from 4 per cent to 15 per cent of the volume of the inclusion. Such cubes have been sometimes observed before, especially in inclusions contained in quartz crystals, and in a few cases have been proved to consist of sodium chloride. They have also been noted in quartz 
phenocrysts of certain Cornish granite-porphyries. ${ }^{a}$ In the present case the small size of the inclusions, and especially the degree of alteration and oxidation to which most of the specimens have been subjected, render experimental determination of the salt impracticable, at least with the material in hand at present. It may be said, however, that in all probability the substance is sodium chloride. Several inclusions were measured to determine the degree of 'saturation when the substance was dissolved in the fluid, assuming that it is $\mathrm{NaCl}$ and that the liquid is a saturated solution of the same salt at ordinary temperature. Results indicate that this was ordinarily from 5 to 20 per cent above the amount contained in water under normal conditions. In one case it was found that the water must have contained 45 per cent salt. Most of the inclusions also contain a small opaque particle, generally measuring only a fraction of the volume of the bubble or the cube. It has no distinct form; occasionally rod-shaped outlines may be observed, but ordinarily it is so small that it only appears as a black speck. One unusually large particle seemed decidedly black in reflected light, while another inclusion, contained also in a Copper Mountain porphyry, seemed distinctly reddish in transmitted light.

These inclusions are certainly a characteristic feature of the granite-porphyries of Morenci and Metcalf. They prove, I think conclusively, that the acidic porphyry magma was accompanied by notable quantities of aqueous solutions containing a large quantity of a salt which probably was $\mathrm{NaCl}$, and also a smaller amount of some compound containing one or several of the heavy metals. From what follows it is extremely probable that this compound was largely ferric oxide. It may well have contained copper also, although direct evidence of this can not be furnished.

These observations gain in interest when we consider that the porphyry has caused a strong metamorphism of adjoining limestone, the principal feature of which is an acquisition of silica and iron, which in atl probability were given off by the porphyry. It is now shown that the magma contained heavy metals in aqueous solution. Very likely. these solutions also contained much silica, but it should be remembered that this material would most likely have been deposited upon the walls of the inclusion when the rock cooled, and in such a case it would naturally have the erystallographic orientation of the host, from which the new substance could not readily be distinguished.

It is perhaps a significant fact that these inclusions are absent in the dioriteporphyries, which as a rule have no connection with the copper deposits.

As to the quantitative importance of the inclusions, it may be estimated that in some specimens they make up a very perceptible percentage of the rock volume.

$a$ Rosenbusch, H., Mikroskopische Physiographie, etc., 3d ed., Stuttgart, 1902, p. 59. 


\section{INCLUSIONS IN VEIN QUARTZ.}

The results of the examinations of the porphyries encouraged search in the vein quartz. In a greatly altered porphyry from the Butler and London tunnel at Morenci, the groundmass is silicified and contains irregular replacement veinlets of quartz. These were found to contain inclusions with cube and opaque body entirely similar to those in the porphyritic quartz. In some cases three small opaque masses were found in one inclusion.

At Metcalf the granite close to the porphyry is greatly shattered and cemented by veinlets of quartz with scattered and minute foils of specularite and occasionally some pyrite. The quartz of the granite has the usual fluid inclusions mentioned above. The cementing veinlets of granular quartz are full of remarkably beautiful and fairly large (up to $0.02 \mathrm{~mm}$.) inclusions of the usual rounded or pyramidalprismatic form. Most of these contain bubble, cube, and opaque body. The bubble varies as usual in its relative size; the cube is sharply defined and of the size described under the inclusions in porphyry. In a few of the inclusions the dark body is unusually large and has a rounded flat form; they are here translucent with reddish color, and there can be little hesitation in identifying them as ferric oxide or specularite. In some inclusions small grains or crystals, beside the cube, are also found; also oceasionally transparent matter adhering to the wall. All this shows that the same or very similar solutions that formed a part of the magma deposited quartz in the immediately surrounding rock or in the solidified porphyry itself. It is clear that these solutions must have been very hot and probably also under great pressure, since they held dissolved not only much larger quantities of salt than can be taken up by water at ordinary temperature, but also a substance that is probably ferric oxide, which is entirely insoluble under ordinary conditions. This directly connects the solutions contained in the magma with those that deposited quartz shortly after the intrusion, and shows that the general quartz cementation which closely followed the consolidation of the magma was probably not due to atmospheric waters, but to eruptive aftereffects.

The specimens described above are not taken from any one of the regular veins of the district, though it was not believed that the irregular seams permeating the altered porphyry had a different origin from the quartz in the normal fissure veins. From careful examination of this vein quartz, which occurs sparingly with much pyrite in the normal lodes cutting across porphyry and sediments at Morenci, it appears, however, that the two kinds of quartz filling are not characterized by exactly the same kind of inclusions.

Specimens from the Montezuma vein from different places showed typical coarsely crystalline vein quartz full of fluid inclusions, either irregularly 
arranged or in places following certain planes in the grains. The quartz grains often show crystallographic outlines, and are occasionally speared by smaller quartz prisms. There are also a few large irregular grains of pyrite. Though some of the inclusions are irregular the majority have rounded outlines, more seldom bipyramidal. The size ranges up to $0.012 \mathrm{~mm}$. The relation of bubble and cavity is not constant; many inclusions are empty, no doubt due to leaking, for the quartz is considerably crushed. No change is apparent upon heating the slide to $40^{\circ}$, and even to $80^{\circ}$. The inclusion almost always contains solid bodies. Cubes, so abundant in the porphyries, are of rare occurrence and seldom well developed. Most frequent are transparent adhesions to the wall, rod-like masses, pyramidal crystals, or irregular grains. None seem to act on polarized light, possibly on account of their minute size. In most cases the inclusions also contain one or two minute opaque bodies, which can not be further determined. In a few inclusions the solid material is so abundant as to cause the bubble to assume a long-drawn form.

Entirely similar inclusions are found in the quartz of the Humboldt vein, occurring as branching veinlets in porphyry.

The granite along Chase Creek, half a mile above the foot of the Longfellow incline, contains many quartz veins with pyrite, chalcocite, and molybdenite. The quartz contains fluid inclusions, though many of the cavities are empty. Most of the inclusions contain some solid material; a few of these are imperfect cubes; most common are transparent adhesions to the walls, while many also contain opaque bodies.

These observations indicate that the quartz in the fissure veins was formed in the presence of aqueous solutions of probably several salts. The cubes, so prominent in the inclusions of the quartz phenocryst in porphyry and in some of the veinlets occurring throughout the altered area in the same rock, appear to be less uniformly present in the quartz of the regular fissure veins. The solutions depositing quartz must have been very hot, for they contained a much larger quantity of salts than can be dissolved at ordinary temperature. The opaque bodies indicate that heavy metals in some combination were also present in the waters.

The quartz veinlets connected with the processes of formation of chalcocite and of copper carbonates contain only few and small inclusions, in which thus far nothing but the fluid and the bubble have been observed.

\section{GENESIS OF THE COPPER DEPOSITS.}

Though the conclusions in regard to the origin of the copper deposits are either clearly stated or implied in preceding chapters, it may be advisable to again present these results in compact form. 
It has been shown that the intrusions of stocks and dikes of granite-porphyry and quartz-monzonite-porphyry, which took place in late Cretaceous or early Tertiary time, produced an important contact metamorphism in the Paleozoic shales and limestones that happened to adjoin them. This metamorphism resulted in metasomatic development of garnet, epidote, diopside, and other silicates, accompanied by pyrite, magnetite, chalcopyrite, and zinc blende. The sulphides are not later introductions, but contemporaneous with the other contact minerals.

The contact zone received very substantial additions of oxides of iron, silica, sulphur, copper, and zinc, enough to form good-sized deposits of pure magnetite and low-grade deposits of chalcopyrite and zinc blende, all of which are entirely unknown in the sedimentary series away from the porphyry.

In view of the evidence, I consider it impossible that circulating atmospheric waters should have effected these changes. The occurrences of metamorphosed rocks are manifold and found under many varying conditions; there is only one common factor and that is the presence of the porphyry. It is shown that the porphyry magma contained much water which held dissolved various salts, among them some of the heavy metals. Sodic chloride and ferric oxide probably predominated. I believe that the magma contained all of the substances mentioned above, and that large quantities of this gaseous solution (for the critical temperature must have been exceeded) dissolved in the magma were suddenly released by diminution of pressure as the magma reached higher levels and forced through the adjoining sedimentary beds, the purest and most granular limestones suffering the most far-reaching alteration and receiving the greatest additions of substance. It is thus held that a direct transfer of material from cooling magma to adjacent sediments took place. The formation of garnet indicates large gains of ferric oxide and silica. If the magmatic waters carried iron only as ferric oxide some of it must have been reduced to magnetite during the metamorphism, for the latter mineral is much more common than the specularite. These contact-metamorphic deposits sometimes occur at the immediate contact of the main porphyry stock and the limestones. But more commonly they seem to be connected with dikes of the same porphyry close to the principal mass, these dikes being probably more highly charged with magmatic waters.

It is shown that fissures and extensive shattering developed both in porphyry and altered sediments after the congealing of the magma ait that these fissures and seams were cemented by quartz, pyrite, chalcopyrite, and zinc blende, forming normal veins largely of the type of replacement veins. The amount of copper contained in these is usually small, though in places possibly large enough to form pay ore. The bulk of the veins consists of pyrite. Two classes 
of veins may be distinguished. The usual type is practically always connected with the granite-porphyry or quartz-monzonite-porphyry; it occurs in these rocks or along dikes of the same. The smaller division consists of veins connected in their occurrence with diabase dikes. The genesis of the former type will first be discussed.

As far as the metallic minerals are concerned, there is a striking similarity between the veins connected with porphyry and the contact-metamorphic deposits, the only difference being in the magnetite, which does not occur in the veins proper and only subordinately in certain of the altered wall rocks. A relationship is also clearly seen in the remarkable action of the vein solutions on the adjoining wall rock wherever this is limestone, tremolite and diopside being formed in it by metasomatic action. On the whole, iron and silica are the main substances added during contact metamorphism as well as during the vein formation.

A study of the fluid inclusions in the vein quartz proves conclusively that the veins were formed in the presence of aqueous solutions and that these solutions were at a high temperature, for they contained various salts-in part those of heavy metals, probably iron, which were separated during the cooling of the crystallized quartz. This entirely eliminates the possibility of deposition by cold surface waters and points to two or three eventualities: Deposition by atmospheric waters heated by contact with the cooling porphyry, or deposition by ascending magmatic waters, or, finally, deposition by a mixture of both. In any case the metals must be derived from the porphyry or from deep-seated sources below the porphyry, for, as stated above, the presence of porphyry is the only common factor in all occurrences. It is clear that a positive solution of these questions must be most difficult, but here again the fluid inclusions offer the only direct evidence. In the quartz seams penetrating the granite near the porphyry contact at Metcalf inclusions were found which are indistinguishable from those characteristic of the quartz phenocrysts in the porphyry, and it must be concluded that the same highly heated and highly charged solutions were active in both cases. This directly connects some of the quartz cementing fractures in porphyry with magmatic water and would appear to be evidence of considerable importance. The vein quartz of Morenci contains inclusions which, in some cases, are identical with those in the porphyry and in other cases slightly different from them, but always indicate highly heated solutions. The metasomatic action of the waters proves them to have been rich in silica and various salts, among which were some of the heavy metals, but entirely deficient in carbon dioxide. Considering this evidence, together with the similarity of the products of these processes with those of contact metamorphism, I think it certain that part of the mineral solutions were directly derived from and formed part of the porphyry magma, and 
I believe it is probable that they were entirely derived from this source. It seems likely that the fissuring, which took place after the cooling, opened rents of escape for magmatic waters under heavy pressure at lower levels, and that they ascended on these fissures, depositing the heavy metals and the silica and acquiring at the same time carbon dioxide from the sediments which they traversed.

As to the depth at which deposition took place no positive evidence is available on account of lack of data as to the extent of erosion. But from stratigraphic considerations it is not likely that the depth from the surface was more than 2,000 or 3,000 feet. The cause of the deposition was no doubt decrease in temperature, just as we see the deposits formed in the cooled fluid inclusions. I think it likely that in most cases the solutions were present as liquids, for, assuming that the waters communicated with the surface, neither pressure nor temperature could have been high enough to reach the critical point. Probably this does not matter much, for the properties of water appear to be very similar for some distance on both sides of this point. Copper, iron, and zine are practically the only important metals present in the main deposits close to the main porphyry stock; but it is interesting and suggestive to note that gold begins to appear in veins which are located some distance away from the central porphyry.

The veins connected with diabase dikes are few in number and opportunity for their study has been limited. It seems, therefore, risky to express a definite opinion on their genesis, except that the copper and iron sulphide were in all probability derived from the diabase itself, either by means of magmatic or heated atmospheric waters.

The deposits thus far described are in general of low grade, only rarely containing enough copper to be classed as economically important. Those in shale or limestone consisted of disseminated sulphides, in places irregularly concentrated or accumulated along certain strata, according to the well-defined tendency of contact metamorphism. Those in porphyry consisted of heavy veins of pyrite and a small amount of other sulphides, surrounded by zones of dissemination of the same sulphides.

It remained for the surface waters, as erosion gradually exposed the deposits, to alter and enrich them in manifold forms.

From evidence presented above, it must be concluded that some of the deposits, especially the fissure veins, were laid bare by erosion and attacked by surface waters at an early date, probably before the principal faulting movement and certainly before the eruption of the Tertiary basalts and rhyolites. Oxidation has thus acted on them for a very long period.

The irregular and tabular deposits of oxidized ore in limestone and shale 
have been formed partly by direct oxidation of sulphides and partly by the influence of sulphate solutions derived from the widely disseminated chalcopyrite due to contact metamorphism; a great enrichment has taken place, due to decrease of volume and addition of copper from the circulating sulphate solutions. Some of the oxidized deposits in shale may, however, be wholly due to adsorption ex rrted by the kaolin in the shale on these sulphate solutions.

In the veins, especially in those which traverse the porphyry stock or follow porphyry dikes, the history is more complicated. It has been shown that oxidation dates back to Tertiary time and that the water level then was considerably higher than it is at the present time. By the action of descending sulphate solutions on pyrite, chalcocite was deposited very extensively and very likely the great vertical extent of the chalcocite zone, ordinarily from 200 to 500 feet, is due to slow and gradual changes in the water level. Disintegration and erosion removed the iron cap (the products of direct oxidation of the primary vein) and began to oxidize the exposed chalcocite zone. In practically all of the veins the surface zone of poor ore is due to the direct oxidation of chalcocite. The solutions from this part descend and add richness to the upper part of the remaining chalcocite zone. But at the present low stand of the water level and in the exceedingly dry climate the lower limit of the chalcocite zone is probably stationary. Considering that the surface zone has been formed by oxidation of chalcocite, the total depth of the chalcocite zone was about 100 feet greater than indicated above, and even this is a minimum, because a certain amount has been removed by erosion.

The copper deposits of Clifton and Morenci are thus believed to have been formed primarily by mineral-laden magmatic waters, partly acting as gas and partly as liquids, and in both cases derived from a magma of granite-porphyry. These solutions were evidently directly released from the magma without a preliminary concentration in pegmatitic or aplitic dikes, which indeed do not occur in this district in association with the porphyry. It is perhaps superfluous to emphasize that these conclusions are meant to apply only to this district, and that the mode of origin deduced for the Clifton-Morenci deposits is not necessarily that of all other ore bodies.

The earlier processes of magmatic origin produced low-grade deposits of pyritic ores, and the final concentration to payable ore bodies has chiefly been effected by descending and oxidizing surface waters of atmospheric origin.

The following scheme of genetic classification of the deposits is presented:

I. First epoch: Formed during the consolidation of porphyry by ascending and laterally moving water gas.

(a) Contact-metamorphic deposits.-Irregular or tabular disseminations in shale or limestone, sometimes following stratification planes or dike contacts. The ores consist of pyrite, chalcopyrite, zinc blende, and magnetite, and are generally not payable. 
II. Second epoch: Formed shortly after the consolidation of the porphyry by ascending hot magmatic waters; contained in porphyry, in granite, or in more or less contact-metamorphosed sedimentary rocks.

(a) Fissure veins.-Lode systems or single veins. Central seams of pyrite, chalcopyrite, and zinc blende, accompanied in porphyry by wide zones of sericitization and pyritization, and generally not payable.

(b) Stockwerks and irregular disseminations.- Same occurrence and character of mineralization; not payable.

III. Third epoch: Fissure veins formed by ascending waters shortly after the intrusion of diabase. IV. Fourth epoch: Formed by descending atmospheric waters acting on Classes I, II, and III.

(a) Concentrations by direct oxidation and secondary chalcocite deposition in Type I; payable.

(b) Concentrations by direct oxidation and secondary chalcocite deposition in Type II, a; payable.

(c) Concentrations by direct oxidation and secondary chalcocite deposition in Type II, b; payable.

(d) Deposits caused by sulphate waters along otherwise barren fault planes; occasionally payable.

(e) Deposits caused by sulphate waters along shale beds; partly payable.

\section{FUTURE OF THE DISTRICT.}

During past years the rich ores from the oxidized deposits in limestone and shale furnished the mainstay of the Clifton-Morenci copper district. At present the very large bodies of low-grade chalcocite ores, requiring concentration, are those responsible for the rapid increase of production. The question as to the extent of these masses is clearly a vital one. Speaking broadly, very large reserves are available both-at Morenci and Metcalf, so that the present production will doubtless be maintained for a number of years. But even the largest reserves diminish rapidly under exploitation on the scale prevailing in these districts and the problem of new reserves is bound to come to the front. As shown above, deep mining has not proved satisfactory, once the pyritic zone has been reached. Lateral exploration within the chalcocite zone is more to be recommended, and a vigorous policy to this effect has been adopted by the three largest companies. As shown on Copper Mountain, the outerops may fail altogether to indicate the value of the ground underneath, and with this in view development work is proceeding actively north and northeast of Morenci. The quartzite fault and, on the whole, the country between Morenci and Metcalf, underneath the high porphyry hills, deserve more careful prospecting. In some places, as in the East Yankie mine, this policy has already borne fruit, and it is likely to prolong the life of the mines many years. Under present conditions and methods it does not seem likely that ores of much lower grade than the lowest now mined can be profitably worked, the present minimum being 2.5 per' cent of copper. 


\section{CHAPTER VI. \\ THE MINES OF MORENCI. \\ TOPOGRAPHY.}

A special map (Pl. XVII) has been prepared on the scale of 1 to 12,000 for the purpose of showing in more detail the important features of the geology at the town of Morenci, where the principal mines of the district are located. The map shows a rectangular area nearly $1 \frac{1}{2}$ miles from east to west and 1 mile from north to south. The topographical and geological discussion of the Morenci district can not conveniently be limited to this small area, but must include some features of the surrounding country south of a line drawn from Gold Gulch on the west to Concentrator Canyon, emptying into Chase Creek, on the east. This comprises the southern end of the mountain lands of pre Tertiary rocks between Chase Creek and Eagle Creek. It forms a belt 5 miles wide, gradually tapering southward, and is bordered by the plateaus of the Gila conglomerate, here reaching elevations of about 4,500 feet.

The central point of the region, topographically, is the high porphyry ridge immediately overlooking Morenci and attaining elevations of 5,500 feet. Toward the west and east its slopes descend to Gold Gulch and Concentrator Canyon. South of this point the drainage is toward San Francisco River, in a southeast or southsoutheast direction, and all of the gulches are more or less completely determined by fault lines. From near Copper Mountain four divides branch out as long, mostly flat-topped ridges, with elevations of from 4,000 to 4,500 feet, dropping off toward the gravel plains of the Gila conglomerate rather suddenly at their terminations. Steep descents toward the east and more gradual slopes toward the west are the results of the dips of the fault blocks.

The eastern limit of the area under discussion follows Chase Creek Canyon, an abrupt $V$-shaped trench sunk 1,000 to 1,400 feet below the ridges at Morenci, its slopes in places broken by almost perpendicular bluffs of Coronado quartzite or Longfellow limestone.

The only important tributary is Concentrator Canyon, which joins Chase Creek a short distance above the foot of the Longfellow incline. The south branch of this canyon, the lower part of which is excessively precipitous and the grade broken by several abrupt falls, heads $1 \frac{1}{2}$ miles westward in the high porphyry 

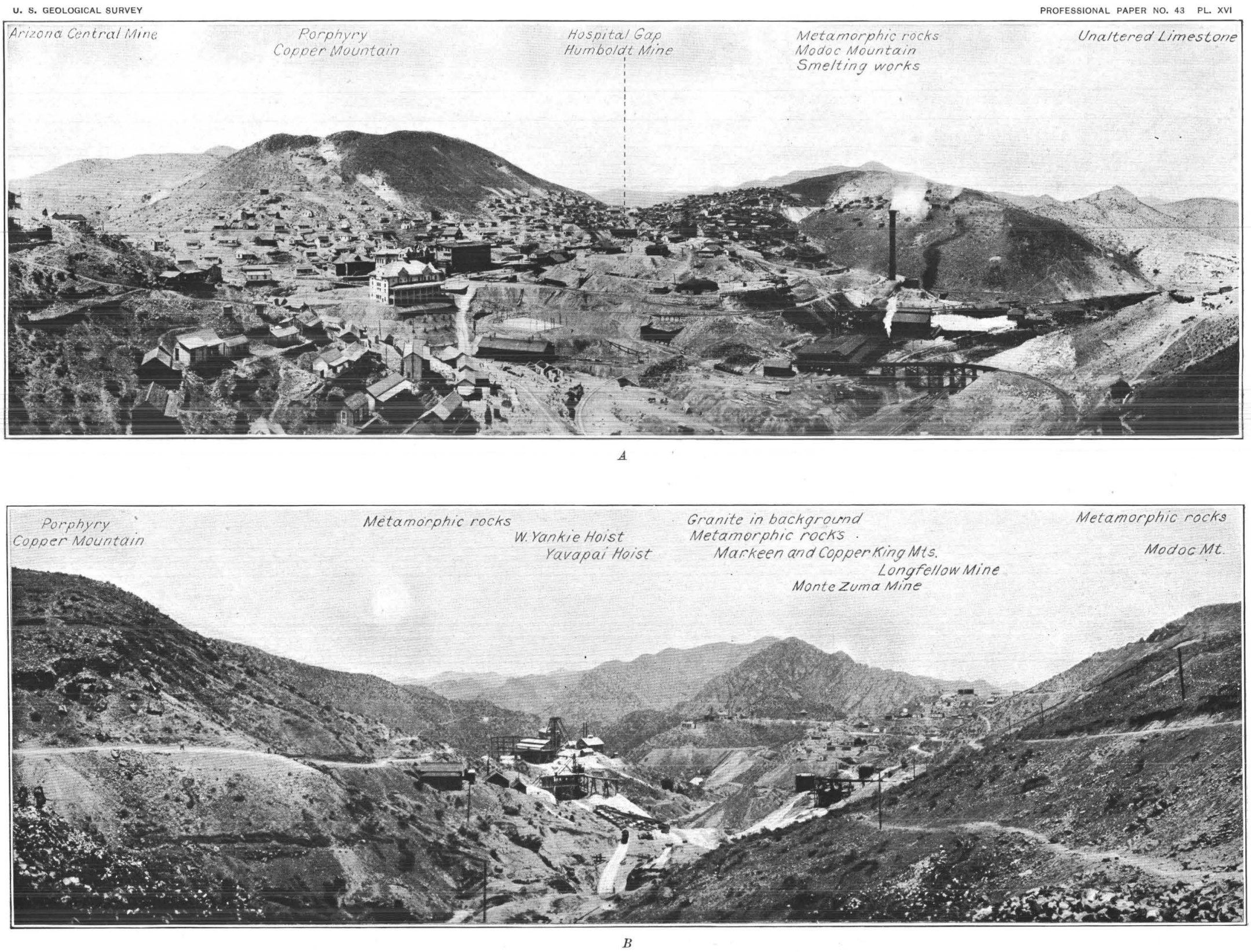

PANORAMIC VIEWS OF MORENCI. 



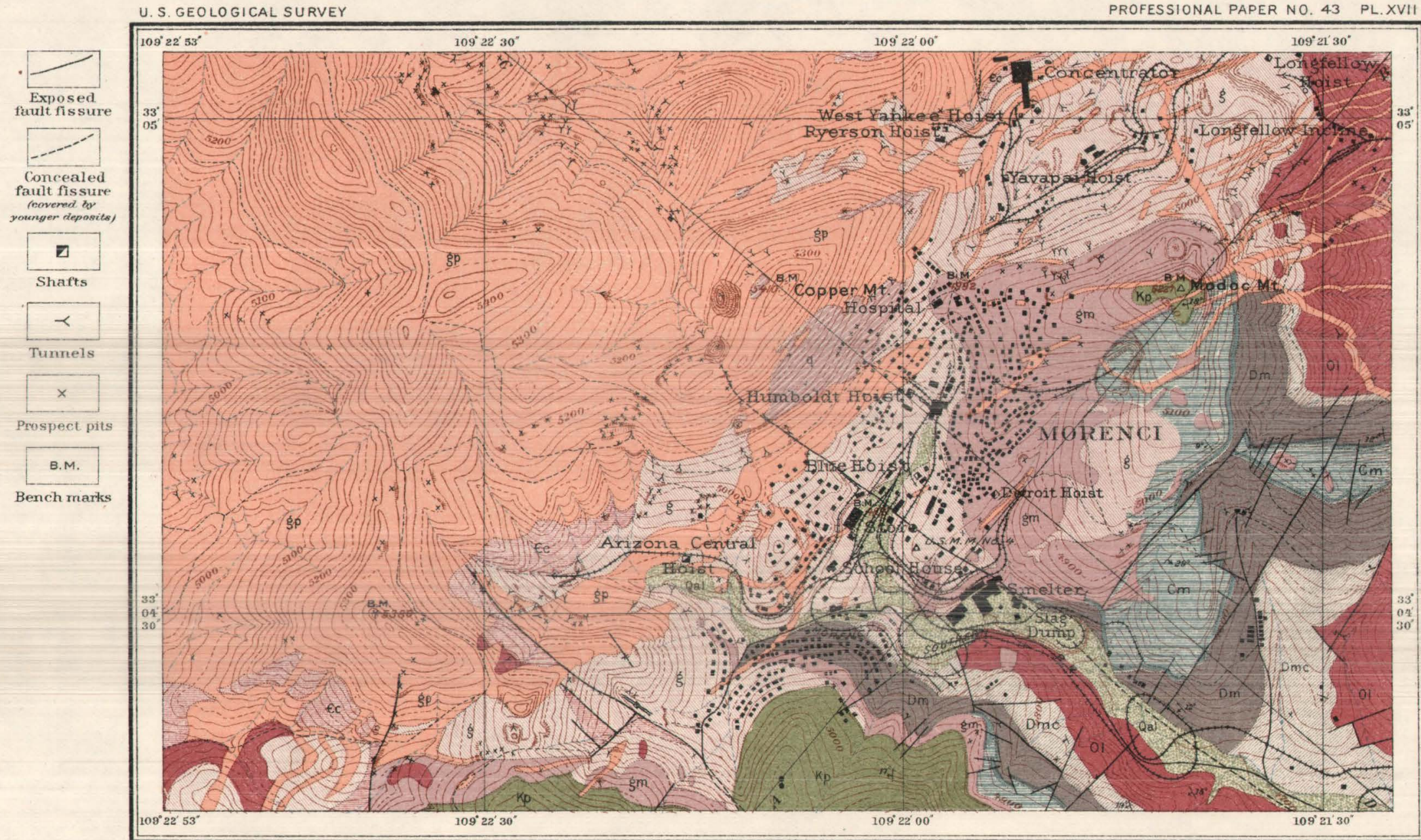

E.M. Douglas, geographer in charge Triangulation and topography surveyed in 1901 .
GEOLOGIC AND TOPOGRAPHIC MAP OF THE VICINITY OF MORENCI, ARIZONA.

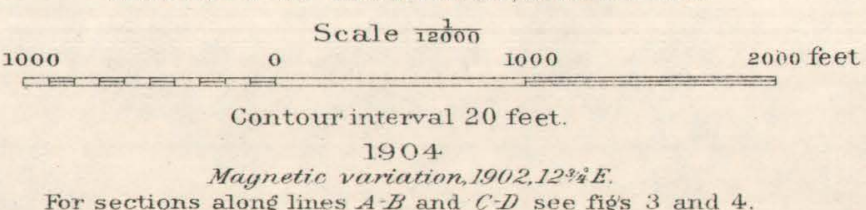

LEGEND

SEDIMENTARY ROCKS

Qal

Alluvial sands and gravels

$\mathrm{KP}_{\mathrm{u}}$

Pinkard formation
Yshates and suntion

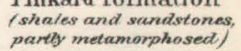

高

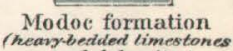
and idoumitisst

$\mathrm{Cmc}$

Modoc formation
Toradiferous Limastone

Morenci formation

Dimc

Morenei formation
Lower tryyllaceous timestone

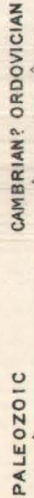

Longfellow formation cencrly limestanes
and lime sheless

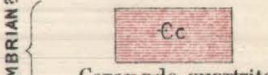

Coronado quartzite METAMORPHIC ROCKS s Contact metamorphic limest
and shale of Paleozoic áse sm Contact metamorphic limeand mannetite. a Metamorphic quartzite IGNEOUS ROCKS

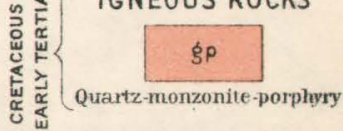



ridges north of Copper Mountain, while the north branch continues for about the same distance northwesterly toward the Coronado quartzite ridge. In the upper parts of the branches the slopes are not excessively steep, though very rocky; a more abrupt bluff sometimes marks the descent of the last 50 feet to the bottom of the canyon. The two concentrators of the district discharge their tailings into this watercourse.

South of Copper Mountain is the head of Morenci Canyon, whose valley opens out like an amphitheater; the town of Morenci is situated on the slopes of these hills. Immediately below the town the canyon becomes narrow, though not particularly deep; a little farther down it is bordered by abrupt walls of limestone and quartzite, 200 to 300 feet high, and after a course of 1 mile enters the open plain of the detrital terrace which occupies so much space on the north side of Gila River. Five miles farther south it discharges directly into San Francisco River.

A high limestone ridge, in part flat topped and sloping west, forms the divide between Morenci Canyon and Chase Creek. The principal points are Modoc Mountain (elevation 5,227 feet) and a sharp peak which, 1,500 feet to the southwest, attains an almost equal elevation. Modoc Mountain is separated from Copper Mountain by a gap (elevation 4,492 feet) connecting the main part of Morenci with the Yankie and Longfellow mines on the east side. A very steep slope, the lower part of which is practically inaccessible, leads down from the limestone ridge to the level of Chase Creek, a total distance of 1,200 feet. The brown cliffs of Coronado quartzite, 200 feet high, and the gray capping slopes of Longfellow limestone form very prominent topographic features $(\mathrm{Pl} . \mathrm{V}, B)$, which mark the margin of the mountain region for nearly 3 miles southwest of the mouth of Morenci Canyon and overlook the long smooth ridges of Gila conglomerate stretching far to the southward $(\mathrm{Pl}$. IV, $A$ ). The ridge west of Morenci Canyon is similar to that forming its eastern wall.

Apache Canyon heads a short distance south of Morenci and pursues an almost straight course of 2 miles down to the plains, following the direction of a fault plane. It is well graded and its walls for a long distance form precipitous bluffs up to 500 feet high. The ridge on its west side is remarkably even, its top being formed of gently westward-dipping limestone.

The fourth canyon is that of Silver Basin Creek; it heads in the flat, wide basin which extends, covered by shales and porphyry, about 2 miles soutbwest of Morenci, contracting near its mouth to a short but almost impassable gorge.

The divide between Gold Gulch and the gulches draining southward continues for $2 \frac{1}{2}$ miles southwest from Morenci as an irregular ridge.surmounted 16859-No. $43-05-15$ 
by sharp knobs, the elevations ranging from 5,000 to 5,500 . This ridge then swings around to the southward and near the southern edge of the mountain area forms conspicuous dome-shaped, light-colored porphyry hills, on the highest point of which bench mark 5,175 is located.

The general aspect of the country is that of barren rocky ridges and hills, . of a color ranging from the light brownish yellow of the porphyry to the bluish gray of the limestone or the dark brown of the quartzite cliffs.

A very scanty vegetation imperfectly covers the ground. There are no trees within the area, except a few cottonwoods in the bottom of Chase Creek Canyon, but small desert bushes, yuccas, maguey plants, and small cactus are fairly abundant, especially on the higher points.

Chase Creek contains a small stream of water, largely derived from the concentrators at Morenci. With this exception none of the watercourses within this area carries permanent water, nor are any springs known. The workings of the mines are all dry. As a consequence of this the water necessary for the town and the mines must be pumped from a considerable distance. A part of it is supplied from San Francisco River, the Arizona Copper Company having one pipe line from Clifton, and the Detroit Copper Company another, which takes its water from San Francisco River several miles below Clifton. The drinking water is furnished by a pipe line from Eagle Creek. This water, although somewhat hard, is much better than that of San Francisco River, which is contaminated in many ways. The pumps in Eagle Creek raise the water against a head of 1,500 feet.

A wagon road connects Morenci with Clifton, following the course of Morenci Canyon. Another road, which, however, is in poor condition, connects Morenci with the pump station of Eagle Creek. It crosses the dividing ridge at the gap immediately south of the town.

The Morenci Southern Railroad, which connects the town with Guthrie station, on the Arizona and New Mexico line, at Gila River, follows Morenci Canyon, and in order to gain the elevation of the town makes four complete loops within a distance of 1 mile. A very extensive system of narrow-gage roads connects the mines, the smelter, and the concentrators. The main line of communication begins near the Arizona Central on the south of Copper Mountain, and continues northeasterly at an elevation of about 4,870 feet. Side tracks connect this level with the Detroit Copper Company's smelter, located at the place where the canyon opens up into the amphitheater of Morenci. A tunnel pierces the ridge between Copper Mountain and Modoc Peak, and the tracks extend from there, at the same elevation, north of the Detroit Copper Company's concentrator, and also follow the contour of the hill to the concentrator of the Arizona Copper Company 
(elevation 4,900 feet). Still another tunnel penetrates Longfellow Ridge. Through this tracks connect with the head of the Longfellow incline (elevation 4,780 feet), which descends the steep slope to Chase Creek (elevation 4,000 feet), where ore bins are located and the transfer of ore is effected to the cars of the Coronado Railroad, which follows Chase Creek from Clifton to Metcalf.

The town of Morenci spreads out irregularly on the slopes of the amphitheater at the head of Morenci Canyon. As a consequence of the topographical features, it has been found impracticable to lay out regular roads or streets. The houses are situated in terraces, one row above another, and are connected by trails. Transportation above or below the railroad tracks is effected by means of the always present and useful burro. The total number of the inhabitants may be estimated as 4,000 or 5,000 .

\section{GEOLOGY.}

The sedimentary formations occupy the larger southeasterly part of the area shown on the Morenci special map (Pl. XVII), while the high ridges of the northwestern area consist of porphyry of intrusive origin. The contact line between the two terranes runs in the main northeasterly, but exhibits the greatest irregularity in detail, masses of sediments being included in the porphyry and dikes of the latter rock that penetrate the water-laid formations.

The strata consist of chiefly Paleozoic limestones and shales dipping $5^{\circ}$ to $25^{\circ}$ westward. In the southeastern part of the area the rocks are unaltered and succession and structure are easily ascertained. Two northwesterly trending faults divide the sedimentary area into three blocks, with downthrow on the east side; the Copper Mountain fault follows Morenci Gulch and the Apache fault courses just west of the town. The sediments are much metamorphosed all along the contact with the porphyry, and the width of this altered zone averages 1,500 feet. Within this belt it is sometimes difficult to ascertain succession and structure of the beds, as great complication results not only from alteration but from dislocation by the intrusion of porphyry and by the later period of faulting.

The principal copper deposits occur either in this altered zone of sediments or in the porphyry close to the contact. A few smaller deposits lie in the porphyry far away from the contact line.

For purposes of a preliminary orientation the rocks and structure of the Morenci hills are described in this paragraph in briefest outlines. Subsequently, the detailed geology of the vicinity of Morenci will be taken up, as the important mineral deposits are all contained within a small area.

The basal pre-Cambrian granite is exposed only in the deep trench of Chase Creek and along the edge of the southeastern foothills for a distance of 3 miles 
southwest of Morenci Canyon. Of the sedimentary series resting on granite, the Coronado quartzite and the Longfellow limestone cover much of the eastern part of the area. The Coronado (Cambrian) quartzite forms almost perpendicular brown bluffs, up to 200 feet high, which follow the west side of Chase Creek Canyon, descending to the bottom at the foot of the Longfellow incline (elevation 4,000 feet), and thence, gradually rising, overlook the Gila conglomerate at the mouth of Morenci Canyon. Capping the granite the Coronado formation

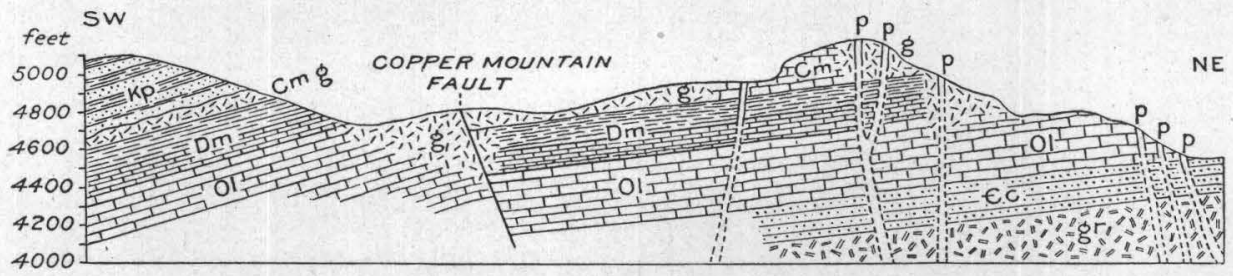

FIG. 3.-Geological section along line A-B of area shown on Morenci special map. Kp., Pinkard formation (Cretaceous); Cm., Modoc formation (Carboniferous); Dm., Morenci shale and argillaceous limestone (Devonian"); Ol., Longfellow formation (Ordovician); Cc., Coronado quartzites (Cambrian?); Gr., granite (pre-Cambrian); qp., quartz monzonite-porphyry and diorite-porphyry (Cretaceous or Tertiary); g., contact-metamorphosed limestone and shale.

continues as a prominent scarp for 3 miles along the foothills until replaced by the covering limestones.

The Longfellow (Ordovician) formation, with its 300 to 400 feet of cherty and partly dolomitic limestones and lime shales, covers all of the principal ridges south and east of Morenci.

The rocks of Devonian age, consisting of the Morenci shales and associated limestones, with a total thickness of 175 feet, are exposed fairly extensively east

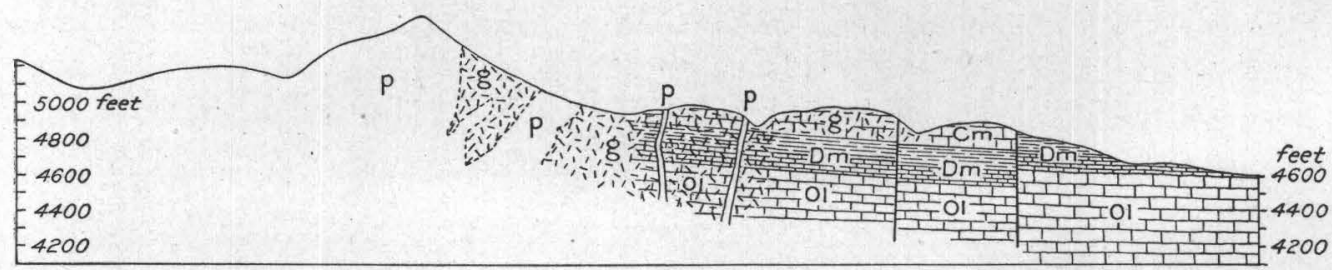

FIG. 4.-Geological section along line C-D of area shown on Morenci special map.

and south of the town. A strip of the limestone is also exposed along the east side of Silver Basin.

The lower Carboniferous is represented by the Modoc limestones up to 160 feet thick. This formation is best seen on the hills adjacent to the east side of Morenci; elsewhere it is not extensively developed. This whole conformable series dips west at angles of from $10^{\circ}$ to $20^{\circ}$.

On Modoc Mountain near Morenci and on the ridge southwest of that town a series of beds are exposed which consist of shales and sandstones, partly altered at this locality, and, though having the same dip as the underlying Carbonifer- 
ous, separated from it by an unconformity due to erosion. While no fossils have been found in them at Morenci, they are referred to the Cretaceous with considerable confidence, for similar beds containing Cretaceous fossils are exposed on a large scale south of Gold Creek, and surround the prominent porphyry hills $2 \frac{1}{2}$ miles south-southwest of Morenci. In the problems of mineral deposition these Cretaceous sediments are of little importance.

Intrusions of porphyry occupy large areas and are of paramount importance for the study of the mineral deposits. These rocks did not, as far as we know, reach the surface during the time of their eruption, but consolidated far below, and have been exposed by later erosion. The main mass of porphyry, the greatest in the Clifton quadrangle, is that extending between the Eagle Creek foothills near Gold Gulch on the southwest up toward Metcalf on the northeast. To this stock belong the high ridges of Copper Mountain; its southern boundary line runs in a northeasterly direction along the divide separating Gold Gulch and Silver Basin. Crossing the ridges into the head of Morenci Canyon, it continues along the foot of Copper Mountain and finally reaches Chase Creek 1 mile below Metcalf. The high yellowish-gray ridges connecting with Copper Mountain consist entirely of this porphyry. At Morenci the stock is a mile wide and is bordered on the north by granite and quartzite. The contact lines are extremely irregular in detail, bearing constant evidence of the intrusive origin of the porphyry, and the Paleozoic sediments adjoining are greatly disturbed and contain many dikes, best exposed in the vicinity of Longfellow mine and Modoc Mountain. Very few dikes are, however, found in the limestones at a greater distance from the contact. The great Morenci stock connects with an elliptical area 1 by 2 miles, which occupies the porphyry hills 3 miles southwest of Morenci. This would seem to be a laceolithic intrusion in the gently inclined Cretaceous strata. The beds on the east side appear to dip under it, and it seems to have been covered by those on the west side. Several smaller rounded laccolithic masses and also some dikes are found in the Cretaceous shales of Silver Basin Creek. Of similar nature is probably the mass which caps the hill of Cretaceous strata 1 mile south of Copper Mountain. The tendency of the porphyry to form laccolithic masses or sllls is further illustrated in the remarkably persistent sheet which, intruded between the quartzite and the covering limestone, follows along the Chase Creek slope from a point near Modoc Peak to the mouth of Morenci Canyon, and is usually about 50 feet thick.

The sill and the laccolithic masses, as a rule, consist of diorite-porphyry, with comparatively little quartz in the groundmass. The light-colored rock carries small crystals of labradorite, hornblende, and biotite in a microcrystalline groundmass. The great stock, on the other hand, and most of the dikes near Morenci 
consist of a much more quartzose rock of an intermediate type, corresponding well to granodiorite-porphyry. The small phenocrysts consist of andesine or labradorite, together with some quartz and a little biotite. The light-colored microcrystalline groundmass consists of quartz and unstriated feldspar.

The structural features of most interest are the faults; which subdivide the area into several blocks. Jointing is pronounced in the porphyry, but in none of the rocks has schistose structure been developed.

One set of faults assumes a northwest or north-northwest direction. There are three or four of these which are of importance and several subordinate ones. The Copper Mountain fault follows the course of Morenci Canyon from its mouth to the summit of Copper Mountain, but has not been traced farther into the porphyry. The east side of this fault shows a drop of about 200 feet, the dip of the fault plane being steeply to the northeast. Apache Gulch is followed by a double fault with the direction of north $30^{\circ}$ west. The east side of this has dropped about 800 feet, the throw probably diminishing northward, where it crosses the extreme western head of Morenci Gulch. Parallel to this fault and half a mile distant to the west is the fault along the east side of Silver Basin, which shows a downthrow on the west side of about 200 feet. A shorter fault, following the lower part of the eanyon of Silver Basin Creek, has a probable throw on the same western side of about 400 feet. The southern part of the mountain area of older rocks is thus divided into four or five long blocks, the most westerly of which is the largest. This last block may be further faulted, though no definite evidence of this has been obtained.

A great number of smaller faults with diverse displacements running in easterly, northeasterly, or southeasterly directions divide these blocks, but do not seem to be continuous across the greater north-northwest fault lines.

More important than these are these east-west dislocations by which the whole southern part of the mountain area has successively dropped to the level which the strata attain near Morenei and south of it. This group may be called the Coronado fault system.

The first of these dislocations is the Soto fault, probably continued eastward along the contact of porphyry and granite to below bench-mark point 6,370 . The south block has dropped from 200 to nearly 800 feet. The second dislocation is the Concentrator fault, by which quartzite and granite have been brought to a level on the bluff overlooking Chase Creek at the Arizona Copper Company's concentrator. The last is the Longfellow fault, near the mine of the same name. The Longfellow limestone on the south side has here dropped 200 or 300 feet. Neither of these two last faults has been traced through the porphyry westward, but their equivalent is prominently shown on the ridge east of 
Chase Creek, where the Cambrian quartzite now rests at the foot of Markeen Mountain, indicating a total displacement of at least 1,500 feet.

Wherever the fault blccks consist of stratified rocks they are fairly uniformly tilted westward, with dips ranging from $10^{\circ}$ to $30^{\circ}$. The relative age of Copper Mountain and the Coronado fault systems is not definitely known, but the two are believed to be about contemporaneous. The faulting as a whole involves a step-like settling of the area toward the south with a simultaneous development of northwesterly dislocations along which diverse displacements have occurred.

\section{LODE SYSTEM.}

The veins of Morenci form a rather complicated system, partly cutting the porphyry, and partly the limestone and shale a few hundred feet southeast of the contact. In character the veins are usually simple-that is, they consist of a single sheet of pyrite or chalcocite lying close to a plane of dislocation-but they are, as a rule, surrounded by wide zones in which metasomatic formation of sulphides has taken place. This zone, together with the central vein, is referred to as a lode. These lodes dip steeply northwest or southeast, or stand vertical and have a strike averaging due northeast. Their outcrops are rarely traceable and they frequently branch or lose themselves, but on the whole form two distinct systems of linked veins. Two miles cover the entire length and the most important part is confined within less than 1 mile.

The first system lies in the porphyry and the veins generally dip northwesterly. The first two members are the Fairplay and Wellington veins (Pl. XVIII). The Fairplay is traceable for 2,000 feet, continues across the Butler tunnel, and probably breaks up in several stringers farther westward, as shown in the Lone Star tunnel. Half a mile farther southwest a vein, possibly identical with the Fairplay, crosses the Eagle Creek road. The Fairplay vein is more easily traceable on the surface by copper-stained croppings than any of the others. A few hundred feet to the southeast the strong Humboldt lode appears, forming a curve with the convex side toward the contact, and eventually crossing the Wellington lode. Its foot wall is one of the most persistent features of the system. The Ryerson vein is a link connecting the Humboldt and the Wellington.

The second system begins near the Humboldt lode on the northeast and forms a long curved array of branching and linked veins not traceable on the surface. It begins in the Montezuma and continues through the Joy. After an interruption, the system appears again in the Williains and Hudson veins, the former continuing up to the Apache fault. 


\section{UNDERGROUND WATERS.}

It has already been mentioned that Eagle Creek and Chase Creek are the only permanent streams near Morenci. Of these Eagle Creek has a comparatively large watershed and carries a stream which even in the driest seasons is said to amount to 100 miner's inches. The underflow in the sandy bed probably amounts to much more than this. Chase Creek, on the other hand, contained originally only a very small quantity of water, which may not have reached much below the foot of the Longfellow incline. Now, however, a large quantity of water is added at the mouth of Concentrator Canyon from the ore-dressing plants at Morenci, this being derived by pumping from San Francisco River. As a consequence of this, Chase Creek contains about 100 miner's inches of water heavily charged with tailings, and this artificial stream continues down to its junction with San Francisco River at Clifton.

None of the canyons in the vicinity of Morenci contains running water except immediately after very heavy rains. The town is situated about 800 feet above Chase Creek and 1,200 feet above Eagle Creek.

Ground water has thus far not been found in any of the workings of the mines at Morenci, the deepest levels of which in the Manganese Blue and Arizona Central mines are at elevations of approximately 4,500 feet, or 500 feet above the stream in Chase Creek. The spring nearest to Morenci is situated in Gold Gulch at an elevation of 4,800 feet. Lately water has also been struck in a winze at the Cayuga mine below the level of Pinkard Gulch and at about the same elevation as the spring. In the Manganese Blue mine a little moisture is met in places, and the same applies to certain drifts of the Arizona Central; but this beyond doubt percolates from the hundreds of dwellings of the town situated immediately above, the water used for domestic purposes being pumped from Eagle Creek.

Though the mine workings are generally dry, the coatings of soluble sulphates which are so frequently found on the walls of drifts from 100 to 200 feet below the surface prove that a certain amount of moisture finds its way down to at least the upper levels after the annual rains.

The present conditions of underground waters may differ greatly from those of past time. Considering that during the early Pleistocene the Gila conglomerate filled Gila Valley up to a marginal level of 4,500 feet (present elevation), Eagle Creek and Chase Creek must at that time have had beds 600 or 700 feet higher than at present and have flowed in broad gravel-filled valleys. The climate during this epoch, corresponding to that of the general North American glaciation, was perhaps moister than at present. This leads to the belief that the surface of the ground water must then have stood several hundred feet-possibly 700 feethigher than now, which would mean that it would not have been far below the surface at Morenci. This theory has a certain bearing on secondary changes in the ore deposits, and has been referred to on page 206 . 


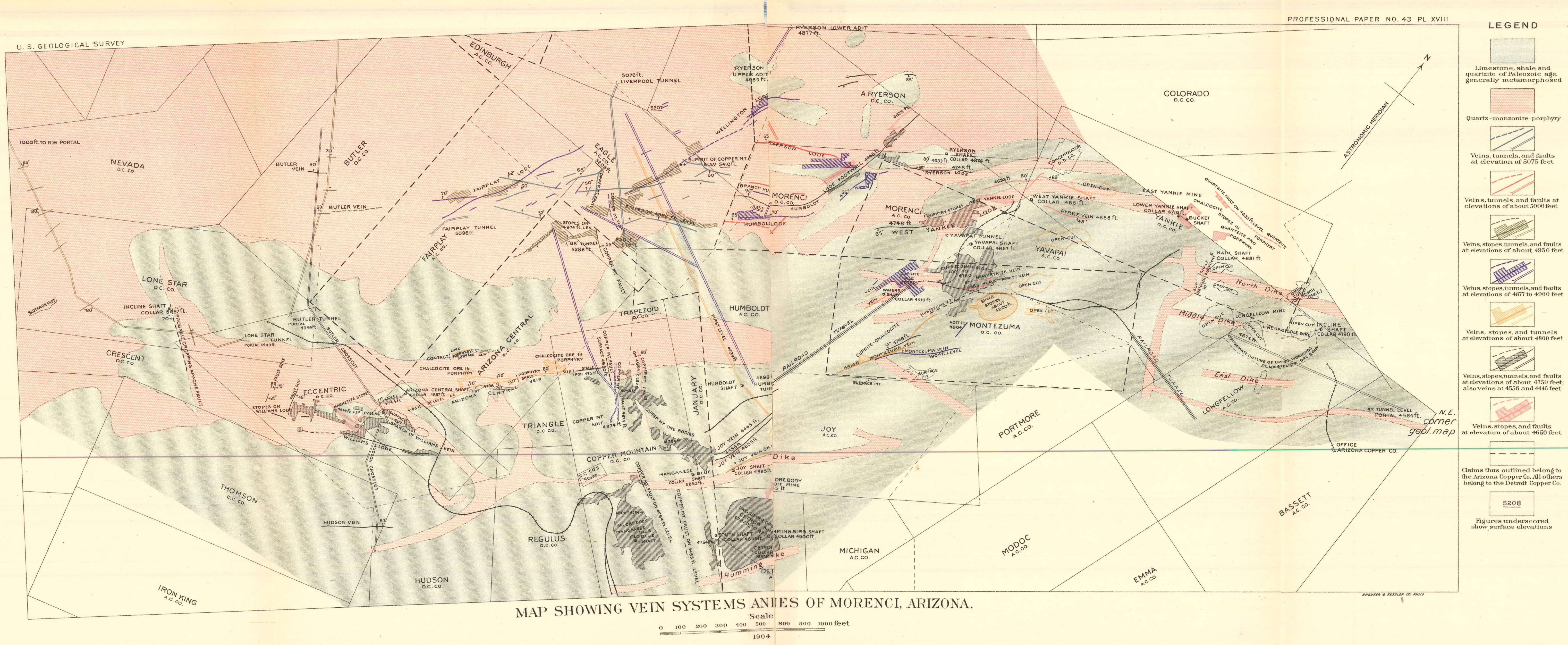


DETAILS OF MINES.

THE LONGFELLOW MINE.

Production and development.-The Longfellow mine is situated on the narrow ridge dividing Chase Creek from Concentrator Canyon, and the croppings have an elevation of 4,900 feet. It was one of the very earliest discoveries in the district, and for many years furnished an immense amount of rich oxide ore to the Lezinsky Brothers, and later to the Arizona Copper Company. The total amount of copper produced from this property can not be determined from the data at hand, but it certainly has amounted in value to several million dollars. At the present time-in 1902 -about 750 tons per month of 7 per cent ore are extracted from various points in the old workings, but the ore bodies are practically exhausted.

In a general way the deposit consists of an irregularly funnel-shaped mass of oxidized ore, the outline of which is partly determined by three almost parallel porphyry dikes, the lowest level having, practically reached the bottom of the deposit. The croppings were found high up on the hill, about 150 feet above the present railroad level, at the head of the Longfellow incline. This corresponds to an elevation of 4,900 feet. The ore bodies under these croppings were partly worked by open pits, partly by stoping, and the whole surface has now caved, forming three large irregular depressions, causing also a settling of this whole part of the hill. The old workings above the railroad level (elevation 4,760 feet) are inaccessible and caved. The developments, as far as the present workings are concerned, consist in tunnels on four levels, the first one being on the railroad level, and the fourth 200 feet below it. Besides there is an incline starting at an elevation of 4,784 feet and reaching down to the fourth level. The fourth level is opened by a long tunnel, starting on the steep slope below the railroad track and extending about 950 feet W. $14 \frac{1}{2}{ }^{\circ} \mathrm{S}$. to a point immediately below the old workings. While the larger part of the deposit lies within the Longfellow claim and belongs to the Arizona Copper Company, a small part of it falls within the East Yankie claim of the Detroit Copper Company. This part of it is developed by four levels from the East Yankie shaft, the lowest having an elevation of 4,630 feet.

Geology.-The surface geology of the Longfellow mine is greatly obscured by reason of the great caves and open pits which are located on the ridge, which render the tracing of the strata and dikes very difficult. Figs. 5 and 6 show the general structure of the sedimentary series. On account of the difficulties created by cavings and old, inaccessible, and unknown stopes, they are only approximately correct. The Coronado quartzite crops 12 feet below the lowest 
tunnel and its beds dip slightly westward. Above this lie the limestones and shaly limestones of the Longfellow formation, partly dolomitic. The thickness of this

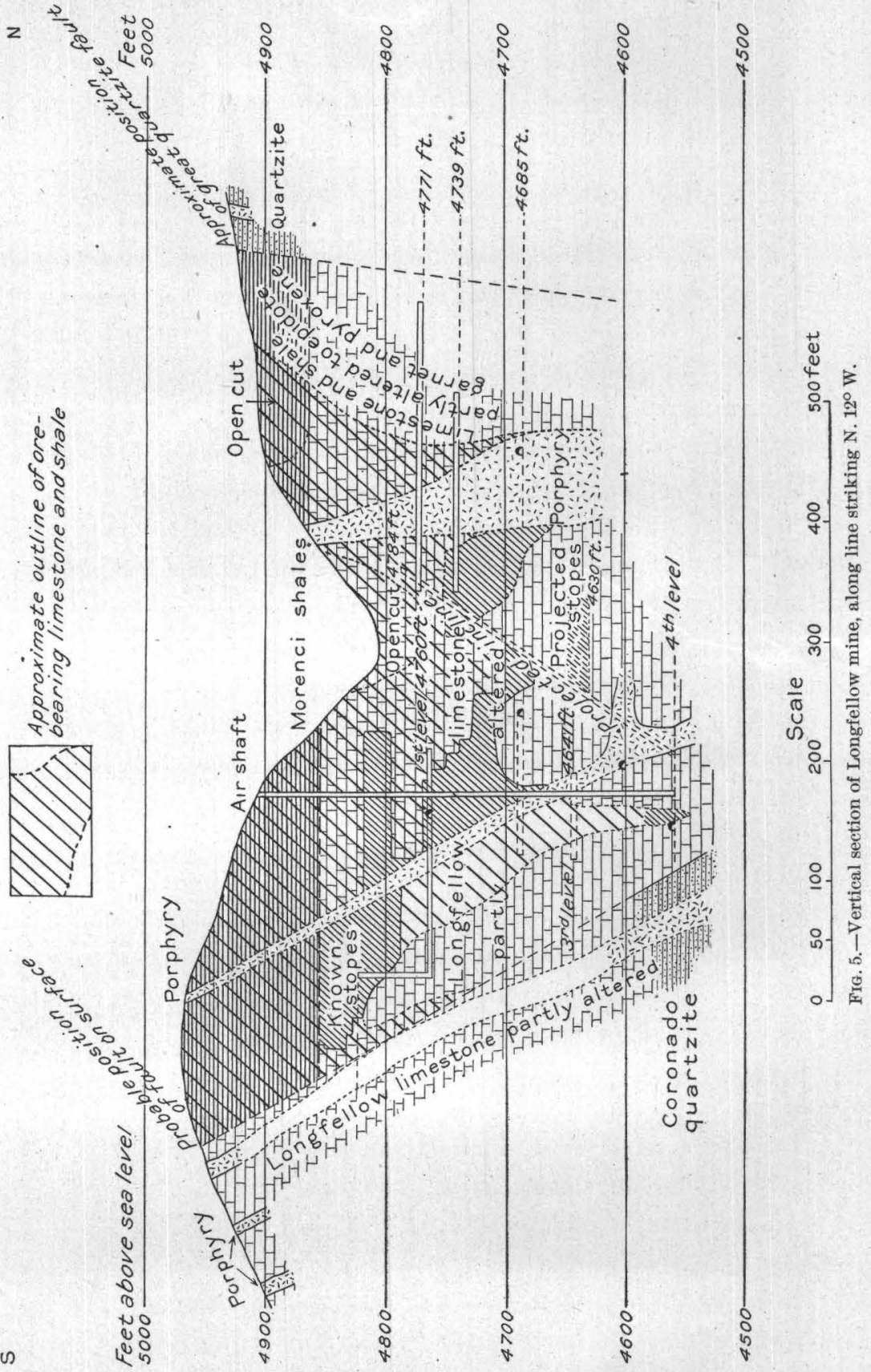

series is 350 feet. The Longfellow limestone is again covered by the Morenci formation, consisting of a lower member 60 feet thick, of very fine-grained lime- 
stone, and an upper division of clay shales somewhat over 100 feet thick. The Morenci shales form the upper part of the ridge and the gap west of the Longfellow

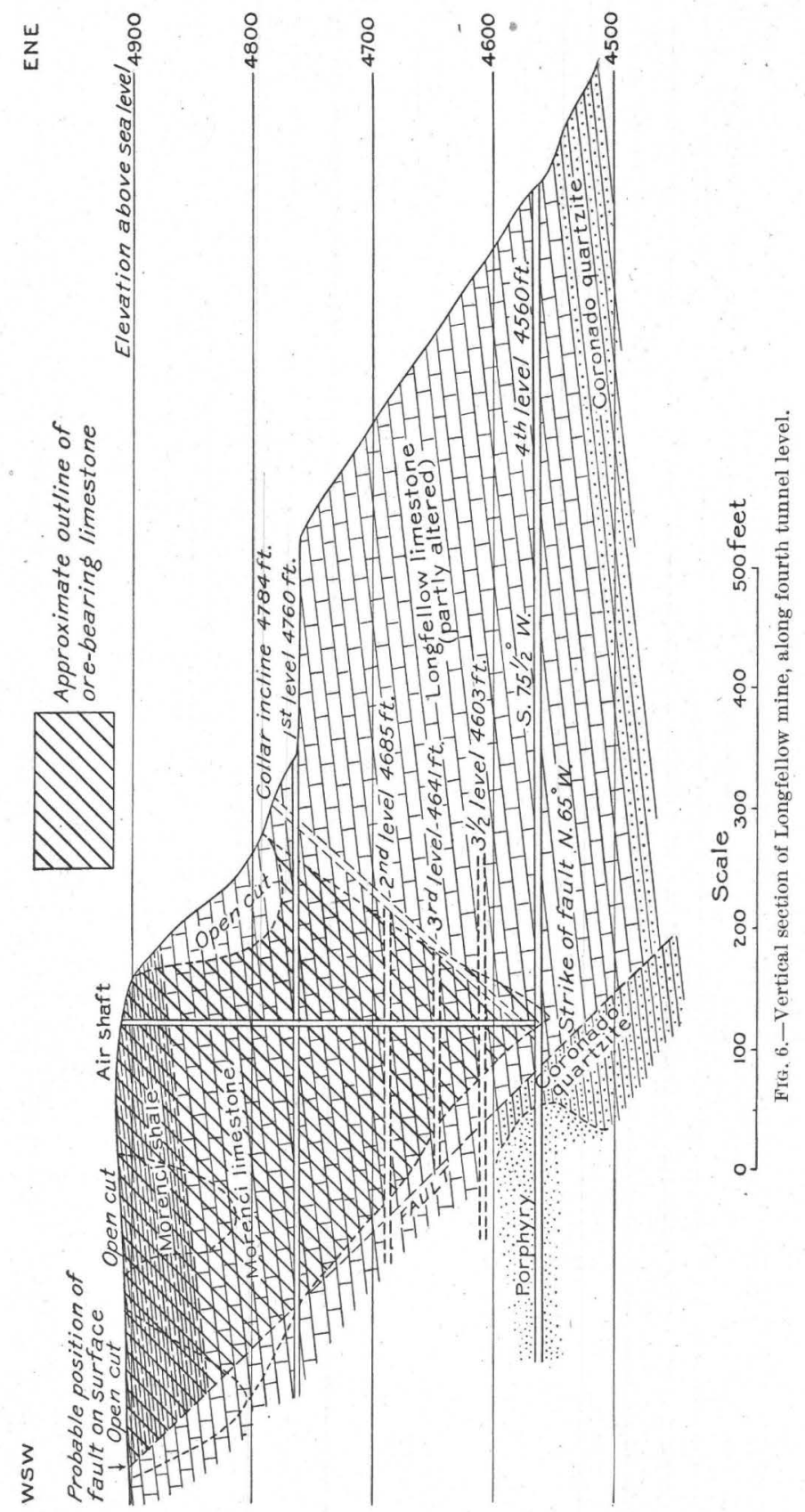

incline. The sediments are broken by at least two faults which have a general east-west direction. The northerly one (Pl. XVIII) is outside of the ore bodies 
and falls a short distance beyond the limit of the area shown on the special map. The throw amounts to several hundred feet, for it brings up the Coronado quartzite on the north side to the level of the Morenci shales. The southerly fault, striking N. $65^{\circ}$ W. (fig. 5), which has been observed only in the mine, brings the Coronado quartzite on the south side up to the level of the Longfellow limestone; its throw is probably 80 to 100 feet.

Several porphyry dikes with an east-northeast trend cut the strata. The north dike is nearly vertical; its thickness is only 20 feet on the surface, but on the second level of the East Yankie this increases up to 70 feet. The middle dike is traceable for only a short distance on the surface, but is found on several levels in the mine. It scarcely averages 20 feet in thickness, but has a tendency to send out sheets or sills between the strata. Such a local widening is seen in fig. 5 near the incline shaft. The miners refer to it as the "sheet-porphyry dike." The south dike is 25 to 30 feet wide and, like the middle one, dips to the north at an angle of about 60 degrees. On the fourth level a crosscut to the north, 90 feet long, is entirely in porphyry, and from this it seems probable that this dike, like the middle one, sends out horizontal sheets in the lower part of the limestone.

The Longfellow porphyry is rarely found in perfectly fresh condition, as it generally contains much sericite, and usually also pyrite. On the three and onehalf level the porphyry of the middle dike is of a reddish-gray color and contains as phenocrysts closely massed triclinic feldspar, largely, as far as can be determined, of andesine. There are no large quartz crystals, but there are a few small partly chloritized biotites and hornblende. The groundmass contains much quartz in microcrystalline intergrowth with unstriated feldspars and a few small prisms of plagioclase. Apatite and magnetite iron ores are accessories. This rock contains no pyrite and comparatively little sericite. The porphyry from the fourth level in the north crosscut is very altered, only showing a hard, greenish groundmass with closely massed small and whitish feldspar crystals. Pyrite in small crystals is sprinkled through the rock. This rock is completely sericitized, the forms of the feldspars being pseudomorphs of sericite and a little quartz.

Rock alteration.-The Morenci shale shows only a very slight alteration, chiefly consisting in a hardening of the rock and in the introduction of epidote. The upper few feet of the underlying Morenci limestone is largely fresh, probably on account of its very dense and compact structure. Irregular masses and seams of garnet, chalcopyrite, and zinc blende occur, however, in it, and also disseminated needles of tremolite. The Longfellow limestone, which is the main ore-bearing horizon, is extensively but irregularly altered. At the 
sharp contact with the middle dike on the fourth level without slip or fault the limestone is greenish and mottled with specks and thin seams of pyrite and chalcopyrite. Under the microscope a great development of small prisms of pyroxene is noted, as well as magnetite intergrown with pyrite (Pl. VII, $B$ ). On the rest of the fourth level the limestone does not seem very much altered, but contains seams of pyrite, some of which follow the stratification, while others are perpendicular to it. This pyrite is said to contain a little gold. On the railroad level, near the office of the Arizona Copper Company, the limestone near the dikes seems very slightly altered. In the East Yankie mine near the north dike the alteration is strongly pronounced. On the surface of the western slope masses of epidote are seen, and on the second and third levels magnetite and garnet occur near the porphyry. Most of these localities are outside of the ore body proper; within it surface oxidation has obscured the earlier metamorphism; garnet has been decomposed to quartz and limonite, and large quantities of pure kaolin have been developed. That the porphyry is quite generally sericitized and in places contains small pyrite crystals has already been noted. Further oxidation results in kaolin and limonite. Seams of cupriferous pyrite intergrown with quartz and defined by slips with kaolin and a little chalcocite occur on the fourth level in the porphyry. The maximum width of these is 2 inches, and in places they contain a considerable amount of copper, but none of this porphyry is payable ore.

Ore bodies. - The main ore body occurred in the Longfellow limestone between the north and middle dikes; another mass was found between the latter and the south dike. In their widest part they occupied a space of about 300 or 400 feet, but narrowed as depth was attained, and on the lowest level only a small ore chamber worth stoping was found. The ore was replaced by fresher limestone which had not been exposed to oxidation. Ore bodies were also encountered from the surface down on the north side of the north dike. These, too, gradually contracted and the hard limestone came in below.

The principal stopes between the north and middle dikes consisted almost entirely of red oxide or cuprite with a small amount of manganese dioxide. On the south side of the middle dike carbonates of copper prevailed with much black manganese. No considerable amount of chalcocite ore was found in the mine. The porphyry dikes were somewhat mineralized, in places enough to be extracted as second-cliss ore, but on the whole no important amount came from this source. As stated above, a small chamber of oxidized ore was stoped on the fourth level, this forming practically the bottom of the ore body. A winze sunk in early days from the surface, happened, curiously enough, to strike the deepest 
neck of the ore body, a fact which naturally raised greater expectations as to its size than were to be fulfilled. On the north side of this stope on the fourth level a small body of red oxide and carbonates was found lying on the quartzite wall of the fault mentioned above.

The gangue consisted of the decomposition products of limestone and porphyry. Among these are kaolin, limonite, and oxides of manganese, together with a variable amount of quartz, not enough, however, to give the ores a siliceous character.

Kaolin, in part very pure, occurs extensively in the Longfellow mine. On the first level all transitions may be seen between softened and pyritic porphyry and almost pure kaolin. It would probably be incorrect, however, to say that all of the kaolin is derived from this rock. On the second level of the East Yankie there are large kaolin stopes adjoined by large masses of limonite. No evidence of porphyry was found here and the mineral seems to be derived from shale or shaly limestone. The kaolin is extracted for use as converter lining.

All of the gangue minerals thus far enumerated are clearly decomposition products due to the oxidizing effect of surface waters. The available evidence points to the conclusion that the primary substance consisted of the same altered limestones which are now found on the outskirts of the ore body, and that its composition included calcite, garnet, epidote, pyroxene, and amphibole, with magnetite, pyrite, chalcopyrite, and zinc blende as ore minerals, the latter three disseminated or as small seams. Zinc blende is reported to have occurred in places on the lower levels. It is certain that the adits contain efflorescences of the sulphates of zine and magnesia.

The ore body resulted from the surface oxidation, and attendant concentration of copper, of rocks like the altered limestone described from the fourth level at the contact with the porphyry; this limestone probably contains from one-half per cent to 1 per cent of copper. As it has been shown that oxidation has penetrated to the fourth level, the possibility of finding other bodies may be conceded. The exploration should be directed either northward toward the great quartzite fault or southward by crosscutting the two porphyry dikes yet to be encountered beyond the south dike. To judge from the developments in. the East Yankie mine, bodies of chalcocite ore may well occur along the quartzite fault. ${ }^{a}$

The fault exposed on the fourth and third levels in part forms the limit of the ore, and probably is to some extent responsible for the ovtlines of the ore body by facilitating the descent of oxidizing solutions. The ores also show a distinct tendency to follow the porphyry contacts. This may be partly due to the more

$a$ Since the above was written I have been informed that good bodies of chalcocite ore have been found in the vicinity of the quartzite fault by crosseutting north from the first and second levels of the Longfellow incline. 
abundant presence of oxidizing solutions in the porous porphyry, but also points to a greater percentage of chalcopyrite in the limestone adjoining the porphyry, a fact abundantly proved at many other places near Morenci.

The general character of the Longfellow ores is shown by the following analyses. A sample taken in 1880 by Wendt from one of the big stopes gave:

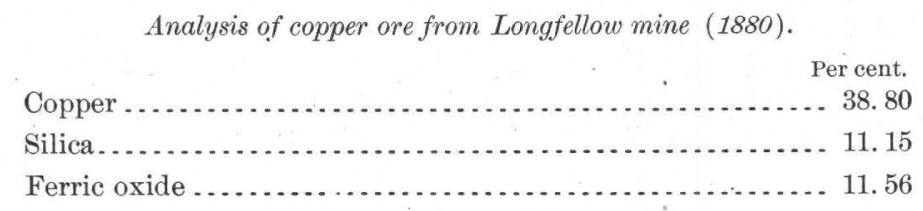

An average sample from over 1,000 tons of ore, taken at the same time, gave:

Analysis of average sample of copper ore from Longfellow mine (1880).

Per cent.

Copper...................................... 17.17

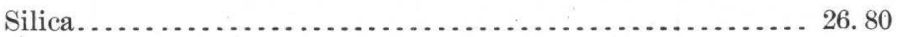

Ferric oxide ................................. 15.29

Manganese oxide................................. 7.49

The character of the ore taken out at present is shown by the following analysis:

Analysis of copper ore from Longfellow mine (1902).

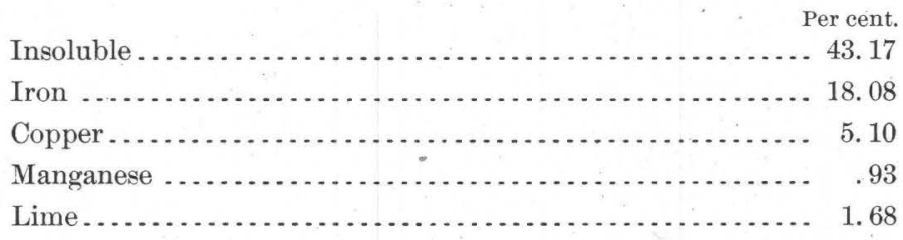

A technical analysis of the porphyry from one of the dikes at the Longfellow mine indicates that it corresponds in general with the other masses of porphyry at Morenci. The analysis shows, besides, a small percentage of pyrite and very little chalcocite. The analysis runs as follows:

Analysis of porphyry from dikes at Longfellow mine.

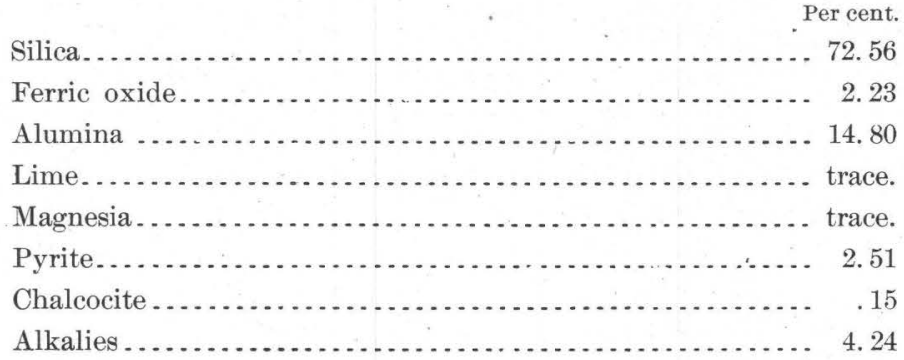


WEST SLOPE OF MODOC MOUNTAIN.

The area of altered limestone west of the Longfellow mine, between it and the Yavapai hoist, shows a number of surface pits with large amounts of epidote rock. From these much oxidized ore was extracted in the early days of the camp, but hard and nonoxidized rock carrying pyrite and chalcopyrite was found at no great depth. The Montezuma workings, partly open cuts, adjoin the Yavapai on the south and contain both fissure veins and beds of shale, with disseminated oxidized ores. Both of these mines will be described later. High up on the north slope of Modoc limestone are the Modoc open cuts. A fair amount of oxidized copper ores has been extracted at this place, but no work is carried on at present. The principal ore mineral was blue chrysocolla, associated with copper-pitch ores and contained as irregular bodies and seams in a garnet rock partly decomposed to limonite and quartzose cellular masses.

Several smaller prospects and open cuts are noted along and just below the garnet rock on the north side of Modoc Mountain, but there are no ore bodies of importance.

Fifteen hundred feet southwest of the summit, in the litfle gully running down to the smelter, the Detroit ore body outeropped below overhanging darkbrown eliffs of garnet rock, and 800 feet farther southwest the Manganese Blue mine is reached. Both of these deserve more detailed description. Briefly, each of them contain several tabular deposits of oxidized copper ores in nearly horizontal strata of more or less altered limestone and shale. Both of them are confined between two dykes of acidic porphyry, 500 feet apart, coursing northeasterly in the direction of the summit of Modoc Mountain. But they are separated by the great Copper Mountain fault, so that the ores in the Detroit are contained in the strata of Carboniferous and Devonian age, while those of the Manganese Blue are contained in the Ordovician limestones.

\section{DETROIT MINE.}

Production and development.-The Detroit mine, belonging to the Arizona Copper Company, is one of those rich deposits of carbonates and cuprite in limestone which lie a short distance south of the main contact of the porphyry at Morenci. In contrast to the Longfellow mine, it consists mainly of several ore-bearing horizons in limestone, separated by barren material.

The deposit was discovered in 1884 and yielded for some years at the rate of several thousand tons per month. For nine years following the first period of great production about 500 tons per month were extracted from the mine, and for many years this and the Longfellow mine formed the two mainstays of the production of the Arizona Copper Company. At the present time the 


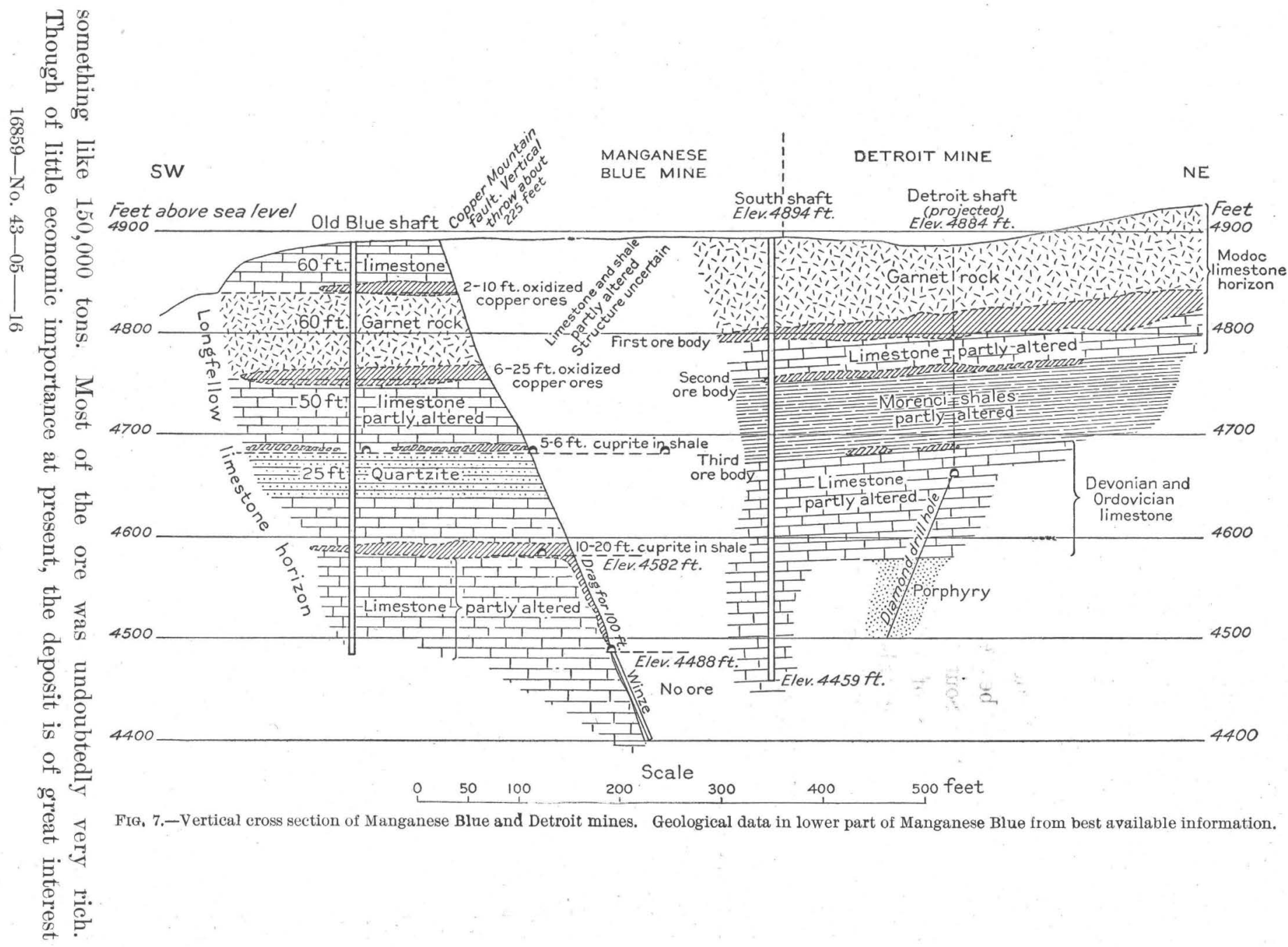

ํํㅇ ㅎํㅇ

웅

$\overrightarrow{w^{2}}$

ब뭉

पू है.

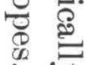

웡

त ह

+

\&

등

동 ज्ञ

등. 喝

$\Rightarrow$

요

富言

킁.

Q.

苛常

8

4

है के

苟 2

की 
from a scientific standpoint, for its structure can be ascertained with accuracy. The ore bodies are opened by means of the Detroit shaft, which is 224 feet deep, and has 4 levels (elevation of collar, 4,884 feet); the workings connect with the upper levels of the Joy shaft, situated 400 feet to the northeast from this point. The collar of the Joy shaft has an elevation of 4,889 feet. The second level, the elevation of which is 4,655 feet, connects with the bottom level of the Detroit shaft. The Humming Bird stopes, a short distance east of the Detroit shaft, open directly on the little gulch which joins Morenci Canyon at the smelter. The shaft and adits are connected by a maze of irregular stopes and workings forming the old ore bodies. The worked ground occupies a space of about 300 by 400 feet and lies between two porphyry dikes 400 feet distant from each other. The so-called South shaft (elevation of collar 4,894 feet) was sunk some years ago to a depth of 400 feet by the Detroit Copper Company to explore the western portion of this block close to the Copper Mountain fault. It is just outside the west line of the Detroit claim and inaccessible at the present time.

Geology.-The block of ground in which the Detroit mine is situated lies on the east side of the great Copper Mountain fault, as far as exposed by mine workings. It consists of the normal Paleozoic series from the Carboniferous to the upper part of the Silurian. The beds dip gently westward, in places turning more southwesterly, at angles of up to $20^{\circ}$. The average dip is probably not more than $10^{\circ}$. The upper 100 feet consist of the horizon of Modoc limestone (Carboniferous), which occupies the whole southwestern slope of Modoc Peak. Its larger and upper part, however, is here entirely metamorphosed to a heavy sheet of dark-brown garnet rock, the lower part of which contains copper ores. As elsewhere, limonite and secondary quartz occur as products of decomposition of garnet. Below this follow 25 feet of less-altered limestone, of the same horizon, in part shaly, which again is underlain by 75 to 100 feet of dark-gray Morenci shales (Devonian?). These are hardened and have undergone considerable metamorphism by the appearance of amphibole and epidote, but their bedding is easily recognized. A hard, dense, and comparatively little-altered argillaceous limestone, the lower member of the Morenci formation, underlies the shale. Mr. Gordon McLean states that very fresh limestone was found near the bottom of the South shaft which contained much zinc blende and a little copper (as chalcopyrite). This material also contained 2 ounces of silver per ton. This block of sediments continues northward toward the main porphyry contact, at least to the Blue shaft, without much disturbance. About 100 feet below the collar of the latter the Morenci shales are again encountered in their proper position. 
Two porphyry dikes of great importance cut the strata of this block and limit the ore on the northwestern and southeastern sides. They are from 400 to 500 feet apart. Their outcrops are difficult to trace continuously on the surface, but the workings give abundant evidence of their position. The northwesterly dike, which may be called the Joy dike, comes from the irregular masses of porphyry near the schoolhouse and continues to the Blue shaft, partly hidden under dumps, etc., and thence northeasterly to the Joy mine, here forming the foot wall of the Joy vein. From here it continues to near the summit of Modoc Peak and, crossing it, descends with the same direction on the steep easterly slopes of this point. The second dike, which may be called the Humming Bird dike, shows first at the post-office near the Detroit Company's office, where it is surrounded by a considerable mass of epidote and garnet and continues along the southeast side of the main stopes of the Detroit mine up along the little gulch emptying at the smelter. Both dip northwest at angles of about $60^{\circ}$ to $70^{\circ}$. The Copper Mountain fault dislocates both dikes, the east side of the fault showing a southeasterly horizontal throw of 50 or 70 feet.

Ore bodies.-The cap rock of garnet, 75 to 100 feet thick, contains copper stains in places, but rarely payable ore. The main ore body is situated immediately below this heavy garnet rock and averages 25 feet thick. Underneath this lie 25 feet of lime shales. The second ore body, about 5 feet thick, underlies this stratum and is again succeeded by 75 feet of barren clay shale. Below this is a third horizon of ore bodies, which, however, have proved unsatisfactory in grade and extent. Extensive prospecting operations by aid of diamond drill have failed to show further ore bodies below this. Drill holes from the bottom of the Detroit shaft have penetrated into the porphyry of the Humming Bird dike and revealed the fact that this porphyry widens considerably in depth. The greatest depth reached by the drill is 300 feet vertically below the bottom of the shaft.

The Humming Bird stopes on the upper ore body open to daylight in the little Smelter Gulch, just below the overhanging garnet rock. The thickness of this ore body varies from 1 to 40 feet, averaging 25 feet. Along the east side of the Humming Bird dike for a distance of 400 feet it is thickest, and the first and second ore bodies here practically join. There is no sharp line separating the first ore body from the garnet rock; smaller masses of this mineral, in places crystallized, were found in the gangue, which besides consisted of quartz, hematite, and kaolin. The ore is entirely oxidized and chiefly contains malachite and azurite, in places associated with black, earthy manganese ore and copperpitch ores. Chalcocite and cuprite occur rarely. The general character of the ore is not strongly hematitic as in the Shannon mine; neither does silica prevail. 
At one place a small mass of unaltered limestone dipping $15^{\circ} \mathrm{SW}$. was found below the garnet cap.

The second ore body is much thinner, but contains about 5 feet of clean ore accompanied by a gangue of yellowish altered rock. The roof is well defined from the ore and consists of gray limestone, usually looking comparatively unaltered and sometimes peculiarly pitted as if by the action of corrosive solutions. Dips of $15^{\circ} \mathrm{SW}$. were observed in this limestone. Hematite is not present in great quantities. The brownish or yellowish gangue is porous and of light weight. Samples contained 17 per cent water and chiefly consisted of a silicate of ferric iron, lime, and magnesia, with only small quantities of alumina. Thin sections show that decomposing epidote and amphibole, the latter in finefelted form, are the principal gangue minerals; garnets were noted in a few places. The rock is clearly a metamorphosed clay shale. The ores consist again of azurite in bunches of crystals, replacing shale, and microcrystalline malachite. Chloritic and serpentinoid products form from the gangue, and kaolin also certainly develops in the shale, usually assuming the form of semitransparent nodules, generally surrounded by impure limonite. The kaolin and chloritic products are doubtless due to oxidizing action.

The extreme western ends of the first and second ore bodies were found in the South shaft on the ground of the Detroit Copper Company.

The main body of shale below the second ore body is a hard greenish gray rock, breaking in sharp fragments; vertical, narrow pyrite seams are often observed in it. Under the microscope it shows considerable alteration and consists, like part of the gangue in the ore body, of a felt of amphibole needles. This metamorphosed shale contains, as a rule, no ore except occasional films of cuprite.

The third ore level, below the main mass of shale, is of little value. No ore occurs on this level along the Humming Bird dike. Bunches and pockets of ore are found between the shale and the underlying dense Devonian limestone, which appears little altered. The small ore bodies often occur at fracture lines which connect with the overlying second ore body. The ores consist of malachite associated with black manganese ore, but no sulphides were found.

The porphyry dikes, as a rule, contain no ore, but are sometimes cut by vertical seams of pyrite.

Summing up the characteristics of this deposit, we first note the tendency of the ore bodies to develop along the bedding plane, both in limestone and shale, though not in the main mass of the clay shale. Oxidation has been very active, and the only sulphides now present consist of a small amount of pyrite in the porphyry and shale in perpendicular seams. The copper carbonates are probably 
due to the decomposition of chalcopyrite. The presence of zinc in oxidized form and as sulphide in the deepest part of the South shaft makes it likely that here, as elsewhere, it entered as zinc blende, together with pyrite and chalcopyrite in the primary ore, and that its removal was due to surface oxidation. Kaolin, quartz, and limonite are also products of oxidation.

While the evidence at this place does not show conclusively that the sulphides were deposited during the time of the metamorphism of the rocks-that is, contemporaneously with the formation of the garnet, epidote, and amphibolite from the limestones and shales-it seems extremely probable that such was the case. As usual in the district, the metamorphism has not affected the beds equally; for while the Modoc limestone is thoroughly garnetized and while the shale is unusually altered, the Devonian limestone seems in places at least remarkably fresh. The presence of a strong vein on the foot wall of the Joy dike and the occurrence of stringers of pyrite in the limestone show that much mineralization has taken place since the consolidation of the porphyry, and yet these phenomena do not appear, as far as the evidence goes, to be at all causally connected with the metamorphism. The solutions circulating on these fissures would scarcely seem sufficient cause for the great amount of metamorphic action in the sediments. The ore bodies are more closely connected with the Humming Bird dike than with the Joy porphyry and fissure vein, for, while lying up closely against the former, they generally do not quite reach the latter.

\section{MANGANESE BLUE MINE.}

Production and development.-The mine known under this name belongs to the Detroit Copper Company and is situated in the center of the town of Morenci. It is confined within the limits of the Copper Mountain claim. The ore bodies were most actively exploited from ten to fifteen years ago and furnished a large amount of high-grade carbonate ore. Before the discovery of the great masses of chalcocite ores below Copper Mounțain the Manganese Blue was for many years the main support of the Detroit Copper Company, just as the Longfellow and Detroit mines were of the Arizona Copper Company. At the present time the deposits are practically exhausted, though a little ore is yet extracted. The old workings are not accessible now, and the description of the principal ore bodies has been obtained from Mr. Gordon McLean, the superintendent of the company.

The property is developed by the Old Blue shaft, now abandoned, 400 feet deep and located in the center of the producing area. The present workings lie a little northward and are opened by the Blue shaft, situated 500 feet northeast 
88

मे जे

COPPER MOUNTAIN
elev. $5345 \mathrm{ft}$.

Do NW FAIRPLAYCLAIM ARIZONA CENTAAL CLAIM

to or 5300 Fairploy vein, Humboldt or

$\stackrel{8}{8}$

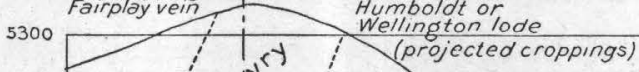

बै Q (a)

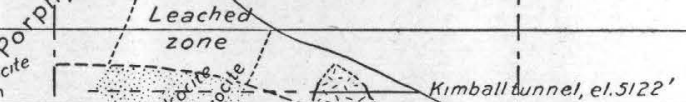

홍

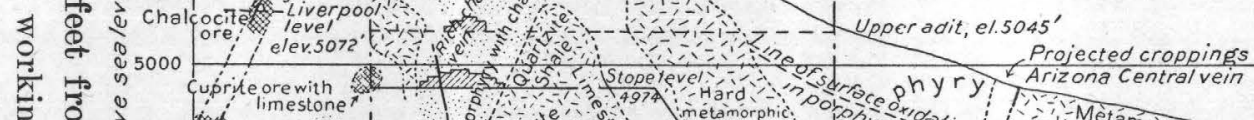
5100 $\sin ^{10^{\circ}}$

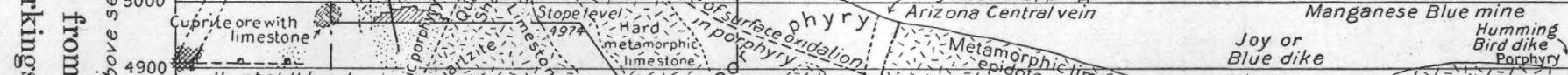

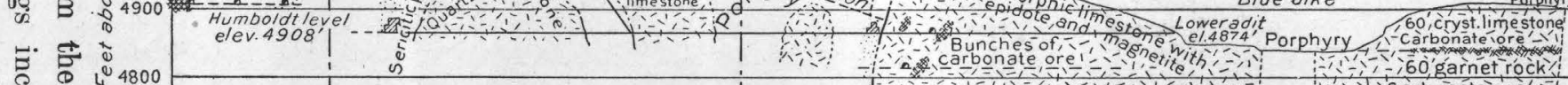

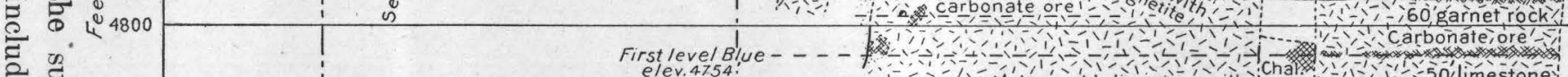

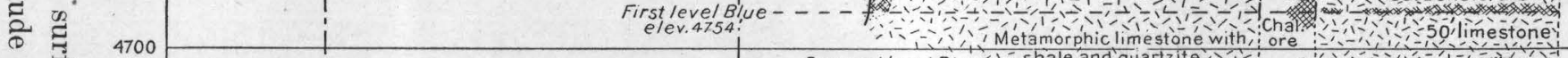

है

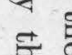

ริ

हैं

${ }_{4500}^{4600}$ $4500+$.

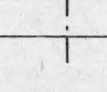

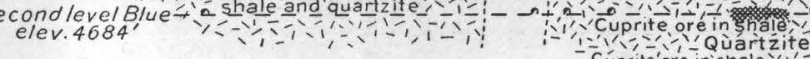

蛋

옹

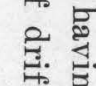

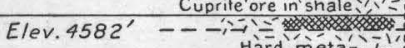

Hard metà:
morphiclime stone'

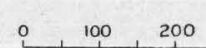

Scale
400

600

soofeet

FiG. 8.-Vertical cross section of Fairplay, Copper Mountain, and Manganese Blue mines. 
and stopes on the several levels; two long exploratory drifts extend up toward the northwestern end of Copper Mountain claim on the second level (elevation, 4,680 feet).

The ores occur in the limestone and shale as five more or less regular beds. To the northwest of the Blue shaft, closer to the porphyry of Copper Mountain, are a number of smaller irregular deposits, chiefly in limestone.

Geology.-The sedimentary rocks near the Manganese Blue mine are well within the metamorphic zone, and the exact identification of the strata is difficult. The Copper Mountain fault, frequently referred to above, runs along the center line of the Copper Mountain claim and divides the sedimentary beds into two parts. The fault crosses the hill between the smelter and the Detroit Copper Company's store in a north-northwesterly direction; its exact position on the surface is known with certainty only for a few hundred feet northwest of the smelter and at the Copper Mountain adit, but the underground workings locate it with exactness in several places and on several levels. The dip of the fault plane is about $63^{\circ} \mathrm{NE}$. or NNE. The vertical throw is about 225 feet, and the horizontal movement of the northeast block is about 70 to 90 feet east-southeast, as shown by the dislocation of the porphyry dikes in the mine on the first, second, and fourth levels. The rocks are greatly crushed near the fault, and often there are two or three parallel planes within a few feet.

Near the smelter the surface stratum of the northeast fault block consists of the heavy garnet into which the Modoc limestone is altered. But higher up on the hill and on the north slope, at the bunk house, and in the rear of the supply depot, the principal rocks exposed are dark-green, hard, metamorphic shales of uncertain horizon. Possibly there is another dislocation along the contact of the main garnetized area.

The rocks exposed on the surface on the southwest side of the Copper Mountain fault are different. On the summit of the hill and along the uppermost railroad track to the smelter crystalline limestone is exposed, sometimes greenish from admixed serpentine. At the Detroit Copper Company's office a large amount of garnet and epidote adjoins both sides of a porphyry dike, and a little more garnet is exposed 200 feet farther north on the same track.

According to Mr. McLean the rocks exposed in the Old Blue shaft are as follows, beginning from the top of the hill: 60 feet limestone, 60 feet garnet rock, 50 feet limestone, and 25 feet quartzite. Below this last is fresh-looking limestone. It is probable that the upper part of this section corresponds to the top of the Longfellow formation, and that the bottom of the Old Blue shaft is very near the top of the Coronado quartzite. The long drifts on the second level 
up toward the northwestern end of the Copper Mountain claim chiefly cut shaly limestone, with some quartzite, probably about the middle part of the Longfellow formation. These rocks are grayish or brownish and are eut by numerous seams of pyrite and magnetite. Thin sections show that these rocks are much more altered than their appearance indicates and contain disseminated tremolite needles as well as grains of pyrite and chalcopyrite, with which magnetite is frequently intergrown.

On the surface near the mouth of the Copper Mountain adit, the limestones are greatly altered and contain much epidote and magnetite. Large masses of magnetite, partly oxidized to hematite and limonite, occur on the east side of the fault on both sides of the Joy porphyry dike. This iron ore has been extensively stoped and used as flux; it contains a small amount of oxidized copper ores. These iron ores occur in general as horizontal beds of a maximum thickness of 20 feet. Above them garnet prevails, intergrown with magnetite and oxidized by copper carbonates and limonite, and below lies a cupriferous, partly metamorphosed clay shale. Similar iron stopes occur to the west of the great fault, extending along it northward of the Blue shaft, chiefly at a horizon of 40 feet below the collar of the shaft. The beds southwest of the fault are nearly horizontal, while on the northeast side they have a slight southwest dip.

The main ore bodies of the mine are contained between the same two porphyry dikes which limit those of the Detroit claim. On the northwest side is the Joy dike, continuous from the Joy mine. Seen on the first level of the Manganese Blue mine is a soft, very much decomposed porphyry, 40 to 70 feet wide, often containing vertical seams of pyrite. It shows on the surface 100 feet southeast from the Blue shaft. The Humming Bird dike lies on the southeast side and is exposed on the surface near the Detroit Copper Company's office. The workings below were not accessible, but the position of the dike was indicated by Mr. McLean. The exploratory drifts on the second level have struck the main mass of porphyry about 600 feet west-northwest of the Blue shaft. One or two smaller dikes without ore bodies were encountered in the lime shales between this mass and the Joy dike. The main porphyry on the second level is a whitish, rather hard rock consisting chiefly of sericite, quartz, and pyrite, the latter both disseminated and in veinlets.

Ore bodies. - The ores in the Manganese Blue mine occurred on four prinçipal horizons and were confined within a horizontal space of 400 by 300 feet. On the northeast they were all squarely cut off by the Copper Mountain fault, and gradually thinned out within 300 feet. On the other side they were limited by the two porphyry dikes and often abutted against them. Vertically they were contained within a distance of 225 feet. Below 60 feet of crystalline limestone 
extended the first ore horizon, forming a solid sheet of high-grade azurite and malachite ore stained by manganese; this had a thickness of 2 to 10 feet. The second body of carbonates was situated 60 feet lower down under a heavy mass of garnet rock; it was from 6 to 25 feet thick, and like the others was cut off by the fault. The third ore body occurred below 50 feet of limestone in a stratum of shale; the ore consisted of cuprite disseminated in this shale. The fourth ore body was found below 25 feet of sandstone or quartzite and consisted of 10 to 20 feet of shale impregnated with cuprite. Some ore also occurred on the fault near this ore body and was followed down for 100 feet to the fourth and lowest level. It was a narrow pipe-shaped shoot and ran out for some distance in the hanging of the fault on this level. There was only a small amount of this ore, which, near the South shaft, changed into very fresh limestone with much zine blende and some copper (probably chalcopyrite). The Old Blue shaft was sunk about 100 feet below the lowest ore body, in fresh hard limestone without ore.

Very little ore was found east of the fault. The South shaft struck the westerly end of the Detroit ore horizons. Just northwest of the Joy dike at the Blue shaft a little ore is mined at the present time, consisting of cuprite and malachite with much gypsum disseminated in shales, lying 20 feet below the iron stopes.

The second level extended northwesterly from the Joy dike on the fault; it encountered no values except at a point 120 feet from the shaft, where a small amount of oxidized ores was extracted from the foot-wall side. From here on to the main porphyry contact practically no ore was found. The shaly limestones contained pyrite and chalcopyrite. Pockets and very irregular masses of malachite and azurite were, however, contained in the limestone 150 to 200 feet above this level, not far from the contact of the principal porphyry area, and they may well have resulted from the oxidation of these disseminated chalcopyrite ores. No payable ore occurred in the Humming Bird dike, but a little chalcocite ore was found in the Joy dike to the west of the Blue shaft. There was, unfortunately, no opportunity to examine the gangue of these ore bodies, as they are worked out and the stopes inaccessible; but their occurrence is so similar to that of the Detroit horizons that it is probable that here too the gangue consisted of garnet, epidote, and tremolite, with their products of oxidation.

It is interesting to note the close relation of the ore bodies of the Detroit and Manganese Blue mines to the porphyry dikes and their apparent independence of any fissures or faults. That the Copper Mountain fault is later than the development of the primary bodies of sulphide ore is certain, but the oxidation of these sulphides has taken place since the fault was formed. 
Assuming that the relation of the ore bodies in the Manganese Blue to the Copper Mountain fault has been correctly interpreted, it is clear that their continuation would be found in the eastern fault block 225 feet lower down vertically. The uppermost horizon on the west side would be continued on the east side about 260 feet below the surface. This is not greatly different from the position of the lowest ore body in the Detroit mine, allowing for a slight westerly dip. Exploration by diamond drill below that horizon disclosed very little ore and comparatively fresh limestone; also that the Humming Bird porphyry dike widens considerably in depth and perhaps sends off horizontal sills. The South shaft is reported not to have struck anything of value below the two ore bodies of the Detroit mine. The space of from 200 to 300 feet between the Detroit side line and the fault does not seem to have been explored very carefully, though it is clear
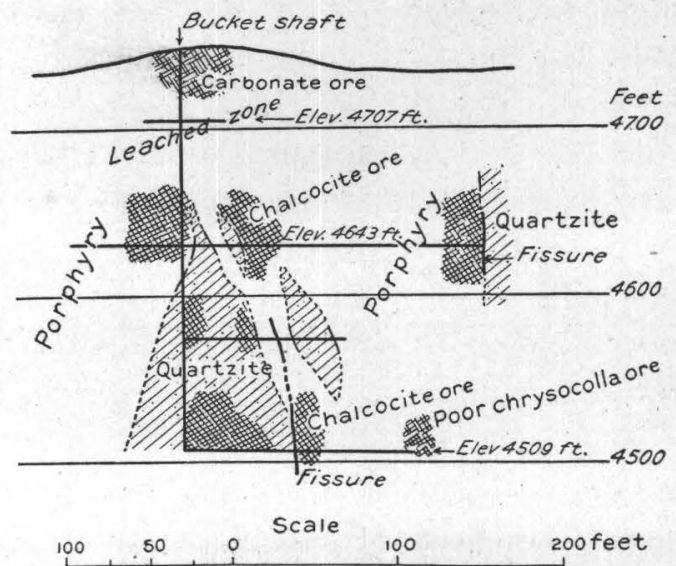

FIG. 9,-Vertical section through the East Yankie mine. that fresh sulphides, including zinc blende, were found in depth on the east side of the fault.

Altogether it is probable that the continuation of the ore bodies on the east side consists of fresh sulphide ore, and that on account of their unoxidized character they are too poor for profitable working.

\section{EAST YANKIE MINE.}

Location and development. - The southeastern corner of the Yankie claim contains a part of the Longfellow ore body and has already been described. For 100 to 200 feet west of this little ore has been encountered in the deep workings, though some carbonate ore was found in several places on the surface. But about halfway between the Detroit concentrator and the Longfellow incline, a little east of the center of the Yankie claim, several ore bodies have been opened which merit special description. The place is known as the East Yankie mine and is situated in the little gulch descending toward Concentrator Canyon from Longfellow Gap. The surface elevation is from 4,700 to 4,800 feet. The mine is developed by the so-called Bucket-shaft, the collar of which has an elevation of 4,750 feet and which is sunk to a depth of 225 feet, four levels being turned from it as follows: Second level, 4,703; third level, 4,630; fourth level, 4,570; fifth level, 4,505.

The total developments amount to at least 4,000 feet. In late years much concentrating ore and some smelting ore have been extracted from the East 
Yankie mine, and recently good-sized bodies of concentrating ore have been developed. The amount thus far mined is small compared to that from the Ryerson mine, but the developments are promising.

Geology.-The locality is one of great complication near the place where the quartzite fault cuts across the main porphyry contact. On the south lies the north dike of the Longfellow mine. For 250 feet north of this follows a belt of impure limestone and lime shale, partly altered to epidote and magnetite, as shown both on the surface and below. A wider dike of porphyry adjoins this on the north, containing inclusions of large irregular masses of quartzite. Finally from 300 to 400 feet northward from the north dike an extensive mass of hard quartzite is encountered, which evidently borders against the other formations along a fault plane. As the quartzite undoubtedly represents the Coronado formation, and as the strata at Longfellow Gap are about on the horizon of the Morenci sbales, the fault is clearly one of great magnitude, and the vertical throw is at least 500 feet. The main mass of quartzite is well exposed in the bold bluff just north of Longfellow Gap, and extends as far north as the concentrator of the Arizona Copper Company. It is cut by several irregular dikes of porphyry which is very similar to that described from the Longfellow mine. A few minor faults with a northerly trend are shown on the third and fifth levels about 300 feet east of the Bucket shaft; these seem to be later than the quartzite fault and cut across it.

Ore bodies.-On the surface, near the mouth of the adit on the second level (elevation 4,703 ), there is an open pit located near the contact of shale and porphyry. A considerable amount of carbonate ore occurred here from the surface down to the second level. This level shows the effects of leaching, the walls of the tunnel being frequently covered with efflorescences of sulphate of copper; in places this leaching also shows on the third level. Below the second level for about 40 feet there was evidently a poor zone, but on the third level chalcocite ore began to appear in the porphyry that here prevails. The stopes about the Bucket shaft on the third level are about 80 feet long, but do not extend high above this level.

The ore is a soft, whitish to yellowish porphyry cut by many seams of quartz and chalcocite. In places it is very rich. Ore is almost continuous northward for 180 feet until a prominent east-west wall of quartzite is reached that seems to cut it off; a large part of it, however, is of low grade. About 200 feet east of the ore body at the shaft another irregular mass of similar ore was found, also in porphyry. Two hundred feet farther east-northeast quartzite was encountered, which in part forms good concentrating ore. A short distance north of this point a well-defined wall of barren quartzite was met which 
has an east-west direction and no doubt represents the continuation of the quartzite fault north of the Bucket shaft. On the third and fourth levels the coarse quartzite near the shaft widens greatly, becomes soft, and contains irregular and generally low-grade bodies of ore, consisting of disseminated chalcocite, generally appearing as a coating on pyrite crystals. Early in 1902 the north drift on the fifth level had penetrated the quartzite and was in porphyry with some ore which appeared partly oxidized. According to reports, this drift has since been continued to about 225 feet from the shaft in a doubtful, soft, and partly oxidized rock, with seams of chrysocolla. The wall of the quartzite fault found on the third level, 170 feet north of the shaft, has not been recognized, but the character of the oxidation leaves little room for doubt that the drift has somewhere in this vicinity crossed an important dislocation. Exploratory drifts eastward along the direction of the quartzite fault have disclosed considerable masses of second-class chalcocite ore in quartzite and some of higher grade.

On the whole the rocks in this vicinity contain much disseminated pyrite. The ore bodies are due to a partial replacement of this pyrite by chalcocite. They seem to occur entirely irregularly and do not have a well-defined shape, but gradually fade out into barren rock. Two lines may be distinguished, however, converging eastward, along which the payable ore is concentrated. The first extends about due east from the shaft; the other follows approximately the line of the quartzite fault, the ore occurring in quartzite and porphyry chiefly on the south side of it. Exceptionally, and near one of the northwardtrending faults which cross the quartzite fault, ore has been found on the north side of the latter. Surface oxidation has evidently in places penetrated as far as the fifth level along the line of the quartzite fault, and this encourages the belief that chalcocite may be found in quantity below the fifth level.

Referring to the shoot at the Bucket shaft it will be noted that the carbonate ore extended about 30 feet down from the surface; further, that this was underlain by a poor zone perhaps 50 feet in depth. The richest chalcocite ore was found 120 feet below the surface, and the same ore continued in porphyry and quartzite for at least 130 feet to the present bottom of the mine. All of the pyritic so-called barren quartzite and porphyry contains a little copper, probably averaging one-half per cent. It is believed that the decomposition of this would yield enough copper sulphate to account for the chalcocite enrichment on lower levels. The mine is situated in a gulch where erosion is somewhat active, a thickness of 150 feet of the croppings having evidently been removed at a relatively recent date. This may account for the fact that the chalcocite ore is here nearer to the surface than it is under Copper Mountain. 
MONTEZUMA MINE.

Location, production, and development.-The Montezuma mine, which belongs to the Detroit Copper Company, is contained within the limits of an ordinary claim, located south of the Yavapai, on the north slope of the gap between Copper and Modoc mountains, and at the northern portal of the Montezuma railroad tunnel.

Although not one of the largest mines of the company, a large amount of ore has been extracted from the Montezuma, partly from flat deposits in limestone or shale, partly from fissure veins in sedimentary rocks or porphyry. Much of the ore has been of high grade. The mine does not possess those large bodies of low-grade chalcocite ores found on the Ryerson, Copper Mountain, and other claims to the north and west. In 1902 a small amount of cuprite ore was extracted from the stopes in shale along the Yavapai line, and very rich cuprite and chalcocite ore was mined in the southwestern corner from the vein, which farther to the southwest is known as the Joy vein.

The developments consist of an adit level at an eleva-

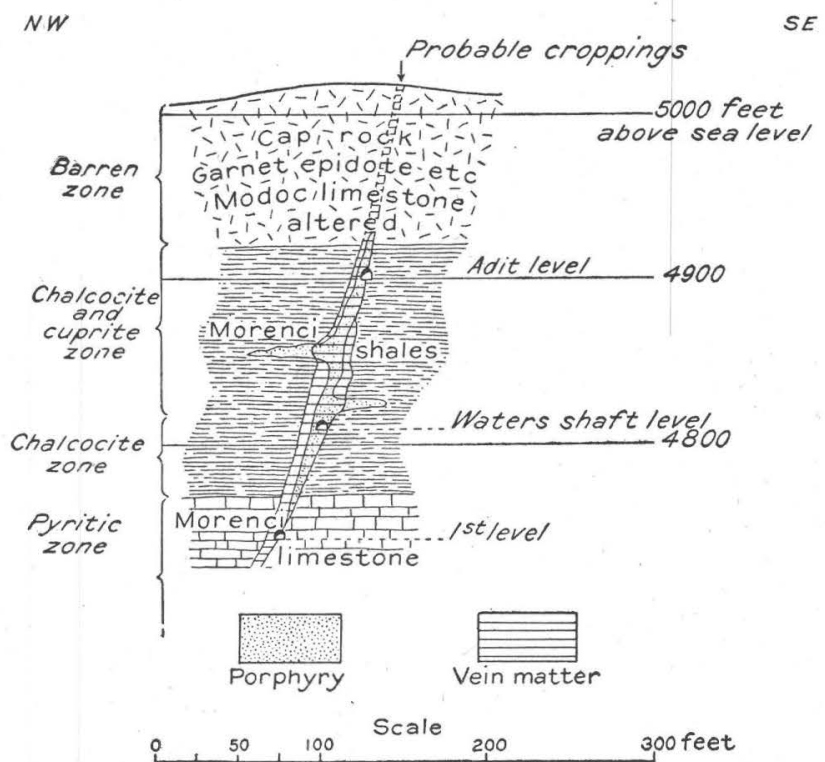

FIG. 10.-Diagrammatic vertical cross section of Montezuma vein. tion of 4,904 feet, 45 feet above the railroad; 90 feet below this is the so-called Waters shaft level, which chiefly explores the ground underneath the railroad tunnel; the first level of the Ryerson (elevation 4,748) is also extensively opened in this claim. The lowest level is the second of the Ryerson mine (elevation 4,688), which, however, is confined to a small space below the stopes on the MontezumaYavapai line. The total developments are approximately a mile in length.

Geology.-Sedimentary but much-metamorphosed rocks occupy almost the whole area of the claim. The highest horizon is that of the Modoc (Carboniferous) limestones, which crop along the southern boundary of the claim; the rocks are entirely altered to heavy masses of garnet and epidote. Below this are extensive outcrops of Morenci clay shales; they are seen all along the slopes from the gap down to the railroad level, and are also exposed in typical development on the 
Waters shaft level and even below this. This suggests that the northeasterly faults which dislocate the quartzite on the slope toward Chase Creek continue toward Montezuma, and that the clay shale has been raised on the south so that the thickness is exaggerated. On the first level, below the clay shale, lie greenish rocks, which contain epidote and pyroxene, and which evidently are metamorphosed equivalents of the Morenci limestones that underlie the shales. Still lower down, on the second level, are the heavy masses of garnet, magnetite, and epidote, which are so extensively developed on the Yavapai claim and which probably represent the upper part of the Longfellow limestone. This horizon also contains chalcopyrite and zinc blende, intergrown with the garnet and magnetite. Disseminated pyrite, as well as horizontal and vertical seams of this mineral, are also very abundant in the shales. Beyond this the clay shales are, however, comparatively little affected by metamorphism, and contain only some secondary epidote.

The stratification, well preserved in the shales, is horizontal or dipping gently westward. In the metamorphosed limestones all trace of it is usually lost. A number of narrow porphyry dikes of the usual Morenci type cut across the sediments, but neither on the surface nor in the workings are they easily traced or connected. At the northern portal of the Longfellow railroad tunnel a dike with east-northeast direction is exposed; it is found again on the Waters shaft level, but is here considerably smaller than on the surface. A second dike with similar direction cuts across the shales on the same level 150 feet farther east, and also on the surface, but can not be found in the workings to the northeast of this point. A third and parallel dike, which is followed with considerable dislocation by the Montezuma vein, is only from 5 to 25 feet wide; it probably continues north-northeast and is exposed in the adit level and on the first level below the railroad tracks near the gas plant. A fourth and very narrow dike with an eastwest direction is exposed on the second level near the thick pyrite vein about 80 feet from the Yavapai line.

Ore bodies.-As at many other mines in the vicinity, the ore bodies either follow fissure veins or form flat and irregular masses in shale or limestone.

Beginning with the latter class, many small masses of ore have been exposed below and in the uppermost stratum of garnet rock, equivalent to the Modoc limestone, but nothing of much importance has been developed. This horizon would correspond to the upper ore body of the Detroit mine. In the northern central part of the claim are several open cuts and extensive horizontal stopes in shale 20 to 40 feet below the railroad track at the gas plant; these, which were exhausted long ago, occupied an area of about 125 by 400 feet. To the north of these, and mostly below them, are the great Montezuma-Yavapai stopes, 
which occupy a space of 500 by 200 feet, and lie at elevations of from 40 feet above the Waters shaft level to 40 feet below the first Ryerson level, and from 50 to 100 feet below the surface. These stopes also extend across the Yavapai line, nearly up to the shaft of the same name, and here lie about the first level of that shaft. In 1902 stoping was in progress below the north portal of the railroad tunnel. The thickness of the ore there is at most 12 feet. The ore is contained in a brownish, somewhat shaly, and partly oxidized rock; immediately above lies clay shale, and below the ore is hard, partly metamorphosed limestone. The horizon is thus probably in the uppermost Devonian limestone, just below the Morenci shale. The rock in which the ore is contained proves to consist of epidote and pyroxene, and is evidently an altered limestone. Narrow porphyry dikes occur at three different places in the stopes.

This ore body does not connect with the stopes noted above as lying to the south at a somewhat higher level, but ends rather abruptly on the southeast side. A persistent vein of pyrites, however, follows that side and probably connects toward the southwest with the Joy vein. The principal ore is cuprite, occurring as seams and coatings on cracks; along with it is some malachite and brochantite associated with gypsum and limonite, and occasionally also a little chalcocite. Efflorescences of zine and magnesium sulphates are common. In spite of its oxidized condition the rock in the ore body contains many small, vertical seams of pyrite. The ore now stoped contains from 4 to 10 per cent of copper.

The western part of the claim contains a system of veins and seams of pyrite and copper ores which merit more detailed description. On the Waters shaft level, below the northern portal of the railroad tunnel and about 100 feet below the surface, three narrow seams of almost solid chalcocite have been found, cutting through the practically barren shale with a north-northeast direction. The most westerly seam is partly in porphyry and appears to run out into the oxide stopes mentioned above. There are also a few narrow seams cutting across with a west-northwest direction. One of these traverses a porphyry dike, 30 feet wide, between the railroad tunnel and the Joy vein, and the ore along it has been stoped both in the shale and in the porphyry; it extends about two sets above the level.

The main Montezuma vein, which is probably identical with the Joy vein, courses with an average direction of north $40^{\circ}$ east and dips about $80^{\circ}$ to the northwest. Its croppings are not well defined, but should appear in the hard garnet cap rock in the southwestern corner of the claim. Three hundred and sixty feet northeast from the southwest claim corner it splits into three branches, the most westerly of which is developed as a thick pyritic vein near the Yavapai line.

On the level of the Montezuma adit (elevation 4,904 feet) the east branch of this vein is struck 160 feet from the portal and continues southwest as a narrow 
and poor streak of pyrite in shale accompanied by efflorescences of chalcanthite; 250 feet southwest of the adit crosscut it strikes a sheet of porphyry, soon turning into a dike, and immediately widens to 24 feet of good chalcocite ore, which, however, does not extend far above the level. Less than 100 feet farther on the porphyry becomes very much crushed and the ore becomes poorer and partly oxidized to malachite; this is 120 feet below the surface.

On the Waters shaft level, 90 feet below the adit, the vein was first struck by a crosscut from the northwest, but at the point encountered proved to be barren. It has been followed 320 feet to the southwest corner of the claim; for the first hundred feet it is in shale widening all along; one set above the level the ore is 30 feet wide. For the rest of the distance to the claim line the vein is partly in porphyry, generally widening in that rock and partly in shale. The greatest width attained is 40 feet. In general the vein may be said to be in porphyry between shale walls, but the porphyry runs very irregularly, is faulted and crushed, and sometimes sends out horizontal sheets in the shales. The ore along this level and above it is chiefly cuprite, sometimes beautifully crystallized. But there is also much chalcocite, and the derivation of the cuprite from the chalcocite is very clearly indicated. The ore does not reach the adit level. Above the cuprite, malachite and brochantite are found, but the vein becomes almost barren a short distance above where the cuprite ore ceases. The change from cuprite to chalcocite takes place along the Waters shaft level. Sixty-five feet below the Waters shaft level and about 280 feet from the surface the vein has been opened by the first Ryerson level. It is here very well defined and shows 1 to 4 feet of almost solid iron pyrites in dense gray limestone with specks and seams of magnetite, pyrite, and zinc blende. The pyrite in the vein contains only about one-half per cent of copper. Chalcocite begins to appear 20 feet above this level and the change to payable ore takes place within a few feetabout 20 feet above the level. At the lowest workable stope the pyrite looks rusty and partly decomposed, and coatings of chalcocite begin to appear.

As stated above the vein branches northeast of the main chalcocite stopes; on the Waters shaft level one fork turns northerly and has been followed for about 300 feet, in which distance it shows 4 to 6 inches of good chalcocite in shale. The continuation of the same vein, turning again north-northeast, is shown on the first level, where it appears as a narrow pyrite vein in dark-green metamorphic rock. On the second level, about 190 feet below the surface, the same vein has been found, but is here up to 5 feet thick, consisting of almost solid granular pyrite, with a little quartz, the pyrite containing one-half per cent of copper. The vein is well defined with distinct walls and dips $80^{\circ} \mathrm{NW}$.; several stringers 1 to 2 inches wide lie in the foot wall and 20 feet away from the 
vein in the hanging wall is a branch vein up to 2 feet wide. The country rock on the foot-wall side is a greenish dolomitic limestone containing a few grains of zinc blende; close to the pyrite seams this changes to a softer rock containing much pyroxene and magnetite. No magnetite was detected in the vein. On the hanging-wall side the metamorphism increases; from this vein across the Yavapai claim to the West Yankie workings the prevailing rock is rery hard and consists of magnetite, garnet, pyroxene, and pyrite, with a little chalcopyrite, all intimately intergrown. This rock shows no dependence upon the pyritic vein, but extends several hundred feet north of it.

The most interesting feature of the Montezuma deposits is the vein with the cuprite stopes. The occurrence of so much cuprite above the chalcocite zone is unusual; the cause may be due to the presence of carbonaceous clay shale in the casing of the vein. The different ore zones are represented diagrammatically in fig. 10. The pyrite vein, which probably represents the primary mineralization, extends to within 250 feet of the surface; above, this changes to chalcocite which maintains itself for 50 feet and then is replaced by cuprite without native copper; the cuprite zone is not of great extent; at its upper limit some malachite is found, but for about 100 feet below the surface the vein is practically barren; this means, of course, that the carbon dioxide was lacking and that the copper has been carried away as soluble salt under the influence of solutions containing sulphuric acid.

\section{JOY MINE.}

Location, production, and development.-The Joy claim, which is one of the properties of the Arizona Copper Company, is situated between the Manganese Blue and the Montezuma mines, at a short distance southeast of the Humboldt shaft. The principal deposit is contained in a strong fissure vein, which probably is the southwestern continuation of the Montezuma vein. The mine has produced a considerable amount of smelting ore from the upper levels. At the present time cupriferous pyrite is mined from the large stopes on the lower levels, and is used for the manufacture of sulphuric acid at the Clifton plant. The developments, which may aggregate 3,000 feet, consist of drifts on four levels almost 100 feet apart, the greatest depth below the surface being 440 feet. The mine is opened by the Joy shaft and connects eastward with the Detroit mine on the two upper levels. At present it is worked from the Humboldt shaft, from which crosscuts are extended to the several levels.

Geology.-The surface along the croppings of the Joy vein is covered by compact garnet-epidote rocks, partly decomposed to limonite and quartz. Along the porphyry dike near the Catholic Church are exceptionally heavy masses of 16859-No. $43-05-17$ 
greenish-yellow epidote. Below this, on the first and second levels, lie the Morenci shales, continuous from the exposures in the Detroit mine, and dipping gently southwestward. In the two deeper levels the sediments probably belong to the Longfellow limestone. Toward the Detroit mine these limestones are fairly normal, but near the dike they contain very irregular but large masses of epidote, alternating with comparatively unaltered limestone.

There is one porphyry dike, the Joy dike already mentioned in the description of the Detroit mine. It is 70 feet wide on the first level and nearly the same

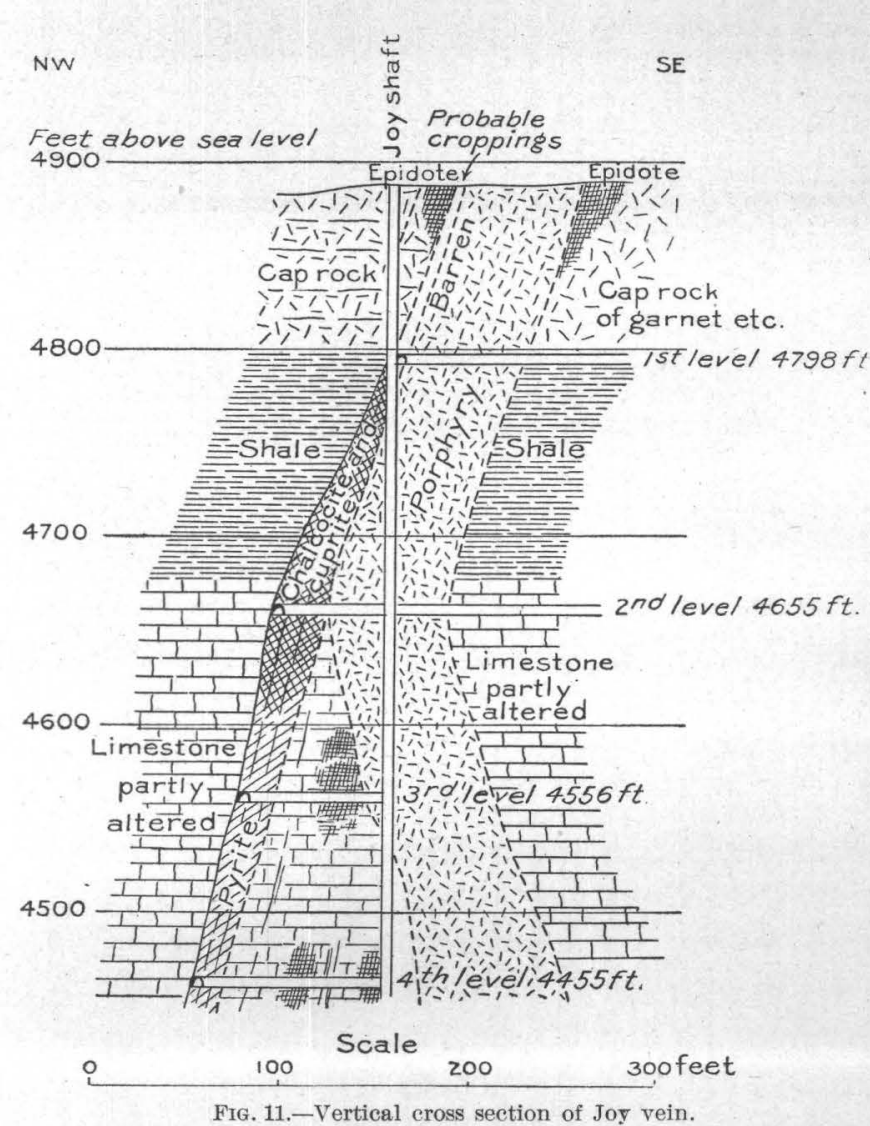

on the surface. Its course is northeast, and it seems to be heading in the direction of Modoc Mountain, but can not be traced continuously on the surface. It is believed to continue south-southwest and to be identical with the dike bordering the Manganese Blue deposits on the northwest. The porphyry appears to be of the usual Morenci type, but is ordinarily soft and sericitized, and contains many seams of pyrite, mostly perpendicular and parallel to the walls.

Ore bodies. - The barren croppings of the Joy vein are thought to be traceable on the surface by a particularly heavy mass of limonite; on all of the four levels the vein is excellently exposed; it has a course of $\mathrm{N} .10^{\circ}$ to $30^{\circ} \mathrm{E}$., and dips toward the west at angles of from $85^{\circ}$ to $70^{\circ}$. The walls are well defined and the deposit is a normal fissure vein, having a width of up to 50 feet. On the first level the vein lies on the northwest side of the porphyry dike and for some distance at least follows the contact between that rock and the Morenci shale. On the second level the porphyry contact cuts across the south drift, 
and north of the shaft on this and deeper levels, the vein is contained in shale or limestone. The stopes on the fourth level reach the line of the Copper Mountain claim, and in the Manganese Blue mine a heavy pyritic vein, which may be the Joy vein, was found on the fourth level east of the fault and on the southeast side of the dike.

South of the Joy shaft an excellent ore body was found on the Joy vein which extended from the first level or from 130 feet below the surface to a point 50 feet below the second level. The ore had a width of up to 50 feet, the shoot being 200 feet long, and consisted of chalcocite with native copper and some cuprite. Below the level indicated it turned into cupriferous pyrite. On the fourth level south the vein is very thick and consists in places of a mass of almost solid granular pyrite, 50 feet wide, with very little quartz. The wall rock is here a sericitized porphyry containing a little pyrite, magnetite, and zinc blende as secondary minerals. On the same level, at the 100 -foot crosscut to the Joy shaft, the vein is a few feet wide and shows several thick seams of pyrite in partly altered limestone. About 50 feet from the vein is a considerable mass of epidote; then follows almost unaltered limestone again, which contains several narrow seams of pyrite, up to 2 inches wide, each surrounded by a zone of altered greenish limestone a few inches wide. Analyses have been made of fresh rock 10 inches from one of these seams, and of the altered zone adjoining the veinlet (see p. 172). These analyses show that the alteration is due to replacement of limestone by tremolite, pyrite, and zinc blende: At the Joy shaft the limestone is again replaced by massive granular epidote. This point is probably not far from the porphyry. In the crosscut on the third level the porphyry begins close to the shaft and is adjoined by epidote rock, which farther out toward the vein changes into less-altered limestone; the line between epidote and limestone seems fairly sharp (fig. 11).

Surface oxidation extends in places, chiefly along the walls of the vein, down to the fourth level, but the vein as a whole is not much oxidized below the third level.

The most interesting features of the Joy vein consist in the succession of the ores. For 130 feet from the surface the vein is almost barren; below this follows a 150 -foot zone of cuprite, native copper, and chalcocite, which again, 280 feet from the surface, gives place to cupriferous pyrite as a strong primary vein. The vein is partly in porphyry, partly in limestone, and offers excellent opportunities to study the character of vein alteration in the latter rock.

Much epidote appears near the porphyry dike. The formation of this mineral shows no connection with the vein-forming agencies, which it seems to antedate. 


\section{RYERSON MINE.}

Location and production.-This mine is one of the most important of the group belonging to the Detroit Copper Company. It is situated about 2,500 feet north of the center of the town of Morenci, on the northeast slopes of Copper Mountain, descending toward Concentrator Canyon. The surface elevation at the shaft is about 4,900 feet. Smaller ore bodies near the surface have been known for a long time, but the great resources of chalcocite ore below Copper Mountain which are opened by this mine were not known until some ten years ago. Since then the exploitation has proceeded actively and the largest production of the company is now from this source. The mine probably averages over 200 tons per day of concentrating ore, besides a considerable quantity of higher-grade

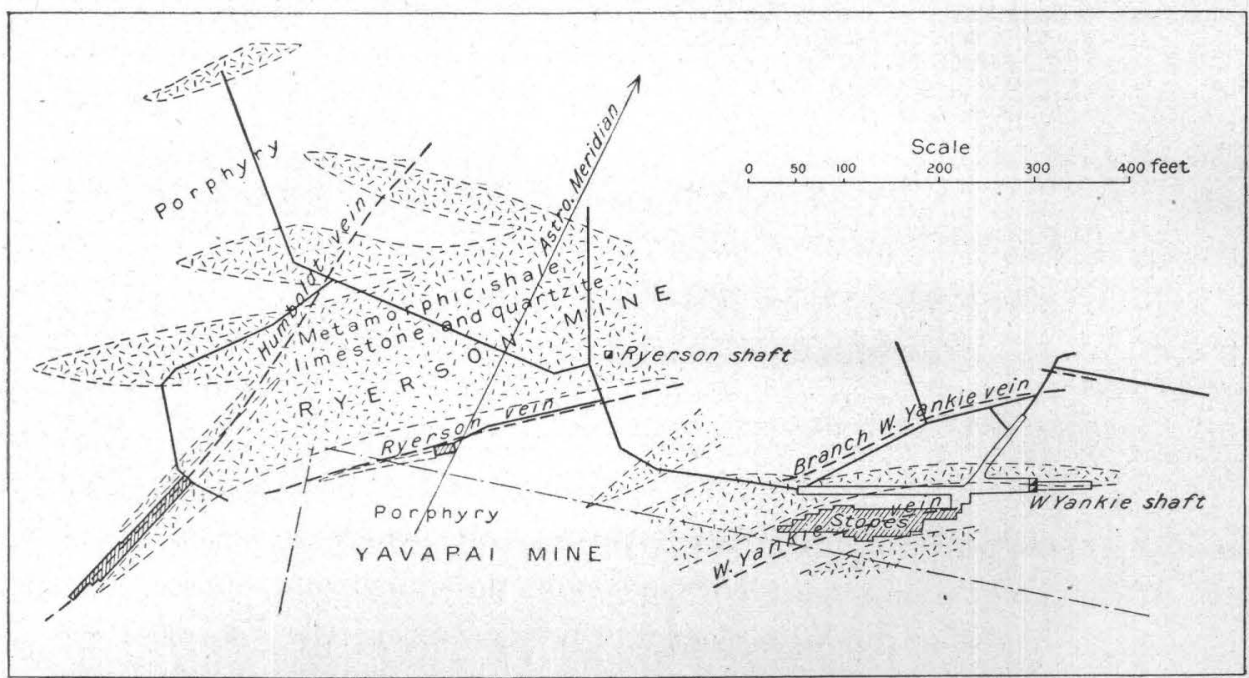

FIG. 12.-Plan showing workings, veins, and probable outlines of bodies of altered sedimentary rocks embedded in porphyry on the third level of the Ryerson mine.

smelting ore. The ores are entirely of the chalcocite type, containing few metallic minerals other than chalcocite and pyrite. The very large ore reserves indicate that it will remain an important producer for many years.

Development. - The mine is developed by a very extensive system of drifts and crosscuts on several levels, and the total length of the workings probably aggregates from 10,000 to 15,000 feet. From the north access is obtained by the Ryerson upper and lower adits (elevations 4,989 and 4,877 feet) as well as by the adit of the first Ryerson level (elevation 4,749). Each of these connects with extensive drifts on the lodes. The eastern part of the mine is opened by the Ryerson and West Yankie shafts; the latter, just over the east line of the Morenci claim, is the main hoisting shaft, and its collar has an elevation of 
4,881 feet. Three levels are turned from this shaft, called the first (elevation 4,749 ), second (elevation 4,693), and third (elevation 4,633). On the upper levels connection is made westward with the Humboldt mine of the Arizona Copper Company. On the lower levels connections are established eastward with the East Yankie and Longfellow mines. From the West Yankie shaft the ore is sent directly to the concentrator, which is situated close by. The workings occupy a space of about 1,500 feet from northeast to southwest, and 800 feet in the opposite direction.

Geology.-The geological relations are very complicated. The mine is situated on the contact of the main porphyry, stock of Copper Mountain with the sedimentary area. The porphyry contains a great number of inclusions of altered sediments, and the limestones and shales contain many porphyry dikes, mainly with an east-northeast trend. Both inclusions and dikes are apt to be very irregular, and it is often very puzzling to connect the areas from the exposures on the different levels. The relations are illustrated in PI. XVIII and on the sections, figs. 12,13 , and 14 .

The sedimentary rocks consist of quartzite, limestone, lime shale, and clay shale. Most of the exposures of quarzite are found on lower levels and nearest to the main porphyry mass. The best-defined horizon is that on the third level north of Ryerson shaft, where the stratification is well preserved, the dip being $14^{\circ}$ south or southwest. The top of the Coronado quartzite is doubtless present here, and the elevation corresponds well with that of the quartzite in the Longfellow mine (figs. 5 and 6). But the quartzite is also found farther west in the mine; for instance, on the first level below the Ryerson adit, where it is about 100 feet higher. The rock is usually very hard and solid; near important veins it frequently contains disseminated pyrite with chalcopyrite, and within the chalcocite zone the pyrite crystals are coated with chalcocite.

The horizon of the shale and limestone exposed between the porphyry dikes can rarely be determined and the planes of stratification are usually indistinct, but from the data already given it is probable that nearly the whole of these rocks belong to the Longfellow (Ordovician) limestone. Probably the least-altered rock is that exposed near the Ryerson shaft, where it contains smaller, local, sheetlike bodies of carbonate ore (azurite and malachite). Along the Yavapai line the altered dolomitic limestones are greenish-gray, compact rocks, containing, besides remaining calcite and dolomite, much pyroxene, magnetite, pyrite, zinc blende, and chalcopyrite. Similar rocks are exposed 30 feet below the first level in the Red winze north of the Ryerson shaft, and at many other places. Epidote appears frequently, especially in the shaly rocks. Near the lodes the rocks are often crushed and shaly by pressure; some difficulty may be experienced in their proper 
classification. On the Ryerson lower adit, between the Ryerson and the Humboldt veins, a great amount of garnet rock is found, rarely encountered elsewhere in this mine. This is a very hard, mottled, greenish and brownish rock, consisting of an intimate intergrowth of epidote, garnet, and chalcopyrite.

On the surface as well as underground porphyry is the prevailing rock, but throughout the area it is very difficult to find fresh specimens. As far as can be determined all of the intrusive rock is of one kind and may be defined as standing between granite-porphyry and quartz-monzonite-porphyry. The freshest rocks of the kind were obtained from a dike in the northwest erosscut to the Wellington vein from the Humboldt vein, on the first level (specimen 211). This is a hard, greenish-gray porphyritic rock with abundant small white feldspar crystals and a few small partly bleached biotite foils in a gray, flinty groundmass. The latter is a microcrystalline mass of unstriated feldspar and quartz, while among the feldspars orthoclase, albite, and oligoclase were recognized. For analysis and discussion of this rock, see pages 81-82. A beginning of sericitic alteration is observed in the feldspars and a partial conversion of the biotite into muscovite and chlorite has also taken place.

As a rule the porphyry of this mine is very much altered; the feldspars are generally completely converted into sericite, a variety of muscovite, while the quartz remains unaltered. Secondary quartz is introduced in places as microcrystalline aggregates and as little seams with pyrite. The structure of the porphyry is frequently retained, but also often entirely obliterated. The final result is a whitish rock, ordinarily soft and chalky, but occasionally, when containing very much quartz, hard and compact; it is composed of finely felted sericite and quartz, together with a large amount of fine-grained quartz. Pyrite is also present in varying quantities and occurs both as disseminated grains and crystals and in thin seams and veinlets. For more detailed study of these rocks see page 81 .

On the surface the porphyry forms light-colored blocky outcrops. The slopes of Copper Mountain are largely covered by débris, but near the top the outcrops are conspicuous and in many places show a distinct jointing, the direction of the joints being north-northeast. The main area of the porphyry begins along an irregular northeast line passing close by the northwest corner of the Detroit concentrator. South of this, between the concentrator and the West Yankie shaft, appear two prominent dikes 150 feet or less wide and in general parallel to the main contact; west of the Yavapai shaft these join the main area of porphyry; they are separated by two long and narrow, slab-like areas of altered limestone. Both of these pass underneath the concentrator and the outer one is adjoined by a narrow strip of quartzite. A few hundred feet west of 
these several very irregular sedimentary masses are inclosed in porphyry, and consist of partly altered limestones, shales, and some very fine-grained quartzite. Two hundred feet west of the Ryerson shaft is a small area of almost unaltered limestone with horizontal stratification. Some of these limestone masses, notably the most westerly one, are flat bodies of no great depth, so that drifts below them are entirely in porphyry. On the several levels below these general relations of porphyry and sediments are preserved, but with great local irregularities, giving evidence of shattering and injection of magma. The relations on the third and deepest level are shown in fig. 12.

Copper minerals in the rocks.-Most of the porphyry, except perhaps that occurring near the surface, shows a small percentage of copper, either as chalcocite

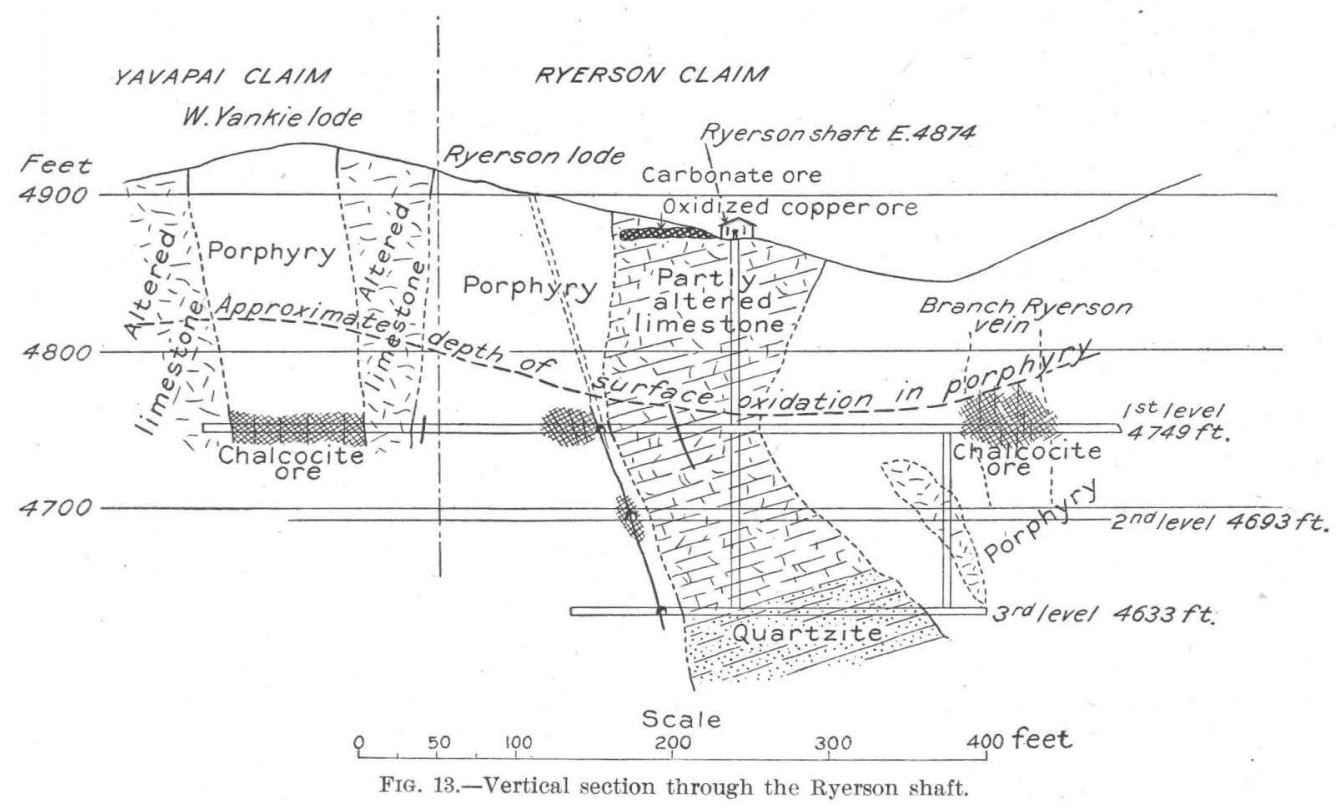

or as chalcopyrite, the latter occurrence being chiefly confined to the lower levels. A very large proportion of the porphyry in the underground workings contains from one-half to $2 \frac{1}{2}$ per cent of copper; this is not payable ore. The altered sediments, and especially the limestone partly converted to pyroxene, epidote, and garnet, quite generally contain magnetite, chalcopyrite, and zinc blende, even above the level of oxidation as applied to the porphyry, for, owing to their more compact nature, these rocks are less easily attacked by surface oxidation than the porous porphyry. Such limestone with chalcopyrite and zine blende is exposed on all of the levels, and large masses of it probably contain up to 2 per cent of copper. With thorough oxidation it is likely that such masses would result in more concentrated payable masses of carbonate ore. Smaller sheets of such ores occur, 
indeed, at the mouth of the Ryerson shaft and at the first level of the lower Ryerson adit. In this mine they are, however, of little economic importance.

Veins.-The exploration has proved that an important vein system courses below the barren outcrops of Copper Mountain. There are four principal lodesthe Wellington, Ryerson, Humboldt, and West Yankie. Their direction varies from east-northeast to north-northeast, and their dip is usually at steep angles toward the north. They are undoubtedly fissure veins of the replacement type, for they are characterized by one or more narrow seams of high-grade ore following fault planes and surrounded in places by large bodies of altered porphyry with disseminated ore; the latter masses rarely show distinct walls, their limit being indicated by the assay value of payable ore. The veins occur in porphyry, shale, limestone, and quartzite and may be productive in either of these forma-

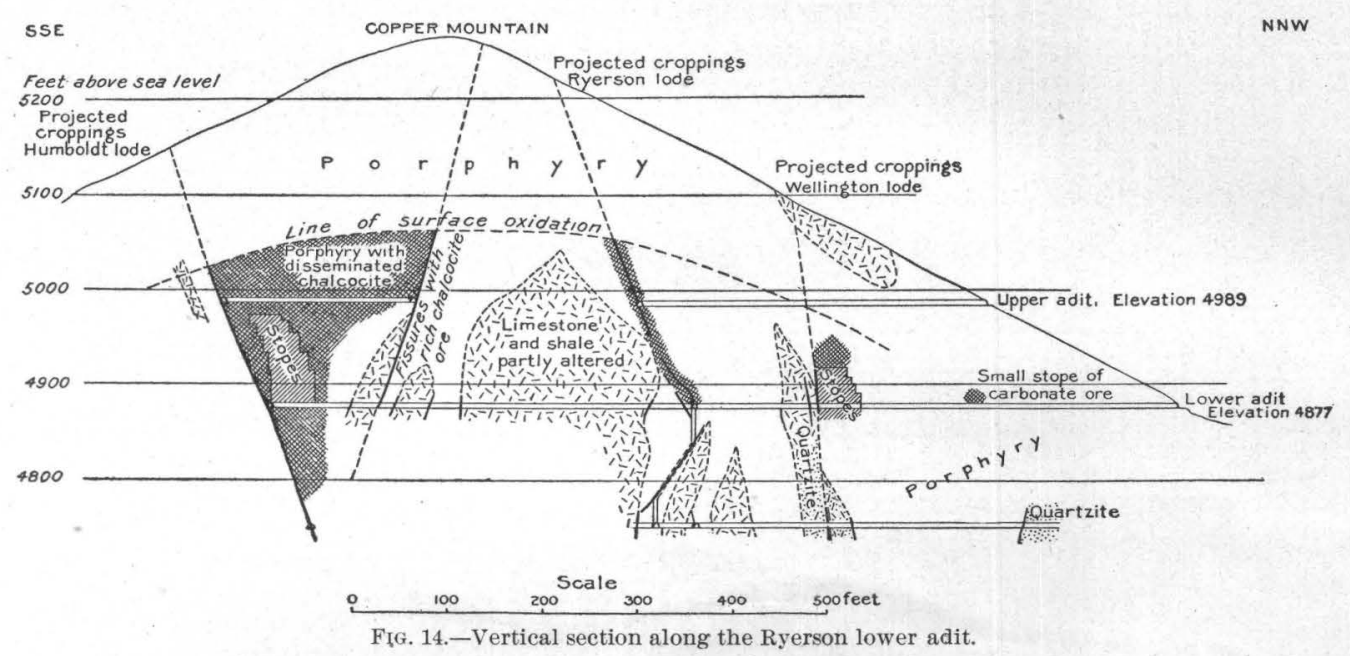

tions; but by far the greater part of the ore occurs in porphyry, and the veins generally become barren on entering the sedimentary areas. Perhaps this is to be expected from what has been said about the greater resistance to oxidation of the metamorphosed cupriferous limestones.

The first lode cut by the upper and lower adits is the Wellington. On the upper tunnel level this is oxidized and practically barren, but on the lower adit it lies in porphyry on the north side of a mass of lime shale; the latter contains a strong, nearly vertical vein of pyrite; the former contains a large mass of ehalcocite ore, the stopes being 50 feet or less wide and, in places, of high grade. Toward the southwest the Wellington vein enters the Humboldt mine of the Arizona Copper Company, but toward the northeast it has been followed for several hundred feet on the first level below the lower adit; it is here chiefly in porphyry and contains good ore at intervals. Below the rich stopes on the lower 
adit the first level struck quartzite with chalcocite ore, which, however, is of lower grade.

The next lode encountered by the upper adit is the Ryerson, which here appears as a very sharply defined rich streak of pyrite and chalcocite, 4 to 18 inches wide, surrounded by several feet of lower-grade chalcocite ore; the dip is $70^{\circ} \mathrm{NW}$, the course east-northeast. This streak has not yet been followed southwest into the Humboldt mine; in the opposite direction it soon runs into shale and becomes poor, turning into a mere pyrite seam. On the lower adit the Ryerson lode is pinched and poor, the ore chiefly consisting of pyrite in altered limestone. As wide stopes of concentrating ore were found in the Humboldt mine along the line of the Ryerson lode, 120 feet west of the lower adit, explorations were recently made in that direction. They disclosed a large mass of

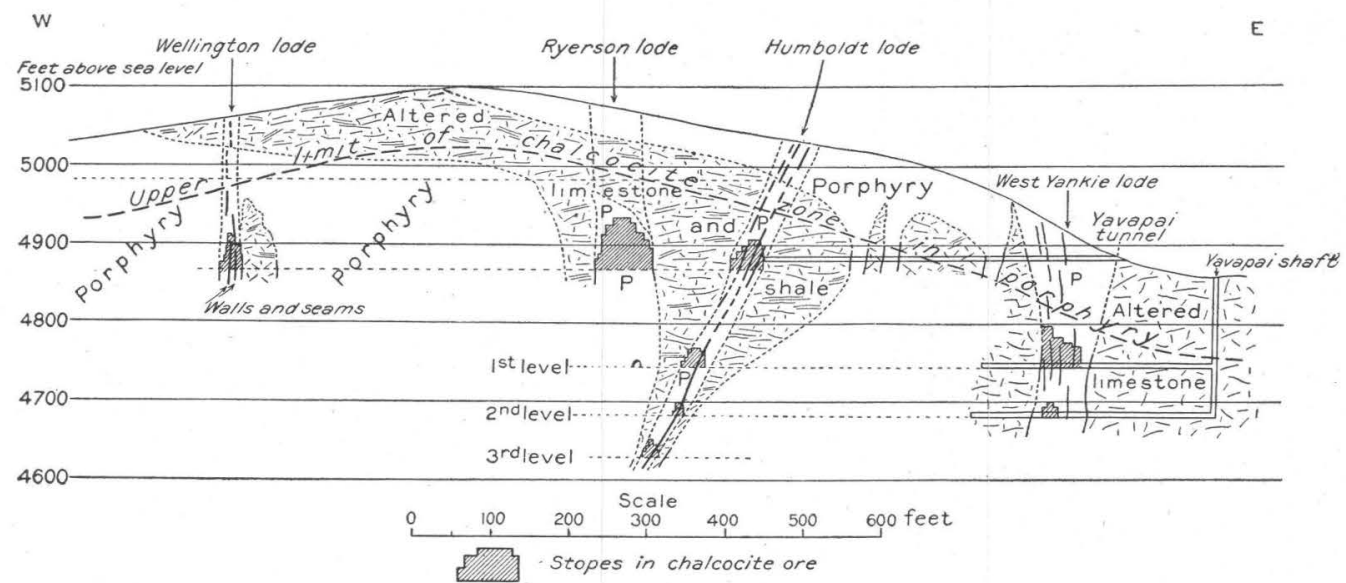

FIG. 15.-Vertical section following line of the Yavapai tunnel across the Yavapai and Ryerson mines.

concentrating ore in porphyry, widening toward the line of the Arizona Copper Company and narrowing to a wedge at the line of the crosscut of the lower adit.

The rich seam of the Ryerson on the upper adit continues down to the lower adit, but at a short distance below that level encounters a mass of shale and is replaced by another seam between the lower adit and the first level, which dips steeply in the opposite southeast direction. Drifting east-northeast from the main crosscut the Ryerson vein was found again, and has developed a mass of ore 300 feet long and 50 feet or less wide, which has been stoped halfway up to the upper adit, and which also extends down to the first level, though in reduced size. At a short distance northeast of this the level runs into the zone of surface oxidation. The Ryerson has been followed on the first, second, and third levels for a distance of about 700 feet to a point 100 feet northwest of the West Yankie shaft (see Pl. XVIII). 
Near the northwest corner of the Yavapai claim large stopes have been developed on the first, and smaller ones on the second and third levels. The lode crosses 100 feet southeast of the Ryerson shaft, where it shows on the first level as a persistent, well-defined vein of about 1 foot of first-class ore, surrounded by 40 feet or less of concentrating ore. On the second and third levels the vein is equally well defined as to strike and dip, but contains more pyrite.

The Humboldt lode is the most important one in the mine. The upper adit developed it near the line of the Humboldt vein and exposed an enormous mass of concentrating chalcocite ore, 200 feet or less wide and 300 feet long, which reaches as far as 70 feet above the level where it encounters the oxidized zone. The rock is a thoroughly altered porphyry containing a few horses of shaly limestone. The Humboldt vein, properly speaking, is formed by a well-defined streak of rich chalcócite ore from 1 to 4 feet wide, coursing east-northeast and dipping $70^{\circ}$ to $80^{\circ} \mathrm{NNW}$. The foot wall is generally a well-defined plane. On the north side, 200 feet from this fissure, is another also containing rich chalcocite ore, but dipping in the opposite direction. The great mass of concentrating ore is confined between these two rich streaks. On the lower adit this mass has contracted considerably, but still contains a large amount of concentrating ore, especially on the southeast side. The northwest vein is here poorer. This chalcocite ore extends down to within 30 feet of the first level, but here the rich streak of the Humboldt lode changes within a few feet to a strong vein of massive low-grade pyrite and chalcopyrite with some zinc blende, in places several feet wide, with well-defined walls of greatly altered porphyry. Occasionally bunches of chalcocite ore are found along it. As shown by the northeast drift on the first level the Humboldt vein continues beyond the big stopes, but swings more northnortheasterly. After a barren interval it has been exposed on the lower adit, first, second, and third levels, near the northwest corner of the Yavapai claim, where it appears to cross the Ryerson vein. The stopes extend for 500 feet with a width of 40 feet or less. They are richest on the first level up to a point 60 feet above it, where surface oxidation begins, but they are also continuous and rich on the second level along the so-called Black stopes. The vein continues down to the third level with good foot wall and stopes 10 feet wide of fair, and in places high-grade, chalcocite ore. Up to a point near the northwest corner of Yavapai claim the vein on this level follows a porphyry dike, but here it breaks across an area of shale with porphyry dikes and becomes impoverished. The vein has been followed on the second level to a point 300 feet northwest of the Ryerson shaft. Beyond this point the surface descends and the drifts approach the oxidized zone.

The fourth lode is the West Yankie. It follows the important porphyry 
dike, which courses east-northeast about 100 feet south of the concentrator, and which may be traced across the Yavapai ground. This lode is, in fact, rather a porphyry dike impregnated with chalcocite and pyrite than a well-defined fissure, although it contains several fairly well-defined streaks of high-grade ore. The concentrating ore is 60 feet wide on the second level and about as much is exposed on the third level. The stopes extend several sets above the second level. This lode continues productive into Yavapai ground.

Dislocations.-Evidences of movement along the walls of the fissures in the way of striation and slickensides are not uncommon, and the crushed condition of the material near the veins and in the great ore bodies indicates the great stress which caused the shattering. The dislocations along the veins do not, however, seem to have been extensive, and the principal dynamic action seems to have

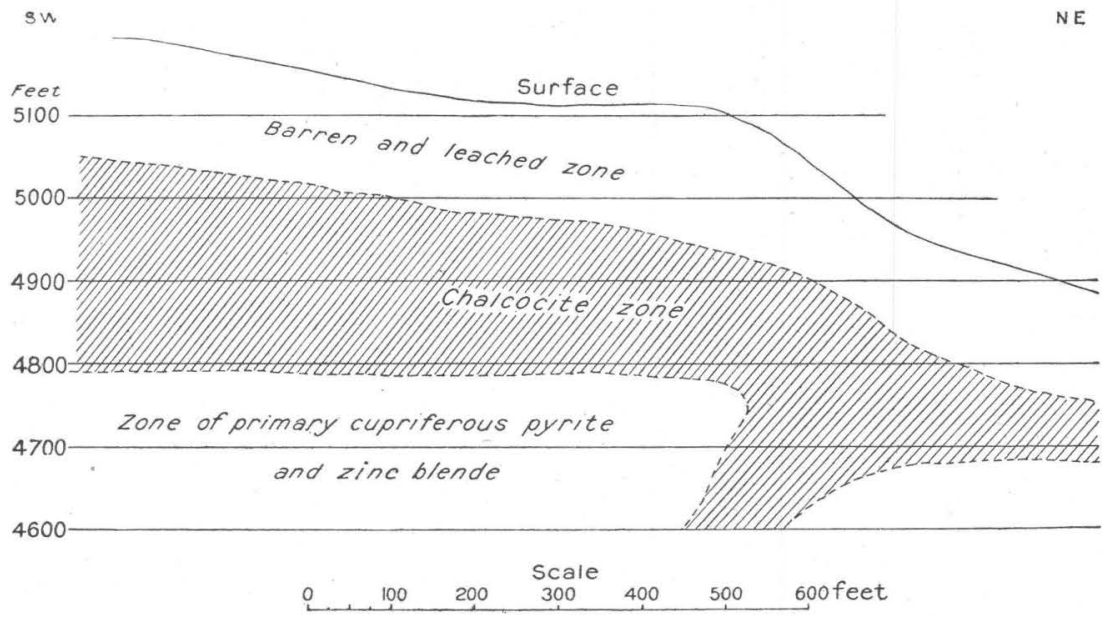

FIG. 16.-Longitudinal section of a part of the Humboldt lode, showing relations of mineral zones.

taken place before the primary ore deposits were formed. In a few places movements have taken place since the deposition of the chalcocite, but they are slight and show no dislocations of importance.

Ores and their distribution.-The ores worked at present in the Ryerson mine contain chiefly pyrite and chalcocite. In part these minerals occur along welldefined fissures with at least one excellent wall, sometimes showing slickensides. This wall is usually in the foot of the ore. In part they occur in disseminated form or in irregular veinlets in the sericitized and bleached porphyry. The former class is often of very high-grade, sometimes indeed massive, chalcocite; the latter may exceptionaliy be of high-grade, but ordinarily forms low-grade, concentrating ore. The pyrite is granular and very rarely erystallized. In some parts of the mine the vein consists almost entirely of this granular pyrite, with which is intergrown some chalcopyrite and zinc blende. Very little quartz occurs 
with it, the only other gangue consisting of little streaks of porphyry altered to sericite and quartz. This type of vein indicates very clearly its origin by replacement along almost closed fissures. Comb and ribbon structures are absent. As mentioned above, the veins are most strongly developed in the softer porphyry and are apt to pinch in shale and limestone.

The chalcocite is deep black, dull or earthy as to appearance, gives a shining streak, and even when purest usually shows grains and remaining masses of pyrite. It is secondary throughout and is deposited by replacement of pyrite according to the processes outlined on page - . Every grade of chalcocite ore may be found, from varieties in which pyrite entirely predominates and the chalcocite simply appears as thin films coating the yellow grains, through richer ores, in which the chalcocite appears as a network pervading and replacing the iron disulphides, to almost solid, dull-black masses which contain only occasional grains of pyrite scattered through it. For illustrations of these occurrences see Pl. XIV.

The normal richer concentrating ore consists of a soft chalky porphyry with occasional little narrow seams of chalcocite running irregularly through the mass, more rarely parallel to the wall of the vein. In the poorer grades both pyrite and chalcocite are visible.

Three zones may be distinguished, in which the occurrence of the ores differs very materially, and these zones are within certain limits dependent upon the surface configuration.

The uppermost division, reaching down to 100 or at most 200 feet below the surface, may be called the zone of oxidation. In porphyry the immediate surface is usually practically barren - that is, it contains less than one-half per cent of copper. The rock consists of a brownish hard porphyry made up of sericite and quartz. A cellular or cavernous strueture is not common, nor is there any unusual amount of limonite. The outcrops of the veins can very rarely be traced over the rough surface of Copper Mountain; this is largely due to the lack of any considerable amount of gangue minerals in the veins. When the veins are contained in shale copper carbonates, limonite, and cellular quartz may occur. At a very short distance below the surface pyrite appears, however, and continues down to the lower level of the zone; it is rusty and partly decomposed, but much of it remains intact. Drifts in this zone soon become covered by efflorescences and incrustations of chalcanthite $\left(\mathrm{CuSO}_{4}+5 \mathrm{H}_{2} \mathrm{O}\right)$, and seams of this mineral may appear in the rock. The quartz seams, less apparent in the rock at lower levels, become more prominent in this zone. Little seams of malachite and brochantite occur in places, but as a rule the carbonates and basic sulphate are lacking, as are cuprite and native copper. Within this zone the assay values run from nothing up to 2 or 3 per cent of copper. 
Below this zone of surface oxidation comes the zone of the chalcocite; the depth of this is not fully ascertained. In the Humboldt vein in the western part of the mine it is about 250 feet, while near the northwest corner of the Yavapai claim it is considerably more and certainly exceeds 300 feet.

In the West Yankie mine the limit is fairly well defined, the chalcocite ore ceasing about 30 feet above the first level, the line seemingly being about parallel to the surface. In the eastern part of the Ryerson vein the line of oxidation descends, as does the surface. But the lower level of the chaleocite zone here shows considerable irregularities. As shown in fig. 16, which is a longitudinal projection of the Humboldt vein on a vertical plane, the chalcocite ceases on the first, second, and third levels along a nearly vertical line, the change from chalcocitic to pyritic ore being on all three levels effected within a distance of two or three sets. At a short distance east of this point the chalcocite ore descends below the third level. The richest ore is generally found at a short distance below the line of oxidation; in the lower levels of the chalcocite zone there is decidedly more pyrite than in the upper parts. In only one place, in the so-called Black stopes on the second level of the Humboldt lode, was chalcopyrite found associated with chalcocite. As this ore body was worked out at the time of the examination no definite information is available as to the relation of the two minerals. In shale or lime and between the ore shoots in the porphyry almost pure pyritic ore may be found within the chalcocite zone. Very quartzose alteration of the porphyry, as, for instance, that obtaining in certain parts of the Ryerson vein near the shaft of the same name, has an unfavorable influence on the conversion of pyrite into chalcocite.

This process, by means of which the cuprous sulphide was formed, is accompanied by a slight deposition of quartz or chalcedony and kaolin. As far as known no sericite is formed, this . process belonging exclusively to the primary alteration of the porphyry by the vein-forming solutions.

In the third and lowest zone the ore minerals consist of pyrite with some chalcopyrite and brown zinc blende, partly in almost solid veins, partly disseminated through the bleached porphyry. This ore is of comparatively low grade, though payable ore shoots of chalcopyrite might well be encountered in this zone of primary mineralization. The ore in the deepest zone shows no evidence of secondary changes, but as its exploration is still very limited, it is difficult to speak of it with as much confidence as of the chalcocite zone.

\section{YAVAPAI MINE.}

Location, production, and development.-The Yavapai mine, which belongs to the Arizona Copper Company, occupies a triangular area equal to half a claim, and is on all sides inclosed by the properties of the Detroit Company. It is 
situated on the railroad line between Morenci and the Detroit Company's concentrator, near the east portal of the railroad tunnel. In spite of its small size it has yielded large quantities of ore, and is far from exhausted at the present time. It has produced about 40,000 tons of first-class ore and 80,000 tons of concentrating grade, thus showing an unusually large percentage of smelting ore. In 1903 the mine averaged 898 tons of first-class and 1,670 tons of second-class ore per month.

The mine is developed by about 3,000 feet of drifts and winzes. The surface elevations westward on the slopes of Copper Mountain attain 5,000 feet, and the main Yavapai shaft, 180 feet deep, has an elevation of 4,863 feet. The two main levels are turned at 118 and 183 feet below the collar, and extend in all principal directions. In 1903 the shaft was sunk to a depth of 283 feet. The western part of the claim is explored by the Yavapai tunnel, 18 feet above the shaft level, as well as by a drift on the first level following the Ryerson boundary line.

Geology.-The rocks consist principally of greatly metamorphosed sediments. The east part, as far as the Yavapai shaft, is oceupied by hard, dark-green metamorphosed limestones, now chiefly consisting of epidote, garnet, pyroxene, magnetite, pyrite, and chalcopyrite in intimate intergrowth, a little calcite remaining between the grains. These are exposed on the surface, though there greatly oxidized. Large outcrops of epidote are seen in the eastern part of the claim. On the bottom level, 100 feet below the surface, the rocks are extremely fresh and hard. In the western part, as far as explored, the limestones are not so much altered, though pyroxene, magnetite, pyrite, zinc blende, and chalcopyrite are generally disseminated through then. The color is greenish gray and they generally effervesce freely with cold acids. The stratification can rarely be ascertained satisfactorily and the exact horizon is in doubt, though the rock probably represent the Longfellow limestone.

In the western part of the claim, which is near the main mass of Copper Mountain porphyry, there is great complication on account of branching porphyry dikes, which include between them irregular masses of altered limestone. Considerable difficulty is experienced in connecting the bodies exposed on the various levels. Most of the porphyry is altered to sericite and quartz and contains disseminated pyrite. The fresh rock is doubtless of the normal Morenci type, frequently described above. Three hundred feet northwest of the Yavapai shaft are outcrops of two dikes, which are 20 to 30 feet wide and probably represent the continuation of the north dike of the Longfellow mine. Underground, on the second level, in the eastern part of the claim, however, these dikes could not be found, and are probably locally pinched. But 200 feet north of this point is a larger dike, referred to as the West Yankie dike. This is 
150 feet wide and passes by the Detroit Copper Company's concentrator; at a short distance north of the Yavapai shaft the North and West Yarkie dikes appear to join and continue as one toward the southwestern corner of the Yavapai claim. The shale and limestone to the northwest are cut by a number of narrower dikes with a general east-northeast direction. On the surface, however, much more porphyry is exposed than underground on the tunnel level and on the first level, so that it must be assumed that the relations are somewhat as shown on fig. 15 .

Ore bodies.-The ores of the Yavapai claim consist chiefly of softened and sericitized porphyry with disseminated pyrite, in which the latter is partly or wholly replaced by chalcocite. The best ore bodies have formed 100 to 200 feet northwest of the shaft, at the point where the two dikes meet, and the richest ore occurred 100 to 150 feet below the surface. The stopes begin along the line of the Yavapai and the West Yankie mines, and extend, though not entirely unbroken, a distance of 350 feet toward the southwest. The width is from 10 to 50 feet, sometimes even 100 feet, corresponding to the width of the West Yankie dike, and the ore is as a rule confined to the porphyry. Seams of chalcocite and pyrite containing very little quartz are common in the dikes and are usually parallel to their direction; sometimes they form brecciated zones. The altered limestone also contains many vertical seams of pyrite which usually do not contain any copper. In the extreme western part of the claim, on the first level, 200 feet below the surface, the porphyry dike was found to contain a strong 10-inch seam of pyrite and chalcopyrite, which a few sets above widened to 10 feet of excellent chalcocite ore.

On the second level the same kind of ore is found, but as a rule contains more pyrite. Along the West Yankie line good ore has been stoped by the Detroit Copper Company on the third level, or 60 feet below the second level of the Yavapai, and it is probable that on this part of the Yavapai claim the chalcocite ore will attain at least the same depth. The distance to the surface is here less than in the western part of the claim.

In the extreme northwestern corner, on the tunnel level, the stopes of the Humboldt lode fall partly within this claim, but on the lower levels the dip of this ore body will probably carry it outside of the lines.

The Yavapai mine thus, contains bodies of chalcocite ore of considerable width, chiefly occurring in the many porphyry dikes which traverse the claim. There is less indication of well-defined fissures than in the Ryerson, though fractured zones are found in places. The porphyry dikes contained disseminated pyrite, which descending sulphate solutions have replaced by chalcocite. 
HUMBOLDT MINE.

Location, production, and development.-The Humboldt mine, which is the principal source of production of the Arizona Copper Company in Morenci, is located in the center of the town at the southeastern foot of Copper Mountain, below the crest of which the principal workings are located. The large bodies of chalcocite ore below the barren croppings on Copper Mountain were discovered about ten years ago, and have been worked continuously since that time. They contain, it is stated, many millions of tons, as far as shown by present developments. Up to May, 1902, the Humboldt mine is reported to have produced 77,000 short tons of first-class ore and 620,500 tons of second-class ore. The output in 1902 was approximately 800 tons of second-class ore per day; this includes the Fairplay and Humboldt mines.

WN W

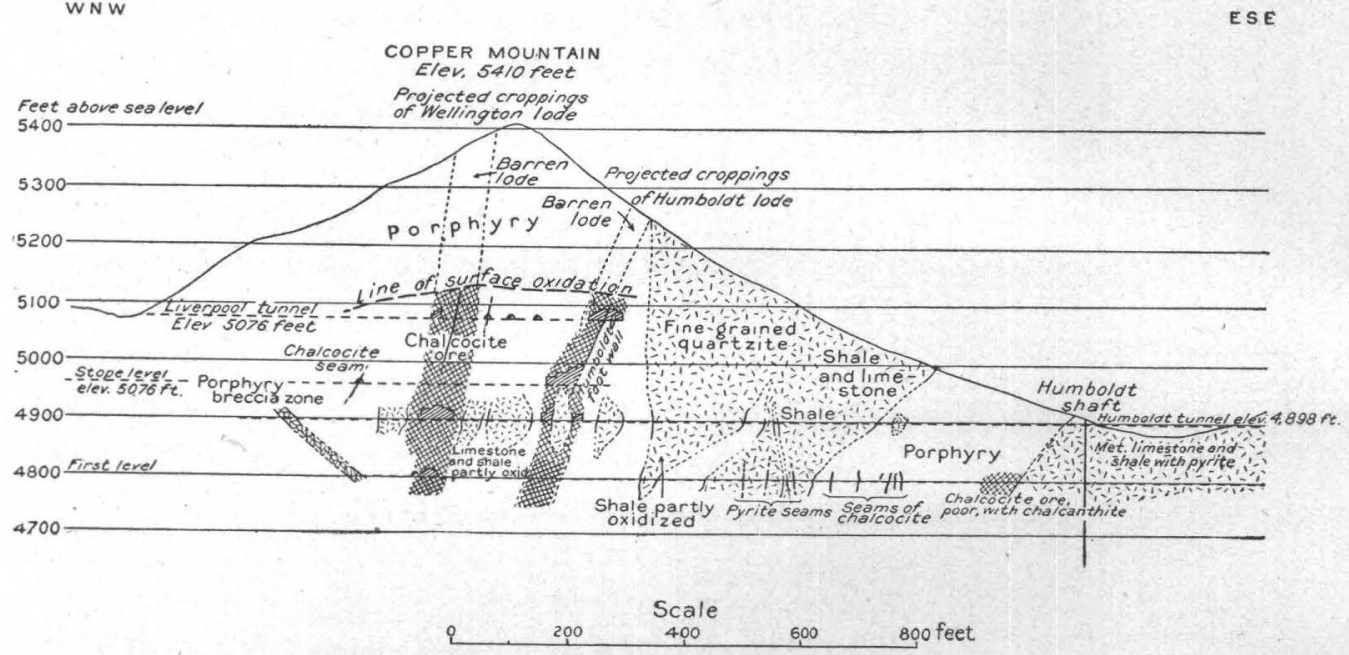

FIG. 17.-Vertical cross section of Humboldt mine.

The ore is divided into first class, containing down to 4 per cent copper; second class, ranging from 4 to 3 per cent or even to $2 \frac{3}{4}$ per cent; third class, from $2 \frac{3}{4}$ to 2 per cent, the latter taken out only when found in development work or when ocçurring with higher-grade ore under conditions necessitating its removal.

The main workings are contained within the horizontal space of an equilateral triangle with a side of 1,000 feet. On the south and east the mine is adjoined by the Ryerson and Copper Mountain mines, and on the north by other property of the Arizona Copper Company that extends for a long distance outside of the main productive area. The developments aggregate several miles in length. The uppermost level is the Liverpool tunnel (elevation 5,076 feet), starting from the northwest side of Copper Mountain and developing the lodes between the 
Fairplay and the Ryerson mines. The Humboldt tunnel (elevation 4,898 feet) enters from the southeast side of Copper Mountain, 182 feet below the Liverpool level, and opens the same territory with a straight crosscut tunnel, 1,650 feet long, having a trend of N. $60^{\circ} \mathrm{W}$. Between the two is an intermediate stope level (elevation 4,962 feet). Near the portal of the Humboldt tunnel is the shaft of the same name, 400 feet deep, the lower levels opening the Joy vein. The first level (elevation 4,799 feet) opens the Humboldt mine by a crosscut 1,300 feet long 40 feet south of the Humboldt tunnel and parallel to it. This was the lowest level of the Humboldt mine in 1902, but in 1903 a winze was sunk 100 feet below it, in the center of the ore body.

Geology.-The ore bodies of the mine are located in the main porphyry area only a few hundred feet northwest of the contact with the altered sediments. The porphyry contains, however, many small detached masses of metamorphosed limestone and shale. The prevailing rock in the Humboldt mine is a bleached and pyritic quartz-monzonite-porphyry. Fresh rock occurs very rarely, and a large part is completely altered to sericite, quartz, and pyrite, chalcocite being usually associated with the latter mineral. On the southeast side of Copper Mountain an irregular mass of metamorphosed sediments separates a dike-like porphyry area (corresponding to the "Arizona Central dike" in the descriptions of Copper Mountain mine) from the principal stock of porphyry. The lower part of this sedimentary mass consists of shaly limestone with epidote, magnetite, and other metamorphic minerals, while the upper part is a peculiar hard, fine-grained quartzite of light color, sometimes very difficult to separate from the silicified porphyry. Along the Humboldt level appears much greenish shale, probably corresponding to the shale member of the Morenci formation. The smaller areas near the lodes consist of lime shale and harder limestone, and are sometimes blocks bounded by faults. Southeast of the Humboldt shaft, on the first level, the rocks consist of irregular masses of garnet and hematite in lime shale; on the two lowest levels in the same direction there is much epidote, together with less altered lime shale. On the whole, intense but irregular metamorphism characterizes the sediments between the Arizona Central and the Joy dikes, the latter coursing a few hundred feet southeast of the Humboldt shaft.

In the southwest part of the mine porphyry prevails, while in the opposite direction, near the line of the Ryerson mine, irregular masses of partly metamorphosed limestones with pyroxene, magnetite, and epidote, but rarely garnet, appear. Quartzite was noted in two or three places on the lowest level. While it is not possible to establish the stratigraphic relations, it is probable that all of the metamorphosed strata belong to the Morenci and Longfellow formations. The 16859-No. 43-05-18 
age of the fine-grained quartzitic rock on the southeast slope of Copper Mountain is in doubt.

The porphyry of Copper Mountain contains, as stated, throughout its mass, pyrite in disseminated form and as veinlets, but this pyrite has been entirely oxidized at the surface and even the resulting brown iron ore has been largely carried away. Below the surface and down to a depth of 100 to 200 feet the rock contains abundant seams of limonite, together with partly decomposed pyrite. Below the depth mentioned the limonite becomes much less conspicuous, though in places partly oxidized pyrite may be found on the lowest level. The oxidation of the metamorphic rocks proceeds very irregularly, almost fresh rocks being sometimes found close to the surface, while again smaller masses of reddish-brown oxidized sediments may occur on the lowest level. Seams of pyrite, chalcopyrite, and zine blende in disseminated form are also common in these rocks.

Lodes and their ore bodies.-Broadly speaking, two lodes meet in the Humboldt mine. Neither of them has well-defined croppings or gossan, the outcrops consisting of yellowish porphyry with irregular quartz seams and very little limonite. This rock is entirely sericitized, but is hard by reason of the great amount of quartz in it. The first is the Wellington lode, which has a direction of N. $25^{\circ}$ E. and an almost vertical dip; the second is the Humboldt lode, with a well-defined foot wall, especially on the upper levels, an east-northeast strike and a steep north-northwest dip. At the place where these lodes meet very large masses of ore, in some cases over 200 feet wide, are formed. To the southwest of the junction the Wellington lode continues into the Copper Mountain mine, while the Humboldt lode continues as a less distinct system of stringers until it joins the Fairplay vein. Stopes are almost continuous all along the lodes from the line of the Ryerson mine to the point where the lodes meet. The larger but isolated mass of ore in the Eagle stopes on the Humboldt level is not clearly connected with any of the known fissure systems. The fissures cut through the metamorphic rocks as well as the porphyry, but in the former they are rarely productive, the softened porphyry being evidently the most favorable ground for the ore. Most persistent is the Humboldt foot wall, traceable for 2,000 feet through the Ryerson and Humboldt mines. The veins usually consist of one or several central seams of high-grade ore, surrounded by large masses of low-grade ore. The rich seams consist of pyrite, containing more or less chalcocite, but very little quartz. Frequently they are bounded by well-defined planes, with evidence of movement, and may also be traversed by slips parallel to the walls. The wall rock immediately adjoining the rich seams is in some cases converted to almost pure kaolin. On both sides of these seams extends a mass of sericitized porphyry, of varying width, containing little seams and grains of chalcocite. To 
this ore there are no well-defined walls, but they gradually fade out into material too lean to constitute ore. Could 2 per cent ore be made payable, the width of the ore bodies would be very much increased. In places the porphyry contains a large amount of chalcocite. On the Humboldt level a mass of ore was found which contained 25 per cent of copper, and had a width of 20 feet and a length of 50 feet: The Wellington and Humboldt veins have proved to be of about the same richness. The best ore is probably found on the Humboldt level. Though rich ore and wide stopes are found on the first level, the ore is more pyritic in character.

In this mine, as elsewhere, the chalcocite gives clear evidence of its secondary character. It is deposited on the pyrite, beginning as slight black films and gradually replacing the mineral entirely. Scarcely any ore minerals other than pyrite and chalcocite are known from this mine. In the upper levels of the chalcocite zone green films of malachite and probably also brochantite are commonly found, but in no place do they form important ore minerals.

Faulting.-The Copper Mountain fault cuts across the southwestern part of the Humboldt mine, but seems to break up into several forks with the same general northwest direction and northeast dip of $50^{\circ}$ to $70^{\circ}$. These fault planes show evidence of dislocating the seams and ore bodies, but definite evidence as to the direction and extent of the movement is not obtainable. There are also, in this mine, several strongly marked zones of brecciated porphyry, which are parallel to and belong to the same class of disturbances as the Copper Mountain fault. Included fragments of chalcocite ore show that the faulting movement took place after the chalcocite was formed. This evidence is in harmony with that from the Copper Mountain mine.

On the Liverpool level the well-defined chalcocite seam of the Wellington lode runs up against the fault 100 feet southwest of the main crosscut, but the exposures give no clue to the amount of the throw; continuing the drift in the same direction, another seam begins 50 to 60 feet west of the fault. As in the Copper Mountain mine, the fault separates good milling ore on the west from barren porphyry on the east, though a low-grade ore again appears on the same level, 100 feet farther east. On the stope level a fault with northwest direction and northeast dip of $70^{\circ}$ is well marked and lies between stopes 9 and 4 in the general direction of the Copper Mountain fault. The fault planes strike N. $50^{\circ} \mathrm{W}$. and dip $66^{\circ}$ to $70^{\circ}$ NE. An included mass of quartzite here forms the foot wall, while porphyry is in the hanging wall. Several small horses of lime shale have been dragged in on the fault. The faulted zone is about 15 feet wide. Minor planes, close by, with the same northwest direction, repeatedly fault a small seam of chalcocite, 2 inches wide. On the Humboldt level occurs a strong fracture approximately in the trend of the fault. Adjacent 
to the Eagle stope and beyond to the northwest is a strong brecciated zone. The development on the lowest level has not extended far enough west to determine the continuation of the fault at this depth.

\section{LOWER LIVERPOOL TUNNEL.}

On the slope from the Liverpool adit down to the main branch of Concentrator Canyon much chrysocolla is noted as coatings and seams in porphyry, and a welldefined line of prospects extends down to the gulch, a distance of 900 feet from the Liverpool adit. A lower tunnel has been started 180 feet below the upper adit, on the same level as the Humboldt tunnel. Driving due south this tunnel has exposed a well-defined vein of rich chalcocite ore up to 18 inches wide, dipping $70^{\circ} \mathrm{W}$. First appearing 100 feet from the portal, this vein follows the tunnel for 400 feet and then becomes less distinct. It is the intention to extend this tunnel level in a northerly direction, starting from the opposite side of the gulch, and explore the country underneath the Clay group of claims, on which some encouraging surface indications have been found.

\section{CARASCO GROUP.}

Going up Concentrator Gulch westward from the mouth of the Liverpool tunnel a persistent system of joints may be noted in the porphyry, striking northeast and dipping $45^{\circ} \mathrm{NW}$. On some of them a little ore has been found. At Carasco mine a shaft 180 feet long on the incline has been sunk at an angle of $20^{\circ}$, following the dip of the joint planes; stopes are extended northeast and southwest from the incline, and the ore consists of disseminated chalcocite in porphyry. In other shallow workings close by to the south the ore follows another set of joint planes dipping due west. The medium-grade chalcocite ore found at this locality almost reaches the surface, an unusual occurrence in this vicinity.

\section{COPPER MOUNTAIN MINE.}

Situation, production, and development.-The mine is situated in the center of the town, the principal outlet being the lower tunnel, which enters on the railroad level immediately back of the Detroit Copper Company's store, at a mine elevation of 5,115 feet, corresponding to a true elevation of 4,874 feet. Extending in a northwesterly direction for 1,000 feet the tunnel runs almost 500 feet below the western crest of Copper Mountain. By means of this tunnel several irregular carbonate deposits in limestone and the Arizona Central vein have been opened. These are described, the former under the heading of the Manganese Blue, the latter under that of the Arizona Central mine. In the northwestern part of the Arizona Central claim the Copper Mountain tunnel has opened a large mass of chalcocite ore in porphyry, and it is this occurrence which is described below. 
As shown on fig. 8, there are above the Copper Mountain adit three levelsstope level, upper adit, and Kimball tunnel, the latter 250 feet above the main tunnel. The stope level is not directly connected with the surface. The production of concentrating chalcocite ore from the great stopes in the Copper Mountain mine amounted to about 65 tons per day in 1902 . The ore reserves are very considerable.

Geology.-A distance of about 700 feet separates the Arizona Central vein on the lower adit level from the main ore bodies below Copper Mountain. Within this distance are several areas of hard metamorphic limestone, and, next to the main body of porphyry, some quartzite. These evidently are irregular large included masses which separate the Arizona Central dike from the main mass. The stratification and geological horizon of these metamorphic rocks are not easily deciphered, but they probably belong to the lowest part of the Longfellow formation. The metamorphic rocks between the two porphyry dikes of the Manganese Blue mine without doubt belong in the upper part of the same formation; hence an upturning disturbance has probably taken place next to the main porphyry mass. The metamorphic rocks and the porphyry between the two ore bodies on the tunnel are largely hard and fresh, but the porphyry contains pyrite and is sericitized in places, while the metamorphic limestone, besides epidote and pyroxene, contains disseminated pyrite, magnetite, chalcopyrite, and zinc blende, which, as a rule, show no oxidation. The lower limit of oxidation in the metamorphic rocks runs very irregularly, often ceasing 50 feet below the surface; occasionally it descends far deeper. Thus, near the boundary between the Copper Mountain and the Humboldt mines, on the stope level, 350 feet below the surface, a bunch of cuprite and copper carbonates occurred associated with a small mass of limestone embedded in porphyry.

Ore bodies.-Near the end of the tunnel a good-sized body of sericitized porphyry with disseminated pyrite coated with chalcocite was found. This expanded greatly on the stope level above, the stopes reaching 100 feet in width. On the upper adit the ore is almost as wide, and on the Kimball tunnel the chalcocite bearing soft porphyry is almost 200 feet wide, the ore, however, not extending high above that level. From the surface down for 100 feet and for 200 feet immediately below the crest of the mountain the ground is leached, containing partly oxidized pyrite with a little limonite, malachite, and brochantite. The immediate surface consists of hard light-brownish porphyry with quartz seams and a very small amount of limonite.

This great body of ore is richest on the three upper levels and grows gradually more pyritic near the main adit; on this level the stopes are only 20 to 30 feet wide, but increase to 100 feet a short distance above. Though the porphyry 
is abundantly seamed with chalcocite and pyrite, there are few central veins or seams such as are normally found in the great ore bodies of Copper Mountain. The lode has been followed with narrowing width of concentrating ore on the stope level nearly to the side line of the claim, and here to the south of the main adit - a well-defined rich chalcocite seam 14 inches wide appears; it strikes N. $15^{\circ}$ E. and dips $70^{\circ}$ E.

The ore body is usually considered to be a part of the Humboldt lode, but it is more probable that this ore forms the extension of the Wellington vein, which crosses the Humboldt vein 300 feet northeast of the Copper Mountain stopes.

As in most of the porphyry lodes, we notice here two zones-first, that of surface leaching, 100 to 200 feet deep; second, that of the chalcocite ore, here about 300 feet deep. Its lower limit has not yet been reached, but probably does not lie far below the level of the Copper Mountain tunnel.

\section{FAIRPLAY VEINS.}

The Fairplay veins, which belong to the Arizona Copper Company, are located on the west side of Copper Mountain, not far below the summit. They have been developed by about 3,000 feet of drifts from the Fairplay tunnel (elevation, 5,096 feet, or 20 feet above the Liverpool level) and the Humboldt level (elevation, 4,890 feet), 200 feet lower. On the northwestern vein three stopes of concentrating ore up to 40 feet wide have been opened on the Humboldt level, and a considerable amount remains to be taken out. The mine was not worked extensively in 1902.

Practically all of the workings are in porphyry, which is bleached, cemented by silica, and contains disseminated pyrite with chalcocite coating.

The principal Fairplay vein, best exposed on the Humboldt level by the long Humboldt-Fairplay tunnel, strikes N. $20^{\circ}$ E. and dips about $70^{\circ} \mathrm{NNW}$. It has been followed for 700 feet, and lies about 300 feet north of the Wellington lode, with which it is strictly parallel; it is the most northwesterly of the great Copper Mountain system of lodes. The Fairplay vein is determined by a strong fissure, which is followed by one or several seams of chalcocite and pyrite associated with an unusually large amount of quartz and having a thickness of up to 8 inches. In places the vein is surrounded by soft porphyry containing veinlets of chalcocite, forming second-class ore. The depth below the surface on this level is about 350 feet. Stringers branch at both ends of the vein in a northeast direction. East of the main vein, at a distance of 150 feet, lies another chalcocite seam surrounded by milling ore. Four large stopes are opened on chalcocite ore along the Fairplay vein, the largest being 100 feet long, 35 feet wide, and at present 160 feet high. 
Two hundred feet above this level the same vein is exposed by the Liverpool tunnel; it carries chalcocite here also, but appears to contain less ore than below. The main vein extends up to a northwesterly trending dislocation (a branching part of the Copper Mountain fault) on this level, but can not be traced across the Liverpool tunnel. On this level are noted two strong eastnortheast fissures with 16 inches or less of chalcocite, dipping from $52^{\circ}$ to $68^{\circ}$ NNW., which form the connection of the Fairplay vein with the Humboldt lode.

\section{LONE STAR TUNNEL.}

The ground below the high porphyry ridge in the western part of Morenci district has been explored by means of the Lone Star tunnel, which opens properties of the Detroit Copper Company. The east portal of the tunnel is situated in the west branch of Morenci Canyon, and is 800 feet west-southwest of the Arizona Central shaft. The general direction of the tunnel is west-northwest, though its eastern end makes a strong bend to the south; its length is about 2,700 feet, and it pierces the ridge entirely, emerging at the head of Gold Gulch on the west side. The elevation is 4,949 feet above sea lovel (Pl. XVIII and fig. 18).

The eastern portal is in partly altered lime shale, which, at about 50 feet in, changes into decomposed porphyry. At a distance of 235 feet from the portal hard and massive quartzite is encountered, the contact being marked by an important dislocation striking nearly northwest and dipping $70^{\circ}$ NE. A comparison with the surface geology shows that this dislocation is identical with the important Apache fault, along which farther south a vertical movement of several hundred feet has occurred. The amount of the faulting movement can not readily be determined at this point, but the relation of the areas on the surface would rather indicate a lesser displacement. The foot wall of quartzite is well exposed from the surface down to 100 feet below the tunnel level. Contact breceia of porphyry and quartzite several feet in thickness is occasionally found on the tunnel level along the fault, which is also marked by a strong clay seam. Bunches of cuprite ore occur all along this fault plane from the surface down, and fair, though not very wide, bodies of payable ore have been found in a drift southwest of the tunnel. This is one of the few instances at Morenci of copper ores occurring on one of the principal faults.

Quartzite continues for 290 feet west of this fault, and considerable quantities of it have been stoped for the purposes of converter lining. At the distance mentioned the quartzite is replaced by porphyry, containing many quartz seams and disseminated pyrite. This porphyry continues through the tunnel to the western portal. 
Eight bundred feet from the mouth a well-defined vein is crossed striking north-northeast and dipping $80^{\circ}$ ESE. This vein is also exposed on the surface 300 feet above the tunnel level. It contains a sharply defined seam of dullblack chalcocite, in places surrounded by a fair amount of second-class ore.

About 1,200 feet from the portal are encountered a series of stringers and small veins, which continue for 500 feet, or to a distance of 1,700 feet from the mouth. Up to this point the porphyry is soft and partly sericitized, with many little stringers of quartz and pyrite and stains of sulphates. Beyond this point it is much fresher, and shows little evidence of mineralization. These veins no doubt represent the western extension of the Fairplay and Butler fissures, but the amount of payable ore thus far encountered is small. There are five or six of them within a distance of 500 feet; they course north-northeast to northeast and dip northwest at steep angles. The tunnel cuts them 300 to 400 feet below the surface. At least three of them show several inches of rich chalcocite ore, and in one 5 feet of payable ore is exposed.

Among these veins is one so entirely different from the ordinary type of Morenci deposits as to necessitate special mention. It is a vertical veinlet 4 inches thick, consisting of a quartz-filled fissure with comb structure and drusy cavities coated with crystals. The associated minerals are pyrite, zinc blende, and chalcopyrite, the two first-named minerals also occurring as crystals in the druses and vugs.

BUTLER TUNNEL.

The main porphyry ridge west of Copper Mountain is opened by the Butler and London tunnel, both claims being the property of the Detroit Copper Company. The south portal is situated on the north side of the gulch, opposite the Lone Star tunnel and 700 feet west of the Arizona Central shaft. It pierces the ridge entirely and its north portal is found near the head of the main west branch of Concentrator Canyon, almost due north of the southern entrance. The total length of the tunnel is 3,200 feet; it does not run straight, but makes a sharp bend to the west. The elevation of the tunnel is 4,949 feet, or 62 feet higher than the collar of Arizona Central shaft. The Butler and London veins, each carrying smaller ore bodies, have been exposed by this tunnel.

The tunnel enters into an area of quartzite of irregular outline, bordering on the north against porphyry; the contact is irregular and evidently intrusive. This hard massive quartzite, which contains several porphyry dikes, continues for 320 feet from the portal. On the second level of the Arizona Central, which also has been pushed forward in this direction 200 feet below the tunnel level to a point a short distance north of the Butler vein, this contact is met about 150 feet farther south, showing that the porphyry dips below the quarzite. 
Porphyry thus begins 320 feet from the south portal and continues the whole distance to the north portal. To a point 800 feet from the south portal the porphyry is sericitized throughout, also containing pyrite seams and copper stains. For the next 900 feet, about the main bend in the tunnel and about 400 feet below the surface, the porphyry is fresh without quartz seams and pyrite. In part it is blocky and hard, with well-developed joints dipping steeply southwestan unusual direction of jointing for this region. In part it seems somewhat disintegrated, showing a tendency to form rounded blocks; this type of porphyry corresponds well with that on the surface above, described on page 80 . It is a light-gray rock, with white, closely massed feldspar crystals and scattered greenish foils of biotite. The groundmass is coarsely microcrystalline, consisting of orthoclase and quartz; the porphyritic feldspar crystals consist of orthoclase, albite, and oligoclase. The rock may be classed as a granite-porphyry or a quartz-monzonite-porphyry. Some 1,200 feet from the north portal sericitization and veinlets of pyrite and quartz begin again and continue to the mouth.

The Butler vein, which evidently forms the continuation of the system of northeast fissures on the Fairplay claim adjoining on the east, and which is here the only representative of the great Copper Mountain vein system, is met at a distance of 540 feet from the south portal. No croppings are seen corresponding to it on the surface. It shows in the tunnel as two narrow fissures, about 10 feet apart, dipping $40^{\circ}$ to $60^{\circ} \mathrm{NW}$. The principal and southerly one shows 6 inches of pyrite and chalcocite. It has been developed by an incline reaching down to the extended second level of the Arizona Central, 200 feet below tunnel level, and shows here a good foot wall with striation and gouge. The vein itself is about 1 foot wide, and consists of massive pyrite with quartz and a little chalcocite. There is practically no ore outside of the vein proper. The dip is $50^{\circ} \mathrm{NW}$. This point is about 380 feet below the surface.

Two hundred feet from the northern portal the London vein is cut; it shows a well-defined wall striking northeast and dipping $30^{\circ} \mathrm{NW}$, along which lies a streak of pyrite with chalcocite, in places rich in copper and 5 feet or less wide. The London vein belongs to the Carasco system of joints and veins, which is so extensively developed at the head of the western branch of Concentrator Canyon. In the last 15 feet of the tunnel surface decomposition has yielded much limonite.

\section{ARIZONA CENTRAL MINE.}

Location, production, and development.-The Arizona Central, which is one of the important producers of the Detroit Copper Company, is situated in the western branch of Morenci Canyon, on the outskirts of the town. The steep hill slopes rise above the shaft somewhat like an amphitheater, the summits of the 
ridges being 400 to 500 feet higher than the mine. The deposits, which are chiefly in the nature of fissure veins, have been worked for fifteen years, and have furnished a large amount of chalcocite ore, much of it of high grade. The average daily output in 1902 was 93 tons of concentrating ore. The veins crop on the surface in part, and have been worked to a depth of 300 feet. The principal workings are contined to a space of 1,000 by 300 feet, extending in an eastnortheast direction, but long crosscuts extend on the second level northwest to the Butler vein and southeast to the Hudson. On the first level the workings connect with the adit level of Copper Mountain mine by means of a winze. The total developments amount to about 2 miles of workings. The mine is opened by the Arizona Central shaft, the collar of which has an elevation of 4,887 feet. Three levels are turned, the first 91 feet, the second 143, and the third 242 feet below the collar. The principal developments follow the Williams lode southwest from the shaft, but on the first and second levels the drifts also extend northeast in the Arizona Central vein, connecting, as stated above, with the Copper Mountain workings.

Geology. - The principal feature near the Arizona Central mine is the long dike-like mass of porphyry from 200 to 500 feet wide, which extends in a northwesterly direction. It connects in two places with the main porphyry mass of Copper Mountain, but is separated from it by long areas of altered limestone, shale, and quartzite, several hundred feet wide. The porphyry of this dike is of the normal Morenci type, approaching granite porphyry in composition; it is light colored and generally altered by disseminated pyrite, sericite, and quartz seams. On the northeast this dike-like mass extends 800 feet beyond the Copper Mountain fault; on the southwest it reaches 1,800 feet from this fault, halfway up the divide toward Gold Gulch, where it is suddenly cut off by the Apache fault and separated from the main porphyry by two smaller irregular areas of quartzite.

On the southeast side of this dike, near the Arizona Central shaft, the sedimentary rock consists of a hard dark-green shale, breaking in sharp fragments, with seams of pyrite, streaks of epidote, and frequent green copper stains. This shale in places shows a stratification dipping gently westward, and should in all probability be referred to the Morenci formation.

An offshoot of the main dike crosses the railroad track 300 feet east-southeast of the shaft. This dike is ore bearing, and good stopes have been developed on it from near the surface to the second level. About the same distance to the southeast crops a smaller dike with an east-northeast strike. Though only partly exposed on the surface, this seems to correspond to the Williams vein, a dislocation following a narrow dike on which large stopes have been opened on the 
first, second, and third levels. Toward the west this dike probably joins the main porphyry mass.

The long crosscuts on the second level have developed moderately altered shale on the northwest side of the Arizona Central porphyry dike, dipping $30^{\circ}$ south. The southeastern crosscut to the Hudson vein has also shown the presence of a large mass of hard black shale on the southeast side of that dike. This shale does not seem much altered and dips south regularly at $15^{\circ}$.

On the south side of the gulch, opposite the shaft, the sedimentary rocks consist of lighter-colored shales and very fine-grained quartzites of uncertain horizon, and the contact becomes very jagged and broken. On the northwest side the porphyry is adjoined along a regular contact by an area of lime shale and limestone. This is in part altered to epidote, magnetite, and pyritic minerals, but in places only contains abundantly disseminated magnetite, pyrite, and chalcopyrite. This should probably be identified with the Longfellow formation; for it appears to rest conformably with moderate southern dip on thick massive quartzite, which no doubt represents the Coronado formation. This quartzite, a few hundred feet wide and 800 feet long, is adjoined on the northwest by the main porphyry area of Copper Mountain, which borders against it with intrusive contact.

The Apache fault crosses the Arizona Central dike 1,050 feet west-southwest of the shaft of the mine; its course is N. $40^{\circ}$ to $50^{\circ} \mathrm{W}$.; its dip $60^{\circ}$ to $70^{\circ}$ $\mathrm{NE}$.; it is crossed by the Lone Star tunnel, and its northerly end has been described under that heading. On the surface it shows porphyry in the hanging wall and quartzite in the foot wall, sut crossing the southerly contact of the Arizona Central dike it enters an area of much-altered shale, and then continues through the gap near the Eagie Creek water tanks down into Apache Canyon. Southeast of this gap the dislocation is great, for it brings the Cretaceous shales on the east side against the Longfellow limestone on the west, which indicates a drop of the northeast block of about 800 feet. What the amount is at the mine can not be determined, for the horizons of the sediments near this place are uncertain and the intrusion of the porphyry has disturbed the strata greatly. The vertical dislocation is probably less than farther south. The horizontal dislocation must be small, for the contact lines of sediments and porphyry are almost unaffected by it. The northeast block here, too, represents the downthrown mass. The quartzite area which forms the foot wall is of small extent and evidently is an included mass in porphyry. A parallel dislocation indicating a tendency to step faulting is noted on the surface 300 feet northeast of the main fault. This tendency is still more emphasized in the mine levels. Twelve 
hundred feet west-southwest of the shaft a peculiar dislocation occurs, starting from the hanging wall of the Apache fault and continuing for a few hundred

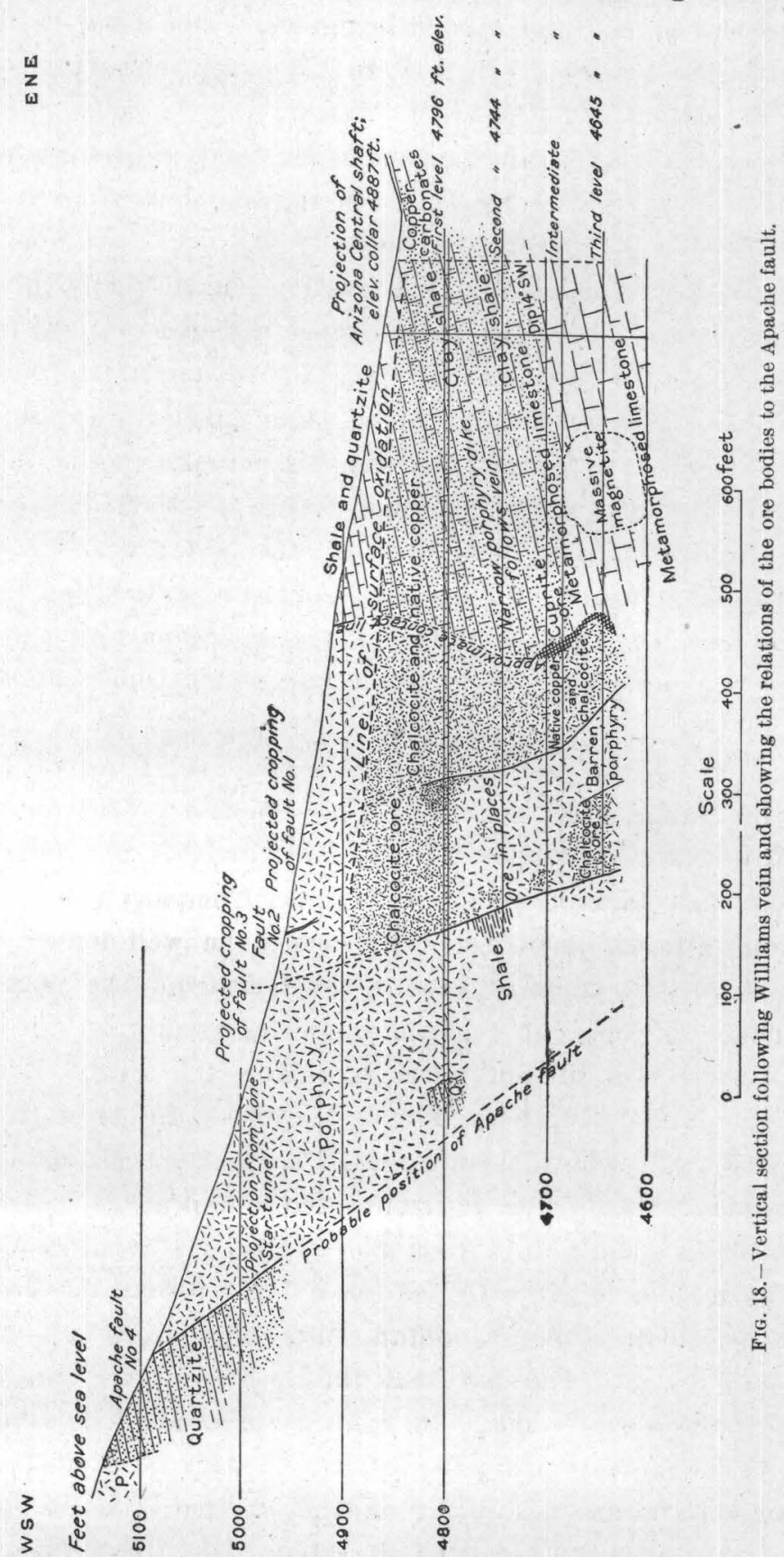

feet N. $80^{\circ} \mathrm{W}$.; it shows a narrow shattered zone of shale between two walls, outside of which on both sides is porphyry. 
From the Arizona Central shaft to the Copper Mountain fault a dislocation follows the southeast contact of the big dike, and the course indicated is that of the Arizona Central vein. It apparently antedates the Copper Mountain fault, for the latter throws the contact 70 feet to the south horizontally, and the vein is also cut off by it.

Croppings consisting of copper carbonates in shaly rocks occurred along both contacts of the Arizona Central dike for 500 feet northwest from the shaft. Ore was found both in porphyry and lime shale.

Croppings of the Williams vein are noted in shale and porphyry 200 to 300 feet east of the shaft. They consist of copper carbonates contained as seams in the rocks.

Arizona Central lode.-As stated above, this lode follows the nearly vertical fault slip on the southeast contact of sedimentary rocks and porphyry from near the Arizona Central shaft, where it seems to join a branch of the Williams lode, to the Copper Mountain fault, a distance of nearly 1,200 feet. The lode is not known with certainty east of the Copper Mountain fault. Some poor chalcocite ore occurs, however, on the first level of the Humboldt mine 500 feet farther northeast along the same contact. This may possibly represent the extension of the lode.

The surface along the line of the lode rises rather rapidly about 130 feet northeast of the main shaft and then runs off about horizontal to the fault. The lode is opened in the Copper Mountain mine by the first adit, which starts on the railroad level just back of the Detroit Copper Company's store (elevation 4,870 feet), cuts across altered limestone, and reaches the well-defined slip separating this limestone from the porphyry about 130 feet from the portal and 100 feet below the surface. Stopes of chalcocite ore in porphyry, 30 feet wide, have been developed here, but do not reach far above the level. Drifting northeast the ore continues, though poorer, for 100 feet to the two great clay-covered northeast-dipping slips, which here represent the Copper Mountain fault. Immediately beyond the fault a very important change appears; the porphyry becomes barren, stained with limonite, and has the appearance usually observed near the surface. Taken in connection. with the known downthrow on the northeast side, which farther southeast along the fault amounts to 225 feet vertical measurement, this would seem to indicate that the fault occurred subsequently to the formation of the chalcocite zone. As from other reasons it seems probable that the fault occurred before the eruption of the Tertiary lavas, that zone would seem to have a very considerable age. Explorations by drifts on the Copper Mountain fault on the first and second levels of the Manganese Blue mine (mine elevations 4,741 and 4,684 feet), have thus far failed to find the northeastern continuation 
of the vein. Assuming a horizontal dislocation along the fault line (shown by the position of the contact line on each side of the fault) of 70 or 90 feet, and a vertical throw of 225 feet, the continuation of the lode as it appears on the first adit should be found 35 feet below the second level at a place along that level 300 feet distant from the northwest boundary line of Copper Mountain claim.

The Arizona Central lode has also been encountered on the first level of the Manganese Blue mine 133 feet below the first adit of Copper Mountain.

The contact slip is developed as above and stands nearly vertical, but there is only a small amount of ore along it. The vein follows the contact continuously and consists chiefly of a streak of pyrite up to 1 foot thick which contains a little chalcocite. A little to the east of the first adit level a considerable amount of copper carbonates. were found in the lime shale adjoining the slip; irregular masses of azurite, malachite, as well as partly oxidized magnetite, occur frequently in the altered lime shale and limestone within 100 feet of the contact slip. The vein has been crosscut on the second level of the Manganese Blue mine 190 feet below the first adit and 270 feet southwest of it, but while this has disclosed the contact and the dike in the proper position, the porphyry is fresh, hard, and pyritic, and the slip on the contact is not well defined. The sedimentary rock adjoining the dike is here brownish limestone with seams of pyrite and zinc blende. It is partly replaced by tremolite, serpentine, pyrite, and quartz.

Between this point and the Arizona Central shaft the contact slip has been found in many places on the first and second levels of that mine. Its strike is due northeast, its dip being from $70^{\circ} \mathrm{NW}$. to nearly vertical. The sedimentary rock is apt to be very hard and greatly altered, now consisting chiefly of magnetite, garnet, pyrite, chalcopyrite, and zine blende. Streaks and veinlets of pyrite and chalcocite parallel to the contact slip occur in the porphyry, and large amounts of concentrating ore have been developed in places, especially on the first level, which is from 100 to 200 feet below the surface. The second level, 170 to 250 feet below the surface, contains good ore in places and several rich chalcocite seams in porphyry, but the ore is on the whole more pyritic than on the upper level. The stopes are in places 60 feet wide and almost entirely confined to the porphyry.

Williams lode.-The principal stopes of the Arizona Central mine occur along the Williams lode, which is situated 200 to 300 feet south of the shaft, and which has been opened on the first and second levels for a distance of about 1,000 feet. Between the shaft and the Williams lode a spur of the latter was encountered which seems to follow a porphyry dike in shale. Stopes extend on this almost to the surface. On the third level neither vein nor dike is visible in the hard contact-metamorphic rock here prevailing. 
On the first level much shale was encountered below where porphyry of the main dike appeared on the surface. The Williams lode was cut 220 feet south of the shaft and has been followed 500 feet west-southwest; the eastern part is mainly in shale, though a little porphyry appears in places, the ore consisting chiefly of disseminated chalcocite with a considerable amount of native copper. Near the faults of the western part of the mine the vein enters the main porphyry dike. In places the stopes are 70 feet wide, though usually less; they do not extend to the surface, though they sometimes reach 50 feet above this level.

On the second level the lode widens greatly and much more porphyry is present than on the first level. Around the shaft the porphyry appears leached and contains no ore. A crosscut to the south, mainly through shale, encountered the Williams lode 300 feet south of the shaft, where it has been opened for 400 feet in an east-northeast direction to a point below the railroad track. The ore is here up to 24 feet wide, shale appearing in both walls, and porphyry coming in here and there. The vein matter seems to be crushed shale and porphyry, the ore consisting of cuprite, native copper, and chalcocite; there is very little azurite and malachite. On the intermediate level, about 50 feet lower, similar conditions obtain; there is evidence of strong shearing, the rocks being chiefly shale with a narrow streak of porphyry along the vein. The stopes on this level are small. Toward the west this main branch of Williams lode has been followed for 400 feet up to the faulted zone, bending slightly more to the west-southwest. Stopes up to 20 feet wide have been worked on it in places. The rock is chiefly shale. About 75 feet north of this streak another line of parallel stopes has been opened, which continues up to the faulted zone. This contains both shale and porphyry and seems to lie on the south contact of the main porphyry dike. Toward the faulted zone porphyry prevails. In a way this may be considered as the westerly extension of the spur mentioned above, or of the Arizona Central lode. The stopes are in places 100 feet wide and the ore is of the same character as above stated. A third drift parallel to the others has been opened in the porphyry about 75 feet farther north and some chalcocite ore developed along it.

On an intermediate level, 60 feet below the second level, drifts along the Williams lode show shale with narrow streaks of porphyry in places along the vein. Evidences of strong sheeting and shearing are plentiful.

Going west the porphyry widens, and near the fault the stopes are 100 feet wide and contain soft white porphyry with disseminated chalcocite and some native copper. Seventy-five feet back from the first fault, at the contact with the metamorphic rock, which here contains much magnetite, stopes of cuprite ore were found, some of the cuprite coating the corroded magnetite in fine crystals and being associated with limonite. Similar cuprite stopes were found on the lowest level. 
Near the south side of the ore on this level a vein of native copper is encountered. It occurs as a massive, almost vertical seam, striking N. $60^{\circ}$ E., and in places contains 8 inches of massive copper. A little chalcocite and cuprite are associated with it, as well as some fine-grained quartz. Some 20 tons of native copper had been extracted from this vein at the time of my visit. Later on the vein was found on the third level, 40 feet below, though in less massive form. To the west this seam, as well as the ore in general, is cut off by the faults described more in detail below.

On the third level conditions are materially different. Driving southward in porphyry hard metamorphic rock is encountered 100 feet from the shaft and continues to a point below Williams lode, which thus far has not been found on this level. This rock consists of an intimately intergrown granular mass of garnet, epidote, magnetite, chalcopyrite, zinc blende, and pyrite, in places also associated with pyroxene. A prominent slip, striking northeast and dipping $45^{\circ} \mathrm{NW}$., was observed below the Williams lode. In the hanging wall a hard rock was found, consisting of alternating streaks of epidote, tremolite, and pyrite, while a softer shale occupied the foot wall. Near this point the dirift contained much magnetite, in places intergrown with quartz. Drifting due west at an angle of $30^{\circ}$ with the Williams lode disclosed the presence of a large body of almost pure granular magnetite which has been stoped for a distance of 150 feet and a width of 40 feet, the material being used as flux in the smelter. This body of almost solid magnetite, lying at an angle of $30^{\circ}$ with the Williams vein, reaches up to the intermediate level, 50 feet above, with decreasing width; below, a winze sunk in the center of the stopes struck shale in 30 feet.

The magnetite has no distinct walls, but gradually changes into normal metamorphic rock on both sides. In places it contains a little chalcopyrite. In a distance of 200 feet west from the place where the magnetite was first met the drift following it gradually enters into a shaly rock, which continues, cut by two dikes of fresh porphyry, to the first fault of the Apache fault zone. Following this the drift turns south and runs into mineralized porphyry with a few narrow streaks of chalcocite and disseminated native copper. At 120 feet from this bend the seam of native copper mentioned under the description of the intermediate level was struck, but was somewhat less massive than it was above. On the west side of the fault the porphyry is barren, but drifts to the east in the direction of Williams lode developed good chalcocite ore in altered porphyry, which 30 to 60 feet east of the fault changes to rich cuprite ore on the contact of shale and porphyry and largely in the shales. Still farther east, near the big magnetite stopes, the metamorphic rocks become barren. A winze sunk 77 feet in this red cuprite ore entered altered limestone with some chalcopyrite at a short distance below the level. 
Faulted zone.-About 500 feet west-southwest of the shaft the drifts following the Williams lode encountered a strong faulted zone (fig. 18). On the surface, as indicated and described above, courses the Apache fault, along which it is known that a considerable downthrow has taken place on the east side. The line of drifts as extended cuts this fault at an angle of about $63^{\circ}$, and thus the projection of the fault on the section is somewhat flatter than the actual dip of the plane. The Apache fault has been eut underground in the Lone Star tunnel, as described above, and is projected on the section. In the Arizona Central mine it has probably not been cut as yet. The first level encounters quartzite, as indicated, and nearly in the proper position for the Apache fault, but no dislocation separates the two. The fault should be found about 30 feet west of the contact.

Two or three parallel faults lie in front of the main one and are probably step faults belonging to the same system. No indication of the total amount of the vertical dislocation has been found. In a smaller fault associated with No. 3 fault, on the second level cutting across a quartzite-shale contact, a downthrow of the east side of 1 foot was actually measured. The two principal front faults have been found on all levels; as a rule they carry little ore, though small quantities of cuprite and chalcocite may be found on them. As to the Apache fault, it contains some good ore on the surface and in the Lone Star tunnel, and may well be found productive in depth also. The faults dip to the east and do not differ much in strike from the Apache dislocation. On the first and second levels there is also a strong fault, appearing as a rolling slip, the strike of which is parallel to the drift (N. $73^{\circ}$ W.); no ore appears on this. On the first level drifts west of fault No. 1 and north of the plane of the section encountered blocks of quartzite dipping $30^{\circ}$ southeast and bounded by dislocations. This quartzite contains small bunches of chalcopyrite. On the intermediate level metamorphic shale and magnetite with chalcopyrite have been encountered on the east side of fault No. 1 and north of the section. Some of this has been stoped as it contained 5 per cent of copper.

On the first level chalcocite ore continues across fault No. 1 up to No. 3, though the payable material is not equally distributed. The porphyry is white, soft, and sericitic, containing irregular seams of chalcocite and pyrite. This ore continues down in places, but on the second level the space between the faults is divided by a smaller dislocation (No. 2) into two parts, the part between Nos. 1 and 2 being barren, while concentrating ore appears between Nos. 2 and 3. On the first level the rock west of fault No. 3 contrasts remarkably with that to the east, the porphyry being somewhat disintegrated, with limonite and little pyrite seams surrounded by quartz zones, but no chalcocite, and appearing in general as if 16859-No. $43-05-19$ 
having been subjected to surface oxidation. This would indicate that the block between the Apache fault and No. 3 had subsided relatively to that between faults Nos. 2 and 3 ; this would, however, contradict the evidence of settling on the east side alluded to above and confirmed by the known general downthrow of that side.

Further explorations of the block next to the Apache fault on the deepest level will probably elucidate these questions.

Hudson vein.-This is exposed on the second level of the Arizona Central by a long crosscut southeast from the Williams lode; black shale dipping $15^{\circ} \mathrm{S}$. or SW. intervenes between the two, the distance being 430 feet. The Hudson vein, which has been drifted on for 200 feet in a southwest direction, courses N. $40^{\circ}$ E. and dips $60^{\circ} \mathrm{NW}$. It is a well-defined fissure breaking through black shale, a dike of fresh porphyry 50 feet wide lying a short distance away in the foot wall. The vein is up to 6 feet wide, and contains bunches of quartz, crystallized pyrite, zinc blende, and some cuprite in the crushed shale. Between the Williams and Hudson veins the shale contains flakes of cuprite and one narrow but well-defined vein striking north-northeast and dipping $50^{\circ}$ SE.; the ore is similar to that of the Hudson vein, both being different in character from the ordinary type at Morenci.

Conclusions.-The relations of structure, composition of rocks, and distribution of ore at the Arizona Central mine are very complicated, and to be adequately described would require much more space than is here available. The difficulties are increased by the inaccessibility of the extensive old stopes and workings. Contacts of porphyry and sedimentary rocks run extremely irregularly and, in the lowest level, masses of hard metamorphic rock, with much magnetite and some pyrite and chalcopyrite, project into the porphyry. A line of dislocation cut off by fault No. 1 no doubt extends along Williams lode and conditions the occurrence of the main ore bodies, which, however, by secondary formation of chalcocite are apt to spread far beyond this line, especially in the porphyry. Toward the east-northeast the lode runs into the prevailing shale and the ore bodies are narrower. On the lowest level the fissure has evidently not been able to maintain itself in the hard metamorphic rock, though the ore appears again in the porphyry near fault No. 1 . There is no reason to believe that the great mass of magnetite and the scattered chalcopyrite in the metamorphic rock are at all due to the vein-forming agencies. They are doubtless due to the general contact metamorphism.

Though the large ore bodies chiefly occur in porphyry, payable ore is also contained in the shale; cuprite is very apt to appear in these stopes. The Hudson vein is a good example of fissures accompanied by ore occurring directly in the shale. 
The ores of the Williams lode nearly reach the surface in the east part of the mine, and on the whole the line of surface oxidation lies higher than in Copper Mountain. A very interesting feature is also the universal occurrence of native copper, sometimes also cuprite, with chalcocite, down to a depth of over 300 feet below the surface, far below the line where the direct influence of surface oxidation is noticeable. Unless bodies of hard metamorphic limestone are again found below the bottom level in the west part of the mine, a continuation of the chalcocite zone is to be looked for at a depth perhaps 100 or 200 feet greater. There is little doubt that eventually pyrite will replace the chalcocite. Another interesting feature is that in some places the metamorphic rock has contained enough chalcopyrite to constitute payable ore. The developments should at any rate be pushed to the Apache fault, and it is not impossible that payable ore may be found west of it along the general direction of the Williams lode. 


\section{CHAPTER VII. GOLD CREEK BASIN. TOPOGRAPHY.}

In connection with the Gold Creek basin may be described the slopes toward Eagle Creek from the divide near Morenci, which embrace the drainage basin of Gold Creek as well as a few shorter gulches north and south of it.

Heading at the porphyry ridge northwest of Morenci, which has an elevation of from 5,000 to 5,500 feet, Gold Creek runs southwesterly, and after a course of 4 miles empties into Eagle Creek Canyon at an elevation of about 3,600 feet. Its watersbed contains 5 or 6 square miles. The descents near its head are steep but by no means inaccessible; lower down the topography becomes less pronounced; somewhat irregular ridges, up to 500 feet high, are separated by little gulches with rapidly sloping sides; the whole forming a moderately hilly and extremely barren landscape. On the north side the trend of the ridges is northerly, while on the south side it is prevailingly southwesterly.

A mile and a half from its head Gold Creek is joined by Pinkard Gulch, which heads in Coronado Ridge, 2 miles northward. Still farther down it is joined by Silver Creek, a small tributary from the south. Near the point of juncture the small but abrupt canyon opens as the watercourse emerges from the older rocks into the open lava-filled valley of Eagle Creek; nearing the latter trunk stream, however, a canyon of different type, narrow and with nearly perpendicular walls, begins, and the junction takes place in a picturesque gorge, 500 feet deep, excavated in the rhyolite tuffs which filled the basaltic Tertiary valley of Eagle Creek. Similar descriptions apply to the short gulches north and south of Gold Creek.

\section{GEOLOGY.}

ROCKS.

Granite.-Granite is exposed only in the upper part of Pinkard Gulch, north of the Cayuga fault, and at the head of Gold Gulch southwest of the benchmark 6,370 at the southern end of the Coronado Ridge. A small area is also exposed by faulting $1 \frac{1}{4}$ miles northwest of the point where Gold Creek emerges 
into the lava-filled valley. It is of the usual coarse-grained reddish type, consisting chiefly of quartz, orthoclase, and perthite. Near the head of Pinkard Gulch, three-fourths of a mile below Las Trajas prospects, it contains locally an unusual dioritic modification.

Sedimentary series.-The Coronado quartzite (Cambrian) is exposed in several detached areas near the head of Gold Creek, usually surrounded by porphyry. Heavy beds of the same formation are brought up on the north side of the Cayuga fault and connect with the great quartzite block of the Coronado Ridge, which dips west at angles of from $10^{\circ}$ to $17^{\circ}$. The thickness of the formation at this point seems to be at least 300 feet.

The Longfellow limestones (Ordovician) are extensively exposed between Pinkard Gulch and the lavas of Eagle Creek, the dip being generally southwesterly from $20^{\circ}$ to $30^{\circ}$. The rocks form heavy benches of light-gray or brown, massive, more or less cherty limestones, and in several places contain characteristic flat gasteropods.

The Morenci shales and associated limestones have been observed at only one place in the foothills of Eagle Creek Valley, 1 mile northwest of Gold Gulch, where they are underlain by the Silurian limestone on the north and adjoined by porphyry on the south. At the same place there is a small amount of the lowest limestone bed of the Modoc formation (Mississippian). Many of the isolated limestone areas surrounded by porphyry are difficult to place, but probably chiefly belong to the Longfellow formation.

North and south of the lower part of Gold Gulch is a series of alternating sandstones and shales, forming irregular areas almost entirely surrounded by porphyry. With some confidence these strata are referred to the Cretaceous as belonging to the same formation so extensively exposed a few miles southwest of Morenci. Along the foothills of Eagle Creek the two areas in fact connect. The dip is variable and frequently shows great disturbances, but is chiefly to the south and west at angles up to $20^{\circ}$. Frequent dikes of porphyry are contained in it.

Porphyry.-Porphyry of the Morenci types occupies nearly the whole of the upper valley of Gold Gulch, and is also intimately mingled with sedimentary rocks as stocks, sheets, and dikes on the lower slopes toward Eagle Creek. Unlike the porphyry between Morenci and Metcalf, the rock does not form precipitous outcrops, but crumbles easily to fragments, forming a sandy soil, and giving the area a light yellowish-gray color. At the head of Gold Gulch, toward the Morenci divide, the rock is rusty and shows indications of mineralization by quartz cementation and pyritic dissemination. Otherwise it is not much altered though greatly disintegrated. 
The larger part of the porphyry is of the Morenci type. It contains small and closely massed white andesine crystals, small and not very abundant quartz phenocrysts, and scant foils of black mica, all of which are embedded in a grayish groundmass of microcrystalline structare, consisting chiefly of quartz and orthoclase.

As products of static hydro-metamorphism, epidote, chlorite, and some sericite have developed in varying amounts. In the foothills toward Eagle Creek and on the ridges south of Gold Gulch a type of diorite-porphyry without quartz phenocrysts and with increasing amounts of hornblende and biotite is more common. By increasing ferromagnesian silicates, this, in a few places, forms transitions into dark-green fine-grained porphyries. This diorite-porphyry forms the southern end of the great stock of Morenci and Metcalf. It connects southward, by a dike breaking across the ridge of Cretaceous rocks, with the laccolithic mass appearing 3 miles south-southwest of Morenci. On the southwest side, in the Gold Gulch basin, it borders against Cretaceous quartzite and shale, as well as Cambrian quartzite and Silurian limestone, with extremely complicated contact, and contains a great number of detached sedimentary fragments. The complication reaches its maximum along the lower part of Pinkard Gulch. A detached and also very irregular area of diorite-porphyry adjoins the basaltic foothills of Eagle Creek and also contains a great number of sedimentary areas of irregular or slab-like form.

Diabase.-A single smaller mass of this rock was found in Pinkard Gulch half a mile above its mouth. It probably occurs as a dike in the prevailing porphyry.

Contact metamorphism.-The Morenci porphyry produces a distinct alteration wherever it comes into contact with the shales and limestones, but in the Gold Gulch drainage this alteration or contact metamorphism is less marked than at Morenci. The Cretaceous shales and sandstones on the ridge south of Gold Gulch, as well as in the area crossing the lower part of that watercourse, are, as a rule, not highly altered, the changes consisting in a hardening or baking of the shales to compact black aphanitic rocks. This is sometimes, as on the high ridge southwest of Morenci, attended with a considerable development of epidote and magnetite. Garnet is not known to occur. The Silurian limestone, where bordering against the main area of Morenci porphyry, is always affected to some degree, though there may be considerable variation in the intensity of the alteration. This change rarely extends very far from the contact, and the interior of the large areas of Longfellow limestone is entirely unaltered. An isolated area of limestone on Gold Gulch, just above the mouth of Pinkard Gulch, is very largely altered into epidote and magnetite with copper stains and pyrite; garnet 
also occurs in lesser amount. In Pinkard Gulch the limestone is locally altered to garnet near porphyry contacts. At the Soto tunnel, driven on the same gulch 1 mile above the mouth, a porphyry dike has induced contact metamorphism in the same limestone, with development of garnet and epidote.

As at Morenci, the diorite-porphyry induces very little alteration, which rather seems to be proportional to the amount of quartz contained in the intrusive rock. The slabs of limestone embedded in the diorite-porphyry along the Eagle Creek foothills north of Gold Gulch show no contact-metamorphic action.

STRUCTURE.

The sedimentary rocks in the lower Gold Gulch basin dip to the southwest, more rarely to the west or south, at angles varying from $10^{\circ}$ to $30^{\circ}$, and this dip holds with surprising regularity even where the rocks are greatly torn by porphyritic intrusions. The porphyry is irregularly jointed, but shows no schistosity or sheeting. While the relation of the porphyry to the sedimentary rocks look very complicated, it is clear that the principal intrusions have taken place parallel to the planes of sedimentation, and that the porphyry largely consists of sills and laccoliths dipping westward like the strata. This relation is perhaps what a great stock breaking up through granite and encountering a thick sedimentary series would be expected to produce; under sufficient pressure the magma would naturally be pressed into the more easily opening joints of the planes of stratification.

The irregularity of structure in the Gold Gulch basin is therefore more the result of intrusive action than of faulting. There is, however, some evidence of the main epoch of faulting, which succeeded those of intrusion and mineralization. An important fault with a downthrow on the south side of several hundred feet crosses Pinkard Gulch at the Soto tunnel, which in fact is driven on the contact of granite and limestone, between the great fault block of Coronado ridge and that of Gold Gulch. This fault is traceable with decreasing throw for about a mile westward. On the east it is in line with the fault-separating granite and quartzite above the Longfellow incline, but is not traceable across the intervening area of porphyry. It may be more likely that it bends slightly northward and crosses the head of North Fork of Gold Gulch at the Producer copper prospect, where porphyry is separated from granite by several well-marked fissures dipping $45^{\circ} \mathrm{S}$.

There is probably another line of disturbance crossing Pinkard Gulch onehalf mile above its mouth, for here the Cretaceous strata are brought to the level of the Ordovician limestones; but no direct evidence of this has been found, and this dislocation may be contemporaneous with the intrusion instead of belonging to the epoch of subsequent faulting. 


\section{MINERAL DEPOSITS.}

\section{GENERAL STATEMENT.}

Gold Gulch basin really contains no mineral deposits of proved value and extent, but has a great number of prospects. Few of these occur in the upper part of the basin in the great porphyry area, but the majority are concentrated along lower Gold Gulch and on both sides of Pinkard Gulch, always, as a general statement, preferring the contact of porphyry and sediments for their appearance. While a number of copper prospects occur, most of the deposits have been located on account of their gold values. The lower Gold Gulch contained placer gold and was profitably worked for this at an early day. Its bed contains gold down to the junction with Eagle Creek, and even now a little money is made by panning along it. There are at least three old arrastres in Gold Gulch and the foothills to the north of it, erected by prospectors who discovered the district about 1880. But although pockets of good value have been found in many places, the deposits thus far opened have seemed to lack regularity and permanence. The gold occurs in free form on narrow little fissures, sometimes between porphyry and limestone or in quartzite or shale, but always in the vicinity of porphyry. The strike is usually northeasterly or easterly. Very little work was being done in 1902, and there was little opportunity of studying the deposits. The fissures usually contain some limonite, and the gold is associated with this. From this it may be surmised that the gold will be combined with sulphides in depth, and that conditions will be less favorable than on the surface.

\section{DETAILED DESCRIPTIONS.}

The road from Morenci to Eagle Creek first descends to the head of Silver Creek after having crossed the divide separating the drainage of San Francisco River from that of Eagle Creek. About 1,500 feet west of the road and at an elevation of 4,800 feet on the southern slopes of Silver Creek are two welldefined fissure planes, the more southerly of which is traceable for at least onefourth mile. They separate porphyry from Cretaceous sandstone and shale, and by friction breccias give evidence of faulting. Both of these have been prospected to some extent, the vein matter consisting of limonite and quartz without copper stain.

A little farther down on the low divide separating Silver Creek from Gold Gulch is a prospect marked by a horse whim. A small mass of magnetite containing copper stains is here inclosed in porphyry and should probably be considered as an inclusion of contact-metamorphosed limestone. 
In the lower part of Gold Gulch and Pinkard Gulch lie a number of claims, located on veins with an east-northeast strike, most of them lying between porphyry and sediments. For 800 feet above the mouth of Pinkard Gulch epidotized limestone with a considerable amount of copper stains is exposed in Gold Gulch and several prospects have been opened without finding any notable amount of copper ores. The Isabella is a narrow vein which crosses Pinkard Gulch 2,000 feet above its mouth. It is developed by several smaller tunnels. Good gold values have been found in spots along it, contained in the limonite along the vein, which seems to follow the epidotized contact of a porphyry dike in limestone.

"The Buzzard's Shadow" is the picturesque name of another fissure vein located at the head of a small gulch draining directly into Eagle Creek; it is at an elevation of 4,800 feet one-half mile northwest of the mouth of Pinkard Gulch. This is a well-defined vein between limestone in the hanging wall and porphyry in the foot wall. The developments are of small extent. The vein consists of a zone 12 inches wide of crushed limestone stained by manganese and said to contain a long shoot with values of $\$ 4$ in gold and 20 ounces silver per ton.

On a point of sandstone and shale, partly baked by contact metamorphism, 2,000 feet northeast of the mouth of Pinkard Gulch, is a prospect with copper stains along a porphyry dike 20 feet wide. From this it is reported that a small amount of ore rich in gold has been extracted.

Old arrastres are located in the gulches draining directly into Eagle Creek; the first is 1 mile west of the mouth of Pinkard Gulch; the other $1 \frac{1}{2}$ miles westnorthwest of the same place; near both places small veins of ferruginous quartz containing gold have been found.

A copper prospect has been developed by the Home Copper Company on the high hill (elevation 4,700 feet) overlooking Eagle Creek Valley, 1 mile south of the junction of Pinkard and Gold gulches. Carbonate ore occurs on the contact of the porphyry and the Cretaceous sandstone and shale.

One mile up from the mouth of Pinkard Gulch are the Soto and Cayuga claims. The former is developed by a tunnel driven on the fault fissure between limestone and granite, but on this nothing of importance has been found, though some oxidized ore had previously been encountered in the limestone; this is probably due to contact metamorphism along a porphyry dike in this limestone.

On the ridge east of the Soto claim are several small ore bodies in limestone. The Cayuga showed a good body of carbonate and silicate ore along a vein with an east-west strike and southerly dip of 55 , which has a foot wall of quartzite and 
a hanging wall of limestone. This fissure is not unlikely the direct continuation of the Soto fault. The structure in this vicinity is complicated. In general, the porphyry has a tendency to form intrusive sheets between the sediments.

Half a mile farther east-northeast the Producer vein, which is, very likely, the continuation of the Soto fault, crosses the north branch of Gold Gulch. Going up the slope toward the main divide, between Eagle Creek and Chase Creek, the outerops of this vein are strongly marked by sheeted ferruginous rock, copper stained in places. The fissure which seems to mark the contact of porphyry and granite dips $45^{\circ} \mathrm{SSE}$. 


\section{CHAPTER VIII.}

\section{CHASE CREEK VALLEY BETWEEN MORENCI AND METCALF.}

The area described in the following paragraphs lies between the great Morenci fault on the south, Coronado Gulch and King Ridge on the north, Markeen Mountain on the east, and the quartzite block south of Coronado Mountain on the west. It embraces many prospects and small mines, but contains no large producers.

\section{GEOLOGY.}

ROCKS.

Granite, porphyry, and quartzite are the only rocks present in the area. Granite occupies the whole of Markeen Mountain and the upper part of the western slopes of Chase Creek. In the central part of Markeen Mountain it is of the normal type, reddish, coarse grained, usually disintegrating and crumbling on gentler slopes, and consisting of quartz, orthoclase, and perthite, the scant ferromagnesian silicates usually decomposing to chloritic products. For a varying distance-up to a mile-from the contacts with the porphyry the granite is greatly modified by fracturing, sheeting, extensive quartz cementation, and pyritic dissemination. On the surface the pyrite is decomposed to limonite. The rock is yellowish red, of a different tinge from the normal granite, and along the canyon of Chase Creek it weathers into fantastic forms by reason of its alternating hard and soft texture. Vertical cliffs and sharp-pinnacled ridges form the salients, and cave-like recesses are often excavated in the steep declivities. Dark-green copper stains cover large areas on the precipices. Granite of this kind is well exposed in the canyon between the Longfellow incline and a point 1 mile south of Metcalf, also on the upper western slopes between the porphyry stock and the quartzite capping the main ridge. At many places the rock is recognizable only with difficulty.

The contacts with the porphyry run extremely irregularly and are in places very difficult to trace. Included fragments of granite or breccias of granite and porphyry are common near the contacts.

The quartzite is best exposed in Chase Creek Canyon a short distance above the Longfellow incline, but also occurs at several places as smaller masses 
included in porphyry. It is light gray or reddish, and should perhaps rather be called a quartzitic sandstone, for the individual quartz grains are often easily recognizable. It weathers dark brown as a rule. The exposures in this area rarely show plain stratification. Near the great faults crossing Chase Creek above the Longfellow incline pyrite appears disseminated in quartzite.

The porphyry forms a continuous belt from Morenci to Metcalf, a little less than 1 mile wide in its narrowest part and near Metcalf broadening to nearly 2 miles. The rock weathers to yellowish-brown or reddish outerops, very roughly and irregularly eroded. On fresh fracture it is yellowish or gray and shows closely massed small phenocrysts of albite or orthoclase, also bipyramidal quartz crystals several millimeters in diameter. The original biotite was sparingly present, and is generally converted into chlorite. The groundmass is microcrystalline and consists of quartz and unstriated fieldspar. This acid rock is most closely allied to the granite porphyries.

Fresh rock is hardly obtainable in this area. Everywhere the porphyry shows more or less extensive alteration, consisting in chloritization of biotite, sericitization of feldspars, cementation by quartz in veinlets, and frequently also disseminations of pyrite which, to judge from the efflorescence of cupric sulphate on dumps of tunnels, and from the "green paint" (p. 121) covering many outcrops, always contain some copper.

The porphyry forms an intrusive stock in granite bordering against the rock with most irregular and brecciated contacts. A great number of small dikes and irregular masses of porphyry are contained in the granite near the contact.

\section{STRUCTURE.}

Complicated and detailed faulting has doubtless taken place, but in the absence of the sedimentary series it can not easily be traced. The area certainly forms a part of the first great fault block south of the Coronado massif, and is adjoined southward by a series of similar blocks dropping southward en échelon. Its southern limit is formed by the fault which crosses Chase Creek at the quartzite-granite contact above the Longfellow incline and continues imperfectly traceable across the porphyry to the southern slopes of the peak, marked bench mark 6370. The downthrow on the south side would appear to be over 1,000 feet at Chase Creek, while it diminishes westward to something like 800 feet, as indicated by the relations of quartzite and granite southwest of bench mark 6370 . In several places along Chase Creek Canyon the granite is cut by distinct and closely massed joint systems, most of the joints having a northeasterly direction. Joint systems and fissures with a north-northeast to north trend also cut the porphyry and most of them contain copper ores. 
The porphyry contains a few well-defined fissure veins, among which may be noted the Fairbanks and Las Terrazas. The whole mass of the porphyry and much of the adjoining granite is doubtless cupriferous, the ore occurring as disseminations of pyrite with chalcopyrite, which accompany the extensive quartz cementation which the rocks have undergone. As a result of this, green copper stains are extremely common, and in any tunnel driven it is common to find efflorescences of cupric sulphate. This has led to extensive prospecting, which, however, in most cases, has been fruitless of important results. Among the oxidized copper minerals chrysocolla, brochantite, and malachite are most common, though azurite also occurs. It is quite possible that underneath the more promising oxidized ores of this kind payable chalcocite ores may be found. But here, as elsewhere, this mineral is secondary and will at a varying depth change into the primary pyritic ores. As an evidence of this the prospect tunnels along Chase Creek Canyon almost invariably encounter ores consisting of quartz, pyrite, and quartz in places with a little zinc blende or molybdenite. The deposits which have been most productive are those situated on the high ridges, like the Copper Queen mine, between Morenci and Metcalf. It is expected by many that exploration of this region by tunnels at moderate depth will lead to the discovery of great low-grade bodies of chalcocite ore in porphyry like those of Copper Mountain.

From the Carasco claim, which still may be considered to belong to the Morenci group, the trail to Metcalf, by way of the Copper Queen mine, passes a number of prospects, some of which are worthy of note.

\section{DETAILED DESCRIPTIONS.}

Fairbanks claim. - On the second ridge northeast from Carasco a clearly defined vein appears, developed by several short tunnels. The principal developments are on the Fairbanks claim, but the vein extends into the adjoining Lancaster and El Capitan claims, all belonging to the Detroit Copper Company. The elevation is approximately 5,200 feet. The country rock is chiefly porphyry, although the granite contact, which runs very irregularly, is not far distant to the east. The deposit is a well-defined fissure vein, striking N. $18^{\circ} \mathrm{E}$. and standing nearly vertical. The vein material consists largely of crushed porphyry, in which appear stringers and smaller masses of malachite, chrysocolla, and brochantite. Good bodies of low-grade ore are said to have been developed along this fissure, but only small amounts have thus far been extracted. Along the con- 
tact of granite and porphyry are several small prospects, most of them contained in a breccia of the two rocks and containing chrysocolla as the principal mineral. In the last gulch crossed by the trail, just below Copper Queen mine, is a prospect, probably on the claim called Copper King. A short tunnel shows a bunch of azurite, partly well crystallized and contained in decomposed porphyry.

Copper Queen deposits.-The Copper Queen deposits outcrop on the summit of the ridge overlooking Chase Creek at an elevation of 5,000 feet. The working tunnels were driven from the Chase Creek slope, 200 or 300 feet below the summit of the ridge, and were connected with the railroad at the bottom of Chase Creek by means of an incline with a vertical descent of about 500 feet. The claims, which belong to the Arizona Copper Company, were worked rather extensively a few years ago, producing oxidized ore of moderate grade. During the last few years, however, work has been abandoned. A tunnel has been begun near the bottom of the incline, probably intended to tap the deposit at greater depth. The croppings show several veins. Forty feet below the summit on the southwest side is a prospect on a fault slip in porphyry, striking east and west, and dipping $48^{\circ}$ north. The system of Copper Queen claims is evidently laid out parallel to this fissure. On the summit of the ridge many other prospect holes have been sunk, showing three strong fissure planes within a distance of 100 feet. The most southerly strikes N. $30^{\circ}$ E., the next one N. $50^{\circ}$ E., and, finally, a large and prominent fault plane, which strikes north and south. At a short distance north of this point several other fault planes are exposed, striking N. $24^{\circ}$ E. and dipping $60^{\circ} \mathrm{N}$, all the others being nearly vertical. A considerable mass of quartz appears on the fault plane farthest north; otherwise on all of them the vein material consists of crushed porphyry containing seams of oxidized ores, chiefly chrysocolla and brochantite. More rarely azurite and malachite are noted. The most prominent system of fissuring in this place, as well as at many other points in the vicinity of Metcalf, is doubtless the one with a northeasterly strike.

Mexican claim.-From the Copper Queen the trail continues in a northerly direction along the summit of the ridge to the Mexican claim, which is about 1,500 feet distant. The Mexican deposit is situated at an elevation of 5,300 feet, near the top of the big bluff overlooking Chase Creek. The principal rock is a quartz-porphyry, in which, on top of the ridge, a small area of quartzite overlies or is included. The Mexican shows a strong fissure, the porphyry striking N. $12^{\circ}$ E. and dipping $70^{\circ} \mathrm{W}$. One hundred feet north of this is another strong fissure striking N. $57^{\circ} \mathrm{W}$., and having a steep dip to the southwest. The developments consist of two tunnels of moderate length. Some very good ore, mainly oxidized, is said to have been found on the Mexican claims. 
From the gap near the Mexican mine overlooking Coronado Creek and Metcalf, and having an elevation of 5,300 feet, a trail descends to the bottom of the gulch. The porphyry is altered and contains seams of quartz.

Las Terrazas.-At an elevation of 5,200 feet the first croppings of this welldefined vein are located. They continue down to Coronado Gulch and have been opened by several tunnels. On the lower part of the slope the outcrops are much obscured by sliding masses of porphyry. The claim belongs to the Arizona Copper Company. The strike of the vein is N. $12^{\circ} \mathrm{W}$, and the $\operatorname{dip} 73^{\circ} \mathrm{E}$. The ore, which occurs as seams in the crushed porphyry, consists chiefly of chrysocolla, azurite, and malachite, and some good-sized bodies are reported to have been exposed.

Standard mine.--The Standard mine is located about 1 mile southeast of Metcalf at an elevation of 4,900 feet, on the southeast side of Standard Gulch, a short dry ravine running north of Markeen Mountain and entering Chase Creek 1 mile below Metcalf. This property has been producing on a small scale, off and on, for the last few years. During 1902, according to reports, $\$ 10,000$ net were obtained from ore shipments. One shipment of 112 tons averaged nearly 18 per cent of copper. A smaller shipment of first-class ore, averaging 40 per cent, was made during the same month. The ore must be packed on burros down to the level of the railroad in Chase Creek, a distance of one-half mile. The developments consist of two tunnels, and a winze sunk from the lower one. The country rock is porphyry throughout, the granite contact being about onefourth mile distant to the southeast. On the surface no well-defined vein is visible, though the rocks in the vicinity are much stained by limonite. The deposit is, however, probably of a fissure vein, along which irregular ore bodies extend into the porphyry. Near the surface the ore consists largely of limonite and malachite. In the lower tunnel and in the winze a considerable body of pure chalcocite ore mixed with some malachite was encountered, and from this the larger part of the ore shipments were derived.

Prospects.-From the Longfellow incline to the porphyry contact, 1 mile below Metcalf, a great number of prospect tunnels have been driven in the altered and silicified granite. A few hundred feet below the main granite and quartzite contact the Arizona Copper Company has driven a large tunnel westward into the quartzite with the object of using the rock as converter lining. It contains abundantly disseminated pyrite and probably also chalcopyrite, for it carries one-half per cent copper.

At the second railroad tunnel above the Longfellow incline the prevailing rock is an altered and bleached granite with veinlets of quartz containing pyrite, all containing about one-half per cent of copper. On a northeast fissure system 
the pyrite is coated with chalcocite, and a body 3 feet wide of 5 per cent ore is said to be exposed.

Half a mile above the incline is the Kingbolt tunnel, driven along a narrow dike of porphyry striking east-west and dipping south. The ore is contained in an indefinite zone of crushed and pyritic granite, the pyrite being blackened by chalcocite.

Fifteen hundred feet below the main granite-porphyry contact a small shaft in the bottom of the creek shows a little cuprite, brochantite, and chalcocite in granite. A few hundred feet above is altered granite with disseminated pyrite and on the west side of the canyon a tunnel driven on a porphyry dike. Seven hundred feet below the contact on the east side, probably on the Bon Ton claim, which extends northeasterly, is a small tunnel on a narrow porphyry dike in highly silicified granite. The dump shows an unusual amount of quartz, with pyrite coated with chalcocite, and much molybdenite. 


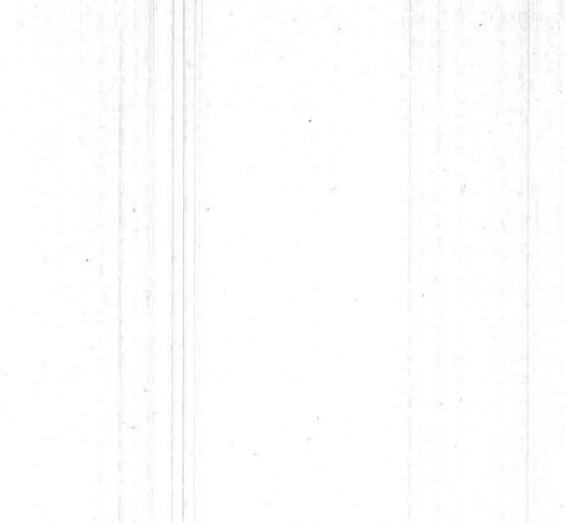

\section{CHAPTER IX. \\ METCALF DISTRICT. \\ TOPOGRAPHY.}

A special map on the scale of 1 to 12,000 , or about 4 inches to the mile, has been prepared in order to show the more important mines in the vicinity of Metcalf (Pl. XIX). This map covers an area of about 6,000 feet by 5,000 feet. The principal drainage line is Chase Creek, which flows from north to south through the western portion of the area. This is joined from the west by Coronado Gulch and from the east by King Gulch, all these streams flowing in deeply incised canyons, as a rule of V-shaped form. The lower part of Coronado Gulch has, however, a broad bottom, deeply covered with bowlders brought down by cloudbursts from above. Narrow bottom lands extend along Chase Creek from the junction of Coronado Gulch southward. The grade of Chase Creek is approximately 180 feet per mile, while King Gulch descends at the rate of 100 feet in 1,000. Coronado Gulch, King Gulch, and the upper part of Chase Creek are dry, containing water only after heavy rains, but from Metcalf down Chase Creek contains a small stream of water, partly fed by springs and partly the result of the drain water from Metcalf. The town is supplied by a pipe line from springs in Chase Creek 1 mile above the mines and also from wells in the creek bottom.

Steep bluffs, 200 to 400 feet high, line the course of Chase Creek above Metcalf. From the elevation of these bluffs slightly gentler slopes, broken by sharp salients, continue up to the heights of the divides, which lie from 1,000 to 1,500 feet above the creek. At the junction of Chase Creek and King Gulch the ridge between these watercourses rises in rocky crags 500 feet above the watercourse. Northeast of this extends a more gently sloping ridge, lying 600 feet above the valley, on which are situated the mines of Metcalf, belonging to the Arizona Copper Company. Above this steeper slopes, dotted by tunnels and open cuts, lead up to the dark summit of Shannon Mountain (elevation 5,628 feet). The immediate summit forms a small, comparatively level area of dark, rough rock (Pls. XX to XXIII).

One thousand feet north of Shannon Mountain the ridge between King Gulch and Chase Creek narrows to a saddle with an elevation of 5,500 feet, but soon rises again to a broader backbone, which has an elevation of 5,700 feet, and continues for a mile northward up to the head of Garfield Gulch. 
Below Metcalf long, steep slopes, broken by craggy outcrops and precipices, extend on both sides of Chase Creek to a height of 1,200 feet above the creek and culminate in sharp ridges. To the west of Chase Creek this high ridge divides the waters of that stream from the headwaters of Concentrator Canyon, emptying into Chase Creek near the Longfellow ineline, while the southern part of the map is occupied by the long and prominent King Ridge, which contains the Jameson and King mines, and which divides King Gulch from Standard Canyon.

The rocky character of the slopes makes travel on horseback difficult or impossible except over the established trails. The only wagon road leads from Metcalf up Chase Creek, communication with the mines being established by the railroad which extends along Chase Creek up to the foot of the Shannon incline, one-half mile above the town. The ore is transported from the mines to the railroad by means of tramways and inclines laid out on the slopes of Shannon Mountain and King Ridge.

\section{GEOLOGY.}

\section{GENERAL FEATURES.}

More than two-thirds of the area shown on the special map is covered by granite-porphyry, which forms the most northerly extension of the great central stock occupying several square miles between Morenci and Metcalf. This porphyry is the most recent rock of the area, and borders against the older rocks in the northern corner with characteristically intrusive contact, forming contact breccias with the granite and sending long dikes with-a general north-northeasterly trend into the sedimentary rocks. As at Morenci, the granite is the oldest rock, forming the floor on which the Paleozoic sediments were laid down. These sediments have a maximum thickness of 700 feet; they consist of a basal quartzite covered by several hundred feet of shale and limestone, well exposed on Shannon Mountain. The total area covered by the sedimentary rocks is about 100 acres. The limestones and shales are greatly altered by contact metamorphism exerted by the porphyry magma. The older rocks have been displaced by the force of the intruding molten rock, and all of them have been affected by extensive dislo. cations which have taken place subsequently to the cooling of the porphyry.

The copper ores chiefly occur on the ridge between Chase Creek and King Gulch. Most of them form irregular bodies, often extended in a general northeasterly direction, following the trend of the porphyry dikes. They occur both in porphyry and in the sedimentary series; very rarely they are found in granite. 


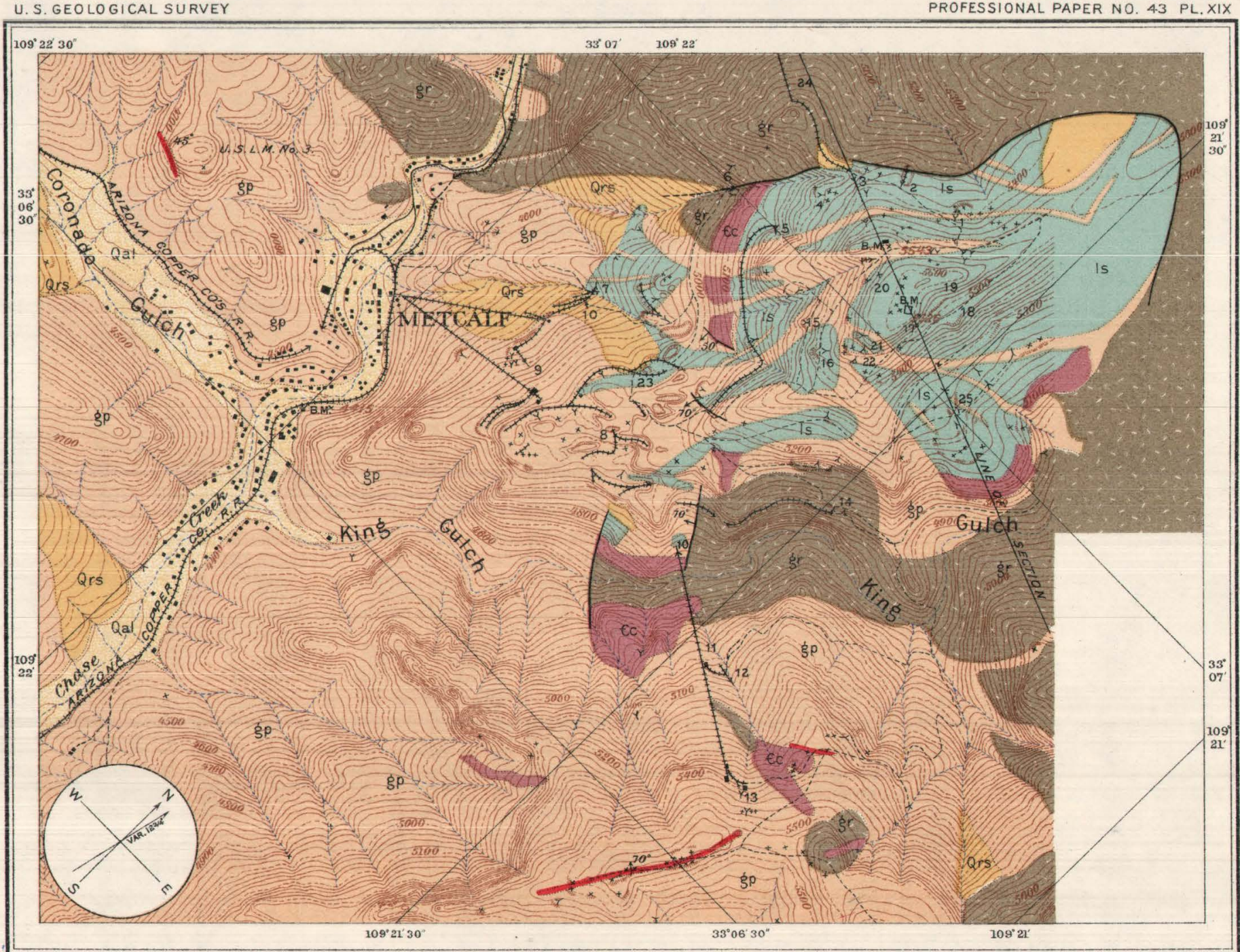

1 CLIMO TUNNEL

3 BOULDER

7 SHIRLEY TUNNE

8 METCALF MINES

9 WILSON TUNNEL

IO RING TUNINEL

11 KING INCLINE

12 JAMIESON MINE

13 KING MINE

14 DARKHORSE MIN

15 SHANNON TUNNE

16 YOUNG TUNNE

17 SMOKY TUNNEL

18 MEXICAN TUNNEL

19 BROWN TUNNEL

20 GREEN SHAFT

21 YOUNG SHAFT

22 SHANNON SHAFT

23 QUARTZITE TUNNEL

24 SHANNON INCLIN

25 WISEMAN TUNNEL

E.M. Douglas, geographer in charge.

Triangulation and topography

by Jeremiah Ahern.

GEOLOGIC AND TOPOGRAPHIC MAP OF THE

VICINITY OF METCALF, ARIZONA.

Geology by W. Lindgren
Surveyed in 1902 . 1000 2000 feet

LEGEND

SEDIMENTARY ROCKS

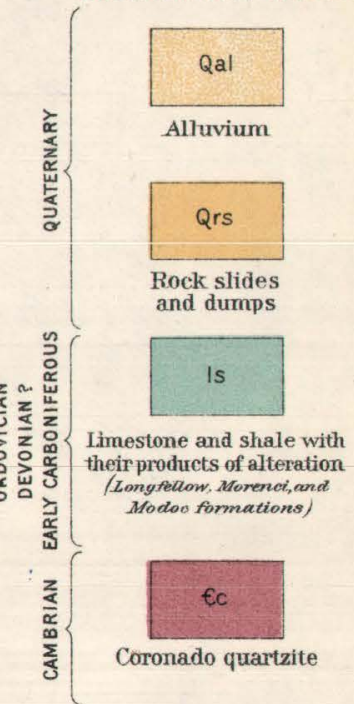

IGNEOUS ROCKS
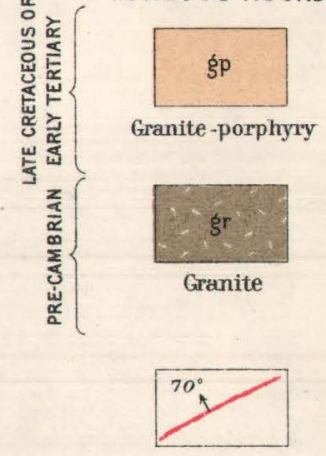

Mineral veins

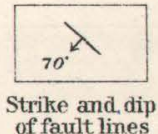

Contour interval 20 feet. 

ROCKS.

Granite.-This rock occupies two distinct areas in the Metcalf district, one extending across Chase Creek along the northwestern margin of the district, the other following King Gulch about halfway down toward its mouth. Both of these larger areas connect with larger masses outside of the district-the first with the great mass of Coronado Mountain and upper Chase Creek, the second with that of Copper King Mountain. They join in one place just outside of the Metcalf district, 2,000 feet north of Shannon Mountain. As the sedimentary rocks were deposited on a granite basement, this rock doubtless also extends under the limestones of Shannon Mountain, at an elevation of less than 5,000 feet.

The granite is normally a coarse, granular, reddish rock consisting of orthoclase, perthite, and quartz, the feldspars being of dark reddish-brown color and the quartz grayish and transparent. Very rarely is any biotite or hornblende seen, nor does the rock contain any muscovite. The ferromagnesian silicates were doubtless originally present in small quantity, but have suffered alteration to chloritic products. Comparatively fresh granite is exposed on the ridge 2,000 feet north of Shannon Mountain and in the extreme western corner of the Metcalf district, on King Ridge. But in King Gulch, in Chase Creek, and at the head of the Shannon incline the rock is very much altered and weathers into gray, hard, and rough bluffs, the gentler slopes below being covered by angular débris. In places, indeed, its character is recognizable only with difficulty. Weathered surfaces often show the true character of the rock better than fresh fractures, which may look very much like a quartzite. The changed appearance is due to a very extensive shattering and subsequent cementation by white vein quartz, penetrating the rock like a network. The reddish color of the feldspars is somewhat bleached, but otherwise the minerals of the granite have not suffered great alteration. The quartz in places contains a little pyrite and specularite as well as abundant fluid inclusions (see p. 213). Except along some porphyry dikes the granite rarely contains any copper ores. At two places-one 800 feet south of the head of the Shannon incline, the other in King Gulch near the edge of the mapped areagranite distinctly underlies quartzite and limestone. The contacts of granite and porphyry run very irregularly, as may be expected from the intrusive character of the latter. Sometimes they are sharp, but on the west side of Chase Creek they are followed by zones of moderate width of a friction breccia of granite and porphyry, often very much cemented by quartz and sometimes containing bright metallic foils of specularite; this latter mineral is clearly of primary character and its formation probably contemporaneous with the cementation by silica. The contacts on the east side of King Gulch are indistinct, complicated by extensive 
injection of porphyry in granite, by quartz cementation of both, and by débris slopes. The areas of granite on King Ridge near the incline appear to be large fragments torn loose by the movement of the porphyry magma and wholly inclosed in it. Vertical sheetings, or shear zones, in the granite, ranging in direction from northeast to north-northeast, are noted in a few places on Chase Creek and on the slopes from Coronado Mountain outside of the area shown on the special map.

Sedimentary series. - The waterlaid rocks exposed on Shannon Mountain form a roughly triangular area containing approxinately 100 acres, bordered on the east and the west by granite and on the south by porphyry. On the whole the beds are horizontal or dipping at most $20^{\circ} \mathrm{W}$. No separation in detail has been attempted on the map, for over large parts of the area the contact metamorphism has been intense enough to obliterate stratification and original characteristics. The apparent thickness of the complex amounts to 730 feet, or 200 feet less than that of the typical section as described from near Morenci (Pls. XIX, XXV). It is possible that this amount has here been reduced by faulting, which in some places might be difficult to detect in the altered rocks, but it appears more probable that the strata are actually less thick than at Morenci, especially as such variations have been observed elsewhere in the Clifton quadrangle. The metamorphism and shattering is most intense on the south side, bordering against the main mass of porphyry; the least-altered part is situated on the steep slope toward King Gulch.

The basal part of the strata consists of heavy-bedded quartzite, clearly corresponding to the Coronado formation of other parts of the Clifton quadrangle; it is presumably of Cambrian age. The rock is light gray and hard, petrographically similar to the Coronado quartzite as exposed elsewhere. The quartz grains are distinct, well rounded, and separated by fine-grained sericitie cement, so that the appellation quartzitic sandstone might be more appropriate. The only alteration which can be observed consists in the introduction of a little pyrite. A thickness of 100 feet is exposed about 100 feet above King Gulch near the northeastern margin of the Metcalf district, 630 feet of limestone and shale resting on top of it. The quartzite lies on granite without basal conglomerate but in places porphyry is intruded between these rocks, probably as a sill or sheet; dikes of porphyry also cut the same rocks and penetrate the overlying limestones.

On the western slope of Shannon Mountain and at nearly the same elevation, approximately 5,000 feet, a belt of the same quartzite is exposed; it is 1,000 feet long, 100 feet in thickness, and is cut by two large porphyry dikes. Presumably the same quartzite has been found at an elevation of 4,978 feet in the so-called quartzite tunnel of the Metcalf mines. A small fragment of this formation lies at an elevation of 5,100 feet on a spur overlooking King Gulch, 1,500 feet south of 
Shannon Mountain. Granite underlies it in the canyon and lime shale covers it, while porphyry adjoins it on both sides. Another fragment of the Coronado quartzite is exposed in King Gulch at the bridge connecting with the King incline: It is 500 feet long, 100 feet thick, and rests on the granite exposed in the bottom of the gulch; porphyry, and in one place a little lime shale, covers it. On the east side of King Gulch, at a somewhat higher elevation, is another mass of quartzite with an apparent thickness of 200 feet. These two masses were evidently once connected and represent a down-thrown block dipping northward at a moderate angle. The fault plane along which it dropped down shows plainly on the west side, separating granite and porphyry.

King Ridge contains four small irregular quartzite areas embedded in porphyry; to some of these masses of granite are still attached, and they must be regarded as fragments torn loose and floating in the porphyry magma during the intrusion.

On the east side of Shannon Mountain, where the sedimentary complex is best preserved, there rest above the quartzite 200 to 250 feet of limestone, at first shaly and sandy, then more massive. This part evidently corresponds to the Longfellow limestone (Ordovician) at Morenci, but is at least 100 feet less in thickness. This might be explained by local faulting were it not for the fact that the basal quartzite is fairly well exposed at intervals around Shannon Mountain at elevations of about 5,000 to 5,100 feet. In the mine workings the Longfellow limestone is well exposed at the Shannon, Wiseman, and Black Hawk No. 3 tunnels. The limestone as a rule contains much silica and many strata are dolomitic in composition.

Above the Longfellow limestone there are about 100 feet of clay shales, manifestly corresponding to the Morenci shales (Devonian?). This horizon is well defined and fairly easily recognizable on account of the relatively slight alteration to which it has been subjected. The upper limit of the shale, which is of gray color and fissile, is found below the central ore body at about the level of the floor of the Brown tunnel (elevation 5,507 feet).

South of the central ore body the shale rises to somewhat higher leyel and dips $20^{\circ} \mathrm{W}$. It is well exposed all about the northern slope of Shannon. Mountain. It crops prominently at the level of the gap near the Shannon boarding house, where the top stratum again reaches 5,500 feet in elevation. The exposures continue on the western slope of the mountain along the road from the boarding house to the Boulder tunnel, and extend from 70 feet above to at least 30 feet below this adit. At this point the top stratum is about 30 feet lower than on the east slope of the mountain, indicating a slight westerly dip. The Morenci shale is also exposed on the southern slope of the mountain, though the metamorphism has been 
more intense, rendering its appearanoe less characteristic. The Morenci shale is excellently exposed in the Boulder and Shannon tunnels, and here contains large bodies of low.grade ore.

The summit of Shannon Mountain is occupied by about 130 feet of sediments, which correspond to the Modoc limestone (Mississippian). At Morenci the total thickness of this formation is 160 feet; very likely the difference is accounted for by erosion which may have removed the uppermost part of the series. As at Morenci the Modoc formation is characterized by a most extraordinary susceptibility to contact metamorphism, practically the whole of it being thoroughly altered. The least-altered exposures are found on the narrow backbone leading up to Shannon Mountain from the gap. About 40 feet south of the lowest point of the gap, which is occupied by clay shale, rests a stratum of somewhat altered limestone, probably corresponding to the coralliferous limestone of Morenci. Above this lies 15 or. 20 feet of quartzite which again is covered by coarsely crystalline limestone, which, as at Morenci, is distinguished by great purity. The dolomitic strata of Morenci appear to be absent. North of the gap the shale is covered by 100 feet of highly altered limestone, usually referred to as the "cap rock."

Metamorphism of the sediments. - The sediments have been subjected to a metamorphism which sometimes has progressed so far as to obliterate their original character. The degree of metamorphism varies first according to the character of the strata. The basal quartzite is not affected; the lower 200 feet of limestone and shaly limestone (Longfellow limestone), which generally contains much silica, is greatly but not excessively altered; the shales of the Morenci formation offer much resistance to metamorphism, and are in most cases easily recognizable. The uppermost limestones, corresponding to the Modoc formation (Mississippian), are in most places within this area excessively metamorphosed.

In the second place, the alteration varies according to the distance from the porphyry. The whole southern part of the area is very much more metamorphosed than the northern half, and the rocks close to the dikes more altered than those more distant from them. Practically all of the metamorphosed rocks contain copper in the form of chalcopyrite, malachite, azurite, brochantite, or chrysocolla, and altogether may possibly average one-half of 1 per cent.

The detached areas in porphyry on the south side of Shannon Mountain generally form rough black outcrops, which consist of silica mixed with oxides of iron. In some places, as in the surface quarries of the Metcalf mines, there may be some doubt as to the urigin of these masses of iron rock, but ordinarily their derivation from limestone or lime shale may be easily demonstrated.

The small area of indistinctly stratified lime shale on quartzite exposed a few 


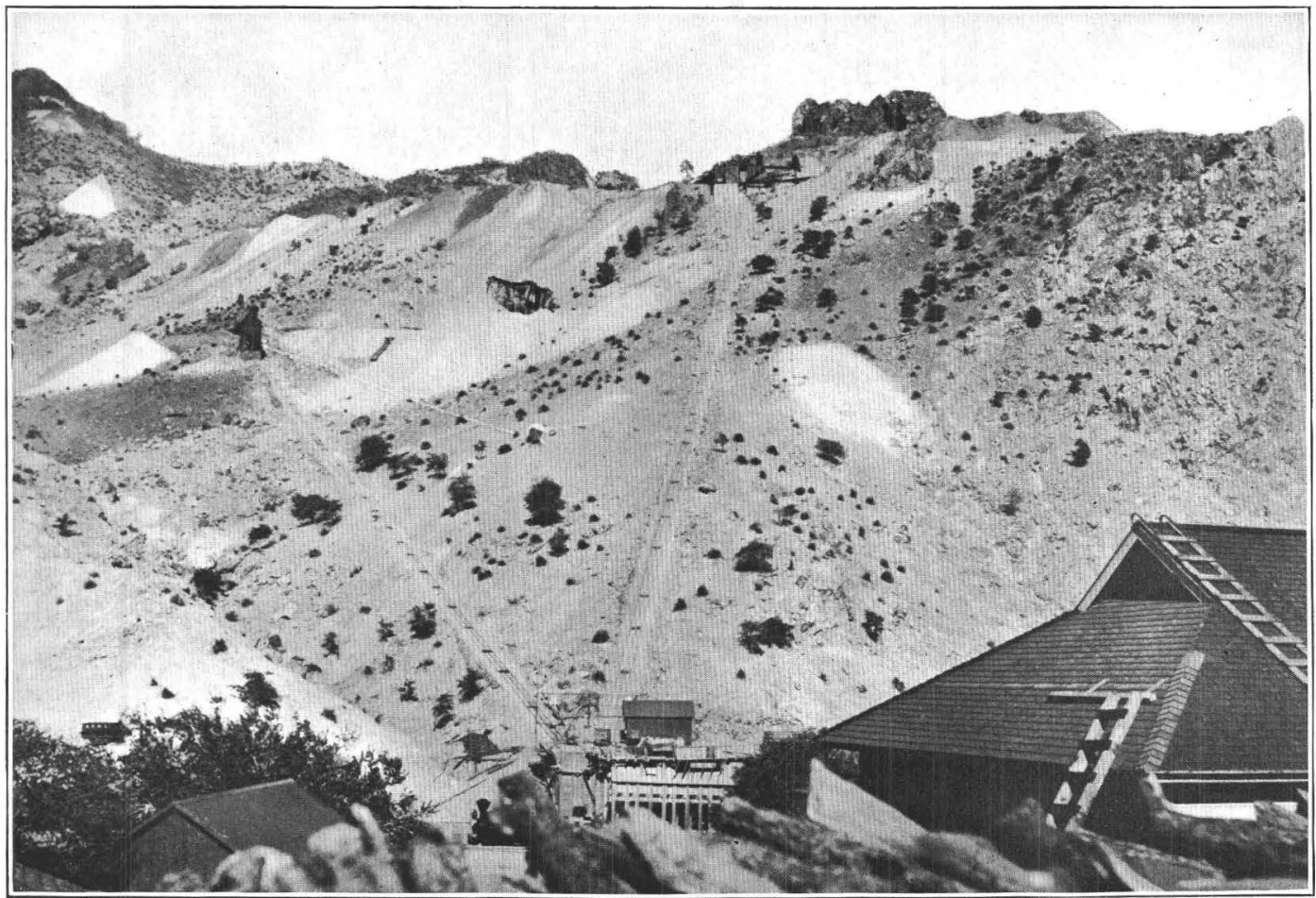

A. VIEW UP TOWARD THE METCALF MINES FROM METCALF.

Shannon Mountain to the left. Granite-porphyry.

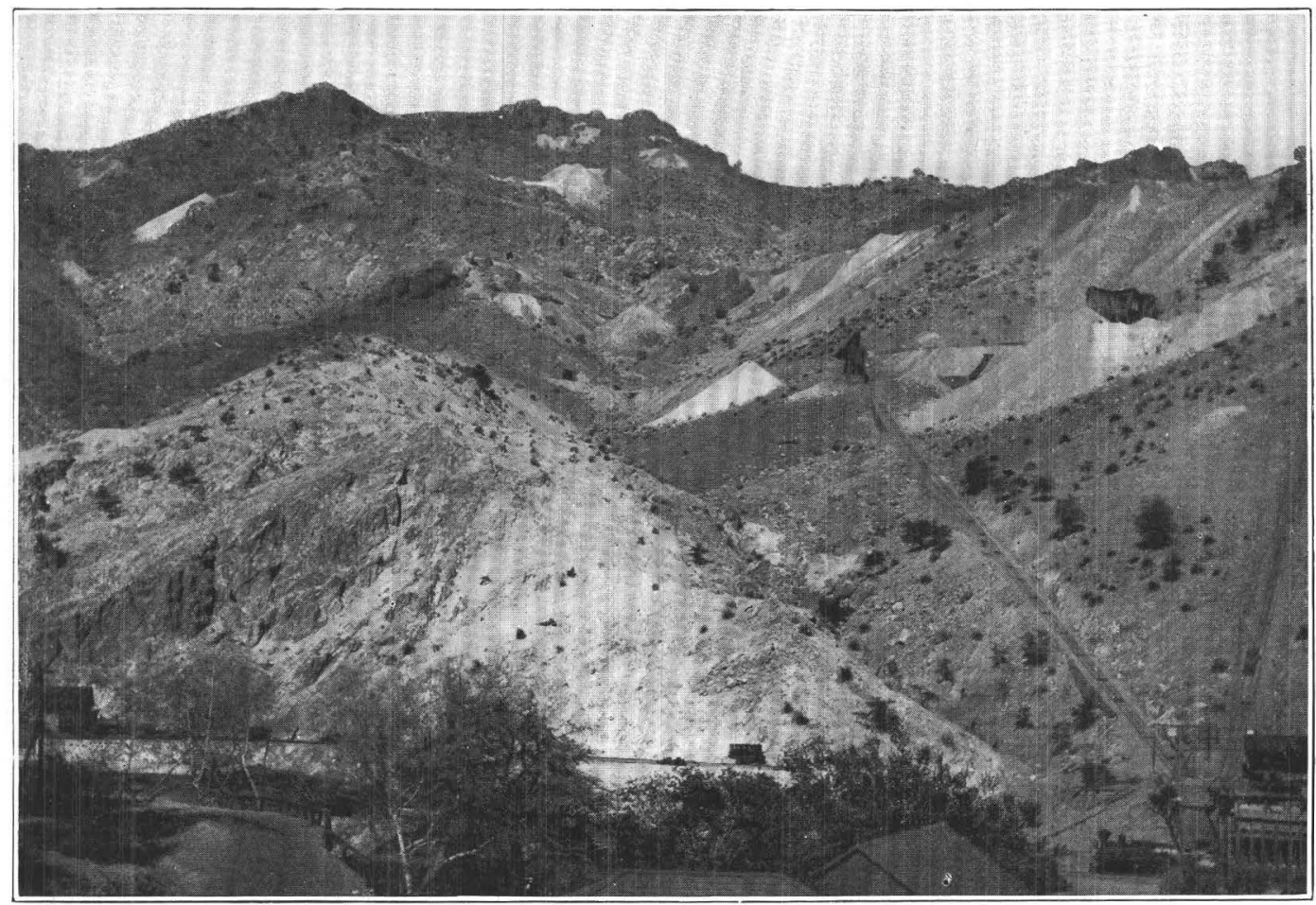

B. VIEW UP TOWARD SHANNON MOUNTAIN FROM METCALF.

Metcalf inclines and open cuts to the right. Shannon tunnel in center background. Foreground occupied by granite-porphyry. Darker background contact-metamorphosed limestones and shales. 

hundred feet southwest of the bridge connecting with the King incline is of greenish-gray color; in places it is siliceous and also contains small quartz veins. Along the west contact with porphyry, which possibly represents a fault, are a number of small prospects; the shale here contains epidote and magnetite with which are intergrown azurite and malachite. The long area beginning 500 feet northwest of King Bridge consists in its southern end chiefly of "iron rock," or an intimate mixture of fine-grained quartz, magnetite, limonite, and hematite, while in its wider northern part there is much shaly limestone only partly altered. A few hundred feet north of this is a similar area, also embedded in porphyry and reaching up to the main southern shoulder of Shannon Mountain. It consists of "iron rock" and its northern part also contains garnet. Similar also is the irregular slab or fragment which extends 1,200 feet north from the quartzite tunnel of the Metcalf mines. The most westerly of these detached areas is that of the Shirley or Little Giant tunnel, which is roughly rectangular in form and is penetrated by several small porphyry dikes. The prevailing rock is a fine granular mixture of hematite and quartz, but there is also some soft dark-colored lime shale containing well-exposed magnetite in the Shirley tunnel. This area shows copper stains throughout and harbors several bodies of rich oxidized ore.

The main limestone area of Shannon Mountain is best entered by the old road which crosses the southeastern porphyry spur at an elevation of 5,280 feet. The formation is here the Longfellow limestone. The contact is crossed 250 feet from the point where the road rounds the spur. For one hundred feet northward from the contact black "iron-rock" is exposed, changing gradually into a partly altered gray limestone, with much copper stain and fissured by veinlets of quartz, calcite, and hematite. At 500 feet north from the contact a porphyry dike 30 feet wide is crossed, which cuts shaly limestone so heavily copper stained as to constitute ore. At 250 feet farther north the main so-called Wiseman dike is crossed, 50 feet wide, and adjoined on both sides by zones of limestone partly converted into epidote. A short distance farther north, at the northeastern margin of the Metcalf district, this dike meets another which continues uphill on the contact of limestone and granite; in the angle between these dikes the limestone is converted to a granular mass of epidote, magnetite, and garnet. Along the contact dike this metamorphosed zone continues, 150 feet wide, for a couple of hundred feet uphill as far as the level of the Morenci shales, which, as usual, are but little altered. The contact dike and the main eastern contact of granite and limestone fall outside of the district, but have nevertheless been indicated on the special map.

In these surface exposures oxidation has more or less obscured the true character of the rocks. Specimens from the levels of No. 3 Black Hawk and 
Boulder tunnels, Shannon mine, show that the alteration of the Longfellow formation is produced by the development of epidote, garnet, pyroxene, magnetite, actinolite, specularite, chalcopyrite, and pyrite by metasomatic processes in the limestone replacing the carbonate of lime. The replacement is rarely complete, as much ealcite remains in the altered rock; much of the limestone is only slightly altered and appears as a greenish-gray fine-grained rock with small crystals of magnetite, traversed by veinlets of pyrite and chalcopyrite. Microscopical examination shows, however, that pyroxene and actinolite have also developed in the rock, sometimes along little veinlets of calcite, magnetite, and chalcopyrite.

The clay shales of the Morenci formation, which are well exposed on the east and west sides of Shannon Mountain, their top stratum having an elevation of from 5,430 to 5,000 feet, are comparatively little altered, except in the immediate vicinity of porphyry dikes, where they often contain bodies of malachite and azurite. Epidote is often developed in the shale, as well as minute seams of pyrite and chalcopyrite. The latter mineral is especially common in the shale opaned by the Boulder tunnel; large masses of this shale are said to average 2 to 3 per cent of copper.

As at Morenci the pure limestones of the Modoc formation occupying the summit of Shannon Mountain exhibit an extraordinary tendency to metamorphism, garnet and magnetite being the two principal minerals formed. At the extreme northern end of the sedimentary area, where it borders against granite, porphyry dikes cut the rocks; above the top of the Morenci shale rest 100 feet of Modoc limestone which now consists entirely of the minerals just mentioned. The narrow ridge leading southward to the summit of Shannon Mountain from Shannon Gap shows the limestone directly overlying the shales; this is partly converted to light-yellow garnet and pyroxene, admirably showing the replacing character of the process. Above this point partly altered limestone continues for some distance along the narrow backbone to an elevation about 60 feet above the gap, where a body of soft, almost unaltered, though very coarsely crystalline limestone remains; at present this is used as flux for smelting purposes by the Shannon Company. Immediately above it lies the black, hard mixture of partly decomposed garnet and magnetite, to which the name "cap rock" is given. Near the irregular contact with the remaining mass of coarsely crystalline limestone the latter contains streaks and masses of yellowish-gray garnet and iron ore, largely magnetite, though now partly oxidized and hydrated. These masses are from a few inches to a few feet in thickness and run out into thin streaks, but have no great regularity as to form. The garnet and magnetite are sometimes separated in larger masses, while at other places they are intimately intergrown. This zone 
of irregular inclusions of garnet in limestone is perhaps 10 feet wide vertically. There are few gradual transitions to be observed from garnet to limestone. The conversion seems to be effected by sudden and almost complete metasomatism, but the garnet and magnetite have certainly developed in the limestone.

This cap rock forms the whole summit of Shannon Mountain and has a thickness of about 130 feet. It is chiefly a heavy dark-brown or brownish-yellow garnet rock mixed with fine-grained quartz, magnetite, and some residual calcite. The garnet is an andradite or iron-lime garnet; the process by which a pure limestone has undergone such a remarkable transformation is discussed in more detail on page 135. The cap rock contains copper stains throughout and considerable quantities of azurite and malachite are shown in many of the prospect holes near the summit, though the amount is scarcely sufficient to constitute payable ore. The " cap rock" is more or less oxidized, both the magnetite and the garnet decomposing to limonitic products rich in zine, probably as silicate, and in manganese as peroxide.

The following analyses made by the chemists of the Shannon Copper Company show the composition of the limestones. Although of great purity the quarry limestone contains more magnesia than the corresponding stratum at Morenci.

Analyses II and III represent the Longfellow limestone; both are partly altered by the introduction of garnet and pyroxene, as indicated by the high percentage of iron and alumina. They are also rich in magnesia and decidedly dolomitic, but as it is known that the limestones of this horizon vary greatly in their percentage of that substance, it is scarcely to be inferred that the analyses indicate normal or average composition.

Analyses of limestones from Shannon mine.

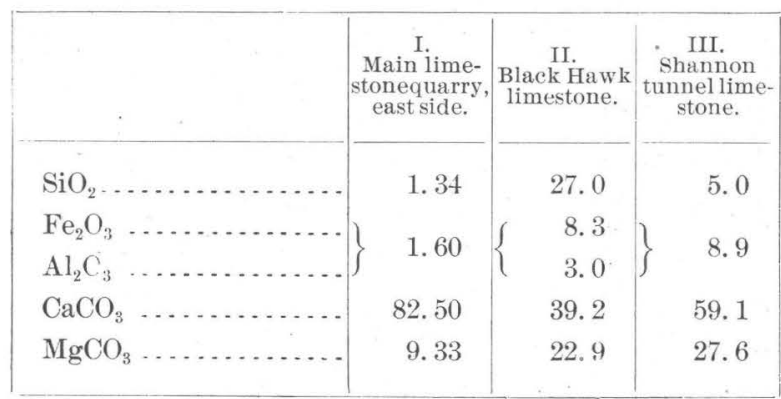

A sories of technical analyses of this "iron cap" are available by the courtesy of the Shannon Copper Company and are herewith appended; they are supposed to represent the average composition of the "iron cap," which evidently consists largely of impure limonite, mixed with magnetite, silica, and some aluminous silicate, 
probably kaolin. Except in those samples which contain very much iron the alumina is rather high--not as high as in the porphyry ores, but decidedly higher than in the ores of the red and central ore bodies. A very notable concentration of manganese and zinc, the latter probably as silicate, seems to have taken place in some of the iron ores. Copper is present throughout, probably largely as chrysocolla and partly as malachite. The original metamorphic rock probably consisted of garnet, magnetite, pyrite, chalcopyrite, and zinc blende. The complete elimination of lime in the oxidized iron cap, evidently derived by metamorphism of limestone, is very remarkable; the sulphides formerly present have been completely oxidized.

Analyses of iron cap from various points near the top of Shannon Mountain.

\begin{tabular}{|c|c|c|c|c|c|c|}
\hline & $\begin{array}{l}\text { I. } \\
\text { Above } \\
\text { lime } \\
\text { quarry. }\end{array}$ & $\begin{array}{l}\text { II. } \\
\text { Above } \\
\text { lime } \\
\text { quarry. }\end{array}$ & $\begin{array}{l}\text { III. } \\
\text { Above } \\
\text { lime } \\
\text { quarry. }\end{array}$ & $\begin{array}{l}\text { IV. } \\
\text { Above } \\
\text { Brown } \\
\text { tunnel. }\end{array}$ & $\begin{array}{l}\text { V. } \\
\text { Above } \\
\text { Brown } \\
\text { tunnel. }\end{array}$ & $\begin{array}{l}\text { VI. } \\
\text { Cave near } \\
\text { Mitchell } \\
\text { tunnel. }\end{array}$ \\
\hline $\mathrm{Cu} . .$. & 1.9 & 6.5 & 1.7 & 1. 2 & 2.88 & 1. 20 \\
\hline $\mathrm{SiO}_{2} \ldots \ldots \ldots$ & 5.2 & 28.4 & 20.4 & 9.3 & 5.02 & 21.30 \\
\hline $\mathrm{Fe}$ & 43. 2 & 17. 4 & 25.9 & 50.9 & 49.46 & 37.30 \\
\hline $\mathrm{Al}_{2} \mathrm{O}_{3} \ldots$. & 21.8 & 17.7 & 10.8 & 4.5 & 1. 68 & 11.50 \\
\hline $\mathrm{CaO} \ldots .$. & Trace. & Trace. & Trace. & Trace. & $\cdots$ & 2.65 \\
\hline MgO . . . . . . . . . . & None. & None. & None. & None. & 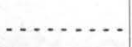 & \\
\hline Mn $\ldots \ldots \ldots \ldots \ldots \ldots$ & 7.6 & 1. & 2.9 & 1. & 2.92 & .... \\
\hline $\mathrm{Zn}, \ldots \ldots \ldots \ldots \ldots \ldots \ldots \ldots$ & 14.5 & 20.4 & 17.8 & 2.2 & ........ & 2. 60 \\
\hline $\mathrm{S} \ldots \ldots \ldots \ldots$ & None. & None. & None. & None. & None. & None. \\
\hline Ignition . . . . . . . . . . . . & 6.8 & 13.1 & 10.7 & 8.1 & 20. & 5. 10 \\
\hline $\mathrm{CO}_{2} \ldots$ & None. & Present. & None. & None. & & \\
\hline
\end{tabular}

Granite-porphyry.-As stated above, the porphyry which covers the southern and larger part of the area shown on the Metcalf special map is the northern end of the great stock intruded between Morenci and Metcalf and occupying a total space of several square miles. It borders against the granite with irregular outlines and at many places sends out dikes and apophyses into it, most of these having a northeasterly direction. The sedimentary formations of Shannon Mountain are even more shattered than the granite, especially near the southern contact, and are penetrated by three prominent dikes with northeasterly trend, which may be referred to as the Black Hawk, Central, and Wiseman dikes, enumerating them from west to east. Toward the south these dikes widen and join as shown on the map, including between them isolated fragments of altered limestone. The contact metamorphism which the magma of the main mass and of these dikes has effected in the sediments has already been described. 
The Metcalf porphyry is rarely seen in fresh condition. One of the best localities for this purpose is in a railroad eut near the mouth of King Gulch. On fracture this rock is of grayish-green color and contains as phenocrysts many quartz crystals bipyramidal in form and up to $8 \mathrm{~mm}$. long; also abundant smaller, square feldspar crystals, usually soft and sericitic; these chiefly consist of orthoclase and albite. There are also many biotite foils, largely, however, converted to chlorite. The groundmass probably originally consisted of orthoclase and quartz in microcrystalline structure, but now chiefly contains sericite and quartz, as shown on page 79. The rock is a sodic granite-porphyry.

This type of rock, usually more altered, however, prevails throughout the northern and central area of the stock, but differs somewhat from the Morenci type of monzonite-porphyry, exposed on Copper Mountain, in containing larger and more abundant quartz phenocrysts. The diorite-porphyry exposed at several places west of Morenci is lacking at Metcalf.

The outcrops which are well exposed throughout the area are very rough and of a yellowish or brownish-yellow color; the quartz crystals stand out prominently, while the smaller feldspar phenocrysts are apt to be weathered out, producing a peculiar pitted appearance. The bluffs on both sides of Coronado Gulch up to elevations of 300 feet above Chase Creek consist of a soft, white porphyry breccia, sometimes with fragments of quartzite. In this rock no copper prospects are found. Higher up on the same spur the normal massive porphyry begins, but is greatly altered and cemented by veinlets of quartz. The eastern slopes along Chase Creek, south of King Gulch, are less altered, but higher up toward the summit of King Ridge the quartz cementation becomes very prominent. Practically all of the porphyry on Shannon Mountain is very soft and chalky, the color as exposed in the tunnels and open workings being brilliantly white. The steep bluff between Chase Creek and King Gulch consists of a normal yellowishbrown quartz porphyry, with many rusty small quartz seams. Weathered outcrops of porphyry often show large stains of "green paint," an efflorescence of dark-green mammillary crusts which have been shown to consist of a mixture of silica, oxychloride, and nitrate of copper (see p. 121).

The hydrothermal alteration of the Metcalf porphyry chiefly consists in a sericitization by which all of the feldspathic constituents, both phenocrysts and groundmass, become converted into a fine-grained sericite felt, while the quartz remains unaffected. In many places, as in the Metcalf mines and in many of the dikes of Shannon Mountain, pyrite and chalcocite have been introduced, the former in small crystals contemporaneously with the sericitization, the latter added at a later date. Finally, the porphyry is nearly everywhere extensively fractured and cemented by quartz veinlets running in all directions, but chiefly northeasterly, 
which seems the dominating structural direction of this district. The veinlets of quartz sometimes also carry pyrite, though on the surface this mineral is everywhere decomposed. Most of the copper is indeed also leached from the porphyry at the surface, though sometimes malachite stains or small stringers of chalcocite are seen. Northeasterly sheeting, or shear zones, may be noted in several places.

\section{DISLOCATIONS.}

Here, as elsewhere in the Clifton quadrangle, there is no evidence of dislocations of the rocks previous to the irruption of the porphyry. This event, by which a stock of intrusive magma 4 miles long and up to 1 mile wide, was introduced into the crust of granite and covering sediments, clearly involved a violent dislocation. Along the contacts and especially in the less compact sedimentary series great complications occur. Apophyses and dikes of porphyry extend from the main mass, chiefly in a northeasterly direction; frequent contact breccias illustrate the violent nature of the intrusion; torn fragments of sediments and granite float in the porphyry, as well illustrated on the map. After the cooling of the porphyry the same forces which had opened a space for the stock along a northeasterly line persisted with less intensity. Northeasterly fissures like the King and Jameson veins were produced, probably by compressive stress; a northeasterly jointing or sheeting of the porphyry-sometimes also of the surrounding granite-took place, but the conditions were rarely such as to lead to the formation of open fissures. Occasional fractures, trending northwest, crossed this sheeting. The intrusion of the porphyry occurred in the Cretaceous period or immediately after it. The main epoch of dislocation by which the whole region was divided into blocks, along which very extensive faulting took place, occurred after the consolidation of the porphyry and after the formation of the jointing and fissure veins, but before the great Tertiary lava flows. On a smaller scale this faulting has probably continued to the present day. The special map and the section (Pls. XIX, XXV) represent at least one of these faults which separates the whole northern and western side of the sedimentary series from the granite. The normal position of the granite is everywhere below the Cambrian quartzite, but along the contact indicated the former rock borders first against the Silurian limestones, then, on the west side of Shannon Mountain, against the Devonian shales, and finally, on the ridge north of the gap, against the lower Carboniferous limestone. Descending on the east side this sequence of contact is reversed, and a little above the level of King Gulch the Cambrian quartzite is again adjoined by granite; along the lower part of this contact line a porphyry dike lies on the junction. Porphyry dikes contained in the sediments stop on reaching the granite. Although the fault plane itself is not indicated 


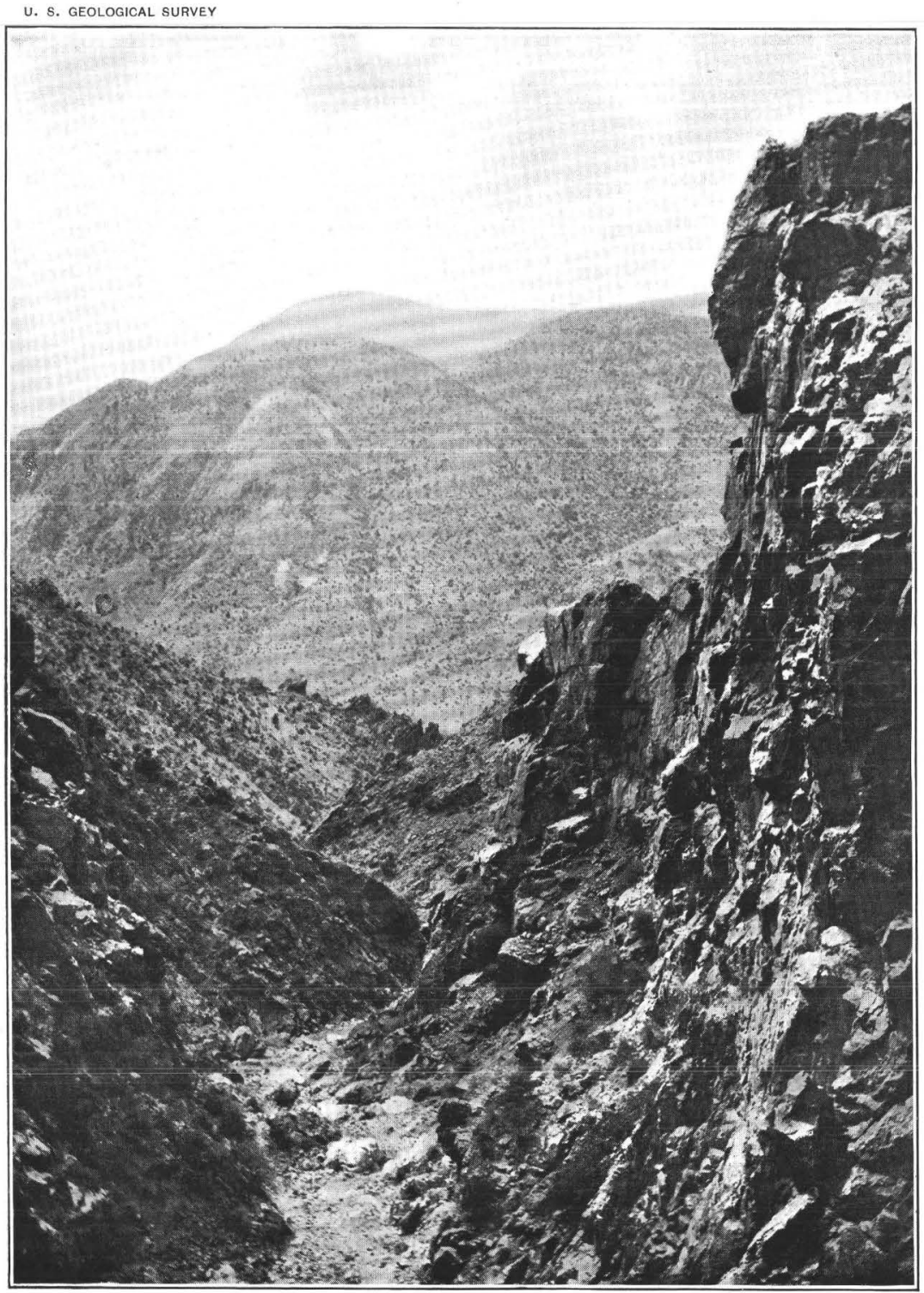

A. KING GULCH, NEAR METCALF, LOOKING DOWN TOWARD CHASE CREEK. Porphyry occuples the foreground and most of the ridges in the background.

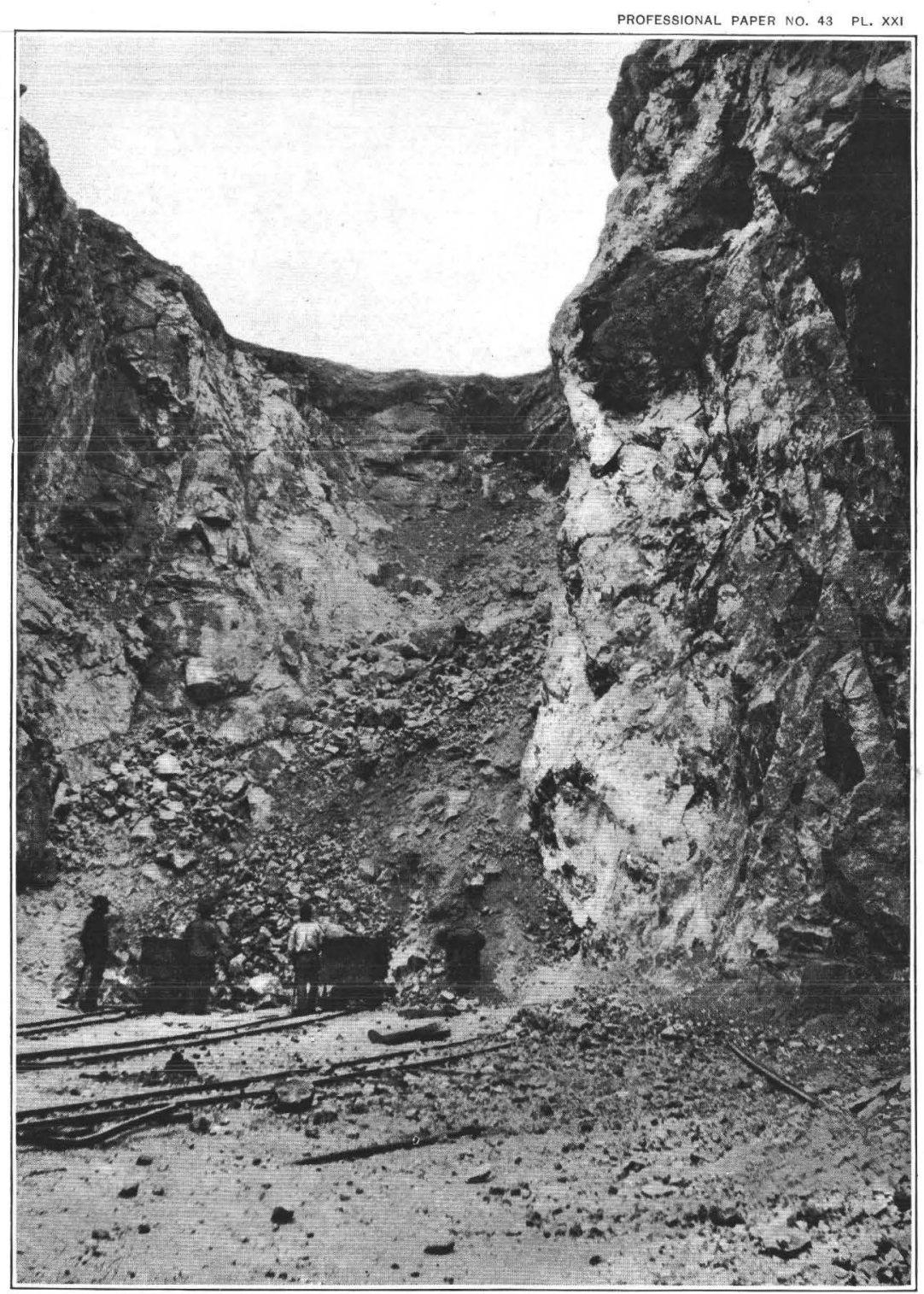

B. OPEN CUT ON FIRST LEVEL OF METCALF MINES. Country rock, granite-porphyry. 

by friction breccia or slickensides, really good exposures being nowhere obtainable, it seems evident that these conditions can not be explained except on the assumption that the granite contact marks a sharply defined fault plane dipping southeast at a moderate angle. Similar phenomena were observed elsewhere in the Clifton quadrangle.

No evidence of faulting was observed along Chase Creek above Metcalf, and it seems more likely that the main fault plane referred to above takes a more southerly trend westward from the Matte tunnel and is hidden below the mass of débris. In no place is there any indication of workable bodies of copper ores along this fault. The dislocation is easily measured by the position of the quartzite. North of the Shannon Gap, a short distance beyond the margin of the Metcalf district, this rock rests on granite at an elevation of 5,700 feet, while in King Gulch the same contact is found at 5,000 feet, 700 feet being probably a close approximation of the vertical component. The quartzite rests on Coronado Mountain at an elevation of 7,000 feet, 23 miles west of Metcalf. A fault of the first magnitude, with a north-northeast strike, is evidently located at the foot of the granite bluffs 1 mile west of Metcalf.

Several minor faults probably traverse the altered sediments, but they are difficult to trace with certainty. One slight dislocation may follow the east contact of the central dike. Other minor faults are those on both sides of the quartzite at the foot of the King incline, throwing a block of this rock 300 feet lower down, or to an elevation of 4,700 .

The altered porphyry of the Metcalf mines contains many smaller slips and fissures, but many of these are of recent origin.

As elsewhere in the quadrangle, the sedimentary blocks have often a slight dip of up to $20^{\circ} \mathrm{W}$. This is noted at several places in the workings of the Shannon mine; but, as the quartzite on the east and west side of the mountain lies at approximately the same level, step faulting has probably taken place.

\section{GROUND WATER.}

As stated above, Chase Creek, below Metcalf, contains a small perennial stream of water, largely fed by springs in the bottom of the creek. At a short distance above Metcalf it is dry for some distance until, about a mile above town, fairly strong springs again appear. These alternating conditions are repeated farther up. Small springs of good water break out in the lower part of Garfield Gulch, 2 miles above Metcalf. Two or 3 miles farther up the bed contains a small but permanent stream of water.

Coronado Gulch is dry, as is King Gulch, up to a point near the northeastern edge of the mapped area, from which point up pools of water of poor quality, 
containing iron and sulphates, remain at intervals in the creek bed, some of them persisting through the summer. Shafts and wells sunk below the bottom of Chase Creek always yield water. The general groundwater surface may be assumed to lie at the level of Chase Creek, rising gently east and west of this line.

Nearly all of the workings on Shannon Mountain and King Ridge are perfectly dry, the only exceptions being found in the Shirley tunnel of the Metcalf mines, 325 feet above Chase Creek. Throughout the inner part of this tunnel there is a small amount of standing water, and in a 60 -foot winze sunk on the north ore body on this level, water stands 20 feet deep and came in fast when sinking was in progress. In the King tunnel, on the same level, a small clay seam in the shale carries a little water. If the condition in the Shirley winze indicates the normal state of affairs, the groundwater surface would have risen 285 feet in 1,500 from the level of the creek. This is a far more rapid rise than would be expected, and it is more probable that the water has accumulated in a local water pocket.

\section{ORE DEPOSITS.}

\section{GENERAL FEATURES.}

It has already been pointed out that widespread alteration has taken place in the porphyry and in the sedimentary series, and that copper in varying amounts as chalcopyrite and as oxidized salts is widely distributed through these rocks. It remains now to describe in detail the bodies which contain a sufficient amount of this metal to be classed as workable ore. With the present cost of mining and extraction in southeastern Arizona, $2 \frac{1}{2}$ or 3 per cent of copper may be considered as a limit below which profits of mining cease.

The copper ores at Metcalf occur as indefinite bodies in porphyry; as more regular bodies by replacement of narrower porphyry dikes; as sheets and irregular masses in limestor e and shale at porphyry contacts; as flat bodies replacing certain strata in the sedimentary series; and, finally, as distinct fissure veins, generally in the nature of composite veins or lodes.

\section{DEPOSITS WEST OF CHASE CREEK.}

Of the deposits west of Chase Creek, but few fall within the limits of the area shown on the map. The lowest tunnel of the Terrazas mine, on a fissure vein in porphyry, is located at the southwest margin. South of Coronado Gulch and on the same point are several insignificant prospects showing copper stains on joint planes of the porphyry. North of Coronado Gulch there is on the Triangle claim, at an elevation of 4,700 feet, a well-defined fissure in porphyry 
striking N. $48^{\circ} \mathrm{W}$. and dipping $45^{\circ}$ NE. It is developed by a small incline shaft; the ore is a copper-stained porphyry with little seams of quartz with pyrite. On the same salient is the Ida, located on a small fissure at an elevation of 5,000 feet, between porphyry and a small granite mass inclosed in it. Still farther up-outside of the area of the special map-are other small fissures carrying a little copper-stained porphyry and striking north, northwest, or northeast. The predominating direction of the joint planes is northeasterly, but another less prominent set of fractures crosses these with a northerly or northwesterly trend.

\section{DEPOSITS SOUTH OF KING GULCH.}

Very few prospects are found among the rough outcrops of porphyry on King Ridge, which, with a northeasterly trend, divides King Gulch from Standard Gulch. Near or on its summit there are, however, the two most prominent fissure veins of the area, on which are the King and the Jameson mines, both the property of the Arizona Copper Company.

The King lode outcrops on the summit of the ridge, at an elevation of 5,560 feet, as a very strong and well-defined fissure vein. The deposit is connected, by an incline and a long tunnel through Shannon Hill, with the Metcalf system of mines. A large amount of fair oxidized ore has been shipped from this mine, and work was in active progress in 1902. The deposit is opened by two levels, 60 and 120 feet below the croppings, both about 1,400 feet long. The upper one of these tunnels penetrates the ridge, and its southeast portal overlooks Standard Gulch. A winze has been sunk 60 feet below the lowest level. The country rock is porphyry, greatly bleached by sericitization and extensively cemented by quartz veinlets. The croppings, which are exposed for a distance of 1,500 feet, are well shown by a number of deep pits. The vein consists of a number of very sharply defined fissure planes striking north-northeasterly, dipping $70^{\circ} \mathrm{NW}$, and in places occupying a width of more than 25 feet. Between these planes lies altered and crushed porphyry containing seams of chrysocolla, malachite, and brochantite. The workings disclose several wide, irregular bodies of low-grade ore, most of which appears between the first and second levels. Good ore is also reported to have been encountered in the winze below the lower level. Copper glance is of rare occurrence, and no pyrite was observed. Much ore was evidently extracted from the croppings, showing that extensive leaching of the surface had not taken place at this locality. The prospects seem good for a zone of chalcocite ore below the second level.

The Jameson vein, a little farther down on the slope of the ridge toward King Gulch, is developed by two tunnels, the lower one at an elevation of 5,040 feet, while the croppings have an elevation of 5,350 feet. Much chalcocite ore 
of good grade has been shipped from this mine by way of the King incline. Active stoping was carried on in 1902. The main working tunnel is a crosscut, which in a short distance strikes a well-defined vein having a northeasterly course and a moderate northwesterly dip. On this level the vein soon opens to an ore body having a width of up to 50 feet. Forty feet above the tunnel level the width is 20 feet. The ore, which occurs in softened white porphyry of the usual Metcalf type, consists of disseminated pyrite coated with chalcocite, the ore body extending on both sides from a central seam of glance and pyrite. The Jameson vein is joined by another, striking a little west of north and dipping $60^{\circ} \mathrm{NE}$. Where these two veins meet a large ore body results. The drift farther northeast on the vein on this level shows much pure pyrite disseminated in porphyry, and the ore is of poor grade. The richest bodies of chalcocite ore were found about 200 feet above this level. Small amounts of oxidized ores occurred near the surface.

\section{METCALF MINES}

The Metcalf mines belonging to the Arizona Copper Company are situated on the southern slope of Shannon Mountain up to an elevation of about 5,200 feet, or 800 feet above Chase Creek. Owing to the prominent outcrops the mine was one of the earliest locations, and active work on a large scale had already been begun in 1879, when the railroad between Clifton and Metcalf was built, and has been carried on without any interruption since that date. The total production is difficult to ascertain, as the ore is smelted with the Longfellow ores. During the last few years the Metcalf mines may have produced, roughly, 5,000,000 pounds of copper per annum, and a total of 20,000 tons is probably a conservative figure.

All of the workings of the Metcalf mines are situated on the south shoulder of Shannon Mountain between the elevations of 4,700 and 5,100 feet. Most of the ore has been taken from a series of open cuts or quarries on top of the ridge, at elevations between 5,000 and 5,100 feet, occupying a triangular area cortaining about 10 acres. A considerable amount has also been stoped from several levels by the square-set method. The levels are as follows:

Levels of the Metcalf mines.

\begin{tabular}{|c|c|}
\hline Level. & $\begin{array}{c}\text { Elevation } \\
\text { abovt sea, } \\
\text { in feet. }\end{array}$ \\
\hline Quartzite tunnel and first level............... & 4,978 \\
\hline Second level............ & 4,933 \\
\hline Wilson level.......................... & 4,836 \\
\hline King and Little Giant levels.. & 4,740 \\
\hline
\end{tabular}




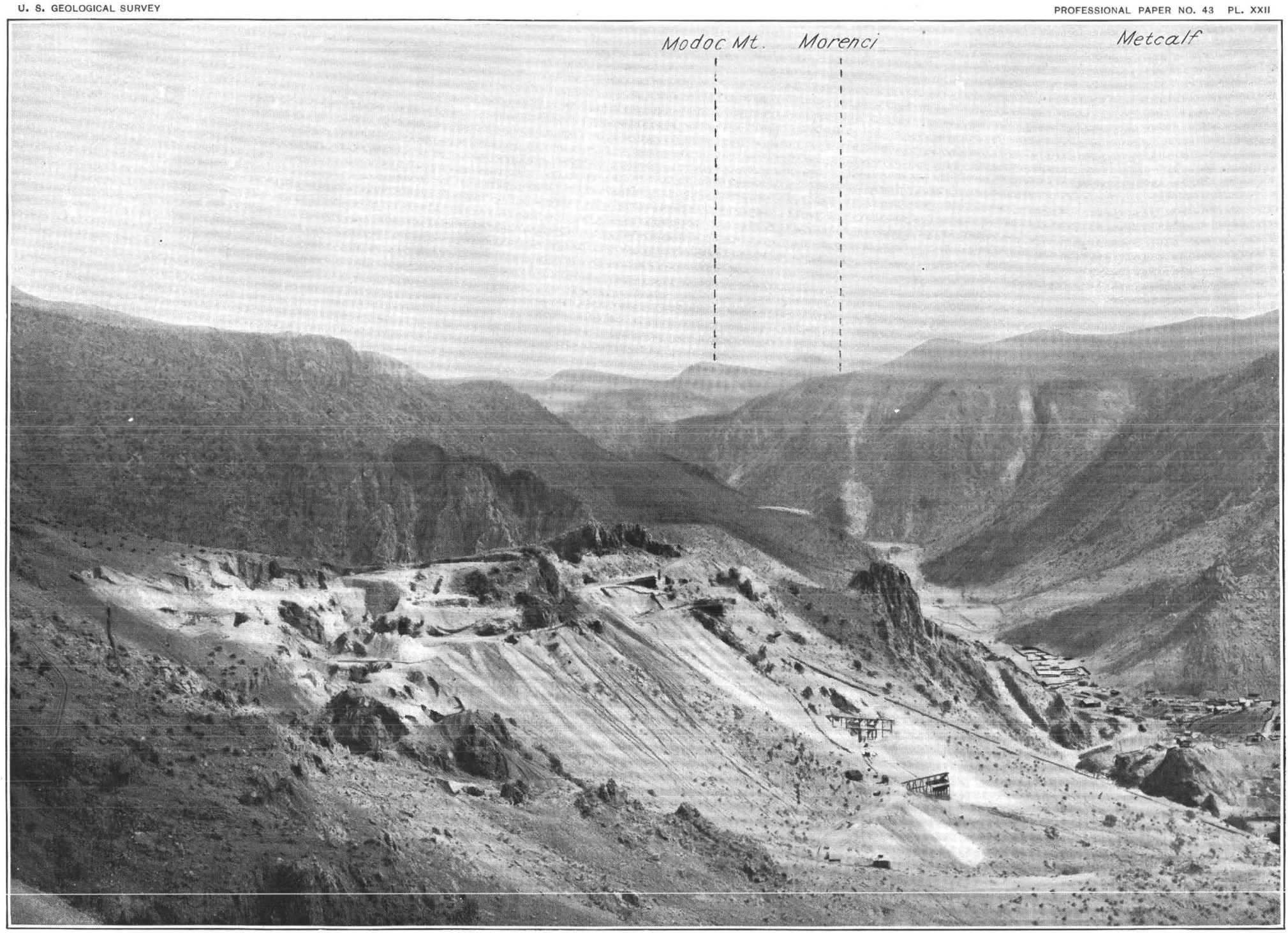

VIEW DOWN OVER METCALF AND THE LOWER CHASE CREEK CANYON FROM SHANNON MOUNTAIN.

Open cuts of Metcalf mines in the foreground. King ridge in left background. Dark outcrops of metamorphic limestone in left foreground. Otherwise all granite-porphyry. 

There are no tunnels below the King level. A shaft was sunk some years ago in the creek bottom at the upper end of the town, hat although some seams with a little chalcocite were found the workings are said to have failed to disclose any ore bodies of value.

The prevailing rock is a soft, white, sericitic porphyry, greatly shattered and cemented by quartz seams. The deposits lie practically entirely in this porphyry close to the point where the main stock breaks up into a maze of dikes and enters the sedimentary area. From the name of the principal claim this mass of porphyry is sometimes spoken of as the "Little Annie dike," although it really only forms a part of the main stock.

In the northern part of the main ore-bearing area the porphyry contains irregular masses of "iron rock," which is chiefly a mixture of limonite and quartz and as to origin mainly a metamorphosed limestone. Most of the underground workings also disclose bodies of shale or metamorphic limestone which appear to be contained as inclusions in the porphyry. The surface to a depth of 30 or 40 feet is leached and contains only a small percentage of copper, the porphyry being stained by numerous seams of limonite. The ore lies below this and consists of a white, soft porphyry with irregular seams of malachite, chrysocolla, brochantite, more rarely azurite, cuprite, native copper, and chalcocite, the latter three minerals occurring in irregular bunches, chiefly in the stopes above the Wilson level. Some very fine specimens of intergrown native copper and cuprite have been found, covered with malachite, azurite, brochantite, and chrysocolla as green and blue crusts. No chalcopyrite has been noted; pyrite oceurs fairly abundantly in seams on the Wilson level. The ores have generally been deposited by replacement in the mass of the porphyry; quartz and sericite, together with a little kaolin and chalcedony, are the only important accompanying minerals.

The general trend of this copper-bearing zone is north-northeast, but its limits are indefinite, gradually shading off into nonpayable, though mostly altered porphyry. The whole ore body may average 2 or $2 \frac{1}{2}$ per cent, which, by sorting, is carried up to $3 \frac{1}{2}$ per cent. A large amount of higher-grade ore, however, has been stoped on the Wilson level. Minor slips and faults are very plentiful, but they run in all directions and do not form a well-defined shear zone or joint system. Slips with an easterly or northeasterly direction are perhaps most prominent. The whole ore body extends in a general north-northeast direction and the underground stopes also have this trend.

The first level, which is 45 feet above the top of the longer incline, runs near the surface, connecting a labyrinth of surface cuts and open quarries.

The so-called quartzite tunnel on this level, 600 feet north-northeast of the top of the big incline, penetrates the hill for 300 feet in a nearly easterly direction. It is driven in the lime shale, which. adjoins the so-called Little Annie $16859-$ No. $43-05-21$ 
porphyry dike on the northwest and struck the Coronado quartzite at its farthest point. No ore bodies of importance are opened by it.

The second level opens the main body of porphyry, and in many places stopes extend to within 30 feet of the surface from it. It is intended to open the whole deposit as a vast quarry from this level and to employ steam shovels in the mining. The main stopes are situated about 600 feet northeast of the mouth of the tunnel near the top of the larger incline. The porphyry on this level contains many streaks of iron rock, most of which represent thoroughly altered fragments of shale and limestone. At only one place, near the north end of the level and not far from the quartzite tunnel, was clearly recognizable shale noted. At this point a body of 7 per cent ore several sets wide was extracted.

The Wilson level, 100 feet below the second level, is for the first 360 feet a crosscut in rather fresh and compact porphyry, containing many small seams of pyrite. At the end of this erosscut the ground below the surface stopes is systematically prospected by a quadrangle of drifts, the farthest point of the workings being 600 feet east of the tunnel portal. In this level the porphyry contains many slips, chiefly running east and west, and some small wedge-like masses of clearly recognizable shale. Pyrite seams are abundant, containing a little chalcocite, but no great amount of ore was found up to about 30 feet above the level. Here a long line of stopes have been opened and are mined up toward the second level. They are approximately 450 feet east of the portal, and extend for over 200 feet in a general north-northeasterly direction up to 50 and even 70 feet wide. At the west side lies a wall of shale not clearly exposed in the second level. The stopes contain in places very rich ore with much cuprite, native copper, and chalcocite in a bleached porphyry. There is also a smaller amount of brochantite and malachite.

On the lowest level, 100 feet below the Wilson, the ridge has been pierced in an east-southeast direction by the King tunnel, 1,700 feet long, constructed as a convenient outlet for the ore from the King and the Jameson mines. Its central part is below the most northerly surface cut and stopes on the second level, but no important ore bodies have been opened by it. The first 550 feet are in porphyry covered with efflorescence of chalcanthite; 350 feet from the mouth the rock becomes harder and contains some pyrite; at 450 feet a well-defined seam with some copper ore crosses and has been opened for some distance east and west, but in the latter direction becomes indistinct upon reaching hard porphyry. A belt of lime shale 200 feet wide begins 550 feet from the portal; it contains seams of pyrite and calcite, but very little copper ore. Near the west contact of this 
shale a distinct vein crosses with 10 feet of breccia and some chalcocite. Beyoncl this follows a belt of hard pyritic porphyry 80 feet wide. Shale then begins again with well-welded contact and continues for over 400 feet. Only one small seam, dipping north, cuts across it. At 400 feet from the east portal hard porphyry begins, but soon becomes softer, and like the rock at the west portal is coated with efflorescence of copper sulphate. At the east portal a slip striking N. $20^{\circ}$ E. and dipping $50^{\circ}$ W. separates pyritic porphyry on the west from quartzite on the east.

Two belts of lime shale occur on the surface above the tunnel, but are much narrower and do not correspond in position with those crossed by the adit.

The universal distribution of pyrite through hard rocks in the center of the ridge and the efflorescence of sulphate near the portals in the decomposed rocks should be noted.

On the same level and not far distant is the Shirley or Little Giant tunnel, which opens a deposit different from those just described and more similar to the Shannon ore bodies. The tunnel runs for 300 feet northeasterly through iron rock and less altered lime shale. It then bends eastward and in this part several short crosscuts have reached porphyry corresponding to the open cuts of this rock mined above. Two main ore bodies are contained in the lime shale; the first lies 100 feet west of the adit, evidently following the course of the narrow porphyry dike which shows above on the surface. These stopes have a northeasterly direction and are 120 feet long and up to 18 feet wide; the ore, which is rich, consists of chalcocite and copper carbonates. A slip dipping $45^{\circ} \mathrm{NW}$. borders the ore body on the northwest side. The second ore body is in the main tunnel and has more the form of a shoot or pipe. Both extend to the surface, and also below tunnel level, as shown by two winzes 90 and 60 feet deep.

\section{SHANNON MINE.}

DEVELOPMENT

This property, owned by the Shannon Copper Company, consists of some 20 claims located contiguously and covering the summit and upper slopes of Shannon Mountain, but extending 'in one place on the west side down to Chase Creek. Originally the property consisted only of the Shannon claim, one of the earliest locations in the district, which contains most of the important ore bodies, but in 1900 a number of surrounding claims were purchased from the Arizona Copper Company and active development of the property began. Smaller quantities of rich smelting ore had been shipped previous to that date from the croppings of what are now known as the central and the Black Hawk ore bodies. Since 1900 
the property has been developed by several thousand feet of workings, chiefly crosseuts and drifts. The principal tunnels are as follows (Pls. XIX, XXIV):

Tunnels of the Shannon mine.

\begin{tabular}{|c|c|c|c|}
\hline & $\begin{array}{l}\text { Elevation } \\
\text { in feet. }\end{array}$ & & $\begin{array}{l}\text { Elevation } \\
\text { in feet. }\end{array}$ \\
\hline $\begin{array}{l}\text { Smoky, Brown, and Kelly tunnels (116 } \\
\text { feet below the summit) } \ldots . . . . . . .\end{array}$ & 5,506 & $\begin{array}{l}\text { Black Hawk tunnel No. } 2 \ldots \ldots \\
\text { Harrison tunnel } \ldots . . . . . .\end{array}$ & $\begin{array}{l}5,298 \\
5,270\end{array}$ \\
\hline Mexican tunnel................... & 5,467 & Wiseman tunnel.............. & 5,179 \\
\hline Young tunnel..................... & 5,422 & Black Hawk tunnel No. $3 .$. & 5,176 \\
\hline 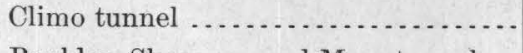 & 5,413 & Matte tunnel ................. & 5,000 \\
\hline Boulder, Shannon, and Maas tunnels .. & 5,339 & & \\
\hline
\end{tabular}

Several shafts and winzes connect these tunnels; Green shaft, at the mine office (elevation of collar 5,530 feet), extends to Black Hawk No. 2 level; Young shaft from the surface to Young tunnel. The developments are very extensive, consisting of several miles of drifts and tunnels.

The Boulder tunnel is used as the main outlet for the present. It connects by a short tramway with the prominent point, 1,000 feet west of Shannon Mountain, from which a very steep slope descends directly to Chase Creek. On this slope the incline has been laid out. This incline is 1,200 feet long and has an average descent of 35 degrees. It is provided with double tracks and extensive ore bins, from which the ore is directly loaded into the cars which convey it down to Clifton, where the Shannon smelter is situated. The incline is of course operated by gravity and is controlled by brakes operated by compressed air.

\section{GEOLOGICAL FEATURES.}

As described above in the paragraphs devoted to the general geology, Shannon Mountain is occupied by horizontal or gently inclined Paleozoic limestones which seem to comprise the whole series from the base of the Ordovician to the lower part of the Mississippian, a total thickness of 530 feet. This body of sedimentary rocks forms a somewhat irregular, equilateral-triangular area with a side of about 2,000 feet. On the south it is adjoined by a very large area of porphyry which near the limestones breaks up into a number of dikes irregularly penetrating the sedimentary rocks. On the north and northwest side the limestones are adjoined by granite and are undoubtedly separated from them by a prominent fault. The sedimentary series is greatly broken by the effect of the intrusion as well as by subsequent faulting, and the horizons are sometimes difficult to identify. At the base lies 100 feet of quartzite resting in places on granite and in places on porphyry, which also breaks through it. 


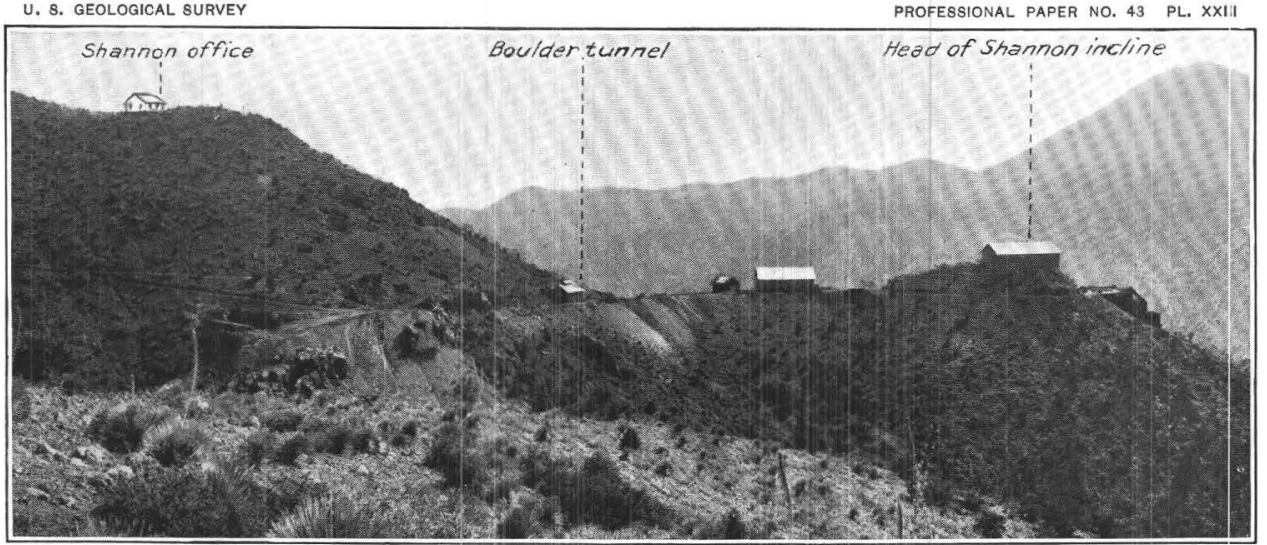

A. SHANNON MINE, LOOKING SOUTH, SHOWING HEAD OF INCLINE AND PRINCIPAL TUNNELS. Foreground and right middle background, granite; left background, contact-metamorphic limestone and shale with porphyry dikes.

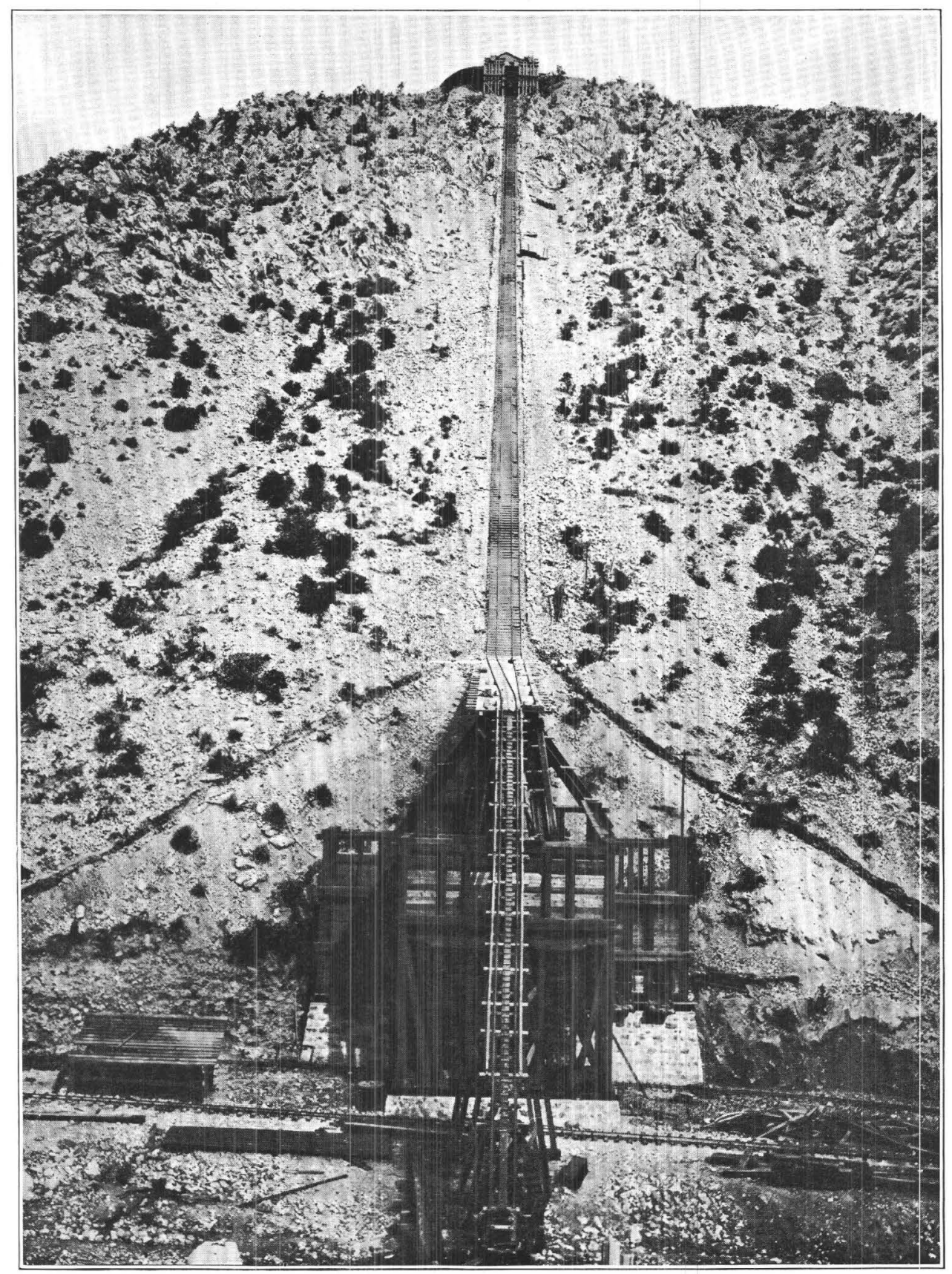

B. VIEW UP SHANNON INCLINE FROM BOTTOM OF CHASE CREEK, ONE-HALF MILE ABOVE METCALF. 



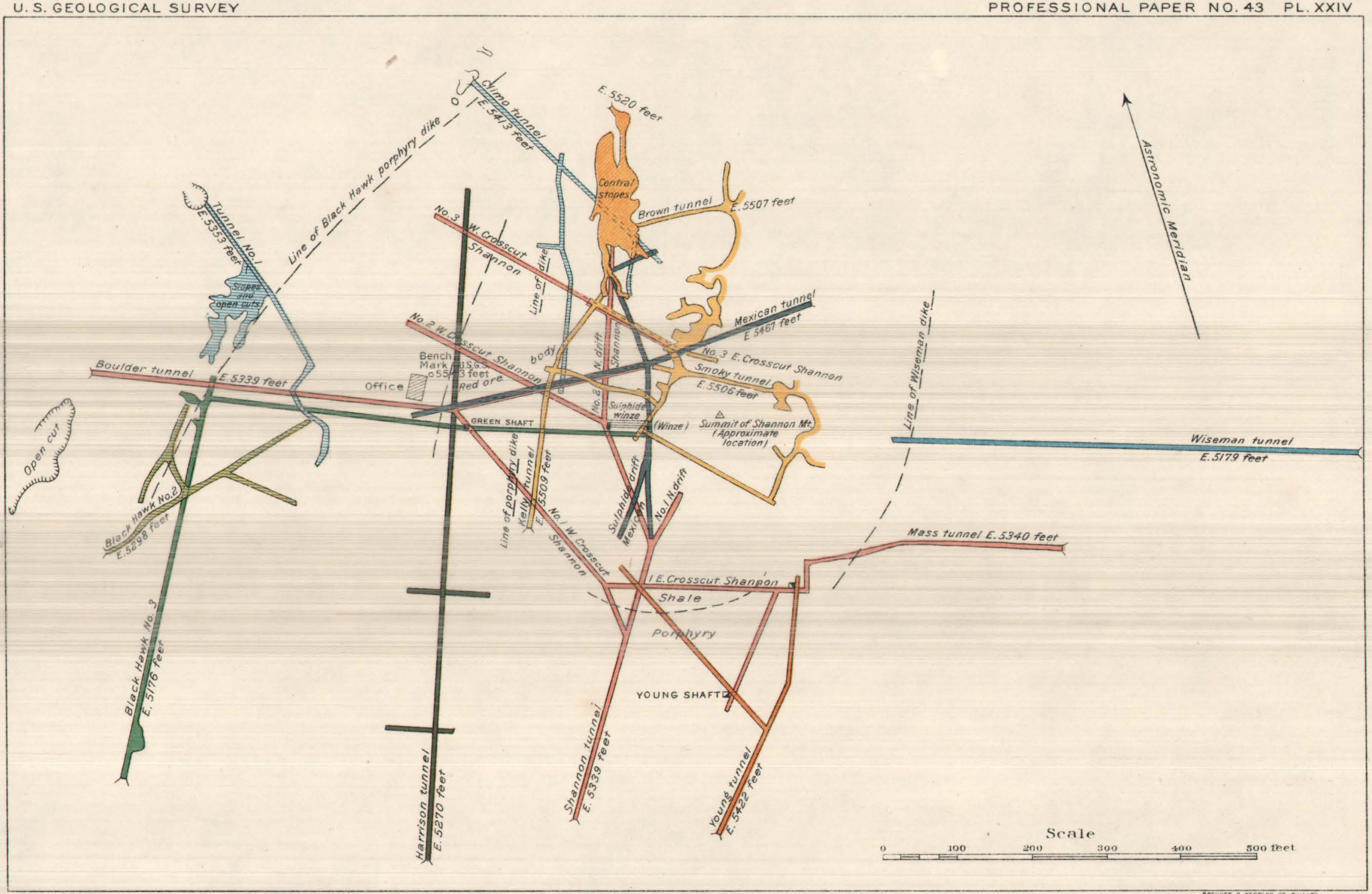

PART OF UNDERGROUNI) WORKINGS OF THE SHANNON MINE. 


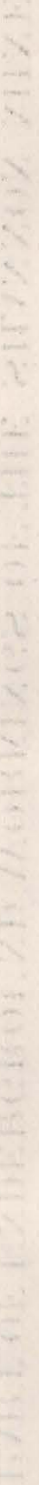


The limestones are affected by very extensive mineralization and contact metamorphism. The top of the mountain consists of a solid mass of garnet, magnetite, and limonite, and most of the limestone on the west side is very greatly altered to magnetite and garnet, these constituents being again decomposed into silica and brown oxide of iron. On the east side, below the cap rock of garnet, the limestones appear somewhat less altered and their stratification and dip can be more clearly ascertained.

The porphyry and sediments of the Shannon claims contain throughout a varying amount of copper, which in places is so high that the rocks may be considered as copper ores.

ORE BODIES.

The developments have disclosed a number of large ore bodies, usually separated indefinitely and irregularly from the surrounding rocks. They consist in part of altered porphyry dikes with disseminated copper minerals, but some of the largest and most important were evidently originally calcareous sediments which have been subjected to contact metamorphism and subsequent oxidation by atmospheric waters.

Comet claim.-This covers Shannon Gap and part of the rising ridge northward from it. Shale is exposed at the gap, but is soon covered by heavy garnetmagnetite rock, which continues to the main contact with the granite, 900 feet north of the gap. This garnet rock, representing part of the Modoc formation (Mississippian), is cut by two dikes. Shale continues at about the level of the gap along the east slope, while on the west slope there is a gentle declivity which is deeply covered by granitic débris, below which granite outcrops. Quartzite was noted in a small outcrop in this area 200 feet north of the Shannon boarding house. The dike which runs on the east side of the boarding house soon bends westward and continues in shale down to the granite contact, beyond which it can not be traced. Its maximum width is 100 feet.

The Comet claim contains indications of ore at several places and may well yield good results upon more thorough prospecting.

Black Hawk ore bodies.--The Black Hawk porphyry dike cuts through the Morenci shales at the gap; near this place it is from 25 to 50 feet wide, soft and decomposed, sometimes sheeted, striking south-southwest and dipping $65^{\circ}$ to $70^{\circ} \mathrm{WNW}$. The first workings of importance are near the Climo tunnel (elevation 5,430 feet), which near the portal cuts this dike. The ores consist of much azurite and some malachite, together with limonite and black-manganese minerals; they occur in the shale on both sides of the porphyry, partly also in the latter, and have been taken out to a width of 20 feet. At 600 feet southwest of the Climo tunnel the Boulder tunnel cuts the same dike and exposes 8 feet of 
cuprite and chalcocite ore on its west side; the ore is largely derived from shale, but is also found of lower grade in the porphyry dike, which as usual is soft and altered. The clay shale adjoining the porphyry on the east contains pyrite, chalcopyrite, and chalcocite in small seams, and for a distance of 300 feet, up to the Office or Central dike, earries from 1 to 3 per cent of copper. Several small masses of porphyry occur in it and these are usually richer, containing much disseminated chalcocite. A short distance south and north of the Boulder tunnel, at slightly higher levels, the Black Hawk stopes follow the dike of the same name, each of them being 120 feet long, up to 50 feet wide, and extending to the surface, a distance of 75 feet. Much rich azurite ore has been extracted from these stopes and considerable of lower grade remains.

Black Hawk No. 2 tunnel, 200 feet south of the Boulder tunnel, at an elevation of 5,298 feet, running northeasterly, develops the same ore. Weathered shale begins at the mouth and continues for several hundred feet. In the northwest drift the same porphyry dike is met, here dipping $45^{\circ} \mathrm{NW}$.; it contains payable ore, and copper carbonates are found in the shale along the contacts. The northeast drift is in clay shale to the end; it dips slightly northeast and contains a little pyrite and chalcopyrite. The part exposed near the roof of the tunnel appears leached, while that near the bottom looks better and is said to contain up to 3 or 4 per cent of copper.

The same ground is exposed by the Black Hawk No. 3 at an elevation of 5,176 feet. The first hundred feet penetrate limestone and shale with some porphyry, all very leached and rusty, with only a trace of copper; 400 feet from the mouth hard limestone begins. The porphyry dike is found 500 feet from the mouth, for which distance the tunnel maintains its northeasterly direction. It contains no payable ore. The compact, bluish-gray, partly dolomitic limestone contains some pyroxene and garnet as well as seams of pyrite and chalcopyrite, and is said to carry up to 3 per cent of copper. In one place the limestone contains a streak of long fibrous asbestos.

Red ore body.-Good ore outcrops on the surface on the western side of the mountain along the road from the Shannon gap to the office of the company at the 5,542-foot bench mark. These outcrops extend for about 500 feet, with a considerable width, chiefly along the eastern side of the porphyry dike designated as the "Central" or "Office" dike. Along the road a few hundred feet north of the office fine azurite and malachite ore with limonite and black-manganese minerals was exposed, the ores contained in greatly altered limestone, some of it still remaining in fairly fresh condition. A little southeast of the office is the Green shaft. At this place the ore is partly contained in the porphyry dike and consists of nearly pure brochantite. The surface extent of this ore body, 
U. S. GeOLOGICAL SURVEY

PROFESSIONAL PAPER NO. 43 PL. XXV

W N W

ESE

Feet above sea level

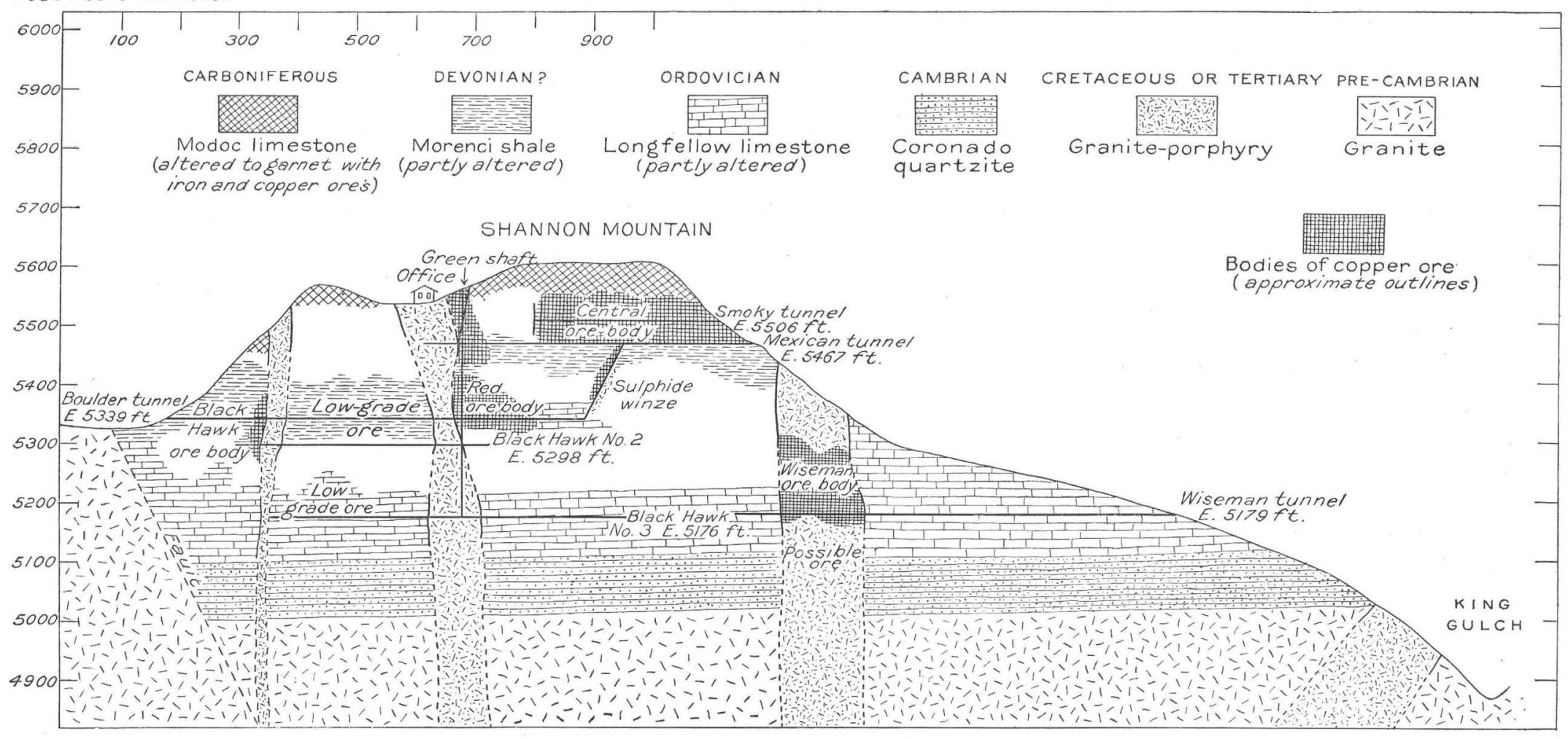

VERTICAL SECTION ACROSS SHANNON MOUNTAIN AND SHANNON MINE, FOLLOWING BOULDER AND WISEMAN TUNNELS. 

which is vertically above the main mass of the red ore body on the Shannon level, is given by Prof. John A. Church, in his report on the Shannon mine, as 500 feet by 250 feet. Below this outcrop is poorer ore, while on the Mexican level, 80 feet below the surface, a body of gray ore (probably altered porphyry) 62 feet wide has been exposed. This again gives out in depth, but a little lower down its place is taken by the great red ore body on the Boulder-Shannon level (elevation 5,339 feet). Vertically below the office this tunnel cuts the porphyry dike, here only 17 feet thick. Immediately east of this begins the red ore body, one of the largest thus far found, which is said to average between 4 and 5 per cent of copper. The width along the Boulder tunnel is 135 feet; its length, as exposed by the two north crosscuts, is 330 feet.

The dark-red soft ore consists of azurite, malachite, and brochantite, with much limonite, but there is little doubt that it originally consisted throughout of contact-metamorphic limestone. Residual bowlders of limestone occur in it and are usually coated by a layer of copper carbonates. Positive confirmation of this transformation was obtained by specimens from the north end in the second west crosscut, which in a mixture of magnetite, fine granular quartz, and partly decomposed garnet contain some remaining grains of chalcopyrite. The specimens are traversed by seams of calcite, limonite, fibrous chrysocolla, and malachite. West of the dike the same level cuts through cupriferous Morenci shales, as described above, so that it seems possible that there may be a slight displacement along the office dike, the eastern block having been relatively raised about 50 feet. In the second and third west crosscuts, near the end, barren shale was, however, met, which seems to dip below the ore body. The exact stratigraphic relations are not quite clear. Through the center of the ore body a narrow and greatly altered porphyry dike passes. East of the red ore body the Boulder tunnel and the second north drift pass through hard dolomitic limestone, clearly of a Devonian or Ordovician horizon; though easily recognizable, this is considerably altered. A specimen from the breast of the second north drift, below the southern end of the Big stope, is a greenish-gray fine-grained rock with disseminated pyrite and chalcopyrite. Part of the lime-magnesia carbonate is irregularly replaced by epodite, pyroxene, and garnet, intergrown with the sulphides mentioned.

The vertical extent of the red ore body is not exactly known; it shows great variations in its tenor and perhaps will not retain its whole areal extent as shown on the Boulder level very far above or below it. On the whole, the ore evidently follows the east contact of the central dike, widening laterally wherever the rocks were favorable to the mineralizing action, a feature also very common in the contact-metamorphic deposits of Morenci. On Black Hawk No. 3 level (elevation 5,176 feet) the office dike is barren and contains no pyrite, while 
the hard, partly metamorphosed, dolomitic limestones on the east contain frequent seams and disseminations of pyrite and chalcopyrite associated with pyroxene, amphibolite, and magnetite.

At 100 feet south of the Green shaft the first west crosscut, Shannon tunnel, passes through a porphyry dike 30 feet wide; south of this is shale, which really immediately adjoins the red ore body on the south. This shale continues for 150 feet southward. It is rusty, contains seams of pyrite and chalcopyrite similar to the shale between the Black Hawk and office dikes of the Boulder tunnel, and forms a large but low-grade ore body the extent of which is not fully known.

Southern ore bodies.-The several porphyry dikes traversing iron rock $\breve{00}$ feet south of the summit of Shannon Mountain converge eastward and run into the strong Wiseman dike, which extends down the southern slope of Shannon Mountain. The surface rock is generally leached, but at a depth of 100 feet becomes productive and contains disseminated chalcocite. The Young tunnel, trending northeast and having an elevation of 5,422 feet, traverses 200 feet of leached porphyry and then exposes a mass of porphyry 200 feet wide, well impregnated with pyrite and chalcocite, forming an ore of very good grade. Similarly, the first few hundred feet of the Shannon tunnel (elevation 5,339 feet), 180 feet east of the Young tunnel, are in low-grade leached porphyry. But the first east drift and the Maas tunnel on the same level exposed the same body of porphyry with disseminated pyrite and chalcocite, forming a body of concentrating ore of excellent grade, said to be up to 200 feet wide. The shale adjoining this dike contains values for a few feet from the contact, but farther away is mostly barren.

The Wiseman tunnel cuts the same dike about 400 feet farther northeast and 160 feet lower (elevation 5,179 feet), penetrating first 500 feet of limestone and lime shale, the latter, in places, containing a little cuprite. The dike is here over 100 feet wide and contains chalcocite and pyrite. The ore is said to be of a good concentrating grade. It is believed that much low-grade ore is avail able between this level and the Young tunnel, 250 feet higher.

Central ore body. - It remains to describe the highest ore body of the hill directly underlying the iron rock of the Shannon Summit. This ore, usually referred to as the central ore body, was discovered at an early date and some rich ore stoped before the organization of the present company. Access to it is obtained from the Smoky and Brown tunnels on the east side of the hill and from the Kelly tunnel near the Green shaft; these are at a level of 5,506 feet, but the ore body in places extends 45 feet above this elevation, and also 
the same distance below, down to the level of the Mexican tunnel, started on the east side of the hill 200 feet south from the portal of the Brown tunnel. Old stopes are found at the mouth of the Brown tunnel, where the heavy iron cap forms a bluff above the shale; the stopes are cut 20 to 30 feet high in the lower part of the iron rock, which, as indicated above, is a replacement of limestone by garnet, magnetite, and copper ores. The so-called Big stopes, which are 30 feet high and from which ore was extracted several years ago, are situated on the level of the Smoky tunnel, 200 feet west of the mouth of the Brown tunnel. South of these the drifts on the Smoky level have disclosed a larger body of ore, 200 by 300 feet in horizontal section, containing 30 to 45 per cent of iron and from 6 to 8 per cent of copper, as malachite, azurite, and brochantite; there is also much pyrolusite, and the mass of the ore consists of hematite and limonite. The primary character of this large mass of oxidized material is not clearly perceived at once, but on the outskirts of the body garnet and magnetite are apt to be found, indicating its original composition. Chalcopyrite is in all probability the mineral from which the oxidized copper has been derived. As stated, the ore extends in places down to the Mexican level in the shale, where chalcocite is occasionally found. The so-called sulphide winze extends from the Mexican down to the Boulder tunnel, near the southern end of the central ore body. Here the central ore body extends down to within 18 feet of the Boulder level along a seam dipping $70^{\circ} \mathrm{W}$. The ore, which is only a few feet wide, but very rich, contains chalcocite, cuprite, and metallic copper; a porphyry dike lies on the east side and shale on the west, the ore making between the two. South of this point the drifts on the Smoky tunnel run into barren shale dipping $20^{\circ} \mathrm{W}$.

On the whole the central ore lies as an irregular horizontal body in the lower part of the Modoc (Mississippian) limestone, only in places reaching down into the shale; it should be considered as the product of surface oxidation acting on a rock consisting of magnetite, garnet, and chalcopyrite, itself a replacement product of limestone, by contact metamorphism. The ore is often loose and cellular, indicating a reduction of volume; cavities with roofs of reniform limonite are sometimes found in it.

Analyses of ores. - The following technical analyses have been kindly put at my disposal by the officers of the Shannon mine. They are not meant to represent the average of the ores as to percentages of copper, but simply to give a general idea of their composition. 
Analyses of oxidized and sulphide ores from Shannon mine.

\begin{tabular}{|c|c|c|c|c|c|c|c|c|c|c|c|}
\hline & \multirow{2}{*}{\multicolumn{8}{|c|}{ Smoky tunnel, central ore body. }} & \multicolumn{3}{|c|}{ Shannon tunnel. } \\
\hline & & & & & & & & & West ore & No. 1 & \\
\hline & I. & II. & III. & IV. & v. & VI. & VII. & VIII. & IX. & $\mathrm{x}$. & XI. \\
\hline $\mathrm{Cu}$ & 34.2 & 11.7 & 10. 7 & 4.4 & 1.6 & 6.3 & 4.8 & 7.8 & 10.4 & 2.62 & 5. 14 \\
\hline $\mathrm{SiO}_{2} \ldots$ & 5.2 & 27.8 & 6.2 & 45 & 20 & 24 & 67.5 & 24.9 & 47 & 36.06 & 16.94 \\
\hline $\mathrm{Fe} . .$. & 18. 7 & 28 & 47. & 26.9 & 49.4 & 39.1 & 12.3 & 30.5 & 9.1 & 19.52 & 1.58 \\
\hline $\mathrm{Al}_{2} \mathrm{O}_{3} \ldots$ & 2.5 & 7 & 4.5 & 5.8 & 5.2 & 9.7 & 3.6 & 9.1 & 13 & 14. 12 & 22.41 \\
\hline $\mathrm{CaO} \ldots$ & None. & None. & None. & Trace. & None. & Trace. & None. & 1.9 & None. & .... & ...... \\
\hline $\mathrm{MgO}$. & None. & None. & None. & Trace. & None. & Trace. & None. & None. & 3.1 & & .. \\
\hline Mn ... & None. & None. & .3 & & .3 & None. & None. & None. & None. & & ..... \\
\hline $\mathrm{Zn}$ & Trace. & None. & .9 & None. & Trace. & 1 & .9 & a 1.6 & 1. 8 & & ...... \\
\hline$S$ & Trace. & None. & None. & None. & None. & None. & .2 & & 3.1 & 7. 76 & 1.52 \\
\hline $\mathrm{SO}_{3} \ldots \ldots \ldots \ldots$ & Trace. & None. & None. & None. & None. & None. & & $\cdots \cdots$ & None. & ........ & ...... \\
\hline $\mathrm{CO}_{2}+\mathrm{H}_{2} \mathrm{O} \ldots \ldots$ & 19 & 11.1 & 7.6 & 5.1 & 2.2 & 6 & 5.6 & 8. 6 & 5.3 & 11.10 & 4. 20 \\
\hline
\end{tabular}

Analyses I-VIII represent the central ore body; the red ore body is in general of similar composition. The ores consist of limonite, malachite or azurite, and silica. But in several of the analyses, after subtracting a sufficient amount of carbon dioxide from the "ignition" to form copper carbonates, there is not enough water left to account for all of the iron as limonite and much of it must be present as hematite or even as magnetite. There is probably also some imperfectly decomposed garnet in most of the samples to which the alumina and some of the silica belong. The absence of lime and magnesia is very striking. Zine and manganese are present in nearly all cases, though they are not concentrated as in the iron rock covering the ore body (see p. 314). The total oxidation of the sulphides is noteworthy, as is also the absence of basic sulphates so prominent in some of the oxidized porphyry ores. No. VIII is an exceptionally siliceous ore, such as may occur in small bunches in the ore body.

Analyses IX, X, and XI represent the porphyry ores containing chalcocite and pyrite, which as a rule are much richer in silica and alumina in form of sericite and kaolin; in $\mathrm{X}$ pyrite predominates over chalcocite.

\section{DARK HORSE ORE BODY.}

At the upper Dark Horse tunnel overlooking King Gulch, 1,100 feet southeast of Shannon Mountain, a small body of rich ore occurs. The elevation is 5,100 feet. The ore was contained in a small body of lime shale, evidently wholly embedded in porphyry. No. 2 tunnel was driven in 144 feet below this 
ore for a distance of 300 feet entirely in highly altered quartz-cemented granite. In its farther end is white, soft ore of fair grade containing disseminated pyrite stained black by chalcocite.

Somewhat similar to this is the small body of ore on the Keystone, belonging to the Arizona Copper Company, and located 2,000 feet north of Shannon Mountain. It contains carbonate ore in dark altered lime shale, wholly surrounded by porphyry.

\section{METASOMATIC ALTERATION.}

In their present form the rocks and ore deposits of Metcalf district are the result of several kinds of metasomatic action often superimposed on the same material. It is the purpose here to analyze and classify these processes, as far as possible, in order to give an insight into their relative characteristics and importance.

\section{CONTACT METAMORPHISM.}

No evidence has been found which would indicate that metalliferous deposits of any kind existed in this area previous to the irruption of the porphyry. Neither the granite nor the sedimentary series is believed to have contained any valuable minerals. Even disseminations of pyrite, so common in many rocks, are absent except in the immediate vicinity of the porphyry. That the porphyry magma carried aqueous solutions of salts of both the heavier and the lighter metals has been shown from the character of the inclusions contained in it (p. 215). This granted, it is easily understood that by the intrusion of the rock into higher levels of the earth's crust and the attendant reduction of pressure, these aqueous solutions should have been released and, pressing outward, exercised an influence upon the surrounding cooler rocks. The alteration produced by these substances, aided by the high temperature obtaining, is called contact metamorphism, and is a phenomenon extensively studied and fairly well understood. In the nature of things calcareous and shaly rocks would be more influenced than silicate rocks like granite or quartz rock like quartzite. The temperature for some distance from the contact of the molten rock would be very high, and the watery solutions would exist as true gases as far as the temperature would exceed $+370^{\circ} \mathrm{C}$. and the pressure 200 atmospheres.

The conditions for the study of contact metamorphism are less favorable on Shannon Mountain than at Morenci, on account of the small mass of sediments involved. But the resulting products in the various members of the series are entirely similar. The contact metamorphism caused a replacement of the limestone by the lıme-iron garnet, diopside, tremolite, epidote, quartz, specularite, magnetite, pyrite, chalcopyrite, and zinc blende, more or less calcite usually remaining in the final product. This replacement was most remarkably complete in the upper and 
very pure Modoc limestone, while the lower dolomitic and siliceous limestone was only partly altered. The clay shale was less extensively affected, but near the porphyry epidote, magnetite, pyrite, and chalcopyrite were developed in it. The replacement usually took place throughout the mass and not along cracks and fissures. In the Modoc limestone the contact-metamorphic sulphides have been thoroughly oxidized, but we can infer from analogy and from occasionally preserved specimens that they consisted of chalcopyrite and zinc blende. But in the lower limestones the process of replacement is followed very easily and indicates the simultaneous formation of garnet, epidote, and chalcopyrite. Cogent evidence that contact metamorphism took place while the magma was as yet fluid is perhaps more difficult to bring at this place than at Morenci. Most favorable to this view is the fact that in the shale and the lower limestone the development of contact minerals is greatest in a zone of varying widths on both sides of the dikes and rapidly diminishes away from it; and, second, the fact that the isolated areas of shale and limestone on the south side of Shannon Mountain have undergone a far more intense alteration than the larger mass of sediments traversed by only a few dikes.

At the close of this first epoch, which I would consider to have been completed at the time of the solidification of the porphyry, the larger part of the outlying masses of sediments inclosed in porphyry and practically the whole thickness of the Modoc limestone must have been converted to garnet, magnetite, and sulphides. Similar conversion had taken place along the contacts of the shale and the lower (Longfellow) limestone with the porphyry dikes contained in them, probably also locally throughout these shales and limestones. Chalcopyrite and zinc blende were disseminated throughout the Modoc limestone, but most concentrated in the space now occupied by the, central and red ore bodies. Chalcopyrite was also contained in varying amounts along the contact of the dikes in shale and lower limestone; but it is certain that all these ore bodies contained a smaller percentage of copper than at present.

\section{ERUPTIVE AFTER-EFFECTS.}

The typical contact metamorphism was followed by a second stage of most interesting phenomena, which are called eruptive after-effects, a word recently introduced by Professor Vogt. I hesitate to draw a strict line between these two processes, which rather seem to blend gradually. The porphyry had consolidated but was probably still very hot. Stresses similar to those which prepared the way for the intrusion of the porphyry stock shattered the porphyry, and also in part the adjoining granite and sediments, producing northeasterly trending zones of joints in the former two rocks and irregular fractures in the third. Solutions soon ascended on these openings, and caused replacement in the granite and porphyry by quartz, sericite, pyrite, chalcopyrite, and specularite. Over large areas 
the massive bodies and the dikes of porous porphyry became filled with disseminated pyrite and chalcopyrite, the latter only in small quantities. In the limestones the solution deposited in addition calcite, epidote, and magnetite in the fissures and caused along the walls of the cracks, by metasomatic replacement, a development of pyroxene, amphibolite, and magnetite. In the shale pyrite, chalcopyrite, and quartz were formed without extensive sericitization or pyroxenic alteration. That these solutions were hot is proved by the character of the liquid inclusions (see p. 216); that they were derived from the porphyry is almost conclusively proved by the similarity of the inclusions in the quartz phenocryst of the porphyry and in the quartz in the veins.

At the close of this epoch the porphyry had suffered extensive sericitization and cementation by quartz. It contained also in places much pyrite and a little chalcopyrite. This alteration was most intense along the King and Jameson fissures, along the line of the present Metcalf mines, and in some of the dikes, notably the eastern or Wiseman dike. Lean ore bodies of disseminated chalcopyrite had formed in the shales of the Shannon tunnel and in places through the whole mass of sediments except the already metamorphosed Modoc limestone, which was probably too compact to be extensively shattered.

OXIDATION AND FORMATION OF SECONDARY SULPHIDES.

The processes described above took place far below the surface. The account of general geology shows that at least several hundred feet of Cretaceous strata covered the Mississippian in this region at the time of intrusion, and this thickness may have been much greater. Whether the porphyry ever reached the actual surface as it existed then is doubtful; it is more likely that it spread out as sheets and laccoliths in the strata instead of breaking through. After the completion of the deep-seated processes an active erosion removed the larger part of the covering strata, and thus exposed the ore deposits or brought them close to the surface. At this time oxidation of the pyritic minerals began, but was probably not continued long, for the whole country during Tertiary time became flooded by lavas of various kinds. Again during the late Tertiary and early Quaternary erosion had full sway, and once more exposed the ores to oxidizing waters. From this time to the present day, it is believed, extended the most important period of surface alteration.

During the early Quaternary the ground-water surface must have been several hundred feet higher than now. It is believed that the most important changes were effected during that epoch, although in a measure the decomposition has progressed to the present time. Most simple is perhaps the oxidation of the ore bodies in contact-metamorphosed limestone. The oxidation of the magnetite produced hematite and limonite, while the garnet yielded limonite and 
silica, the lime being carried away in soluble form. The zine blende was in part directly converted into hydrous sulphate, easily soluble and carried away by the percolating waters; in part into silicate and carbonate, which were more tenaciously held by the rock. The pyrite was oxidized into limonite and ferrous sulphate, the latter easily removable. Similarly the chalcopyrite yielded limonite, ferrous sulphate, and cupric sulphate; most of the latter was precipitated as malachite and azurite, and in part as brochantite, by reaction with solutions and rocks containing calcic carbonate. This process was accompanied by a reduction in volume and an enrichment of copper.

Many of these ore bodies crop on the surface and the basic copper salts have stubbornly resisted further leaching. But wherever pyritic porphyry adjoins these ores there has taken place a metasomatic replacement of pyrite by chalcocite by the action of sulphate solutions or the former mineral. When waters with free oxygen reached this chalcocite it changed to cuprite, metallic copper, brochantite, malachite, azurite, and chrysocolla, the cuprite usually being formed first. The larger bodies of ore in porphyry are usually covered by a leached zone 30 to 50 feet in depth. Below this brochantite, malachite, azurite, chrysocolla, and cuprite are found on seams in the rock; lower down there is an increasing amount of chalcocite, which at still greater depth is replaced by disseminated pyrite and chalcopyrite. On Shannon Mountain the lower limit of this chalcocite zone would seem to lie about 250 to 300 feet below the present surface. It is apparently entirely independent of the present water level, but the suggestion is offered that it may mark the approximate ground-water surface during the early Pleistocene or latest Tertiary. In other districts the occurrence of the secondary chalcocite usually indicates the water level, and it has been found that the replacement of pyrite by chalcocite takes place only when oxygen is excluded or present in but small quantities. Under present conditions the oxidizing waters easily reach a considerable depth, and the chalcocite zone is being slowly converted into basic sulphate and carbonate.

Many other less important reactions take place by means of oxidizing and acidic waters. Among these may be mentioned a concentration of manganese in the garnet-magnetite rock, and the leaching of aluminum from shale and also from porphyry in the form of hydrous sulphate by the action of sulphuric acid. Once formed the sulphate is easily removed, as it is very soluble.

\section{SUMMARY OF METCALF DEPOSITS.}

\section{DEPOSITS IN PORPHYRY.}

Deposits in porphyry may occur as irregular masses, or as fissure veins, or as dike deposits - that is, of deposits consisting of the altered material of a porphyry dike, following its strike and dip. Of the irregular deposits the Metcalf 
mines form the most conspicuous example. No regular fissures can be detected; the seams in the porphyry run in all directions, but a certain elongation of the deposit in a northeast direction is noted. Briefly, the uppermost 40 feet are practically barren, with evidences of leaching and deposition of limonite. The next 125 feet contain ore bodies of great extent and low grade characterized by the mingling of chrysocolla, brochantite, azurite, and malachite, with a little cuprite and chalcocite; in the lower part of this zone cuprite and chalcocite prevail, the chalcocite yielding cuprite as a result of oxidation. Below this only very low-grade pyritic ores disseminated in porphyry have thus far been found. The deposit lies on the summit of the ridge between King Gulch and Chase Creek. Irregular masses of dark iron ores, mixtures of silica and limonite, occur at many places, as well as some remaining recognizable shale.

As an explanation of the above conditions the following may be advanced. The porphyry at this place contained many shattered fragments of sedimentary calcareous rocks, which, at the time of intrusion, suffered contact metamorphism with the formation of garnet, magnetite, chalcopyrite, and pyrite. The surrounding porphyry, like so much of this rock in the Metcalf district, after solidifying became impregnated with slightly cupriferous pyrite. Oxidation of this material converted the chalcopyrite in the limestone to soluble salts, which upon filtering down through the porous porphyry replaced the pyrite by chalcocite. Long-continued erosion reduced the level of the ridge and simultaneous oxidation altered the chalcocite partly to sulphates, silicates, etc. The oxidation, most intense near the surface, leached almost completely the uppermost 30 or 40 feet. The deposition of chalcocite is probably largely a thing of the past, and the only important process now active is that of the oxidation of this mineral and gradual carrying away of the product of oxidation.

The fissure veins, like the King and the Jameson, offer similar though slightly differing phenomena. The former shows as a lode cropping on the high summit, 500 feet above the Metcalf mines. Here a depth of only 200 feet below the croppings has been attained, and the ores consist only of chrysocolla, malachite, and brochantite. This deposit, it should be observed, has suffered less from degradation than that of the Metcalf mines, and has thus remained undisturbed a longer period, during which oxidation could pursue its processes. We may assume a primary deposition of low-grade pyrite, oxidized to a depth of several hundred feet below the surface. In striking contrast to the relations at Copper Mountain, Morenci, the oxidized payable ores here reach the surface. A zone of chalcocite ore should be expected about 400 feet below the csoppings.

At the Jameson vein, the croppings of which are 200 feet lower down on the steep slope toward King Gulch, a considerable body of chalcocite-pyrite ore 
was found, extending from near the surface to a depth of 300 feet, at which point the ore is becoming more pyritic. The upper parts of the croppings, with probably a large amount of green oxidized ores, have doubtless been carried away during the erosion of King Gulch.

These relations to some extent confirm the belief that the chalcocite zone was formed during a previous epoch and under a different and higher level of ground water. Almost all of the porphyry dikes on Shannon Mountain contain disseminated copper ores and important ore bodies occur on the three largest ones. The surface is usually poor ore, but invariably contains some copper. The rock here is soft and crumbling, filled with seams of limonite, and chalcanthite effervesces on the walls of the tunnels. In other words, all or nearly all of the copper is in a soluble state and is being gradually carried away by atmospheric waters. This zone of leaching extends to a depth of ahout 100 feet from the surface, when disseminated chalcocite appears and the porphyry assumes the character of an ore. At a varying and not yet fully determined depth the chalcocite disappears and somewhat cupriferous pyrite takes its place; this change is effected gradually within a distance of 200 or 300 feet. When the pyritic zone is reached we are evidently below the zone of alteration by surface waters. The rock is in the condition in which it was left at the close of the first mineralization. Whether payable ore will be found within this pyritic zone is doubtful. Judging from analogies none will be found. The chalcocite is without doubt deposited as a replacement leached from the decomposing cupriferous pyrite of the primary pyrite above by the action of descending copper solutions. On the whole, this course of alteration is the same as at Morenci.

The Black Hawk dike is leached on the surface, but contains smaller bodies of ore-cuprite and chalcocite-on the Boulder and Black Hawk No. 2 levels, while it is barren on the lowest level attained in the No. 3 tunnel. The central dike is generally poor in its eastern part, but at the Green shaft contains a rich body of brochantite almost at the surface. It is not payable on the Boulder and Black Hawk No. 3 levels; in fact, on the latter level it does not even contain pyrite. The largest ore body is found in the Wiseman dike. Here again the upper 100 feet are barren, or at most contain stains of brochantite or other copper salts. High-grade chalcocite ore, at least 100 feet wide, containing but little pyrite, is exposed on the Young level. On the Wiseman level, 250 feet below the Young, the dike, here 100 feet wide, contains chalcocite mixed with pyrite.

\section{DEPOSITS IN LIMESTONE AND SHALE.}

There remain to be considered the copper ores contained in the altered limestone. These occur in three ways: As vertical, tabular, or pipe-like bodies following the contacts of porphyry dikes; as horizontal tabular bodies following the stratification planes; and, finally, as irregular masses in the shale or limestone. 
To the first kind belong the Black Hawk ores and some others lining the eastern part of the central dike; also many other occurrences, as at the Shirley tunnel and in some places along the Wiseman dike. To the second belong the central and to some extent also the red ore body. To the last division belong the disseminated chalcopyrite and chalcocite in the shale of the Shannon tunnel and the disseminations of chalcopyrite on the Black Hawk No. 3 level. The latter rocks, which are very fresh, represent the original condition of most of the ore bodies; they contain a not inconsiderable amount of chalcopyrite and in some places may fairly be considered as ore. But oxidation is necessary to concentrate the copper to a higher percentage by reduction of the bulk, and such oxidation has produced the rich masses of malachite and azurite in the central, red, and Black Hawk ore bodies. The zone of oxidation in the case of these ore bodies extends at most to a point 300 feet below the surface. Primary dissemination of chalcopyrite in greater abundance along certain suitable strata or along eruptive contacts was doubtless the first requisite for the formation of the ore body. Oxidation easily doubled or quadrupled the original percentage of copper. Chalcocite occurs very sparingly in these ore bodies, the abundant carbon dioxide converting all of the soluble copper salts to stable carbonates. Large amounts of oxides of iron and manganese accompany these ore bodies. Basic sulphate and chalcanthite are rarely formed. The altered limestones are not as pervious to waters as the porous porphyries; hence we find no such welldefined chalcocite zone as exists in the latter rocks. Neither is there such a prominent zone of leaching at the surface as in the porphyries. In many cases in the contact ores on the central and Black Hawk ore bodies the richest kind of azurite ore cropped practically on the surface.

In shale, on the other hand, there is more evidence of surface leaching, as, for instance, in the first 100 feet of Boulder and Black Hawk No. 3 tunnels. The shale also contains a little chalcocite and appears to preserve its primary chalcopyrite better than does the limestone.

Nothing definite can be said about the age of these oxidized ore bodies in limestone. The fact that they have resisted leaching so vigorously emphasizes the slowness of processes of oxidation, and it would not be surprising if a large part of this oxidation had been effected in Tertiary time before the eruption of the basalts and rbyolites. The oxidation is of course still in progress at the present time.

16859 - No. $43-05-22$ 


\section{CHAPTER X. \\ CORONADO MOUNTAIN. \\ GENERAL STRUCTURE.}

On the south and east sides of the great granite "massif" of Coronado Mountain, 3 to 4 miles north-northwest from Morenci, are located several mines and prospects, most prominent among which is the Coronado mine.

One of the dominant topographic features is the quartzite ridge which begins 1 mile north of Morenci and continues with elevations of from 6,000 to 6,300 feet up to the Coronado mine. This forms the divide between Eagle Creek and Chase Creek; the slopes toward the latter are more precipitous, broken by many salients, while gentler declivities lead down to the sloping lava plateau filling the basin of Eagle Creek. Northward the great mass of Coronado Mountain forms the second topographic unit, rising with dark-red, bare or scantily forested slopes, its sides deeply scored by ravines, sometimes lined with nearly perpendicular bluffs.

The geological features are simple in contrast to the confused.complication of the structure near the Morenci mines. The Coronado massif consists of coarse granular pre-Cambrian granite; on the gentler slopes this is generally disintegrated to coarse sand or loosely coherent rock, in which red orthoclase and quartz are the only recognizable minerals. Thoroughly fresh granite is not obtainable on the surface. On the flat top rest 200 feet of Coronado quartzite, the basal member of which is a coarse conglomerate of quartz and quartzite. On the north, east, and south side this massif is limited by fault lines along which profound dislocations have taken place. It may be considered as a solid block, a remainder of a larger area, the peripheral parts of which have been broken off and sunk down. On the south it is limited by the great Coronado fissure, with a downthrow of 1,200 feet on the southern side. In evidence of this the ridge south of the fault is covered by the same quartzite which caps the top of the mountain and in the absence of any indication of fissuring in the granite between these quartzite areas it is probable that the whole of the dislocation has occurred on the known fault plane. The thrown block dips to the west, gently near the top of the ridge and more decidedly farther west in Horseshoe Gulch. On the Chase 
Creek side granite is generally found at a short distance below the crest, while on the west side the quartzite covers the whole slope for $1 \frac{1}{2}$ miles; finally near the point where the older formations disappear below the lavas of Eagle Creek the dip, increasing to $20^{\circ}$ and $30^{\circ}$, brings in the Silurian and Devonian limestones, which overlie the quartzite. in the normal section. Thi great quartzite block is again cut by minor, chiefly northeasterly, faults (PI. I), and south of Horseshoe Gulch has again sunk relative to a smaller triangular block of granite and quartzite, here bordering against the basalts of Eagle Creek.

Southeast of Coronado Mountain the great fault runs out in granite and. can not be readily traced. But the bluffs and the sheeting of the rock indicate that it bends northeasterly and runs at a short distance west of the Metcalf stock of porphyry, which thus assumes the character of a deeply sunken block. East of the great mountain the presence of the limestone masses in Chase Creek near Garfield Gulch indicates the same or a closely related fault, the plane of which $\operatorname{dips} 45^{\circ}$ E. and the throw of which is about 2,000 feet.

\section{ORE DEPOSITS.}

The majority of the deposits in this area are fissure veins containing oxidized copper ores in their upper levels. The exploration is rarely extensive enough to indicate their exact character in depth. Some of them, notably the Coronado vein, differ very much from the prevailing types of Morenci and Metcalf deposits, first, in their position on fault planes, which usually, in this region, are barren, and second, in their association with diabase instead of with the normal Morenci or Metcalf porphyry.

\section{CORONADO VEIN.}

The great Coronado vein follows for 2 miles the fault dividing the granite of Coronado Mountain from the quartzite block on the south. Its outcrop crosses the ridge at the contact of the two formations at an elevation of 6,100 feet. Eastward from this point it is traceable for only one-half mile, but westward follows for $1 \frac{1}{2}$ miles the trend of Horseshoe Gulch.

This deposit was one of the first locations, as may well be inferred from its prominent position and copper-stained outcrops. The exploitation began at an early date and a large part of the present development work was done at the time when Wendt first described the mine in 1886 . The production has proceeded somewhat intermittently since 1881. A large amount of ore has been extracted above and below the tunnel level, from the workings near Horseshoe shaft, and from the open cut still farther down on the western slope. In 1902 oxidized ore was extracted from the last two places. 
Development.--The vein is opened by a tunnel which pierces the ridge at an elevation of 5,750 feet, about 300 feet below the summit. It follows the vein from east to west and is about 1,500 feet long. Old stopes extend to the surface. Below the highest point of the surface a winze with several levels is sunk from the tunnel level to a depth of 300 feet. Another winze, 200 feet deep, is located on the same tunnel near the western portal. At the east portal a shaft is now being sunk to facilitate the extraction of ore below the tunnel level. Farther west, about 3,500 feet from the summit of the ridge, the Horseshoe shaft is located; it is 200 feet deep and developed by several levels. About 1,500 feet farther west on the north side of the gulch is an open cut which was worked in 1902 . A distance of 2,000 feet west from this point a small shaft has been sunk on outcrops, evidently belonging to the same vein.

A branch railroad leads up Coronado Gulch from Metcalf to an incline, which rises 1,200 feet in a horizontal distance of 2,500 feet, up to a tramway which leads to the mine, three-fourths mile farther west. An aerial tramway crosses the ridge from the east portal and descends on the west side to a loading platform near Horseshoe shaft. The ore from the lowest open cut is packed on burros to this loading platform. Wendt states that up to $1883 \$ 600,000$ had been spent in improvements, and it is doubtful whether more than $\$ 1,000,000$ in copper values have been extracted from the mine up to 1902 .

Country rock.- On the slopes leading up to the Coronado mine from the east are granite outcrops, cut by occasional dikes of porphyry. The same normal coarse-grained granite is found all along the north side of the vein, both along the croppings and in several places in the main tunnel. The quartzite that forms the summit of the ridge south of the fault is a hard rock, consisting nearly exclusively of quartz grains, the rounded outlines of which are usually clearly visible. On the east side at the level of the portal of the main tunnel a thin quartzitic conglomerate is exposed at the base of the quartzite, resting on granite. Going south from this point several minor east-west faults dislocate this contact. On the west slope the beds of quartzite continue down, dipping at first very gently to the west. The dip increases gradually to $18^{\circ}$ near Horseshoe shaft.

- In Horseshoe Gulch erosion has exposed a part of the underlying granite, which outerops for a distance of 2,000 feet. A small thickness of conglomerate here also underlies the quartzite. A similar granite area partly bounded by dislocations is exposed in a lateral gulch south of the fissure. On the ridge between the two forks of Horseshoe Gulch the Silurian limestones cover the quartzite conformably, with dips of $20^{\circ}$ to $30^{\circ}$, and in West Fork, near the place where the vein disappears below the lava, there is also a small area of Devonian limestone. 
The vein is followed intermittently by a diabase dike of a width ranging from a few feet up to 70 feet. The rock is generally altered by development of sericite, often so as to render it almost unrecognizable. The freshest specimens were obtained from the surface along the main vein, 100 feet vertically above Horseshoe shaft, and from a small lateral vein on the south side of the gulch, 200 feet vertically above the same shaft. These specimens were dull green, of medium grain, and contained small grains of pyrite. Under the microscope the rock is of typical structure, showing much pyroxene pressed in between lathlike labradorite crystals, and containing much ilmenite or magnetite. Chlorite results from decomposition of the pyroxene, and the feldspars are well filled with sericite. The occurrence of irregular masses of this diabase in the vein matter would seem to indicate that at least a part of the faulting took place later than the intrusion of the dike.

Fissure.-The Coronado vein is a clearly defined fissure, striking nearly due east and west in its western part, but soon turning east-northeast, which direction it maintains across the dividing ridge. The dip is $70^{\circ}$ to $80^{\circ} \mathrm{S}$., and it usually lies between well-defined walls. In only one place,

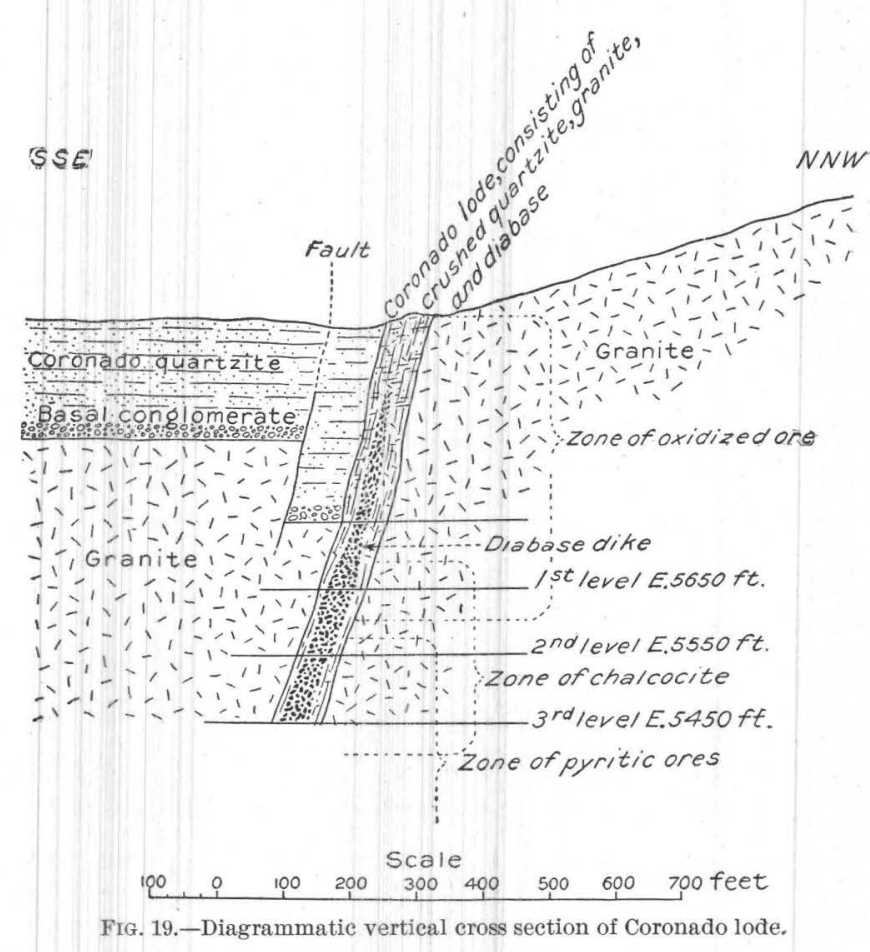
a short distance below Horseshoe shaft, was a dip of $85^{\circ} \mathrm{N}$. observed. At the east portal of the tunnel a well-defined dike of highly altered diabase 12 feet wide lies between quartzitic conglomerate and granite. From this point eastward the vein is not easily traced, though it is believed to continue onefourth mile farther, and to cross the first ravine coming down from the north near its junction with the main gulch. At the summit of the ridge and at several places on both slopes the vein is marked by copper-stained croppings 10 to 50 feet wide, which appear to consist of quartzite or quartzite breccia. 
The width of the broken zone varies very considerably. On the tunnel level is a crosscut extending 400 feet south and revealing 80 feet of vein matter between fresh granite on the north and fresh quartzite on the south. Most of this vein matter consists of the two rocks mentioned, more or less crushed, but there may also be some diabase. The foot wall is sharply defined. On the 100 -foot level in the winze granite and a large amount of diabase are exposed. On the second level 70 feet of diabase are exposed; crosscuts in the foot wall soon run into granite. At the west portal the vein is 8 feet wide between well-defined walls of granite and quartzite. Here, again, part of the vein matter is probably altered diabase. For 1,500 feet west of this place, down into Horseshoe Gulch, the vein lies between quartzite and granite, and is indicated by heavy masses of quartzite breccia; it then runs into granite and widens greatly. At Horseshoe shaft the lode is fully 200 feet wide, and consists of altered granite and contact breccia, often stained blue by chrysocolla. No distinct diabase is here visible, though it may be present in excessively altered form. One-fourth mile east of the shaft fairly fresh diabase, 70 feet wide, was noted, but it is soon cut off and seems rather to form irregular masses along the vein. From the shaft to the open cut, which is located near the bottom of the gulch, the vein again runs on the contact, forming a wide, shattered zone. For 700 feet west from the open cut the width of the lode is 50 feet and it is again accompanied by a dike of altered diabase. From the open cut westward the vein crosses the 300 - to 400 -foot ridge separating the two forks, and probably strictly follows the sbarp fault plane between the Silurian limestone and granite. At the top of the ridge are croppings of hematitic material 15 feet wide. No development work has been done along this part of it, but near the bottom of the west fork, at the contact of granite and Devonian limestone, it is again exposed by a small shaft and the croppings are marked by black-stained quartz.

Ores.-The first information concerning the Coronado mine was given by Wendt; ${ }^{a}$ and while his geology requires correction, it is of interest to read his conclusions concerning the ores. He states that the Coronado mine presents an extreme case of rapid depreciation in depth. At the surface average samples gave from 6 to 45 per cent copper, and bodies of pure copper glance cropped at several places. In 1884 he drove a tunnel on the Boulder claim which for the whole of its height and a distance of over 150 feet was run on a vein of solid glance, 6 inches wide and averaging 46 per cent of copper. Wherever the glance has been followed down, he says, it disappears 150 to 200 feet from the surface, and the vein either becomes barren or is replaced by yellow sulphides scattered through the gangue; these yellow sulphides, by which is evidently 


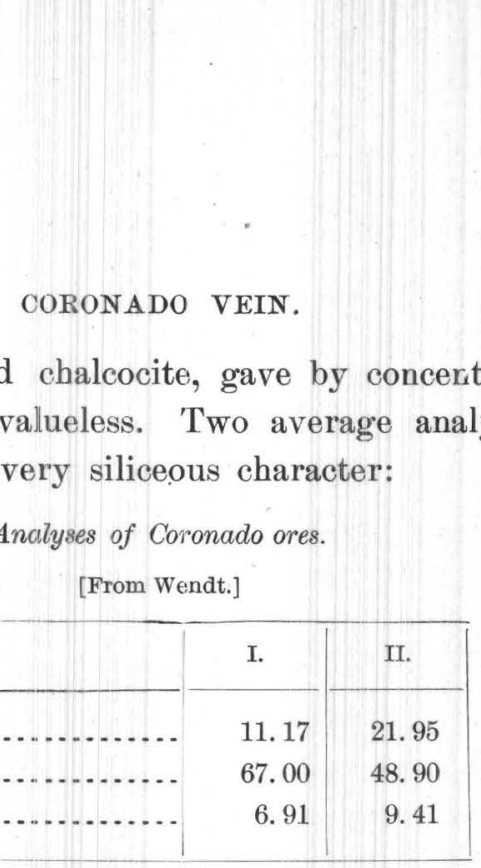

meant a mixture of pyrite and chalcocite, gave by concertration tests an 8 per cent ore, which in 1886 was valueless. Two average analyses show the grade of the ore then mined and its very siliceous character:

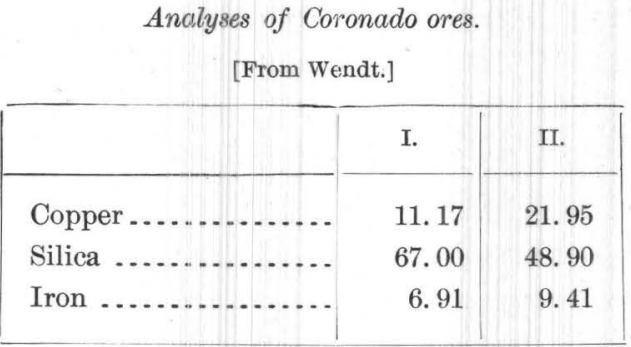

As indicated above, the ores of the vein consist partly of oxidized minerals, such as chrysocolla, malachite, and, more rarely, azurite, partly of chalcocite or "glance," and partly of pyrite and chalcopyrite. From the main tunnel the oxidized ores extended to the surface and have been stoped 5 to 15 feet wide; this shoot occurred below the summit of the ridge. Below the tunnel level it was followed by a winze 300 feet deep. Although, as indicated by Wendt, some of the chalcocite occurred near the surface, it was only below the tunnel level that this mineral appeared in force. On the first level of the winze chalcocite ore occurs, and stopes extend from this down to the 300 -foot level. The best ore body was found around the winze, and its richest part probably occurred between the first and seeond levels, where it is 60 feet wide. On the second level the ore contains much pyrite. The third level was stated to show a smaller amount of ore. Another smaller ore body appears near the western portal. Chalcocite ore of good quality, 30 to 40 feet wide, was found below the tunnel level in a 200-foot winze.

At the third ore shoot, near Horseshoe shaft, the surface indications were very good, the ore consisting of brecciated rock, possibly a much altered diabase, with seams of chrysocolla and malachite, with a little chalcocite, but the developments in depth are said to have been disappointing. However, good chrysocolla ore was met in a tunnel connecting with the shaft at the level of the loading platform, and this body, 20 feet wide, was actively mined in 1902. Finally, at the open cut, one-fourth mile farther west, a quarry was opened in 1902 on ore of very good grade. The rock along the fault is bleached, and its original character, whether quartzitic friction breccia or diabase, is not recognizable in the resulting mass of quartz and kaolin. It contains chrysocolla and malachite on seams replacing the substance of the rock. The most westerly croppings of the vein disclose no copper ore, but on the dump of the little shaft lie fragments of a peculiar lead-manganese ore, and the iron-stained quartz is said to contain some gold values. 
From this review it will be seen that the Coronado ores do not consist of a filling of open fissures, but that a sericitic alteration accompanied by quartz cementation has taken place in the friction breccia and crushed material along this great fault; that the malachite and chrysocolla, the latter specially abundant, occur in this material as seams, usually replacing the rock and associated with quartz and kaolin as the last product of oxidizing action; further, that this oxidized ore is underlain by chalcocite ore of secondary origin, which in the main workings occupies a vertical distance of 200 or 300 feet, the upper limit at the highest point of the ridge being about 300 feet below the surface. Below this chalcocite it is likely that pyrite and chalcopyrite of the primary ore deposition will be found to make up the ores of the fissures. Whether the latter will be payable or not I have no data for ascertaining. It will almost surely be of low grade.

The statements of Wendt do not apply without modification to present conditions; for while at that time 3 to 5 per cent material would have been rejected as waste, it is now considered as payable ore. The Coronado mine contains good reserves of such ore, both above and below the tunnel level, and it is very possible that other bodies of chalcocite ore will be found. ${ }^{a}$

The main features of primary deposition of pyrite and chalcopyrite, secondary sulphide deposition of chalcocite, and finally surface oxidation, producing malachite, chrysocolla, and limonite, are the same here as at Metcalf and Morenci.

Age.-The Coronado lode lies along a fault fissure of great importance, with a probable vertical throw of 1,200 feet, and is followed by a diabase dike. The mineralization of this fissure took place subsequently to the intrusion of diabase, which probably followed the break producing the fault. The system of fault fissures to which the Coronado lode belongs seems to be somewhat later than the principal deposits at Metcalf and Morenci. The conclusion may thus be established with some confidence that the intrusion of diabase was later than that of the porphyries and that the veins dependent on diabase dikes were formed later than those connected with the porphyries. The examination of the unaltered part of the Coronado lode did not lead to definite conclusions as to its mode of formation, but there seems to be reason to doubt that it is due to ascending waters.

\section{SMALLER VEINS.}

Several similar smaller veins lie to the south of the Coronado. One of these, owned by the Arizona Copper Company, is accompanied by a dike of fresh diabase and lies one-fourth mile southeast of Horseshoe shaft, partly in granite, partly in quartzite, and shows on the surface chrysocolla and azurite ore with indications

$a$ Siu se this was written extensive exploration on the third level has developed large bodies of concentrating ore, and a winze sunk to the 500 -foot level on the west side of the ridge is also stated to have reached ore. The surface drops off rapidly toward the west. 
of chalcocite below. Another also with chrysocolla ore lies one-fourth mile southeast of the open cut on the Coronado, on a small fault fissure between granite on the south and quartzite on the north, and is known as the Keating vein.

The Dewey and Copper Plate claims lie 1 mile south of the Coronado vein, near the foothills of the Eagle Creek plateau. The vein cuts, with a northeast strike and a dip of $80^{\circ}$ SE., first granite, then quartzite conglomerate and quartzite; the ore consists of a dike of Metcalf porphyry, 3 feet wide, with disseminated malachite. It continues up in a northeasterly direetion to the next fault fissure, which brings the quartzite to the level of the Silurian limestone; here the dike is apparently cut off.

The Las Trajas property, also 1 mile south of the Coronado vein and on the main ridge, is developed by a shaft 100 feet deep and by several surface cuts. The vein cuts through quartzite and seems to be located on a subordinate fault fissure. East of the shaft it is accompanied by a porphyry dike up to 200 feet wide, which, however, does not seem to follow the fissure. The ores consist of chrysocolla and malachite and have been stoped along surface cuts to a width of 3 feet.

One-half mile northeast of Las Trajas, near the edge of the bluff breaking off toward Chase Creek, are several prospects, said to contain promising ore, which belong to the recently organized Coronado Mining Company. They are contained in the limestone which here covers the quartzite in a small fault block, as shown on Pl. I, separated from the main quartzite by a northwest fault, along which it has dropped some 200 feet.

On the trail leading from the bottom of the incline up to Coronado mine the Emerald claim is located, having an elevation of 5,200 feet. A porphyry dike 80 feet wide here crosses the narrow canyon cut in the prevailing granitic rock. The ore appears to form along the contact of porphyry and granite. Following the same contact also appears a dark, dense pyritic rock of doubtful origin. The ore consists of chalcocite and carbonate.

Exposures, probably belonging to the same vein, have been found close to the Coronado incline on the Pyramid claim, at an elevation of 5,200 feet. This deposit, which is developed by two small tunnels, contains a considerable amount of chalcocite ore, much of which has been shipped. The claim is the property of the Arizona Copper Company. A porphyry dike, which is probably identical with the one shown at the Emerald claim, was also noted at the Pyramid tunnels, near which place it appeared to join the main mass of Metcalf porphyry. The vein strikes $\mathrm{N}$. $72^{\circ} \mathrm{E}$. and dips $65^{\circ} \mathrm{S}$.

Ascending Santa Rosa Canyon, which is mainly eut in normal granite of Coronado Mountain, several veins of smaller importance are encountered. The 
first one appears in the upper part of the box canyon occupying the lower part of Santa Rosa Gulch, and is called "Dad Wright." It is a strong fissure vein, striking east and west and dipping $80^{\circ} \mathrm{N}$., and occurs at an elevation of 5,150 feet. Its position indicates that it may be an extension of the important system of the Coronado fissures. The developments are of slight importance, and the ore thus far encountered is of poor quality. Above this box canyon the gulch becomes more open, the grade, however, still remaining very steep. No porphyry dikes were noted, except a small one in a side canyon a quarter of a mile below the claims of the Santa Rosa Company. This recently organized company controls 15 claims in this vicinity, all of them contained in granite. The principal claims are the Grant and the Flor del Miza The strike of the veins is chiefly northeast, and the $\operatorname{dip} 60^{\circ}$ to the southeast. Three small tunnels have been driven on the Miza claim and some 50 tons of ore shipped. The vein forms a quartz-filled streak in granite, accompanied by irregular masses of a fine-grained rock, looking very much like shale-possibly an inclusion of older pre-Cambrian sediments into intrusive granite. The ores along this fissure chiefly consist of chalcocite, and occur both in the granite along the vein and in the quartz accompanying the deposit. Another set of fissures have a north-northwest direction, and these also contain some copper ores. At the surface and also in the veins is a little malachite and other oxidized ores, but unaltered pyrite is evidently not far from the surface. On the east side of Santa Rosa Gulch appears another narrow but well-defined vein with a northeasterly strike, which is exposed in several places. The country rock is granite of a very hard character. The ores found along the narrow fissure consist of pyrite with a little chalcocite. One of the higher tunnels shows a considerable amount of glance ore scattered through the granite adjoining the vein. The croppings on top of the ridge show a fair amount of oxidized ore, mainly azurite, some of which has been packed down to Metcalf and shipped. Many smaller seams belonging to the north-northwest system cross this fissure. 


\section{CHAPTER XI. GARFIELID AND KING GULCHES. \\ GARFIELD GULCH.}

ROCKS.

Garfield Gulch is a short tributary joining Chase Creek $1 \frac{1}{2}$ miles above Metcalf. A great number of prospects and small mines are located here; their description is best prefaced by a brief summary of the rather complicated geological features shown in a somewhat generalized way in PI. I.

The rocks are very similar to those of the districts already described. The basal granite shows on Chase Creek up to a point one-half mile above Garfield Gulch, and in the imposing cliffs leading up toward the summit of Coronado Mountain. It is also exposed in the lower parts of Garfield and Trinidad gulches, and in King Gulch up to a point due east of the mouth of Garfield Gulch. In appearance it is the same coarse, reddish orthoclase-quartz rock frequently described from other districts, comparatively hard in the bottom of the gulches, but soft and disintegrating on the upper slopes. The extensive brecciation and cementation by quartz so common near Metcalf is rarely observed.

The Coronado quartzite covers a small area on both sides of Chase Creek above Garfield Gulch; also the ridge between the latter and Trinidad Gulch, and the whole summit between Chase Creek and King Gulch from near Shannon mine to near the gap at the head of Garfield Gulch. It is a reddish, hard quartzitic sandstone, usually resting directly on granite; at only one place in Chase Creek, 2,500 feet above the mouth of Garfield Gulch, is quartzitic conglomerate exposed 20 feet thick. The rock is roughly bedded in heavy benches, the maximum thickness being about 200 feet. The quartzite is covered by the usual Ordovician limestones (Longfellow formation), which may be seen at several places, at the Mammoth mine, and on both sides of Chase Creek above Garfield Gulch. On the top of these limestones rest 100 feet of Morenci shales (Devonian), exposed on Stevens Hill west of Chase Creek and as a narrow faulted block on the ridge between Garfield and Trinidad gulches. About 100 feet of light-gray Mississippian limestone (Modoc formation) overlie the shales at the two places just mentioned, and it is also exposed from the Mammoth mine along the road up to the 
head of the main gulch; it usually contains fossils, crinoid stems being particularly abundant. The series is best exposed at Stevens Hill on the west side of Chase Creek, one-half mile above Garfield Gulch; the section obtained there is as follows:

Geological section at Sterens Hill.

\begin{tabular}{|c|c|c|}
\hline Member. & Formation. & $\begin{array}{l}\text { Thick- } \\
\text { ness. }\end{array}$ \\
\hline Gray limestone & Modoc... & $\begin{array}{l}\text { Feet. } \\
150\end{array}$ \\
\hline Dark-gray clay shale ... & Morenci... & .90 \\
\hline Porphyry sill ............ & ...... do ....... & 40 \\
\hline Dark-gray dense limestone. & .... do ...... & 60 \\
\hline Heavy brown limestone. & Longfellow . & \\
\hline Gray sandy limestone. & ..... do. & 140 \\
\hline Lime shale ........ & ..... do ... & \\
\hline Quartzite ............ & Coronado.... & 100 \\
\hline
\end{tabular}

While the thickness of the Modoc and Morenci formations corresponds closely with the sections from Morenci, there is a great difference in the case of the Longfellow formation, which is only 140 feet thick here, against nearly 400 feet at Morenci. This vicinity is very much disturbed, and the discrepancy might be attributed to imperfectly recognized faults, were it not for the fact that the same formation at Metcalf shows a similar deficiency.

The intrusive rocks are represented by several dikes, sills, and intruded masses of porphyry breaking through the granite, especially in the sedimentary series. The quartz porphyry of Metcalf extends one arm in this direction, forming an irregular mass with many apophyses on the west side of Chase Creek and crossing it as a more sharply defined dike in quartzite 2,000 feet above Garfield Gulch; but the numerous dikes and sills of Stevens Hill and the upper part of Garfield Gulch consist of diorite-porphyry. This is a normally light-gray rock with closely crowded phenocrysts of andesine and probably some orthoclase, but no quartz. Foils of biotite or prisms of dark-green hornblende are usually present. The groundmass is microcrystalline and consists of quartz and granular, not striated feldspar. It is very similar to some of the Morenci porphyries, but on the whole contains less quartz. Epidote, chlorite, and sericite are the secondary minerals. A dike of this rock cuts across the limestone at the Mammoth mine and other places. Horizontal sheets or sills, rarely over 50 feet thick, occur on Stevens Hill in the Morenci shales and near the head of Garfield Gulch in the Mississippian limestone. This porphyry has exerted only a slight contact metamorphism on the adjoining limestones; and the action does not compare at all in intensity 
with the results observed at Morenci and Metcalf. A little epidote and magnetite with copper stain occur frequently close to the contact, but this alteration rarely extends more than a couple of feet from the contact, and in places no metasomatic alteration is visible.

Narrow dikes of diabase occur in the granite at the Brunswick mine and at the Trinidad prospects. The rock is of a dull dark-green color and is usually so altered that the individual rock-forming minerals are no longer recognizable by the naked eye.

At 300 feet above Garfield Gulch heavy masses of Tertiary lavas begin, and form for a long distance the eastern wall of the canyon. These lavas extend due easterly from this point across the head of Garfield and King gulches, and in fact cover the whole country for many miles in a northeasterly direction. The lower part of the prominent bluffs consists of black or brown vesicular basalt from 200 to 400 feet thick; above this lies a light-gray or yellowish-gray rhyolite breccia up to 1,000 feet in thickness, forming very conspicuous and steep bluffs. The Tertiary lavas rest as thick sheets on an irregularly eroded surface. No ore deposits have been found in them.

\section{STRUCTURE.}

Great complication by normal faulting is characteristic of this vicinity. The faulting is chiefly confined to the pre-Tertiary rocks and has not appreciably affected the basalts and rhyolite tuffs. The main feature is the great fault on the east side of the Coronado massif, which has thrown the quartzite and the overlying fimestones down to the level of Chase Creek. In the description of the Coronado district it has been emphasized that the mountain of this name forms a central mass surrounded by peripheral faults. The steep, in places almost perpendicular, granite bluffs, which continue for a couple of miles above Garfield Gulch on the west side of Chase Creek, are the visible expression of this dislocation, which doubtless was still more prominent topographically before the Tertiary lavas flooded the country. The contact of the limestone of Stevens Hill with the granite is sharply defined, though rarely well exposed, and indicates beyond doubt a fault with a northerly trend, and an easterly dip of about $42^{\circ}$. Sheeting is very pronounced in the granite bluffs west of Chase Creek and north of Stevens Hill, the joints dipping east about $70^{\circ}$. The vertical distance, indicating the vertical displacement between the contact of quartzite and granite on Coronado Mountain and the same contact in Chase Creek, is 2,000 feet. It is possible, of course, that there may have been intermediate step faults, not clearly traceable now, in the intervening granite, but at any rate the contact 
of granite and limestone on the west side of Stevens Hill indicates a very important dislocation. On the south side of Stevens Hill two minor faults with the same direction compass a narrow block of quartzite between limestone and granite. The block of Stevens Hill dips $10^{\circ}$ to $16^{\circ} \mathrm{W}$. and continues unbroken, as indicated by the quartzite-granite contact, to the north fork of Garfield Gulch, but here the relations become very complex. One-half mile southeast, on the ridge between King Gulch and Chase Creek, lies another block of quartzite at an elevation of 5,700 feet, or 600 feet higher than the first; it also dips gently westward. Between the two blocks lies a triangular area dislocated by several northeast and east-northeast faults, as shown on PI. I.

\section{MINERAL DEPOSITS.}

\section{GENERAL STATEMENT.}

As stated above, a great number of prospects and a few producing mines are located in this vicinity. They are in part fissure veins and in part irregular bodies on or near the contacts of intrusive masses. Few, if any of them, appear to have any connection with the numerous fault planes, which here have dissected the crust into blocks. The ores consist chiefly of oxidized copper minerals, mostly chrysocolla, hut also malachite and more rarely chalcocite; few of the workings have penetrated to the primary constituents, which here, as elsewhere, probably consist of pyrite and chalcopyrite. A little galena containing much silver has been found on Stevens Hill.

One class consists of irregular deposits in limestone at or very near to porphyry contacts; most of these carry chrysocolla ore as irregular pockets surrounded by limonite. Such are many of the deposits on Stevens Hill, those along the porphyry sills at the head of Garfield Gulch, and those at the Iolanthe mine, $1 \frac{1}{2}$ miles east of the mouth of Garfield Gulch. Some of these, like the lastnamed deposit, are doubtless due to contact metamorphism, but, in view of the weakness of contact action of the Garfield porphyry, it is perhaps more plausible that in most cases the mineralization occurred somewhat later, after the consolidation of the intrusive rock. But in explaining the origin of these deposits their most evident direct connection with the porphyry must be kept in mind.

A second class, represented by the Mammoth, also contains chrysocolla ore and forms fissure veins between limestone and porphyry.

A third class forms fissures in granite, like the Antietam on King Gulch, or in granite and following a diabase dike, as in the case of the Brunswick vein. There is no evidence as to the age of this last class of veins compared to the others, porphyry and diabase not occurring in close juxtaposition. 
DETAILED DESCRIPTIONS.

Stevens group. - This group of 15 claims is situated a short distance west of Chase Creek, about one-quarter mile northwest of the mouth of Garfield Gulch. They are located in the small area of limestone with dikes and sheets of porphyry described above as projecting at the foot of the great granite slope which forms the eastern declivity of Coronado Mountain. The limestone is evidently separated from the granite by a fault of great magnitude, the fault plane being inclined about $45^{\circ}$ eastward. Oxidized ores have been found at a number of places within this limestone area, and a fair amount of development work has been done. In 1902 the claims were being more actively prospected by a new company. The geological structure, which is somewhat complicated, may be briefly described as follows:

Ascending the small gulch emptying into Chase Creek from the west, a few hundred feet above Garfield Gulch, granite continues up to a distance of 1,500 feet from the mouth. Here a dike of porphyry 200 feet thick crosses the gulch. Beyond that follows a granite area 200 feet wide, then a strip of quartzite, evidently separated by a fault from the granite. This quartzite is also 200 feet wide. Beyond the quartzite lies a narrow porphyry dike, and then the main mass of the limestone area begins. The prevailing dip of the limestone, which includes the middle part of the series from the Silurian up to the base of the Mississippian, is $16^{\circ} \mathrm{W}$. The first prospects are noted on the south side of the gulch, at an elevation of 5,000 feet, and occur in limestone containing a few dikes of diorite-porphyry. The croppings are extensive, are stained by copper, and consist of limonite and ferruginous silica. They form irregular masses in limestone, the ore containing much chrysocolla. Several tunnels have been driven, developing smaller masses of ore which seem to have a general tendency to follow the planes of stratification dipping westward. On the opposite northern side of the little gulch the narrow dike of porphyry widens, and there is here some direct evidence of contact-metamorphic action. Along its contacts much magnetite appears, frequently stained by copper. Going up the same gulch toward the big fault separating the limestone from the granite of Coronado Mountain, a sheet of porphyry 40 feet thick and several hundred feet long is first encountered. This, however, does not seem to be accompanied by ore. Near the western contact of the limestone, but some little distance from the granite, smaller chimneys of rich chrysocolla ore have been extracted. The ore occurred in limestone and was surrounded by soft limonite. Fragments of dioptase were found at this locality, the only place in the Clifton district where this mineral has been encountered. Another interesting feature of this prospect is that some galena occurred in it, with a considerable amount of silver. 
Prospects continue from this place, which is situated near the bottom of the gulch, up to the small gap about 300 feet higher, separating the limestone from the granite. At 100 feet below this gap on the north side a main tunnel has been driven in the upper part of the Devonian shale. This tunnel struck an ore body of chrysocolla averaging 20 per cent copper and containing about 800 tons. The ore shoot, which was 12 feet wide, occurred between limestone on the south side and soft limonite on the north. The horizon was evidently the lowest part of the Mississippian.

Going down from the gap to Chase Creek, a porphyry sill 40 feet thick was found again in the lower part of the Devonian series in limestone. A little epidote occurs all along on the contact, but the metamorphism is not intense.

A small mass of limestone of uncertain horizon is also found on the west side of Chase Creek, nearly opposite the large area described above. This mass, which is evidently faulted down to its present position, and which is covered by basalt at 100 feet above the creek, also contains irregular masses of chrysocolla associated with limonite. Two small tunnels have been driven, the upper one containing most of the ore. A little ore is said to have been shipped from this prospect.

Two tunnels have been driven by the Stevens company on the west side of Chase Creek in the quartzite and granite underlying the limestone. The upper one is 80 feet above the creek level, at a distance of 1,500 feet above the mouth of Garfield Gulch. It starts in sandy limestone immediately above the quartzite, dipping $10^{\circ} \mathrm{W}$. Stringers of partly oxidized pyrite follow the stratification. In places this pyrite is associated with a little copper glance. A still lower tunnel near the creek level crosscuts 200 feet of porphyry dike, and extends into the basal granite underlying the quartzite. The total length of the tunnel is 500 feet. The granite contains a little scattered pyrite. This tunnel has been driven with the expectation that it would eventually intersect larger ore bodies occurring in the western part of the limestone.

Garfield.-This property, belonging to the Shannon Copper Company, is located about 200 yards north-northwest of Mr. Stevens's house, at the mouth of Garfield Gulch. A considerable amount of ore has been extracted from this claim, but at the present time it is idle. The vein strikes east and west and occurs along the contact of a narrow diabase dike cutting the prevailing country rock of normal granite.

Alaska. - This is located on an irregular deposit in limestone on the ridge between the north fork of Garfield Gulch and Chase Creek, just above the quartzite and just below the basalt. The elevation is 5,300 feet. It contains oxidized copper ores associated with specularite and magnetite. Some rich ore is said to 
have been extracted, and it is reported that it contained much silver, a rather unusual feature.

Brunswick.-This claim, which is the property of the Arizona Copper Company, is situated in Garfield Gulch one-fourth mile above the mouth. The property has been worked for six or seven years in a small way, and a considerable amount of first-class ore, containing 30 per cent of copper, or more, has been shipped, the production amounting to about 30 tons per month. During the last three years concentrating ore has also been shipped. A wagon road connects the mine with Metcalf.

The mine is developed by two tunnels a few hundred feet long, the lower being located only a short distance above the bottom of the gulch. A winze 60 feet deep has been sunk in the lower tunnel down to the water level.

The deposit is a fissure vein occurring on the contact between the normal granite and a narrow dike of diabase. The vein strikes a few degrees east of north and stands nearly vertical. Its width varies from 1 to 12 feet, and it seems to consist largely of crushed and altered granite. The diabase dike rarely contains much ore. Near the end of the lower tunnel the vein appears to fork, some diabase occurring along each branch.

Ahove the lower tunnel level the ore consists, approximately, of 25 per cent chalcocite and 75 per cent oxidized material, largely malachite. In two places chalcocite and pyrite occurred intermixed. The winze is reported to have exposed some good chalcocite ore.

Trinidad.-This prospect, which is the property of the Arizona Copper Company, is located one-fourth mile southeast of the Brunswick mine in the smail gulch next south of Garfield Canyon, and at an elevation of about 5,200 feet. A trail connects it with the Brunswick mine. A long tunnel has here been - driven in a south-southeast direction along a vein which followed a narrow dike of diabase in the prevailing granitie country rock. A little malachite was noted, partly in granite, partly in diabase. No large ore bodies appear to have been found.

Virginia.-Several prospects are located on the quartzite ridge overlooking Placer Gulch, 3,000 feet south-southeast of the Mammoth mine. The developments are of slight extent and show a certain amount of mineralization, which appears to follow several dikes of dark-green diabase, probably identical with the Brunswick rock.

Mammoth.-The Mammoth deposit is located in Garfield Gulch, one-half mile east from the mouth of the canyon. It is owned by the Arizona Copper Company and has been worked at intervals during the last ten or fifteen years. The production is said to amount to approximately 30,000 tons of ore containing up to 16859-No. $43-05-23$ 
30 per cent copper. The amount shipped per month sometimes reaches 400 tons. The developments consist of a tunnel 800 feet long, together with extensive stopes above it. A winze 100 feet deep has been sunk from the lower tunnel level. The Mammoth appears to be a fissure vein, striking northeast and dipping $50^{\circ} \mathrm{NW}$; it follows in the main a contact between limestone and a porphyry dike 200 feet thick. The geologic structure in the vicinity is very much complicated by extensive faulting. The limestone apparently belongs to the Ordovician, and dips $10^{\circ} \mathrm{NNW}$. The porphyry dike continues in a northeast direction for one-fourth mile, after which it, as well as the inclosing limestone, is entirely covered by basalt and rhyolite.

The ores consist almost entirely of chrysocolla; other oxidized ores, as well as sulphide ores, appear to be lacking. The largest bodies occurred above the tunnel level, chiefly in the limestone and not in the porphyry. They are accompanied in places by large masses of nearly pure kaolin. At the northeast end of the tunnel the main fissure appears to break into the porphyry and is complicated by faulting.

Near the head of the gulch are at least two intrusive sheets of porphyry in limestone, and prospects with indications of ore may be seen at many places along the contacts of these. The deposits as far as developed are not extensive and consist of oxidized ores accompanied by much limonite.

\section{KING GULCH.}

A number of smaller deposits have been located in this vicinity and a few of them may be briefly described.

On the divide separating King Gulch from Placer Gulch, and about 1 mile east of Mammoth mine, the Arizona Copper Company owns a group of claims known as the Iolanthe, Dead Pine, and El Moro. The elevation is from 5,800 feet to 5,900 feet. The locality is connected by trail to Mammoth and by wagon road thence to Metcalf. It is stated that considerable first-class ore has been extracted from these prospects; in 1902, however, no work was being prosecuted. The deposits form irregular masses on the contact of Carboniferous limestone with a large area of normal porphyry. They are developed by two or three tunnels situated on three levels on the north side of the ridge. The surface is marked by heavy limonite croppings containing some epidote and serpentine. The ores consist chiefly of chrysocolla, azurite, and malachite. While the exposures are unsatisfactory, and the character of the deposit masked by extensive oxidation, it is probable that we have here a contact deposit originally characterized by the normal garnet and epidote gangue.

The Antietam claim is located in King Gulch at an elevation of 5,300 feet. 
The developments in 1902 consisted only of a smalı shaft near the bottom of the gulch and about 50 feet deep. The deposit, which is contained in granite, consists of a fissure vein striking north and south, nearly vertical, and said to be traceable for at least one-half mile north and south of the point of discovery. The width of the mineralized zone is up to 40 feet, and it is claimed that the pay streak, 10 feet wide, was found on the surface; the ore is reported to contain 4 per cent of copper as well as $\$ 8$ of gold and 5 ounces of silver per ton, and to consist chiefly of chalcopyrite and pyrite in an altered granite. The only oxidized ore noted consisted of small pockets of native copper and cuprite. This vein is said to continue northward into the Boulder claim, owned by the Arizona Copper Company, and southward into the Buckeye and the Jumbo, the latter the property of the Shannon Copper Company.

On the ridge between Placer Gulch and King Gulch a number of claims have been located. Near the Antietam are the Leo C. and Defiance, both on fissures parallel to the Antietam and 600 feet eastward of that vein. Leo C. occurs in granite; Defiance in a porphyry dike. On the same ridge a small area of quartzite rests on the granite, and on top of this quartzite a small area of limestone occurs. Near the contact of limestone and quartzite a number of small prospects occur in the limestone, and several chimneys of oxidized ore have evidently been extracted. The true character of the deposits is in doubt.

Near the head of Placer Gulch appears a large area of diorite-porphyry, similar to that occurring near the Mammoth mine. This porphyry is apparently separated from the granite of King Mountain by a dislocation; it contains a great number of included fragments of limestone shale and quartzite. The Last Chance claims are located around a body of quartzite inclosed in the porphyry near where the trail crosses the ridge to King Gulch. Still higher up, near the head and principally following the southeastern granite contact, are a number of prospects, some of which are clearly sunk on small bodies of contact-metamorphic origin and due to the mineralization of included masses of limestone. One of these, called the Prosperity, occurs between quartzite and porphyry; some copper carbonate, containing a notable amount of gold, has been extracted from it. The Raber claim lies a little farther northeast along the same contact. Many of these prospects contain magnetite, and all show stains of copper, but no important development work has been done. 


\section{CHAPTER XII. \\ COPPER KING, RIDGE. \\ TOPOGRAPHY.}

Unảer this heading it is proposed to describe the granitic "massif" rising on the west side of San Francisco River and comparable in structural position to the granitic block of the Coronado Mountain. The Copper King Ridge begins 4 miles north-northwest of Clifton, near Markeen Mountain, where, with an elevation of 6,300 feet, it overlooks Chase Creek and the sunken limestone blocks of Morenci, and continues for 4 miles northeast as a series of imposing buttresses towering high above San Francisco River.

The deep scar of Rocky Gulch separates Markeen from Copper King Mountain; exceedingly rough and precipitous amphitheaters lead down from the summits of the latter to the gentler slopes of Colorado and Dorsey gulches, which also empty into San Francisco River. The last buttress, limited by Sycamore Gulch on the south and Silver Creek on the north, has an elevation of 6,000 feet, and rises boldly with dark-red cliffs 2,000 feet above the basalts here filling the bottom of San Francisco Canyon. This point is $4 \frac{1}{2}$ miles northeast of Markeen Mountain.

Northwest of Copper King Ridge lies a slight depression indicated by the upper courses of Placer and Sycamore gulches, and occupied by sunken limestone blocks. Only a short distance northwest of this limestone rise the jagged volcanic ridges of Malapais Mountain, elevation 6,900 feet, forming the southern outlier of the enormous mass of lavas covering the northern part of Clifton quadrangle. A wagon road extends along San Francisco River, and a well-constructed grade leads up from this to Dunham Camp on Hickory Gulch. With these exceptions trails form the only lines of communication.

\section{ROCKS.}

Granite is the prevailing rock, and is of the same coarse granular type described elsewhere, consisting chiefly of quartz, orthoclase, and perthite, with a small amount of usually decomposed biotite. Its dark-red angular outcrops are cut by irregular joint planes, which aid erosion in producing the conspicuous cliffs so characteristic of the slopes toward San Francisco River. 
The Coronado quartzite is present only on the summit of the ridge at its northeasterly end, north of Sycamore Creek, where in several detached areas it covers the granite from 100 to 200 feet deep. Smaller areas also occur included in the porphyry 1 mile north of Copper King Mountain.

The Longfellow limestones are present with their usual characteristics in the narrow fringe of sediments between the granite and the lavas of Malapais Mountain. In places they are covered by small areas of the Morenci shales. The same series, covered by the Modoc limestone near Hackberry Spring, is also present along San Franciseo River from Evans Point to near Clifton.

The main body of the Metcalf stock of porphyry reaches up on the flanks of Markeen Mountain, and from this point, as well as from the vicinity of Shannon mine, a system of northeasterly trending porphyry dikes, rarely over 100 feet wide and usually much less, penetrates the granite up toward the end of the area here described. The porphyry is light-colored, with closely massed, small feldspar crystals and a few bipyramidal quartz phenocrysts, together with scant biotite foils embedded in a groundmass of quartz and feldspar. Sills, dikes, and other intrusive bodies of similar character are also contained in the limestones and shales which fringe the lava masses of Malapais Mountain eastward from Garfield Gulch. The largest body of this kind, which is a quartzmonzonite-porphyry, occupies a semicircular area north of Copper King Mountain, at the head of Placer Gulch, and contains as included masses fragments of quartzite, limestone, and shale. The contact-metamorphic action of this porphyry is, as a rule, slight. Only close by the contacts of the smaller masses included in the porphyry is a slight development of magnetite, epidote, and occasionally copper stains noted.

Northeast of Malapais Mountain a large stock of diorite-porphyry is intruded, partly in granite, partly in Silurian limestones. Diabase is noted as a dike along the so-called "black lode," crossing from east to west on the southern slopes of Copper King Mountain. Remarkably fresh diabase also occurs as a sill in granite near the mouth of Sycamore Gulch.

Tertiary lavas rest on the deeply eroded surface of the older rocks and cover most of the country east of San Francisco River and the high hills about Malapais. The lower part of this complex consists of dark-colored, fine-grained, and vesicular basalts, and augite andesites, which again are covered by light-colored rhyolites of a lithoidal or glassy type, generally tuffaceous or brecciated. A fringe of these rocks lies on top of the basalt on the west side of San Francisco River, on the gentler slopes near the bottom of the canyon, and again forms the summit and ridges projecting westward on Malapais Mountain. Dikes of lightcolored, white or pink lithoidal rhyolite cut the granite on Colorado and Dorsey 
gulches, generally with a northeasterly trend. Similar dikes occur in the porphyry and limestone north of Copper King Mountain and also penetrate the basalt of Malapais.

On the west side of San Francisco River, covering the lower slopes at the foot of the granite bluffs, lie masses of granitic and voleanic débris, in places 1,000 feet thick. These correspond to the conglomerates of the Gila formation and are consequently to be referred to the early Pleistocene, when the Gila Valley was filled by detritus to a general marginal level of 4,500 feet.

\section{STRUCTURE.}

The dominant structure lines of Copper King Ridge trend northeasterly. The oldest determining factors are the porphyry dikes, which with few exceptions take this course. Again, the earliest dislocations after the porphyry intrusions followed these lines, and very often coincide with the walls of the dikes. The principal period of faulting resulted in important northeasterly displacements, sinking blocks on both sides of Copper King Ridge and leaving the latter similar to Coronado Mountain as a central block or buttress. On the northwest side a practically continuous line of straight or curved faults determined a downthrow which, north of Copper King Mountain, probably amounted to 1,000 feet, but which at the northeasterly end of the granite ridge had diminished to a few hundred feet.

On the southeast side of this buttress, following the base of the granite bluff, occurs the most prominent fault of the Clifton quadrangle. Its actual plane, whether single or a series of closely massed step faults, is concealed at first by the Gila conglomerate, and farther north by the rhyolite flows near the bottom of the canyon. No quartzite remains on Copper King Mountain, but assuming that its now eroded beds had rested at an elevation of 7,000 feet, or at the same level as on Coronado Mountain, and recognizing that the Longfellow limestone is exposed in the bottom of the canyon, 3,300 feet lower, we must conclude that there is here a displacement of about 3,700 feet at least, and that the steep declivities of the granite ridge toward the river indicate the influence of a fault plane on the topographic features. Toward the northern end of the granite ridge the foot of the escarpment is deeply covered by rhyolite, but on the upper slopes we find, as recorded on the map, evidence of step faults with repeated downthrows on the side toward the river. The maximum amount of faulting probably took place southeast of Copper King Mountain. These structural relations will be more fully described in the text of the Clifton folio.

The Tertiary eruptions were ushered in by stresses, acting in different directions. None of the rhyolite dikes trend northeast, but all of them have a more or less pronounced northwesterly direction. 


\section{MINERAL DEPOSITS.}

GENERAL STATEMENT.

As in other parts of the district, the mineral deposits consist partly of contact-metamorphic masses, partly of fissure veins. The former are slightly developed along contacts in the porphyry stock lying at the head of Placer Gulch, and thus far of no great importance. In the limestones and granites on the east side of the river no indications of metalliferous deposits were observed.

The most important division here consists of nearly vertical fissure veins, which as a rule follow the trend of the porphyry dikes, extending into the granite with a northeasterly direction from the great porphyry stock in Chase Creek Canyon. None of the deposits has a great production to its credit, though some of them contain good ore bodies. This is largely due to the isolated position of the prospects, usually located high up in the rough country, where water is scarce and supplies must be packed to the mine. In these veins the well-defined fissures have caused a considerable amount of crushing, both of granite and porphyry. The ores near the surface consist of malachite and other oxidized minerals, which at a depth of from a few feet to 200 feet are replaced by secondary chalcocite, coating and replacing pyrite. In depth the primary ores will doubtless be found to consist of pyrite and chalcopyrite. The ores are accompanied by a scant quartz gangue and generally occur as replacements of granite or porphyry. The ore bodies occur in shoots of variable form and rarely attain 20 feet in thickness. A remarkable change occurs in the contents toward the northeasterly end of the district. About Markeen Mountain copper is almost the only valuable metal present, but on Copper King Mountain the ores contain some gold in addition, and in Dorsey and Colorado gulches gold values predominate, often with silver, and the copper ores are subordinate. At the surface the gold is to some extent free, but will doubtless be contained in the sulphides as depth is attained.

The so-called "Black lode" crosses from east to west north of Markeen Mountain and south of Copper King. It follows a diabase dike, though near the west end porphyries are also found along it, and the replacement ores consist of magnetite, pyrite, and chalcopyrite, a very unusual combination for a fissure vein. This deposit is probably later than the fissures following the porphyry dikes.

The gravel benches along San Francisco River below these deposits contain some placer gold. Some ten years ago attempts were made near Oroville to drift them or to work them by the hydraulic method. The results are said to have been unsatisfactory. 


\section{DETAILED DESCRIPTIONS.}

Markeen Copper Company.-The Markeen camp is situated in Rocky Gulch at an elevation of 5,350 feet. The trail from Morenci to Copper King Mountain passes by it. At this place on the west side of Rocky Gulch is a mass of porphyry 200 or 300 feet wide, which is continuous for a short distance westward. It also crosses the canyon and continues, narrowing, northeasterly, parallel to the Copper King vein. A shaft has been sunk in the porphyry mass, not far from the bottom of the gulch, to a depth of 200 feet, disclosing porphyry impregnated with pyrite and some chalcocite. Crosscuts 50 and 30 feet long are said to extend east and west from the bottom of this shaft. No ore is known to have been shipped.

Black lode.-A quarter of a mile above the Markeen camp two important veins cross the gulch. The first is the Copper King vein; the second the so-called Black lode, which is traceable in a straight line with an almost due east and west direction, and is opened by prospects right along. It seems to have a steep southerly. dip. A little porphyry accompanies this vein, but does not seem to follow it continuously. Three different kinds of this rock were noted at the gap north of Markeen Mountain, where this vein crosses-(a) a dark fine-grained porphyry with small feldspar crystals; (b) a normal diorite-porphyry similar to the rock from Morenci; and (c) typical Metcalf porphyry with large quartz crystals. At the little gap one-half mile south-southwest of Copper King mine the lode is accompanied by a dike of normal diabase, like that from the Coronado and Brunswick, up to 40 feet in width. Along the lode magnetite, pyrite, chalcopyrite, and epidote have been formed by replacement in porphyry and diabase as well as in granite. Although good prospects have been found at many places, no ore bodies have thus far been developed. A little native copper is occasionally found along this vein, evidently a product of secondary decomposition. A shaft sunk 1,500 feet above the Markeen camp, near the intersection of this vein with the Copper King vein, encountered the vein at a depth of 110 feet. The Clifton Consolidated Company owns the Eclipse claim on this vein.

Copper King vein.-This important vein crosses Rocky Gulch 1,500 feet above Markeen camp where it intersects the black lode, and continues for at least 2 miles in a northeasterly direction, possibly extending as far as Dorsey Gulch. It has not been traced far southwest of Rocky Gulch. The Clifton Consolidated Company owns the claims of Olivette, Missing Link, and Alice Winifred on this vein. Between these holdings, on the same rein, lie the two claims of the New England Copper Company. At intervals this prominent fissure is accompanied by a dike of granite-porphyry, but this rock is not continuous along the surface. On the Olivette claim in Rocky Gulch the vein is opened by a tunnel 700 feet long. 
The mouth of this tunnel is in porphyry, the remaining distance chiefly in granite containing small bunches of porphyry. It shows a distinct fissure, dipping $70^{\circ}$ NW., with slickensides, white sericitic material, and extensive impregnation with pyrite. Quartz, pyrite, and some chalcopyrite appear along the vein in some places; in the gouge accompanying the fissure some rich chalcocite occurs. Very little carbonate has been found and no ore bodies of great value have thus far been developed. A great amount of crushing and brecciating is very evident along the dike.

The New England Mining Company owns two claims on the Copper King rein - the Solid Copper and the Copper Bullion; this property is generally known as the Copper King mine. Besides, the company owns two claims on the black dike-the Monte Carlo and the Copper Verde. A great deal of work has been done on the first two claims and an extensive body of ore exposed, but owing to the isolated location of the mine comparatively little ore has thus far been extracted. A small smelting plant was erected some years ago on San Francisco River near Oroville, but owing to difficulties of ore transportation was only operated for a short time. The developments altogether amount to 3,500 feet, and consist of two shafts and a tunnel 300 feet below the collar of the west shaft. The latter is called the Solid shaft, and is 238 feet deep; sinking being now in progress. The North shaft is situated 150 feet above the Solid shaft and is 335 feet deep. Three levels with drifts and crosscuts have been turned; the vein strikes northeast and dips $76^{\circ} \mathrm{NW}$. The croppings are plainly indicated by heavy masses of stained and leached quartz.

The prevailing country rock is granite, but a dike of porphyry of the Morenci type is found in places along the vein, varying in width from a few inches to 20 feet, and chiefly following the foot wall, but not always regularly. Along the surface carbonate ores were found which descended 200 feet below the surface. The main ore bodies consist, however, of pyrite and chalcocite; sometimes also of pure chalcocite. In a few places the copper glance appeared at the surface, but only in places where the rock was exceptionally hard. There are two shoots developed corresponding to the two shafts. The Solid shoot pitches northeast and follows the hanging wall, the foot wall being more irregular. It shows a fine hody of ore from 6 to 8 feet wide and said to be 400 feet long on the third level. The North shaft contained an ore body of pyrite and glance in the upper levels. In depth this ore body was lost, and only mineralized granite accompanied the vein. Wherever much solid glance occurs in the ore, quartz usually accompanies it. ${ }^{a}$

a Since the above was written I am informed by the manager, Mr. A. P. Ayling, that the Solid shaft has been sunk to a total depth of 800 feet. Ore of decreasing but well-payable tenor is stated to be developed down to the lowest level. The oxides and the chalcocite are said to occur more rarely below the 30j-foot level. The New England and Clifton companies have consolidated to the New England and Cifton Copper Company. 
On the whole the deposit is a fissure vein with a small amount of quartz and a large amount of mineralization of adjoining rocks. The secondary depth of chalcocite appears to be attended with a likewise secondary deposit of quartz. Practically no other minerals occur in the vein. Together with the pyrite some chalcocite is oceasionally found. All of the ore contains some gold, varying from $\$ 1$ to $\$ 4$ per ton.

The Copper King vein, continuing its course from Copper King mine on the holdings of the New England Copper Company, crosses near the summit of Copper King Mountain, and descends northeastward over the steep bluffs which form the eastern slope of that mountain. Two claims on this vein are owned by the Clifton Consolidated Copper Mines. Near the summit of the mountain are several shorter tunnels developing the vein. Some chalcocite and malachite occur in these. There seems to be but little porphyry along the vein in this part of its course. Lower down it has been opened by two tunnels, the lowest at an elevation of about 5,500 feet, and the other 200 feet higher. The latter two tunnels are first crosscuts through granite. In striking the vein the latter appears somewhat irregular, and but little porphyry occurs along it. Bunches of malachite and even a little chalcopyrite have been found in the lower levels, but no large ore bodies have thus far been exposed.

It is claimed that the Copper King vein is traceable down to Colorado Gulch, and even across to Dorsey Gulch; the latter, however, seems somewhat uncertain.

Claims northwest of Copper King vein.--Above the point where the Copper King vein crosses Rocky Gulch several prospects have been opened, continuing up to the divide toward Placer Gulch. Most of these are located on porphyry dikes similar to that of the Copper King. A short distance above the Copper King vein the Virginia is met, a prospect owned by the Markeen Company, which is reported to have opened some good ore bodies of chalcocite ore. Above this follows the Raton, on which occurs a large body of porphyry, impregnated in several places with malachite. Next follows the Delaware claim, on which has been discovered a strong vein, which is reported to be traceable up to the Trilby claim near the top of Copper Mountain, with a general north-northeast direction.

A short distance across the divide and down on the trail toward Placer Gulch is the Veiled Prophet group, showing several prospects along narrow porphyry dikes in granite. Some of these dikes are an approximately northeasterly continuation of the King mine on the divide between King Gulch and Standard Gulch.

The Mansfield claim is located at an elevation of 6,350 feet, about one-half mile north-northwest of Copper King Mountain. It is the property of the Clifton Consolidated Company. On the surface a porphyry dike with the usual northeasterly direction cuts through the granite, and along it a pocket of high-grade malachite 
ore containing a little gold and silver was found. Nothing was developed below this, and a tunnel run 150 feet below, along the vein, exposed only small amounts of ore. The tunnel is 300 feet long and follows the porphyry dike, which is up to 50 feet wide. Near the breast a small amount of voleanic material was encountered, probably a dike of basalt or andesite. The main body of ore on this level was found at a cross fracture, and consisted mainly of oxidized ore, 6 feet in width, said to contain 6 per cent of copper.

Veins in granite northeast of Copper King Mountain.-The vein system connected with porphyry dikes, which has already been described in part, continues for some miles farther in a northwesterly direction, and these veins, on which but little development work has been done, contain a more considerable amount of gold and silver. A stamp mill was built some years ago at Evans Point, probably in the belief that the gold would continue free in depth. The ruins of this are still standing.

Several veins cross Colorado Gulch. The Colorado vein follows a decomposed dike of porphyry, and is said to contain a notable amount of gold. A dike of rhyolite follows this porphyry, but contains no ore. A number of veins cross above this point, but the developments amount to but little. On Dorsey Gulch some claims are actively worked at present. One of these is known as the Black Prince, and is said to be an extension of the Poland. The developments consist of a shaft and short tunnel. The Golden Eagle is located at an elevation of 4,400 feet, a quarter of a mile lower down on Dorsey Gulch, and the vein is claimed to be the same as the Copper King vein. It was developed in 1902 by the Polaris Company, the workings consisting of two tunnels. The vein follows a porphyry dike in granite, strikes north $50^{\circ}$ east, and dips $80^{\circ}$ north. The width is up to 6 feet. The ore contains copper, gold, and silver, and has a rusty and decomposed aspect, yielding some light gold in pan. Two or three feet of fine-grained siliceous ore exposed in the lower tunnel contain pyrite, chalcopyrite, and chalcocite. On the northeast side of the gulch it is stated that the same vein has been found, and that from one pocket a small amount of ore has been shipped containing $\$ 9$ of gold and 4 ounces of silver per ton. Lead is also said to oceur on it. The Poland claim, like the others but little developed, is located on the high ridge separating Dorsey Gulch from Sycamore Gulch, at an elevation of about 5,000 feet. The ore consists of rusty altered granite; some porphyry occurs close by. Many other fissures occur in the upper basins of Colorado and Dorsey creeks, but very little development work has been done on them.

The most northeasterly prospect in this part of the district is on Sycamore Gulch at an elevation of 4,500 feet, and is known as Fischer's mine. A small tunnel is here run on the vein, with a northerly direction, following a dike of 
normal diorite-porphyry dipping $45^{\circ}$ E. The ore contains calcite, pyrite, and zinc blende. A small 3-stamp mill has been erected to reduce the same, but has not been operated lately. No prospects are known to occur northeast of this point. A few miles farther on, beyond Silver Creek, the older formations are covered by.Tertiary lavas. At an elevation of 4,500 feet on Silver Creek, granite, porphyry, and lime are exposed, and old adobe buildings seem to indicate that prospecting has been carried on in this vicinity.

Weaver claims. -These prospects are located high up on the slope of Copper King Mountain, between the summit and San Francisco River, at an elevation of 5,200 feet. A trail extends up to it from Oroville, on the river, which is about 1 mile distant. The property consists of two claims, called the Good Luck and the Gray Cliff, and is developed by two tunnels. On the Gray Cliff the developments consist of a crosscut of 280 feet, together with 200 feet of drifts and a 90 -foot winze. The tunnel on the Good Luck is stated to be a crosscut 140 feet long. The vein, which strikes northeast, follows a porphyry dike 75 feet wide, the ore occurring as black sulphide and green stain in the mass of the porphyry. 


\section{IN D EX.}

A.

\begin{tabular}{|c|c|}
\hline 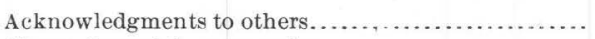 & 28 \\
\hline Ahern, Jeremiah, surveys by..................... & 27 \\
\hline laska mine, location and character of ... & -353 \\
\hline Alunite, occurrence and character of............. 11 & -120 \\
\hline Amphibole, formation of ................ 124-125, 16 & 176 \\
\hline occurrence and character of.............. & 109 \\
\hline oxidation of $\ldots \ldots \ldots \ldots \ldots \ldots \ldots \ldots \ldots \ldots$ & 178 \\
\hline 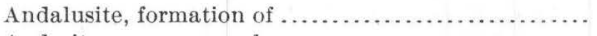 & 124 \\
\hline desite, occurrence of ............................ & 17 \\
\hline dradite, analysis of $\ldots \ldots \ldots \ldots \ldots \ldots \ldots \ldots \ldots \ldots \ldots \ldots \ldots$ & \\
\hline
\end{tabular}

Antietam mine, location and character of $350,354-355$ Antimony, occurrence of ....................... 108 Apache fault, location and character of. 227, 230, 283-284, 289 ore on. section of, figure showing....................... 284

A pache Gulch, location and character of .............. 225 rocks at..............................60,111,225

Apatite, oxidation of ......................... 179

Arizona, copper production of ....................... 48

Arizona Central dike, character and location of .... 165, 283

Arizona Central mine, character of.

depth of .

(n................................. 282

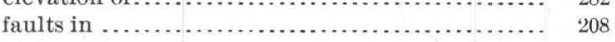

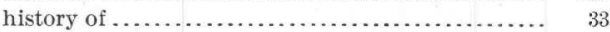

location of ........................... 35, 281-282

minerals in . . . . . .......... 102, 106, 109, 191, 283, 285-288 ores of, character of ............. 99, 187, 193, 203-205 production of .......................... 36, 282 rocks of...................... 83, 155, 157, 282-285 photomicrographs of ................... 136,142 section of, diagram showing ................. 284 veins of .............................. 285-290 Arizona Central vein, location and character of ...... 21, Arizona Copper Co., dividends of . 207, 285-286 history of ......................................... $40-41$ mines of, location of .... ................. 40-42, $233,269,272,278,319-320,344,354$

ores of, analysis of ....................... 44 character of ............................. 21

concentration of ....................... $42-43$

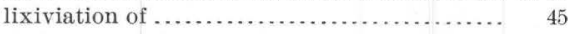

native copper in....................... 101

smelting of ............................. 44-45

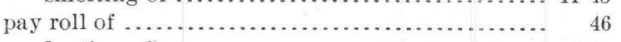

production of $\ldots \ldots \ldots \ldots \ldots \ldots \ldots \ldots \ldots \ldots \ldots \ldots \ldots \ldots \ldots \ldots \ldots \ldots, 46,48$

smelter of, products of, composition of .......... 45

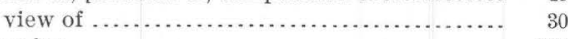

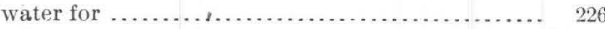

Arsenic, occurrence of ......................... 108

Asaphus sp., occurrence of .................... 65
Asbestos, occurrence and character of ............. 111

Assistance from others . . . . . . . . . . . . . . . . . . . . . . ${ }_{2} 28$

Astarte sp., occurrence cf....................... 74

Auriferous veins, occurrence and character of ....... 211

Azurite, character of ......................... 117-118

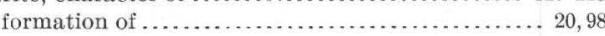
occurrence of............... 97,117-118, 192-193, 197 photomierograph of $\ldots \ldots \ldots \ldots \ldots \ldots \ldots \ldots \ldots, 152$

B.

Barrell, J., on metamorp.ism ..................... 161

Basalt, occurrence of .......................... 17

Benton formation, occurrence of ................. 17

Biotite, formation of ......................... 124

metamorphism of .......................... 125

occurrence and character of................... 110

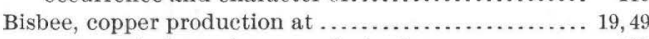
copper-pitch ore from, analysis of ............ 115 mines at .................................. ${ }_{27}$

Black lode, location and character of ............ 211, 360

Black Hawk dike, location and character of ....... 314, 336

Black Hawk tunnel, limestone from, analysis of ...... 65 See also Shannon mine.

Black Prince claim, location of .................. 363

Bolbocephalus sp., occurrence of ................... 65

Bornite, occurrence and character of............... 108

Boutwell, J. M., fossils found by ................. 61,6

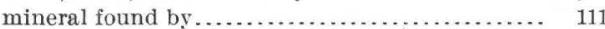

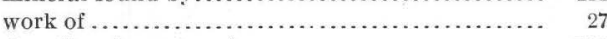

Brochantite, character of...................... 119

occurrence of ............................ 97,119

Brögger, W. C, on metamorphism................. 161

Brunswick mine, location and character of .......... 41, 353

Brunswick vein, eharacter of ...................... 209-210

Butler tunnel, location and elevation of ............ 280 rocks in ............................. 280-281 veins in .................................. 281

Butler vein, location and character of ............ 281 ore from, photomicrograph of .................. 150

Butte, mine waters of ......................... 181

Buzzard's Shadow claim, location and character of ... 297

C.

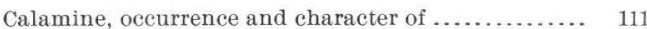

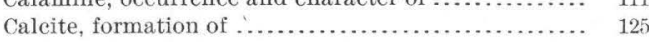
occurrence and character of .................. 116

Calumet and Arizona Co., production of ............ 49

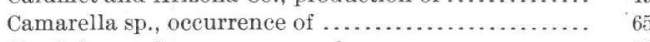

Cambrian rocks, occurrence of .................. 17

Carasco mine, ore of, character of ............... 276

Carbonate ores, exhaustion of..................... 20

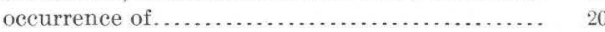

Cardium sp., occurrence of...................... 7

Cayuga claim, location and character of ............... 297 
Page.

Cayuga mine, water in ...................... 232

Cenozoic rocks, description of .................. $74-78$

occurrence of

Central dike, location and character of .......... 314,336

Cephalopoda, occurrence of ....................... 65

Chalcanthite, occurrence and character of.......... 121

Chalcedony, occurrence and character of........... 102

Chalcocite, character of ...................... 107-108 formation of .................... 25, 125, 182-186, 204 importance of ..................... 97 occurrence of.............. 20-21,32,99-100, 107-108, 223 photomicrograph of $\ldots \ldots \ldots \ldots \ldots \ldots \ldots \ldots \ldots \ldots . .150$

Chalcocite zone, character of .................. 203-204 depth of ........... 25, 182, 201, 204, 213, 222, 252, 269, 278 exploration in ........................... 223 ores of . oxidation in ................... 186-189, 201, 203-204, 222 surface and, relations of ..................... 206-207 values in.

water level and, relations of.................... 206

Chalcopyrite, character of ...................... 106-107 formation of . occurrence of................... 21, 106-107,157, 202 oxidation of value of.

Chase Creek, cany character of ................ 53-55, 225-226, 232, 305-306

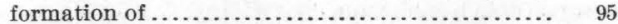

gold near ............................... 211-212

location of .................................. 52, 225 metamorphism on .......................... 307

ore deposits near ........................ 318-319 rocks on ................... 22, 57, 59, 70, 76, 78-79, 91, 170 sections on ................................. 62-63

valley of, faulting in ........................ 300 geology of .......................... 299-300 metamorphism in $\ldots \ldots \ldots \ldots \ldots \ldots \ldots \ldots \ldots \ldots . \quad 300$ mineral deposits of ................ 112,121,301-304 rocks of ................. 225, 227-229, 231, 299-300 structure of ............................. 300 veins on ..................................200, 204 views of and from ...................... 260,324

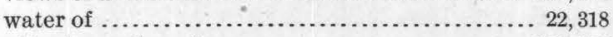

Chlorite, formation of ........................ 124, 178 occurrence and character of ................... 110

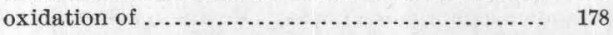

Chrysocolla, analysis of $\ldots \ldots \ldots \ldots \ldots \ldots \ldots \ldots \ldots \ldots . \quad 113$ character of ................................... 112-14

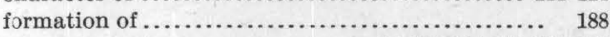
occurrence of................ 97, 112-114,179, 189, 198

Clay shale, analysis of .

Clifton, copper mines at, character of ............... 31 copper mines at, discovery of ................... 32 copper production at ...................... 18-19,49 furnaces at ................................. 33 location of . ................................ 29 mines at ..................................... 27

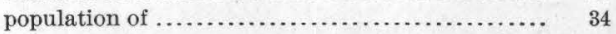

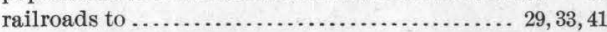
rocks near .......................... 67,87 view of water from

Clifton Consolidated Co, mines of

Clifton formation, character and oceurrence of ....... 133

Clifton quadrangle, index map showing position of... 28 rocks of

Climate, character of ........................ 29-30, 232

Colorado vein, location and character of............. 363
Page.

Concentration, processes of.............. 36-37,42-43,47

Concentrator Canyon, eharacter of .............. 224-225

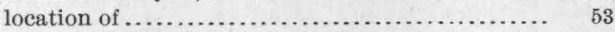

Concentrator fault, location and character of .... 91-92, 230

Contact deposits, paragenesis of ................... 194

See also Ores; Metamorphism by contact.

Contact metamorphism. See Metamorphism by contact.

Copper, development of ......................... 18

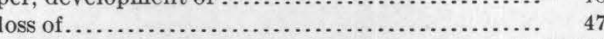
occurrence of ........................... 18,97, 163 production of $\ldots \ldots \ldots \ldots \ldots \ldots \ldots \ldots . .18,34,48-49,97$ future of ............................... 223

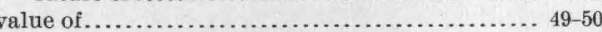

Copper, native, description of ..................... 101 occurrence of ............................ 97, 101 Copper Bullion mine. See Copper King mine.

Copper deposits. See Ores.

Copper King mine, character of................. 100 elevation of ...................................... 356

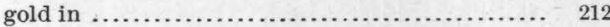
location of ............................... ores of, character of ................ 100, 203-204, 207

Copper King Mountain, location of ............... 55 rocks of ........................... 56-57,75 veins of, character of ................ 21-22, 100,199, 211

Copper King Ridge, faulting on................. $\quad 358$

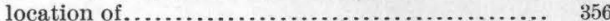
ores of, character of ....................... $359-364$

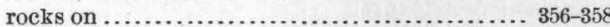

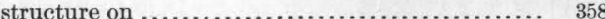
topography near.............................. 356 veins on ..................................... 359-368

Copper King vein, character of ..................... 204 course of............................... 200-201 Copper Mountain, character of.................... 224-226 copper mines at, character of ................ 19, 34

discovery of $\ldots \ldots \ldots \ldots \ldots \ldots \ldots \ldots \ldots \ldots \ldots \ldots \ldots \ldots \ldots \ldots \ldots \ldots \ldots \ldots, 35$ developments at........................... 34 metamorphism on ......................... 165 ores of, character of ...................... 110,203

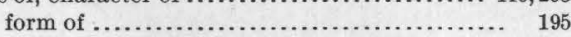
oxidation on, depth of ...................... 22-23 porphyry on, analyses of .................. 166-169 rocks of and near........................ 84,110 veins on ............................204, 208, 264

Copper Mountain faults, character of ............ 230, 275 location of... 199, 208-209, 227, 230, 240, 243, 247, 275, 285-286 Copper Mountain mine, character of ............. 19,276 development of ........................ 276-277 elevation of.................................. 276 fault in ............................... 208-209

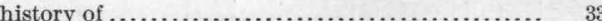

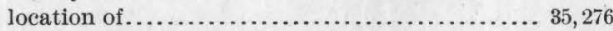
metamorphism in ........................ 156 minerals in ............................ 111, 119,277 ores of, character of .................. 99, 277-278 production of ................................ 36 rocks of .............................. 157, 277-278 section of, diagram showing.................. 246 Copper Mountain mining district, organization of.... 32 Copper ores. See Ores.

Copper pitch, analysis of $\ldots \ldots \ldots \ldots \ldots \ldots \ldots \ldots \ldots \ldots .114$ oceurrence and character of.............. 114-115, 192-193 Copper Plate claim, location and character of........ 345

Copper Queen mine, development of ............. 302

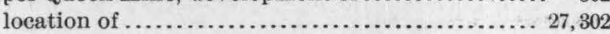


Page.

Copper Queen mine, minerals in .............. 119, 302 production of

Corbula sp., occurrence of ........................ 74

Coronadite, analysis of . ......................... 104 occurrence and description of ....... 100, 103-106 Coronado fault, location and character of..... 90-91, 230-231

Coronado Gulch, location and character of ... 53-54, 305, 315 ore deposits near . railroad to .................................. 42

Coronado mine, location of ....................... 42,100

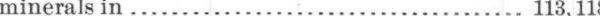
ore of, character of ..................21,31, 100,210 production of .............................. 340

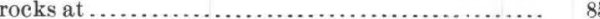

Coronado Mountain, character of ............... 53, 338

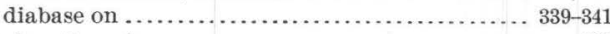
elevation of $\ldots \ldots \ldots \ldots \ldots \ldots \ldots \ldots \ldots \ldots \ldots \ldots \ldots \ldots \ldots \ldots, 338$

faults on ......... 338-339

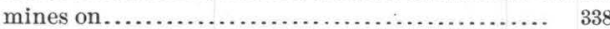
ores of, analysis of ....................... 343 character of . ...... 339-346 rocks of .................................. 59, 338 structure of ............................... $338-339$

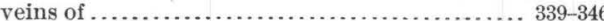

Coronado quartzite, age of.................... 61 character of $\ldots \ldots \ldots \ldots \ldots \ldots \ldots \ldots \ldots \ldots . \ldots \ldots 9-60,227,347$ correlation of ............................... 55,61-62 deposition of $\ldots \ldots \ldots \ldots \ldots \ldots \ldots \ldots \ldots \ldots \ldots, 60,93-94$

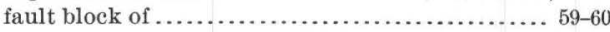
fluid inclusions in $\ldots \ldots \ldots \ldots \ldots \ldots \ldots \ldots \ldots \ldots .214$

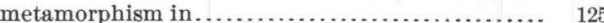
occurrence of .................. 59-60, 205-206, 228, 233-234, 251, 261, 283, 293, 299-300, 308-309, 347, 357

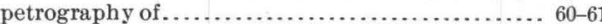
Coronado Railroad, location of .................. 227 Coronado vein, age of $\ldots \ldots \ldots \ldots \ldots \ldots \ldots \ldots \ldots \ldots \ldots \ldots \ldots \ldots \ldots . .34$ character of .................. 100, 103, 210, 339-344

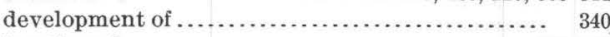
location of ......................... 199, 339 minerals in ........... 342-344 ores of, analysis of .......................... 343 character of ........................... 342-344 rocks along ...................... 86,339-341 section of, diagram showing .................. 341 Covellite, occurrence and character of ............ 108, 182

Cretaceous rocks, dislocation of .................. 88 metamorphism in....................... 126-127 occurrence of....................... 17,72,74,229

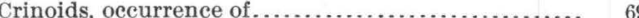
Cuprite, character of .......................... 106

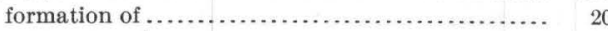
oceurrence of ......................... 97,106

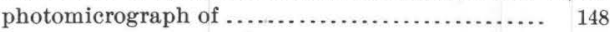

Cyrena? sp., occurrence of ...................... 74

D.

Dad Wright vein, location and character of......... 345 Dalmanella hamburgensis, occurrence of .

Dark Horse ore body, location and character of..... 330-331 Dead Pine mine, location and character of......... 41,354 Defiance claim, location and character of............ 355 Delaware claim, location and character of........... 362 Dentalium sp., occurrence of...................... 74

Detroit Copper Co., developments by .............. 33-34 furnace of................................... 40

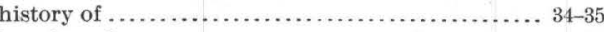

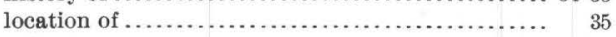

Detroit Copper Co., mines of ... 35-36, 233, 245, 253, 260, 282, 301 ores of, analyses of ....................... 38-39

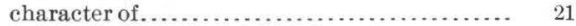
concentration of ....................... 36-37 smelting of . production of .............................. $18,36,48$ smelter of .................................. 38

limestone at, analyses of................ 64,68 products of, composition of ................ $\quad 39$

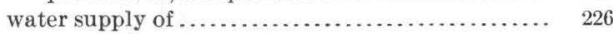

Detroit mine, eharacter of ....................... 19 copper pitch from, analysis of............... 114 development of ......................... 240-242 dikes in ................................... 243 elevation of............................ 242

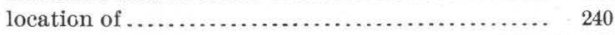
metamorphism in ..................... 153, 242,245 minerals in .......................... 106, 117, 118 ores of, eharacter of.................. 41, 99, 240, 242-245 form of.............. 196 photomicrographs of $\ldots \ldots \ldots \ldots \ldots \ldots \ldots \ldots, 152$ production of ........................... 240-242 rocks of...................... 155, 193, 197, 242-243 section of, diagram showing................. 241

Devonian rocks, metamorphism in ............... 129 occurrence of ............................ 17,255 See also Morenci shales.

Dewey claim, location and character of........... 345 Diabase, age of ........................... 86,92-93 character of ................................. 85 occurrence of ................. 85, 294,339-341,349, 357 petrography of ............................ 86 veins and, relations of ................... 209-210, 221 Dikellocephalus? sp., occurrence of ............... 65 Dikes, occurrence of............... 58, 78, 85, 128-133, 229 Diopside. See Pyroxene.

Dioptase, occurrence and character of ........ 111-112, 351 photomicrographs of $\ldots \ldots \ldots \ldots \ldots \ldots \ldots \ldots \ldots \ldots \ldots \ldots \ldots \ldots$ Diorite porphyry. See Porphyry.

Dodge, Phelps \& Co., copper mines bought by ........ $\quad 35$ Dolomite, occurrence and character of ............ 116-117 Dorsey Gulch, claims on ...................... 363 Douglas, E. M., work of ......................... 27 Drainage, data concerning ....................... 51-52 Dumble, E. F., on Dragoon quartzites............... 62 Dynamometamorphism. See Metamorphism by pressure.

$\mathrm{E}$.

Eagle Creek, character of .................... 52, 232

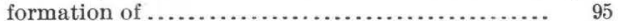
gravel on ............................... $77-78$ intrusion near ........................... 126

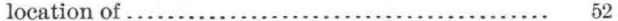
rhyolite on, view of ........................ 52 rocks on and near............... 73, 76, 79-79, 87, 294 veins near

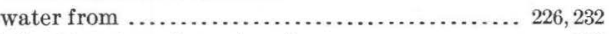

East Yankie mine, character of ................. 250 development ............................ 250-251

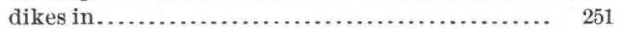
fault in ...................................... 251-252 location of .......... 35, 250 metamorphism at................... 156, 170,252 minerals in ............................ 103, 111 ores of, character of ........ 99, 205-206, 209, 233, 251-252 production of ........................ 36, 250-251 rocks of ................................. 214, 237,251 
East Yankie mine, section of, diagram showing El Moro mine, location and character of ...

Emerald claim, location and character of.

Emmons, S. F., work of .

Endoceras sp., occurrence of

Epidote, formation of ..... occurrence and character of.................. 109-110

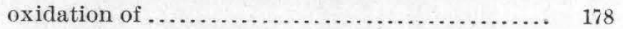
Epsomite, occurrence and character of............. 121 Erosion, effects of................. 17-18,24,51,60,77.95 Eruptive after-effects, eharacter of ............... 332-333 Evans Point, view at ..........................

$$
\text { F. }
$$

Fairbanks claim, description of Fairbanks vein, location of. $301-302$ ine, location, character, and development of. pres of charater......................... 278 section of, diagram showing .................. 246 Fairplay veins, location and eharacter of .............. 231 Fault blocks, formation of . .................. 89-93 occurrence of ................... 59,62, 227, 230-231

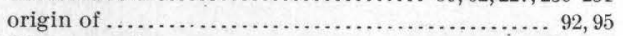

Faulting, age of ...................... 92-93, 208-209 eharacter of ................................ 89-90 occurrence of ............................ 17, 89-92, $95,227,230-231,236,283-285,289-290,300,316-317$ veins and, relations of ...................... 208-209

Favosites sp., occurrence of .................... 72

Feldspars, formation of ......................... 124 occurrence and character of .................... 108

Fenestella sp., occurrence of ...................... 72

Fischer's mine, location and character of ............ $363-364$ Fissure veins. See Veins, fissure.

Fissures, cementation of................... 23-24,95, 219 origin of . 95,219

Flor del Miza claim, location and character of....... 345

Fluid inclusions, occurrence of, in granite......... 214 occurrence of, in metamorphic limestone ......... 214

in porphyry .......................... 215-216

in quartz............................ 217-218

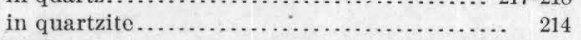

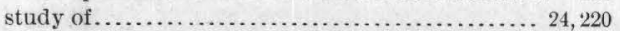

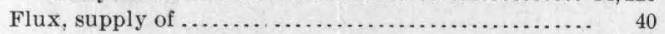

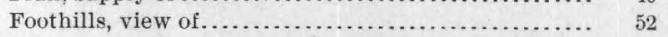

Formations. See Geological formations.

Fossils, occurrence of ............. 61, 65-66, 68-69, 71+72

Furnaces, construction of ...................... 33

Future of distriet............................. $\quad 223$

G.

Galena, occurrence and character of ............. 107 Gangue minerals, eharacter of .................... $\quad 98$ Garfield, rocks at and near .................... ; 85 Garfield Gulch, character of ...................... $\quad 347$ copper mines on $. \ldots \ldots \ldots \ldots \ldots \ldots \ldots \ldots \ldots \ldots \ldots . . \quad 41$ diabase at................................ 349 faulting at ................................ 349 intrusion at ................................ 126

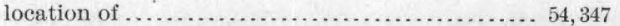
minerals at ............................. 111, 348 ore deposits at ......................... 198,350-354 rocks un and near ............. $63,67,79,84,87,347-349$ section at ................................ 848 structure at ................................. $349-350$ veins at, character of ............. 100, 199-200, 209-210
Page.

Garfield Gulch, water in ..................... 317

Garfield mine, location and character of............

Garnet, analysis of ........................... 134 decomposition of ........................ 20,177-178 development of, photomicrographs of. ........136, 138 formation of ................... 19, 23, 124, 127, 160 occurrence and character of .................. 108-109, $134,153-156,158-159,247$ oxidation of ............................ 177-178

Genesis of ores. See Ores, genesis of.

Geological formations, descriptions of............. 55-87

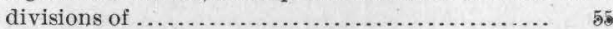
structure of. See Structure, geological.

See also individual formation names.

Geological history, details of ............... 93-96

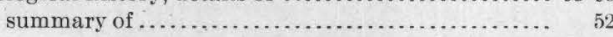

Geological structure. See Structure, geological.

Geology, description of . ............... 51-96, 227-231

Gerhardite, occurrence and character of ............ 121

Gila conglomerate, age of ..................... 77

character of .............................. $75-77$

deposition of . . . . . . . .

gold in ..................................... 212

occurrence of ........................ 17-18, 75-77

view of:...................................... 52

Gilbert, G. K., on Gila formation ................... 75

Girty, G. H., fossils determined by ................ 71

Glauconia coalvillensis, occurrence of ............. 74

Glauconite, occurrence and character of ............. $\quad 111$

Globe, faulting at, age of ........................ 93

Gold, oceurrence of .............................

$97,100-101,195,200,211-212,237,355,359,363$

search for........... 33

Gold-bearing veins, occurrence and character of..... 211

Gold Creek, basin of, faulting in ................ 295 basin of, geology of . ..................... 292-295

metamorphism in.

mineral deposits of ....................... 296-298 rocks of ................................... 292-295 structure of ............................ 295 topography of ........................ 292 character of ............................. 53,292 diabase on .............................. 85, 294 gold in ......................... 101, 211-212, 296

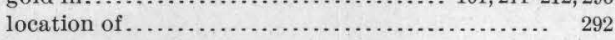
metamorphism on ......................... 126-127 ores on, eharacter of ................ 102, 109, 296-297 porphyry from, analysis of ................... 81 prospects on ............................. 296-298 rocks on and near ............... $73,80,85-86,292-294$ veins near .............................. 199 Golden, - , exploration by ...................... 32 Golden Eagle claim, location and character of....... 363 Good Luck claim, location and character of ........ 364 Goslarite, occurrence and character of............. 121 Granatocrinus sp., occurrence of ................ 72 Granite, character of . .............. 57, 307-308,314-316 dikes in ................................... 58 fluid inclusions in . . . . . . . . . . . 214 metamorphism in ................ 125, 170-171, 314-315 occurrence of . . . . . . . . . . . 292-293, 299-300, 306-308, 314-316, 347, 356-357 petrography of ....................... 57-58,315 veins in ............................. 200, 315-316 Granite-porphyry. See Porphyry.

Grant claim, location and character of............ 345

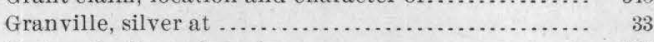

Graton, L. C., analyses by ....................... 168 
Page.

Gravels, age of

occurrence of .

(t) Gray Cliff claim, location a: d character of........... 364 Gray Cliff limestone, occurrence and character of. $70-71,153$ Gypsum, occurrence and character of .............. 120

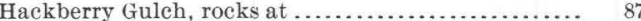
Heinrich, Carl, on Morenci copper deposits.......... 31-32 Hematite, formation of ........................ 177-178 occurrence and character of ........ 103

Hillebrand, W. F., analyses by ......... $67,81-82,84,114,116$ mineral identified by........................ 111 on coronadite........................... 103-105 on gerhardite............................. 121-122 on goslarite................................. 121 on morencite ............................ 115-116

on spangolite........................... 120-121

History, geological. See Geological history.

History of district ............................ 32-34

Home Copper Co., claim of ......................... 297

Hormeyer mine, gold in ...................... 101-212 ore of, character of ......................... 101-212

Horseshoe Canyon, location of ..................... 53

Hudson vein, character and location of ........... 231, 290 ores of, character of ..................... 106,290

Humboldt mine, character of ................ 19, 41, 279

development of......................... 272-273

elevations of............................... 273

faults in ................................ 275-276

location of ............................. 41,270

metamorphism in ......................... 273

minerals in ......................... 111,273-274

ores of, character of ................41,269,274-275

banding of............................ 42-43

production of $\ldots \ldots \ldots \ldots \ldots \ldots \ldots \ldots \ldots \ldots \ldots \ldots \ldots \ldots, 272$

rocks of ..................................

section of, figure showing ................... 272

veins in ............................... 274-275

Humboldt vein, character of.. 21, 204-205, 231, 264, 266, 274-275 foult in

$21,231,274$

location of

ore from, photomicrograph of

(1)

section of, diagram showing................... 267

Hummingbird dike, eharacter and location of.. 243, 248-250

Hummingbird mine, character and location of..... 242-244

Hydrometamorphism. See Metamorphism by water.

Hydrothermal metamorphism. See Metamorphism by hot water.

Igneous rocks, age of

description of

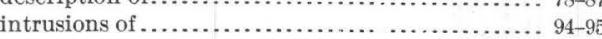

occurrence of ...................................... 17

Intrusions, dislocations due to .................. 88-89

Intrusive rocks. See Igneous rocks.

Iolanthe mine, location and character of ..........41,354

Iron, occurrence of ................... 97, 163

Iron cap, occurrence and analyses of............. 314

Isabella vein, location and character of............. 297

$$
\text { J. }
$$

Jameson mine, location and character of ...... 42,319-320 Jameson vein, location and character of .............. 204, $207,319-320,335-336$

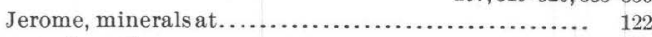
mines at.

$16859-\mathrm{Nc} .43-05-24$
Jerome. See also United Verde district.

Joy dike, character of ................... 165, 248-249,258 location of ................. 243, 258

Joy mine, character of ........................ 257

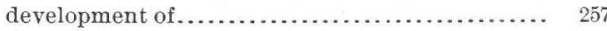

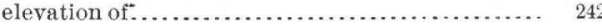

location of ............................. 242, 257

metamorphism in ..................... 172, 173, 259

minerals in ...................... 101, 106, 109, 258, 259

ores of, character of ................ 202-204, 258-259

outcroppings of ............................... 258

oxidation in, depth of ...................... 213,259

production of ............................. 257

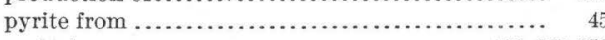

rocks in ............................. 171, 257-259

section of, diagram showing ................. 258

Joy vein, character of ...................... 207, 257,259 location of .............................. 253, 259

section of, diagram showing.................. 258

K.

Kaolin, occurrence and character of ....... 111, 192-193, 238

King Gulch, copper mines on ................. 41,354-355 location and character of .................... 305

metamorphism in ........................ 307-308

ore deposits near .......................... 319-320

porphyry from, analysis of ................... 80

view of

King mine, character of ....................... 100, 319 location of .............................. 42, 100,319 minerals in ...................................... 319

King Ridge, location of........................... 306 mines on .................................. $319-320$ rocks on .................................... 309

King vein, location and character of.... 207,319,335,360-362 Knight Creek, location of ........................ 53 Koenig, G. A., analysis by ....................... 115

\section{L.}

Labor, character and cost of ...................... 34-35

Lake Superior copper, value of .................. 49-50

Last Chance claims, location of ................... 355

Las Terrazas vein, character and location of......... 303, 318 minerals in......................... 112-113, 301, 303

Las Trajas elaim, loeation and character of .......... 345

Lava, analysis of ............................. 87 effusion of ................................. 86-87 metamorphism in .......................... 125 occurrence of ........................... 17, 86,349,357

Leaching process. See Lixiviation.

Leo C. claim, location and character of ............. 355

Lezinsky Brothers, work of..................... . 33, 40-41

Libethenite, occurrence and description of ..... 100,118-119 photomicrographs of......................... 136

Limestones, analyses of................... 64-65, 172 deposits in...... ........................ 336-337 oxidation of .......................... 20,189-191 metamorphism in ........................ 19, 160,176 minerals developing in, photomicrographs of. 136,

138,140 petrography of ............................... 173 veins in ................................ 200

Limestones, metamorphic, fluid inclusions in ....... 214 Limonite, formation of .................... 20, 177-180 occurrence and character of .................... 103,192

Lindgren, W., work of......................... 27 Lingulella sp., occurrence of ..................... 61 Literature .................................... $30-32$ 
Lithostrotion? sp., occurrence of

Liverpool mine, tunnel of, ore in.

Lixiviation, introduction of process of.

Lodes, occurrence of

London vein, location and character of..............

Lone Star tunnel, location and elevation of . . ores of character of ... $102,106-107,203,280$, 289 rocks in ................................. 279 veins in ................................. 280

Longfellow, town of. See Morenci.

Longfellow fault, location and character of.......... 230

Longfellow incline, elevation of .................. 227 location of .......................... 33,41 metamorphism at.......................... 170 rocks near ............................... 128-132

Longfellow limestones, age of .................... 65 analyses of ........................... 64-65, 313 character of ...............................62, 156 correlation of ........................... fossils in ................................... $65-66$ metamorphism of ............... $65,125,129,156-159$ minerals in ...................... 63-65, 109,116,117 photomicrographs of ..................... 136 occurrence of ...................... $62-63,156-158,228$, $234-235,247-248,258,261,283,293,309,311,347,357$ ores in ....... 197-198 rocks of, photomicrographs of ............... 136,144

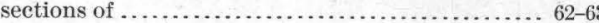

Longfellow mine, character of ............... 19, 31, 233 developments at........................... 233

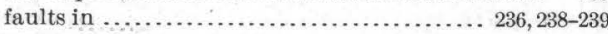

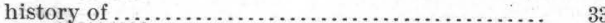

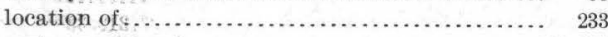
metamorphism in ........................ 236-237 minerals in .......... 111, 114, 236-239 ores of, analysis of ........................ 44, 239 character of ............. 20,41,99, 198, 209, 237-239 form of ............... 195 photomicrographs of $\ldots \ldots \ldots \ldots \ldots \ldots \ldots \ldots \ldots . .148$

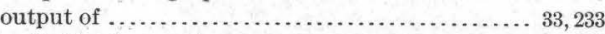
oxidation in ............................... 238 porphyry in, analysis of ................... 239 rocks of.................... 82, 193, 197, 233-237, 239 photomicrographs of sections of, diagrams showing................ 234,235

Loxonema sp., occurrence of ..................... 69 $\mathrm{M}$

MeLean, Gordon, information from.......... 242, 245, 247 Mactra warreniana, occurrence of

Magme, chargeter of ......... agnetite, character of ...................... 102 decomposition of ........................ 20 formation of . .................. 19,23, 124-125, 160,222 occurrence of ........................ $38,102,156-157$ oxidation of ............................ 178-179 photomicrograph of ...................... 144 production of .................................. 36

Malachite, character of ........................ 117 formation of ........................ occurrence of ........................... 97, 117 photomicrograph of ........................ 152

Malapais, Mount, elevation of ..................... 356 location of ............................... 55, 356 rocks of ................................. 87,357

Mammoth mine, location and occurrence of. . 41, 350, 353-354 mínerals in ............................... 111-112
Page.

Mammoth vein, character of ................... 20, 210-211
Manganese Blue mine, character of ............ 19,240

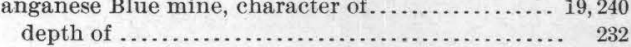

development of ............................. 245-247

dikes in ................................. 249-250

elevation of ........................... 246-247

faults in ........................... 247, 249-250

location of .......................... 35, 240,245

metamorphism in ...................... 156-247 minerals in ........... 102, 103, 106, 109, 117, 121, 247-250 ores of, analyses of ........................ 38 character of ............... 20,99, 198,240, 247-250 form of .............................. 196

oxidation in, depth of ....................... 213 production of ........................... 245-247 rocks in ..................... 155, 197, 240, 247-248 section of, diagrams showing ............. 241, 245 Mansfield claim, location and character of ......... 362-363 Map of Metcalf and vicinity .................... 306 of Morenei and vieinity ...................... 224

Map, geological, of Clifton-Morenci district......... Pocket of Metcalf and vicinity ...................... 306 Map, index, showing position of district............ 28 Maps, areas of .................................... 224, 305

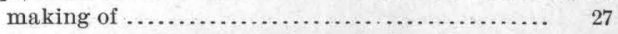
Markeen Copper Co., mines of, deseription of ........ 360 Markeen Mountain, elevation of .............. 356 location of ........................... 55,356 rocks of ............................... 299, 360 veins of, character of ................... 21-22,211 Menophyllum sp., occurrence of ............... $\quad 72$ Mesozoic rocks, description of ................... $72-74$ occurrence of Metamorphism, by ascending hot water, description of ................................ 124-125, 164-177 by ascending hot water, effects of ............. 125 , $159-160,170-177,315-316$ in granite..................... 170-171,315-316

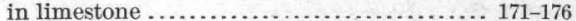
in quartzite ........................... 170-171 in shale .............................. 171-176 of porphyry .......................... 164-177

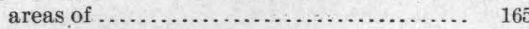
character of...................... 165-177 by ascending hot water and by contact, relations of ................................ 176-177 by contact, additions received during ......... 162-165 age of ............................... 198-199 agents of.......................... 124, 126, 194 description of........................ 126, 164 summary of ................... 124, 160-164, 194 effects of . occurrence of ....................... 19-20, $23,124,294-295,306,310-314,331-333$ paragenesis in . . principal areas of ................ 126-160, 294-295 products of .................. 19,23,124,194, 331 rock products of, photomicrographs of ..... 136-144 by descending oxidizing water, age of ........ 198-199 effects cf ......................... 125, 177, 194 in fissure veins. . . . . . . . . . . . . . . . . 182-189, 194 in limestone ............................. 182-191 in ore deposits ..................... 183-191, 194 in porphyry........................... 189-191 in shale. processes of .......................... 177-194 by descending sulphate waters, processes of .... 180-181 by descending waters, effects of .............. 124-126 
Metamorphism by pressure.

character of

classes of .

processes of ............................... 123-194

See also Oxidation.

Metasomatism, processes of. See Metamorphism.

Metcalf, copper at .............................. 18, 101 copper mines at, character of.............. 19,31,42

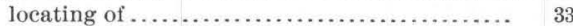

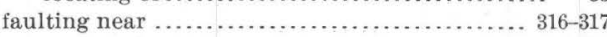

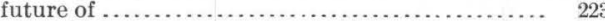
geology near............................ 306-317

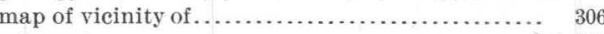
mines at ................................ 320-331 minerals at .......... 103, 109, 111, 117, 119, 121,312, 319-337 metamorphism at ....... 100, 306, 308, 310-316, 318, 331-334 ore deposits at, summary of ................ 334-337 ores at, character of ............. 207, 318-331,334-337

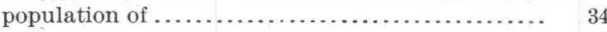
railroad to

rocks at and near . 78-79,110,202,214-218,307-310 topography near ......................... 305-306 underground water at .................... 317-318 veins at ............................ 16t,171,199-209

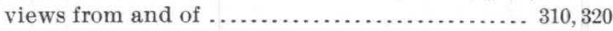
water supply of .......................... 305 Metcalf, Bob, exploration by .................... 32

Metcalf mines, description of ................... 320-323

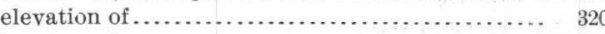
location of ............................ 305, 320 minerals in .................. 100, 106,113, 118, 119, 321 native copper in ......................... 101 open cut on, view of ....................... 316 ores of, eharacter of ............... 203-204,320-323 photomicrographs of $\ldots \ldots \ldots \ldots \ldots \ldots \ldots \ldots . \quad 148$ production of ......................... $4 t, 320$ rocks in ................................... 321-323

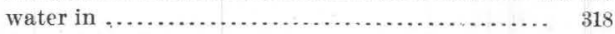

Mexican claim, description of ................... 302

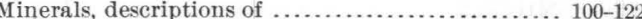
occurrence of $\ldots \ldots \ldots \ldots \ldots \ldots \ldots \ldots \ldots \ldots .57-58,101-122$ paragenesis of ............................. 194

Mines, character of ............................ 19

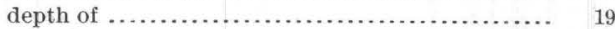

Mining, cost of

Mining companies, list of

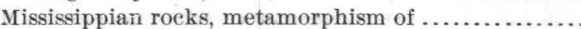
occurrence of ............................... 17,228 See also Modoc limestone.

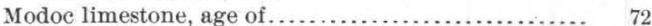
analyses of ................................ 71 character of ....................... 69-70, 158-159 correlation of................................ 72

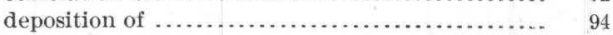
fossils of ................................ $71-72$ metamorphism in ....................... 127 $131,133-134,153-155,158,245,247,312-313,332$ minerals in ....................... $70-71,109,116$ occurrence of ...... $69-70,133,228,242,253,310,347-348,357$ ores in ............................... 197 sections of

specimen of, photomicrograph of .................

Modoc mine, minerals in............. 103,111, 113,114, 116

Modoc Mountain, elevation of .................... 225

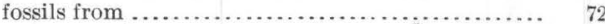
limestone from, analysis of................... 71 metamorphism on ........................ 127-133 minerals on $25,228-229,240,242$ sections at and near .................... $62,68,70$ west slope of, mines on..................... 240

Molybdenite, occurrence and character of .......... 107

Montezuma mine, character of ................... 253 development of .............................. 253 dikes in and near...................... 165, 254-255 elevation of.............................. 253

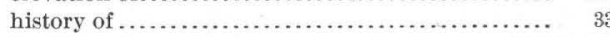
location of ........................... 35, 240,253 metamorphism in ...................... 156,175 minerals in ........................ 106, 119, 254-257 ores of, analyses of ....................... $\quad 38$ character of ........... 20, 198, 202-204, 240, 253-257

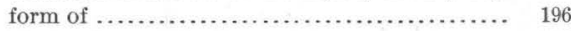
photomicrograph of .................... 146 production of ............................ 253 rocks of...................... 83, 155, 157, 253-257 photomicrographs of ..................... 146

veins in

Montezuma vein, character of ............. 207, 254, 257

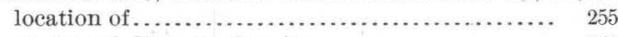
section of, diagram showing.................. 253

Morenci, character of ........................ 227 copper at ................................. 18,27 copper mines at, character of ............ 19,21,31-32 developments at............................ 33 dikes near ................................ 128-133 elevation of........................... 22,232 furnaces at................................ 33-35

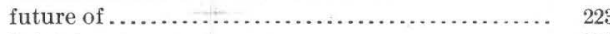
intrusion near .............................. 12

limestone from, analyses of .................. 71 location of.............................. 34,225 map of vicinity of ....................... 224 metamorphism at and near ........ 19, 100,126, 127-158 areas of ............................. 133-158 minerals at ................. 103,106-107, 109,111,119 mines of, descriptions of. .................. 233-291 native copper at.......................... 101 ores of, character of ....................... 195-199 Paleozoic column at....................... 59 population of ............................ 34,227 porphyry at, analysis of $\ldots \ldots \ldots \ldots \ldots \ldots \ldots \ldots . .64,168$ railroad to $\ldots \ldots \ldots \ldots \ldots \ldots \ldots \ldots \ldots \ldots \ldots \ldots \ldots, 34-35$ rocks at and near........................ 62 $67-68,78-79,84,110,202,214-218,227-231$ sections at and near ....................60,63,73, 15 diagram showing....................... 59,228 topography near........................ 224-227 underground water at................... 226, 232 vein system and underground workings at, dia-

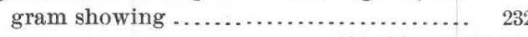
veins at...................... 164,171,199-209, 231

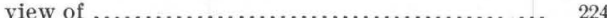
Morenci Canyon, eharacter of................... 53, 225

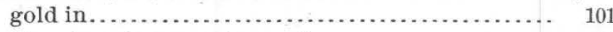
limestone from, analyses of .................. 64

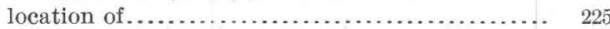

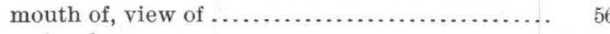
rocks of................................. 73,80

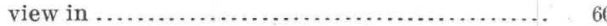

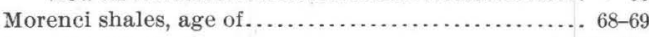
analyses of ............................... 67,130 character of ............................... 66

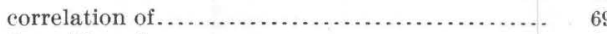
deposition of .............................. 94 
Morenci shales, fossils in . . ........ $68-69$ metamorphism in...... 127-128, 130-131, 155-156, 236-237 minerals in ......................... 67-68,111, 16 occurrence of ........................ 66-67,155-156, $228,235-236,242,253,258,283,293,309-310,312,347,357$ ores in ................................. 197-198 specimen of, photomicrograph of .............. 138

Morenci Southern Railroad, location of ........... 226-227

Morencite, analysis of ........................... 116 formation of occurrence and description of........... 100,115-116 Muscovite, formation of......................... 124 occurrence and character of.................. 110

$\mathrm{N}$.

New England Mining Company, mines of

Nicholas, Paul, acknowledgments to.

North Yankee dike, location of.

Olivette claim, location and character of........... 360-361 Ophileta sp., occurrence of...................... 65

Ordovician rocks, oceurrence of ................. 17,66 Ores, analyses of ................................. 239 character of .................... 18-20,97-99, 195-223

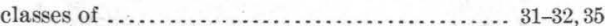
concentration of............................... 198-199 copper deposits of, age of.................... 198 character of ................ 18-20,97-99,237,318 classes of ........................... 31-32,98-99 formation of, order of . . . . . . . . . . . . . . . 222-223 forms of $\ldots \ldots \ldots .20,97,164,195-196$ occurrence of ............ 31, 99-100, 227, 306, 325-329 origin of ...

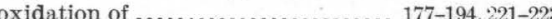
relations of porphyry and $\ldots \ldots \ldots \ldots \ldots \ldots \ldots \ldots .98$ copper in, per cent of ................... 35, 38, 42 genesis of ................. 19-20, 23-25,32, 96, 218-223 handling of, methods of ...................... 35 of chalcocite zone. See Chalcocite zone.

of pyritic zone. See Pyritic zone.

of surface zone. See Surface zone.

origin of ..

oxidation of .

paragenesis of .................... 194 photomicrographs of .......................... 138-152 production of

tenor of................. 47-48,223, 255, 263,318

Ores, carbonate, age of ........................ 198-199 character of ............................... 195-196 croppings of ........................ 197

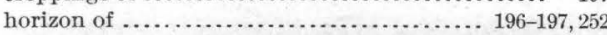

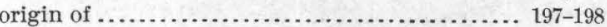

Ores, concentrating, character of .................. 35

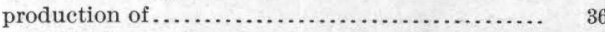

Ores, oxidized, age of ..................... 198-199, 221 eharacter of .............................. 35, 195 croppings of ................................ 197 exhaustion of ............................. 20

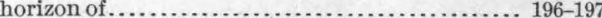
in limestone and shale ..................... 171-176 occurrence of ......................... 20,97, 99, 233 origin of ......................... 197-198, 221

Ores, pyritic, value of........................... 202

Ores, smelting, character of ......................... production of .

Ores, sulphide, character of $\ldots . . . . .35-36$.
Page.

occurrence of

Oroville, gold at ............................. 33, 101, 359

Orthis sp., occurrence of ........................ $\quad 72$

Orthothetes inæqualis, occurrence of ................

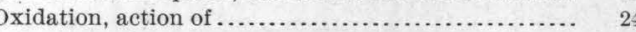

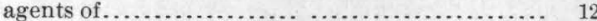

beginning of depth of $\ldots \ldots \ldots \ldots \ldots \ldots \ldots .22-23,197,199,213,252,268-269$ effeets of.... 20, 24-25, 125, 177, 201, 223, 238, 311-312, 333-334 enrichment from . $98,221-223,238,334$ of chalcocite zone ......................... 186-189

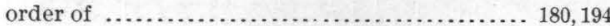
processes of ..................... 177-194, 201,333-334 rate of ..................................... 207

$\mathrm{P}$

Paleozoic rocks, character of .................... 308

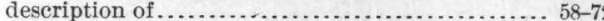

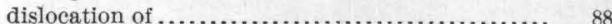

divisions of $\ldots \ldots \ldots \ldots \ldots \ldots \ldots \ldots \ldots \ldots \ldots \ldots \ldots \ldots \ldots \ldots \ldots \ldots \ldots+59$

metamorphism of ....................... 19

occurrence of ..................... 17, 227,306,308, 324

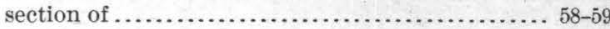
diagram showing

Paragenesis of minerals.......................... 194

Penfield, S. L., on dioptase ....................... 112

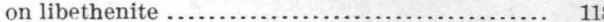

on spangolite

See also Pirsson and Penfield.

Pennsylvanian rocks, deposition of .................. 94

occurrence of .............................. 59

Petrography, character of …................ $57-58$, $60-61,63-65,67-68,70-71,79-80$

Photomicrographs of ores and rocks............. 136-159 Physiography, description of................... 88-89

Pinal schists, character of ..................... 56

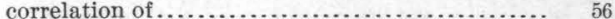
occurrence of .............................. 56

Pinkard formation, age and correlation of .......... $\quad 74$ character of ................................ $\quad 73$ fossils in ................................. 74

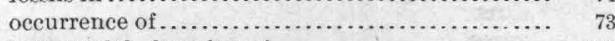

Pinkards Gulch, location of . . . . . . . . . . . . . . . . . . 292 metamorphism at............................ 127 ores of, character of .................... 109, 296-297 rocks on ................................. 292-295

Pirsson and Penfield, minerals identified by .......... 111

Placer Gulch, metamorphism at................. $\quad 128$ rocks in ............................... $79-80$

Platycrinus, occurrence of...................... $\quad 72$

Pleurotomaria sp., occurrence of ................. 69

Poland claim, location and character of............ 363

Porphyry, age of .............................. 85 analyses of .......................... 80-82, 166-169 character of .................. $78-79,314-316,335,348$ contact metamorphic rock near, photomicrographs

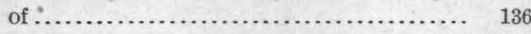
fluid inclusions in ......................... 215-216 intrusion of ............... 94-95, 229

dislocation due to .................. 88-89, 316-317 metamorphism by... 19, 23, 85, 95, 128-158, 160, 219-221, 227 metamorphism in ................ 125, 164-170, 202,315 occurrence of .............................. 17 , $229,236,293-294,299-300,306,310-311,315,348,357$ ore deposits in, eharacter of ................. 334-336 petrography of ....................... $79-84 ; 385$ 
Page.

Porphyry, photomicrographs of . . . veins in ................. 200,335-336 Pre-Cambrian rocks, character and occurrence of.... 17, $56-58,227-228$

Producer vein, location of ..................... 298 Prosperity claim, location and character of ......... 355 Pyramid claim, location and character of ........... 345 Pyrite, chalcotization of ........................ 183-189 character of ................................ 106 formation of .............. 19,23, 124-125, 160, 166, 222 occurrence of ......................... 21, 106, 157 oxidation of ......................... 179-180,204

Pyritic ores, formation of ...................... 222 photomicrographs of .................... 142,146

Pyritic zone, character of....................... 202-203

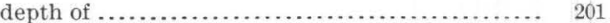

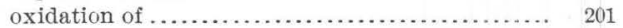

Pyrolusite, occurrence and eharacter of ............. 103

Pyroxene, development of, photomicrograph of ...... 186 formation of ................... 23, 124-125, 160, 176 occurrence and character of.................. 109 oxidation of

\section{Q.}

Quartz, fluid solutions in ................. 217-218,220 formation of ..................... 124-125, 177-178 occurrence and description of ............... 101-102 photomicrographs of ...................... 146 Quartz-monzonite-porphyry. See Porphyry.

Quartzite, metamorphism in.

$170-171$

\section{R.}

Raber claim, location and character of............. 355 Railroads, construction and location of .... 33-35, 41, 226-227 Rainfall, amount of .................... 29-30 Ransome, F. L., on Apache group.

on Bolsa quartzites.

on Devonian rocks ............................................... 69

Raphistomina sp., occurrence of ............... $65-66$

Rattlesnake claim, minerals from................ 114

Relief of district, description of .............. 52-55

Rhipidomella Michelini ?, occurrence of........... 72

Rhyolite, bluffs of, view of ...................... ${ }_{52}$ occurrence of ................................. 17

Roads, location of $\ldots \ldots \ldots \ldots \ldots \ldots \ldots \ldots \ldots \ldots \ldots \ldots . .226$

Rocks, photomicrographs of ................... 138-152 See also Geological formations.

Rosenbusch, H., on metamorphism.............. 161-162

Rutile, occurrence and character of............ 102

Ryerson mine, character of ....................... 19,260

development of ............................260-261

dikes in .................................. 261-262

elevation of............................. 260-261

faults in ............................... 267

location of ................................ 260-261

metamorphism in ....................... 156, 262

minerals in $\ldots 106,111,117,119,263-264,267-268$

ores of, analysis of ....................... $38,81-82$ character of ............ 99, 182, 202-203, 260, 267-269 photomicrograph of ..................... 150 plan of, diagram showing ................. 260 porphyry from, analyses of .................. 166-168 character of ........... 261-262 production of .............................. 36,260 rocks in............................. 157, 261-263 sections in, diagram showing ............ 263, 264,265 Ryerson vein, character of ........... 204-205, 231, 264-265 location of.

S.

San Francisco River, data concerning......... 51-52, 55, 95 gold on ................................ 101,212 gravel on .................................. $77-78$ rocks on .................. $59-60,62,67,75-76,87,91,358$ smelting on ................................ 361

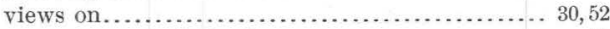

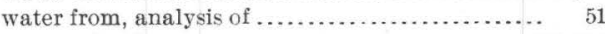
supply of............. 226, 232

Santa Rosa Canyon, claims in ................... 345-346 location of ..................................... $53-54$ Sardine Creek, rocks on .......................... 87 Schizophoria ivanofi, oceurrence of ............... $\quad 69$ McFarlani, occurrence of................... 69 Sea, intrusion of ............................. 93-94 Selenium, occurrence of..................... 40,108 Seminula humilis?, occurrence of ................. 72 Sericite, analysis of ........................... 170

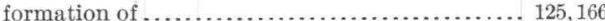
occurrence and character of ................. 110 oxidation of ............................. 178 Serpentine, formation of .................... 124, 178 occurrence and character of ................... 110 Shales, deposits in . . . . ...................... 336-337 metamorphism in ..................... 19, 160, 191-194

Shannon Copper Co., eapital of ................... 46

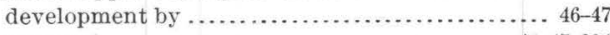
mines of ............................. 46-47,324 ore of, handling of.......................... 46-47

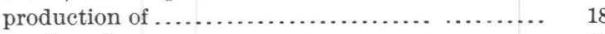

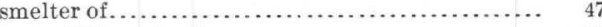

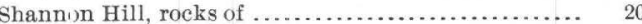

Shannon mine, description of .................... 323-331 geology of ............................ 324-325 map of workings of ........................ 324 metamorphic rock from, photomicrograph of .... 142 metamerphism in ......................... 171 minerals from ................. 106,111,117, 327-329

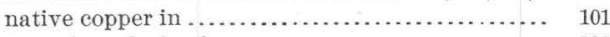
ores of, analysis of....................... 330 character of ................. 20,198, 207,325-329 form of............................... 196 rocks of .................................... 197 section of, diagram showing .................. 526 tunnels of ................................. 324

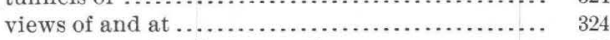

Shannon Mountain, character of .................. 54 copper in ................................ 19 dikes on ........................... 158-159, 165 geological features of...................... 324-325 iron cap on, analyses of .................... 313 character of . . . . . . . . . limestone of, analyses of .................. 71,313 metamorphism on ....................... 158-159 minerals in ............................ 109, 119 mines on, elevation of ..................... 22,41,46 ores in, character of ..................... 195-199 rocks of .................. 63, 79, 102, 306-316, 324-325 section on ............................. 70,326

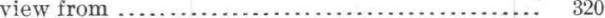

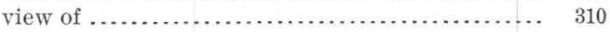
Shirley tunnel, water in ..................... 213, 318 Silica, formation of ............................ 20 

Silver, oceurrence or........................ Page.
$45,195,200,211,242,350-351,355,359,363$ Silver Basin Creek, faults in ...................... 296

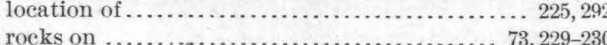
rocks on ............................... 73, 229-230 Smelting, processes of ............................... $38-40,44-45,47-48$ Solid Copper claim, location and character of....... 361 Soto claim, location and character of .............. 297 Soto fault, location and character of ............... 91, 230 Spangolite, occurrence and character of ............. 120-121 Specularite, formation of ........................ 160 Sphalerite. See Zine blende.

Spirifer centronatus, occurrence of.

Forbesi, occurrence of

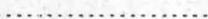

keokuk, occurrence of............................

Spiriferina, occurrence of .

Springs, oceurrence of ................

Square Butte, section at........................ ${ }_{63}$

Standard mine, description of ...................... 303

minerals in ............................ 117, 303

Stanton, T. W., fossils identified by ............... 74

Steiger, George, analysis by ...................... $\quad 87$

Stevens, I., exploration by ...................... 32

Stevens Hill, rocks on ....................... 348-350

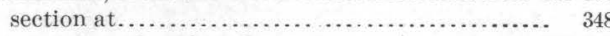

Stevens mines, location of...................... 198, 351

ore of, eharacter of ................ 195, 198, 351-352

Stockwerks, character and occurrence of ........... 99

formation of .............................. 223

Structure, geological, description of ........... 52, 88-93

dislocations in ............................ $88-89$

Sullivan, E. C., on Morenci shale.................... 192

Sulphate waters, metamorphism by ........ 180-181, 198, 223

Sulphides, oxidation of....................... 20,125

Sulphur, occurrence of ......................... 163

reactions of metals and...................... 182

Summary of paper.......................... 17-25

Sunset Peak, rocks on .......................... 87

Surface zone, depth of ......................... 201

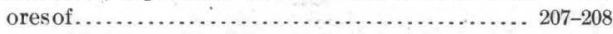

Sycamore Creek, rocks of ...................... 85-86

Sycamore Gulch, veins at................... 199, 863-364

Syntropia sp., occurrence of.

\section{T.}

Tellurium, oceurrence of .

................... 40,108

Tertiary lavas. See Lavas.

Thompson mine, ores of, character of ............. 111

Timbering, cost of............................ 35

Topography, character of ..... 29, 51-55, 224-231, 305-306, 356

Tremolite. See Amphibole.

Trinidad mine, location and character of............ 353

Tugnellus fusiformis, oceurrence of............... 74

Tule Spring limestone, occurrence and character of .. $\quad 72$

Turitella sp., occurrence of ..................... $\quad 74$

\section{U.}

Ulrich, E. O., on Longfellow limestone fossils........ 65

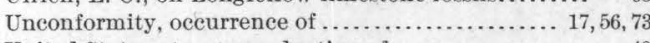
United States, copper production of ............... 48 United Verde district, copper production of ......... 19,49

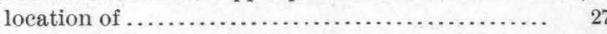
See also Jerome.

Uplift, occurrence of ........................ 17
$\mathrm{V}$.

Page.

Vegetation, character of .......................... 30

Veiled Prophet group, location and eharacter of ...... 362

Veins, fissure, character of ........... 21-22, 99, 170, 199, 231 classes of ........................ 24, 99, 219-220 diabase and, relations of................ 209-210,221 formation of ................... 23-24, 95, 219-221, 223 leaching of ............................... 21 location of ................................ 199 metamorphism near............... 176-177, 203,231 Morenci and Metcalf type of ................ 200-209, 231 occurrence of .............. 20-22, 97, 99, 164-165, 199-200 ores of .............................. 201, 204-206 oxidation of ............................ 177-189, 201 paragenesis in .................... 194 related deposits and ...................... 199-200 structure of .............................. 200-201 zones in ................................ 201-208 Veins, auriferous, occurrence and character of ...... 211 Vesuvianite, occurrence of ................... 161 Virginia mine, location and character of.......... 353, 362 Vitriol, blue, occurrence and character of........... 121 Volcanic eruptions, oceurrence of ....................

\section{W.}

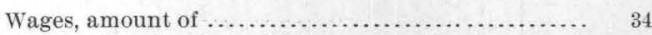

Walcott, Charles D., fossils determined by ........... 61,65 on Devonian rocks ....................... 69 Wallace, L. R., analyses by ............................... $64-65,67-68,71$

Ward, Captain, organization by .................. 34 Ward Canyon, rocks of ........................ 76 Water, effect of ........................ 23-24, 98, 219-223 oxidation by .......................... 20,23-24,98 use of, in concentration ............... $36-37,42-43,51$ Water, ground, conditions of........ 22, 212-213, 232, 317-318 Water, sulphate, metamorphism by ........... 180-181, 198 Water gas, effeets of ........................ 163, 222 Waters, ascending, effect of .................. 223 metamorphism by. See Metamorphism.

Waters, descending, enrichment by ........... 221-222, 223 metamorphism by. See Metamorphism.

Weaver claims, location and character of........... 364

Weed, W. H., ore classification by .................. 164

Wellington vein, character of... 205-206, 231, 264-265, 274-275

Wendt, A. F., on Clifton copper deposits........... 31,33

West Yankie dike, character and location of.... 165, 270-271

West Yankie mine, ores of, eharacter of............. 269 porphyry from, analysis of ................. 167-168

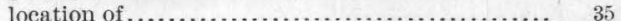

West Yankie vein, character of........ 204-205, 264, 266-267 Whitewater Creek, roeks on .................... 87 Willemite, occurrence and character of............ 111 Williams, H. S., on Morenci fossils ............... $68-69$ Williams vein, character and location of........... 205, $207,231,285-288,291$

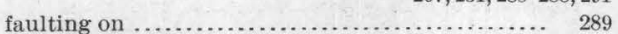

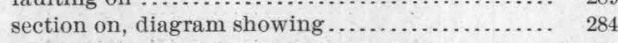
Winchell, H. V., experiment by ................. 18 Wiseman dike, location and character of ...... 311, 314, 336 Wollastonite, formation of .................... 124 oceurrence of ............................ 161

Y.

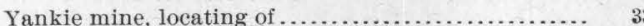

Yavapai mine, character of . . . . . . . . . . . . . . . . . development of .............................. 270 dikes in .................................. 270 
INDEX.

Page.

Yavapai mine, elevation of.

location of....

metamorphism in

minerals in

ores of, character of

production of .

rocks in.

section of, diagram showing

$Z$.

Zaphrentis sp., occurrence of.

Zeolite, formation of .

Zine, occurrence of .
270

, 269-270

156,270

$254,270-271$

109,271

46,270

$-271$

265

69,72

124

124
38

Zinc blende, chalcocitization of

Page. character of

2-183

beter of

formation of ....................... 19,23, 160,222

occurrence of . . ........................ 21, 107,157

oxidation of $\ldots \ldots \ldots \ldots \ldots \ldots \ldots \ldots \ldots \ldots \ldots \ldots \ldots, 180$

solution of ............................... 20

Zine ore, occurrence and character of............. 117

Zircon, occurrence and description of............ 102, 163

Zirkel, F., on metamorphism................... 161

Zone, chalcocite. See Chalcocite zone,

Zone, prritic. See Pyritic zone.

Zone, surface. See Surface zone.

O 
. 


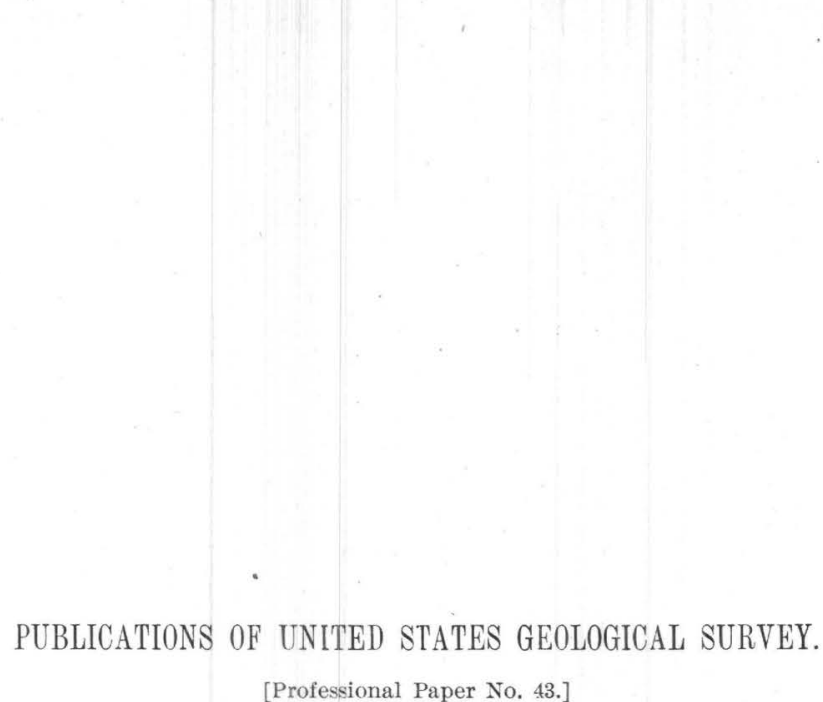

The serial publications of the United States Geological Survey consist of (1) Annual Reports, (2) Monographs, (3) Professional Papers, (4) Bulletins, (5) Mineral Resources, (6) Water-Supply and Irrigation Papers, (7) Topographic Atlas of the United States-folios and separate sheets thereof, (8) Geologic Atlas of the United States-folios thereof. The classes numbered 2, 7, and 8 are sold at cost of publication; the others are distributed free. A circular giving complete lists may be had on application.

Most of the above publications may be obtained or consulted in the following ways:

1. A limited number are delivered to the Director of the Survey, from whom they may be obtained, free of charge (except classes 2, 7, and 8), on application.

2. A certain number are allotted to every member of Congress, from whom they may be obtained, free of charge, on application.

3. Other copies are deposited with the Superintendent of Documents, Washington, D. C., from whom they may be had at practically cost.

4. Copies of all Government publications are furnished to the principal public libraries in the large cities throughout the United States, where they may be consulted by those interested.

The Professional Papers, Bulletins, and Water-Supply Papers treat of a variety of subjects, and the total number issued is large. They have therefore been classified into the following series: A, Economic geology; B, Descriptive geology; C, Systematic geology and paleontology; D, Petrography and mineralogy; E, Chemistry and physies; F, Geography; G, Miscellaneous; H, Forestry; I, Irrigation; J, Water storage; K, Pumping water; L, Quality of water; M, General hydrographic investigations; N, Water power; O, Underground waters; P, Hydrographic progress reports. This paper is the fifty-seventh in Series A, and the sixty-eighth in Series B, the complete lists of which follow. $(\mathrm{PP}=$ Professional Paper; $\mathrm{B}=$ Bulletin; $\mathrm{WS}=$ Water-Supply Paper. $)$

$$
\text { SERIES A, ECONOMIC GEOLOGY. }
$$

B 21. Lignites (f Great Sioux Reservation: Report on region between Grand and Moreau rivers, Dakota, by Bailey Willis. 1885. 16 pp., 5 pls. (Out of stock.)

B 46. Nature and origin of deposits of phosphate of lime, by R. A. F. Penrose, jr., with introduction by N. S. Shaler. 1888. $143 \mathrm{pp}$. (Out of stock.)

B 65. Stratigraphy of the bituminous coal field of Pennsylvania, Ohio, and West Virginia, by I. C. White. 1891. 212 pp., $11 \mathrm{pls}$. (Out of stock.)

B 111. Geology of Big Stone Gap coal field of Virginia and Kentucky, by M. R. Campbell. 1893. 106 pp., 6 pls.

B 132. The disseminated lead ores of southeastern Missouri, by Arthur Winslow. 1896 . $31 \mathrm{pp}$.

B 138. Artesian-well prospects in Atlantic Coastal Plain region, by N. H. Darton. 1896. 228 pp., 19 pls. (Out of stock.)

B 139. Geology of Castle Mountain mining district, Montana, by W. H. Weed and L. V. Pirsson. 1896.164 pp., 17 pls.

B 143. Bibliography of clays and the ceramic arts, by J. C. Branner. $1896.114 \mathrm{pp}$.

B 164. Reconnaissance on the Rio Grande coal fields of Texas, by T. W. Vaughan, including a report on igneous rocks from the San Carlos coal field, by E. C. E. Lord. $1900.100 \mathrm{pp} ., 11 \mathrm{pls}$

B 178. El Paso tin deposits, by W. H. Weed. 1901. 15 pp., 1 pl.

B 180. Occurrence and distribution of corundum in United States, by J. H. Pratt. 1901.98 pp., 14 pls. (Out of stock.)

B 182. A report on the economic geology of the Silverton quadrangle, Colorado, by F. L. Ransome. 1901 . . $266 \mathrm{pp}$., $16 \mathrm{pls}$. (Out of stock.)

B 184. Oil and gas fields of the western interior and northern Texas Coal Measures and of the Upper Cretaceous and Tertiary of the western Gulf coast, by G. I. Adams. 1901.64 pp., 10 pls. (Out of stock.)

B 193. The geological relations and distribution of platinum and associated metals, by J. F. Kemp. 1902. 95 pp., 6 pls. (Out of stock.)

B 198. The Berea grit oil sand in the Cadiz quadrangle, Ohio, by W. T. Griswold. $1902.43 \mathrm{pp} ., 1 \mathrm{pl}$. 
PP 1. Preliminary report on the Ketchikan mining district, Alaska, with an introductory sketch of the geology of southeastern Alaska, by Alfred Hulse Brooks. 1902.120 pp., 2 pls.

B 200. Reconnaissance of the borax deposits of Death Valley and Mohave Desert, by M. R. Campbell. 1902.23 pp., 1 pl. (Out of stock.)

B 202. Tests for gold and silver in shales from western Kansas, by Waldemar Lindgren. $1902.21 \mathrm{pp.}$

PP 2. Reconnaissance of the northwestern portion of Seward Peninsula, Alaska, by A. J. Collier. 1902.70 pp., 11 pls.

PP 10. Reconnaissance from Fort Hamlin to Kotzebue Sound, Alaska, by way of Dall, Kanuti, Allen, and Kowak rivers by W. C. Mendenhall. 1902. 68 pp., 10 pls.

PP 11. Clays of the Unitcd States east of the Mississippi River, by Heinrich Ries. 1903.298 pp., 9 pls.

PP 12. Geology of the Globe copper district, A rizona, by F. L. Ransome. 1903. 168 pp., 27 pls.

B 212. Oil fields of the Texas-Louisiana Gulf Coastal Plain, by C. W. Hayes and William Kennedy. 1903.174 pp., 11 pls.

B 213. Contributions to economic geology, 1902. S. F. Emmons, C. W. Hayes, geologists in charge. 1903.449 pp.

PP 15. The mineral resources of the Mount Wrangell district, Alaska, by W. C. Mendenhall and F. C. Schrader. 1903. 71 pp., 10 pls.

B 218. Coal resources of the Yukon, Alaska, by Arthur J. Collier. 1903. 71 pp., 6 pls.

B 219. The ore deposits of Tonopah, Nevada (preliminary report), by J. E. Spurr. 1903.31 pp., 1 pl.

PP 20. A reconnaissance in northern Alaska in 1901, by F. C. Schrader. 1904.139 pp., 16 pls.

PP 21. Geology and ore deposits of the Bisbee quadrangle, Arizona, by F. L. Ransome. 1904.168 pp., 29 pls.

B 223. Gypsum deposits in the United States, by G. I. Adams and others. 1904. 129 pp., 21 pls.

PP 24. Zine and lead deposits of northern Arkansas, by G. I. Adams, assisted by A. H. Purdue and E. F. Burchard, with a section on the determination and correlation of formations, by E. O. Ulrich. $1904.118 \mathrm{pp} ., 27 \mathrm{pls.}$

PP 25. The copper deposits of the Encampment district, Wyoming, by A. C. Spencer. 1904.107 pp., 2 pls.

B 225. Contributions to economic geology, 1903, by S. F. Emmons and C. W. Hayes, geologists in eharge. $1904.527 \mathrm{pp} ., 1 \mathrm{pl}$.

PP 26. Economic resources of the northern Black Hills, by J. D. Irving, with contributions by S. F. Emmons and T. A. Jaggar, jr. 1904. 222 pp., 20 pls.

PP 27. A geological reconnaissance across the Bitterroot Range and Clearwater Mountains in Montana and Idaho, by Waldemar Lindgren. $1904,122 \mathrm{pp}, 15 \mathrm{pls}$.

B 229. Tin deposits of the York region, Alaska, by A. J. Collier. $1904.61 \mathrm{pp}, 7 \mathrm{pls}$.

B 236. The Porcupine placer district, Alaska, by C. W. Wright. $1904.35 \mathrm{pp} ., 10 \mathrm{pls}$.

B 238. Economic geology of the Iola quadrangle, Kansas, by G. I. Adams, Erasmus Haworth, and W. R. Crane. 1904 . 83 pp., 11 pls.

B 243. Cement materials and industry of the United States, by E. C. Eekel. 1905. 395 pp., 15 pls.

B 246. Zinc and lead deposits of northwestern Illinois, by H. Foster Bain. 1904. 56 pp., 5 pls.

B 247. The Fairhaven gold placers, Seward Peninsula, Alaska, by F. H. Moffit. 1905.85 pp., 14 pls.

B 249. Limestones of southeastern Pennsylvania, by F. G. Clapp. 1905.52 pp., 7 pls.

B 250. The petroleum fields of the Pacific coast of Alaska, with an account of the Bering River ceal deposits, by G. C. Martin. 1905. 64 pp., 7 pls.

B 251. The gold placers of the Fortymile, Birch Creek, and Fairbanks regions, Alaska, by L. M. Prindle. 1905.89 pp., 16 pls. WS 117. The lignite of North Dakota and its relation to irrigation, by F. A. Wilder. 1905.59 pp., 8 pls.

PP 36. The lead, zine, and fluorspar deposits of western Kentucky, by E. O. Ulrich and W. S. T. Smith. 1905.218 pp., 15 pls. PP 38. Economic geology of the Bingham mining district of Utah, by J. M. Boutwell, with a chapter on areal geology, by Arthur Keith, and an introduction on general geology, by S. F. Emmons. 1905. 413 pp., 49 pls.

PP 41. The geology of the central Copper River region, Alaska, by W. C. Mendenhall. 1905.

B 254. Report of progress in the geological resurver of the Cripple Creek district, Colorado, by Waldemar Lindgren and F. L. Ransome. 1904. $36 \mathrm{pp}$.

B 255. The fluorspar deposits of southern Illinois, by H. Foster Bain. 1905.75 pp., 6 pls.

B 256. Mineral resources of the Elders Ridge quadrangle, Pennsylvania, by R. W. Stone. $1905.86 \mathrm{pp} ., 12 \mathrm{pls.}$

B 259. Report on progress of investigations of mineral resources of Alaska in 1904, by A. H. Brooks and others. 1905 . 196 pp., 3 pls.

B 260. Contributions to economic geology, 1904; S. F. Emmons, C. W. Hayes geologists in charge. 1905.620 pp., 4 pls.

B 261. Preliminary report on the operations of the coal-testing plant of the United States Geological Survey at the Louisiar a Purchase Exposition, St. Louis, Mo., 1904; E. W. Parker, J. A. Holmes, M. R. Campbell, committee in charge. 1905. $172 \mathrm{pp}$.

B 263. Methods and costs of gravel and placer mining in Alaska, by C. W. Purington. 1905. 273 pp., 42 pls.

PP 42. Geology of the Tonopah mining district, Nevada, by J. E. Spurr. 1905. 295 pp., 24.pls.

PP 43. The copper deposits of the Clifton-Morenci district, Arizona, by Waldemar Lindgren. $1905 . \quad 372 \mathrm{pp} ., 25 \mathrm{pls}$.

\section{SERIES B, DESCRIPTIVE GEOLOGY.}

B 23. Observations on the junction between the Eastern sandstone and the Keweenaw series on Keweenaw Point, Lake Superior, by R. D. Irving and T. C. Chamberlin. 1885. 124 pp., 17 pls. (Out of stock.)

B 33. Notes on geology of northern California, by J. S. Diller. $1886.23 \mathrm{pp}$. (Out of stock.)

B 39. The upper beaches and deltas of Glacial Lake Agassiz, by Warren Upham. 1887. 84 pp., 1 pl. (Out of stock.)

B 40. Changes in river courses in Washington Territory due to glaciation, by Bailey Willis. 1887 . 10 pp., 4 pls. (Out of stock.)

B 45. The present condition of knowledge of the geology of Texas, by R. T. Hill. 1887. 94 pp. (Out of stock.)

B 53. The geology of Nantucket, by N. S. Shaler. 1889.55 p.p., 10 pls. (Out of stock.) 
B 57. A geological reconnaissance in southwestern Kansas, by Robert Hay. 1890.49 pp., 2 pls.

B 58. The glacial boundary in western Pennsylvania, Ohio, Kentucky, Indiana, and Illinois, by G. F. Wright, with introduction by T. C. Chamberlin. $1890.112 \mathrm{pp} ., 8 \mathrm{pls.}$ (Out of stock.)

B 67. The relations of the traps of the Newark system in the New Jersey region, by N. H. Darton. 1890.82 pp. (Out of stock.)

B 104. Glaciation of the Yellowstone Valley north of the Park, by W. H. Weed. 1893. 41 pp., 4 pls.

B 108. A geological reconnaissance in central Washington, by I. C. Russell. 1893.108 pp., 12 pls. (Out of stock.)

B 119. A geological reconnaissance in northwest Wyoming, by G. H. Eldridge. $1894.72 \mathrm{pp} ., 4 \mathrm{pls}$.

B 137. The geology of the Fort Riley Military Reservation and vicinity, Kansas, by Robert Hay. $1896.35 \mathrm{pp} ., 8 \mathrm{pls}$

B 144. The moraines of the Missouri Coteau and their attenciant deposits, by J. E. Todd. $1896.71 \mathrm{pp} ., 21 \mathrm{pls}$.

B 158. The moraines of southeastern Sonth Dakota and their attendant deposits, by J. E. Todd. 1899.171 pp., 27 pls.

B 159. The geology of eastern Berkshire County, Massachusetts, by B. K. Emerson. 1899. 139 pp., 9 pls.

B 165. Contributions to the geology of Maine, by H. S. Williams and H. E. Gregory. 1900. 212 pp., 14 pls.

Ws 70. Geology and water resources of the Patrick and Goshen Hole quadrangles in eastern Wyoming and western Nebraska, by G. I. Adams. 1902. 50 pp., 11 pls.

B 199. Geology and water resources of the Snake River Plains of Idaho, by I. C. Russell. $1902.192 \mathrm{pp} ., 25 \mathrm{pls}$.

PP 1. Preliminary report on the Ketchikan mining district. Alaska, with an introductory sketch of the geology of southeastern Alaska, by A. H. Brooks. 1902.120 pp., 2 pls.

PP 2. Reconnaissance of the northwestern portion of Seward Peninsula, Alaska, by A. J. Colljer. 1902.70 pp., 11 pls.

PP 3. Geology and petrography of Crater Lake National Park, by J. S. Diller and H. B. Patton. 1902.167 pp., 19 pls.

PP 10. Reconnaissance from Fort Hamlin to Kotzebue Sound, Alaska, by way of Dall, Kanuti, Allen, and Kowak rivers, by W. C. Mendenhall. 1902. 68 pp., 10 pls.

PP 11. Clays of the United States east of the Mississippi River, by Heinrich Ries. 1903.298 pp., 9 pls.

PP 12. Geology of the Globe copper district, Arizona, by F. L. Ransome. 1903. 168 pp., 27 pls.

PP 13. Drainage modifications in southeastern Ohio and adjacent parts of West Virginia and Kenuteky, by W. G. Tight. 1903. $111 \mathrm{pp}, 17 \mathrm{pls}$.

B 208. Deseriptive geology of Nevada south of the fortieth parallel and adjacent portions of California, by J. E. Spurr. 1903. 229 pp., 8 pls.

B 209. Geology of Ascutney Mountain, Vermont, by R. A. Daly. 1903.122 pp., 7 pls.

WS 78. Preliminary report on artesian basins in southwestern Idaho and southeastern Oregon, by I. C. Russell. 1903. 51 pp., 2 pls.

PP 15. Mineral resources of the Mount Wrangell district, Alaska, by W. C. Mendenhall and F. C. Schrader. 1903.71 pp., 10 pls.

PP 17. Preliminary report on the geology and water resources of Nebraska west of the one hundred and third meridian, by N. H. Darton. 1903.69 pp., 43 pls.

B 217. Notes on the geology of southwestern Idaho and southeastern Oregon, by I. C. Russell. 1903.83 pp., 18 pls.

B 219. The ore deposits of Tonopah, Nevada (preliminary report), by J. E. Spurr. $1903 . \quad 31 \mathrm{pp} ., 1 \mathrm{pl}$.

PP 20. A reconnaissance in northern Alaska in 1901, by F. C. Schrader. 1904. 139 pp., 16 pls.

PP 21. The geology and ore deposits of the Bisbee quadrangle, Arizona, by F. L. Ransome. $1904,168 \mathrm{pp} ., 29 \mathrm{pls}$.

WS 90. Geology and water resources of part of the lower James River Valley, South Dakota, by J. E. Todd and C. M. Hall. 1904. 47 pp., 23 pls.

PP 25. The copper deposits of the Encampment district, Wyoming, by A. C. Spencer. 1904.107 pp., 2 pls.

PP 26. Economic resources of the northern Black Hills, by J. D. Irving, with contributions by S. F. Emmons and T. A. Jaggar, jr. 1904.222 pp., 20 pls.

PP 27. A geological reconnaissance across the Bitterroot Range and Clearwater Mountains in Montana and Idaho, by Waldemar Lindgren. 1904, 122 pp., 15 pls.

PP 31. Preliminary report on the geology of the Arbuckle and Wichita mountains in Indian Territory and Oklahoma, by J. A. Taff, with an appendix on reported ore deposits in the Wichita Mountains, by H. F. Bain. 1904.97 pp., 8 pls.

B 235. A geological reconnaissance across the Cascade Range near the forty-ninth parallel, by G. O. Smith and F. C. Calkins. 1904.103 pp., 4 pls.

B 236. The Poreupine placer district, Alaska, by C. W. Wright. 1904,35 pp., 10 pls.

B 237. Igneous rocks of the Highwood Mountains, Montana, by L. V. Pirsson. 1904. 208 pp., 7 pls.

B 238. Economic geology of the Iola quadrangle, Kansas, by G. I. Adams, Erasmus Haworth, and W. R. Crane. 1904. $83 \mathrm{pp} ., 1 \mathrm{pl}$

PP 32. Geology and underground water resources of the central Great Plains, by N. H. Darton. 1905.433 pp., $72 \mathrm{pls}$

WS 110. Contributions to hydrology of eastern United States, 1904; M. G. Fuller, geologist in charge. 1905.211 pp., 5 pls. B 242. Geology of the Hudson Valley between the Hoosic and the Kinderhook, by T. Nelson Dale. $1904.63 \mathrm{pp} ., 3 \mathrm{pls}$. PP 34. The Delavan lobe of the Lake Michigan Glacier of the Wisconsin stage of glaciation and associated phenomena, by W. C. Alden. 1904.106 pp., 15 pls.

PP 35. Geology of the Perry Basin in southeastern Maine, by G. O. Smith and David White. $1905.107 \mathrm{pp} ., 6 \mathrm{pls}$.

B 243. Cement materials and industry of the United States, by E. C. Eckel. 1905. 395 pp., 15 pls.

B 246. Zine and lead deposits of northeastern Illinois, by H. F. Bain. 1904.56 pp., 5 pls.

B 247. The Fairhaven gold placers of Seward Peninsula, Alaska, by F. H. Moffit. 1905.85 pp., 14 pls.

B 249. Limestones of southwestern Pennsylvania, by F. G. Clapp. 1905.52 pp., 7 pls.

B 250. The petroleum fields of the Pacific coast of Alaska, with an account of the Bering River coal deposit, by G. C. Martin. 1905. 65 pp., 7 pls. 
B 251. The gold placers of the Fortymile, Birch Creek, and Fairbanks regions, Alaska, by L. M. Prindle. 1905.89 pp. 16 pls.

WS. 118. Geology and water resources of a portion of east central Washington, by F. C. Calkins. $1905.96 \mathrm{pp}, 4 \mathrm{pls}$.

B 252. Preliminary report on the geology and water resources of central Oregon, by I. C. Russell. 1905.138 pp., 24 pls.

PP 36. The lead, zinc, and fluorspar deposits of western Kentucky, by E. O. Ulrich and W. S. Tangier Smith. 1905. 218 pp., 15 pls.

PP 38. Economic geology of the Bingham mining district of Utah, by J. M. Boutwell, with a chapter on areal geology, by Arthur Keith, and an introduction on general geology, by S. F. Emmons. 1905. 413 pp., 49 pls.

PP 41. The geology of the central Copper River region, Alaska, by W. C. Mendenhall. 1905.

B 254. Report of progress in the geological resurvey of the Cripple Creek district, Colorado, by Waldemar Lindgren and F. L. Ransome, 1904. $36 \mathrm{pp}$

B 255. The fluorspar deposits of southern Illinois, by H. Foster Bain. $1905 . \quad 75$ pp., 6 pls.

B 256. Mineral resources of the Elders Ridge quadrangle, Pennsylvania, by R. W. Stone. 1905.85 pp., 12 pls.

B 257. Geology and paleontology of the Judith River beds, by T. W. Stanton and J. B. Hatcher, with a chapter on the fossil plants, by F. H. Knowlton. $1905.174 \mathrm{pp}, 19 \mathrm{pls}$

PP 42. Geology of the Tonopah mining district, Nevada, by J. E. Spurr. 1905. 295 pp., 24 pls.

WS 123. Geology and underground water conditions of the Jornada del Muerto, New Mexico, by C. R. Keyes. 1905. 42 pp., 9 pls.

WS 136. Underground waters of Salt River Valley, Arizona, by W. T. Lee. 1905. 194 pp., 24 pls.

PP 43. The copper deposits of the Clifton-Morenci district, Arizona, by Waldemar Lindgren. 1905.372 pp., 25 pls.

Correspondence should be addressed to-

The Director,

United States Geological Survey,

SEPTEMBER, 1905.

Washington, D. C. 


\section{LIBRARY CATALOGUE SLIPS.}

[Mount each slip upon a separate card, placing the subject at the top of the second slip. The name of the series should not be repeated on the series card, but additional numbers should be added, as received, to the first entry.]

\section{Lindgren, Waldemar, I860-}

... The copper deposits of the Clifton-Morenci district, Arizona, by Waldemar Lindgren. Washington, Gov't print. off., I905.

375 , v p. illus., $\mathrm{XXV}$ pl. (incl. maps, 1 in pocket) diagrs. $29 \frac{1}{2} \times 23^{\mathrm{cm}}$. (U. S. Geological survey. Professional paper no. 43)

Subject series: A, Economic geology, 57; B, Descriptive geology, 68.

Literature: p. 30-32.

1. Copper ores-Arizona.

\section{Lindgren, Waldemar, r86o-}

... The copper deposits of the Clifton-Morenci district, Arizona, by Waldemar Lindgren. Washing-

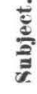
ton, Gov't print. off., I905.

375 , v p. illus., $\mathrm{XXV}$ pl. (incl. maps. 1 in pocket) diagrs. $29 \frac{1}{2} \times 23^{\mathrm{cm}}$ (U. S. Geological survey. Professional paper no. 43)

Subject series: A, Economic geology, 57; B, Descriptive geology, 68.

Literature: p. 30-32.

1. Copper ores-Arizona.

U. S. Geological survey.

Professional papers.

no. 43. Lindgren, $W$. The copper deposits of the CliftonMorenci district, Arizona. 1905.

U. S. Dept. of the Interior.

see also

U. S. Geological survey. 